\title{
Matewan Before the Massacre: Politics, Coal, and the Roots of Conflict in Mingo County, 1793-1920
}

\author{
Rebecca J. Bailey
}

Follow this and additional works at: https://researchrepository.wvu.edu/etd

Part of the Political History Commons, and the Social History Commons

\section{Recommended Citation}

Bailey, Rebecca J., "Matewan Before the Massacre: Politics, Coal, and the Roots of Conflict in Mingo County, 1793-1920" (2001). Graduate Theses, Dissertations, and Problem Reports. 7148.

https://researchrepository.wvu.edu/etd/7148

This Dissertation is protected by copyright and/or related rights. It has been brought to you by the The Research Repository @ WVU with permission from the rights-holder(s). You are free to use this Dissertation in any way that is permitted by the copyright and related rights legislation that applies to your use. For other uses you must obtain permission from the rights-holder(s) directly, unless additional rights are indicated by a Creative Commons license in the record and/ or on the work itself. This Dissertation has been accepted for inclusion in WVU Graduate Theses, Dissertations, and Problem Reports collection by an authorized administrator of The Research Repository @ WVU.

For more information, please contact researchrepository@mail.wvu.edu. 
Matewan Before the Massacre:

Politics, Coal, and the Roots of Conflict in Mingo County, 1793-1920

Rebecca J. Bailey

\author{
Dissertation submitted to the \\ Eberly College of Arts and Sciences \\ at West Virginia University \\ in partial fulfillment of the requirements \\ for the degree of
}

Doctor of Philosophy
in
Modern American History

Ronald Lewis, Ph.D., Chair

Van Dempsey, Ed.D.

Elizabeth Fones-Wolf, Ph.D.

Kenneth Fones-Wolf, Ph.D.

Barbara Howe, Ph.D.

Department of History

Morgantown, WV

2001

Keywords: West Virginia, mine war, Hatfield-McCoy feud, Sid Hatfield, Baldwin-Felts Detective Agency

Copyright 2001 Rebecca J. Bailey 


\section{UMI Number: 3022034}

Copyright 2001 by

Bailey, Rebecca J.

All rights reserved.

\section{UMI}

UMI Microform 3022034

Copyright 2001 by Bell \& Howell Information and Learning Company.

All rights reserved. This microform edition is protected against unauthorized copying under Title 17, United States Code.

Bell \& Howell Information and Learning Company 300 North Zeeb Road

P.O. Box 1346

Ann Arbor, MI 48106-1346 


\begin{abstract}
Matewan Before The Massacre:

Politics, Coal, and the Roots of Conflict in Mingo County, 1793-1920
\end{abstract}

Rebecca J. Bailey

On May 19, 1920, gunshots rang through the streets of Matewan, West Virginia, in an event soon known as the "Matewan Massacre." Most historians of West Virginia and Appalachia see this event as the beginning of a long series of events known as the second mine wars. This dissertation argues that this event was, rather, the culmination of an even longer series of events that unfolded in Mingo County, dating back at least to the Civil War, and setting the stage for the second mine war. Equally important, while it is outside the scope of this dissertation, the conflicts in Mingo County's history that crystallized around the massacre continued to resonate throughout the twentieth century while the county's residents worked to balance their lives against the public's knowledge of the best known events of their history, including the massacre and the earlier Hatfield-McCoy feud. This dissertation's strength is that it provides the first comprehensive history of the area that became Mingo County in 1895, a history that begins here in the late eighteenth century and continues to the massacre. The dissertation interweaves the area's economic history, including the development of coal mining and struggles over land ownership; labor history, including early efforts at unionization; transportation history, including the role of the $\mathrm{N} \& \mathrm{~W}$ Railroad; political history, including the role of political factions in the county's two major communities - Matewan and Williamson - and the impact of the state's governors and legislatures on the county; and history of violence, including the Hatfield-McCoy feud. Equally important, this dissertation argues that the history of the southern West Virginia coalfields is far more complex than we have believed previously. Mingo County did not have the large immigrant population of its neighbors. Nor did it have the large-scale mining operations that could withstand fluctuations in the coal markets better than did the small mines in Mingo County. The dissertation draws on extensive use of county court records, local newspapers, oral history interviews, correspondence with a Matewan local historian, and the papers of coal company owners to address the question of why the massacre happened in Matewan on that date - a question that can only be answered by knowing the history of the county before that date. 


\section{Acknowledgments}

Unfortunate circumstances prevent me from being able to express fully my gratitude to all who in many ways contributed to the completion of this dissertation. But to anyone who might seek to find their names on this page please allow me to say simply I remember you all and thank you from the bottom of my heart. I just hope that someday I will have the opportunity to thank the people who did not expect to be acknowledged here. 
For the people of Matewan and Mingo County, who gave my education a purpose.

For Momma, Daddy, and the rest of my family, because they give me roots.

But most and last,

For Bill,

You showed me my wings and then gave me the sky. 


\section{TABLE OF CONTENTS}

\begin{tabular}{|c|c|c|}
\hline Introduction & & $\begin{array}{l}\text { Pages } \\
\text { xii-xxxvi }\end{array}$ \\
\hline PART I & THE EARLY HISTORY OF THE TUG VALLEY, 1671-1894 & $1-78$ \\
\hline \multirow[t]{4}{*}{ Chapter 1} & $\begin{array}{l}\text { BEFORE THE RAILROAD CAME: LIFE IN THE TUG } \\
\text { VALLEY, 1793-1880s }\end{array}$ & $2-31$ \\
\hline & $\begin{array}{l}\text { I. Antebellum Life in the Tug Valley: Geography and Human } \\
\text { Enterprise, 1793-1860 }\end{array}$ & $3-15$ \\
\hline & $\begin{array}{l}\text { II. The Civil War and Its Aftermath Set the Stage for the } \\
\text { Industrialization of the Tug Valley, 1860-1888 }\end{array}$ & $15-27$ \\
\hline & III. Conclusion & $27-31$ \\
\hline \multirow[t]{6}{*}{ Chapter 2} & $\begin{array}{l}\text { THE ARRIVAL OF THE RAILROAD AND THE } \\
\text { INDUSTRIAL TRANSFORMATION OF THE TUG } \\
\text { VALLEY, 1888-1894 }\end{array}$ & $32-78$ \\
\hline & $\begin{array}{l}\text { I. Development Follows The Path of the Ohio Extension, } \\
\text { 1888-1894 }\end{array}$ & $33-40$ \\
\hline & II. The Reconfiguration of Logan County Politics, 1890-1894 & $41-53$ \\
\hline & III. The Panic of 1893 and the King Land Case (1894-1913) & $53-71$ \\
\hline & $\begin{array}{l}\text { IV. Industrialization Alters the Economy of the Tug Valley, } \\
\text { 1888-1894 }\end{array}$ & $71-76$ \\
\hline & V. Conclusion & $76-78$ \\
\hline PART II & THE INDUSTRIAL TRANSITION, 1895-1911 & 79-208 \\
\hline \multirow[t]{5}{*}{ Chapter 3} & $\begin{array}{l}\text { THE CREATION OF MINGO AND THE PATTERN OF } \\
\text { COUNTY POLITICS, } 1895-1911\end{array}$ & $80-126$ \\
\hline & I. The Creation of Mingo County: A Reexamination & $82-87$ \\
\hline & II. The Pattern of County Politics Emerges, 1895-1902 & $88-98$ \\
\hline & $\begin{array}{l}\text { III. Factionalism Undermines the Influence of the Coal Men, } \\
\text { 1904-1911 }\end{array}$ & $98-113$ \\
\hline & IV. The Rise of the "Hatfield Machine," 1895-1911 & $113-126$ \\
\hline
\end{tabular}


CRISIS AND CONFLICT SHAPES THE THACKER COAL 128-173 FIELD, 1895-1911

I. The Panic of 1893 Affects Industrial Development and

129-147 Relations, 1895-1896

II. The New Century Brings New Struggles in the Thacker $148-172$ Coal Field, 1900-1911

III. Conclusion

172-173

Chapter 5 THE POLITICAL ECONOMY OF A PERIPHERY:

174-210 INDUSTRIALIZATION'S SOCIAL IMPACT ON MINGO COUNTY, 1895-1911

I. The Railroad and Coal Industries Transform the Social

174-187 Landscape of Mingo County

II. Industrialization and the Culture of Honor: Greed, Violence, 188-208 and the Law, 1895-1911

III. Conclusion

208-210

PART III

THE DESCENT INTO CRISIS, 1912-1920

211-487

Chapter 6

THE PROGRESSIVE ERA?: MINGO'S POLITICAL MACHINES AND FACTION WARS, 1912-1920

212-280

I. The Hatfield Machine and Republican Control, 1912-1916 214-234

II. The Faction Wars of Mingo's Democrats, 1912-1916 234-258

III. The Republican Decline and Democratic Ascendance, 258-279 1916-1920

IV. Conclusion

$279-280$

Chapter 7

STORM CLOUDS ON THE HORIZON: THE

281-312 WILLIAMSON-THACKER COAL FIELD FALLS BEHIND, 1912-1916

I. The Intensification of Long-Standing Systemic Industrial 281-288 Problems, 1912-1916

II. The First Mine War and Its Impact on the WilliamsonThacker Coal Field, 1912-1913

288-300 
III. The Unexpected Results of Coal Industry Reforms, 1912- 301-311 1916

IV. Conclusion

$311-312$

Chapter 8

WORLD WAR I AND THE MARGINALIZATION OF THE 313-345

WILLIAMSON-THACKER COAL FIELD, 1914-1919

I. The Boom Before America's Entry in the War

$314-318$

II. Wartime Regulation Transforms Coal Industry Relations

$318-323$

III. The Establishment of the Fuel Administration and the

$323-333$ Effect of its Policies

IV. Federal Regulation Fails to Benefit the WilliamsonThacker Field

V. Conclusion

Chapter 9

WORLD WAR I AND THE ESCALATION OF CLASS TENSIONS IN MINGO COUNTY

$346-417$

I. Wartime Policies and the Ascendance of Mingo's "Better Classes"

$347-357$

II. The Persistence of Traditional Patterns of Violence and

$357-363$

Conflict Resolution

III. The War's Impact on the Local Social Infrastructure 363-385

IV. Benevolent Paternalism and Wartime Policies Sow the 385-398 Seeds of the Miners' Discontent

V. The War Revives the Desire to Unionize Southern West 398-414 Virginia

VI. Conclusion

“THE WORST HAS COME": THE MATEWAN

$418-487$ MASSACRE, MAY 19, 1920

I. Prelude to Tragedy: The Convergence of Contributory

418-439 Factors, January - May, 1920

II. The Matewan Massacre and Its Local Impact, 1920-1960s

$439-461$

III. Repercussions: The Massacre's Influence on Subsequent 461-483 State and National Developments, 1920-1933

IV. Conclusion 
CONCLUSION Construction of the Matewan Myth: Elevation Through

488-504

Denigration

Bibliography

$505-530$

viii 


\section{LIST OF MAPS}

Map 1 The Tug Valley Border Country 553

Map 2 Mingo County, West Virginia, ca. 1895

Map 3 Coal Fields of the Norfolk \& Western Territory 555

Map $4 \quad$ The Southern West Virginia Coal Fields, ca. 1921 


\section{LIST OF TABLES}

Table $1 \quad$ Land Valuations in Logan County by Magisterial District, $1891 \quad 52$

Table 2 Land Valuations in Logan County by Magisterial District, $1892 \quad 52$

Table $3 \quad$ Population of Mingo, Logan, and McDowell Counties, 1890- 149 1920

Table $4 \quad$ Population of Mingo, Logan, and McDowell Counties, 1890- 164 1920

Table 5 Comparison of Land Values in Mingo, Logan, and McDowell 166 Counties, 1900-1910

Table 6 Town Growth and Decline in Mingo County, 1891-1896 176

Table $7 \quad$ Mingo County Towns that Had Not Existed in 1891 and their $\quad 176$ Populations in 1895-1896

Table 8 Democratic Factions in Mingo County, 1912-1916 237

Table 91916 Republican Primary Election Precinct Officers Appointed by 244 Greenway Hatfield

Table 10 The Impact of Federal Control on the Coal Industry in Mingo 344 County, 1917-1918

Table 11 Impact of Federal Control of the Coal Industry in Logan County, 345 1917-1918

Table 12 Impact of Federal Control of the Coal Industry in McDowell County, 1917-1918

Table 13 Population Growth of Mingo County's African-American Community, 1900-1920

Table 14 Comparison of the Hungarian Population in Mingo, Logan, and McDowell Counties, 1910-1920 


\section{APPENDICES}

Appendix 1

Appendix 2

Appendix 3

Appendix 4

Appendix 5
1920 West Virginia Gubernatorial Election Results

531

Mingo County’s Native Miners, 1920: A Statistical Analysis

The Miners of Lick Creek Tent Colony: Mingo County miners or imported agitators

"The Smoking Gun": Documentary Evidence of the Role of Politics in the 1920 Unionization Drive in the Williamson-Thacker Coal Field

The Impact of Coal Production on: Mingo, Logan, and McDowell Counties

i. Tri-County Population Growth Comparison, 1900-1920

ii. Tri-County Comparison: Average Land Per Acre Value

iii. Tri-County Number of Mines Comparison

iv. Tri-County Comparison: Ethnicity of Population

v. Tri-County Comparison: Coal Production, 1895-1940

vi. Tri-County Comparison: Coal Production, 1895-1922

vii. Tri-County Comparison: Coal Production, 1923-1940
$532-534$

535

$536-542$

543

544

545

546

$547-549$

550

551

552 


\section{INTRODUCTION}

I. An Overview of the Matewan Massacre of May 19, 1920

At 11:47 a.m., on the morning of May 19, 1920, agents of the Baldwin-Felts Detective Agency arrived in Matewan, Mingo County, West Virginia, to process evictions for the Stone Mountain Coal Company. Sid Hatfield, Matewan's chief of police, and C. C. Testerman, the mayor, challenged the agents' authority to process the evictions within the town's municipal limits. Despite the objections of the town's officers, the agents proceeded with the evictions. After eating an afternoon meal at the Urias Hotel, the Baldwin-Felts men headed to Matewan's depot to catch the train back to their company's headquarters in Bluefield. While on their way, Chief Hatfield and Mayor Testerman requested a conference with the agents' leader, Albert C.

Felts. Accounts of the exchange between the three men differ, but apparently both Hatfield and

Felts attempted to arrest each other, whereupon guns were drawn. Both Felts and Mayor

Testerman fell mortally wounded during the first volley. Within minutes, eight other men, including six agents and two innocent bystanders, also lay dead or dying on the streets of Matewan. ${ }^{1}$

\footnotetext{
${ }^{1}$ The time of the Baldwin-Felts agents' arrival was noted in the Charleston Gazette, 21 May 1920. For a sample of the variety of accounts of the Massacre, see also: Williamson Daily News, 20 May 1920; West Virginia Federationist, 20 May 1920; "Testimony of Sid Hatfield" U.S. Congress, Senate, Committee on Education of Labor, West Virginia Coal Fields: Hearings . . to investigate the recent acts of violence in the coal fields of West Virginia and adjacent territory and the causes which led to the conditions which now exist in said territory (Washington: GPO, 1921), 205-221; various eyewitness testimonies from the "Massacre trial" State of West Virginia v. Sid Hatfield, et al , H. C. Lewis Collection, Eastern Regional Coal Archives, Craft Memorial Library, Bluefield, West Virginia. The Lewis Collection is comprised of the papers of the Baldwin-Felts Detective Agency founder Thomas L. Felts and contains the only known copies of trial records from the Matewan Massacre Trial (January-March 1921) and
} 
The Matewan "Massacre," as it came to be known, was a pivotal episode in West Virginia's second "mine war." ${ }^{2}$ This brief, but bloody exchange set in motion a chain of events that resulted in a twenty-eight month long strike that led to two dozen deaths, West Virginia's longest and most controversial murder trial to date, a United States Senate investigation, the retaliatory assassination of Chief Hatfield, and the largest armed civilian insurrection since the Civil War. ${ }^{3}$ Because the Matewan Massacre occurred in the heart of the "stompin' grounds" of the Hatfields and McCoys, it entered the annals of American history as one of the most wellknown incidents of West Virginia and Appalachian history.

Beginning with contemporary press accounts and continuing through to current academic and popular presentations of the event, the Matewan Massacre has been treated primarily as an episode of labor-related violence. In the eight decades since May 19, 1920, an orthodoxy has evolved that pits Hatfield, Testerman, and the armed men of Matewan against the jack-booted agents of capitalist oppression. The principal goal of this study is to reconstruct, and thus reintroduce, what has become the single most overlooked, but central question of the Massacre story. Of all the towns and coal camps of southern West Virginia and eastern Kentucky, why did

the trial of C.E. Lively, William Salter, and George Pence (October 1921) for the murders of Sid Hatfield and Ed Chambers.

${ }^{2}$ The term "mine wars" generally refers to the episodic attempts to organize West Virginia's coal fields by the United Mine Workers of America. According to one of the men who popularized the phrase, H.B. Lee (who served as state attorney general, 1925-1933), there were four mine wars between 1900 and 1933. (H.B. Lee, Bloodletting in Appalachia: The Story of West Virginia's Four Major Mine Wars and Other Thrilling Incidents of Its Coal Fields [Morgantown, W.Va.: West Virginia University Library, 1969]).

${ }^{3}$ Commonly used in feud lore, the phrase, "stompin' ground" was immortalized in John Sayles' 1987 film, Matewan, and a t-shirt sold by a Matewan merchant after the film's release. 
the Massacre occur in Matewan? A brief survey of the treatment of the Massacre story illuminates how this critical issue was lost.

\section{Historiographic Synopsis: The Construction of the "Anatomy" of the Massacre Story ${ }^{4}$}

Within twenty-four hours of the events of May 19, news of the Matewan gun battle spread across the nation. Journalistic reports appeared not only in local and regional newspapers, but even in the New York Times. ${ }^{5}$ In less than two weeks, a story on the incident and its underlying causes appeared in Nation, one of America's leading news magazines. ${ }^{6}$ That first story, entitled "Private Ownership of Public Officials," set the tone and defined the parameters of the contemporary accounts of the story.

According to the United Mine Workers' of America, reform-minded journalists, and liberal politicians of the day, the violence of May 19, 1920, resulted from the coal operators' attempt to defeat the UMWA's effort to organize the miners of Mingo County. ${ }^{7}$ The principal

${ }^{4}$ The term "anatomy" as used here is a paraphrase of a term used by E.P. Thompson in the preface to the Making of the English Working Class. According to Thompson, one of the flaws of intellectual analysis is the attempt to "anatomise" phenomena, in this case to reduce an event to discrete, easily defined causative and interactive categories. (E.P. Thompson, The Making of the English Working Class [New York: Vintage Books, 1966], 9).

5"Twelve Men Killed in Pistol Battle in West Virginia," New York Times, 20 May 1920. The actual number of deaths was ten, although several more men were wounded, either during the battle or in related incidents nearby.

${ }^{6}$ Arthur Gleason, "Private Ownership of Public Officials," Nation 110 (29 May 1920): 724-725.

${ }^{7}$ United Mine Workers Journal, 31 (1 June 1920): 5; Winthrop D. Lane, Civil War in West Virginia: A Story of the Industrial Conflict in the Coal Mines (New York: B.W. Huebsch, 1921 [reprint 1994]), 15; "Personal Views of Senator Kenyon," U.S. Congress, Senate, Committee on Education and Welfare, West Virginia Coal Fields: Personal Views of Senator Kenyon and views 
agents of the story thus became the labor union and its corporate foes, the anti-union coal operators of southern West Virginia. The critical issue was the right of coal miners to come together and defend their rights against the overwhelming force of "industrialism gone mad." The coal industry had enslaved southern West Virginia's miners in the "worst economic serfdom in America." Moreover, the coal operators "owned" the political and legal systems at the local and state levels, which further deprived their employees of nonviolent redress for their grievances. ${ }^{10}$ Worst of all, the miners lived in isolated, company-owned communities, policed and brutalized by armed guards, "private gunmen" who answered only to the operators. ${ }^{11}$ With such coercive power arrayed against them, it was little wonder that the "ignorant, primitive mountaineers" reverted "to their ancient way of settling trouble" by taking down their guns and killing their oppressors. ${ }^{12}$

As creatures of their age, most of the journalists who covered the Massacre and subsequent events structured their accounts to titillate their readers and possibly to inspire

of Senators Sterling, Phipps, and Warren .... (Washington: GPO, 1922) [67th Congress. 2d Session Senate Report 457]. Lane's pamphlet consisted of articles first published in the New York Evening Post in the Spring of 1921. Senator William S. Kenyon of Iowa chaired the subcommittee that investigated the Massacre and strike.

${ }^{8}$ Arthur Warner, "West Virginia-- Industrialism Gone Mad," Nation 113 (5 October 1921): 372-373.

${ }^{9}$ Neil Burkinshaw, “Labor’s Valley Forge," Nation 111 (8 December 1920): 639.

${ }^{10}$ Gleason, "Private Ownership," 724.

${ }^{11}$ Arthur Gleason, "Gunmen in West Virginia," New Republic 28 (21 September 1921): 90-92.

${ }^{12}$ Ibid, 91; Gleason, "Private Ownership,” 724. 
support for industrial reform. Details of the story were simplified, the causes of the conflict were generalized and broadly drawn, and individual players in the drama became archetypal caricatures. At the same time, issues that would complicate, or muddy the picture, were ignored. Matewan and Mingo County were simply spots in a barren landscape of an isolated and dysfunctional industrial empire. Sid Hatfield became a mountain Gabriel avenging the demoralized miners' brutalization. The detectives and the coal operators became the heartless tools of a remote and uncaring corporate monolith. As one journalist later observed in his memoir: "In the public mind, fed by newspaper emphasis on the sensational and with so little reporting of the background and personalities of [the] strike, the Matewan massacre ... meant merely one more example of union violence. It was not as simple as that." ${ }^{13}$

The historiographic legacy of the contemporary journalistic accounts of the Massacre can be measured by their influence on subsequent treatments of the story. For decades, not only popular accounts, such as Lon Savage's Thunder in the Mountains and John Sayles's film Matewan, but also scholarly studies have perpetuated the flaws first created by the partiality and biases of the reporters.

A. F. Hinrichs published the first academic analysis of the Matewan Massacre and Williamson-Thacker strike in 1923. His The United Mine Workers of America and the NonUnion Coal Fields drew heavily on newspaper accounts, the published Senate investigation

${ }^{13}$ Malcolm Ross, The Death of a Yale Man (New York: Farrar and Rinehart, 1939), 96. Ross also wrote one of the now classic accounts of the decline of the coal industry, Machine Age in the Hills. 
records, and trial transcripts as well as Hinrichs's own firsthand observations. ${ }^{14}$ Although his sources were virtually identical to those cited by the journalists, Hinrichs's study emerges as a mirror image juxtaposition. The journalists dramatized and sensationalized their subject, while Hinrichs pared down the sources to those which would best lend themselves to objective examination. In keeping with the contemporary vogue for dispassionate scientific inquiry, Hinrichs asserted that his purpose was to "examine the case for and against the extension of the United Mine Workers of America into the nonunion coal fields." ${ }^{15}$ Hinrichs's report is essentially a compilation of narrowly focused issue analyses. For example, utilizing the statistical evidence provided by the union and the operators themselves, Hinrichs tested the UMWA's claim that employment conditions were worse in the non-union coal fields. After allowing for the discrepancies between the similar, but not identical sources submitted by the antagonists, Hinrichs concluded that overall conditions in union and non-union fields were about the same. ${ }^{16}$ Although Hinrichs acknowledged that both sides had legitimate grounds for the positions they took in the conflict, invocation of broader and deeper "philosophicopsychological" reasons, such as political liberty, only clouded the argument. ${ }^{17}$ The larger issue to

${ }^{14}$ A.F. Hinrichs, The United Mine Workers of America and the Non-Union Coal Fields (New York: n.p., 1923). This was apparently a printing of Hinrichs' dissertation for Columbia University's Political Science department.

\footnotetext{
${ }^{15}$ Ibid, 9.

${ }^{16}$ Ibid, 9-12.

${ }^{17}$ Ibid, 10 .
} 
Hinrichs and most of his academic contemporaries was the threat posed to the American public's dependency on coal by the systemic causes of inefficiency in the coal industry. ${ }^{18}$

After New Deal legislation legitimized America's unions, academic studies of the Massacre and strike marked a return to the partial and flawed contemporary journalistic accounts. Four of the most well-known of these works are: John L. Dunbar, "Two Periods of Crisis in Labor Management Relations in the West Virginia Coal Fields, 1912-1913 and 1919-1922” (1946); John M. Barb, "Strikes in the Southern West Virginia Coal Fields, 1912-1922” (1949); William R. Trail, "The History of the United Mine Workers in West Virginia, 1920-1945" (1950); and Thomas E. Posey, "Some Significant Aspects of the West Virginia Labor Movement” (1951). The monographs produced by Dunbar, Barb, and Trail were masters' theses, while Posey wrote his essay for a meeting of the West Virginia Academy of Science.

Typical mid-century "institutional” histories, the studies by Dunbar, Barb,Trail, and Posey focused on assessing the success or failure of the UMWA's effort to unionize West Virginia's coal miners. The Massacre and strike were thus treated as episodes in a larger study. How and why District 17 officials chose Matewan and Mingo County to be the center of the union's 1920 organization drive were not addressed. These and later studies launch their discussions of the background of the Massacre with the failure of the 1919 Armed March on Logan, and, without any explanation, simply turn to Mingo with observations that in the spring of

${ }^{18} \mathrm{Ibid}, 12$; Joseph T. Lambie, From Mine to Market: The History of Coal Transportation on the Norfolk and Western Railway (New York: New York University Press, 1954), 330. By 1923, Lambie explains, academic economists and the Interstate Commerce Commission had concluded that the policy of imposing freight rate differentials had promoted the development of an inefficient and unfair coal transportation network. 
1920, the union renewed its effort to organize southern West Virginia in Mingo County. ${ }^{19}$

Prejudice, a glaring lack of citation for significant observations, and an unquestioning citation of biased sources further undermines these early academic treatments. ${ }^{20}$

The most partisan of the four works, Trail's "History of the United Mine Workers," baldly insinuates that the violence of the Massacre and strike resulted from the criminal conspiracies of cowardly miners. Without citation, Trail claims that the murder of the Massacre trial's star witness was "planned at a union meeting at Blackberry City," just across the river from Matewan. ${ }^{21}$ Other explanations of strike-related violence, again uncited by Trail, undoubtedly originated in the contemporary anti-union publications of the Mingo operators. For

${ }^{19}$ John M. Barb, "Strikes in the Southern West Virginia Coal Fields, 1912-1922," (master's thesis, West Virginia University, 1949), 13-14; Merle T. Cole, "Martial Law in West Virginia and Major Davis as 'Emperor of Tug River'," West Virginia History 43 (Winter 1982): 118-144, 126.

${ }^{20}$ Listed chronologically: John L. Dunbar, "Two Periods of Crisis in Labor Management Relations in the West Virginia Coal Fields, 1912-1913 and 1919-1922" (master's thesis, Columbia University, 1946); John M. Barb, "Strikes in the Southern West Virginia Coal Fields, 1912-1922" (master's thesis, West Virginia University, 1949); William R. Trail, "The History of the United Mine Workers in West Virginia" (master's thesis, New York University, 1950); and Thomas E. Posey, "Some Significant Aspects of the West Virginia Movement," West Virginia Academy of Science Proceedings, vol. 22 West Virginia Bulletin Series 51, no.12-13 (June 1951): 120-127.

${ }^{21}$ Trail, 16. Lacking a source citation, readers are left to wonder why Trail pinpointed Blackberry City, a small community (actually, at that time, just a cluster of houses) on the Kentucky side of the Tug River. The best clue appeared, coincidentally, nearly forty years later in an oral history interview. According to a 1989 Matewan Oral History Project narrator, Blackberry City was a community owned and occupied by union miners, which was a source of aggravation to the operators because "they couldn't send their thugs in there to drive the miners ou." (Kenny Phillips interview with John Hennen, Summer 1989 Matewan Oral History Project). Although archived at all of the major West Virginia repositories, including West Virginia University, the original interview materials are owned by the Matewan Development Center, Matewan, West Virginia. 
example, Trail states that West Virginia state policemen injured or killed during the strike, were "all shot in the back."22 Had Trail's poor scholarship simply gathered dust when later accounts were being written, his work could have been dismissed for what it was, an anti-union diatribe. Unfortunately, some of his conclusions, drawn from what amounted to operator propaganda, reappeared in one of the most recent works on the Massacre and Strike. According to Trail, the "Three Days in May" Battle of 1921, turned local Mingo County citizens into "law and order" partisans and allies of the operators. ${ }^{23}$ Nearly fifty years later, in Power, Culture, and Conflict in the Coalfields, Roger Fagge asserted that organization of Mingo's volunteer militia in the aftermath of the battle stemmed from the growing antipathy of the local middle-class and elites. ${ }^{24}$ In contrast to Trail's thesis, John M. Barb's "Strikes" is generally sympathetic to the miners. Unlike Trail, who describes the union men assaulting unarmed men from behind or from ambush, Barb, in his account of the Massacre, noted that Hatfield and his allies were provoked by the actions of the "armed detectives." ${ }^{25}$ Barb's apparent pro-union outlook did not inhibit an attention to details overlooked by later scholars. For example, in discussing the population of the

\footnotetext{
${ }^{22}$ Ibid. Compare Trail's account to these quotes from, The United Mine Workers in West Virginia, submitted by the Bituminous Operators' Special Committee to the United States Coal Commission, (New York: Evening Post Job Printing Office, 1923). "Ernest Ripley, State Policeman, was shot in the back" (53) and this description of the deaths of four federal troopers, "all shot in the back" (56).

${ }^{23}$ Ibid, 18. The United Mine Workers in West Virginia (1923), 58.

${ }^{24}$ Roger Fagge, Power, Culture and Conflict in the Coalfields: West Virginia and South Wales, 1900-1922 (New York: University of Manchester Press, 1996), 144.

${ }^{25}$ Barb, 61. Barb's liberal use of contemporary newspapers and Senate investigation testimony indicates that he would have been aware of the debate over exactly who did the provoking and who fired first.
} 
striking miners' tent colonies, Barb noted that the inhabitants were area natives, not industrial migrants, and therefore were less likely to relocate in order to escape the colonies' dismal living conditions. ${ }^{26}$ However, like Trail, Barb failed to cite the sources which would have substantiated his assertion regarding the miners' nativity. ${ }^{27}$

Already undermined by their authors' biases and methodological inconsistencies, the mid-century studies were also weakened by their perpetuation of the idea that the Massacre and

\footnotetext{
${ }^{26} \mathrm{Barb}, 89$. In the most recent accounts of the Massacre and strike, New Left and labor scholars have stressed the heterogeneity of southern West Virginia's coal communities at the expense of the particular accuracy of Mingo's mining population. Beginning with David Corbin's Life, Work, and Rebellion (1981) and more recently with David Skeen's thesis (1996), commentary on the nativity and ethnicity of southern West Virginia's miners has stressed the diversity of the broader population, (across several counties and coalfields) because the authors sought to emphasize what they considered a more significant issue -- the emergence of a working class culture, at the expense of accuracy in the description of the population of Mingo's tent colonies. However, this author would argue that Mingo's higher proportion of regional natives directly affected the progress of the strike and the emergence of union loyalty. It was the native miners who emerged as leaders of the strike, and persisted in their devotion to the cause. David A. Corbin, Life, Work, and Rebellion: Southern West Virginia's Miners, 1880-1922 (Urbana: University of Illinois Press, 1981); David O. Skeen, "Industrial Democracy, Social Equality, and Violence: The West Virginia Mine Wars: 1912-1921,” (Masters' thesis, California State University, 1996). See Appendix 2 for a statistical analysis of the nativity of Mingo County's mining population in 1920.

${ }^{27}$ The nativity of the striking population was a hotly contested issue during the Senate inquiry in the Mingo situation. Union advocate Neil Burkinshaw and Mingo County Sheriff G.T. Blankenship both stressed that the strikers' dedication stemmed from their nativity and reluctance to leave the area. By contrast, operator spokesmen and attorneys asserted that the majority of the tent colony population were Kentucky natives who had "never" lived in West Virginia. Olmsted offered as proof the interrogations of the men taken into custody after the Lick Creek tent colony raid on June 14, 1921. Testimonies of Neil Burkinshaw, G.T. Blankenship, and Harry Olmsted, and interrogation documents filed with the committee, 19 September 1921, West Virginia Coal Fields: 5-8, 486-490, 223-277, and 559-601. Based on the operators' own evidence, while most of the Lick Creek tent colony miners were not West Virginia natives, the majority had, in fact, been employed in the Williamson-Thacker field when the lockout and strike began in the summer of 1920. See Appendix 3 for an analysis and refutation of the evidence the operators' attorneys submitted concerning the nativity and work history of the Lick Creek colonists.
} 
strike-related violence were culturally rooted. Like the theses by Trail and Barb, Dunbar's “Two Periods of Labor Crisis" (1946) explained the violent actions of Mingo's miners in terms that reflected the pseudo-sociological observations of the New York Times. According to Dunbar, "there had always been strife in Mingo County -- always localized, intensely insulated strife in a kind of shut-off little world." ${ }^{28}$ In "Significant Aspects" (1951), Thomas E. Posey, a former student of Selig Perlman of the Wisconsin school of American labor history, attributed the failure of West Virginia's labor movement to develop a politicized class consciousness to the belief in direct action of "its freedom-loving, individualistic hillbillies."29

The invocation of "feuding" and "mountain traditions" as reasons for the violence of the Massacre and the Williamson-Thacker strike persisted from the 1920s through the 1960s. To the contemporary observer-reporters and scholars of the 1920s, the extralegal and violent “tendencies" of southern West Virginia's miners were a traditional social dysfunction that had been exacerbated by the new order. That commercial coal mining had not, as an agent of progress, eliminated this antiquated behavior was just another piece of evidence that southern West Virginia's coal industry itself needed to be reformed. Decades later, when scholars again turned to the study of Appalachia's labor and economic problems, episodes from the past, such as the Massacre seemed to indicate that as a region, Appalachia suffered from historical, systemic cultural defects that impeded efforts to improve living and work conditions. This "new" outlook, later known as the "Culture of Poverty" model, viewed the mountaineer-miners' violence as the

\footnotetext{
${ }^{28}$ Dunbar, 44.

${ }^{29}$ Posey, 121.
} 
outbursts of a people overwhelmed by the abrupt dislocation of their lives by the advent of industrialization. ${ }^{30}$

Since the 1970s, scholars have reexamined southern West Virginia's "mine wars," and rather than focusing on "what went wrong," they have pursued a revisionist course that incorporates these episodes of Appalachian history into a broader context. The 1977 John L. Lewis biography by Melvin Dubosfky and Warren Van Tine illustrates the new focus of labor scholars. Dubofsky and Van Tine critically assessed Lewis's leadership of the post-World War I organization drives of the United Mine Workers of America. Nevertheless, when addressing the 1919-1922 effort in southern West Virginia, they still felt safe in remarking, "historically, violence in Mingo and Logan counties had been personal and familial." ${ }^{31}$

Just four years later, David Corbin's Life, Work, and Rebellion: The Southern West Virginia Miners, 1880-1922, appeared to chart a new course for the academic analysis of the mine wars. Corbin persuasively constructed the "world" of southern West Virginia's miners as a rural-industrial order that fostered the development of a defiant class-consciousness which resulted in periodic clashes between miners and operators. Primarily a labor history, Corbin's work begins with the emergence of post-bellum commercial mining and its transformative influence on economic, social, and political relations in the region's new coal communities.

${ }^{30}$ Dwight B. Billings, Mary Beth Pudup, and Altina L. Waller, “Taking Exception with Exceptionalism: The Emergence and Transformation of Historical Studies of Appalachia," Appalachia in the Making: The Mountain South in the Nineteenth Century (Chapel Hill: University of North Carolina Press, 1995): 1-24, 5-6. This essay is a co-written introduction to Appalachia in the Making, which Billings, Pudup, and Waller also edited.

${ }^{31}$ Melvin Dubofsky and Warren Van Tine, John L. Lewis: A Biography (New York: The New York Times Book Company, 1977), 77. 
Seeking to underscore how the miners were proleterianized by their surroundings, Corbin departed from traditional scholarship in asserting that the advance of corporate capitalism into southern West Virginia "quickly and ruthlessly destroyed old cultures." ${ }^{32}$ To Corbin, the miners' violence stemmed not from an ingrained cultural proclivity, but from their oppression in the "company system" imposed by their employers. ${ }^{33}$

Despite taking a dramatic stand on the antecedents of the mine wars' violence, Life, Work, and Rebellion did not undo decades of flawed interpretations of the Matewan Massacre and the Williamson-Thacker strike. Like the earlier studies by Trail, Barb, Dunbar, and Posey, Corbin's work also focused on the decades-long unionization struggle in southern West Virginia. The new orthodoxy simply reconfigured the old anatomy of the conflict. The old formula consisted of a traditional, and thus culturally backward, people spontaneously striking back against an oppressive corporate monolith. Reliant on a similarly simplistic causative string, the new equation asserted that dislocated people from several cultures, trapped in an exploitive system and denied other forms of protest, struck out at the agents of their domination. Corbin did not change the essential dialectic of the struggle. Instead, he only replaced the violent hillbilly miner with an archetypal working-class rebel. Like the traditional versions of the Massacre and strike, Corbin reduced the story to the point of obscuring its essential elements.

${ }^{32}$ David A. Corbin, Life, Work, and Rebellion, The Southern West Virginia Miners, 18801922 (Urbana: University of Illinois Press, 1981), 77.

${ }^{33}$ Ibid, 240-247. 
Subsequent scholars, whether in emulation of, or reaction to Corbin, have done little to alter the basic pattern he established nearly twenty years ago. ${ }^{34}$

The new labor history approach to the Massacre and strike, first pioneered by David Corbin, veils and/or ignores the aspects of the story that explain why the Massacre occurred in the town of Matewan, rather than one of the other towns or coal camps of southern West Virginia. For example, if it were the abject demoralization of company town life that radicalized miners to the point of fighting back, why did the Massacre occur in Matewan, an independent municipality, rather than a company town like Holden in Logan County or Gary in McDowell County? The cause and effect structure imposed by Corbin and others also generates narrative inconsistencies that prohibit a more nuanced understanding of the event's place in local and regional history. Again, if the coal companies "owned" the local political and legal systems, how and why did Mingo County sheriff G.T. Blankenship come to power and defend the miners during his term in office? Why did Judge Damron oversee the invalidation of eviction processes and the indictment of the surviving Baldwin-Felts agents? The revisionist approach, by drawing such a clear parameter around the "origins" of the story, first obliterated the need for factual accuracy, and then surrendered the story's most relevant historical context. By isolating the

\footnotetext{
${ }^{34} \mathrm{~A}$ typical factual error caused by the leftist "equation" of the story is that the surviving Baldwin-Felts agents were not tried for the gun battle. For example, Fagge falsely asserts that the agents were never tried, because the operators had the power to prevent it. Fagge, 146. Actually, the agents were tried in a non-coal county (Greenbrier) and acquitted by a friendly jury. Undated newspaper clipping, Bluefield Daily Telegraph, Matewan Omnibus Collection, ERCA. To some it may seem to be splitting hairs to observe that the operators had the power to "rig" but not prevent the agents' trial. However, this author asserts that acknowledging the existence of the agents' trial is critical to understanding the coal operators' slavish devotion to observing the form, if not the spirit, of legal justice. Besides, it was the agents' prerogative to request a change of venue.
} 
Massacre's relevance to the industrial era and the broader struggle of unionization, what the story could reveal about the deeper roots and lasting ramifications of violence in Appalachia have been lost.

\section{A Reexamination of the Matewan Massacre from a Local Perspective:}

The genesis of this study may be found in a convergence of the author's personal history and academic career. Although I was born and reared in Virginia, my parents' families were from McDowell and Mercer Counties. Moreover, my maternal grandfather was a teenager working in a Welch pool hall in the summer of 1921, and thus was a witness to the aftermath of the murder of Sid Hatfield and Ed Chambers on the McDowell County Courthouse steps on August 1, 1921. Until my grandfather's death in 1982, any recitation of his memories of working in the mines of McDowell County invariably included a story of seeing Sid Hatfield "shot down like a dog. ${ }^{, 35}$ However, my own parents' departure from West Virginia in the mid-1950s severed our family's direct link to the area and I grew to adulthood with no understanding of the historical context of my grandfather's memories.

An opportunity to reconnect with the historical heritage of my family roots in southern West Virginia began with my arrival at West Virginia University in the fall of 1988. During my first class in the Public History program at WVU, my instructor announced that the community of Matewan, in Mingo County was seeking graduate students to work on an oral history project

${ }^{35}$ For readers who might not understand the full import of the phrase, "shot down like a dog," what my grandfather was imparting was that, in his opinion, Hatfield had been murdered, and not in a "fair fight," where as a man, he would have had the opportunity to shoot back. The use of the phrase also implies that the method used by Hatfield's assailants also reflected a lack of respect of his humanity and dignity as a man. 
in the summer of 1989; I was one of two students chosen to go Matewan. Funded by the State of West Virginia Humanities Council, the Matewan Oral History Project ultimately included two ten-week field work sessions in the summers of 1989-1990. During the first summer, my colleague and I noticed that the narrators of the project mentioned individuals, issues, and events that either had not appeared in previous accounts of the Massacre and strike, or if they had, not in the context that the narrators stressed. For example, narrators revealed the familial connection between the Massacre participants and local officials. ${ }^{36}$ The oral history project focused primarily on the Hatfield-McCoy feud and the Matewan Massacre, but we were given liberty to explore other events in Mingo County history. Because a documented comprehensive history of Mingo County had never been written, the oral histories gathered in our project placed the Feud and the Massacre in their local context for the first time. My colleague and I were allowed to pursue a line of questioning that facilitated the emergence of a sense of the community's historical continuum. For example, the narrators discussed how the Massacre affected subsequent social, political, and economic relations in the county. ${ }^{37}$

In the opinion of Dr. Barbara J. Howe, my Public History instructor and an advisor to the Matewan projects, my own familial connection to the area played a pivotal role in encouraging

\footnotetext{
${ }^{36}$ The pivotal family relationship revealed centered around the Chambers family of Matewan. Five of the men originally indicted for participation in the Massacre were related by blood or marriage to the Chambers: Reece, Hallie, and Ed Chambers, and Clare Overstreet and Isaac Brewer. In addition, it was learned that G. T. Blankenship, the sheriff of Mingo County at the time of the Massacre, was also related to these men by marriage. Moreover, familial and marital connections also linked the Chambers families to the Hatfield and Chafin clans.

${ }^{37}$ Yet again, a primary subject was the Chambers family. Virtually alone among the county elite in their affiliation with the union cause in 1920-1922, the Chambers's loyalty was rewarded by Mingo's miners in the 1930s, after unions were legalized. For the next thirty years, Chambers family members or their allies "ran" Mingo County.
} 
the project narrators to speak so openly about the community's history, and in particular, the impact of the Massacre on the participants' families. As Dr. Howe noted, as the granddaughter of a southern West Virginia miner, I was “of, but not from the culture.” Lacking the bias and prejudice that might have colored the interviewing methodology of a community resident, I had an inborn understanding of the mores and values of the people with whom I interacted that a “true outsider" would not have possessed. For example, because of my own family's past, I knew that otherwise upstanding citizens and "good Christian" people could, and often did, act outside the law. During the Great Depression, my grandfather had supplemented his meager earnings as a miner by making bootleg whiskey, while his wife had sold her vote to a corrupt politician.

Inspired by what I had learned during my summers in Matewan, I entered the doctoral program in history at West Virginia University intent on discovering why there was such a disparity between the oral histories from Mingo County and the traditional accounts of the Massacre and Williamson-Thacker Coal Field Strike, 1920-1922. Throughout the decade-long process of uncovering and accumulating the hitherto little used archival resources on the history of Mingo County, my experiences from the summers of 1989-1990 guided and informed my research. Because I had won the trust of the people of Matewan, I was also able to re-establish contact with one narrator, Margaret Hatfield, who proved to be an invaluable resource. ${ }^{38}$ Before her death in the summer of 1998, Margaret Hatfield and I corresponded frequently about my

\footnotetext{
${ }^{38}$ Margaret Hatfield was a retired Mingo County teacher, and a local history enthusiast. Like myself, she had been a sickly child who had spent her early years "on the porch" absorbing the knowledge of her community's past from the conversations of elders who normally did not speak of such things in the presence of young people.
} 
research. Many of the connections drawn in this study would not have been possible if I had not had access to her knowledge of the genealogical, social, political, and economic bonds between the long-overlooked players in Matewan's history.

However, the bond forged with Margaret Hatfield reinforced my belief that a special debt was owed to the narrators of the Matewan Oral History project. When the time came to write this study the decision was made to focus on the story of what came before, rather than after the Massacre. In choosing this course, the complexity of the Massacre story, which had not appeared in previous analyses could be revealed without exploiting the deeply personal remembrances that had been shared by the people I interviewed. Anyone who listens to the Matewan interviews will sense how traumatic the events of 1920-1922 were for the people who lived through that time. How the Massacre affected the people of Matewan and Mingo County is a story best left to that community, or at least to another study where the methodological imperative of impartial historical analysis does not interfere with the power of Matewan's communal memory as expressed in the Matewan Oral History project interviews.

As the project gestated, Appalachian scholars began to reevaluate the accumulated knowledge of the region. The resulting deconstruction of events and issues exposed the inadequacies of previous generations' attempts to explain the region's apparently aberrant social, political, and economic history. Among the studies that inspired this author were: Altina L. Waller's analysis of the Hatfield-McCoy Feud; Paul Salstrom's and Wilma Dunaway's interpretations of Appalachian economic development, Ronald L. Lewis's work on the industrial 
transformation of rural West Virginia, and Dwight Billings' and Kathleen Blee's case study of the historical roots of chronic poverty in eastern Kentucky. ${ }^{39}$

In each case, these works, as well as others, helped to illuminate a new way of looking at the Matewan Massacre. Waller's work on the Hatfield-McCoy Feud exposed the necessity of understanding the broader context of familial and social relations when seeking to situate an event in the fabric of community history. ${ }^{40}$ Salstrom and Dunaway, by reformulating Appalachia's economic history, eradicated false assumptions about the transformative effect of industrialization. ${ }^{41}$ Lewis's study of commercial timbering revealed that the course of

\footnotetext{
${ }^{39}$ Altina L. Waller, Feud: Hatfields, McCoys, and Social Change in Appalachia, 18601900 (Chapel Hill: The University of North Carolina Press, 1988); Paul Salstrom, Appalachia's Path to Dependency: Rethinking a Region's Economic History, 1730-1940 (Lexington, Ky: University Press of Kentucky, 1994); Wilma A. Dunaway, The First American Frontier: Transition to Capitalism in Southern Appalachia, 1700-1860 (Chapel Hill: University of North Carolina Press, 1996); Ronald L. Lewis, Transforming the Appalachian Countryside: Railroads, Deforestation, and Social Change in West Virginia, 1880-1920 (Chapel Hill: University of North Carolina Press, 1998); Dwight B. Billings and Kathleen M. Blee, The Road to Poverty: The Making of Wealth and Hardship in Appalachia (Cambridge: Cambridge University Press, 2000). Although not "Appalachian" in focus, Richard E. Nisbett's and Dov Cohen's "cultural psychology" interpretation of southern violence also proved useful. According to Nisbett and Cohen, in communities where individuals feel compelled to personally protect their status and property, violence can be justified for reasons that defy legal and cultural norms. Richard E. Nisbett and Dov Cohen, Culture of Honor: The Psychology of Violence in the South (Boulder and Oxford: Westview Press, 1996).

${ }^{40}$ In addition to Feud, Dr. Waller has also published an essay that evaluates the creation of the Appalachian feud stereotype and its influence on the interaction between American and Appalachian culture during the industrial transformation of the region. Altina L. Waller, "Feuding in Appalachia: The Evolution of a Cultural Stereotype," in Appalachia in the Making: The Mountain South in the 19th Century, edited by Dwight Billings, Mary Beth Pudup, and Altina Waller (Chapel Hill: University of North Carolina Press, 1995), 347-376.

${ }^{41}$ In addition to Appalachia's Path to Dependency (Salstrom), and Appalachia's First Frontier, (Dunaway), Drs. Salstrom and Dunaway have also published essays that examine a particular aspect from the subject matter of their longer works. Salstrom, "Newer Appalachia as One of America's Last Frontiers," in Appalachia in the Making, 76-102; Dunaway, "Speculators
} 
industrialization in West Virginia was directly influenced by the conflict over the transformation of the political and legal philosophies of the state's elites. Nisbett's and Cohen's explication of the cultural ramifications of economic scarcity and governmental weakness broadens the historical perspective of reactive violence. ${ }^{42}$ Although just published, Billings's and Blee's study of poverty in Clay County, Kentucky, has perhaps been the most influential, for three reasons. First, The Road to Poverty accomplishes a goal parallel to the one pursued in this study. The Road to Poverty dissolves the boundaries between periods in the county's history. Second, it weaves a new narrative that reveals the persistence of local attitudes and behaviors over time. Third, Billings and Blee created a vocabulary to define and describe the long-term influences on Clay County, which this author shamelessly borrows and otherwise hopefully emulates.

The primary goal of this dissertation is to show that the local history of Matewan and Mingo County created a unique set of circumstances that culminated in the violence of May 19, 1920. To that end, the following chapters will identify and trace the evolution of three factors that created the vortex which spun out of control on the streets of Matewan that day.

and Settler Capitalists: Unthinking the Mythology about Appalachian Landholding, 1790-1860," in Appalachia in the Making, 50-75.

${ }^{42}$ During the 1960s and 1970s, Appalachian scholars, in their efforts to dispel the traditional stereotype of the inherently violent hillbilly, stressed the abrupt and alienating transition to industrial work as a cause of violence. Nisbett's and Cohen's work melds with the new focus of Appalachian scholarship which seeks to remove the "preindustrial/industrial" historical barrier to understanding the region's history and culture. For example, Nisbett and Cohen assert that their "Culture of Honor" model applies not only to the historical American South, but also to herding societies around the world and contemporary American inner city subcultures. 
First, this study will show that the introduction of commercial coal mining did not render “traditional mountain politics" obsolete. ${ }^{43}$ Moreover, this study will prove that, unlike the surrounding coal operator-dominated counties, Mingo County was not "ruled" either by, or on the behalf of, a single corporate-backed party. Rather, from the time of its creation until after the resolution of the strike, politics in Mingo County exhibited a comparatively astonishing volatility. The faction wars of Mingo's dueling "clientelist" political systems, as revealed in the pages that follow, ultimately created an opportunity in the spring of 1920, upon which the United Mine Workers of America hoped to capitalize. ${ }^{44}$ Sections of Chapters 1 and 2 contain segments that outline the antebellum and pre-industrial roots of Mingo's political relationships. Chapter 3 reveals that the political opportunism which led to Mingo County's creation set the stage for the survival of old political habits, despite the introduction and expansion of a new economic system. Chapter 6 and a segment of Chapter 10 explain how Mingo's "stunted public sphere" contributed to the county's selection by UMWA District 17 as the focal point of the 1920 organization drive. $^{45}$

${ }^{43}$ Corbin, Life, Work, and Rebellion, 12. The assumption that "pre-industrial" power networks were swept aside as the rail and coal industries "opened" southern West Virginia, originated with John Alexander Williams. John A. Williams, West Virginia and the Captains of Industry (Morgantown: West Virginia University Libraries, 1976), 117-120.

${ }^{44}$ The term "clientelist," borrowed from Billings and Blee, means that local political (and in some cases economic) relations were constructed around a patron-client relationship, in which higher status holding individuals offered protection, financial remuneration, and/or employment to lower status "clients" in return for political loyalty. Billings and Blee, Road to Poverty, 131133.

${ }^{45}$ Billings and Blee, Road to Poverty, 134-135. Again, Billings and Blee created this phrase to describe how communities were governed by elites whose decisions were influenced not by a concern for the public good, but by a desire to maintain or enhance their own status, and power. 
Second, this study will demonstrate that prior to the Matewan Massacre and WilliamsonThacker Coal Field Strike, 1920-1922, the Williamson-Thacker coal field of Mingo County was not an integral part of the economic monolith hitherto known as the "non-union coalfields of southern West Virginia." ${ }^{\circ 6}$ Sections of Chapter 2 and Chapter 4 will show that the opening and early development of the Williamson-Thacker field followed the basic developmental pattern established in southeastern West Virginia's coalfields. For example, Williamson-Thacker was opened in the aftermath of the arrival of a coal-hauling railroad and the corporate backing for the field's development also originated from similar sources. Many of the coal company investors and officers from the older fields also contributed to the establishment and growth of mines in Mingo.

However, these same chapters, along with Chapters 7 and 8, will also illustrate that from its opening the Williamson-Thacker coal field differed from the surrounding fields. The accumulated comparative analyses highlighted in these chapters will prove that the WilliamsonThacker field was a "peripheral" field of the larger, and more productive, fields to its east and north. Lacking the community-shaping leadership of pioneering entrepreneurs, and undeserving of on-site management by corporate representatives, the Williamson-Thacker field by 1920 had become the Achilles heel of nonunion southern West Virginia. These chapters will also expose the history of unionizing efforts in Mingo County before 1920. The discussion of the prelude to

${ }^{46}$ Southern West Virginia's nonunion coalfields (Winding Gulf, New River, Pocahontas, Williamson-Thacker, and Guyan) covered the political boundaries of six counties in West Virginia: Fayette, Raleigh, Mercer, McDowell, Logan, and Mingo, as well as some contiguous territory in southwestern Virginia and eastern Kentucky. See Map 4 "The Southern West Virginia Coal Fields, ca. 1921." 
the Massacre in Chapter 10 will draw together all of these elements and demonstrate that the unique mix of politics and labor issues in Mingo County set the stage for the Massacre.

The third theme of this study addresses the issue of violence as a means of conflict resolution from within the framework of Mingo County's social transformation. Rather than merely reciting details of isolated and probably unrelated episodes of violence that preceded the Massacre, I have chosen to include only those stories of criminal acts that reveal a behavior pattern or social notion that appears later in the local reaction to the Massacre and to evaluate the evolution of local attitudes regarding the issue of moral versus legal "rights." Of particular importance is the persistence of "fact" manipulation or obsfucation in order to marshall public acceptance and legal sanction for otherwise illegal acts. This discussion thus begins in Chapter 2 with the local reaction to the "land grab" that accompanied the arrival of the Norfolk \& Western railroad. Analysis of the most famous legal case from this period, the King Land case, will illustrate how elites, by cloaking themselves as defenders of local interests, defeated a competing claim to the mineral wealth of southern West Virginia. ${ }^{47}$

Chapter 5 expands on the theme of manipulation of the law and adds to it the theme of "ownership of the law," particularly in relation to the definition of acceptable and justifiable acts of violence. Episodes that highlight how Mingo Countians approached "lawing" and killing each other, whether over conflicting land claims, affronted male dignity, or self-defense by murder, illuminate how people in Matewan and Mingo County reacted to the events of May 19, 1920.

\footnotetext{
${ }^{47}$ The King Land case is actually an umbrella term for a series of lawsuits that were brought, between 1893 and 1913, by and against Henry C. King, a claimant to 500,000 acres of southern West Virginia coal lands. See Chapter 7 of Edwin A. Cubby, "Transformation of the Tug and Guyandot Valleys, Economic Development and Social Change in West Virginia, 18881921," (Ph.D. diss., Syracuse University, 1962).
} 
Chapter 9 illustrates how the domestic social and economic policies imposed during World War I facilitated the ascendance of Mingo's industrial elite and the crystallization of class and social differences in the county.

Finally, Chapter 10 analyzes the Matewan Massacre and its aftermath. Readers will understand that what propelled the men of Matewan and the Baldwin-Felts agents into bloody confrontation was not as simple as a group of mountaineers striking back at the agents of their oppression. Nor was the incident simply an act of retributory justice on behalf of an heroic and embattled union. Both sides had legitimate claims to legal authority and could have chosen to withdraw and continue the confrontation through other channels on another day. However, the influence of conflicting issues and agendas led the men who faced off on the streets of Matewan on May 19, 1920, to attempt to "bluff" their opponents into submission. ${ }^{48}$ Unfortunately, someone blinked and gunfire erupted. I have chosen not to contribute yet another analysis of the success or failure of the strike that followed the Massacre, but to focus instead on how the community reacted to the Massacre and how the forces behind the conflict, that is the union and the operators, molded presentations of the Massacre story for their own purposes.

This study concludes with a deconstruction of the mythology of the Matewan Massacre. First, I will examine how the agendas of those retelling the story crept into the scholarly analysis of West Virginia and Appalachian labor history and truncated and trivialized the Massacre's

\footnotetext{
${ }^{48}$ Massacre witness testimony offer conflicting versions of the "bluff" story. One witness alleged that before the Massacre, Albert Felts told Sid Hatfield that during the Paint Creek and Cabin Creek strike "they (the miners) tried to bluff me out" by shooting at him and his men, but that it did not work. Yet another witness testified that a union miner observing the Stone Mountain evictions observed angrily that it was the Baldwin-Felts agents perpetrating the bluff by making a show of the evictions. "Trial Testimony of Dan Chambers," and "Statement of Miss Jennie Mullens," 21 August 1920, Lewis Collection, ERCA.
} 
impact on the community where it occurred. For example, the Massacre's galvanizing effect on subsequent local political, economic and social relations in Matewan and Mingo County has gone undocumented except for notations that Mingo's miners enthusiastically joined the union in the $1933 .^{49}$ Second, I will show how the resultant lionization and demonization of the Massacre and strike participants forced the communities of Matewan and Mingo County into silence. An observation from a Feud retrospective published in the Williamson Daily News in 1982 offers insight into why the citizens of Matewan and Mingo County refused to tell their story until the late 1980s. The author noted that after the Feud ended, Tug Valley residents did not publicly discuss what they had seen and more importantly what they knew. "Implicit in their silence was embarassment at being part of a culture that produced the feud. It was better to bury the memories and overcome the legacy."50 I hope this study honors the effort of the men and women who broke the cycle of silence to reclaim their history in the summers of 1989 and 1990.

\section{A Note on Sources:}

For nearly eight decades the transcripts of the Matewan Massacre and C. E. Lively trials were believed lost, and the records of the Baldwin-Felts Detective Agency were alleged to have been utterly destroyed. A. F. Hinrichs, whose dissertation was published in 1923, was the last

${ }^{49}$ Richard D. Lunt, Law and Order vs. The Miners: West Virginia, 1906-1933 (Charleston, W.Va.: Appalachian Editions, 1992), 181. Lunt observes that after the passage of the National Industrial Recovery Act in 1933, it took one week to organize southern West Virginia's coal counties.

${ }^{50}$ Charlotte Saunders, “The Hatfields and McCoys Special Commemorative Edition," Williamson Daily News, 2 August 1982. This issue of the Daily News is dedicated entirely to stories about the feud and interviews with both families' descendants. 
academic to cite material from the Massacre trial until now. No one will ever know how different the historiography of the Massacre and Williamson Coal Field Strike might have been if the wealth of these sources hadbeen available to the generations of scholars who have written about the events in southern West Virginia between 1920 and 1922. ${ }^{51}$

${ }^{51}$ The rediscovery and curation of the surviving trial and Baldwin-Felts records is due to the efforts of Dr. Stuart McGehee, chair of the History Department of West Virginia State College and the archivist at the Eastern Regional Coal Archives. 
PART I: THE EARLY HISTORY OF THE TUG VALLEY, 1671-1894 


\section{CHAPTER 1}

BEFORE THE RAILROAD CAME: LIFE IN THE TUG VALLEY, 1795-1880s:

"'Mate Creek' -- A country post office in Logan County, 13 miles southwest of Logan (court house), 172 from Wheeling, 35 from Louisa, Ky., on the Chattaroi Ry., its shipping point. Mail,daily." ${ }^{1}$

-- West Virginia State Gazetteer and Business Directory, 1882-1883

Until recently, the history of Appalachia was divided into two distinct periods, preindustrial and industrial. Prior to the arrival of the railroad and the advent of commercial coal mining, the native mountain population was believed to have lived isolated, subsistence-oriented lives. The transition from farmer to worker, cabin to coal camp, was depicted as violently abrupt and alienating. The new industrial order supposedly swept away, or at least subsumed, the mountaineers' traditional social, economic, and political patterns of behavior. The native mountain people were identified by one of two characterizations: helpless victims of external forces they could not understand or combat, or cooperative betrayers of their own people. ${ }^{2}$ However, recent scholarship has shown that while Appalachia's industrial transformation profoundly affected social, economic, and political relations, the "new" order did not simply destroy and replace old patterns of interaction.

1"Mate Creek," West Virginia State Gazetteer and State Business Directory 1882-1883, vol. 2 (Detroit: R.L. Polk \& Company, 1883), 246.

${ }^{2}$ Robert Eugene Lanham, "The West Virginia Statehouse Machine: Structure, Function and Process," (Ph.D. diss., Claremont Graduate School and University Center, 1971), 247. For a concise overview of the evolution of Appalachian historiography, see the Introduction to Appalachia in the Making: The Mountain South in the Nineteenth Century, edited by Mary Beth Pudup, Dwight B. Billings, and Altina L. Waller (Chapel Hill: University of North Carolina Press, 1995), 1-24. 
To illustrate that the background story of the Matewan Massacre predates the industrial development of southern West Virginia, Part I of this study explores how the political, economic, and social relations that dominated life in Matewan and Mingo County in 1920 took shape long before the arrival of the railroad and the advent of commercial coal mining. The first chapter of this section reveals both the issues that influenced the establishment of white settlement and the creation of the basic patterns of life in the area that became Mingo County. In particular, Chapter 1 addresses the impact of geography, landownership, and social and economic stratification on the first century of human habitation of the Tug Valley.

\section{Antebellum Life in the Tug Valley: Geography and Human Enterprise, 1790s-1860}

The town of Matewan lies on the bank of the Tug Fork of the Big Sandy River, in the southeastern half of Mingo County, West Virginia, but several "boundaries" intersect and divide the geographic region in which Matewan is located. ${ }^{3}$ First, the Tug Fork river and valley are part of the Big Sandy river and valley system, which covers the area from the southwestern tip of Virginia in the Cumberland Plateau region to the northwest, where the Tug Fork and Big Sandy converge into the Ohio River system at the Catlettsburg, Kentucky, Huntington, West Virginia, and Ironton, Ohio triangle. ${ }^{4}$ Second, this system straddles the border of the states of West Virginia and Kentucky. Third, until 1895, Matewan was in Logan County, which itself was divided by a mountain ridgeline. East of the ridgeline, Logan falls into the Guyandot watershed,

\footnotetext{
${ }^{3}$ In her work on the Hatfield-McCoy feud, Dr. Altina Waller explains how the physical geography of the region influenced the development of social, political, and economic relations in the Tug Fork Valley and surrounding region. Waller, Feud, 25. A map illustrating Waller's observations appears on page 27 of Feud.

${ }^{4}$ Willard Rouse Jillson, The Big Sandy Valley: A Regional History Prior to the Year 1850 (Louisville, Ky.: John P. Morton \& Company, 1923), 93.
} 
while west of the ridgeline, the area that became Mingo County in 1895 lies in the Tug Fork watershed.

The physical geography just described profoundly affected life in the Tug Fork Valley. The steep and forbidding terrain coupled with a seasonally unnavigable river system made the area inhospitable to constant human habitation. ${ }^{5}$ The area encompassing present day Mingo County was little more than a hunting ground for various Indian tribes. ${ }^{6}$ White explorers Batts and Fallam first traveled to the Tug Valley in 1671, but few references to the area appeared until the mid-eighteenth century after the exploration journey of Dr. Thomas Walker and the ill-fated Big Sandy expedition of 1756 during the French and Indian War. ${ }^{7}$

White settlers first attempted to establish homes in the Tug and Big Sandy Valleys in the 1770s and 1780s. Some of these pioneers were veterans of the Revolutionary war, while others were merely continuing the westward drive initiated earlier in the century. In every case, hostile actions by the Shawnee drove the whites back to safer territory. Unlike the bluegrass region to the south and west, the population of this area between the Cumberland Plateau and the Ohio Country remained scarce, which led Willard Rouse Jillson, geologist and historian of eastern Kentucky, to liken the Tug and Guyandot valleys to a "cul-de-sac" of Indian supremacy surrounded by white habitation. ${ }^{8}$

${ }^{5}$ Ibid., 29-31.

${ }^{6}$ Ibid., 41-42.

${ }^{7}$ Ibid., 45. Recent scholarly analysis of the Batts-Fallam expedition indicates that the western terminus of their journey was the site that eventually became the town of Matewan. Alan V. Briceland, "Batts and Fallam Explore the Backbone of the Continent," in Appalachian Frontiers: Settlement, Society, \& Development in the Preindustrial Era edited by Robert D. Mitchell (Lexington, KY: University Press of Kentucky, 1991): 23-36, 33.

${ }^{8}$ Ibid., 75-76, 54, 66, 38. 
Once settled by white families, Dr. Jillson's “cul-de-sac" became a peripheral region beset by difficulties created by the area's forbidding landscape and complicated by human efforts to impose order through political boundaries. Although old bison trails eventually evolved in wagon roads that connected the valleys of the Big Sandy watershed to settlements to the north and east, until the arrival of the railroad, the river remained the primary means of accessing the area. ${ }^{9}$ Frozen in the winter and reduced to stagnant puddles in the summer heat, the Tug was not easily navigated during high water because of rocky shoals and the debris swept down from mountainsides.

The problematic river even affected the establishment of the Valley's political boundaries. In 1799, after the creation of the state of Kentucky, Virginia and Kentucky resolved their border dispute with a conference at the Tug and Levisa forks of the Big Sandy. Surveyors representing the new state and Virginia agreed to make the eastern bank of the larger of the two "forks," the Tug and the Levisa, the border. According to local legend, a rainstorm delayed the actual survey of the line. To celebrate their agreement and while away the delay, the two parties engaged in a drunken revel. When the weather cleared, the government officials declared the Tug Fork the larger river and thus the new border. Not waiting to see that at normal levels the Levisa was actually the larger stream, the outlanders retreated to civilization. ${ }^{10}$

On one level, the story humorously depicts how nature played a trick on men who lacked the stamina to withstand the harshness of the frontier. On a deeper level, the story illustrates how, out of ignorance, impatient and capricious outsiders created a boundary that little reflected

${ }^{9}$ Jillson, 93; Otis K. Rice and Stephen W. Brown West Virginia: A History, 2d edition (Lexington, Ky.: University of Kentucky Press, 1993), 87.

${ }^{10}$ Jillson, 116. 
the reality of life in the Tug Valley. Despite the imposition of the political boundary between Virginia (later West Virginia) and Kentucky, the social habits of the residents of the valleys in the Big Sandy watershed were primarily influenced by geography. Individuals and families were identified by the "holler" or creek they lived on, not by the state line. ${ }^{11}$ Activities organized around official political events, such as elections and "court day" in either state drew participants and spectators from both sides of the river/state border. ${ }^{12}$ The day-to-day irrelevance of the political boundary between Kentucky and West Virginia, however, contrasted sharply with the times when the law and social customs were breached. The ability of criminals, especially murderers, to "swim the river," "slip over the line," and "hide out" to evade the law became a common occurrence and source of frustration. ${ }^{13}$

Absentee ownership of land in the Tug Valley not only predated the land grab of the industrial transition period, it began before the permanent establishment of white settlement. After the War for Independence, and until "Mad" Anthony Wayne's defeat of the Shawnee at the Battle of Fallen Timbers in 1794, the continuing threat of Indian reprisals made most veterans unwilling to move west. Consequently many sold their "soldier warrants" to land speculators. ${ }^{14}$

\footnotetext{
${ }^{11}$ This habit persists among residents to this day, especially when describing "branches"of larger families, e.g., the "Hatfields of Grapevine Creek" or the "Hatfields of Beech Creek." Correspondence between Margaret Hatfield and the author, letter no. 12. For a broader Appalachian or southern perspective on this phenomenon, see Barbara Allen, "The Genealogical Landscape and the Southern Sense of Place," in Sense of Place: American Regional Subcultures, edited by Barbara Allen and Thomas J. Schlereth (Lexington, Ky.: University Press of Kentucky, 1990), 152-161.

${ }^{12}$ Waller, Feud, 72. For example, one of the pivotal incidents of the Hatfield-McCoy feud, the murder of Ellison Hatfield, occurred in Pike County on election day. Ellison, who was a resident of West Virginia, had no political reason to be there.

${ }^{13}$ Examples of this behavior will be discussed in subsequent chapters.

${ }^{14}$ Aaron M. Sakolski, Land Tenure and Taxation in America (New York: R. Schalkenbach Foundation, 1957), 76.
} 
Even before Fallen Timbers removed the threat of Indian attack, interest in Virginia's western frontier and the "Ohio Country" reached new heights in the last decade of the eighteenth century. Speculation and settlement converged in 1792, when the Commonwealth of Kentucky was carved from the Commonwealth of Virginia. ${ }^{15}$ Also in 1792, the legislatures of Virginia and Kentucky authorized the sale of unclaimed lands. In 1793, the Virginia "peddled" Appalachian lands for two cents an acre. ${ }^{16}$ The sale of the unclaimed and less desirable land of the eastern Kentucky-western Virginia borderlands proceeded at such a pace that within five years, more than two and a half million acres were sold to fourteen individuals. ${ }^{17}$ Ultimately, over three million acres were claimed or sold in the territory that became Logan County, although the county only covered 512,000 acres. ${ }^{18}$ The rampant speculation by absentee capitalists, the border dispute between Virginia and Kentucky, and the propensity of pioneer settlers to claim ownership by right of possession forged a dilemma that would take nearly a century to bear its bitter fruit.

In the forty years between the late 1790s and the early 1830s, pioneers settled in the Tug Valley. Some, like Ephraim Hatfield (the grandfather of William Anderson, commonly known as "Devil Anse" Hatfield) arrived seeking land. ${ }^{19}$ Others, like Anthony Lawson and James

\footnotetext{
20.

${ }^{15}$ Carol Crowe-Carraco, The Big Sandy (Lexington, KY: University Press of Kentucky, 1979),

${ }^{16}$ Wilma A. Dunaway, "Speculators and Settler Capitalists: Unthinking the Mythology about Appalachian Landholding, 1790-1860," in Appalachia in the Making, 50-75, 52.

${ }^{17}$ Ibid., 53, 60-61.

${ }^{18}$ George W. Summers, "Owned A Sixth of W.VA. Died in Prison For Debt," Pages From the Past: Recollections, Traditions, and Old Timers' Tales of the Long Ago reprint in West Virginia Heritage Encyclopedia vol. 21, supplemental series, edited and published by Jim Comstock, (Richwood, WV: 1974): 56-74, 61.

${ }^{19}$ Waller, Feud, 34-35.
} 
Nighbert, backed by entrepreneurial capitalists, came seeking economic opportunity. ${ }^{20}$ From the beginning, the social position and power held by these "first families" were influenced by land ownership. The men and families who claimed the land at the natural crossroads of overland trails and the river's tributaries quickly rose to position within their local communities. ${ }^{21}$ In each of these cases, the power and influence wielded by these men illustrate that by no means was the "pre-industrial" society they inhabited egalitarian.

Through their ownership of several prime locations along the Tug and its tributaries, intermarriage throughout the surrounding valleys, and their own proliferation, the Hatfields became an influential family. By virtue of their early arrival and sheer numbers, the landowning Hatfields emerged as a force in local politics and law enforcement. Possessing only a nominal literacy and almost no contacts with the outside world, members of the Hatfield clan were still respected community leaders. Devil Anse's father Ephraim ("Big Eaf”) served as a justice of the peace and several of Anse's uncles and brothers held a variety of public offices. ${ }^{22}$ Although not untarnished, the Hatfields' "position" survived even the disruptive impact of the "feud" with the

\footnotetext{
${ }^{20}$ Mary Beth Pudup, "Social Class and Economic Development in Southeastern Kentucky, 1820-1880," in Appalachian Frontiers: Settlement, Society, and Development in the PreIndustrial Era, edited by Robert D. Mitchell, (Lexington, Ky.: University Press of Kentucky, 1991): 235-260, 250. External backing in the case of Logan County's Lawson and Nighbert came from Andrew Beirne of Monroe County. The most complete biography of Beirne appears in Oren F. Morton, A History of Monroe County, West Virginia (Staunton, VA: The McClure Company, 1916), 309-310.

${ }^{21}$ For details on Hatfield, Lawson, and Nighbert, see Waller, Feud. For additional details on Lawson and Nighbert, see Robert Y. Spence, Land of the Guyandot: A History of Logan County (Detroit: Harlo Press, 1976).

${ }^{22}$ Waller, Feud, 35-37
} 
McCoys. Devil Anse's sons and nephews continued the family tradition of holding local office; one nephew, Henry Drury Hatfield, served as governor of West Virginia. ${ }^{23}$

Although they inhabited roughly the same geographic sphere of influence as Devil Anse Hatfield, Anthony Lawson and James Nighbert represented a different stratum of what came to be known as the native elite. From England and Germany respectively, Lawson and Nighbert were "Johnny-come-latelys" in the eyes of pioneering families like the Hatfields, although they arrived in Logan County within five years of its creation in $1824 .^{24}$ The most likely reason for the distinction between Nighbert and Lawson and the men who preceded them into the area by two decades is that Lawson and Nighbert arrived seeking their fortunes, not land. ${ }^{25}$ These two individuals were recruited by early Trans-Allegheny capitalist, Irish immigrant Andrew Beirne to become part of a fur and ginseng trade network that stretched throughout southwestern (West) Virginia. $^{26}$

The exploitation of Appalachia's natural resources began not with timber and coal, but with the equally lucrative and far more portable commodities of fur and ginseng. ${ }^{27}$ Even during the first century of English habitation in Virginia, the desire to establish a viable fur trade went hand-in-hand with the conquest of the unknown frontier. ${ }^{28}$ The fur trade played a pivotal role in keeping alive Virginia's fitful exploration of and expansion into the west, and provided an

\footnotetext{
${ }^{23}$ Neil Shaw Penn, "Henry D. Hatfield and Reform Politics from 1908-1917” (Ph.D. diss., Emory University, 1977), 293.

${ }^{24}$ Spence, 106; Waller, Feud, 143.

${ }^{25}$ Spence, $161-164$.

${ }^{26}$ Morton, 309-310.

${ }^{27}$ Jillson, 115-116, 124; Dunaway, First Frontier, 24.

${ }^{28}$ Dunaway, First Frontier, 14.
} 
important, although auxiliary, commodity for Virginia in the English imperial and international markets. ${ }^{29}$ Before the War of 1812, the bearskins from Appalachia sold by frontier hunters for the sum of one to four dollars were used in the crafting of the hats of Napoleon's grenadiers. ${ }^{30}$

Along with fur, the Appalachian frontier abounded in ginseng, a plant whose root was prized by the Chinese and Europeans for its medicinal value. ${ }^{31}$ In his diary, William Byrd of Virginia described how chewing on the root invigorated his constitution and settled a number of other digestive complaints. ${ }^{32}$ The harvesting of "sang," as it was called by the native Appalachians, drew the remote upcountry South into a national commercial network as early as the $1820 s^{33}$

The unequal exploitation of these early resources heavily influenced the stratification of the early society of the Appalachian frontier. ${ }^{34}$ Many, if not most, of the native mountaineers gathered ginseng for trading purposes. However, only a few enterprising merchants, like Lawson and Nighbert, whom we are now discovering were not "pioneers" as much as early arriving entrepreneurs, actually profited from the sale of ginseng. ${ }^{35}$ The capital accumulated by these mountain merchants facilitated their emergence as an elite class who owned more land and

${ }^{29}$ Ibid., 16.

${ }^{30}$ Crowe-Carraco, 22.

${ }^{31}$ Spence, 163.

${ }^{32}$ Ibid.

${ }^{33}$ Ibid., 161.

${ }^{34}$ Pudup, "Social Class and Economic Development," in Appalachian Frontiers, 238.

${ }^{35}$ Examples from the Tug and Guyandot Valleys (Logan County) include Anthony Lawson and James Nighbert. See Spence, 106-107; Waller, Feud, 143-146. 
livestock, lived in better housing, and sent their children beyond the mountains to be educated. ${ }^{36}$ Within the infrastructure of the local communities, the merchants often parlayed their positions as community postmaster and banker into political and legal domination of the communities. ${ }^{37}$ It was this faction of the "squire class" who later promoted the incursion of the railroad and extractive industries into America's last continental frontier. ${ }^{38}$

Although Anthony Lawson died while returning from a business trip to Philadelphia in 1846, members of his extended family remained significant figures in Logan County's development. ${ }^{39}$ His son served as a delegate to the Virginia Assembly and the Secession Convention of $1861 .^{40}$ After the war the second Anthony Lawson purchased the Burke's Garden, Virginia, plantation that had belonged to Virginia governor John B. Floyd. ${ }^{41}$ Almost thirty years after the war, another kinsman, Dr. Sidney B. Lawson, while serving as a Logan County Delegate to the West Virginia Legislature, proposed the division of Logan County. ${ }^{42}$ James Nighbert amassed an estate of thousands of acres and twice married into "buckskin" elite. ${ }^{43}$

\footnotetext{
${ }^{36} \mathrm{Ibid}$; and Sara Lubitsch Tudiver, "Political Economy and Culture in Central Appalachia, 1790-1977,” (Ph.D. diss., University of Michigan, 1984), 93-94.

${ }^{37}$ Ibid; Jillson, 83.

${ }^{38}$ John Hennen, "Benign Betrayal: Capitalist Intervention in Pocahontas County, West Virginia, 1890-1910," West Virginia History 50 (1991): 46-62, 49.

${ }^{39}$ Spence, 161.

${ }^{40}$ Ralph Mann, "Diversity in the Antebellum Appalachian South: Four Farm Communities in Tazewell County, Virginia," in Appalachia in the Making: 132-162, 147.

${ }^{41}$ Ibid., 154. Lawson was credited with introducing entrepreneurial farming to the area.

${ }^{42}$ Sidney B. Lawson, Fifty Years a Country Doctor: Autobiography and Reminiscences of Sidney B. Lawson, M.D. (Logan, WV: n.p., 1941), 45.

${ }^{43}$ Waller, Feud, 153; Lawson, 43; Spence, 261. Nighbert first married Alice Lawson and then Vicie (Straton) Ferguson.
} 
Comparison of the lives of the Hatfield, Lawson, and Nighbert families illuminates several elements of the interconnection of land, power, and wealth in antebellum Appalachia. Land ownership, over and above any other factor, determined one's access to power and influence. However, an individual or family could be essentially illiterate, cash poor and live without the luxuries wealth brings and still possess influence and power. In the decades before the Civil War, the Hatfield family held this position. By contrast, their fellow elites, the Lawsons and Nighberts, were wealthier, better educated, and were connected to external sources of capital and political prestige. Thus, the Lawsons and Nighberts were more actively involved in the early efforts to exploit the area's natural resources.

In 1837, the first steamboat steered its way up the Big Sandy, initiating a new interest in the area's abundant natural fuel resources, which included oil, natural gas, timber, and coal. ${ }^{44}$ Between 1849 and 1852, local elites and outside capitalists launched the first efforts to exploit these resources and move them into the national and international markets. ${ }^{45}$ In the 1830 s and 1840s, Kentucky and the federal government authorized expenditures to clear the Big Sandy river system's channel; both also launched canalization projects. ${ }^{46}$ The river was cleared of "simple obstructions" and surveyed, but no other work proceeded until after the Civil War. Despite aggressive lobbying by Governor John B. Floyd, the Virginia legislature grudgingly appropriated

\footnotetext{
${ }^{44}$ William Edward Lightfoot, Folklore of the Big Sandy Valley of Eastern Kentucky (Indianapolis: Indiana University Press, 1976), 55.

${ }^{45}$ Ibid; Spence, 161-162.

${ }^{46}$ Mary Verhoeff, "The Big Sandy River Navigation," Proceedings and Papers of the Ohio Valley Historical Association for the year 1919 (Columbus, OH: F. J. Heer Printing Company, 1925): 25-42, 34.
} 
only fifteen thousand dollars to clear the entire Big Sandy system. ${ }^{47}$ Loathe to spend public funds improving access to a remote corner of the state, the eastern Virginia-dominated General Assembly preferred to authorize private ventures. ${ }^{48}$

Privately funded development projects in the Tug and Big Sandy valleys included: the Warfield Salt and Coal Company, the Guyandotte Navigation Company, and the Peach Orchard Coal Company. Partially owned by Governor Floyd's brother, the Warfield Salt and Coal Company operation included a two-story red brick building and a village that, in its isolation, bore "a remarkable resemblance to western cowtowns." 49 In 1849, the Virginia Assembly incorporated the Guyandotte Navigation Company and authorized the new company to improve the navigation of the Guyandotte from its mouth to Logan Courthouse. ${ }^{50}$ Primarily interested in timber, the company cleared the river and acquired land from which to base its operations. ${ }^{51}$ For both companies, Virginia's failure to supplement their developmental efforts led to their demise. ${ }^{52}$ Only the Peach Orchard Coal Company survived the Civil War.

\footnotetext{
${ }^{47}$ Ibid; William Ely, The Big Sandy Valley: A History of the People and Country from the Earliest Settlement to the Present Time (Catlettsburg, Ky.: Central Methodist Publishing Company, 1887), 311.

${ }^{48}$ Barbara Rassmussen, "The Politics of the Property Tax in West Virginia," Journal of Appalachian Studies, 6 (Spring 1996): 141-147, 142. For a more extensive analysis of the history of land development and taxation in Virginia and West Virginia, see Barbara Rasmussen, Absentee Landowners and Exploitation in West Virginia, 1760-1920 (Lexington, Ky.: University Press of Kentucky, 1994).

${ }^{49}$ Jillson, 143.

${ }^{50}$ Spence, 161 .

${ }^{51}$ Ibid.

${ }^{52}$ Jillson, 144; Spence, 162.
} 
In 1847, New York and Ohio businessmen opened the first coal mine at Peach Orchard, Kentucky, less than sixty miles from the West Virginia border. ${ }^{53}$ A model village was constructed that included forty houses and steam-powered saw and grist mills. The finishedboard-sided houses, school, and church far surpassed the living conditions of most of the area's native inhabitants. However, the difficulty of transporting coal from Peach Orchard to the river barges limited the mine's production and the profits of its owners. ${ }^{54}$

The Civil War suspended industrial development in the Big Sandy Valley. ${ }^{55}$ Loyalties in the region were deeply divided. Like their counterparts elsewhere in Kentucky, many of the Big Sandy's merchant or town elites were Unionists, while their farmer or rural neighbors were Confederates. ${ }^{56}$ Just across the Tug Fork and Levisa rivers, southern West Virginia was almost entirely Confederate. ${ }^{57}$ Almost to a man, the miners of Peach Orchard abandoned the area to return to their native states, or to join Union regiments; the mine and other company property was left in the hands of a caretaker. ${ }^{58}$

Serious efforts to continue mining at Peach Orchard were not resumed until the late 1860 s and early 1870s. ${ }^{59}$ By that time the infant railroad system connecting the Kentucky side of the Big Sandy Valley to the east and northwest had been absorbed by the Chesapeake and Ohio

\footnotetext{
${ }^{53}$ Mary Lucille Chapman, "The Influence of Coal in the Big Sandy Valley" (Ph.D. diss., University of Kentucky, 1945), 282.

${ }^{54}$ Jillson, 204-205.

${ }^{55}$ Ibid., 205; Spence, 162.

${ }^{56}$ Crowe-Carraco, 29.

${ }^{57}$ Waller, Feud, 30.

${ }^{58}$ Jillson, 205.

${ }^{59}$ Ibid.
} 
Railroad under the leadership of Collis P. Huntington. ${ }^{60}$ Although a "rail line from Virginia to the Ohio had been conceived as far back as 1851," construction on what became the West Virginia side of the greater Valley did not begin until the 1880 s. $^{61}$

II. The Civil War and Its Aftermath Set the Stage for the Industrialization of the Tug Valley, 1860-1888

On the eve of the Civil War, the atmosphere in the valleys along the Virginia and Kentucky border was energized, but restless. The early ginseng, fur, and timber companies had kept the people of the Tug, Guyandot and Big Sandy Valleys aware of the outside world and desirous of more reliable intercourse. Local entrepreneurs exported marketable goods and established the first linkages with outside capital, despite the impediments of geography, limited financial resources, and disinterested state governments. ${ }^{62}$

However, land travel did not allow for goods' shipment beyond what peddlers could carry on a few pack horses. ${ }^{63}$ The weather limited both land travel and river traffic. During the winter, sections of the river were frozen solid, and in the summer bone dry. ${ }^{64}$ Even during fair weather, river traffic could be hazardous, as fallen trees and rock outcroppings challenged both

\footnotetext{
${ }^{60}$ Ibid., 205-220.
}

${ }^{61}$ Spence, 107; E. F. "Pat" Striplin, The Norfolk and Western: A History (Roanoke: Norfolk and Western Railway Company, 1981), 81.

${ }^{62}$ Barbara Rasmussen, "Politics of the Property Tax," 142. According to Rasmussen, "internal improvements ... were paid for by higher taxes," which eastern Virginia were loathe to impose in the first place, much less spend in the remote western section of the state.

${ }^{63}$ Crowe-Carraco, 24.

${ }^{64}$ Tyrel G. Moore, "Economic Development in Appalachian Kentucky, 1800-1860," in Appalachian Frontiers: Settlement, Society, and Development in the Pre-Industrial Era, edited by Robert D. Mitchell (Lexington, KY: University Press of Kentucky, 1991): 222-234, 223; Jillson, 115. 
pushboaters and timber rafters. ${ }^{65}$ The cost of river improvement, although more economical than railroad building, still exceeded the means of private funding by local businessmen, and assistance from the state governments of Virginia and Kentucky remained grudging and insufficient. $^{66}$

Despite their dissatisfaction with the policy of western neglect practiced in Richmond, the vast majority of southwestern Virginians supported Virginia's secession from the Union in the Spring of 1861. Having struggled for decades with eastern Virginia leaders over issues involving political and economic equity, local elites considered themselves loyal sons of Virginia who, when forced to choose between loyalty to the Union and their home state, chose Virginia. One such individual was James Lawson, the delegate from Logan, Boone, and Wyoming counties, who was one of only four southwestern Virginians to vote against the ordinance of secession. Nevertheless, he, along with the other three holdouts, eventually signed. ${ }^{67}$

There are several reasons why less prominent Logan residents supported Virginia joining the Confederacy. As Altina Waller observes in Feud, "Tug Valley residents in choosing the South were not embracing the ideal of southern nationhood so much as defending their autonomy." 68 The threat of an invading army entering Virginia translated into a threat against their own homes. ${ }^{69}$ Despite an extremely small and scattered African-American population,

\footnotetext{
${ }^{65}$ Verhoeff, 35.
}

${ }^{66}$ Moore in Appalachian Frontiers, 233; Pudup, "Social Class and Economic Development," in Appalachian Frontiers, 240; Rasmussen, "Politics of Property Tax," 142.

${ }^{67}$ Kenneth W. Noe, Southwest Virginia's Railroad: Modernization and the Sectional Crisis (Urbana: University of Illinois Press, 1994), 104-105.

\footnotetext{
${ }^{68}$ Waller, Feud, 31.

${ }^{69}$ Ibid., 32-33.
} 
some in the Tug Valley, as elsewhere in the Appalachian South, were also influenced by a deeply rooted racial animus. ${ }^{70}$ Correspondence between West Virginia Governor Henry D. Hatfield and West Virginia University professor and West Virginia historian Charles H. Ambler illustrates how many white southerners perceived African-American emancipation as a distinct threat. In reply to Ambler's request, Hatfield sent the transcription of a song often sung by his kinsman, "Uncle Jim" Vance, a Confederate veteran and Hatfield-McCoy feudist:

"I am a Rebel Soldier, the truth to you I'll tell,/ I voted for secession, and I would do it over again--/ I fought in many a battle, and many a Yankee slain./ Now you give your daughters, likewise your old maids,/ To any big buck negro, you are all of equal grades./ It is an honor to your service your dirty monger crew/ The Red, The White, The Blue. ${ }^{71}$

When local elites raised volunteer companies, men from all levels of mountain society joined. One such company, the Logan Wildcats, raised by Capt. David Wilkinson, included both future feudists William "Devil Anse" Hatfield and Randolph "Ranel" McCoy. ${ }^{72}$ For a generation after the war, a man's or his father's record of service, was second only to his family name as a means of "identifying" him to the community he inhabited. ${ }^{73}$ In the Tug and Big Sandy valleys,

\footnotetext{
${ }^{70}$ One of most in-depth analyses of race relations in the antebellum upcountry South is John Inscoe's Mountain Masters, Slavery, and the Sectional Crisis in Western North Carolina (Knoxville: University of Tennessee Press, 1989).

${ }^{71}$ Governor Henry D. Hatfield to Charles H. Ambler, 3 December 1953, Henry D. Hatfield Papers, West Virginia and Regional History Collection, West Virginia University, Morgantown, West Virginia. Hereafter Hatfield Papers, WVRHC.

${ }^{72}$ Waller, Feud, 30.

${ }^{73}$ Ibid., 32-33.
} 
as in other parts of Appalachia and the South, one's family name and wartime affiliations provided critical social, political, and economic meaning. ${ }^{74}$

The skirmishes between the Union troops and the Confederates in the Tug Valley (which constituted a part of the upper Big Sandy Valley) made the years between 1861 and 1865 chaotic. In Logan and its neighboring counties, the Union army decimated entire towns and burned the county courthouses before marching on to other locales. ${ }^{75}$ The Confederate Army was hardly more solicitous. Undersupplied and underfunded, it often simply took what local citizens would not allow to be requisitioned or could not afford to give away. ${ }^{76}$

The departure of regular troops did not end the suffering of the native population. Once the Union and/or Confederate Army passed through the area, bands of deserters and self-styled "home guard" units roamed the hills, extorted food and valuables, and generally terrorized their neighbors. ${ }^{77}$ Such wartime experiences survived long in the memories of the communities' elders. In 1989, nonagenarian Basil Hatfield recounted his grandparents enduring the theft of livestock, foodstuffs, and his grandmother's "best" dress. ${ }^{78}$ The pattern of the story's recounting

\footnotetext{
${ }^{74}$ The perception of "local" versus "outsider" would become extremely critical in the $1880 \mathrm{~s}$ and 1890s land rush. The Logan Banner, which began publication in 1889, frequently noted the war records and nativity of the lawyers and land speculators who facilitated the industrial transformation of the area. Many of the land deals so negatively portrayed by subsequent analysts were brokered by men who had been automatically granted welcome and trust because of "who they were." As one descendant of a pioneering family noted, "in many cases the people of Appalachia weren't ignorant hillbillies taken in by slick outsiders, but like Joseph, were sold into slavery by their own blood kin." Hatfield correspondence, letter no. 17.

${ }^{75}$ Waller, Feud, 32-33.

${ }^{76}$ William D. Barns, "The Grange and Populist Movements in West Virginia, 1873-1914" (Ph.D. diss., West Virginia University, 1946).

${ }^{77}$ Crowe-Carraco, 45-46; Waller, Feud, 32.

${ }^{78}$ Basil Hatfield interview with Rebecca J. Bailey, Summer 1989 Matewan Oral History Project.
} 
revealed the family's sense of having been abused. They could understand, if not approve, being deprived of the food, supplies, and livestock, but that a bunch of men would take his grandmother's dress seemed like an act of wanton cruelty or capriciousness.

The Civil War disrupted what had been a gradual capitalist development of the Tug Valley and its geographic environs. Impeded by obstacles such as remoteness from markets and an increasingly inadequate mode of transportation (the river system), the inhabitants of the vestigial frontier never abandoned the outside world nor their desire to be a part of it. ${ }^{79}$ How this subregion of Appalachia might have developed if the Civil War had not exacerbated the economic changes already occurring will never be known. The Civil War "caused a sharp break in regional development, and exposed the exhausted area to later transformations industrialization wrought." ${ }^{10}$ The "rediscovery" of the richness of area's timber and coal reserves during and after the Civil War coincided with technological advances and the political and economic will to exploit those resources on a national scale. ${ }^{81}$

When the Civil War ended, the disruption endured by communities in Logan County during the war continued. The divided loyalties of the inhabitants and the hostility engendered by soldiers and partisans of the Union and the Confederacy impeded the restoration of normal public relations. In 1867 because "threats of armed resistance had prevented the collection of

\footnotetext{
${ }^{79}$ Altina Waller asserts that because of their wartime experiences, Tug Valley residents were forced to "[reconstruct] their community," which profoundly affected their perceptions of the region and the nation. Waller, Feud, 33.

${ }^{80}$ Kenneth Noe, "'Appalachia's' Civil War Genesis: Southwest Virginia As Depicted By Northern and European Writers, 1825-1865" West Virginia History 50 (1991): 91-108, 105.

${ }^{81}$ Many of the early post-bellum efforts to revive external interest in the exploitation of the region's resources were led by Civil War veterans, who had first traveled to the Appalachian upcountry during military campaigns. One such individual was Jedidiah Hotchkiss, a Confederate officer and mapmaker.
} 
taxes since the war, troops were sent in to do the collecting." ${ }^{82}$ Elections held in the late 1860 s also precipitated shows of force. In Logan and other West Virginia counties, "federal bayonets [guarded] ballot boxes." 83

The decade of the 1870 s was "one of many plans," all of which focused on reconnecting the area to regional and national markets. ${ }^{84}$ In the Tug Valley, this transformation encouraged increased socioeconomic stratification, an increase in entrepreneurial activity, and an intensification of the efforts to link southwestern West Virginia to external markets. ${ }^{85}$ For example, mercantile entrepreneur Anthony Lawson moved to expand his local empire by laying claim to an old three hundred thousand acres' land grant. ${ }^{86}$ In the larger Big Sandy Valley, Catlettsburg, Kentucky, became the center of the region's timber market and the largest hardwood market in the world. ${ }^{87}$ Regional entrepreneurs and outside capitalists also launched two railroads, the Big Sandy Railroad Company and the Chatteroi Railway Company. ${ }^{88}$ Although economic activity intensified in the 1880 s and 1890 s, it is important to see the initial impact of these conditions in the 1870 s, because they precipitated a transformation of the local community's internal relations, as well as the community's intercourse with the outside world.

\footnotetext{
${ }^{82}$ Barns, 13.

${ }^{83}$ Ibid., 13-14.

${ }^{84}$ Jillson, 417.

${ }^{85}$ Ibid.

${ }^{86}$ Summers, "Owned One-Sixth of West Virginia," 60.

${ }^{87}$ Ely, 325; Jillson, 213.

${ }^{88}$ Jillson, 207.
} 
For most of the twentieth century, journalists, writers, and scholars viewed antebellum and immediately post-bellum Appalachia as a "pre-industrial" subsistence-oriented and basically egalitarian society. ${ }^{89}$ It was widely accepted that Appalachians lived in a virtually isolated world, and little attention was paid to evidence of socio-cultural and economic stratification, much less their intensification after the Civil War, even before the onslaught of industrialization. ${ }^{90}$ Some writers, for instance, the first chronicler of the Hatfield-McCoy feud, New York journalist T. C. Crawford, purposefully omitted any acknowledgment or description of the elite of Logan Courthouse who feted him during his 1889 visit. $^{91}$

In reality, social stratification and cultural differentiation had accompanied white settlement of Appalachian areas like the Tug Valley. From the beginning, local elites consciously lived "better" than their neighbors and felt few qualms about benefitting from others' misfortunes. ${ }^{92}$ The local elites, who were dominated by the merchant-large landholders, lived in clapboard covered frame houses decorated with luxury details such as wallpaper, store-bought furniture, and glass windows. ${ }^{93}$ They sent their children, in some cases girls as well as boys, to schools in eastern Virginia or larger communities in Kentucky. ${ }^{94}$ In lifestyle and aspirations,

\footnotetext{
${ }^{89}$ Dwight B. Billings, Mary Beth Pudup, and Altina L. Waller, "Taking Exception with Exceptionalism: The Evolution and Transformation of Historical Studies of Appalachia," in Appalachia in the Making: 1-24, 3-9.

${ }^{90}$ Ibid.

${ }^{91}$ Edwin A. Cubby, "The Transformation of the Tug and Guyandot Valleys: Economic Development and Social Changes in West Virginia, 1881-1921, (Ph.D. diss., Syracuse University, 1962), 6; Waller, Feud, 222-228.

${ }^{92}$ Morton, 310; Noe, 43; Pudup in Appalachian Frontiers, 238, 260.

${ }^{93}$ Jillson, 128.

${ }^{94}$ Logan Banner, 17 March 1892. Hatfield correspondence, letter no. 29. Before being sent to college at age 15, Henry D. Hatfield, who lived on Mate Creek in West Virginia, traveled to
} 
there was little to distinguish them from rural elites in other parts of the country. ${ }^{95}$ Lewis

Prichard, a founding member of the innovative Catlettsburg-Huntington timber firm of Vinson,

Goble and Prichard, initially financed his medical education by marketing unclaimed logs that

had broken loose from a dam and washed up on his family's farm. ${ }^{96}$ The misfortune of his valley

neighbors launched Prichard on a career that culminated in the presidency of the Charleston

National Bank, the financial epicenter of West Virginia's capitol. ${ }^{97}$

Despite remoteness from the mainstream American marketplace, increasing economic

stratification also occurred in the Tug Valley over the course of the nineteenth century. Between

1850 and 1870 , tenancy increased from 30 percent to 50 percent. $^{98}$ At the same time, the

landholding of the area's elite rose. Between 1850 and 1860, James Nighbert, who had come to

Logan County with his merchant father in the 1840s, had expanded the family's landholding

Blackberry Creek, Kentucky, to attend school. According to a relative, "Doc's" mother Betty made weekly trips on muleback to take him back and forth, a hardship made worse by his possession of a single pair of overalls. Homer Claude McCoy, "The Rise of Education and the Decline of Feudal Tendencies in the Tug River Valley of West Virginia and Kentucky in relation to the Hatfield and McCoy Feud (masters' thesis, Marshall College, 1942), 40.

${ }^{95}$ Sara Lubitsch Tudiver, "Political Economy and Culture in Central Appalachia, 1790-1977" (PhD. diss., University of Michigan, 1984), 93-94.

${ }^{96}$ A. M. Prichard, Descendants of William Prichard (Charleston, W.Va: Tribune Printing Company, 1912), 44. Lewis Prichard eventually abandoned his medical practice and succeeded his brother-in-law as president of the Charleston National Bank. His younger brother, R. H., invested with Wallace J. Williamson, and Z. T. Vinson in the development of the town of Williamson. Prichard, Williamson and Vinson also incorporated the Huntington and Kenova Land Development Company with Vinson's early political patron, Johnson Newlon Camden. Logan Banner, 16 July 1891 and Huntington Advertiser, 18 February 1891.

${ }^{97}$ Ibid.

${ }^{98}$ Waller, Feud, 38. 
threefold all while the land's value rose 400 percent. $^{99}$ By the 1880 s, Nighbert was one of the county's wealthiest and most influential citizens. ${ }^{100}$ Despite Logan County's remoteness in the era before the railroads, James Nighbert and his second wife, Alice Lawson, "wintered" in Hot Springs, Arkansas. ${ }^{101}$

In the financially unstable years after the Civil War and before the advent of the railroad, the communities of the Big Sandy, Tug and Levisa valleys imported more than they exported although they rafted over 1.2 million dollars worth of wood products, corn, and peltries" down river. ${ }^{102}$ In the 1870 s, only the export of coal from the Big Sandy and tributary valleys decreased; "because of the dangers and irregularities of river transportation [it] could no longer be shipped [at] a profit."103 In 1876, Maury's and Fontaine's Resources of the State of West Virginia observed of Logan County, "the land is seven-eighths [covered] in timber... and the land in large tracts may be bought at from $\$ 1$ to $\$ 10$ dollars" an acre. ${ }^{104}$ Until the completion of the Ohio Extension of the Norfolk and Western Railroad in 1892, which enabled the profitable exportation of coal, exploitation of the timber resources of Logan County and southwestern West Virginia dominated the local export market. ${ }^{105}$

\footnotetext{
${ }^{99}$ Based on data extrapolated from the 1850 and 1860 Agricultural and Manufacturing Census reports for Logan County, West Virginia.

${ }^{100}$ Waller, Feud, 143.

${ }^{101}$ Logan Banner, 1 January 1891.

${ }^{102}$ Verhoeff, 38.

${ }^{103}$ Ibid., 38-39.

${ }^{104}$ M.F. Maury and William M. Fontaine, Resources of West Virginia (Wheeling: The Register Company, 1876), 387-388.

${ }^{105}$ See Cubby "The Transformation of the Tug and Guyandot Valleys" for a more in-depth analysis of the impact of the timber boom and the early impact of the Norfolk and Western
} 
Because anyone who owned or had access to land from which timber could be cut and rafted down river, the entrepreneurial spirit spread out of the traditional elite class. Timbering especially affected another segment of the "first" families, who, as true pioneers, were locally influential, but not as well-educated, or as well-connected to the outside world, as the more recently arrived merchant elite. ${ }^{106}$ While the merchant elite typically sold or leased their land to outside owned companies, the lesser elites worked their own operations, with recognizable but more limited success. ${ }^{107}$ The most infamous and illustrative individual "timber" entrepreneur was William Anderson "Devil Anse" Hatfield.

Devil Anse Hatfield's grandfather, Ephraim, was one of the first permanent settlers of the greater Big Sandy Valley. ${ }^{108}$ The Hatfield family's early arrival helped them obtain control of choice acreage in the valley. Several mouths of the rivers' main tributary creeks, the natural crossroads of the area, were owned and occupied by different branches of the Hatfield clan. ${ }^{109}$ The family's large numbers also assured their influence. As an early historian of the Big Sandy Valley noted, at political gatherings it was not uncommon that two to three hundred members of the crowd were Hatfields. ${ }^{110}$

railroad. See Ronald L. Lewis' Transforming the Appalachian Countryside for a more recent and far reaching analysis of the same period.

${ }^{106}$ Example of first families: Hatfields; examples of merchant elite: Nighbert and Lawson.

${ }^{107}$ Spence, 234. The most prominent example in Logan was the timber firm Cole and Crane.

${ }^{108}$ Waller, Feud, 34.

${ }^{109}$ Hatfield correspondence, letter no. 12.

${ }^{110}$ Ely, 202. 
Sometime in the 1860s or 1870s, Devil Anse Hatfield, who had inherited no land from his father, entered the timber business. ${ }^{111}$ With little land of his own in the beginning, Devil Anse first harvested timber from his brothers' lands but eventually acquired or controlled thousands of acres through purchase, skillful use of local merchants as creditors, and by manipulating the legal system. ${ }^{112}$

Devil Anse's aggressive tactics unfortunately coincided with tense economic conditions and a rapidly evolving social atmosphere. In 1878, a court case involving Devil Anse's kinsman, Floyd Hatfield, launched twelve years of intermittent violence and constant legal wrangling. ${ }^{113}$ The Hatfield-McCoy Feud, as it came to be called, might have destroyed all of Devil Anse and Elias Hatfield's achievements as timbermen if not for the coming of the railroad and the coal industry. ${ }^{114}$ The younger sons of the brothers' Hatfield, who were born as their fathers prospered, but were too young to be caught up in the feud, found ways to adapt to the new industrial order and salvaged the family's political and economic, if not social, influence. ${ }^{115}$

Like the rest of the country, West Virginia and its people faced several turning points in the 1880s. Timber, railroad, and coal ventures were transforming the farms and forests. ${ }^{116}$ After a century of struggling with inadequate transportation links to the national marketplace and a

${ }^{111}$ Waller, Feud, 40.

${ }^{112}$ Ibid., 40-50.

${ }^{113}$ The two best works on the Hatfield-McCoy feud are: Otis Rice's Hatfields and McCoys which is recommended for a clear narrative of the feud, and Altina Waller's Feud: Hatfields, McCoys and Social Change in Appalachia, 1860-1900 for a deeper and more detailed analysis of how the feud reflects the impact of rural industrialization.

${ }^{114}$ Waller, Feud, 236.

${ }^{115}$ Ibid., 242-243.

${ }^{116}$ Lewis, Appalachian Countryside, 7. 
cash-poor economic system, many West Virginians embraced the new era. ${ }^{117}$ The railroad dramatically increased consumer contact with the outside world, but more importantly, many farmers believed the railroad would connect them to a larger market. ${ }^{118}$ What was not obvious at the time was the limitations of the railroad, which served primarily as a conduit for finished goods coming into the state and raw materials heading out of the state; it "did little to cut through the internal compartmentalization of the mountains." ${ }^{119}$ Traditional political leaders on the local and state level lost ground to transplanted outsiders and a new native generation who received their educations and professional training outside of the state. ${ }^{120}$ West Virginia's timber and coal helped fuel the industrial transformation of the nation, but the positive results for most West Virginians were limited, superficial, and fleeting. ${ }^{121}$

However, the pace of progress overwhelmed most objections to the course development was taking. Moreover, its means and validation bore the stamp of legality. Nineteenth century American society was "in a hurry and the contract was the legal instrument that helped them to move fast." ${ }^{122}$ The ascendancy of the modern written contract meant that many states had to reconfigure their legal and judicial systems. One such state was West Virginia, whose most

${ }^{117}$ John Alexander Williams, "Davis and Elkins of West Virginia: Businessmen in Politics" (Ph.D. diss., Yale University, 1967), 41.

${ }^{118}$ Harry M. Caudill, Night Comes to the Cumberlands: A Biography of a Depressed Area (Boston: Little, Brown, \& Company, 1963), 76.

${ }^{119}$ Dudley H. Plunkett and Mary Jean Bowman, Elites and Change in the Kentucky Mountains (Lexington, Ky.: University Press of Kentucky, 1973), 20.

${ }^{120}$ See Chapter 8 "New Men Versus Old Men" of Lewis, Appalachian Countryside, 211-234.

${ }^{121}$ Rasmussen, Absentee Landowning, 102.

${ }^{122}$ Robert R. Bell, The Philadelphia Lawyer: A History, 1735-1945 (Selinsgrove, Penn.: Susquehanna University Press, 1992), 108. 
dedicated booster, Gov. William Alexander MacCorkle, bluntly identified the single largest barrier to the state's industrial development. “"The land law of West Virginia is peculiar,"” MacCorkle observed, because it "reflected the activities of several generations of large and small speculators, spasmodic and inconsistent attempts at revision and reform, and a chaotic system of land registry inherited from Virginia." ${ }^{123}$ In West Virginia, legislators and jurists spent several decades clarifying land titles so that the railroad, timber, and coal companies contracts could be considered ironclad and binding. ${ }^{124}$

A series of "land laws" were passed by the West Virginia legislature that clarified land titles and facilitated the efforts of natives and outsiders to launch massive extraction efforts in timber and coal. ${ }^{125}$ During the decade that followed, obstructions to the full-scale industrialization of southwestern West Virginia were also removed. In 1880, the United States Army Corps of Engineers reported that 148 miles of the Big Sandy River system had been cleared of obstructions, and navigation had been improved by the construction of a series of wing dams. ${ }^{126}$ By the end of the decade, the N\&W railroad had wound its way from southwestern Virginia, through southeastern West Virginia, and was poised to enter the Tug Valley on its way to Ohio and the Great Lakes.

\section{Conclusion:}

\footnotetext{
${ }^{123}$ MacCorkle quoted in Williams, "Class, Section, and Culture," in Appalachia in the Making, 215.

${ }^{124}$ See Lewis, Appalachian Countryside and Rasmussen, Absentee Landowning.

${ }^{125}$ Lewis, Appalachian Countryside, 86-87.

${ }^{126}$ Quoted in Prospectus of the Big Sandy Land and Manufacturing Company in Logan, Wyoming, and McDowell counties, West Virginia (Camden, N.J.: n.p., 1882), 12. WVRHC.
} 
The first one hundred years of white settlement in the Tug Valley influenced the ways in which the valley's inhabitants reacted to industrial development and conflict. First, the geography of the Tug Valley fostered a system of clientelist political, economic, and social interaction that little reflected the area's political boundaries. While the area was isolated and enjoyed little intercourse with external markets, land ownership and family size and connections could be parlayed into local influence and power. Conversely, cash-based wealth and contacts with the outside world empowered another elite faction to represent the valley beyond its boundaries. $^{127}$

Second, the pre-railroad, "pre-industrial" economy of southwestern Virginia was neither solely subsistence-oriented nor static. Nor was the "company system" of the coal industry something new to the valley's inhabitants. As early as the 1840 s, the Valley's residents were familiar with the "piecework" system of ginseng gathering and trading. Although many locals harvested the root, they were subcontractors in a system that primarily benefitted the merchants who bought their neighbors' roots and amassed a financially significant amount of product. Merchant James Nighbert ran a "ginseng factory" that employed several people to dry and process the roots he had purchased before transporting them to Philadelphia. ${ }^{128}$

Merchants like Nighbert, who capitalized on the ginseng trade, also provided the primary financial infrastructure for their local communities. Utilizing a mixture of barter and seasonal credit systems, they provided their clientele with goods that could not be produced locally while

${ }^{127}$ According to Billings and Blee, in the community they studied, Clay County, in eastern Kentucky, whole families were often integrated in an interlocking grid of these relationships. The author documents a similar situation in this study. Billings and Blee, Road to Poverty, 131,133 .

${ }^{128}$ Spence, 164. 
simultaneously providing a conduit to outside markets. One Logan County merchant offered a "good pair of boots or a fine suit of clothes" for a "pound of seng." ${ }^{129}$ The notoriety of the company store system has overshadowed this earlier experience with credit purchasing. In retrospect, the exploitive nature of most company stores obscures the possibility that in the early years of industrialization, mountaineers may have expected the neighborly patience and forbearance that many were extended by old-time merchants. ${ }^{130}$

Third, the benefits that accrued to the merchants in the "pre-industrial" era were not only economic, but also social and political. As was the case with the economy in which they figured so prominently, the merchant class was not monolithic. One group of merchants emerged primarily from the first settlers of the area. The "capital" of this group was largely their control of "prime" locations at natural crossroads and the heads of waterways. ${ }^{131}$ The confluence of natural advantage and economic activity enhanced the social and political position of these individuals who garnered local governmental responsibilities as magistrates, justices of the peace, and sheriffs. The hierarchical "place" held by these men was reflected in their possession of the old Virginia appellation of "squire." 132

${ }^{129}$ Logan Banner, 14 August 1890 quoted in Cubby, 29 and Eller, 22.

${ }^{130}$ Spence, 164.

${ }^{131}$ Eller, 11.

${ }^{132}$ Eller, 12; Hennen, "Benign Betrayal," 49. The correlation between "first settler status" and political power was not unique to the Appalachian South, but also occurred in the rural Midwest. John Mack Farragher asserts, "original settler families held a monopoly of political power." John Mack Farragher, "Open-Country Community: Sugar Creek, Illinois, 1820-1850," in Steven Hahn and Jonathan Prude, eds. The Countryside in the Age of Capitalist Transformation:Essays in the Social History of Rural America (Chapel Hill, NC: University of North Carolina Press, 1985): 233-258, 243. 
A more affluent tier of merchants appeared in the decades between 1810 and 1850, during the first push to nationalize the American economy. Primarily via the river system, these merchants entered the remote areas of the country like central Appalachia and established trade networks that provided the national and international markets with commodities such as ginseng and fur. In contrast to their neighbors who ran trading posts and dealt in small amounts of commodities for a local and small regional market along the Big Sandy river system, the later arrivals were better capitalized and traded in more bankable commodities in financial centers like Philadelphia and Baltimore.

For Anthony Lawson and James Nighbert, putting down roots in remote areas placed them at the pinnacle of their local society. They were connected to and knowledgeable of the outside world, better educated, and enjoyed a somewhat more refined lifestyle. From this class of merchants were chosen the area's state and national representatives. Considered more capable of interacting with remote powerbrokers, the community's best educated and most prominent members were entrusted with the protection and advancement of local interests. The resultant dovetailing of personal and public interest in the operation of the region's politics profoundly affected the area's industrial transformation.

Although a member never resided in Logan County until the family fortunes declined, the Floyd family of southwestern Virginia spearheaded efforts to improve navigation of the Big Sandy and its tributaries, which serviced the iron and saltworks purchased by George Rogers Clark Floyd in $1853 .{ }^{133}$ The Civil War effectively destroyed the Floyds' hopes for their industrial

\footnotetext{
${ }^{133}$ Jillson, 143-144 and Troy Floyd, Jr. to Robert L. Floyd 4 September 1951, in George Rogers Clark Floyd Papers, WVRHC.
} 
investments on the Tug Fork. ${ }^{134}$ Still, when G. R. C. Floyd moved to Logan County, the connection forged between the Floyds and the Hatfields proved instrumental to the exercise of influence by both families. ${ }^{135}$

Fourth, after nearly a century of struggling to improve transportation into their region, the residents of southwestern West Virginia welcomed the announcement of the Norfolk and Western's intention to build a railroad through the Tug Valley. However, none of the Valley residents could have predicted the impact of the realization of their fondest dream. The railroad's path accelerated development only in one half of Logan County, and less than three years after the completion of the railroad, the county was divided.

Chapter 2 explains how the arrival of the Norfolk \& Western Railroad in the Tug Valley profoundly affected economic, political, and social relations in Logan County. Previous scholars have asserted that the industrial development which occurred in the wake of the railroad's arrival utterly transformed the region and created a whole new dynamic of public intercourse. By contrast, this study shows that, while the economic stakes were raised and political alliances were reconfigured, the basic pattern of human interaction remained unchanged.

${ }^{134}$ Jillson, 144. In 1857 the Floyd family lands in Burke's Garden Virginia were sold to Anthony Lawson of Logan County, who in turn sold forty-six thousand acres in the Logan area to George Rogers Clark Floyd. After a checkered political career, Floyd moved to Logan. Both his son John B. Floyd and grandson George Rogers Clark Wiles were an important Democratic politicians in southern West Virginia.

${ }^{135}$ G. R. C. Floyd was an early mentor of Henry D. Hatfield, who later became governor of West Virginia. Henry D. Hatfield to C. H. Ambler, 5 December 1953, Hatfield Papers, WVRHC. Floyd's son, John B. Floyd, a political ally of Devil Anse Hatfield, was the likely connection between Hatfield and West Virginia governor E. Willis Wilson during the feud. Waller, Feud, 175. 


\section{CHAPTER 2}

\section{THE ARRIVAL OF THE RAILROAD}

AND THE INDUSTRIAL TRANSFORMATION OF THE TUG VALLEY, 1888-1894

"The native mountain people were sold, like Joseph into Egypt, by their blood kin."

--Margaret Hatfield

When the Norfolk \& Western announced its intention to build an "Ohio Extension" to connect Virginia to the Ohio River market system, the pace and extent of land speculation in southwestern West Virginia increased dramatically. As historian Altina Waller has observed, "the year 1888 was the most important turning point in the history of the Tug Valley" -- it was the year the N\&W surveyors appeared. ${ }^{2}$ As the railroad's construction proceeded through Logan County in the late 1880s and early 1890s, profound economic and political changes followed in its wake.

The forces unleashed by the arrival of the railroad in the Tug Valley precipitated the creation of Mingo County. First, the railroad made possible the advent of commercial coal mining and precipitated an economic boom along the railroad's route in the Tug Valley which constituted the western half of Logan County. ${ }^{3}$ Second, because the railroad bypassed Logan Courthouse, the county seat, industrial development became a divisive issue among the political elites of the county. Third, the N\&W's dual construction drive, from the northwest and the southeast, fostered the rise to prominence of two different groups of elites and outsider allies in

${ }^{1}$ Margaret Hatfield correspondence, letter no. 17.

${ }^{2}$ Waller, Feud, 199.

${ }^{3}$ Prior to 1895 , Logan County included both the Guyan and Tug Valleys. When the 1895 West Virginia legislature authorized the creation of the new county, Mingo, the division roughly followed a natural barrier, the Guyan ridgeline which separated the two halves of the county into the Guyan and Tug Fork watersheds. 
western Logan County. The chapter concludes with a discussion of how two crises, the Panic of 1893 and the King Land Case (1894-1913), brought all of these issues to a head and created the framework for future political, economic, and social relations in Mingo County.

\section{Development Follows The Path of the Ohio Extension,1889-1894}

The route of the Ohio Extension of the Norfolk \& Western Railroad determined which part of Logan County would first experience industrial growth. The final decision concerning the route was made on February 1, 1889, and set in motion a "rush to acquire coal leases in Mingo." ${ }^{4}$ Two developments prompted the drive: the confirmation of the specific route that the Ohio Extension would follow through Logan County and the incorporation of the Guyandot Coal Land Association (GCLA). Because of the railroad's route, the economic development and transformation of the western half of Logan County quickly outstripped development in the eastern half of the county. ${ }^{5}$ The catalyst for the boom in western Logan County was the purchase of a large tract of land by the Guyandot Coal Land Association, a corporation with very close ties with the Norfolk \& Western. ${ }^{6}$

\footnotetext{
${ }^{4}$ Waller, Feud, 154; Walter R. Thurmond, The Logan Coal Field of West Virginia: A Brief History (Morgantown: West Virginia University Library, 1964), 29. Thurmond's observation was written many years after Mingo County was created. In 1890, the year to which he refers however, the area which became Mingo was still the western half of Logan County.

${ }^{5}$ Cubby, "Transformation," 18.

${ }^{6}$ Coal Trade Journal 29 (23 April 1890): 199. Members of the Association were: E.W. Clark, Stephen A. Caldwell, William W. Justice, and Edward W. Denniston, all of Philadelphia, Pennsylvania, and Jedidiah Hotchkiss of Staunton, Virginia. The board of directors included: Clark, Caldwell, Denniston, Hotchkiss, and Justice, and S.H. Chauvenet and J.H. Dingee. The association officers were: president, Clark; vice-president, Justice; secretary-treasurer J. Milton Colton. The managers were Clark, Denniston, and Hotchkiss. Clark, Denniston and Colton were business associates in E. W. Clark \& Company, a Philadelphia investment banking firm. S. A. Caldwell was associated with the Fidelity Insurance Company of Philadelphia; Justice the Justice, Bateman \& Company wool merchant firm, and S. H. Chauvenet, the Robinson Furnace;
} 
In addition to reporting the creation of the Guyandot Coal Land Association, the April 23 1890 issue of the Coal Trade Journal reported that the Ohio Extension was under "vigorous construction. ${ }^{17}$ By the end of 1890 , the Journal reported that the N\&W had completed the surveys and purchased the rights of way needed to complete the extension. ${ }^{8}$ A news item from a Logan County newspaper emphasized the local impact of the N\&W's initial undertakings. On December 18, 1890, the Logan Banner announced, "Mr. H. K. Shumate has had a seven foot vein of coal opened." ${ }^{9}$ The correlation between the commencement of the N\&W's construction projects and the opening of Shumate's was not coincidental. Shumate was one of the first West Virginia lawyers hired by the railroad. ${ }^{10}$

Along the railroad's main construction route in the western half of the county, all was not well. In September, the N\&W advertised a two hundred dollar reward in the Logan Banner for information regarding shots that had been fired into its assistant engineer's office at Miller's Creek, on Tug River. ${ }^{11}$ The announcement offered no clues to the shooter's motivation, but there were at least three likely reasons. First, the shots were accidental, stray bullets fired by a hunting party without malice or forethought. Second, the shots constituted an act of retaliatory vandalism by a disgruntled employee or someone with a grievance against an employee of the railroad. The

and J. H. Dingee was identified only as a Philadelphia banker and representative of English investors. For more on the history of E. W. Clark \& Company, see Frederick Winslow Clark, "A Case Study of E. W. Clark and Company: Investment Banking Firm, 1837-1957" (master's thesis, University of Nebraska, Lincoln, 1958).

${ }^{7}$ Coal Trade Journal 29 (23 April 1890): 199.

${ }^{8}$ Coal Trade Journal 29 (17 December 1890): 609.

${ }^{9}$ Logan Banner, 18 December 1890.

${ }^{10}$ Mingo Republican, 10 February 1911.

${ }^{11}$ Logan Banner, 10 September 1891. 
third and more intriguing possibility is that the shots constituted "an act of resistance" against the agents of development, an act not without precedent in West Virginia. In 1889, squatters in Randolph county had resisted violently the loss of their land to "foreign capitalists." 12

In February 1891, public advertising of the coal resources of the Guyandot Coal Land Association (GCLA) began in industry publications and in southern West Virginia newspapers. The GCLA did not equivocate about its corporate motivation or its development interests. The company identified itself as "a corporation owning 260,000 acres of coal land . . . [that] proposes to lease out suitable tracts to coal men at a royalty of ten and twelve cents a ton." ${ }^{13}$ Only a week later, the Huntington Advertiser revealed something of the scope of investments along the N\&W. The February 18 issue of the Advertiser noted, "within the past eighteen months millions of Northern and English capital has been spent in the purchase of coal and timber lands tributary ... [to] the Norfolk \& Western." ${ }^{14}$ In the same issue, the Advertiser identified another group of investors. Johnson Newlon Camden and several business associates had formed a "syndicate" and "purchased the most desirable portion of this valuable property."15

Nearly two years of financial development and advertisement preceded the first mining company incorporation. At least three nationally known experts were brought in to examine the potential of the GCLA coal lands: Jedidiah Hotchkiss, I. C. White, and Andrew Roy. Identified by the Coal Trade Journal as "the well-known mining expert of Ohio," Roy worked for the GCLA for at least six months and, during that time, wrote one of the first descriptions of what

\footnotetext{
${ }^{12}$ Barns, 686.

${ }^{13}$ Coal Trade Journal 30 (11 February 1891): 69.

${ }^{14}$ Huntington Advertiser, 18 February 1891.

${ }^{15}$ Ibid.
} 
made the GCLA's lands so attractive. Published in the Coal Trade Journal, Roy's article, "The Advantages of the Coalfield To Be," depicted the GCLA land in glowing and tempting terms.

all the mines will be drift ... requiring neither machinery to lift coal nor pump water; the dip and rise of the strata is ... sufficient for natural drainage and easy and inexpensive haulage. The roof is sandstone in many places, easily worked where blasting is necessary ... [and] the coal is remarkably free from sulphur. ${ }^{16}$

While all of the above observations may have been accurate, their enticement value is immeasurable. Because of several natural "advantages," Roy's article implied that mines could be opened in the field for a minimal capital outlay, all while producing a highly desirable coal for market. $^{17}$

Coal mines were opened in Wayne County at Fleming and Dunlow a year before any mines were opened in western Logan County. ${ }^{18}$ This early development had been made possible by the N\&W's dual construction drive; the rail line was being constructed from the west and the east. ${ }^{19}$ Located to the west of Logan's worst geographic barriers, and closer to Charleston, Fleming and Dunlow were more quickly accessed. ${ }^{20}$ Unfortunately for the operators of the

${ }^{16}$ Andrew Roy, "The Advantages of the Coalfield to Be," in Coal Trade Journal 30 (24 June 1891): 302 .

${ }^{17}$ Ibid.

${ }^{18}$ Coal Trade Journal 31 (9 March 1892): 136.

${ }^{19}$ Logan Banner, 29 September 1892.

${ }^{20}$ Author's assertion based on available geographic information. 
mines, the coal veins were also thinner and of poorer quality. ${ }^{21}$ By the time other mines in the GCLA holdings were opened, those at Fleming and Dunlow had failed. ${ }^{22}$

The first coal company located in the area that became Mingo County was incorporated in August 1891. The five investors of this company, the Williamson Mining and Manufacturing Company, were a who's who of southwestern West Virginia's pro-industry Democrats: Z. T. Vinson, lawyer and business associate John C. C. Mayo and Johnson Newlon Camden, R. H. Prichard, businessman and brother of Lewis Prichard, president of the Charleston National Bank, John Q. Dickinson, salt manufacturer and banker, also from Charleston, Thomas H. Harvey, Logan County's "law and order judge" from Huntington, and Wallace J. Williamson, who although an area native, had made his fortune in timber and banking in Catlettsburg, Kentucky. ${ }^{23}$

Before creating the Williamson Mining and Manufacturing Company, Wallace J.

Williamson and his business associates capitalized on the coming of the railroad by buying land and creating the town of Williamson in honor of Wallace J. Williamson's father Benjamin. ${ }^{24}$ In the middle of July 1891, the Logan Banner excitedly announced the venture, "'Ho, For Williamson'." According to the Banner, Williamson and his fellow investors bought twelve hundred acres of his brother's farm for thirty thousand dollars. ${ }^{25}$ Two weeks later, the Banner

\footnotetext{
${ }^{21}$ Thurmond, 24.
}

${ }^{22}$ Peter Roper, Jedidiah Hotchkiss: Rebel Mapmaker and Virginia Businessman (Shippensburg, PA: White Man Publishing Co., 1992), 174-175.

23"Williamson Mining and Manufacturing Company," Reports of Incorporation in Acts of the West Virginia Legislature for 1891 (Charleston, WV: Moses W. Donnally, 1891), 88; (Wallace J. Williamson) Ely, 290, 324; (R.H. Prichard) Prichard, 53-54; (J.Q. Dickinson), West Virginia Heritage Encyclopedia, 6: 1337.

${ }^{24}$ Logan Banner, 16 July 1891.

${ }^{25}$ Ibid. Disagreement appears in the accounts of Wallace J. Williamson's purchase of family landholdings in order to start the town; the confusion largely stems from his father and brother 
reported that Z. T. Vinson, John S. Marcum, John A. Sheppard, and U. B. Buskirk intended to start a newspaper, The Sandy New Era in Williamson. ${ }^{26}$ At an August 26, 1891, city lot sale, seventy-five lots sold at an average price of three hundred dollars, with a range between two hundred and six hundred twenty-five dollars. ${ }^{27}$

However, the early enthusiasm for western Logan's development diminished when the $\mathrm{N} \& \mathrm{~W}$ abandoned plans to build a connecting line to the county seat. A minor note in the Logan Banner from January 15, 1891 portended the splinter of Logan into two counties: "Locating the line of the Guyandotte Branch of the N\&W has been directed to stop." ${ }^{28}$ Without a branch line extending over the Guyan ridgeline, the natural barrier that divided the county in two became a line of demarcation. West and south of the ridge, railroad construction continued, population concentrations appeared along the track lines, and plans to open coal mines proceeded. East of the ridgeline, development slowed to a standstill with only periodic efforts at revival for over a decade. $^{29}$

The single most important Norfolk \& Western news of 1892 occurred on September 22, 1892, when "the two halves of the Ohio Extension joined . . . near the mouth of Lick Creek -about midway between Williamson and Hatfield Bend." 30 The importance of the completion of

both being "Benjamin" Williamson.

${ }^{26}$ Logan Banner, 30 July 1891.

${ }^{27}$ Logan Banner, 26 August 1891.

${ }^{28}$ Logan Banner, 15 January 1891.

${ }^{29}$ These assertions are based on extrapolations from data in the United States Census and West Virginia Department of Mines reports. Specific details and citations appear later in this and subsequent chapters.

${ }^{30}$ Logan Banner, 29 September 1892. N\&W President Kimball described Hatfield Bend as "the worst place on the Ohio Extension" because of lawlessness and violence. Kimball 
the railroad cannot be overstated. Since the Tug Valley had been settled in the late 1790s, the area's geography had consistently impeded economic growth and contact with the outside world. An example from a contemporary newspaper best illustrates this dilemma. In 1892 the editor of Wayne County's Twelve Pole Monitor complained that it cost $\$ 1.25$ to transport a $\$ 1.00$ chair from Huntington to the Logan-Wayne County area. ${ }^{31}$ The completion of the railroad, while it alleviated the problem of the cost of importing goods, dramatically altered the rest of the area's social, economic, and political fabric. The railroad gave Logan Banner editor Henry Clay Ragland a whipping boy for the area's social woes and a scapegoat for the difficulties of southern West Virginia's Democrats.

The ebb and flow of local opinion was reflected in and sometimes led by the editorials of the local newspaper editor. After giddily heralding the N\&W's approach, Henry Clay Ragland quickly turned into one of the railroad's most vocal critics. In the pages of the Logan Banner, Ragland bemoaned the rise in taxes and blamed a rise in crime and epidemic disease on the Italian and African-American railroad workers. ${ }^{32}$ Ragland was not just a concerned newspaper editor. He was also a practicing lawyer and local speculator whose early aspirations for the railroad's impact on Logan's economy, and his own fortunes, were squelched when the route bypassed eastern Logan County. ${ }^{33}$

correspondence cited in Cubby, 160. However an observation by one Hatfield descendant offers another explanation for why the inhabitants roused the ire of Kimball. According to Margaret Hatfield, the Hatfields and related families of the Bend could not be cheated out of their land. Hatfield correspondence, letter no.12. So, perhaps it was this recalcitrance, and not just the Hatfield's misdeeds, that roused Kimball's ire.

${ }^{31}$ Undated article from Twelvepole Monitor quoted in Chapman, 17.

${ }^{32}$ Logan Banner, 30 July 1891 quoted in Cubby, Transformation, 161-164.

${ }^{33}$ Edwin A. Cubby, "Railroad Building and the Rise of the Port of Huntington," West Virginia History 32 (October 1970): 234-247, 234, 238-239. 
Between 1890 and 1892 tension over the impact of development continued to rise. As early as April 1890, Logan Banner editor Ragland revealed to his readers the negative impact of the land speculation that accompanied the arrival of the railroad:

The value placed upon our lands by the speculators is no fair criterion of their value ... our home market for grain has enabled our farmers to live, but when the $\mathrm{N} \& \mathrm{~W}$ is completed the present price for grain will be reduced more than one half. We hope that the prevalent custom of putting the small farmer in the clutches of the speculator will be avoided in the reassessment. ${ }^{34}$

In this one editorial, Ragland touched on two issues that became common complaints across the United States in the last quarter of the nineteenth century: the ascendancy of the "non-producer" speculator and the railroad's complete reconfiguration of the small producer's place in local, regional, and national marketplaces.

By 1892, Ragland still praised local entrepreneurs but loudly criticized "outsider" operations. Ragland celebrated R. B. Lawson's single shipment of twenty-five rafts of logs and noted that Lawson was "the largest individual timber man in the county, and is doing, probably more than any other man in the county to circulate money." ${ }^{135}$ Conversely, in an editorial titled, "People Exploited by Monopoly," Ragland complained that "the chief industry of this community is getting out logs for the Little Kanawha Lumber Company." ${ }^{36}$ Ragland's statement underscores that in the industrial transformation period, southern West Virginians were aware of the threat dependency on a single industry presented to local economic vitality.

\footnotetext{
${ }^{34}$ Logan Banner, 24 April 1890.

${ }^{35}$ Logan Banner, 31 March 1892.

${ }^{36}$ Logan Banner, 17 March 1892.
} 


\section{The Reconfiguration of Logan County Politics, 1890-1894:}

Beginning in 1890, issues related to industrial transformation dominated Logan County politics. Although united in the antebellum period in their pursuit of economic development, after the Civil War, the county elites aligned with different leaders of the state's Democratic party. However, because Logan Countians already understood who the local politicians followed, contemporary press coverage of elections generally focused on issues that affected the factional schism. For example, the two issues that dominated the Logan Banner's coverage of the 1890 election, race and outside corporate control of local development, permeated all subsequent elections. ${ }^{37}$

Both issues reflect the local perception of the threat from the railroad and coal developers. Not surprisingly, the Banner did not criticize Logan's home-grown entrepreneurs or editor Ragland's fellow Democratic politician-capitalists. The Banner reserved its criticism for the railroad and the coal developers coming in from out of state and Logan's southeastern predominantly Republican neighbors. Logan's Democratic candidates for the state legislature faced Republican candidates from counties to the east, counties already accessed by the N\&W and producing coal.

The first issue that dominated the 1890 Logan County election was race. As a former Confederate stronghold, Logan County was not known for racial or ethnic tolerance in the late nineteenth and early twentieth centuries. The Banner's editor, Henry Clay Ragland, while a proeconomic growth lawyer was also a racially bigoted Confederate veteran. One of the first railroad-associated criticisms Ragland lobbed was an attack on the African Americans and Italians who worked on the $\mathrm{N} \& \mathrm{~W}$ construction crews. According to Ragland, the construction

\footnotetext{
${ }^{37}$ The subsequent elections referred to are the Mingo County elections.
} 
camps were havens of vice, gambling, and drinking and the workers themselves were responsible for an unprecedented rise in the Logan's crime rate. ${ }^{38}$

Ragland's racial vitriol intensified and became more overtly political as the 1890 election approached. In the October 16, 1890, issue of the Banner, Ragland accused the Republican Party of "[scheming] to Africanize West Virginia by colonizing it with negroes from North Carolina."39 Ragland's commentary illustrated the local reaction to what was perceived as an onslaught of imported African-American rail and coal industry laborers whose political loyalty bolstered the development of powerful Republican organizations in the counties undergoing industrial development. ${ }^{40}$ On election eve, Ragland exploited his readers' worst racial fear by suggesting that a Republican victory would result in school desegregation. ${ }^{41}$

The second issue Ragland stressed during the 1890 campaign underscored his disillusionment with the forces that were guiding southern West Virginia's development. To Ragland, the diehard Democrat, the southern West Virginia Republican party had passed completely under the control of business interests. On October 23, Banner readers were reminded that "a party which has sold itself to corporations and trusts is always to be watched." 42

${ }^{38}$ Logan Banner, 30 July 1891.

${ }^{39}$ Logan Banner, 16 October 1890. West Virginia Democrats had effectively played the "race card" as far back as 1870, when it facilitated their recapture of the state legislature. Milton Gerofsky, "Reconstruction in West Virginia" (master's thesis, West Virginia University, 1942), 71.

\footnotetext{
${ }^{40}$ Rice and Brown, 206.

${ }^{41}$ Logan Banner, 6 November 1890.

${ }^{42}$ Logan Banner, 23 October 1890.
} 
A week later, on October 30, Ragland reiterated the issue: "remember that in the fight ... one side represents a happy home and the other side a gilded hell."43

Ragland's partisan attacks during the 1890 campaign, combined with the rhetoric of local entrepreneur-lawyers obscured the equally exploitive role played by many Democrats. For example, Z. T. Vinson, one of the leading attorneys in the King cases, was a lieutenant of Johnson Newlon Camden, a wealthy Parkersburg capitalist, one of the leaders of the West Virginia Democratic party, and the representative of Standard Oil's interests in the state.

To understand how both the Republican and Democratic parties were pro-industrial development while publicly maintaining a "party of the people" stance, one must examine the post-Reconstruction evolution of the local parties. After the Civil War and the Democratic "Redemption" of the state, Union Army veteran Nathan Goff preserved the West Virginia Republican party. Goff's party re-building/maintaining strategies had included: sending bands of the party faithful as relief workers into flood-ravaged areas during a cycle of devastating floods in the 1870s and helping Union veterans apply for their pensions. However, Goff lost control of the party following the resolution of the 1888 gubernatorial race, which deadlocked with three men, including Goff, claiming to be governor. ${ }^{44}$

In a bitter year-long battle over who actually won the election, Goff's Democratic opponents focused their argument on allegations of illegal voting by African Americans in several counties. One of the counties under scrutiny was McDowell, through which the Norfolk \& Western had already passed on its way to Logan. Strong Republican organizations had emerged by 1888 in McDowell and the neighboring counties penetrated by the railroad by 1888 .

\footnotetext{
${ }^{43}$ Logan Banner, 30 October 1890.

${ }^{44}$ Rice and Brown, 206.
} 
Republicans had or would control most of these southeastern West Virginia counties for over four decades. The charges raised during the 1888 contested election hearings and the arrival in Logan of a significant (in his view) number of African-American railroad workers combined to convince Henry Clay Ragland that with the arrival of the N\&W, a "Black Republican" net seemed to be closing in around Logan County. ${ }^{45}$

In the early 1890s, Logan County became an isolated Democratic stronghold in a bloc of relatively new but powerfully backed Republican county organizations. ${ }^{46}$ Even though Logan County remained Democratic, the tensions aroused by the railroad's routing and the King case split the County's faithful between factions led by former West Virginia Governor E. Willis Wilson and Johnson Newlon Camden. ${ }^{47}$ Camden's influence was most apparent among the prodevelopment native elite and lawyer-business elite whose activities in the 1880s focused on land, timber, and railroad ventures. ${ }^{48}$

\footnotetext{
${ }^{45}$ James Henry Jacobs, "The West Virginia Gubernatorial Contest, 1888-1890," West Virginia History 7 (April 1946): 159-220.

${ }^{46}$ John Alexander Williams, "The New Dominion and the Old: Antebellum and Statehood Politics as the Background of West Virginia's 'Bourbon Democracy'," West Virginia History 33 (July 1972): 317-407.
}

${ }^{47}$ Ibid., 391. The Wilson faction coalesced around Devil Anse Hatfield. Ludwell H. Johnson III, "The Horrible Butcheries of West Virginia: Dan Cunningham on the Hatfield-McCoy Feud," West Virginia History 56 (1985-1986):25-44, 38. Camden's influence in Logan centered around the courthouse; his allies included Henry Clay Ragland and Z. T. Vinson. Waller, Feud, 146.

${ }^{48}$ Evidence of Camden's influence can be traced through patronage appointments and Camden's investments in some of his lieutenants' business ventures. Father and son S. S. and Z. T. Vinson were key campaigners for Camden in his 1894 run against E. Willis Wilson for a senatorial appointment. S. S. Vinson, a pioneering timberman of Wayne County, had served as U.S. Marshall for southern West Virginia in the early 1890s. Both Vinsons and Camden were investors in the Huntington-Kenova Land Development Company. John Alexander Williams, "A Note and Documents on the Wayne County Shooting Incident During the Election Campaign of 1894," West Virginia History 33 (January 1972): 152-156, 152-153. 
Although from northeastern West Virginia, Governor Wilson gained support in Logan County for two reasons. First, while governor he had intervened on behalf of the Hatfields during the Hatfield-McCoy feud. He had opposed allowing Kentucky vigilante-posses (McCoy allies) to arrest West Virginia citizens (Hatfields) and take them back to Kentucky for trial. Second, as the Feud furor died down and an anti-N\&W sentiment increased in Logan, Wilson's anti-railroad, pro-farmer, pro-small businessman platform attracted voters from among those who had not materially benefitted from the arrival of the railroad and coal industry. ${ }^{49}$

Exactly why Logan County became a scene of Camden-Wilson factional fighting in 1890 is not clear, given the recurrence of the struggle in 1894 , but both men were probably jockeying for the allegedly solidly Democratic Logan support in a bid for the U.S. Senatorship. The rift between Logan's Camden and Wilson Democrats, which only widened between 1890 and 1894, also reflected the exacerbation of local social and economic tension by development initiatives. ${ }^{50}$

One of the election return reports from the November 6, 1890, issue of the Banner illuminates the political turmoil that beset Logan County and led to its division: "M. A. Ferrell and J. E. Rutherford brought in the returns from Mates Creek. In that precinct the Democrats gained five and the Republicans lost ten on the vote of 1888."51 First, it should be noted that Mate Creek was located in western Logan County where the railroad, identified as a conduit for Republicanism, was being constructed. ${ }^{52}$ Second, because of the close connection between the

\footnotetext{
${ }^{49}$ Waller, Feud, 176.
}

${ }^{50}$ Williams, "New Dominion," 391; Lawson, 45. Sidney B. Lawson, the Logan delegate who proposed the bill to create Mingo County, revealed in his memoirs that he had been chosen to run for office specifically because he was young and his political inexperience meant that he had no enemies.

\footnotetext{
${ }^{51}$ Logan Banner, 6 November 1890.

${ }^{52}$ Williams, Captains of Industry, 230.
} 
railroad and Republicanism, the decrease in Republican votes between 1888 and 1890 may have reflected the disillusionment and/or racial fears aroused by the railroad's arrival.

Most important, the shifting vote count of the Mate Creek precinct underscored the political impact of the changes occurring in western Logan County, chief among these were those affecting the Hatfield clan for whom the Mate Creek precinct was home. By 1890, the feud with the McCoys was drawing to a close, and several Hatfields had been tried and sentenced to prison. On February 18, 1890, Ellison "Cottontop" Mounts was executed for participating in one particularly brutal attack on the McCoy family. Sometime that year, or shortly thereafter, Devil Anse, and his brother Elias moved their families from the Mate Creek area, which was right on the border with Kentucky and into the interior of Logan County. ${ }^{53}$

By 1890, the Hatfields and several marriage-allied families in the Mate Creek area had sold thousands of acres to the railroad land companies and other outside capitalists. ${ }^{54}$ Devil Anse's son Johnse and Ellison's son Valentine also worked as land agents for these outside interests. ${ }^{55}$ As the popularity of the railroad and outsider entrepreneurial activity waned, perhaps the Hatfields' close affiliation with these groups compounded the family insecurity over their personal safety.

William Ely's 1887 History of the Big Sandy Valley reveals why where the Hatfields lived was important. As Ely noted "at a large gathering ... to listen to a political discussion there were

\footnotetext{
${ }^{53}$ Waller, Feud, 228-231, 198, 243. Devil Anse Hatfield built a home on Main Island Creek, while his brother Elias settled in Logan Courthouse.

${ }^{54}$ Logan Banner, 11 April 1889. Several Hatfields, Mahons and Vance sold nearly eight thousand acres to outside developers.

${ }^{55}$ Darrell G. Brumfield and Richard N. Ellis, More Stories About Gilbert, West Virginia and Surrounding Communities (Baltimore, MD: Gateway Press Inc, 1995), 415 (Johnse); Hatfield correspondence, letter no.13 (Valentine). Altina Waller states that Johnse was a detective for U.S. Coal \& Coke. Waller, Feud, 245.
} 
... over three hundred voters in the crowd who were either Hatfields or had Hatfield blood

coursing through their veins." ${ }^{56}$ In an era when Logan County probably had between one and two thousand voters, wherever the Hatfields lived, they controlled that precinct, and whichever party secured the Hatfields' support won the political contest at hand.

The persistence of viva voce voting magnified the Hatfields' influence at public political gatherings. ${ }^{57}$ Although West Virginia had passed a law replacing viva voce voting with ballot voting in 1868 , the practice of eligible voters convening at a polling station and voting aloud was not unheard of in southern West Virginia as late as $1901 .^{58}$ Well into the 1880 s, male citizens of Logan County met at designated poll sites and "voted" by group acclaim or physically moving to stand together in support of their candidate. According to a Hatfield family historian, the mere presence of Devil Anse Hatfield at such a gathering often secured success for "his" candidate. When a Hatfield family friend ran for state senator, the election officer who was a political rival refused to call the Hatfield ally's name. Devil Anse and several of his men arrived armed, on horseback, and Floyd's name was called. ${ }^{59}$

${ }^{56}$ Ely, 202.

${ }^{57}$ Gerofsky, 111. Delegates at the 1872 West Virginia Constitutional Convention sanctioned exclamatory voting when it determined that voting "should be by ballot, but the voter was left free to make it open or secret." According to Gerofsky, this constitutional acknowledgment and endorsement "existed in no other state."

${ }^{58}$ Affirmation of ballot voting, Acts of the Legislature, 1891: 226-264; William N. Miller to A. B. White, 5 May 1902, A. B. White Papers, WVRHC.

${ }^{59}$ G. Elliott Hatfield, The Hatfields (Stanville, KY: Big Sandy Valley Historical Society, 1974), 72-73. Floyd, whose uncle and grandfather both had been governors of Virginia, was born in Logan County in 1855. Educated at Rock Hill College in Maryland and the University of Virginia, Floyd studied history, literature, and international and constitutional law. Floyd first went to the state legislature in 1881 as Delegate from Logan and then in 1883 as state senator. "John B. Floyd," in George W. Atkinson and Alvaro F. Gibbens, Prominent Men of West Virginia, (Wheeling, WV: W. L. Callin, 1890), 720-721. 
William A. MacCorkle, West Virginia's governor from 1892 to 1896, recounted a similar instance in his memoirs. During an election in which MacCorkle stood as a candidate, Devil Anse tried repeatedly to get his district convention to support him. Finally, Hatfield informed those assembled that if they did not endorse MacCorkle, he would "go over to [his] house and get [his] Winchester and ... see justice ... done." When queried about why he liked MacCorkle, Hatfield stated simply, "he is just the same kind of man I am."60

The Democratic fissure which had first appeared in 1890 deepened considerably in 1892. The controversy stemmed from one faction's alignment with Johnson Newlon Camden and the other's support of a coalition of William Alexander MacCorkle and E. Willis Wilson. Z. T. Vinson, the business associate of Wallace J. Williamson and co-founder of Williamson, also served as a legal advisor, minor business associate, and political lieutenant of Johnson Newlon Camden, one of the leading Democrats in the state. ${ }^{61}$ The Camden-Vinson-Williamson faction's power emanated from the river cities of Catlettsburg and Ashland, Kentucky, and Huntington, in West Virginia and Ironton, Ohio. ${ }^{62}$ Through their close association with Vinson and Williamson, several of Logan County's attorneys, therefore, allied politically with Camden, and thus actively pursued railroad and industrial development.

Despite the power exerted by Camden, in 1892 the Democratic faction in control of Logan County was aligned with a coalition forged in support of William Alexander MacCorkle

${ }^{60}$ William Alexander MacCorkle, Recollections of Fifty Years of West Virginia (New York: G.P. Putnam's Sons, 1928), 285-286.

${ }^{61}$ Festus P. Summers, Johnson Newlon Camden: A Study in Individualism (New York: G.P. Putnam's Sons, 1937), 511.

${ }^{62}$ author's assertion based on previously discussed individuals and events. 
and E. Willis Wilson. ${ }^{63}$ In Logan, the most visible ally of the MacCorkle-Wilson faction was

Devil Anse Hatfield. ${ }^{64}$ Wilson had won the Hatfields' loyalty by using his influence as governor of West Virginia to protect them during the feud. Eureka Detective Agency detective Dan Cunningham who trailed the Hatfields for years, complained bitterly in his memoirs about the family and their political patrons. ${ }^{65}$ According to Cunningham, for years, Governor Wilson of West Virginia opened the state treasury to protect the Hatfields, whom Cunningham considered a gang of murderers, and who, in turn, displayed portraits of their protector Wilson in their homes. ${ }^{66}$ MacCorkle had forged a relationship with Devil Anse and Elias Hatfield while traveling through southern West Virginia as a young circuit-riding lawyer. ${ }^{67}$

The rivalry between the Camden Democrats and the MacCorkle Democrats splintered an important political and legal alliance in Logan County. As the Logan Banner of April 21, 1892, revealed, Z. T. Vinson and John S. Marcum, two of the most prominent lawyers in southwestern West Virginia, were "attending court, and for the first time championing different candidates for Governor."68 Three weeks later, at the Logan County Democratic Convention, the MacCorkleWilson faction carried the convention and the state delegates from Logan were instructed to vote

${ }^{63}$ Williams, "New Dominion," 391.

${ }^{64}$ Ibid.

${ }^{65}$ Johnson, "Horrible Butcheries," 38.

${ }^{66}$ Ibid. Pursuing Hatfields became something of a career for Cunningham. Nearly two decades after the end of the feud, Cunningham, then serving as a U.S. Marshall, investigated the role of Devil Anse's son Elias in a peonage case. Kenneth Bailey, "A Temptation to Lawlessness: Peonage in West Virginia, 1903-1908," West Virginia History 50 (1991): 25-45, 37.

${ }^{67}$ Mingo Republican, 24 March 1911.

${ }^{68}$ Logan Banner, 21 April 1892. 
for MacCorkle-Wilson. ${ }^{69}$ Two of the county's six districts (two of the three westernmost districts) were represented at the county convention by Hatfields or Hatfield allies: Joseph Hatfield was the Magnolia District delegate, and the Lee District delegates were Johnse Hatfield, Thomas B. Farley, and Sidney B. Lawson. ${ }^{70}$ Historian John Alexander Williams reveals why the support of Devil Anse Hatfield was so important to MacCorkle and how MacCorkle repaid the debt. According to Williams, Hatfield was the political leader of Logan County, the state's staunchest Democratic bastion. When Logan delivered a solid vote to MacCorkle, he expressed his gratitude by protecting Hatfield's family. ${ }^{71}$

Ironically and probably unbeknownst to the their far removed Logan County partisans, Camden actually supported MacCorkle's gubernatorial candidacy. After winning the election, MacCorkle rewarded Camden by appointing him to complete John E. Kenna's unexpired U.S. Senatorial term. The degree to which Logan's factions continued to battle underscores the vast distance between local politicians like Hatfield and West Virginia's party powerbrokers, like Camden. $^{72}$

In September 1891, the Logan Banner reprinted a portentous story from the Wayne News regarding a meeting held at Dunlow, Wayne County, in the last week of August, 1891. The

${ }^{69}$ Logan Banner, 12 May 1892.

${ }^{70}$ Logan Banner, 19 May 1892.

${ }^{71}$ Williams, "New Dominion," 391. The "Kanawhans" Williams refers to are also known as the "Kanawha Ring," one of the four major factions in West Virginia's Democratic Party in the late nineteenth century. The core of power in the Kanawha Ring centered on two Charleston law firms, Kenna and Watts and MacCorkle and Chilton. The Kanawha Ring was a conservative, pro-industry faction. In Transforming the Appalachian Countryside, Ronald L. Lewis explains how these Charleston lawyers ingratiated themselves to voters like Anderson Hatfield. Lewis, Appalachian Countryside, 213-244.

${ }^{72}$ Summers, 447; Oscar Doane Lambert, Stephen Benton Elkins (Pittsburgh: University of Pittsburgh Press, 1955), 177. 
Banner dismissed what it referred to as "The New County Scheme" for three reasons: the Wayne and Logan "contingencies" were unlikely to agree on the location of the new county's seat, because the area needed "better" not "new" county governments, and most importantly, "the people find taxation high enough to maintain . . counties now formed. The Banner asserted that "the Logan County people do not want the county unless they can get the courthouse either at the Mouth of Pigeon on Tug River or at the Mouth of Breeding on Twelvepole."73

1892 proved a significant year in the development of the Tug Valley of western Logan County. As Altina Waller notes in Feud, "where there had not been a single town or village, two suddenly appeared . . . at the Mouth of Pond Creek [and] a few miles from the Hatfield enclave on Mate Creek." 74 The Pond Creek town was Williamson and the one on Mate Creek was Matewan. Williamson's founders were a group of investors that included T. H. Harvey, while the town of Matewan was created by investors who were friends and political allies of Banner editor H. C. Ragland. ${ }^{75}$ Although no sources identify the "creators" of Matewan, the likely candidates were R. W. "Bob" Buskirk, son of Williamson co-founder U. B. Buskirk, and Hiram S. White, two of the earliest tradesmen in Matewan. ${ }^{76}$

Just as towns were appearing in the Tug Valley, land values rebounded from their low in 1891, underscoring yet again the impact of the completion of the N\&W's Ohio Extension. In 1891 overall land valuation in Logan County had fallen over three quarters of a million dollars

\footnotetext{
${ }^{73}$ Logan Banner, 3 September 1891 ( reprint of undated article from Wayne News).

${ }^{74}$ Waller, Feud, 200. Waller cites two Logan Banner articles, 5 March 1891, and 4 April

${ }^{75}$ Ibid.

${ }^{76} 1891-1892$ West Virginia State Gazetteer and Business Directory; Ragland had actively supported White's candidacy for a seat in the state legislature in the 1890 election. Logan Banner, 30 October 1890.
} 1892. 
from the previous year. According to Banner editor Ragland, the decline in land values resulted from delinquent lands being "dropped from the books."77 The Logan County total land valuation for 1892 was $\$ 1,535,929$, an 82 percent increase over 1891 's $\$ 838,535 .^{78}$ The following tables illuminate how industrial development affected land values in Logan County. Note in particular the shift in the value of land in Magnolia, Lee and Hardee districts, which would become Mingo County in 1895 .

Table 1:

Land Valuation Losses in Logan County by Magisterial District, 1891

\begin{tabular}{llll}
\hline \hline Chapmanville & down $\$ 5,081$ & Magnolia & down $\$ 70$ \\
Logan & down $\$ 449$ & Lee & down $\$ 3,683$ \\
Triadelphia & down $\$ 5,230$ & Hardee & down $\$ 11,451$ \\
\hline \hline
\end{tabular}

Source: Logan Banner, 16 July 1891.

Table 2:

Land Valuation Increases in Logan County by Magisterial District, 1892

\begin{tabular}{lcllll}
\hline \hline Chapmanville & $\$ 54,000$ & $\begin{array}{l}41 \% \\
\text { increase }\end{array}$ & Magnolia & $\$ 124,000$ & $\begin{array}{l}128 \% \\
\text { increase }\end{array}$ \\
Logan & $\$ 199,000$ & $\begin{array}{l}60 \% \\
\text { increase }\end{array}$ & Lee & $\$ 24,000$ & $\begin{array}{l}100 \% \\
\text { increase }\end{array}$ \\
Triadelphia & $\$ 76,000$ & $\begin{array}{l}67 \% \\
\text { increase }\end{array}$ & Hardee & $\$ 191,000$ & $\begin{array}{l}150 \% \\
\text { increase }\end{array}$ \\
\hline \hline
\end{tabular}

Source: Logan Banner, 7 April 1892.

Table 2 illustrates that land values rose all over Logan County, but again, as in 1891, in 1892 the three westernmost districts Magnolia, Lee, and Hardee increased the most in value. The completion of the N\&W's course through the county undoubtedly influenced the escalation, which is reflected in the rise of land values in the districts intersected by the railroad. In

\footnotetext{
${ }^{77}$ Logan Banner, 16 July 1891.

${ }^{78}$ Logan Banner, 7 April 1892.
} 
combination, compared to the three eastern districts of Logan County, the western districts' land increased in value 378 percent, while the eastern districts' increased only 168 percent. $^{79}$

\section{The Panic of 1893 and the King Land Case (1894-1913):}

Just as land values peaked in Logan, the railroad and coal industries teetered on the edge of an economic chasm. As mentioned before, the tumultuous economic conditions of the $1880 \mathrm{~s}$ and early 1890 s had wrought havoc in the coal industry. Increasing competition, production costs, and vacillating prices compelled coal men to seek new fields where coal could be mined more cheaply. ${ }^{80}$ Opened in the midst of this crisis, the Thacker coal field of western Logan County (eventually Mingo County), came to rely on the distress of other fields to grow. The field's reaction to the Panic of 1893 set the pattern of this reaction.

The Panic of 1893, one of the worst depression in United States history, left almost a quarter of the American workforce unemployed. Fifteen thousand commercial firms and six hundred banks failed. ${ }^{81}$ Known in the Tug Valley as "Cleveland's Panic," the depression fostered anxiety even in the valley's remote sections. ${ }^{82}$ As one man recalled, because the Gilbert area of Logan (Mingo) County "was largely self-supporting," it took some time for the crisis to affect people, "but when it did come it was very bad." ${ }^{83}$ Many years later, the same man, who was the

${ }^{79}$ Logan Banner, 7 April 1892.

${ }^{80}$ Paul Salstrom, Appalachia's Path to Dependency: Rethinking a Region's Economic History, 1730-1940 (Lexington, Ky.: The University Press of Kentucky, 1994), 40, 72-73.

${ }^{81}$ Ron Chernow, The House of Morgan: An American Banking Dynasty and the Rise of Modern Finance (New York: Simon \& Schuster, 1990), 66.

${ }^{82}$ John Edward Stafford, "Memoirs," in Stories About Gilbert,16.

${ }^{83}$ Ibid. 
son of a saw and grist mill owner, remembered that "family men came and begged Father to let them work . . a at a wage of 25 cents for a ten hour day." ${ }^{84}$ As this story of Gilbert, West Virginia, illustrates, the Panic of 1893 reached into every corner of the country. In terms of response to the Panic of 1893, there was an important difference between the reaction of the southwestern West Virginia coal field and its neighbors to the East. As mining ground to a halt in southwestern Virginia and southeastern West Virginia, efforts to open the Thacker field forged ahead.

Despite the single-minded focus of its president, Frederick J. Kimball, the Norfolk \& Western Railway Company nearly collapsed during the Panic of 1893, primarily from construction cost overruns. Although Kimball had initially projected a six million dollar price tag for the Ohio Extension, its final cost approached nearly eight million dollars. In order to avoid "excessive curvature" along the grade for the railroad's roadbed, the Tug Fork and three tributaries were bridged sixty-one times, and eight tunnels were constructed, including one that measured 3,340 feet. The work had been so difficult, several contractors had abandoned their work and disappeared in the middle of the night. ${ }^{85}$

Even though the Panic started in May, two mining companies in western Logan County had been incorporated by the end of 1893. The Pearl Mining Company's incorporation was reported in the Coal Trade Journal in July 1893. Because the company was backed and would be operated by experienced Pennsylvania coal men, the Journal confidently proclaimed that the Pearl mine would be the first to ship coal from the new field." 86 Two months later, the Journal

\footnotetext{
${ }^{84}$ Ibid.

${ }^{85}$ Lambie, 130.

${ }^{86}$ Coal Trade Journal 32 (12 July 1893): 436.
} 
announced the incorporation of the Thacker Coal \& Coke Company, the "first large company" in the area. ${ }^{87}$ In fact, the Thacker Coal \& Coke Company was so prominent, both the new field and the coal it produced were known as "Thacker" for over a decade. ${ }^{88}$

Despite the adverse atmosphere precipitated by the Panic, efforts to open the Pearl and Thacker mines continued. There were two possible and probably interrelated reasons for the push to get these mines into production. First, according to pioneer coal operator W. R.

Thurmond, the initial Ohio Extension route "soon proved to be unsatisfactory due to excessive grade and distance" from the first mines. ${ }^{89}$ The first line of the Ohio Extension had followed the course of the Tug Fork River as it flowed northwestward towards Wayne County, West Virginia, Ashland Kentucky, and Huntington, West Virginia. Spur lines were constructed, including a line to Dingess, which had a 1.5 mile long tunnel. ${ }^{90}$ The orientation of the Ohio Extension sparked at least one historical debate. According to Joseph Lambie, the course of the Ohio Extension was chosen to maximize the profits of the Guyandot Coal Land Association. ${ }^{91}$ However, Jedidiah Hotchkiss's biographer Peter Roper uncovered correspondence that proved that the majority of the GCLA tract was at least a mile away from the main line of the railroad, which in turn cost the railroad thousands of dollars by adding the expense of settling several rights-of-way cases. ${ }^{92}$ The

${ }^{87}$ Coal Trade Journal 32 (6 September 1893): 666; Phil Conley, History of the West Virginia Coal Industry (Charleston, W.Va.: Education Foundation Inc., 1960), 258.

${ }^{88}$ Dr. Henry M. Payne, "The Future of Williamson and the Tug River Coalfield," Illustrated Monthly West Virginian 2 (August 1908): 45-49, 45.

${ }^{89}$ Thurmond, 24.

${ }^{90}$ Lambie, 130.

${ }^{91}$ Ibid., 124.

${ }^{92}$ Roper, 174-175. 
additional costs of correcting several significant problems with the railroad was only one of two major problems encountered during the opening of what was then the N\&W's youngest coal field.

The failure of the field's first mines constituted the second major problem confronted in the new field. Located at Fleming and Dunlow in Wayne County, these mines had failed by 1893 after less than four years, because production was low and the coal was of poor quality. According to Roper, "the failure of the mines around Fleming and Dunlow made the development of seams near Dingess . . . all the more important." When the Pearl Mining Company was determined to be an excellent gas coal and locomotive fuel, demand was sufficient despite the recession to require a two shift operation. ${ }^{193}$ To understand the significance of the opening of production at Dingess and Thacker, one has only to look at what happened to the east in the Pocahontas field and the coal field around Graham, Virginia.

In William C. Pendleton's History of Tazewell County and Southwest Virginia, there is an eerie description of the Panic's impact on the coal fields east of the Thacker field. Pendleton wrote:

what was known as the 'boom,' when men became wild with their schemes to build towns and cities, and gambled recklessly . . . came in 1890. The [town] of Graham [was] laid off, and [its] founders aspired to make [it an] industrial center. Things moved along nicely until 1893. Then came the direful panic ... The coal mining industry became stagnant throughout the United States and it was almost discontinued in the Pocahontas fields ... Graham presented an air of desolation. The coke ovens at Pocahontas were idle and abandoned; and it was told that calves were grazing about and hogs [were] sleeping in the coke ovens. ${ }^{94}$

${ }^{93}$ Ibid.

${ }^{94}$ William C. Pendleton, History of Tazewell County and Southwest Virginia, 1748-1920 (Richmond: W.C. Hill Printing, Co., 1920), 664. 
The collapse of the national economy affected the coal industry of the Tug Valley in 1894. To stay afloat, the Guyandot Coal Land Association created the Mingo Coal Company, which paid the "most pressing" of the association's debts by buying between nine and ten thousand acres of the association's land. ${ }^{95}$ Despite the economic woes of the land company, the four coal companies of the new Thacker field produced over fifty-two thousand tons of coal. ${ }^{96}$ The four companies were: Union Mining \& Manufacturing Company at Dingess, Lynn Coal \& Coke and Alma Coal \& Coke at Matewan, and the Glen Alum Cannel Company at Glen Alum. ${ }^{97}$ The first two shippers of coal were the Thacker Coal \& Coke Company at Thacker Creek and the Union Mining \& Manufacturing Company. Despite successfully launching production, Thacker had to curtail shipments because of the railroad's failure to furnish cars, a problem which plagued the $\mathrm{N} \& \mathrm{~W}$ for the next several years. ${ }^{98}$

Despite the difficulty in obtaining cars to transport coal, the new mines of the Thacker field probably survived the first year of the depression because of the United Mine Workers of America's first general strike. Founded in 1890, the UMWA called the strike in an effort to improve conditions, but the strike simply encouraged the new fields to expand production. ${ }^{99}$ The

\footnotetext{
${ }^{95}$ Roper, 17.
}

${ }^{96}$ Conley, 258.

${ }^{97}$ Ibid., 258-9.

${ }^{98}$ Cubby, 245.

${ }^{99}$ Jerry Bruce Thomas, "Coal Country: The Rise of the Southern Smokeless Coal Industry and its Effect on Area Development, 1872-1910," (Ph.D. diss., University of North Carolina, 1971), 237. 
strike also temporarily revived the Peach Orchard mines in Kentucky, whose workforce in the 1890s was predominantly Hungarian. ${ }^{100}$

Although the Panic had threatened industrial development in southeastern West Virginia, while simultaneously spurring expansion into southern West Virginia, the actual turning point in southern West Virginia's development came with the filing of the State of West Virginia v. Henry C. King lawsuit in $1894 .^{101}$ The antecedents of the King case trace back to the land speculation boom of the 1790s. In 1795, Robert Morris acquired the title to approximately a million acres of land, shortly thereafter he conveyed the bulk of the land to James Swan. Swan sold thousands of acres, but the majority of the "Morris Tract" was forfeited in the 1830s to the Commonwealth of Virginia for nonpayment of taxes and non-entry upon the land books, which was required by Virginia for recognition of title to the land. ${ }^{102}$

Despite the mass forfeiture, in 1838 the General Assembly of Virginia resurrected the Morris Tract for the use and benefit of Swan's creditors, most of whom were "French officers in American service during the Revolution." The title was conveyed to John Peter Dumas as trustee for the French creditors. In 1881, after the Civil War, and after the transfer of old Virginia land

\footnotetext{
${ }^{100}$ Chapman, 49-50. The mining experience at Peach Orchard probably would have been known in Mingo County. Mr. Howard Radford, a narrator from the 1989 Matewan Oral History Project, had family ties to the area; his mother hailed from Peach Orchard. Harold (Howard) Radford interview with John Hennen, Summer 1989 Matewan Oral History Project. Although correctly referred to as "Howard" by Mr. Hennen, Mr. Radford's interview is indexed as "Harold Radford" interview.

${ }^{101}$ For the most detailed account of the King case, the author suggests Chapter 7, "A Pandora's Box of Litigation: Disputed Land Claims," of Cubby's "Transformation of the Tug and Guyandot Valleys." In writing his analysis of the case, Cubby had access to a critical primary source -1894 issues of the Logan Banner, to which the author herself did not have access.

${ }^{102}$ Cubby,"Transformation," 181, 182. Cubby's source is: "State of West Virginia v. Henry C. King," in Reports of the West Virginia Supreme Court of Appeals 64 (March 3,1908-December 23, 1908): 553-557. For textual clarity, Cubby is cited.
} 
laws and titles to the land books of the new state of West Virginia, a five hundred thousand-acre section of the old Morris Tract was declared delinquent. West Virginia allowed Dumas's successor to redeem the tract, and in 1891, a subsequent trustee sold it to John V. LeMoyne and David W. Armstrong, who in turn sold the title to Henry C. King. ${ }^{103}$

The legislature of the state of West Virginia repeatedly attempted to prevent successful resuscitation of the Morris claim. In the 1870 s and 1880 s, the legislature passed several laws that sought to clarify land laws and titles. Finally, in 1893, empowered by these statutes, the state of West Virginia filed a lawsuit to end Henry C. King's claim to the Morris tract. However, the final resolution of the King case, as it came to be called, did not come until October $27,1913 .{ }^{104}$

The body of reform laws that threatened Henry C. King's title to the Morris tract were referred to as the "School Land Laws" because the state of West Virginia set aside the profits of land sales to support public education. The first such laws, passed in 1872-1873, allowed county commissioners to authorize sheriff's sales of both waste and unappropriated lands and forfeited and delinquent lands. Because forfeited and delinquent lands differed from waste and unappropriated lands in that individuals lost their titles for failure to register their claims and/or pay their land taxes, the lack of any differentiation in the 1872-1873 laws, between the two types of land provided those who had been stripped of their land a means of protest. Legal challenges to land sales processed under the School Land Law of 1872-1873 were based on the argument that allowing forfeited lands to be sold under the same conditions as waste lands denied those who faced loss of title through forfeiture of due process, which meant that they had been denied adequate opportunity to redeem their title. More important, those who opposed the School Land

\footnotetext{
${ }^{103}$ Ibid., 182.

${ }^{104}$ Ibid., 210.
} 
Law of 1872-3 also claimed that individuals who purchased forfeited lands under the law actually did not hold valid title. ${ }^{105}$

In 1882 , to protect the titles of those who had purchased land under the 1872-3 law, the West Virginia legislature revised it, adding an important procedural provision to the School Land Law. In response to complaints about the lack of a due process clause, the 1882 law required the circuit court clerk of any county intending to sell forfeited lands to issue a summons announcement that the county would be petitioning the circuit court for permission to sell the land. This important change allowed former owners an opportunity to show cause why the lands should not be sold and also made the entire proceeding judicial and not administrative. Translated loosely, the "former" owners of forfeited lands were guaranteed their day in court. ${ }^{106}$ Unfortunately, the school commissioners of Logan, Wyoming, and McDowell counties throughout the 1880 s continued to operate under the old law. When land values began to rise because of the construction of the $\mathrm{N} \& \mathrm{~W}$ and the development of coal properties, violations of the 1882 reforms opened a window of opportunity for speculators like Henry King to "reassert" their claims. The lawyers and local politicians of southern West Virginia scrambled to reform the School Land Laws yet again, to preserve the title validity for the lands they had speculated in themselves and the lands they had helped the great land associations to acquire. ${ }^{107}$

In 1891, the School Land Law reform required that no suit could be brought to reassert the old claims until authorized by the circuit court of the county in which the disputed land was located. The School Land bill of 1893 proposed by state senator of the seventh district, John A.

\footnotetext{
${ }^{105}$ Ibid., 183.

${ }^{106}$ Ibid., 184-185.

${ }^{107}$ Ibid., 185.
} 
Sheppard of Logan County, provided for the most sweeping resolution of the title reclamation issue. First, any (West Virginia) land forfeited to the State of Virginia before 1863 was declared irredeemable. Second, all previous sales of land for the benefit of the School Fund were declared valid, "no matter how irregular" the sale. Third, redemption of land based on old land titles was limited to land still held by the state. The 1893 Legislature passed the bill and launched a twodecade long legal struggle over the ownership of five hundred thousand acres of southern West Virginia's most valuable mineral lands. ${ }^{108}$

Concern over the outcome of the King case swept over Logan County in 1894. A survey commissioned by the initial lawsuit established the boundaries of the land tract under contest. Known as the W. D. Sell survey, it officially designated the acreage affected in the southern counties-- 327,000 in Logan, Wyoming and McDowell counties. Of the 327,000 acres, 286,000 were in Logan (after 1895, 200,000 in Logan, 86,000 in Mingo), 24,000 were in McDowell, and 17,000 in Wyoming. If King prevailed, not only would the railroad and coal developers suffer, private citizens could also lose their homes. ${ }^{109}$

Fear of what a King victory would mean precipitated several citizens' meetings throughout Logan County. ${ }^{110}$ Published resolutions of a gathering at Wharncliffe, in the southeastern corner of the county reveal how local residents responded to the threat posed by King's claim. ${ }^{111}$

\footnotetext{
${ }^{108}$ Ibid., 185-186.
}

${ }^{109}$ Ibid., 200. Again, Cubby's source was another King case: "State v. King," Reports of the West Virginia Supreme Court of Appeals 47 (November 11, 1899- April 14, 1900): 437-454, 442,446 .

${ }^{110}$ Ibid., 190.

${ }^{111}$ Ibid., 190-191. 
Whereas ... we believe it [King's] intention to annul our land titles and take our homes from us; and

Whereas, we recognize no right or title of [his] to any of the lands of our county; therefore be it

Resolved that we earnestly protest against [his] claim, and ask the citizens of the several counties concerned to hold mass meetings for the purpose of deciding upon a line of action to be pursued. ${ }^{112}$

King's attorney, V. A. Wilder, dismissed the resolutions as "'the fevered imagination of some foolish people," and fed a story to the New York Weekly World that "an armed band of forty 'drunk and ugly settlers' had threatened him on a visit to King's land. ${ }^{113}$ The secretary of the Wharncliffe meeting, J. M. Hatfield, in a letter to the Logan Banner, angrily replied that Wilder's charges and the World's story were a deceitful ploy to prejudice outsiders against "the people of this county." ${ }^{114}$ Wilder apologized for his remarks, but the damage had been done. His actions galvanized local and public support behind his opponents, the native speculator-elites and the attorneys for the land companies and railroad. ${ }^{115}$

The lawyers who defended the interests of the state and local citizens were corporate attorneys, among them the state's Attorney General Edgar P. Rucker (State v. King) and Z. T. Vinson (State v. King and King v. Mullins). Rucker was well-known for his close ties to the Norfolk \& Western Railroad and Vinson was becoming widely known for his ties to Johnson Newlon Camden and his own entrepreneurial pursuits. ${ }^{116}$ Along with state senator John A. Sheppard, these anti-King lawyers claimed to be fighting for "the people," but in reality, they

${ }^{112}$ Logan Banner, 2 August 1984, quoted in Cubby, "Transformation," 191.

${ }^{113}$ Ibid., 191-192.

${ }^{114}$ Ibid., 191.

${ }^{115}$ Ibid., 150-152.

${ }^{116}$ (Rucker) Williams, Captains of Industry, 83; (Vinson) Summers, Johnson Newlon Camden, 494. 
were scrambling to preserve their own and corporate investments in the disputed land. In

courtrooms and on the floor of the state senate and house of delegates, listeners were exhorted to remember that what was at stake were "the vine-clad mountain homes" of many southern West Virginians. ${ }^{117}$

In King v. Mullins and later cases, King's attorneys raised serious charges against their opponents. King's lawyer, V. A. Wilder, asserted repeatedly that his opponents' constant harping about "the vine clad mountain homes" of Logan County just obscured their true objectives. Although the lawsuit included leading merchant-landholder J. A. Nighbert, the primary defendant in the ejectment case was "Black" Mullins, who occupied one small parcel of the immense tract. Wilder's observation about Mullins's role in the case illuminates the alleged manipulative actions of the native entrepreneurial elite. According to Wilder, in his testimony Mullins, 'told ... of his dear wife and imperiled family ... how the King land case ... had robbed him of his 'little vine clad mountain home.' . . . But ... Mullins never had a home until he got it through the King land case. He was poor when King first crossed his horizon ... Sheppard and Buskirk of Logan County ... they skinned him . . . took all he had ... After having been well cleaned out by Buskirk, et als., the King Land case again put Mullins on his feet, and now it is said he is worth $\$ 50,000$ and more coming. ${ }^{118}$

A Boston attorney active in another county described a legal strategy similar to the Mullins' situation. According to Henry L. Shattuck, a lawyer for the Gauley Coal Land Company, a "tenant" was hired to live on the disputed land, which placed the burden of proof of

${ }^{117}$ V.A. Wilder, "Senate Bill \#212 West Virginia Legislature. The King (Land Case) Is Dead. Long Live the King (Land Case). The West Virginia Legislature 'Dough' and Confiscation: A Diatribe Dedicated without permission to the Authors and Enactors of Senate Bill \#212," (n.p.:n.d.). Pamphlet 4133 in the Pamphlet Collection of the West Virginia and Regional History Collection, West Virginia University.

${ }^{118}$ Ibid. 
ownership on the contestant, who had to sue to eject the hired occupant. ${ }^{119}$ The parallels between Shattuck's story and Wilder's accusations suggest that Wilder's claims were valid.

The King Land case eventually encompassed more than a half dozen lawsuits and countersuits. Four of the cases, including King v. Mullins, reached the Supreme Court of the United States. In King v. Mullins, Justice John Marshall Harlan ruled against King and said that proceedings for the collection of public revenue by taxation do not have to meet the standards required of other legal proceedings in order to satisfy the rights associated with judicial due process. In particular, Harlan asserted that "summary measures may be used in tax collection that would not be allowed in judicial proceedings." The subsequent U.S. Supreme Court hearings were dismissed. Justice Oliver Wendell Holmes explained that the dismissals were based on the principle that the latter cases just reargued the earlier case. After seventeen years, the King Land case was dismissed for the final time on October $27,1913 .{ }^{120}$

The significance of the King case cannot be overstated for "it symbolized the new era evolving in the Tug and Guyandot Valleys and hinted at the nature of struggles to come."121 Before the final resolution in the King case came in 1913, the political structure of southern West Virginia was transformed by the creation of a new county, political alliances fell apart and were reconfigured, and most importantly, a pattern of deceptive political rhetoric was established. ${ }^{122}$

\footnotetext{
${ }^{119}$ Henry L. Shattuck, "Horse and Buggy Days in the West Virginia Appalachians," Massachusetts Historical Society Proceedings 80 (1968): 71-78, 74. This article, removed from its parent journal, was accessioned by the West Virginia and Regional History Collection as Pamphlet 12796, WVRHC.

${ }^{120}$ Cubby, "Transformation," 193-198, 210.

${ }^{121}$ Ibid., 210.

${ }^{122}$ The legacy of this deceptive style of politics is revealed in David Corbin's description of attorney John A. Sheppard as "a leading defender of the occupants' property rights." Corbin, Life, Work, and Rebellion, 3. As this discussion has shown, the "real" occupants were the native
} 
The Democrats carried West Virginia handily in 1892, but the Panic of 1893 proved to be a turning point in West Virginia politics. ${ }^{123}$ Prior to the Panic, defiance of rising corporate influence in the state had come from the Agrarian wing of the Democratic Party. After the Panic, the challenge came from labor. ${ }^{124}$ National civil service reform precipitated another important change in state level party politics, as did the advent of civil service examinations which severely curtailed patronage distribution. ${ }^{125}$ In response to civil service reform, party leaders simply adopted a more direct and appealing system of reward -- "payment . . . immediately after the task was completed." ${ }^{126}$ In West Virginia, "payment" covered a range of financial exchanges between state and county level party bosses, which ran a gamut from fronting the cost of local campaigns to actions like paying election officers to manipulate poll returns and buying votes on election day. $^{127}$

The most significant change in West Virginia politics in the early 1890 s was the emergence of a reinvigorated Republican party. ${ }^{128}$ The catalyst for the change traditionally has

elites who had bought up their neighbors' claims and needed to defeat King's claim in order to profit from their investment. The native elites and their corporate allies disguised their role in the dispute by hiding behind "Black" Mullins, thus eliciting more local support for their actions. This type of deliberate obsfucation of the "real" issue became a staple of southern West Virginia politics.

${ }^{123}$ Williams, "Davis and Elkins," 269.

${ }^{124}$ Ibid.

${ }^{125}$ Gordon B. McKinney, Southern Mountain Republicans: Politics and the Appalachian Community, 1865-1900 (Knoxville: University of Tennessee Press, 1998 [1978]), 143.

${ }^{126}$ Ibid.

${ }^{127}$ Assertion based on data collected on subsequent elections which will be cited fully as discussed.

${ }^{128}$ McKinney, Mountain Republicans, 9, 150. McKinney's study of southern mountain Republicans, asserts that the Republican "machines" of the Appalachian South were similar to 
been attributed to the onslaught of the railroads and industrial development. ${ }^{129}$ A new class of legal and business elites, many of whom migrated to West Virginia, replaced the native statemakers and Union Army veterans like Nathan Goff. ${ }^{130}$ Senator Stephen B. Elkins, who was West Virginia's Republican Party boss from the early 1890s until his death in 1911, personified the power and influence wielded by this new group of political and economic leaders. ${ }^{131}$

The Republicans' most dramatic advance in membership occurred in the southernmost counties in the state. In Fayette, Raleigh, Mercer, and McDowell counties, the Republican party's growth and power stemmed from the development and expansion of railroad and coal industries. The rapidity with which formerly strong Confederate and Democratic counties became bastions of the Republican party inspired leading West Virginia historian John Alexander Williams to observe, "by 1893, it was axiomatic that the opening of mines or a railroad ... was practically certain to add [the county] to the Republican column." Williams extended his observation by adding, "the traditionally Democratic mountain clans were completely transformed . . . the clash

"other community political organizations in the Gilded Age" which were highly "centralized ... [to] insure personal control." In West Virginia, the apex of the Republican Party was first occupied by Nathan Goff, and then Stephen B. Elkins.

${ }^{129}$ John Alexander Williams, "Class, Section, and Culture in Nineteenth-Century West Virginia Politics," in Appalachia in the Making: 210-232, 228. An example relevant to this study is Mercer County, where "the influence of the [coal] operators began to be felt in 1888." Princeton Observer, 5 August 1937, William Y. Cooper Papers, ERCA.

${ }^{130}$ McKinney, Mountain Republicans, 150. Also a capitalist and coal mine investor, Goff dedicated his tenure as a judge to rectifying land titles, in order to "[encourage] a faster development of the state." G. Wayne Smith, Nathan Goff, Jr.: A Biography (Charleston, WV: Education Foundation Inc, 1959), 255.

${ }^{131}$ McKinney, Mountain Republicans, 150. 
was between an older order of political leadership and a new one represented by Elkins and his men."132

Williams chose the Hatfields of Logan County as his paradigm clan and justified the selection solely on the apparently close relationship established between the Hatfields, the N\&W, and the coal industry. Most of the evidence cited as proof of this relationship extends only to the superficial biographical data of Devil Anse's nephew, Henry D. Hatfield, who began his professional life as an $\mathrm{N} \& \mathrm{~W}$ company doctor and later served as a Republican governor and United States senator. ${ }^{133}$ A closer examination of the political history of the three southern West Virginia counties where the Hatfields and their kinsmen exerted influence exposes the holes in Williams' thesis. ${ }^{134}$

The Hatfield "clan" wielded considerable political power in Logan, Mingo, and McDowell counties. While McDowell did fall under the sway of the Republican party, neither Logan nor Mingo moved irrevocably into "the Republican column," even though both counties underwent an industrial transformation precipitated by the railroad and coal industries. For over forty years, between the late 1880s and the early 1930s, Logan County remained under the

\footnotetext{
${ }^{132}$ Williams, Captains of Industry, 230, 231.
}

${ }^{133}$ Ibid.

${ }^{134}$ Significant portions of Chapters 3 and 6 of this work are dedicated to revealing how, in direct contradiction to Williams assertion, Henry D. Hatfield relied on kinship networks and traditional mountain politics to rise to power in the Republican party, often incurring the wrath of powerful industrialists-politicians. 
control of the Democratic Chafin family, kinsmen through marriage to Devil Anse Hatfield. ${ }^{135}$

Mingo County shifted back and forth from Democratic to Republican control and back again. ${ }^{136}$

Williams and other historians have also overlooked the history and importance of the clan's divided and shifting political loyalties. In 1887, Big Sandy Valley historian William Ely noted that, while traditionally the Hatfields had all been Democrats, after the Civil War, they almost all had become Republicans. ${ }^{137}$ However, Devil Anse and his sons remained Democrats; two of them, Joe D. and Tennyson or "Tennis," were active members of their cousin Don Chafin's machine. ${ }^{138}$ By contrast, Devil Anse's brother Elias's sons Greenway and Henry D. became Republicans. Although Henry D. remained staunchly Republican, Tennis, Joe D., and Greenway Hatfield switched their party affiliation when shifting political winds either so allowed or required to remain in power. ${ }^{139}$ As the younger generation of Hatfields matured and stepped into the political arena in the 1890s, however, they still relied on their name and kinship

${ }^{135}$ Spence, 465. Don Chafin's father first served as Logan County sheriff in 1894-1898; other family members and close business associates alternated in the office until the 1920s. For more on Logan County politics, see Raymond Chafin and Topper Sherwood, Just Good Politics: The Life of Raymond Chafin, Appalachian Boss (Pittsburgh: University of Pittsburgh Press, 1994).

${ }^{136}$ The assertions regarding the nature of political control in each county is based on available election data (primarily from newspaper reports) from Logan, Mingo, and McDowell counties in the period between 1888 and 1932.

${ }^{137}$ Ely, 204.

${ }^{138}$ Chafin, 20.

${ }^{139}$ It should be noted that after Tennis Hatfield helped bring down Don Chafin; both he and Joe D. Hatfield served terms as sheriff of Mingo County. The split with Chafin and Henry D.'s ascendance to the United States's senatorship allowed Joe D. to move closer to his Republican cousin. Greenway Hatfield was three times sheriff of Mingo County, twice as a Republican and once as a Democrat. As Margaret Hatfield observed, if it served their purposes, few Mingo County politicians were above "kissing their elbows" and claiming to be a member of whatever party they thought could get them elected. Hatfield correspondence, letter no.1. 
networks for influence and power, regardless of their relationship with the new economic and political order. ${ }^{140}$

As the younger Hatfields moved to the fore, local and state politics were transformed by two events which began in 1893, the King Land Case and the Panic. Political alliances were broken and reconfigured, reputations made, and patterns of political and legal behavior set. The men whose economic, legal, and political careers began in this period were the same men who controlled the local and state government when the Matewan Massacre and Williamson-Thacker strike rocked West Virginia a quarter of a century later.

Several key figures in the King land cases became Republicans in the years between 1894 and 1913, some after years of active participation in the Democratic Party. For example, after serving Logan County as Democrats and playing active roles in the resolution of the King case, both John A. Sheppard and F. H. Evans became important figures in the Republican Party in Mingo County. ${ }^{141}$ The King Case also contributed to the disintegration of close working relationships and political alliances. Although they had supported different gubernatorial candidates in 1892, Z. T. Vinson and John S. Marcum had remained business associates until the King case intervened. ${ }^{142}$

${ }^{140}$ This assertion is supported at length in following chapters.

${ }^{141}$ The role of Sheppard and Evans in the Mingo County Republican party will be discussed and documented in subsequent chapters. Many of the "natives" who defected from the Democratic to Republican party coalesced as a party faction around members of the Hatfield family. F.H. Evans' membership in this group was secured by his aunt's marriage to James Hatfield. "Obituary of James Hatfield," Mingo Republican, 25 November 1915.

${ }^{142}$ Samuel S. Vinson to Johnson N. Camden, 5 September 1894, Political Correspondence 1894 O-Z, Johnson Newlon Camden Papers, WVRHC. This letter illustrates that by 1894, "the Marcums" had permanently defected into the faction headed by Camden's rival E.W. Wilson. 
Although fractures had appeared in the southwestern West Virginia Democratic Party years before the King case, the concurrent stresses of the Panic and the lawsuit accelerated factional discord. Without mentioning the King case by name, newspaper coverage of the political campaign of 1894 reflects the issues raised by the case. In the local press, the central "campaign issue" was the 1893 School Land Law. ${ }^{143}$ John A. Sheppard, who had proposed the law, ran for reelection in 1894. H. K. Shumate led the opposition against Sheppard, claiming that Sheppard was only acting to protect his own investments and was therefore unfit to represent the people of Logan County in the legislature. ${ }^{144}$ The Logan Banner denounced the Republican party generally as interlopers, but saved its worst for Sheppard's Republican opponent W. H. H. Cook of Wyoming County. Banner editor Ragland described Cook, a supporter of King's claim, as a "boodle accepting" hireling of outside capital. ${ }^{145}$

Although the King Land case exacerbated Logan's local political fractures which had begun as a result of the state level Democratic factional in-fighting in 1890, the Panic precipitated the fatal factional crisis among the Party leadership. In 1894, the Republican Party regained control of the state legislature and two years later the governor's office. In southern West Virginia, the pivotal battle occurred between Sen. Johnson Newlon Camden and former Gov. E. Willis Wilson. The fall out from this, their last major confrontation, promoted the

${ }^{143}$ Logan Banner, 25 October 1894.

${ }^{144}$ Logan Banner, 13 September 1894, quoted in Cubby, "Transformation," 188.

${ }^{145}$ Charleston Evening Mail, 21 September 1894. Ragland's vicious attacks on Cook led the Evening Mail to simultaneously mock and chide Ragland for being "so rough" on a fellow Missionary Baptist. 
political realignments that facilitated the cleavage of Logan County, southern West Virginia's bastion of the "Democracy."146

IV. Industrialization Alters the Economy of the Tug Valley, 1888-1894

Rampant land speculation followed the advance of the railroad. In February 1890, the Logan Banner noted, "there have been over eight hundred transfers of real estate made during the present year." ${ }^{147}$ For the most part, the average citizen in Logan County did not benefit materially from the real estate boom because the opening of the railroad had coincided with a decades-old agrarian crisis. ${ }^{148}$ As previously noted, the increase in tenancy in the Tug Valley had reduced the number of people who had land to sell. This situation stemmed partly from the inability of mountain families to continue to subdivide their land but also from the local elites' acquisition of land in the post-Civil War recessions. ${ }^{149}$ Chief among these local speculators were James A. Nighbert and Wallace J. Williamson. ${ }^{150}$ These men, along with the speculators who arrived in the area two or three years before the announcement of the Ohio Extension's route, benefitted greatly from the mad scramble that came after. ${ }^{151}$

${ }^{146}$ Lawson, 47.

${ }^{147}$ Logan Banner, 27 February 1890.

${ }^{148}$ Crandall Shifflett, Coal Towns: Life, Work and Culture in Company Towns in Southern Appalachia, 1880-1960 (Knoxville, Tenn.: University of Tennessee Press, 1994), xiii.

${ }^{149}$ Waller, Feud, 37-39. The elites generally acquired land by virtue of their ability to pay the taxes on it. For example, Anthony Lawson laid claim to part of the old Morris tract by paying the taxes on it, starting in 1865. Summers, "Owned A Sixth," 60.

${ }^{150}$ Waller, Feud, 153-154.

${ }^{151}$ Williamson Daily News, 4 March 1914. One prominent early outside speculator, Stuart Wood of Philadelphia, left an estate worth fifteen million dollars when he died in 1914. 
In May 1890, the Logan Banner observed that lands purchased by Philadelphia capitalist Stuart Wood "purchased for less than a dollar an acre, now [are] worth ten to twenty-five dollars an acre." 152 What makes the escalation of value in the Stuart Wood lands even more dramatic is the realization that the increase occurred in less than three years. ${ }^{153}$ Wallace J. Williamson, a native of the Pond Creek area and contemporary of Devil Anse Hatfield, in October 1890 sold one hundred acres at the Mouth of Pigeon Creek for ten thousand dollars. Again, the Banner underscored the dramatic escalation of land value, when it noted that land "five years ago [was] worth 25 cents now [is] worth $\$ 15$ and if the land titles could be settled . . \$100 per acre."154 However, land values did not rise evenly around the county. In the same October Banner, it was reported that Henry Mitchell whose family had intermarried with the Hatfields and Chambers, sold his land on Mate Creek for fifteen dollars an acre. ${ }^{155}$

Just a few months before the N\&W surveyors arrived in the Tug Valley in 1888, the last skirmish of the Hatfield-McCoy Feud occurred. Known as the "Battle of Grapevine Creek," the incident revealed how the feud had been transformed from "a dispute between neighbors over timber rights," into "a symbol of conflicting historical forces." ${ }^{56}$ Devil Anse Hatfield had been transfigured from a nascent native entrepreneur into archetypal backwoods traditionalist who violently resisted the modernization of his world. In reality, after Grapevine Creek, Devil Anse

\footnotetext{
${ }^{152}$ Logan Banner, 8 May 1890.
}

${ }^{153}$ Assertion based on records of Stuart Wood's land purchases from the Logan County Grantee Index, W-Z. Logan County Grantee Index, W-Z, Logan County Courthouse Records, West Virginia County Records on Microfilm, Reel 172, WVRHC.

${ }^{154}$ Logan Banner, 16 October 1890.

${ }^{155}$ Ibid.

${ }^{156}$ Waller, Feud, 185. 
and several members of his family moved away from the scenes of the feud and used the proceeds of the sales and leases of their land to reconstruct their lives. However, the Hatfields did not simply retreat into the untouched wilderness of Logan County. The sons of Devil Anse and his brother Elias and their cousins, some educated by the proceeds of the family "capitulation," and others employed by the land and coal companies, forged a political organization that ultimately reigned over three counties in southern West Virginia. ${ }^{157}$ An accurate portrayal of the transformation of the Tug Valley and the lives of its residents did not fit the needs of those who profited from the depiction of mountaineers as "a peculiar people" in need of the uplifting hand of progress.

The most telling evidence of the divergence of perceptions of the Tug Valley emerges from a comparison of local and national press representations of the area. Contemporary national reporters and missionaries depicted the lifestyle of Logan Countians as a throwback to pioneer days. These outsiders informed the rest of the nation about people in the southern upcountry who inhabited roughhewn log cabins, lived according to the rhythms of nature, and were out of step with the contemporary world. ${ }^{158}$

In contrast, the local social news reported in the Logan Banner revealed that Logan's elites lived lives not dissimilar to their contemporaries around the country. S. S. Altizer, an important lawyer-politician, educated his daughters in Virginia. ${ }^{159}$ George Rogers Clark Floyd, whose father and brother had served as governor of Virginia, and who himself was the mentor of a future governor of West Virginia, kept a personal library that included the works of

\footnotetext{
${ }^{157}$ Rice, Hatfields and McCoys, 123.

158"Taking Exception," in Appalachia in the Making, 1.

${ }^{159}$ Logan Banner, 17 March 1892.
} 
Shakespeare, Plutarch, and the novels of Tolstoy and Benjamin Disraeli. ${ }^{160}$ For this segment of local society, Henry Clay Ragland reported the death of the poet Walt Whitman in the Logan Banner. ${ }^{161}$ However, the lives of the Nighbert, Altizers, and Floyd did not attract the attention of late nineteenth century America, and therefore they were not the subjects of the dime novels set in Appalachia. ${ }^{162}$

Even as the Hatfield family dispersed and yet recovered their political influence, reporters and dime novelists continued to focus attention on their violent deeds. A dime novel, The Hatfield-McCoy Vendetta, or Shadowing a Hard Crowd, published in 1894, captures the juxtaposition between the press image and the reality of the Tug Valley's transformation. The novel's plot focuses on a private detective's search for a missing Louisville, Kentucky, heiress. The detective's investigation leads him to the Tug Valley, where he uncovers proof that several years before, Devil Anse Hatfield had helped kidnap the infant heiress. With the assistance of an African-American "dwarf" who communicated coded messages in sign language, the detective frees the heiress and reunites her with her long-lost father. One particular passage stands out poignantly against the reality of how and why the Hatfields' valley had changed. The novel begins with this observation by the detective, who was in fact a long-absent native of the area:

Here and there along the road were spaces of cleared land and cultivated fields and in almost every valley could be seen a rude cabin, built of logs. They were for the most part unoccupied. The deeds of the Hatfields and . . . the McCoys ... had terrified that part of the country to such an extent that a great many families had abandoned

${ }^{160}$ Troy Floyd to Robert L. Floyd, Floyd Papers, WVRHC and Hatfield to Ambler, Hatfield Papers, WVRHC.

${ }^{161}$ Logan Banner, 31 March 1892.

${ }^{162}$ Altina L. Waller, "Feuding in Appalachia: Evolution of a Cultural Stereotype," in Appalachia in the Making: 347-376, 367. 
their homesteads and sought safety in the villages and the towns until such time as they might pursue their peaceful occupations again. ${ }^{163}$

The dislocation of families from their pastoral lifestyle was far easier to blame on the backward and violent ways of the natives themselves than to look to the influence of changes wrought by a modern industrial society. No mention was made of the roar and smoke of the trains that already snaked through the bottomlands, nor that most of the inhabitants who had "fled" their homesteads had been pushed or lured into coal camps in search of a better life by the rapid economic transformation of southern West Virginia. ${ }^{164}$

However, this passage from The Hatfield-McCoy Vendetta indirectly refers to two issues overlooked by many historians and social analysts: first, that the "pre-industrial," or more accurately the "pre-railroad," era in Appalachia, particularly in the Tug Valley, was not a pastoral idyll. Even before the incursion of industrialization, the valley's residents "were no strangers ... to exploitation, oppression, political impotence ... [or] economic hardship."165 A second, if misguided observation in the passage refers to the existence of towns and villages. For decades, historians of the Appalachian coalfields have overlooked the contemporaneous development of independent and company towns. Historians had accepted uncritically what began as coal industry propaganda -- that coal companies had been forced to build "company towns" because "local housing, stores, schools, and other facilities did not exist" -- as if the coal companies had

${ }^{163}$ W.B. Lawson, The Hatfield-McCoy Vendetta or Shadowing a Hard Crowd (New York: Street and Smith, 1894), 8. Microfilm copy acquired from the Hess Collection, University of Minnesota.

${ }^{164}$ Shiflett, 24. Shiflett cites as an example the grandfather of Charlie Blevins, who along with seven sons, abandoned farming in Clay County, Kentucky to work in the mines on the Pike County, Kentucky - Mingo County, West Virginia border.

${ }^{165}$ Ibid., 7. 
discovered a barren wilderness. ${ }^{166}$ In Mingo County, at least, independent towns and villages in some cases pre-dated or appeared simultaneously with the coal camps. The existence and struggle of these independent entities for survival and prosperity culminated in subsequent labor incidents like the Matewan Massacre.

\section{Conclusion:}

The early to mid-1890s marked the beginning of the end of the Tug Valley's first century. The Ohio Extension of the Norfolk\& Western Railway had bridged the geographical barriers that had made political, economic, and social intercourse with the rest of the world almost impossible. Although the easily accessed stands of timber in the Big Sandy Valley were almost gone, coal was in ample supply and great demand, and the valley's population was growing.

But, because the railroad intersected Logan County west of the Guyan ridge, greater development occurred in the county's three westernmost districts of Hardee, Lee, and Magnolia. Moreover, beyond the boundaries of the Tug Valley, storm clouds were brewing. Twenty years of boom and bust economic cycles had destabilized the American economy, and hardest hit were industries like coal and timber. During the 1880s and 1890s, coal prices were declining, and the rush to open new fields to find a cheaper better coal, especially those in southern West Virginia resulted, in part, from an effort to offset the losses incurred from the older fields. ${ }^{167}$ Ironically, the first boom of development in the Tug Valley was, therefore, generated by depression in the national coal industry.

\footnotetext{
${ }^{166}$ Robert F. Munn, "The Development of Model Company Towns in the Bituminous Coal Fields," West Virginia History 40 (Spring 1979): 243-253, 244.

${ }^{167}$ Salstrom, Path to Dependency, 40, 72-73.
} 
Industrial development also dramatically affected political relations in Logan County. The postbellum upsurge in commercial timber extraction destabilized the deferential, clientelist elite hegemony, because anyone who owned or could access land with standing timber could become a man of influence. Men from pioneering families throughout the county who engaged in the timber trade or negotiated with capitalists seeking their timber were no longer as dependent or deferential to the county seat elite. Also, once it was known that the railroad would bypass Logan Courthouse, even more power shifted to the emerging communities along the rail line. ${ }^{168}$ Further complicating the economic impact on political relations was a schism in the Democratic party itself. In the early 1890s, local factions, loyal to either the pro-industrial Sen. Johnson Newlon Camden or the pro-agrarian former governor, E. Willis Wilson, threatened to tear apart Logan County's Democratic party. The division among the courthouse elite spread throughout Logan when Camden lieutenants founded the town of Williamson, while allies of the disaffected Ragland migrated to Matewan, a town emerging on the lands of the Hatfields, who supported Wilson because he had protected them during the Feud. The rise of the Republican party in the developing counties to the east of Logan also heightened tensions in Logan because former Democrats in those counties abandoned the party in order to share the power held by the Republican rail and coal elites.

The Panic of 1893 intensified the conflict between the factions, while simultaneously increasing the need for party unity. As the party in power when the Panic hit, West Virginia's

${ }^{168}$ Devil Anse Hatfield is the most notable example of this group. During the Civil War he had joined the Confederate company organized by a Logan Courthouse elite. In the timber boom of the 1870s and 1880s, his business relations with the merchant elite became less stable, as Hatfield alternately depended on or challenged their economic support of his ventures. Several of these men sought to capitalize on Hatfield's misfortunes during the Feud period. For a detailed analysis of Devil Anse Hatfield's relationship with the Logan Courthouse elite, see Waller's Feud. 
Democrats faced losing control of the state in the 1894 midterm elections. Desperate to hold as many counties as possible, one group of Democrats devised a scheme to transform loyal Logan into two counties. In the summer of 1894, the citizens of Logan Courthouse gathered in the streets of the town to celebrate the venture's success with a grand barbeque. ${ }^{169}$ Unfortunately, the creation of the new county was not made official until the state legislature convened in 1895 . By that time, the Democrats had lost West Virginia. Although Logan remained loyally Democratic, the Republican Party carried thirty-three of the state's fifty-four counties, and all four Congressional seats. ${ }^{170}$

Chapter 3 chronicles the political ramifications of the decision to divide Logan County. Born in a time of intense factional discord in the Democratic party and the emergence of a powerful Republican party in southern West Virginia, Mingo became the region's most politically fractious county. The constant battle for local primacy among the elites and powerbrokers of Mingo County overshadowed all other concerns and profoundly affected economic and social relations in the county.

${ }^{169}$ Charleston Daily Mail, 21 July 1894 (reprint of an undated article from the New York Tribune).

${ }^{170}$ McKinney, Mountain Republicans, 156. 


\section{PART II: THE INDUSTRIAL TRANSITION, 1895-1911}




\title{
CHAPTER 3
}

\section{THE CREATION OF MINGO COUNTY AND THE PATTERN OF COUNTY POLITICS,} 1895-1911

\author{
"The actual accomplishment of the new county set up \\ was not simply automatic ....[it] required considerable \\ conniving, ... and a whole lot of friendly co-operation." \\ -- Dr. Sidney B. Lawson
}

Historians who have analyzed southern West Virginia have asserted that the region's industrialization destroyed traditional patterns of political behavior. The new elite and the company towns they constructed transfigured community life, eradicating customs learned in the formerly homogeneous communities. ${ }^{2}$ The mountain patriarch and his loyal clan, they allege, was replaced by the omnipotent coal operator who owned the communities and controlled the lives of the men he employed. As long as they could not autonomously combine and challenge the operator's power, his politics were their politics, and the mountaineers turned miners were thus, in essence, disfranchised. Those who have held this opinion cited as evidence the political hegemony and absolute power exercised by the coal operators and their minions in Logan, McDowell, and Mercer counties. ${ }^{3}$

${ }^{1}$ Lawson, Fifty Years, 47. Lawson sponsored the bill that created Mingo County.

${ }^{2}$ This view of the transformative effect of industrialization has been argued by both John Alexander Williams and David A. Corbin. See Williams, Captains of Industry, 117-120 and Corbin, Life, Work, and Rebellion, 12.

${ }^{3}$ While it is true that a single party controlled politics in each of these counties, in McDowell, Mercer, Raleigh, and Fayette counties, it was the Republican party, while in Logan, it was the Democratic party. No scholar has pondered the significance of the party switch from east to west in southern West Virginia, or that the buffer between the two areas is Mingo, which never, during this period, passed into the unassailable control of either party. 
This study acknowledges that a new elite entered southern West Virginia with the arrival of the rail and coal men in the 1880s and 1890s, and agrees that the free expression of individual political preference was severely constrained by the coercive power of the coal companies. However, at least in Mingo County, traditional mountain politics survived into the industrial era. The clan patriarchs gave way, not to the coal operators, but to party bosses whose power derived not only from the patronage of the coal companies, but also from their ability to manipulate the traditional style of politics to keep challenges to the new order out of public discourse. ${ }^{4}$ In part because outsider capitalists entered the Tug Valley at roughly the same time from different directions, before Mingo was created, dual and dueling alliance systems emerged and thrived, preventing the construction of a single hegemonic center of political power in the county. This unique development ultimately contributed to Mingo County becoming the epicenter of the struggle that led to the Matewan Massacre.

Between 1895 and 1911 the five central elements of Mingo County politics emerged: the battle for political primacy between Williamson and Matewan, the lack of party unity and recurrent "bolting," a propensity for election day violence, especially in Matewan, the creation and manipulation of diversion to subvert the political process, and the institutionalization of the necessity of purchasing Mingo's political loyalty. Participation by industrial elites in Mingo

\footnotetext{
${ }^{4}$ John Gaventa explains this phenomenon in Power and Powerless: Quiescence and Rebellion in an Appalachian Valley. According to Gaventa, instead of effectively dealing with the issues of equitable taxation and infrastructure development and maintenance, local politics were reduced to "ritualized battles" over corruption, stolen ballot boxes, various and sundry "dirty tricks," and broken promises. As this and subsequent chapters will show, Gaventa might as well have been describing Mingo County, not the Clear Fork Valley in the Cumberland Gap region of Kentucky, Virginia, and Tennessee. John Gaventa, Power and Powerless: Quiescence and Rebellion in an Appalachian Valley (Urbana: University of Illinois Press, 1980), 144.
} 
politics did not substantively affect these systemic patterns of behavior. In fact, by choosing to ally with factions led by native elites, the coal elite facilitated the apparently syncretistic rebirth of the Hatfield family's political power in the county. ${ }^{5}$

\section{The Creation of Mingo County: A Reexamination}

The Bill authorizing the creation of Mingo County was passed on January 23, $1895 .{ }^{6}$ The last West Virginia county to be created, the West Virginia legislature carved Mingo from Logan County for a variety of political and economic reasons. Politically, the mid-1890s were a tumultuous period in West Virginia politics, and the bill creating Mingo was passed in the first legislative session dominated by the Republican party in over twenty-five years. ${ }^{7}$ For decades historians have assumed that the ascendancy of the Republican Party, in both the state government and in southern West Virginia, precipitated the cleavage of the Democratic Party's most loyal county. ${ }^{8}$ However, a closer examination of the motivations and actions of the principal players in Mingo's early development reveals that both Republican and Democratic politicians, as well as industrial entrepreneurs sought to manipulate the new county's founding to their advantage.

${ }^{5}$ The term syncretistic is used here because the leader of the Hatfield reemergence, Dr. Henry D. Hatfield, built a political machine that simultaneously drew support from a traditional kinship network, the operator-backed southern West Virginia Republican organization, and the desire for genuine political reform across party, economic, and regional lines throughout the state.

6"Chapter 68: An Act establishing the County of Mingo," Acts of Legislature of West Virginia, Twenty-Second Regular Session (Charleston, WV: Moses W. Donnally, 1895): 212-214.

${ }^{7}$ Rice and Brown, 208.

${ }^{8}$ Williams, "New Dominion," 391. 
First put forth in the 1890s by a disgruntled Henry Clay Ragland, the Democratic editor of the Logan Banner, the theory that Mingo's creation resulted from a "Republican Statehouse conspiracy" has been accepted as fact by historians for several reasons. ${ }^{9}$ First, the Republican Party regained control of the West Virginia legislature in the 1894 midterm elections. Second, because the political power of the Hatfield family was so strong in western Logan County, the defection of several Hatfields to the Republican Party seemed to indicate that it was the Republicans who had the most to gain from the division of Logan County. The third and primary reason for the general acceptance that Republicans were behind Mingo's creation is that as the railroad and coal industry had moved into other southeastern West Virginia, the counties of Mercer, McDowell, Fayette and Raleigh had become Republican strongholds. ${ }^{10}$ Because the public offices of those counties were dominated by Republicans, and supported by the coal operators and the railroad, historians have drawn on the voluminous records of the manuscript collections of the operators' associations and the operators' private papers to construct an image of the southern West Virginia counties as a solid Republican bloc. ${ }^{11}$

The assumption that Mingo was just one of several obedient Republican counties has obscured a significant aspect of the county's history that profoundly influenced subsequent events. Unlike in Logan, McDowell, and Mercer, political control of Mingo County shifted from one party to another with nearly every election. To know why political influence was so divided in Mingo County, the story of the county's founding has to be reexamined.

\footnotetext{
${ }^{9}$ Logan Banner, 20 October 1898, quoted in Cubby, "Transformation," 188.

${ }^{10}$ Williams, Captains of Industry, 230.

${ }^{11}$ Ibid.
} 
While it cannot be disproven that Republicans were behind the division of Logan County, previously ignored sources reveal that several Democrats played significant roles in the accomplishment of the deed. ${ }^{12}$ In his memoirs, Fifty Years a Country Doctor, the man who proposed the bill that created Mingo County, Dr. Sidney B. Lawson, asserted that he and another Democrat, H. K. Shumate added names to the Mingo "enumeration" and made corrections to the surveyor's work to keep one or both of the counties Democratic. ${ }^{13}$ Lawson stated simply that the Democrats supervised the division because they feared that to not do so would "either make the new or leave the old county more or less of Republican complexion." ${ }^{14}$ Lawson, while a lifelong Democrat, was also a close personal friend and professional associate of Henry D. Hatfield, who became southern West Virginia's most famous native Republican. Lawson and Hatfield were cofounders of the Hatfield-Lawson Hospital in Logan. ${ }^{15}$ Lawson's summation of Mingo's creation as the result of "considerable conniving, many hours of tiresome work and a whole lot of friendly cooperation" reinforces the assertion that Democrats played an equally important role. ${ }^{16}$

\footnotetext{
${ }^{12}$ The most unequivocal piece of evidence that Democrats wanted to divide Logan is the following: The Williamson Mining and Manufacturing Company "paid all of the expenses for the surveys made by the engineers to make a separate county." Phil M. Conley, "The Founder of the City of Williamson," West Virginia Review 2 (February 1925): 162.

${ }^{13}$ Lawson, 48.

${ }^{14}$ Ibid.

${ }^{15}$ Ibid.,, 47. Like Henry D. Hatfield, Lawson could be described in some aspects as a "Progressive." He notes with pride that in addition to the bill creating Mingo County, he proposed bills requiring the use of silver nitrate to protect newborn eyesight and also doctors to pass a state examination.

${ }^{16}$ Ibid., 48.
} 
An anecdotal history of Mingo County published in 1960 corroborates the "cooperation" story first set forth by Sidney Lawson. In An Early History of Mingo County, Nancy Sue Smith claims that the new county resulted from a political compromise between Wallace J. Williamson, an emerging Democratic force in western Logan County, and Republican state senator James A. Hughes of Huntington. ${ }^{17}$ According to Smith, in return for allowing the creation of the new county, Hughes was allowed to name the first sheriff. ${ }^{18}$ Two facts enhance the credibility of Smith's account. First, James A. Hughes was the brother-in-law of Z. T. Vinson, Wallace J. Williamson's closest business associate. ${ }^{19}$ As in the case of Sidney B. Lawson and Henry D. Hatfield, Williamson's and Hughes' differing political affiliations should not overshadow the non-political and probably closer personal and business ties of the two men. Second, the phraseology of the story, that Williamson rewarded Hughes' "cooperation," implies that the proactive agent was Williamson the Democrat, not Hughes the Republican.

The last and most significant line of evidence that points to a Democratic desire for the division of Logan County centers on the role of Wallace J. Williamson. In the early 1890s Wallace J. Williamson, Z. T. Vinson, and a group of associates incorporated the first mining company of the new Thacker coalfield. ${ }^{20}$ This same group of bankers, lawyers, timbermen and

\footnotetext{
${ }^{17}$ Nancy Sue Smith, An Early History of Mingo County, West Virginia (Williamson, WV: Williamson Printing Co., 1960), 8-9.

${ }^{18}$ Ibid.

19 "Memorial for Congressman James A. Hughes" Memorial Services Held in the House of Representatives of the United States, Seventy-First Congress, 2d Session, House Document \#506 (Washington: GPO, 1930), 35.

20"Incorporation of the Williamson Mining and Manufacturing Company," in Acts of the Legislature of West Virginia, Twentieth Regular Session (Charleston, WV: Moses W. Donnally,
} 
capitalists bought the Williamson family homestead and created a town. ${ }^{21}$ When the N\&W designated the new town the western terminus of its Ohio Extension, Williamson was poised to eclipse Logan Courthouse, the county seat of Logan.

The years Wallace J. Williamson spent as a timberman and banker in Catlettsburg, Kentucky probably affected his aspirations for Williamson the town. Unlike West Virginia, which until 1895 had only fifty-four counties, Kentucky had nearly one hundred. In Kentucky, counties were often created for base economic and political motives. Land speculators pushed for the establishment of counties in order to increase the value of their holdings, which often became the center of the new county. Politicians often sought the creation of counties as gerrymanders to maintain or expand their influence because the new county created more public offices to distribute and control. ${ }^{22}$

After spending the formative years of his career in Kentucky, Williamson seized the opportunity presented by the pending arrival of the railroad to look homeward. However, despite the influx of capital, including his own, and connection to powerful state leaders, political control of Logan had eluded Wallace Williamson. Logan County remained under the control of a

1891), 88. The incorporators were: Z. T. Vinson, Wallace J. Williamson, R. H. Prichard, J. C. Alderson, J. Q. Dickinson, and T. H. Harvey.

${ }^{21}$ Logan Banner, 16 July 1891 . The men behind the new town project were identified as: Z. T. Vinson, Wallace J. Williamson, R. H. Prichard, T. H. Harvey, J. Q. Dickinson and J. C. Alderson.

${ }^{22}$ Robert M. Ireland, Little Kingdoms: The Counties of Kentucky: 1850-1891 (Lexington, KY: University Press of Kentucky, 1977), 2. 
competing Democratic faction. ${ }^{23}$ Williamson's town, with its railroad connection, coal companies, bank, and other businesses, was a ready-made county seat, if only there could be a new county. ${ }^{24}$

In January 1895, Dr. Sidney B. Lawson whose family lands bordered the Williamson farm on Pond Creek, took his seat as a first time member of the West Virginia House of Delegates, and proposed the division of Logan County. The bill passed on January 23, and was approved by Democratic governor William Alexander MacCorkle on January 30, 1895. ${ }^{25}$ Williamson was named as county seat "until otherwise provided by law," and three county commissioners were appointed to serve until the general election of $1896 .{ }^{26}$ Between February 1895 and November 1896, the blueprint of Mingo's political future took shape. A pattern hallmarked by bitter rivalry between the county seat and outlying towns and districts, vicious factional in-fighting, and elections so corrupt, the nickname "Bleeding Mingo" appeared a decade before labor strife ever occurred. ${ }^{27}$

${ }^{23}$ See Chapter 2 for details on the conflict between Williamson and the coalition faction comprised of former Governor E. Willis Wilson and Governor William Alexander MacCorkle.

${ }^{24}$ See pages 215-234 of Lewis' Transforming the Appalachian Countryside for more on this phenomenon in West Virginia during the industrial transformation period. As Lewis found in at least two cases, similar situations in Tucker and Randolph Counties resulted in "county seat wars."

25"Act Establishing Mingo County," Acts of the West Virginia Legislature, 1895, 214.

${ }^{26}$ Ibid., 213. The three commissioners were: J. K. Anderson, J. L. Deskins, and Alex Stafford.

${ }^{27}$ undated "Bleeding Mingo" newspaper articles circa 1908 election, Roy H. Keadle Papers, West Virginia and Regional History Collection, West Virginia University. The bulk of this small collection consists of newspaper clippings, correspondence, and political and social ephemera, which were pasted into a ledgerbook. 


\section{The Pattern of Mingo County Politics Emerges, 1895-1902:}

One of the primary reasons for the political turmoil that beset Mingo at its birth was the competition over the permanent location of the county seat. ${ }^{28}$ Scarcely a month after the creation of the county, a public meeting was held at Burch (Mouth of Rockhouse) to challenge Williamson's right to remain county seat. ${ }^{29}$ Before Williamson and Matewan appeared in 1891, Burch had a population of 150 , two general stores, a post office, a combination saw and grist mill, two carpenters and a blacksmith. ${ }^{30}$ However, by 1895 both Williamson and Matewan had surpassed Burch in population and occupational diversity. ${ }^{31}$ Rockhouse, also known as Burch was a tiny village, off the rail line, "with only its central location to recommend it." ${ }^{32}$ In the years between Mingo's founding and the Massacre, Burch, like several other older communities in the county off the railroad or without coal development, stagnated as newer communities prospered and grew.

As the other significant contender for county seat, in 1895 Matewan had less than half of Williamson's population and business development. ${ }^{33}$ However, as the political center of

\footnotetext{
${ }^{28}$ W.T. Meade, a leading Democrat from the northwest section of the county and the Democratic candidate for sheriff in the first county elections of 1896, later claimed that he lost the election because "the Williamson crowd sold him out to gain the the necessary votes to locate the county seat in Williamson." Mingo Republican, 30 July 1914.

${ }^{29}$ Logan Banner, 27 February 1895, quoted in Cubby, "Transformation," 172.

${ }^{30} 1891-1892$ Gazetteer and Business Directory.

${ }^{31}$ 1895-1896 Gazetteer and Business Directory.

${ }^{32}$ Cubby, "Transformation," 172.

${ }^{33} 1895-1896$ Gazetteer and Business Directory.
} 
Magnolia district, Matewan's prominence was enhanced by its position as the homebase of the county's first prominent Republicans (including several Hatfields) and also because the first large coal operation at nearby Thacker rivaled Williamson in size. ${ }^{34}$ In 1896 the vote for Williamson's retention of the countyseat was 821 for and 804 against. ${ }^{35}$ Although a victory for Williamson, the near parity in the number of votes presaged the future temper of county politics. The balance of power in the county would swing back and forth between Williamson the county seat, financial and industrial center, and Matewan, the center of the county's second largest industrialized district. $^{36}$

A second reason for continuous upheaval in Mingo County politics between 1895 and 1920 was the factional in-fighting and party jumping engaged in by Republicans and Democrats. Although the founders of Williamson were Democrats, the other Democrats in what became Mingo County considered them interlopers. ${ }^{37}$ In the quarter century between the county's founding and the Massacre, Democrats from the "rural districts" of the county often coalesced into a minority opposition party within a party. The issues that fostered internal opposition were

${ }^{34}$ Ibid. Williamson's population was 500; Thacker's was 400.

${ }^{35}$ Mingo County Court Commissioners' Record Book no.1, page 173, quoted in Cubby, "Transformation," 72, note 72.

${ }^{36}$ Initially Williamson was part of Lee District but was eventually redistricted independently. From 1895 through 1920, in population and coal employment figures Williamson/Lee District and Matewan/Magnolia district were roughly equal in size.

${ }^{37}$ Cubby, "Transformation," 171. According to Cubby this opinion arose from the belief that the Williamson Mining and Manufacturing Company was backed by outside capital. Cubby cites three Logan Banner articles from the Spring of 1895 to support this assertion. The animosity may also have been a carry over of the Logan County Camden-Wilson faction wars of the early 1890s. See Chapter 2 for details. 
the distribution of patronage positions and the allocation of county and state funds for roads and similar infrastructure improvement projects. $^{38}$

The election of 1896 was the first general election for the new county. Fraught with political and personal tensions the campaign and election set the standard for subsequent elections in Mingo. News coverage from the Logan Banner reveals that the burning national debate over the Gold Standard carried into southern West Virginia. Stuart Wood, a Philadelphia capitalist and land speculator, who owned thousands of acres in southern West Virginia, weighed in on the local debate of the issue with a patronizingly pointed analogy. In reply to a Ragland editorial, Wood wrote that "the business community 'would no more adopt a silver currency ... because it cost less than gold than Anse Hatfield would buy a cheap gun if he were expecting visitors from Pike County." 39 Wood's attempt to sway the voters of Logan and Mingo counties died unheeded. Mingo and Logan went for Bryan, Mingo by a majority of six hundred votes. ${ }^{40}$

Although Republicans dominated the most powerful public offices for the year between the county's founding and the first general election, the incumbents did not fair well in the fall of 1896. The only Republican victors for local offices were N. J. Keadle who was elected sheriff,

\footnotetext{
${ }^{38}$ See Chapter 6 for a detailed discussion of the faction wars between Mingo's "County" and "City" Democrats. The leadership of the County faction came predominantly from Matewan, in Magnolia district, and Kermit, in Warfield district.

${ }^{39}$ Logan Banner, 30 September 1896, quoted in Cubby, "Transformation," 103-104. Although two newspapers reportedly had been started in Mingo by the Fall of 1896, no issues have been located by the author, hence the citation to a Logan Banner article, rather than one from Mingo County. Also, the West Virginia and Regional History Collection's issues from the 1896 Logan Bannerend with 10 June 1896.

${ }^{40}$ Cubby, 81; B. Randolph Bias, "Condensed Facts: Relating to the Republican Organization in Mingo County, W.Va," (n.p., n.d.), 2, Pamphlet 8662, Pamphlet Collection, WVRHC.
} 
and Jonathan Estep who was elected commissioner of the county court. ${ }^{41}$ The weak showing of the party that supposedly had conspired to create the county can probably be blamed on at least two factors. First, the coattail affect of Bryan, whose inflationary proposals lured anxious Mingo voters back to their traditional Democratic alignment. Second, there was dissension in the party ranks. Within days of the Mingo County's first Republican county convention, Hiram S. White one of the party's leading members, "bolted" the convention to support William T. Meade, N. J. Keadle's Democratic opponent for Sheriff. ${ }^{42}$ White's maverick shift in loyalty set a pattern of behavior that plagued Mingo County politics for decades.

The most significant and ominous occurrence linked to the 1896 general election in Mingo County was the fatal confrontation at Matewan between "Cap" Hatfield and the mayor's son, John Rutherford. Unrelated to the feud, the gun battle which left three men dead serves as an example of the link between politics and public violence in the County and establishes yet another pattern in local politics -- Matewan as a focal point for election day disorder. ${ }^{43}$

On election day 1896, Cap Hatfield and his stepson Joe Glenn arrived in Matewan armed, but in accordance with a town ordinance, surrendered their weapons to Mayor Rutherford. Hatfield and Glenn reportedly spent the day avoiding the mayor's son John Rutherford with

41 "Condensed Facts," 2, P8862, WVRHC.

${ }^{42}$ Ibid., 1-2. At the 1896 Mingo County Republican convention, the first Central Committee (one representative from each magisterial district) chosen consisted of: N. J. Keadle, R. B. Clark, Henry D. Hatfield, W. A. Johnson, and J. B. Bartram. In turn the Central Committee elected the following to serve as the Executive Committee: N. J. Keadle, chairman, J. K. Anderson (one of commissioners of the county court), secretary, E. E. Musick and James Turner.

\footnotetext{
${ }^{43}$ Examples of subsequent election day violence in Matewan include: the general elections of November 1896 and 1910, and the municipal election of 1919.
} 
whom Cap shared some unknown antagonism. Not long before Cap's intended departure from the town, and after he and Glenn had reclaimed their weapons, trouble began at Hiram S. White's store, which was also the town's polling place. When the younger Rutherford and several friends who had been drinking confronted Cap, he shot Rutherford, and then Rutherford's brother-in-law Henderson Chambers, who had rushed from White's store to see what was happening. John Rutherford's nephew Elliott Rutherford was shot by a hidden Joe Glenn, because Glenn feared that Rutherford was in turn about to shoot Cap who was facing in another direction. ${ }^{44}$

Although sources do not reveal how, Cap and Glenn escaped immediate arrest. After eluding Sheriff Keadle's posse for several days, Hatfield and Glenn were captured on Grapevine Creek by two detectives, J. H. Clark and Dan Christian. According to several accounts, Sheriff Keadle convinced Devil Anse to allow the "rule of law to prevail" and Cap and Joe Glenn were tried for the three deaths in April 1897. Cap was convicted of involuntary manslaughter and sentenced to one year in the county jail. Glenn was sent to the West Virginia Reform School for Boys in Pruntytown. Allowed great liberties during his incarceration, Cap "escaped" after a particularly noisy party and after a brief absence simply went home. According to noted West Virginia and Hatfield-McCoy Feud historian Dr. Otis K. Rice, Keadle and the other county officials had tired of the extra expense of holding their notorious inmate, and decided not to force Cap to return to jail. ${ }^{45}$

\footnotetext{
${ }^{44}$ Rice, Hatfields and McCoys, 118-119. Dr. Rice identifies the Mayor as "Dr. Jim" Rutherford, but Historic Survey Records and Nancy Sue Smith identify Mayor Rutherford as Elliott Rutherford. Supervisor's Report on Mingo County history, 3 January 1938, Historic Records Survey, Mingo County, Reel 125, WVRHC, and Smith, Early History, 6.

${ }^{45}$ Rice, Hatfields and McCoys, 119-120. After Cap and Joe Glenn escaped Matewan on November 3, 1896, Elliott and Lewis Rutherford circulated a handbill promising a \$500 dollar
} 
While a relatively minor event, the narrative of the 1896 election day shooting in Matewan swirls with several significant enigmas. First, the Rutherfords and Hatfields had been close, as evidenced by Devil Anse naming one of his sons after Dr. Elliott Rutherford. ${ }^{46}$ What had occurred between the 1880s and 1896 to sour the relationship, or was the ill-feeling simply between Cap and John Rutherford? Second, did Cap's murder of Henderson Chambers create an antagonism between members of the Chambers and Hatfield families that would resurface in Matewan's future political contests when the Republican Hatfields faced off against the Democratic Chambers? Third, why did violence finally erupt in front of the polling place, Hiram S. White's store, and moreover what role, if any did White play in this scenario? White, (the same White who had been a Democrat in Logan) had openly antagonized Sheriff Keadle by bolting the party to support Keadle's opponent, and was also the uncle of M. Z. White who, by 1920 had become co-chairman of Mingo's Republican Party along with Greenway Hatfield, Cap's first cousin. ${ }^{47}$ Unfortunately no public records shed light on these questions, however, this event occurred when several old alliances were disintegrating or changed irrevocably.

reward for their capture. The two detectives Clark and Christian tracked and caught Hatfield and Glenn. Clark could not claim his portion of the reward outright because he had outstanding criminal charges of his own, so he signed over his share to Lewis Runyon. On January 25, 1897, Clark and Christian sued the Rutherfords for payment. After several twists the suit was resolved by a decision of the West Virginia Supreme Court of Appeals in 1904 and the Rutherfords were forced to pay \$307.50. "Runyon v. Rutherford," Reports of the West Virginia Supreme Court of Appeals, 55 (February 9 1904-June 1904), 436-442.

${ }^{46}$ Waller, Feud, 41.

47"M. Z. White," in West Virginia Heritage Encyclopedia 23:5079. H.S. (Hiram Solomon) White was the oldest brother of West Virginia's state geologist Israel C. White. Herman L. Fairchild, "Memoir (Memorial) of Israel C. White," (n.p., n.d.), 127. 
Perhaps the most important enigma in the story is the role of Sheriff N. J. Keadle. Born near the Wayne-Logan county line, after being orphaned Keadle was reared in Jackson County, Ohio by his uncles. According to his obituary, Keadle counted among his childhood friends both Mark A. Hanna and William McKinley. ${ }^{48}$ In the 1880 s, Keadle returned to Logan County and lived there until the new county was created in 1895. As mentioned earlier, local historian Nancy Sue Smith asserts that Republican Congressman James A. Hughes agreed to the division of the county primarily because he was allowed to select Keadle as Mingo's first sheriff. If the Hughes story is accurate, did Keadle possess some cachet because of his connection to Hanna and McKinley? On another level, did Keadle bear any influence or responsibility for Henry D. Hatfield's entry into the Republican fold? Keadle's obituary also noted that he counted Devil Anse among his closest friends and favorite hunting companions. ${ }^{49}$ How had this bond been forged? Is that why Keadle's posse did not capture Cap and why ultimately Keadle did not bother to re-incarcerate him? Regardless of these unanswered questions, Keadle's decision to allow Cap to just go home without finishing his sentence set another precedent in Mingo. Depending on who you were, regardless of what you had done, the Sheriff of Mingo possessed vast discretionary power over how you were punished. ${ }^{50}$

As discussion of later elections in Mingo County, and especially Matewan, will show, the county's competing factions orchestrated diversionary conflicts in order to diminish their

\footnotetext{
${ }^{48}$ N.J. Keadle obituary, Keadle Papers.

${ }^{49}$ Ibid.
}

${ }^{50}$ Actually this was a common reality at least in the South and especially Appalachia. In Little Kingdoms, Robert Ireland discusses the impact of the allegiances between "feuding" families and local sheriffs in the outcome of interelite violence. Ireland, Little Kingdoms, 77. 
competitors' presence at important political events. ${ }^{51}$ The first illustration of this behavior appears in a report by a leading southern West Virginia Republican to then Governor A. B. White. Edgar P. Rucker, an N\&W backed politician from eastern southern West Virginia described the 1902 Mingo County Republican convention thusly:

The Caldwell crowd, composed of a few respectable Republicans, a bunch of hirelings, and a crowd of Democrats, tried to create all the confusion possible in our Mingo Convention, but were outgeneraled and outvoted. ... The Caldwellites engineered the appearance of a bolt to induce our people to compromise in order to avoid a split. [But] Scott is clearly entitled to the delegation from [Mingo] and will get it. ${ }^{52}$

In this particular case, the state level conflict between Nathan B. Scott and J. L. Caldwell generated the local factional fighting. Caldwell's political ties and economic investments extended throughout southwestern West Virginia and crossed party lines, which unfortunately for his political aspirations proved to be a double-edged sword. His business associates included fellow southwestern West Virginians Wallace J. Williamson, a Democrat and Z. T. Vinson, who had only recently turned Republican. ${ }^{53}$ Caldwell's rumored support for William Jennings Bryan in 1896 also complicated his standing in the party. ${ }^{54}$ Scott was a powerful lieutenant to state

\footnotetext{
${ }^{51}$ Held less than a week after the Matewan Massacre, the 1920 primary election in Matewan was abnormally quiet and voter turn out small. After noting this the Williamson Daily News suggested that perhaps the two events were related. Williamson Daily News, 27 May 1920.

${ }^{52}$ Edgar P. Rucker to A.B. White (letter \#7981), A. B. White Papers, WVRHC.

${ }^{53}$ Along with Williamson and Vinson, Caldwell had invested in the Huntington and Kenova Land Development Company and the Williamson Mining and Manufacturing Company. He had also been involved in starting the town of Williamson. See Chapter 2 for citation details.

${ }^{54}$ Roper, 185 .
} 
Republican party leader Stephen B. Elkins, but previously had faced opposition from southern West Virginia Republicans. ${ }^{55}$

Both of the leading scholars of West Virginia politics, John Alexander Williams and Gordon McKinney agree that despite recurrent factional flare-ups, by 1900 the West Virginia state Republican party was far less fractured than the Democratic Party. ${ }^{56}$ Ironically, despite the evidence in the Caldwell-Scott struggle, Williams in particular denies the existence of regional animosity within the Republican Party. ${ }^{57}$ Gordon McKinney offers a more accurate explanation for the overarching unity among West Virginia Republicans. McKinney's Southern Mountain Republicans reveals that following Reconstruction, the Republican Party at both the national and state level reorganized itself into a "Party-Army" a hierarchical, militarily structured organization. ${ }^{58}$ Even the terminology of intraparty communications reflected this, as in the cited letter from Edgar P. Rucker to Governor White. When Rucker wrote to White of the defeat of the Caldwellites by Scott's supporters, he observed that the Caldwellites had been "outgeneraled." 59

${ }^{55}$ Williams, Captains of Industry, 82; Scott's problems with southern West Virginia continued into the next decade. In 1912 Scott supported Taft in the quest for the Republican presidential nomination while most southern West Virginians like Henry D. Hatfield supported Teddy Roosevelt. Carolyn Karr, "A Political Biography of Henry Hatfield,"West Virginia History, 28 (October 1966/January 1967): 35-63/137-170, 55.

${ }^{56}$ Williams, Captains of Industry, 230; McKinney, Mountain Republicans, 194.

${ }^{57}$ Williams, Captains of Industry, 230.

${ }^{58}$ McKinney, Mountain Republicans, 62-123.

${ }^{59}$ Rucker to White, White Papers, WVRHC. 
The final noteworthy incident in the Republican campaign of 1902 underscores both the character of Mingo County politicians and how the state Republican leaders kept the local Republicans in line. In 1902, B. Randolph "Dick" Bias was a young coal company attorney serving as postmaster of Williamson, when state party leader Nathan B. Scott named him the Republican candidate for the sixth district state senate seat. As described by his detractors, Bias, despite having a majority of four thousand loyal Republican votes in the district, "was avaricious enough to demand of senator Scott $\$ 3,000.00$ to make his campaign." Scott replied that "he was not a national bank and that [Bias] had better get down and out if it would cost him that much to make his campaign." Scott's lieutenants soon found a replacement for Bias, W. H. H. Cook, a Baptist minister from Wyoming County. Cook won the state senate seat and proved to be an ideal party hack. According to his critics, Cook rarely attended legislative sessions, and only appeared to vote for Scott." ${ }^{60}$

Scott's response to Bias' demand underscores that, as in a military structure, the true decision-making power in the Republican party emanated from the center. It also illustrates a more important political trend identified in McKinney's Southern Mountain Republicans. McKinney asserts that after the passage of civil sevice reform legislation, the river of patronage dried up and the leadership of both the Democratic and Republican parties resorted to direct cash

\footnotetext{
${ }^{60}$ Undated, unknown newspaper article in Keadle Papers, WVRHC. In 1894, W. H. H. Cook had been the Republican opponent of the then Logan County Democrat John A.Sheppard for a seat in the state legislature. At the time Cook was denounced as a "boodler" Logan Banner editor H. C. Ragland. Ragland depicted Sheppard as the defender of the small landholder and Cook as the tool of the railroad and outside corporate interests. Logan Banner, 13 September 1894 article reprinted in Charleston Daily Mail, 21 September 1894. See Chapter 2 of this work for a more thorough analysis of John A. Sheppard's role in the development boom that led to Mingo County's creation and Sheppard's own bolt to the Republican party.
} 
payment as a means of maintaining loyalty and rewarding faithful service. ${ }^{61}$ Thus, although the party created the atmosphere in which minor party officials and candidates like Randolph Bias could logically expect financial remuneration or assistance from their leaders, the power to grant the requests rested solely with those at the apex of the organization. When Bias demanded more than his party chief Scott deemed him worth, he was replaced with a less expensive and more malleable candidate. However, Scott and other state party leaders also learned how to secure the loyalty of Mingo's political leaders -- they could buy it.

III. Factionalism Undermines the Influence of the Coal Men, 1904-1911:

The factions that dominated the Republican and Democratic parties in Mingo County until 1920 were well-established by 1904. The Republicans were divided between the "Old Liners" and the "Regulars," while the Democrats were split between the courthouse elite and the leaders of smaller communities in the County's outlying districts. ${ }^{62}$ All four factions included native and outsider elites, all of whom in one way or another were dependent on Mingo's emergent industrial economy. Examination of the definitions of "native" and "industrial

${ }^{61}$ McKinney, Mountain Republicans, 143.

${ }^{62}$ The names of the Republican factions were given here because they can be documented in the sources cited for events discussed in this chapter. The lack of records on Democratic factional politics until 1911, when a reliable run of local newspapers begins prevents naming the Democrats' factions here. The only pre-1911 evidence of Democratic factional politics can be found in the anecdotal memoir of West Virginia governor John J. Cornwell. In 1904, Cornwell who was making his first bid for the governor's office visited Mingo and met with faction leaders Hi Williamson and outgoing Sheriff Greenway Hatfield, whom he misidentified as Ali Hatfield. John J. Cornwell, A Mountain Trail: To the School Room, the Editor's Chair, the Lawyer's Office, and the Governorship of West Virginia (Philadelphia: Dorrance and Company Publishers, 1939), 97. In-depth discussion of Mingo County Democratic politics begins in Chapter 6. 
dependence" underscores the complexity of Mingo's local politics, and illuminates some of the reasons why none of the factions could establish unassailable domination of the county.

Democrat Wallace J. Williamson and Republican Greenway Hatfield, as descendants of pioneering Tug Valley residents were true natives who also directly affected the county's development -- Williamson as a returning capitalist entrepreneur and Hatfield as a land agent for an outside corporation. Their factional opponents were G. T. Blankenship and Hiram S. White respectively, both "quasi-natives." An N\&W railway agent, Blankenship came to Mingo in 1900 and married into the Chambers family of Matewan, who themselves had only arrived in the Tug Valley in 1870, but had intermarried with the Hatfields. The brother of West Virginia state geologist Dr. Israel C. White, Hiram S. White had come to Logan Courthouse in the 1870s and then Matewan in the early 1890s. Hatfield and Williamson built "machines" whose domination of local politics was periodically challenged by the factions led by White and Blankenship. White's faction consisted mainly of disaffected Republican coal industry elites. The bolts of White's faction also followed the pattern of the schismatic national Republican politics between 1900-1912. By contrast, Blankenship and his Chambers in-laws gradually established a reputation as the advocates of the people most threatened by the coal industry: the miners, farmers, and independent small businessmen of the county. ${ }^{63}$

As revealed by the 1896 election day incident involving Cap Hatfield, Matewan possessed a notorious reputation almost from its birth, and a quarter of a century before the Massacre. Although the historic record of the 1896 events do not reveal any political

${ }^{63}$ Citations for the biographical details of these four individuals have or will appear in other sections of this study. Citations for their economic activities appear in discussions of their political activities that most clearly reflect their business orientations. 
underpinning for the violence of that day, what happened in Matewan on election day 1904 set a pattern for the interconnectedness of physical intimidation and political control of the town. Moreover, the story of Matewan's role in determining Mingo's disputed 1904 election also illuminates how domination of Matewan directly influenced the balance of power in the County.

The general election of 1904 was held on November 8. The elections of the sheriff, house of delegates representative, county assessor, prosecuting attorney, county commissioner for the short term and county commissioner for the full term were all contested. As a result, the determination of which party would control the county through these offices could not be finalized until late February, 1906, more than seventeen months after the votes were first tabulated. In the meantime a total of seven cases detailing the conduct of the election went before the West Virginia State Supreme Court of Appeals. ${ }^{64}$ As a body of evidence themselves, the case reports of the high court's decisions expose three aspects of political behavior in Mingo County.

First, several of the cases demonstrated that county officials repeatedly failed in their duty to prevent the subversion of the election's outcome. Before the election, the county court granted the request of several Republican politicians for the creation of new precincts and more

\footnotetext{
${ }^{64}$ The seven cases were: "Williamson, et al v. County Court," "Hurst, et al v. Same," "Stafford, et al v. Same," (These cases were heard together), Reports of the West Virginia Supreme Court of Appeals, 56 (June 14, 1904): 38-43; "Stafford v. Board of Canvassers," Reports of the West Virginia Supreme Court of Appeals, 56 (June 14, 1904): 670-675; "Stafford v. Sheppard," Reports of the West Virginia Supreme Court of Appeals, 57 (January 24, 1905April 25, 1905): 81-90; "Stafford v. County Court," Reports of the West Virginia Supreme Court of Appeals, 58 (April 25, 1905-February 6, 1906): 88-94 and "Williamson v. Musick," Reports of the West Virginia Supreme Court of Appeals, 60 (April 24, 1906-November 27, 1906): 58-75. Citation for the duration of the controversy was derived by mathematical deduction, the date of the election to the conclusion of the last case found in "Williamson v. Musick," 59.
} 
convenient voting places. Although Democrats appealed the decision based on West Virginia statutory requirement that "no consolidation, division, change or alteration [could be] made in any election precinct within ninety days preceding any election," the state supreme court upheld the county court action. Despite the obvious violation of state law, the high court decided that Mingo's county court had acted appropriately in creating the new precincts and more important that in seeking satisfaction through a writ of prohibition, the Democrats had sought redress through the wrong legal action. ${ }^{65}$

The failure of Mingo County officials to protect election evidence after November 8, however did draw criticism from the high court. Because the county clerk refused to take possession of the precinct boxes containing the packaged ballots, the county court had been forced to prevail upon the Sheriff to guard the returns. The ballots sat in a courtroom for a week, until an official recount of the results could be undertaken. When the Mingo County Board of Canvassers met, the packages of the Matewan precinct appeared to have been tampered with, as a result, the victors in the races for sheriff and prosecuting attorney could not be determined without appeal to the state supreme court of appeals. ${ }^{66}$

Again, the high court sidestepped the implication of political corruption in the dereliction of duty by Mingo's county officials. Instead, the high court restricted its deliberations to whether even prima facie evidence of ballot tampering at one precinct "vitiated," or corrupted the

65"Williamson et al," 39-41. The case was submitted to the West Virginia State Supreme Court of Appeals on 29 September 1904, and decided on 18 October 1904.

66"Williamson v. Musick," 70,72,60. In Little Kingdoms, Ireland cites examples of the complicity of county court clerks, who by leaving their office doors open or unlocked, facilitated the theft, falsification, or destruction of records entrusted to them. Ireland, 145. 
election's entire outcome, or even at the precinct in question. In the final case affected by their decision, the justices acknowledged that they believed many of the Matewan ballots were suspect. However, the majority of the judges decided that because ballots were not the only evidence of the election's actual outcome, the "true result" could still be ascertained by throwing out only the questionable ballots from Matewan. By rejecting only a portion of the suspicious ballots the judges' decision threw the election from Democrat H. H. "Hi” Williamson to Republican E. E. Musick, even though if the Matewan results had been dismissed completely, Williamson would have won. ${ }^{67}$

The lengths to which the West Virginia State Supreme Court of Appeals went to avoid directly confronting the subversion of Mingo County's 1904 election is revealed by the contrast between the details offered about the course of election day in Matewan and the court's own attempt to protect the interests of the town's "honest voters." The court acknowledged twentyfive irregularities in the conduct of Matewan's election, including the presence of guns and alcohol on the poll's premises, and inappropriate treatment of voters by election officials. Two examples capture both the atmosphere at the poll in Matewan on November 8, 1904, and the supreme court's disregard for the evidence of "fraud." The court dismissed as immaterial the accusation that R. W. Buskirk "usurped" the legitimate poll clerk by "jabbing his pistol down in his pocket" and proclaiming, "By God, if I don't be poll clerk, nobody else will be!" The court also disregarded the testimony of one of the morning election commissioners who claimed that

\footnotetext{
${ }^{67}$ Ibid., and 74-75.
} 
he failed to vote because when he went to vote himself, he was first told he could not vote, and then told the denial was only a joke. ${ }^{68}$

The majority of the court's justices decided not to invalidate the entire election at Matewan because they feared that in so doing they were "disfranchising" the voters of Matewan. However, Judges Poffenbarger and McWhorter dissented angrily from the Court's decision. Judge Poffenbarger, passionately citing the breadth of the court's discretionary power, observed that if a court of contest could "see that a man is elected ... it has the power to declare him elected," regardless of the vote tally. Judge Poffenbarger chastised his fellow judges for their decision and cited as proof of their error the following assertion from the majority's own decision, "when it becomes apparent that an election is a subversion rather than expression of the will of the people, or that the result is attended with such uncertainty that it may not be ascertained, the election should be set aside." ${ }^{69}$

As Judges Poffenbarger and McWhorter realized, by not holding the politicians of Mingo County accountable for their actions, the West Virginia Supreme Court of Appeals not only validated acts of subversion, but also ensured future corruption of legitimate political processes in Mingo County. The Republicans had been allowed to regain control of the county for the first

\footnotetext{
${ }^{68}$ Ibid., 63-65. This story was included because Matewan's local lore is full of the characterization, "he was the kind of fellow who would be laughing and joking one minute and would kill somebody in the next minute." The Hatfields in particular were said to have this type of temperament. Ely, 203. One account of Sid Hatfield's approach to Albert Felts on the day of the Massacre illuminates the duality. Allegedly as Hatfield approached Felts during the Stone Mountain evictions, Felts ordered Sid to stop, telling him "this is private property" to which Hatfield replied, "That's alright, I'm a private man," and kept coming towards Felts. See Chapter 10 for full citation.

${ }^{69}$ Ibid., 75, 65.
} 
time in a decade, through legitimized theft. The lasting effect of the outcome of the 1904 election dispute was the creation of a blueprint for how to control Matewan's elections and thus influence the county election as well. ${ }^{70}$

In 1908 a statewide schism in the Republican Party highlighted the growing division in Mingo County's own Republican ranks. Although the first hint at the cleavage had come during the first county elections in 1896 when Hiram S. White bolted to support the Democratic candidate for sheriff, the deep-seated reasons for the antipathy between the "Old Line" and "Regular" factions had grown over a course of ten years. In the interim, control of the party passed from the "Old Liners" and their coal elite allies to the "Regular-Renegades" a group that eventually coalesced around Greenway Hatfield, a native elite with his own industrial ties. The events that marked the transference of power from the "Old Liners" to the "Regulars" fell largely between 1906 and 1908. For nearly a decade after the 1908 election, the various members of the deposed "Old Liner" faction alternated between acquiesence to Hatfield rule and co-option of schismatic national Republican third party issues in their efforts to overthrow the Hatfielddominated "Regular" faction. ${ }^{71}$

Despite bolting the party in 1896, Hiram S. White's "Old Liner" faction dominated the county Republican Executive and Central Committees for several years. Like White, the other

\footnotetext{
${ }^{70}$ At the time of the 1904 Election dispute, it should be noted that all five justices of the West Virginia State Supreme Court of Appeals were Republicans. Lewis, Transforming the Apppalachian Countryside, 112. The role of the Court in solidfying Republican primacy throughout the state is also addressed by Lewis in this work; see Chapters 3 and 8 of Transforming the Apppalachian Countryside.

${ }^{71}$ The 1914 political campaign was particularly fractious for Mingo's Republicans. Throughout the year, Bias, Leftwich and other former "Old Liners" fought the Hatfield Machine as much as they did the "Democracy." Mingo Republican, 20 April 1914 and 28 October 1914.
} 
"Old Liners" had been drawn to Mingo because of its industrial development. The Old Liners based in Williamson were represented by B. Randolph Bias and Everett Leftwich, attorneys who represented and invested in the local coal companies, and brokered land development deals. ${ }^{72}$ The other industry men were actual coal entrepreneurs such as James Little or corporate managers like S. T. Lambert. ${ }^{73}$ The issues championed by the "Old Liners" reflected turn-of-the century business progressivism: fiscal accountability in local government, opposition to blatant patronage system abuses, and equitable expenditure of tax revenue. ${ }^{74}$ Unfortunately, the "Old Liners" had to vie for control of Mingo not only with the Democrats who controlled Williamson, (and the county until 1904), they also had to fend off an insurgent movement in their own party.

From 1900 until 1906 every addition of an "Old Liner" to an executive position in the Count party was matched by one from the "Regular" faction. The "Regulars"'s names reveal the primary source of their influence: S. A. Ferrell, A. G. Rutherford, and John A. Sheppard. Ferrell and Rutherford, like Greenway Hatfield, who joined them on the Executive Committee in 1906,

\footnotetext{
72"B. Randolph Bias" in 1905 Progressive West Virginians. Robert E. Murphy, compiler, Progressive West Virginians: Some of the Men Who Have Built Up and Developed the State of West Virginia (Wheeling, WV: The Wheeling News, 1905), 271; Leftwich in same, 97.

${ }^{73}$ A native of Scotland, James Little personifies the early presence of the migratory coal entrepreneur in Mingo. His biographical information was found in the returns of the Twelfth United States Census (1900). The James Little Coal \& Coke Company started operations in August 1897. Coal Trade Journal 36 (25 August 1897): 454; The James Little company appeared in the Annual Report of the West Virginia Department of Mines from 1897-1899. Lambert's personal background is detailed in a 1908 political advertisement from an 11 February 1908 unknown newspaper clipping, Keadle Papers, WVRHC.

${ }^{74}$ Ibid.
} 
were scions of pioneering Tug Valley families. ${ }^{75}$ Sheppard, although a Virginia native, had gained local prominence and trust during the early phase of the King Case. ${ }^{76}$ However, the difference between the "Old Liners' and the "Regulars" cannot be distilled down to a fight for primacy between the industrialists and traditionalists, natives and outsiders, reformers against machine men. Examples from their 1908-1910 factional warfare illustrate that neither groups' leaders allowed principle to interfere with the pursuit of power.

By the time the West Virginia legislature met in special session in the Spring of 1908, Mingo's Republicans were deeply divided. When state senator and "Old Liner" Hiram S. White proposed a bill calling for the creation of a Mingo County criminal court, Delegate and "Regular" F. H. Evans, also of Mingo, opposed the bill even though he had sponsored a criminal court bill for the county in another session. ${ }^{77}$ This lack of unity in the county's legislative delegation however, only hinted at the warfare to come.

The primary excuse for the open confrontations between Mingo's Republicans in 1908 centered around the selection of the 1908 Republican candidate for governor. ${ }^{78}$ Of the two leading candidates, secretary of state Charles W. Swisher and attorney general Arnold C. Scherr, only Scherr had a direct connection to Mingo. His son, Harry after graduating from West Virginia University's Law School, had moved directly to Mingo in 1905, and rapidly ascended

\footnotetext{
${ }^{75}$ Confirmation of this assertion can be found in the discussion of pioneering families in Ely, Jillson, and Waller, Feud. See Chapter 1 for complete citations of their works.

${ }^{76}$ Sheppard's biographical facts can be found in 1905 Progressive West Virginians, 101.

${ }^{77}$ Miscellaneous 1908 newspaper clippings, Keadle Papers, WVRHC.

${ }^{78}$ Ibid.
} 
the party ranks. ${ }^{79}$ The younger Scherr, who resided in Williamson, had aligned with the "Old Line" faction led by Hiram S. White. ${ }^{80}$ The fight over which candidate Mingo's Republicans would support revealed the reasons for the division between the "Old Line" and "Regular" factions. The local issues that disrupted County level politics included accusations of fiscal corruption and the growing dependence of one faction on African-American voters.

The acrimony deepened to the point that White's faction produced its own newspaper, "The Old Liner," in Matewan in order to exorciate their rivals for using elected office to enrich themselves and their own districts. For example, "The Old Liner" claimed that the poor people of Mingo County should oppose the road tax because all the money went to Guy White and R. W. Buskirk for roads between Matewan and Thacker, which had left "the rest of the county with poor roads and less development." The "Regulars" also were accused of bleeding the public coffers dry with their expense reimbursement requests. The "Old Liner" published a list of the Regulars who had made reimbursement claims with the observation, "Just read ... the figures and you will see why this gang wants the earth and a fence around it -- [and] wants no 'Old Liner' on the Executive Committee." Twelve individuals and one law firm on the reimbursement claim list declared the county owed them over fifty-two thousand dollars. E. E. Musick, the incumbent Sheriff, claimed twenty-three thousand or nearly half the total amount. His fellow claimants

\footnotetext{
${ }^{79}$ George S. Wallace, Cabell County Annals and Families (Richmond: Garrett \& Massie, 1935), 482-3. Harry Scherr had served as assistant prosecuting attorney since 1905 and in 1906 had been elected treasurer of the county organization.

${ }^{80}$ Details of Scherr's movements through the ranks of Mingo's Republian leadership can be found in "Condensed Facts," P8662, Pamphlet Collection, WVRHC.
} 
included: Guy White, Greenway Hatfield, R. W. Buskirk, John Sheppard, James Damron, M. Z. White and Valentine Hatfield. ${ }^{81}$

The "Old Liner" assault on the integrity of the "Regulars," "To The Honest Voters of Mingo County" reveals the methods used by the "Regulars," also known as the Hatfields and their allies, to manipulate election results. According to the circular, the "Regulars" used "election day rumors," "stories" and "affidavits" to distract voters, "hired ruffians . . to bluff and bulldoze the decent," and ballot box stuffing to steal the election. The circular also urged the arrest of illegal voters, who were to be taken to Williamson. ${ }^{82}$

The charge to watch for illegal voting amounted to an open invitation to interfere with the voting by the county's African-American population. ${ }^{83}$ The connection between race and charges of illegal voting in the area dated from 1890, when Mingo was still part of Logan. ${ }^{84}$ Since the Republican loyalty of the African-American population in other southern West Virginia counties had helped transform those counties into Republican strongholds, efforts to gain control of Mingo's black voters waxed heavy. The relative smallness of the county's black population

\footnotetext{
${ }^{81}$ The Old Liner appears to have been a brief run newspaper published during the 1908 political faction wars in Mingo County. It is highly probable that some of the undated, unidentified newspaper articles previously cited from the Keadle Papers came from the Old Liner, however, this assumption cannot be verified. Keadle Papers, WVRHC.

82"To The Honest Voters of Mingo County" 1908 election broadside, Keadle Papers, WVRHC.

${ }^{83}$ In "West Virginia and the Election of 1896," Barbara Ferrell notes that both Republicans and Democrats "rounded up" African-American voters on election day; Republicans generally did so to "vote" the men at several precincts, while Democrats did the same to keep them from voting. Barbara A. Ferrell, "West Virginia and the Election of 1896" (Masters' thesis, West Virginia University, 1967), 37.
}

${ }^{84}$ See Chapter 2 for details. 
however, allowed for two-prong initiatives. ${ }^{85}$ While cautioning white voters to watch for efforts to coordinate illegal voting by African Americans, the "Old Liner" also invoked the racist actions of "Regular" politicians to undermine their attractiveness. In prior campaigns, "Regular" John A. Sheppard allegedly circulated "the picture of a colored schoolteacher whipping a white child and preaching the doctrine of negro equality." ${ }^{86}$ The paper also charged Sheppard with "[helping] Judge Evans with his famous Jim Crow Bill." ${ }^{17}$

Despite the efforts of the Old Liner, the "Regulars" overwhelmed the "Old Line" Republicans at the county convention. Their success stemmed from two significant developments. First, M. Z. White and Greenway Hatfield had masterminded a Democratic bolt that swelled the "Regulars" ranks by fifty. ${ }^{88}$ Second, the "Old Liners" were betrayed from within by a "Judas ... who . . sold out his party ... to Mont and Jack," when Bias broke from

\footnotetext{
${ }^{85}$ In 1916, Mingo's Democrats undertook a similar campaign. See "Damaging Facts Disclosed,"Williamson Daily News, 2 November 1916 and "Vote for George Wiles and Be Safe," Williamson Daily News, 4 November 1916.

86"When Johnie Comes Marching Home" Old Liner, 21 March 1908, newspaper article in Keadle Papers, WVRHC.

${ }^{87}$ Ibid. The Evans' Jim Crow bill controversy illuminates an important difference between the Mingo's Republicans and the State Party leaders. By 1908, whatever their personal feelings, the State Republican leadership accepted the growing importance of the industrial black vote in maintaining control of the state. However during the 1907 legislative session, Mingo Delegate F.H. Evans broke ranks and proposed Bill\#18 "The Evans' Jim Crow Bill." The bill was tabled after public outcry by the state's leading African Americans. Charleston Advocate, 14 February 1907. Only four years earlier, in 1903, Mingo's Democratic Delegate G.R.C. Wiles had proposed a similar bill. Williamson Enterprise, 4 June 1908.
}

${ }^{88}$ Williamson Enterprise, 4 June 1908. 
the "Old Liners" to support the "Regulars." 89 Thus, at the 1908 county convention, the "Regulars" orchestrated the selection of M. Z. White as county chairman and the deposition of both Harry Scherr and B. Randolph Bias from Mingo’s Republican Executive Committee. White's victory fulfilled the Old Liner's fearful prophecy that "a complete change in the control of affairs in the county" would come if the "Regulars" triumphed. ${ }^{90}$ From that time until the 1930s, either M. Z. White, Greenway Hatfield, or another member of their faction served as the head of Mingo County's Republican party. ${ }^{91}$ Only the coal men who made peace with the faction's methods of achieveing and maintaining power substantively affected Republican politics in the county.

An astute politician with personal and business ties with all of Mingo's political and economic leaders, White wisely sent Mingo's delegation to the state convention without voting instructions. $^{92}$ Although the Swisher-Scherr contest for the 1908 Republican gubernatorial nod dramatically affected politics in Mingo County, neither man won the nomination. William M. O.

${ }^{89}$ Undated Old Liner newspaper clipping, Keadle Papers, WVRHC. "Mont” was M. Z. White and "Jack" was J. K. Anderson, one of Mingo's first county commissioners and the General Manager of the United Thacker Coal Company. Williamson Enterprise, 4 June 1908.

${ }^{90}$ Williamson Enterprise, 4 June 1908, and undated, unknown articles in Keadle Papers, WVRHC.

${ }^{91}$ Assertion based on available Handbooks of the West Virginia Legislature, (later known as the West Virginia Bluebook, 1908-1935, WVRHC.

${ }^{92}$ Williamson Enterprise, 4 June 1908. 
Dawson, an associate of Elkins, who also possessed reformer credentials, emerged as the compromise candidate and went on to win the governorship in November. ${ }^{93}$

In 1908, the only exceptions to the campaign factional fighting in Mingo were the personal advertisements of two coal industry candidates for local office. Neither man attacked his competitor, nor made overt reference to his own factional association. However, each man revealed his political alignment by the elements of personal biography stressed in the advertisements, and in turn these revelations illuminated where both stood on the current conflict within the party.

J. R. Booth and S. T. Lambert were pioneer coal men in Mingo County. Booth had been the superintendent of the Pearl Mining Company at Dingess in the northeastern section of the county, while Lambert had been superintendent of several mines at or near Thacker in the southcentral section of the county. Both were also long-time members of the Republican Party. In 1908, Booth who was no longer working as a superintendent, ran for house of delegates. Lambert, the superintendent of the Mate Creek Coal Company ran for sheriff. Booth defined himself as a self-made man. He had worked as a coal miner, foreman, and superintendent and was now on his own as a lumberman. The message of his advertisement to the voters of Mingo

\footnotetext{
${ }^{93}$ Dawson's close affiliation with West Virginia Republican party boss has generally been overshadowed by his reputation as a reform advocate and his later leadership of the West Virginia Progressive Party. The source cited here for the connection is George C. McIntosh, a veteran West Virginia newspaperman who participated in the Scherr faction's bolt in 1908. Unpublished typescript memoir of George C. McIntosh, WVRHC. For more on Dawson, see Nicholas C. Burckel,"Progressive Governors in the Border States: Reform Governors of Missouri, Kentucky, West Virginia, and Maryland, 1900-1918" (Ph.D. diss., University of Wisconsin, 1971). Again, information is lacking regarding the role of coal men in Mingo's Democratic Party until the post-1911 period. By the late teens, the most prominent Democrat of Mingo's coal elite, L.E. Armentrout, the superintendent/vice-president of Borderland, one of the largest concerns in the County had been elected county commissioner. See Chapter 6 for details.
} 
was "I am a common man like you." Lambert, like Booth had come to the county in the early

1890s because of the opportunities in the coal industry. However, he did not make any reference

to coal. Lambert's advertisement stressed that he had come to Thacker from Kentucky at the urging of Republican friends and had been a loyal party man ever since. Without emphatic assertion, both men revealed their factional loyalty. Both Booth and Lambert aligned with the Hiram S. White faction which claimed to represent the legitimate party. ${ }^{94}$

The 1908 campaigns of J. R. Booth and S. T. Lambert inadvertently reveal why the "coal men" in Mingo County did not wield the local political power enjoyed by the industrial elites in the surrounding counties. ${ }^{95}$ Mingo's coal industry elite were a diverse group divided by nativity, religion, education, party affiliation and occupational status. ${ }^{96}$ Moreover, whether entrepreneurs or corporate managers, like Booth and Lambert, the county's coal men also disagreed about the choice of which faction to support. Assessment of the timing of their presence in Mingo's party organizations and public offices reveals the degree of their influence over Mingo's political affairs.

${ }^{94}$ J.R. Booth and S.T. Lambert, 1908 political advertisements in undated, untitled newspaper clippings in Keadle Papers, WVRHC.

${ }^{95}$ Despite prosopographic studies like Kenneth Sullivan's "Coal Men of the Smokeless Coalfields," that reveal the diversity of political affiliation among southern West Virginia's coal elite, West Virginia histories typically stress the ideological unity of southern West Virginia's operator class. However, as episodes in this study will show, the political alignment strategies of this group varied from field to field and directly affected the operators' coercive power. Kenneth Sullivan, "Coal Men of the Smokeless Coalfields," West Virginia History 41 (Winter 1980): 142165.

${ }^{96}$ Assertion based on a group biography study of the Williamson-Thacker coal elite, compiled for the seminar paper, by the author. Data was drawn from the U.S. Census (1900-1920) and various West Virginia biographical publications, all available in the West Virginia and Regional History Collection. 
After the state legislature created Mingo County, coal men figured prominently in local politics. J. K. Anderson, the General Manager of the United Thacker Coal Company holdings in southern West Virginia, was one of Mingo's first three county commissioners. ${ }^{97}$ S. T. Lambert, who worked as a superintendent for several mines between 1893 and 1918, served as Magnolia District's first justice of the peace. ${ }^{98}$ As mentioned earlier, other coal men such as James Little represented their districts in the County organization. Little disappeared from the political records after his mine closed. Lambert and Booth, by aligning with a losing faction, asserted little power during the reign of their factional opponents. However, J. K. Anderson, who represented one of the largest coal interests in the County, backed the Hatfield faction and influenced local politics through them. ${ }^{99}$

IV. The Rise of the "Hatfield Machine," 1895-1911:

97"United Thacker Coal Company," advertisment, Williamson Enterprise, 4 June 1908. See Chapter 7 for a description of UTCC's holdings.

${ }^{98}$ Supervisor's report on Mingo County history, 3 January 1938, Historic Records Survey, Mingo County Book I, WVRHC. Lambert served as mine superintendent for several companies: Red Jacket Coal Company (1902), Vulcan Coal Company (1903-1904), Mate Creek Coal Company (1905-1906), Magnolia Coal \& Coke Company (1915), and Stone Mountain Coal Corporation (1918). Annual Reports, West Virginia Department of Mines, 1902-1918.

${ }^{99}$ The largest of Mingo's earliest coal companies, Thacker Coal \& Coke was managed in this early period by T. E. Houston, who ultimately became one of the most powerful coal men in southern West Virginia. According to S. D. Stokes, Houston "purchased" Mingo County for 1920 Republican gubernatorial candidate Ephraim Morgan from M. Z. White and Greenway Hatfield for fifty thousand dollars. This incident suggests both how and why the big corporations' representatives, like Anderson and Houston, influenced the political activities of Mingo's factional leadership. See Chapter 10, and Appendix 4. 
In the waning days of the Hatfield-McCoy Feud, Elizabeth "Betty" (Chafin) Hatfield twice a week traveled on horseback between her home on Mate Creek to Blackberry Creek to collect or deposit her younger son Henry Drury at school. ${ }^{100}$ One reason for the regularity of the trips was that "Drewy" as the extended family called him, owned only one pair of suitable trousers. ${ }^{101}$ However, the sacrifices necessary to send Drewy to the superior Blackberry school paled in comparison to the opportunity to better his education. Something of a child prodigy, Drewy also benefitted from the tutelage of Logan County's most prominent resident before departing the Tug Valley for college at age fifteen. ${ }^{102}$ As one descendant recalled, once identified as the "promising pup" of the family litter, Drewy had been culled from the group, and no expense was spared to cultivate his abilities. ${ }^{103}$ He encapsulated his family's aspirations and ambitions for the future.

Liberally educated at Franklin College, Ohio and the University of Louisville, Kentucky, Hatfield received additional medical training at New York University, at the time one of the most advanced and premier medical institutions in American medicine. ${ }^{104}$ Drewy Hatfield returned to the Tug Valley in 1894, a doctor at age 19. He began his medical career in the southern West

${ }^{100}$ McCoy, "The Rise of Education," 40.

${ }^{101}$ Ibid.

102"Henry D. Hatfield," Men of West Virginia, vol.2 (Chicago: Biographical Publishing Company, 1903): 727-728, 727. Hatfield's early mentor was George Rogers Clark Floyd, the son and brother of two Virginia governors. Henry D. Hatfield to C. H. Ambler 5 December 1953, Hatfield Papers, WVRHC.

${ }^{103}$ Hatfield correspondence, letter no. 29.

${ }^{104}$ Wallace, Annals, 403. According to Wallace, Hatfield graduated from Franklin 1890, Louisville 1894, and NYU 1904. 
Virginia coalfields as a company doctor, and his lifelong commitment to quality healthcare for miners and their families is evidenced by the miners' hospitals he helped establish. ${ }^{105}$ However, Henry D. Hatfield chose to enter politics, and it was in this public sphere that the twin influences of his family background and professional training at times warred and in others dovetailed to mold him into one of West Virginia's most successful reformers, and yet most corrupt politicians.

The sheer size of the Hatfield family made them a force with which to be reckoned in southern West Virginia politics. By the time Henry D. Hatfield first ran for state office in 1910, the Hatfields and/or their relatives were a dominant force in the politics of three counties: Mingo, Logan and McDowell. ${ }^{106}$ Through his mother, Betty Chafin, Henry D. was related to the Democratic Chafins who ran Logan County. Two of Devil Anse's sons and thus double first cousins to Henry D. Hatfield: Joe D. and Tennyson or "Tennis," were part of the Chafin machine until the mid-1920s. ${ }^{107}$ Henry D.'s second cousins, brothers William "Bill," and McGinnis "Mac"

${ }^{105}$ Karr, 36-37.

${ }^{106}$ In Logan, Francis M. "Marion" Chafin served as Logan County sheriff, 1894-1898. Devil Anse's brother and father to Greenway and Henry D., Elias Hatfield was Town Marshal of Aracoma in the early 1890s, and after the name was changed to Logan (Courthouse) became Chief of Police in 1895. James M. "Jim" Chafin, Marion Chafin's brother served as a county clerk in Mingo. Marion's son John Chafin served as Logan Circuit Court Clerk for 18 consecutive years. West Virginia Heritage Encyclopedia, 5: 919-21 and Lawson, 41; In Mingo, Greenway and Henry D. Hatfield were both senior members of the Republican Party, "Condensed Facts," 7, 1; In McDowell, Henry D. "Drewy", William "Bill", and McGinnis "Mac" Hatfield joined the Republican party faction led by former McDowell County Sheriff W.W. Whyte. Sodom and Gomorrah Today, or the History of Keystone, West Virginia, (n.p. 1912), no page numbers. "Condensed Facts" is Pamphlet 8662 and "Sodom and Gomorrah" is in the Rare Books Collection, both in the WVRHC.

${ }^{107}$ Raymond Chafin, with Topper Sherwood, Just Good Politics: The Life of Raymond Chafin, Appalachian Boss (Pittsburgh: University of Pittsburgh Press, 1996), 20. 
Hatfield were an emerging force in McDowell County Republican politics. ${ }^{108}$ Henry D. himself had helped found the Republican party in Mingo in 1895-1896, before moving to McDowell County. ${ }^{109}$

Exactly why Henry D. moved to McDowell has never been irrefutably established. One possible reason may have been the lure of better pay and working conditions at the larger mining operations of the Pocahontas coalfield. Based on family descriptions of his character, Hatfield may also have been disgusted with the imbroglios of his cousins Cap and Elias in 1896 and 1899. ${ }^{110}$ Hatfield family descendants assert that "Doc," who had been educated far away from the feud, did not want his own reputation tarnished or his personal aspirations tainted by the "shameless goings-on in Mingo."111 Whatever the reason for his departure, once Henry D. Hatfield moved to McDowell, he and cousins "Bill" and "Mac" Hatfield forged an alliance with the coal and industry elite of that county. As one Hatfield later recalled, the McDowell political scene suited the three kinsmen better because there "they were playing to the opera and box seats, not the peanut gallery." 112

\footnotetext{
${ }^{108}$ McDowell County DAR, McDowell County (Fort Worth, TX: University Supply and Equipment Company, 1959), 113.

109"Condensed Facts," 1-2. P8662, Pamphlet Collection, WVRHC.

${ }^{110}$ Hatfield correspondence, letter no. 31 .

${ }^{111}$ Ibid. Acording the elder members of the Hatfield family, Henry D. Hatfield is described as being the Hatfield most like his famous uncle, Devil Anse: shrewd, proud, loyal and formidable. Governor Hatfield was also known for his temper; his ire reportedly was most often raised by assaults on his honor or will, and by people who were dishonest, cowardly, or greedy.

${ }^{112}$ Hatfield correspondence, letter no.28.
} 
Despite the Hatfield family historians' characterization of McDowell as a "cleaner," or perhaps more refined political climate than Logan or Mingo, the contemporary accounts of political contests at the time reveal a different view. If politics were less combustible in Logan and McDowell it was because they were ruled by single party machines, not that the politics were less dirty or dependent on corruption.

When the coal industry entered Logan in 1904, it was considered an efficiency expedient to pay the Chafins, of whom Don Chafin was the emerging leader, to maintain order. ${ }^{113}$ The Republican primacy in McDowell depended on the loyalty of the county's African-American population, whose percentage of the total population exceeded the combined figure for native and foreign born white. ${ }^{114}$ In the coal camps and predominantly black towns like Keystone and Kimball, the Hatfields helped build a machine that provided the patronage and protection to keep the African Americans in line. ${ }^{115}$

By 1910, when Henry D. decided to run for a seat in the state senate, his older brother Greenway had carved his own niche among the Republican elite of their home county. A report on a contested Congressional seat from the 1910 election exposed how the Hatfield brothers built a machine that drew power both from their kinship ties and their connection to the coal industry.

\footnotetext{
${ }^{113}$ Lee, Bloodletting, 137-138. Shortly before federal legislation legalized unions, James D. Francis, the president of Island Creek Coal Company, visited the Sheriff Joe D. Hafield to discuss ending the coal company subsidy of the sheriff's deputies. Francis allegedly gave as a reason that the companies had initially paid the money to help keep order in the county, but that under Don Chafin, it had transformed into an extortion racket.

${ }^{114}$ Kenneth R. Bailey, "A Judicious Mixture: Negroes and Immigrants in the West Virginia Mines, 1880-1917," West Virginia History 34 (January 1973): 141-161, 158.

${ }^{115}$ The report of the Wiley v. Hughes case and "Sodom and Gomorrah Today" offer several examples of the white-black political relationships in McDowell County.
} 
The report also reveals that while "Doc" Hatfield espoused support for a variety of reforms, including the institution of primaries, workers compensation, and mine guard legislation, he also used the tools of a corrupt party boss to enhance his own power. The abuses orchestrated by the Hatfield brothers to win Mingo and McDowell County were so flagrant that Rankin Wiley, the defeated candidate for the fifth district United States congressional seat sought and a secured a Congressional investigation of the election proceedings in Mingo and McDowell counties. ${ }^{116}$

Although they examined a wide range of charges, including questions concerning Hughes' citizenship, the congressional committee found the charges regarding McDowell County especially disturbing. After noting that the majority of McDowell's population was predominantly immigrant or African-American and that all of the county officers were Republican, the committee observed that "the method of conducting elections [there] ... make it a most fruitful place to perpetuate wholesale election fraud." Even though they noted with concern Wiley's assertion that he had not campaigned in McDowell because he had been threatened with bodily harm, the congressmen were more dismayed by the actions of the Republican President of the County Court Henry D. Hatfield. According to evidence brought before the committee, Hatfield had openly violated well-established election laws when he

\footnotetext{
${ }^{116 " C o n t e s t e d ~ E l e c t i o n ~ C a s e ~ o f ~ R a n k i n ~ W i l e y ~ v . ~ J a m e s ~ A . ~ H u g h e s ~ f r o m ~ t h e ~ F i f t h ~}$ Congressional District of West Virginia," Sixty-Second Congress, 2d session, Report No.1229 [Mr. Covington, from the Committee on Elections No.1 submitted the following report to accompany H.Res.703] (Washington: GPO, 1912). Unfortunately for Rankin Wiley, his Republican opponent in the 1910 election was James A. Hughes of Huntington, who had already served five terms in Congress. Hughes was a native of Canada whose family had immigrated to the United States after the Civil War. The brother-in-law of Z. T. Vinson, the Democrat-turnedRepublican business associate of Wallace J. Williamson, Hughes helped broker the deal that created Mingo County. In return he had named Hatfield family friend, N. J. Keadle sheriff. See earlier section of this chapter for citation details.
} 
refused to appoint Democrat as well as Republican election supervisors for each precinct in the county. ${ }^{117}$

The committee was also shocked to learn that upon his own election to the state senate in 1910, the West Virginia legislature, instead of censuring Hatfield, elected him president of the state senate. However, despite their own disgust with Hatfield's behavior, the congressional committee declared that the lack of bipartisan oversight of the McDowell polling stations in and of itself did not constitute fraud nor prove that fraud had been committed. ${ }^{118}$

The congressional investigation focused most closely on the conduct of the election in Mingo County. After noting that violations had occurred at nine precincts, the committee chose to concentrate on alleged activities at the Matewan precinct. The precinct was so notorious the committee report noted, people went to extraordinary lengths to secure a fair election:

Conditions had in recent years become so outrageous at this precinct that a number of women belonging to the Woman's Christian Temperance Union determined to put a stop to fraudulent elections there, and with the finest spirit of American womanhood repaired to the polling place at daybreak and begged the election officials to see to it that a fair election was held that day. ${ }^{19}$

${ }^{117}$ Ibid., 3.

${ }^{118}$ Ibid.

${ }^{119}$ Ibid., 4. Unfortunately, no other accounts of this action have been located. The annual report of the West Virginia Woman's Christian Temperance Union does not include any record of the incident. However, both the 1908 and 1910 reports of local WCTU memberships hint at who might have been involved. In 1908, the president of the Red Jacket chapter was Mrs. Jennie Turner, the wife of Dr. James Turner; Dr. Turner was involved in another incident at Matewan on election day 1910. The 1910 WCTU membership of Matewan included Mrs. Martha Hoskins and Mrs. Dora Lambert, the wives of Magnolia District Constable W. R. Hoskins and coal company superintendent S.T. Lambert. Women's Christian Temperance Union of West Virginia, Report of the Twenty-Sixth Annual Meeting of the Women's Christian Temperance Union of West Virginia, held at Huntington, WV, October 2-6, 1908, edited by Mrs. K. M. Murill (Charleston, 
Despite the women's efforts, the election at Matewan proceeded as corruptly as ever. The committee observed that while "negro floaters" were transported and illegally voted around the county, in Matewan they were housed in "vacant buildings" and for "two or three days ... and food was carried to them in tubs." On election day, Republican officials tried two methods of providing the African Americans with the names they were to use when voting. The failure of both methods resulted in Greenway Hatfield shouting the "name" of the voter to the election commissioner or poll clerk. To quantify the fraud, Democratic commissioner secretly marked each African-American voter on the back with a piece of chalk -- one man had twelve marks before the poll closed. When Dr.Turner, a "respectable citizen" and fellow Republican, "remarked in the presence of Greenway Hatfield that it was a shame to permit these `darkies' to vote ... he was struck in the face and driven from the polls." ${ }^{120}$

The extent to which the franchise of Matewan's legally registered voters was undermined is highlighted by the committee's citation of a few statistics. According to the investigators, in the 1910 election 327 votes were cast at Matewan, 237 by African Americans, even though Matewan had only ten registered African-American voters at the time. The committee stripped Hughes of his plurality in Mingo and awarded it to Wiley. However, it was not enough to turn the entire district's vote to Wiley's favor. Despite openly acknowledged irregularities and in

WV: Tribune Printing Company, 1909), 79 and West Virginia Woman's Christian Temperance Union, Twenty-Eighth Year, Charleston, WV, October 5,6, 7, 1910 (Fairmont, WV: Index Print, n.d.), 113. Both Lambert and Hoskins subsequently served as mayor of Matewan. In 1910 W. R. Hoskins was Constable for Magnolia District, but while mayor of Matewan in 1911, he was shot and killed by Tom Chafin. For more on WCTU activities in West Virginia in this period see: Barbara J. Howe, "West Virginia Women's Organizations, 1880s-1930 or `Unsexed Termagants . . Help the World Along," West Virginia History 59 (1990): 81-102.

\footnotetext{
${ }^{120}$ Ibid., 2-3.
} 
some cases proven fraud, James A. Hughes retained his seat as United States congressman, thanks to the Hatfield machine of Mingo and McDowell Counties. ${ }^{121}$

After taking his seat in the state senate, Henry D. Hatfield almost suffered repercussions for his role in the scandalous 1910 election. As one of several candidates for the state senate's presidency, Hatfield only received the honor after Logan County state senator E. T. England conceded the caucus nomination to Hatfield for the sake of party unity. As the Mingo Republican noted archly, "the scepter he (England) wields in his home county was not bestowed by the power of a machine." ${ }^{122}$ The attack on native son Hatfield by the Republican reflected a connection between the rise of the Hatfield machine and the emergence of reformist tendencies in Mingo. ${ }^{123}$

\footnotetext{
${ }^{121}$ Williamson Daily News, 8 August 1914. In 1914, the News alleged that Buskirk "voted his bulldog for Jim Hughes" in the 1910 election. Hughes' re-election in 1910 was one bright spot in a dismal mid-term campaign; he was the only Republican in West Virginia's congressional delegation to retain his seat. According to Gary J. Tucker, by 1910, the importance of the African-American electorate in Mingo, McDowell, and several other southern West Virginia counties led to their designation as West Virginia's "Blackbelt" counties. For more on the 1910 election see: Gary J. Tucker, "William E. Glasscock and the Election of 1910," West Virginia History 40 (Spring 1979): 254-267. As mentioned earlier in this chapter, in response to the Republicans abusive overuse of black voters, Democrats repeatedly attempted to keep blacks from voting. In 1910, according to the Mingo Republican, "with the connivance of a Democratic roadmaster, nearly all the colored men on the extra force were taken to Burnwell before the polls were opened and kept there until after dark. One escaped and reached home just in time to vote." Mingo Republican, 8 November 1912.

${ }^{122}$ Mingo Republican, 3 February 1911. During the 1920-1922 strike, England, who by then was Attorney General, was openly critical of the southern West Virginia operators and politicians, many of whom had backed Hatfield rather than England in the 1911-1912 period. "Testimony of E. T. England,"West Virginia Coal Fields: 719-731.

${ }^{123}$ In 1911, the editor of the Mingo Republican was Fred O'Brien. Although O'Brien's father (who had served a term as Williamson's mayor) and his father-in-law John L. Stafford (see the section on the 1904 election in this chapter) were Democrats, he himself was a liberal Williamson Republican. In 1911, O'Brien ran unsuccessfully for mayor against the machine-
} 
Although the liberal wing of his own party opposed his elevation to the Senate presidency, once in control of the session, Hatfield shepherded several reform bills through the legislature. ${ }^{124}$ As a result, Hatfield gained a reputation for unlocking the impasse that had kept reform measures from being passed for a decade. At the end of the session a bi-partisan delegation presented the young senator with a silver platter in thanks for his efforts as a peacemaker in the tumultuous session. ${ }^{125}$

An examination of two bills passed during the 1911 legislative session exposes the secret of Hatfield's success. One of these, the West Virginia Primary Election Law transferred the responsibility or the right of picking a party's slate of candidates from the county and state conventions to a direct primary. Like similar legislation around the country, the West Virginia bill was meant to "democratize" the candidate selection process and thereby undermine the influence of "cliques" and machines. ${ }^{126}$ However, the bill's limitations as an effective anticorruption measure was noted almost immediately after its passage. One month after the end of

backed incumbent Democratic mayor. "Obituary of Fred W. O’Brien” Mingo Republican, 9 February 1912.

${ }^{124}$ Karr, 46-47. According to Karr, Governor Dawson's allies in the liberal-reformist wing of the party "flatly refused" to endorse Hatfield's selection.

${ }^{125}$ Mingo Republican, 24 March 1911. The leader of the delegation was former Governor William Alexander MacCorkle (D) who spoke of knowing Hatfield since his boyhood, when MacCorkle, as a young circuit riding lawyer had forged a twenty-five year friendship with Hatfield's father and uncle, Elias and Devil Anse Hatfield. One of Hatfield's many achievements was saving M. Z. White's election as Mingo county's state senator. White had been elected by a "near unanimous vote" but the Democrats still tried to get him unseated. Mingo Republican, 16 November 1916.

${ }^{126}$ Steven J. Diner, A Very Different Age: Americans in the Progressive Era (New York: Hill and Wang, 1998), 209. 
the 1911 session, John J. Cornwell, former Democratic gubernatorial candidate and editor of the Hampshire Review, wrote an editorial about the law and its impact. Cornwell prophesied that "party primaries would usher in a period of unparalleled disunity and corruption in Republican politics." 127 Subsequent primary elections in Mingo County affirmed the accuracy of Cornwell's prediction. $^{128}$

The other important bill passed in 1911 was the West Virginia Prohibition Act. As historian Frederick Barkey has observed:

prior to the passage of the West Virginia Prohibition Act ... a very important source of patronage was the granting of liquor licenses . . . [which were)] approved by the county court ... [The licenses] were often granted or withheld on the basis of direct financial support of the controlling political organization or the patronizing of party approved wholesalers. ${ }^{129}$

The early records of the Mingo County Court substantiate Barkey's observation. The conference of three saloon licenses in 1895 illustrates the link between politics and the liquor traffic in Mingo County. ${ }^{130}$ The two saloons operated at the village and coal camps at Thacker were

\footnotetext{
${ }^{127}$ John J. Cornwell editorial in Hampshire Review, 11 April 1911, quoted in Lucy Lee Fisher, "John J. Cornwell, West Virginia Governor, 1917-1921," West Virginia History 24 (April 1963/July 1963): 258-288, 370-389, 272.

${ }^{128}$ From 1912 through 1920, primary and general elections in Mingo were racked with corruption. One of the ring leaders of a state legislature corruption scandal in 1913 was from Mingo County. The 1916 election in Mingo caused a Federal investigator to observe that Mingo was one of the most politically corrupt places he had ever seen. Dicussions of and citations for these events will appear in this and subsequent chapters.

${ }^{129}$ Frederick A. Barkey, "The Socialist Party in West Virginia from 1898 to 1920: A Study in Working-Class Radicalism" (Ph.D. diss., University of Pittsburgh, 1979), 51.

${ }^{130}$ S. D. Stokes to Carl E. Whitney 19 September 1921, Stokes Papers, WVRHC. Stokes describes M. Z. White's dismay at the loss of the liquor graft and his salvation by receiving an appointment as warden of the West Virginia state penitentiary from Henry D. Hatfield in 1913.
} 
licensed to Mont (M. Z.) White and Eli Baker, the bondholder was R. W. Buskirk. At Matewan, the liquor license was granted to Buskirk's wife Melda Buskirk, her bondholders were Wallace J. Williamson and R. H. Prichard. ${ }^{131}$ Williamson, White and Buskirk were three of the most powerful political forces in Mingo's first quarter of a century. While acknowledged by many as one of the founders and guiding forces of the town of Matewan, Buskirk was also known as "a purveyor of vice" who had originally come to the Matewan area from Logan with that intent in mind. ${ }^{132}$

The sheer volume of liquor licenses granted by the Mingo County Court also underscores the conflict between the graft game operated by machine politicians and the demand for social reform which culminated in the passage of the Prohibition Act. Between 1895 and 1900, 121 liquor licenses were granted in Mingo County, that averages to twenty-four a year, or one saloon for every ninety-four persons. Condemned as constant companions, drunkenness and violence were also seen as simultaneously new and old social problems. ${ }^{133}$ On the one hand, "drinking epitomized how things had things had got out of control in the new order." ${ }^{134}$ However, the

See Appendix 4.

131 "Mingo County Commission Records," 14 February, 1895, Book I, Historic Records Survey, Mingo County, Reel 125, WVRHC.

${ }^{132}$ Hatfield correspondence, letter no. 17.

${ }^{133}$ Not unknown anywhere in 19th century America, in Mingo County history, drunken violence seemed especially common on election day, well into the 20th century. Several examples are cited in the chapters of this study.

${ }^{134}$ David Thelen, Paths of Resistance: Tradition and Dignity in Industrializing Missouri (Columbia: University of Missouri Press, 1991), 155. Thelen's work focuses on the industrial transformation period in the Ozarks of Missouri. The close parallels between the "BaldKnobbers" of the Ozarks and the Hatfields and McCoys of the Tug Valley are discussed by 
drinking habits of the native mountaineers and lower classes were also associated with an embarrassing and backward past. ${ }^{135}$ Conversely, temperance advocacy became a badge of one's membership in the middle class. ${ }^{136}$

The "new order" required a sober work force, which would not disrupt the peace of the modern towns that had grown up around the coal industry. ${ }^{137}$ As a political issue however, prohibition divided rather than united the ruling elite. Native elites and machine politicians who depended on the political support of the lower classes generally opposed prohibition, while the industrial elites who drew their power from external sources generally supported prohibition at least for their work force. ${ }^{138}$ Only occasionally did genuine tee-totalers appear, as in the case of

Altina Waller in Feud. Thelen is quoted directly here because his assertion encapsulates the opinion of many West Virginia prohibitionists in this period, who were especially concerned about the drinking habits of the ethnic working class. In 1914, when prohibition went into effect in West Virginia, a group of unnamed citizens in Williamson started a "law and order league" to "help enforce temperance." Williamson Daily News, 3 July 1914 and 21 July 1914.

${ }^{135}$ Waller, Feud, 203-205.

${ }^{136}$ Waller, Feud, 203. The growing acceptance of prohibition and temperance among the middle class in turn-of-the century America some historians have argued, stemmed from their own status anxiety. In Retreat from Reform, Jack Blocker observed that many in the middle class advocated temperance in order "to shore up their damaged society and prove themselves to be caring and potent members of that society." Jack S. Blocker, Jr., Retreat from Reform: The Prohibition Movement in the United States, 1890-1913 (Westport, CT: Greenwood Press, 1976), 241.

${ }^{137}$ Ibid.

${ }^{138}$ This trend reflected parallel situations in the broader contemporary society. Diner, 73 . 
Colonel William Leckie. Leckie, a Scots immigrant, pioneer operator of the Pocahontas coalfield, and investor in the Williamson-Thacker field, devoutly opposed liquor. ${ }^{139}$

\section{Conclusion:}

In contrast to the prevailing historical opinion regarding the impact of industrialization on southern West Virginia politics, Mingo County did not come under the hegemonic influence of a new elite. No single party dominated the county and within each party rival factions consisted of mixed coalitions of natives and outsiders. As a result, the most powerful politicians in the county were masters of seemingly syncretistic sources of influence. For example, Democrat Wallace J. Williamson and Republican Greenway Hatfield were native elites who actively and lucratively participated in Mingo's economic development. Drawing on their kinship networks and business connections, Williamson and Hatfield constructed machines that withstood both the forces unleashed by their own political rivalry, and intraparty reformist efforts to topple them. How their machines survived the Progressive Era and contributed to the escalation to violence in Matewan on May 19, 1920, is best illustrated by the political career of Greenway Hatfield's most powerful, but problematic ally, his younger brother Henry D. Hatfield.

Henry D. Hatfield's rapid rise to the power in the state stemmed from his mastery of both corrupt political methods and the language of reform. In essence, for awhile he was able to be all things to all people, which was probably why he attracted the support of southern West

\footnotetext{
${ }^{139}$ Leckie's personal papers archived at the Eastern Regional Coal Archives contain literature illustrating his devotion. Whenever he traveled he apparently stayed only at inns where no alcohol was served -- ever. William S. Leckie Collection, ERCA.
} 
Virginia's most powerful industrial elite. Observing Hatfield's ascent through the state party ranks, a former judge of West Virginia's State Supreme Court of Appeals noted that by 1911, Hatfield was "one of the strongest men in the state . . all factions could unite behind him."140 However, when the death of Stephen B. Elkins opened a power vacuum at the apex of West Virginia's Republican party in early 1911, Henry D. Hatfield seized the opportunity to break free from his corporate sponsors. Chapter 6 tells the story of how the Hatfield brothers' empire expanded and then collapsed. Ironically, the combined impact of election reform and prohibition on politics in Mingo County contributed to the Hatfield's undoing.

In the interim, Chapters 4 and 5 assess Mingo's economic and social transformation. Chapter 4 illuminates an issue first raised in this chapter, the relative weakness of Mingo's coal elite, by documenting the peripheral status of the Williamson-Thacker coalfield. Chapter 5 closes the section on Mingo's transformation period by analyzing the social ramifications of the county's political volatility and economic marginality. Mingo's elite failed to establish hegemonic political control and lived in the shadow of the economic primacy of the surrounding coalfields. As a result, local methods of conflict resolution, and use of and attitudes towards violence, lay the groundwork for the events of May 19, 1920.

\footnotetext{
${ }^{140}$ Judge Joseph M. Sanders interview from the Huntington Herald Dispatch, 22 December 1911, quoted in Penn, 249.
} 


\title{
CHAPTER 4
}

\section{CRISIS AND CONFLICT SHAPES THE THACKER COAL FIELD ${ }^{1}$}

\author{
"Development ... has just simply been started ... \\ there is a slender thread of coal operations extended along the river, \\ stretched over a distance of over fifty miles."2 \\ -- Williamson Enterprise, June 1908
}

The same year that the mines in what would become Mingo County went into production, one of the nation's worst depressions gripped the United States. Throughout the coal industry companies responded to the lingering economic crisis by increasing production and imposing cost-saving measures, such as wage reductions. Because the crisis lasted into the closing years of the century, and their employers showed no signs of restoring old pay rates, miners gradually abandoned their traditional policy of cooperation and began flocking to the fledgling United Mine Workers of America. ${ }^{3}$

In this atmosphere, the pattern of industrial relations in Mingo County's Thacker Coal Field took shape. The long slow recovery from the national depression also coincided with a

\footnotetext{
${ }^{1}$ The boundaries of southern West Virginia coalfields and counties do not exactly coincide. Moreover, the names of the coalfields evolved over time and varied according to the descriptor's point of reference. All of Mingo County fell into the original "Thacker" field, which also included a small section of Wayne County, West Virginia and Pike County, Kentucky. Not long after the term "Williamson-Thacker" came into use, the Pike County section of the field came into its own as the Pond Creek Field. Also since railroad publications and other industrial publications frequently subdivided coalfields into production and/or distribution units, therefore in some of these publications the field was referred to as the "Kenova-Thacker district."

${ }^{2}$ Williamson Enterprise, 4 June 1908.

${ }^{3}$ John H.M. Laslett, Colliers Across the Sea: A Comparative Study of Class Formation in Scotland and the American Midwest, 1830-1924 (Urbana: University of Illinois Press, 2000), 144-145.
} 
broad-reaching transformation of the American coal industry. The first half of this chapter traces the impact of the Panic of 1893 on the early development of the Thacker Coal Field. The second half addresses how the trends of the dawning modern age of coal mining increasingly put the Thacker field in the shadow of neighboring fields. Moreover, the growth and expansion of the coal industry in Mingo County not only obscured the differences between it and surrounding fields, but also disguised the long-standing systemic problems that precipitated the descent into crisis in the Spring of 1920.

I. The Panic of 1893 Affects Industrial Development and Relations in Mingo County, 1895-1902:

The economic ramifications of the Panic of 1893 profoundly affected the initial stage of Mingo County's industrial development, even though the Thacker coal field continued to expand in 1894-1895. ${ }^{4}$ A new company, the Mate Creek Consolidated Coal Land Company, was incorporated, backed by a combination of "local and Chicago capital." ${ }^{5}$ Coal production more than doubled from 52,673 tons in 1894 to 106,712 in 1895 , but expansion in the Thacker field did not necessarily signify fiscal soundness for the coal companies, the Guyandot Coal Land Association, or the N\&W. ${ }^{6}$ The construction of the Dingess branch line further imperiled the GCLA because its landholdings did not cover the acreage traversed by the line. To extend its

\footnotetext{
${ }^{4}$ The national unemployment crisis precipitated by the Panic of 1893 eased briefly in 1895, but revived when the depression actually worsened in 1896. Michael Nash, Conflict and Accommodation: Coal Miners, Steelworkers and Socialism, 1890-1920 (Westport, CT: Greenwood Press), 13.

${ }^{5}$ Conley, History of the West Virginia Coal Industry, 259.

${ }^{6}$ Ibid; Annual Reports 1911, 8; Prior to Mingo's separation from Logan in 1895, production figures for mines in the "Thacker" field were reported as part of Logan's figures.
} 
control over the land between its original holdings and the new rail line the company was forced to pay twenty-eight dollars an acre for the missing 140 acres. $^{7}$

Rather than cooperatively confronting the impact of overproduction and overcompetition, coal men rapaciously sought ways to produce cheaper coal. ${ }^{8}$ As miners in the older coalfields came together and founded an organization to protect themselves from their employers' efforts to lower wages, many operators searched for areas where they could start fresh and avoid the issue. ${ }^{9}$ In this climate of crisis, the pattern of industrial relations in the Thacker coalfield was established. From the beginning, coal companies in Mingo County operated under a siege mentality; deprived of the benefits enjoyed by the Smokeless coalfields to the east, the operators of Thacker field were slow to organize in pursuit of common interests. The story of the United Mine Workers of America's early organizational efforts underscores not only the vulnerability of the Thacker field, but also the roots of the union's own tenuous relationship with Mingo's miners.

When the Norfolk \& Western opened the coalfields of southeastern West Virginia, it required all of the companies served by its line to sell their coal through the N\&W's own sales agency. ${ }^{10}$ While most of the benefits of this arrangement accrued to the railroad, the companies' themselves were compensated by other aspects of the deal. First, because their coal was sold

${ }^{7}$ Roper, 177, 174-175.

${ }^{8}$ Salstrom, Path to Dependency, 36, 72-73

${ }^{9}$ Hinrichs, 117.

${ }^{10}$ According to pioneering operator W. P. Tams, the Smokeless operators were compelled to use Castner, Curran \& Bullitt as their agents. W.P. Tams interview with Richard Hadsell, A\&M 2584, typescript pages 3-4, WVRHC. 
under a single label, the Smokeless operators benefitted from the rapid advance in demand for their product. Second, and most important, the companies were guaranteed a minimum price for their coal. ${ }^{11}$

However, after the Panic, the continued instability of the coal market had frequently required the $\mathrm{N} \& \mathrm{~W}$ to undercut itself by compensating the coal companies for the shortfall between the prearranged price and the actual market value of the coal. After entering receivership in 1895 , the $\mathrm{N} \& \mathrm{~W}$ embarked on a new coal sales policy. In late February, the railroad abolished its coal sales company, the Pocahontas Coal Company and turned over its coal sales contract to Castner, Curran, and Bullitt of Philadelphia, which had been the N\&W's seaboard agent. The new arrangement in coal sales promised to help stabilize the railroad's operating costs, and raise its coal hauling profit margin. ${ }^{12}$

For the coal companies in the Flat Top, Pocahontas, and Thacker fields, the withdrawal of guaranteed price supports removed an important safety net. In the midst of a failing market, the operators faced a further drop in coal prices. ${ }^{13}$ All of the N\&W's southern West Virginia's fields suffered because of the loss of the guaranteed price support. But as the youngest of the fields, only two years into production, and lacking the established reputation enjoyed by the Smokeless fields, the Thacker field was hit hardest by the N\&W's decision. ${ }^{14}$ Forced into open competition

\footnotetext{
11 "Shifting the Deal," Bluefield Daily Telegraph, 21 February 1895 in David E. Johnston Papers, ERCA.

${ }^{12}$ Ibid.

${ }^{13}$ Ibid.

${ }^{14}$ The southeastern West Virginia fields produced a high quality, "low volatile"-- hence "Smokeless" coal, while the Thacker field produced a lesser quality "high volatile" coal. The
} 
much earlier in its productive life, the Thacker field never escaped the shadow of the better known and established Smokeless fields.

Set adrift in a fiercely competitive coal market, the fledgling companies of the Thacker field launched their own effort to protect and improve sales of "Thacker" coal, only three months after the N\&W announcement. On May 1, 1895, three of the Field's four producing companies founded the Thacker Coal Company, which would sell all Thacker coal at the same price. However, the refusal of the Maritime Coal Company to participate undermined the goals of the other three companies. A year later, A. Moore, the president of Thacker Coal \& Coke, who also served as the president of the sales agency, resigned his appointment as the head of the sales agency and withdrew Thacker Coal \& Coke from its contract. In an explanatory letter to the new president Moore blamed his action on the April 1896 sale of Thacker coal below the contracted price. Two months later the sales agency went into receivership and sued Thacker Coal \& Coke for failing to fill its order of coal. The lower court found for the defendant, but W. P. Slaughter, the agency's receiver, appealed the decision. ${ }^{15}$

The West Virginia State Supreme Court of Appeals upheld the lower court's decision, but not because it accepted Thacker Coal \& Coke's defense. All but one of the judges found the

differences between these coals and the impact of this variation on the fields' development is explored later in this chapter.

${ }^{15}$ "Slaughter v. Thacker Coal \& Coke Company," Reports of the West Virginia Supreme Court of Appeals, 55 (February 9, 1904-June 9, 1904): 642-644. The demise of the Thacker Coal Company is surrounded by shady events. For example, as his successor reminded Moore, as president of the sales agency, he had authorized the below market sale. After the new president threatened to sue for breach of contract, Moore, in collusion with the new owners of the Lynn Company, engineered the dissolution of the sales agency. Same, 644-645. All efforts to find additional information on A. Moore, even his first name, have failed. 
original contract to be an illegal restraint of trade and thus void, meaning, "no recovery [could] be had on it." President of the Court Judge Poffenbarger disagreed with the other judges' decision because he believed that the Thacker Coal sales agency represented the interests of companies "developing a new field" whose product could be sold "more advantageously and economically through one agency." Moreover, in Judge Poffenbarger's opinion, the Thacker Coal sales agency represented such a small segment of the industry, "it is impossible to see how the public was, or could have been, injured by ... the contract." ${ }^{16}$ The majority opinion prevailed however, and efforts at concerted action among Mingo's coal operators were set back for years. ${ }^{17}$

Cut adrift by the $\mathrm{N} \& \mathrm{~W}$, forced into competition with bigger, better known coal fields, and denied the opportunity to emulate the sales strategy of these same competitors, the Thacker Field struggled to survive the aftereffects of the Panic. Not unlike coal operators around the nation, Thacker companies competed for skilled workers to help boost production, only to impose wage reductions as soon as they thought they could. ${ }^{18}$ Thus, less than four years after opening, conflict between the miners and the companies wracked the Thacker coal field.

${ }^{16}$ Ibid., 651-652, 647-649.

17"Lack of cooperation" among southern West Virginia's operators was a typical state of affairs. Richard M. Hadsell and William E. Coffey, "From Law and Order to Class Warfare: Baldwin-Felts Detectives in Southern West Virginia" West Virginia History 40 (Spring 1979): 268-286, 275. This author argues that it particularly adversely affected the Williamson-Thacker Coal Field. For example, it should be noted that in contrast to Mingo's coal companies after the dissolution of the Thacker Coal Company, most of the coal companies along the $\mathrm{N} \& \mathrm{~W}$ to the east still sold their coal through Castner, Curran \& Bullitt and thus benefitted from the use of a single coal agency. Tams interview, 3-4, WVRHC.

${ }^{18} 30$ August 1898, Bert Wright Diary, Roland Luther Collection, ERCA. A mine superintendent in the Pocahontas Field, Wright knew about conditions in the Thacker Field because he had hired a labor agent to "canvass" the Thacker Field and find experienced miners willing to relocate. 
In 1899, the noted self-taught mining engineer and miners' advocate Andrew Roy published an account of a recent visit to the Thacker Coal Field. His article, in addition to analyzing the various advantages and disadvantages of the young field, also included this description of a typical employee of the Thacker Coal \& Coke Company:

the miner keeps his dress suit in his own closet while at work in the mine. After bathing in the evening he dons this suit and places his mining garb in the closet and emerges from the bathroom as "clean as a new pin' and looking more like a congressman [than a miner]. ${ }^{19}$

The implications of Roy's depiction are clear. The miners of Mingo's Thacker Field enjoyed the fruits of the latest innovations in American mining. ${ }^{20}$ After working in one of the Mingo's thoroughly modern mines, Thacker's miners emerged from the company washhouse cleansed of the coal grime that would otherwise mark their occupational status. Thus liberated, the miners could move among local society, the equals of any man. What Roy's observation does not reveal however, is that his visit coincided with a tumultuous time in the Thacker Coal Field, when local miners undertook their first efforts to join the United Mine Workers of America.

Although the UMWA included West Virginia in its first organization drive in 1894, the production crisis precipitated by the union's success in Ohio, Illinois, and Indiana only fueled the

\footnotetext{
${ }^{19}$ Andrew Roy, "The Thacker Coal Field of West Virginia," Mines and Minerals 19 (May 1899):472. Roy's emphasis on the classless appearance of the miners reflects his adherence to the dominant ideology of the American mining industry in the nineteenth century. See Grace Palladino, Another Civil War: Labor, Capital, and the State in the Anthracite Regions of Pennsylvania, 1840-1868 (Urbana and Chicago: University of Illinois Press, 1990).

${ }^{20}$ Thacker was the first West Virginia Coal Field that opened mechanized. Keith Dix, What's a Miner to Do: The Mechanization of Coal Mining (Pittsburgh: University of Pittsburgh Press, 1988), 13.
} 
growth of newer fields like the Thacker field. ${ }^{21}$ The miners' response to the change in the N\&W's coal sales policy in 1895 , hints at a possible reason for their refusal to join the 1894 strike. According to the Bluefield Daily Telegraph, the miners of southern West Virginia, in recognition of the hardship faced by their employers, offered to "concede to some wage reduction" in return for a guarantee of full-time work. ${ }^{22}$ The cooperative stance of the Thacker miners revealed their adherence to a traditional philosophy of labor-management relations. Until the late nineteenth century, miners believed in a "harmony of interest," that they and their employers had a common interest in maintaining production. ${ }^{23}$ However, persistent adverse economic conditions and evolving managerial philosophies negated the importance of the miners' sacrifices. ${ }^{24}$ As a result, between 1897 and 1902, miners in the Williamson-Thacker Field answered the United Mine Workers of America's strike call six times.

Scanty records limit analysis of the 1897, 1898, 1899, and 1900 strike efforts in Mingo County. Brief in length, Mingo's 1897-1900 strikes reflect the painful transition of turn- of- the century American mining. ${ }^{25}$ The reasons for these early strikes included: increased wages (a

${ }^{21}$ Thomas, "Coal Country," 237.

22"Shifting the Deal," Bluefield Daily Telegraph, 21 February 1895 in David E. Johnston Collection, ERCA.

${ }^{23}$ Laslett, Colliers, 144-145.

${ }^{24} \mathrm{Ibid}$.

${ }^{25}$ The 1897 strike was called July 4, 1897; in West Virginia the strike lasted as briefly as 1 day (Mason County) and as long as 77 days (Ohio County), in Mingo the strike lasted 30 days. According to the 1898 Annual Report, a second attempt at a strike was made on April 1, 1898 -hence the reference "the 1897-1898 strike." 1898 Annual Report of the West Virginia Department of Mines, 47. 
perennial cause), the firing of a local union president, and safety concerns. ${ }^{26}$ While the 1897 , 1899, and 1900 strikes ended in capitulation, the 1898 walkout ended when the operators hired replacement workers. The small amount of available information on these local attempts to participate in larger efforts seems to indicate that the 1897-1900 strikes in Mingo County were plagued by a lack of cohesion and cooperation among the miners. ${ }^{27}$ The operators' success in forestalling the unionization of their employees stemmed not from grand strategy but rather from their ability to "starve" their men out or find area natives who were more than willing to hire on as replacements. ${ }^{28}$

Strike activity in Mingo's Thacker field was transformed in 1901 when, as part of the 1900-1902 UMWA's effort to organize West Virginia, the union organized two sub-districts in southern West Virginia, one in the Thacker field and another on the New River. Although these sub-districts rapidly amassed a combined membership of five thousand miners, the strikes

\footnotetext{
${ }^{26}$ From 1898-1903, the Annual Report of the West Virginia Department of Mines reported yearly on strike activity in the state's coal producing counties. Information on Mingo's strikes was taken from these tables.

${ }^{27}$ Based on details from the source cited in note 26, in this period, reasons for Mingo's strikes varied from mine to mine. For example, in 1900, miners at the Mingo Mining Company struck "to compel miners to use [a] better grade of oil. 1898-1900 Annual Reports of the West Virginia Department of Mines, Part III: 286. The 1898-1900 Annual Reports were published in a single volume, divided by "parts".

${ }^{28} 30$ August 1898, Bert Wright Diary, Luther Papers, ERCA. The willingness of locals to scab is documented in an oral history with native miner William Carey, who observed that members of strikers' own families often accepted replacement work. William Carey interview with Keith Dix, 17 October 1971 at Red Jacket, Mingo County, West Virginia, Oral History Collection, WVRHC.
} 
undertaken in 1901 and 1902 also collapsed in failure. ${ }^{29}$ Accounts of these strikes suggest that, just as later during the mine wars, the operators defeated the miners through "injunctions, deputies, strikebreakers, and intimidation."30 The now classic work on the unionization of southern West Virginia's miners also accepted without question, the UMWA's condemnation of the miners for the strikes' defeat. ${ }^{31}$ However, analysis of the available records of the 1901 and 1902 strikes in Mingo's Thacker field suggests that the local story of these strikes exposes heretore unacknowledge connections between the early organization efforts and the 1920-1922 initiative, including the partial culpability UMWA for their failure. ${ }^{32}$

The early success of the 1901organization drive in the Thacker field resulted from the miners' ability to attract support that, at least initially, undermined the strike breaking efforts of their employers. First, the miners persuaded imported replacement workers to join them or

${ }^{29}$ Andrew Roy, History of the Coal Miners of the United States (Columbus, OH: Press of J. L. Trauger Printing Co. 1902 ), 395.

${ }^{30}$ Fagge, 114.

${ }^{31}$ Corbin, Life, Work, and Rebellion, 27. Corbin's failure to acknowledge Mingo's early strike efforts, led many to assume, until Fagge's Power, Culture, and Conflict was published in 1996, that until 1920, Mingo's miners had quiescently accepted their own oppression.

${ }^{32}$ The connections include: the participation of the same individuals in the early and later strikes, the support of Mingo's sheriff for the strikers, and most important, the significance union organizers placed on the area's connection to the Hatfield-McCoy feud. 
return home. ${ }^{33}$ Second, Mingo's sheriff refused to interfere in the conflict. ${ }^{34}$ Third, when the operators sued the union for unlawful enticement the local court ruled against them. ${ }^{35}$ Despite these startling accomplishments, the operators prevailed and the 1901 Thacker strike collapsed within months. ${ }^{36}$ Union organizers and officials condemned the miners for the failure, claiming that the miners "lost interest" in the union when they "discovered that they had to pay initiation fees." $" 37$

A close examination of the few remaining primary sources from the 1901 strike demonstrates that it failed for a variety of reasons, and not just the lack of will of Mingo's miners. First, although the operators lost their court case locally, they managed to keep the suit alive for five years, which ultimately wore down the union's resolve. ${ }^{38}$ Second, in a related vein,

\footnotetext{
${ }^{33}$ Men imported from North Carolina at the company's expense never worked for the company. In two other cases, men who contracted with Thacker to mine coal "broke" and "violated" their agreements shortly after beginning to work, all because they were "induced and enticed away" by the union. "Thacker Coal \& Coke Company v. Burke et al," Reports of the West Virginia Supreme Court of Appeals 59 (February 15, 1906 - April 24, 1906): 253-262, 260261.

34"Miners in Conference" United Mine Workers Journal 11 (4 July 1901): 2. According to the $U M W J$, Sheriff Hatfield and a posse arrived at a mine to perform guard duty, but "refused to serve" and returned to Williamson. In a public statement, Sheriff's Deputy (M. Z.) White explained, "We declined to take a hand in the controversy because the demand of the operators that all intercourse between the strikers and the non-union men be suspended was manifestly unjust. We agreed to preserve order, prevent interference of a violent nature and protect property, but beyond this we could not in fairness go."

35"Thacker v.Burke," 254.

${ }^{36} 1901$ Annual Report of the West Virginia Department of Mines, 114.

${ }^{37}$ Corbin, Life, Work, and Rebellion, 47.

${ }^{38}$ The last certifiable legal action, "Thacker v. Burke" was heard by the West Virginia State Supreme Court of Appeals in the spring of 1906. Operators quickly learned that "tying up union
} 
the cost of the strike led to local internal dissension and disaffection with the union. Writing to UMWA president John Mitchell, the president of the miners' local at Matewan exposed the most critical obstacle to organizing the Thacker field. On behalf of his beleaugured men, the president wrote:

"we are not being treated right here ... if there is not more attention paid to the actual needs of our men in justice to myself and men I will resign and in this declaration I voice the sentiments of all the officers of our L.U. [local union]. ${ }^{39}$ The UMWA's effort in the Thacker field collapsed, not only because the men returned to work as non-union employees, but also because the national union failed to provide adequate funding and capable leadership. ${ }^{40}$

Despite historians' claims that deputies and intimidation were used to break the 1901 strike, the most egregrious abuse of union men, in particular the imported organizers, occurred in McDowell County. ${ }^{41}$ Intimidated, the organizers and the national union retreated before the

funds" through legal battles was an effective method of strike breaking. Rhodri Jeffreys-Jones, Violence and Reform in American History (New York: Franklin Watts, 1978), 96.

${ }^{39}$ S. S. Morrison to John Mitchell, 3 July 1901, John Mitchell Papers, Microfilm Reel 3, Charles C. Wise Library Microfilm Collection, West Virginia University, originals archived at Catholic University, Washington D.C. Other letters from Morrison, and fellow local union leader Alvin Hunter, reveal the escalating costs of the local effort. Funds were needed for: legal and transportation fees stemming from the fight against an operator's injunction, relief and construction of shelters for the strikers's families, and transportation to other fields for miners and their families.

${ }^{40}$ See note 39 for explanation of the fiscal challenge to the union effort.

${ }^{41}$ W.H. Crawford to John Mitchell, 30 August 1901, Mitchell Papers. A native of Ohio, Crawford was a professional UMWA organizer. In this and subsequent letters, Crawford repeatedly appealed for permission to go home, because as he observed in this letter to Mitchell, "I do not wish to work in a region where officers of the law are assassins." 
operators' stiffening resolve led to pitched battle. ${ }^{42}$ As Matewan' local president Morrison observed to President Mitchell, "had we this company to fight only it would have been settled long ago, but right here in this Thacker field we are fighting nearly every operator in the State of West Virginia. ${ }^{״ 3}$ According to union organizer W. H. Crawford, the Thacker miners had told him that when they saw that to "fight was the only chance ... they would take their Winchesters and defend themselves. ${ }^{" 44}$ To underscore the sincerity of his report Crawford reminded his superiors:

Thacker is in a region where they certainly will use guns to settle differences of opinion being the center of the Hatfield-McCoy feud. Those people are there yet and both sides to the controversy are with the miners. ${ }^{45}$

Weakened by dysentery and unnerved by the death of a fellow organizer, which he initially ascribed to poison, Crawford turned on the miners of southern West Virginia. ${ }^{46}$ Derided as violent but weak by the UMWA, thereafter the miners themselves became the sole scapegoats of the failed early efforts to organize southern West Virginia. ${ }^{47}$

\footnotetext{
${ }^{42}$ The violent clashes over unionization during the late nineteenth and early twentieth centuries "forced trade unions to set a premium on respectability," and thus union leaders were loathe to publicly endorse violent acts by their members. Jeffreys-Jones, 10, 18.

${ }^{43}$ S. S. Morrison to John Mitchell, 25 August 1901, Mitchell Papers.

${ }^{44}$ W. H.Crawford to John Mitchell, 30 August 1901, Mitchell Papers.

${ }^{45}$ Ibid.

${ }^{46}$ W. H.Crawford to John Mitchell, 7 August 1901 and same, 25 September 1901, Mitchell Papers.

${ }^{47}$ Crawford to Mitchell, 30 August 1901 and same 9 September 1901, Mitchell Papers.
} 
The UMWA's continuing inability to undertake a decisive and sustained effort in 1902 is reflected in the the following description from West Virginia's Department of Mines' Annual Report. As noted in the Annual Report, in 1901 there were strikes in eight West Virginia counties, including Mingo but, "were of short duration" and were the result of the operators refusing to grant demands made by the miners for an eight hour day, recognition of organized labor, and in two cases the result of wage differences. The strike was so weak and disorganized West Virginia's state mine officials did not even acknowledge that the Union had intended to undertake a mass drive. ${ }^{48}$

Defeated in 1901, castigated by their own leaders, and still fighting their employers in the court system, in 1902 for the fifth time in six years miners tried to unionize the Thacker field. On June 7, 1902, 132 miners at four Mingo County mines responded to a strike call from the United Mine Workers of America. ${ }^{49}$ The number of men thrown out of work by the strike grew by 60 percent when the Grapevine mine locked out its eighty miners. ${ }^{50}$ Since 80 percent of the rest of the state's miners also responded, the UMW focused its attention on the previously unorganized Fairmont field of northcentral West Virginia and the other southern fields. ${ }^{51}$ Left to

\footnotetext{
${ }^{48} 1901$ Annual Report of the West Virginia Department of Mines, 38.

${ }^{49} 1902$ Annual Report of the West Virginia Department of Mines, 94. Contemporary newspaper accounts do not mention the activities of Mingo's miners. Eleven days after Mingo's strike began, striking miners of Mercer and McDowell counties marched throughout the Flat Top Pocahontas field. At one mine, the marchers "disarmed the guards and drove the non-union men from the mines after giving them a good beating." Huntington Advertiser, 18 June 1902.

${ }^{50}$ Ibid.

${ }^{51}$ Fagge, 115; C. E. Lively joined the UMWA at Black Band, Kanawha County in 1902. "Testimony of C. E. Lively," 25-26 February 1921, unknown newspaper, Matewan Omnibus Collection, ERCA; Thacker v. Burke started in 1901, was submitted to the West Virginia State
} 
their own devices, the miners of the Thacker field for a time succeeded without assistance.

Nearly twenty years later, the Williamson-Thacker operators' association acknowledged that in 1902, the Williamson-Thacker field had been organized "without much objection." ${ }^{12}$ But, isolated and unsupported, the miners lost their battle again in just over three months. On September 1, 1902, four days before it ended in the Kanawha, Flat Top and New River fields, the strike in Mingo was called off and the men returned to work still without union recognition or union contract. ${ }^{53}$ If native miners like Sam Artis, a co-defendant in the 1901 Thacker v. Burke case, maintained ties to the union they did so secretly. The miners in Mingo County did not strike for the union again until July, $1920 .^{54}$

Except for success in the Kanawha field, the 1900-1902 United Mine Workers of America's effort to organize West Virginia's miners went down to ignominious defeat. ${ }^{55}$ UMWA Vice-President T. L. Lewis had been assigned to direct the campaign but "ignored his

Supreme Court of Appeals in 1903, and decided in March 1906. How much longer the case lasted is not known, but the supreme court's 1906 decision only clarified the case in order to remand it to the circuit court. Thacker v. Burke, 261.

${ }^{52}$ The United Mine Workers in West Virginia, 54.

${ }^{53} 1902$ Annual Report, 94; Huntington Advertiser, 5 September 1902. According to the Advertiser, the strike in the other southern fields ended when the operators agreed to allow eight thousand striking miners to return to work.

${ }^{54}$ Legal document from the Thacker v. Burke case, John Mitchell Papers. Sam Artis also participated in the 1920-1922 strike. On May 19, 1920, he was shot and wounded by William Cummins, the superintendent of Red Jacket. Mingo Republican, 8 July 1920. Artis was also the father-in-law of the pro-union Mingo County deputy sheriff, J. P. "Toney" Webb, who was a defense witness in the Matewan Massacre trial. "Testimony of Jesse P. Webb," Lewis Collection, ERCA.

${ }^{55}$ Fagge, 115. 
responsibility" and spent most of his time scheming to usurp the union's presidency from John Mitchell. ${ }^{56}$ At least two organizers sent to West Virginia were accused of accepting bribes. ${ }^{57}$ However, in communications with President Mitchell, the organizers asserted that "the miners were quick to accept both company promises and advice to stay away from the union." ${ }^{58}$ The operators had learned to buy off the union leadership, and the union itself found it easier to blame its failure on the miners.

The ramifications of the "abortive strike of 1902" were far reaching. ${ }^{59}$ At the 1902 UMWA Convention President Mitchell announced that although the 1900-1902 West Virginia organization drive had added five thousand new members, the operators were more antagonistic than ever. ${ }^{60}$ A more subtle, but no less significant, changed occurred in southern West Virginia when following the strike, British miners abandoned the region for the unionized coal fields of the Midwest. ${ }^{61}$ The exodus of the British Isles miners affected conditions in the southern coal fields in two significant areas.

${ }^{56}$ Ibid.

${ }^{57}$ Ibid., 114.

${ }^{58}$ Corbin, Life, Work, and Rebellion, 27.

${ }^{59}$ Fagge, 190.

${ }^{60}$ Ibid.

${ }^{61}$ Ibid. Fagge refers to the miners of the Smokeless fields, but based on data triangulations from the 1900 and 1910 United States Census and the Department of Mine reports for 1900-1910 by this author, the same phenomenon occurred in the Thacker field. See also: Corbin, Life, Work, and Rebellion, 27-28. 
First, when the British miners immigrated to the United States, and then as they were recruited to open new coal fields, they carried with them a tradition of trade unionism, which made them natural leaders of union organizing campaigns. ${ }^{62}$ Their absence in the southernmost counties after the 1902 strike deprived the native and new immigrant miners of that organic link to traditional union philosophy. The native miners who eventually acquired a dedication to unionism, did so because they saw in the union a means to address grievances peculiar to their own situation. ${ }^{63}$ Also, they were too few in number to lead effectively because they were frequently jailed and/or driven from the coal field in which they proselytized for the union. ${ }^{64}$

Second, the British miners were the core of the skilled craftsmen working in the mines. Their passage from southern West Virginia also marked the beginning of the end of the handloading era ${ }^{65}$ Until mine mechanization began in the late 1880 s and early 1890 s, miners possessed a quasi-autonomous sub-contractor status. The mine owner-operator contracted with

${ }^{62}$ Corbin, Life, Work, and Rebellion, 27-28.

${ }^{63}$ David A. Corbin, “'Frank Keeney is Our Leader and We Shall Not Be Moved': Rank and File Leadership in the West Virginia Coal Fields," in Essays in Southern Labor History: Selected Papers from the Southern Labor History Conference, 1976 edited by Gary M. Fink and Merle E. Reed (Westport, CT: Greenwood Press, 1976): 144-156, 147.

${ }^{64}$ A. D. Lavinder interview with Bill Taft and Lois McLean, 22 June 1973, at Matewan, Oral History Collection, WVRHC. One such miner was A.D. Lavinder, a native of southwestern Virginia who, in a career that spanned sixty-three years and almost every coal field from the New River to the Kanawha, remained a dedicated union activist and Socialist.

${ }^{65}$ Corbin, Life, Work, and Rebellion, 27-28. The author's description of the conditions in the mining industry was gleaned from this and these other works which reveal the impact of the transformation of American coal mining: McAlister Coleman, Men and Coal (1943), Keith Dix, Work Relations in the Coal Industry: The Handloading Era 1880-1930 West Virginia University Bulletin, Series 78, no.7-2 (Morgantown, WV: Institute for Labor Studies, 1977); Carter Goodrich, The Miner's Freedom (1925), John H.M. Laslett, Colliers Across the Sea (2000), and Homer Morris, The Plight of the Bituminous Coal Miner (1934). 
the miner to extract a certain amount of coal by a certain time or date and it was the miner's responsibility to fill the order. The miner generally provided his own tools, and paid for the powder and other necessary equipment. The miner also had to secure and prepare his own work space at the coal face, for which he was not compensated. ${ }^{66}$

The "freedoms" the miner enjoyed in the handloading era to a degree offset the responsibilities and costs shouldered by the "sub-contractor" miner. The miner, within the limits of his contractual obligations, controlled the pace and length of his work day. Depending on the agreement with the mine operator or superintendent, if the miner determined that he had earned enough for that day or had chores to do at his home he packed up his tools and walked out of the mine. It was this type of mining that first attracted the native population who also continued to farm. $^{67}$

Mechanization dramatically altered the nature and pace of mining. The process of mining became increasingly compartmentalized and de-skilled. Men were hired only to timber, or shoot the coal, or load the coal. This division of labor also separated the workforce and made camaraderie and unity of action more difficult. As mechanization increased, the miners worked according to the clock and not tonnage allotment. The miner was reduced from a craftsman who had acquired a variety of skills over a number of years to a "machine tender" who required minimal training before assuming his responsibilities. ${ }^{68}$

${ }^{66}$ Laslett, Colliers, 24 and 131-132.

${ }^{67} \mathrm{Ibid}$; Corbin, Life, Work, and Rebellion, 27.

${ }^{68}$ Dix, Work Relations, 16; Curtis Seltzer, Fire in the Hole: Miners and Managers in the American Coal Industry (Lexington, KY: University Press of Kentucky, 1985), 13. This process was not confined to coal mining as David Thelen proves in his study of community reaction to 
All of these changes took decades to transform the industry. The "miner's freedom" was not lost all at once. ${ }^{69}$ The gradual and piecemeal transition itself contributed to danger and discord in the work place. ${ }^{70}$ Skilled craftsmen, like the British miners, chafed at the problems created by working alongside men who had only recently entered their profession. The threat posed by unskilled men could inspire outright resistance. In the 1900 strike at the Mingo Coal Mining Company, miners went out on strike to compel their fellow miners to use a better grade of oil. ${ }^{71}$ Improper or careless handling of the tools of the trade could and often did have deadly consequences.

In the early years of mechanization when only a few miners could run the new machines, the division of skills also undermined workplace camaraderie. Companies competed for the skilled men, who could "name their price" and were paid much higher wages than their fellow miners. James McCoy, the father of Rosa McCoy Wolford was one such miner. Mrs. Wolford explained companies frequently sought to lure her father away from where he worked. The demand for his skill affected their standard of living -- if conditions in a camp proved substandard, the family could always move on because Mr. McCoy was virtually assured of

industrialization in the Ozarks. According to Thelen, "when employers replaced artisans with machines, they also ensured that the new workers would never have the skills . . to rise from worker to employer in the time-honored manner. Thelen, 50.

${ }^{69}$ Dix, Work Relations, 16.

${ }^{70}$ Thelen, 51. Thelen observes, "loss of control over access to the workplace ... [led] established workers to view new arrivals as competitors, not comrades."

${ }^{71} 1900$ Annual Report of the West Virginia Department of Mines, 286. 
finding work. ${ }^{72}$ Sometimes these skilled miners led unionization efforts in order to secure better wages or to protect their interests. In other cases, the demand and competition for the skilled machine men inured them to the complaints of their fellow miners and as favored employees they were occasionally actually hostile to unionization efforts. ${ }^{73}$

The transition to mechanization often proved difficult in part because it occured unevenly and because the miners often lost autonomy without a corresponding lessening of responsibilities. ${ }^{74}$ The advent of shift work imposed limits on miners' time at the coal face but the men were still expected to mine a set amount of coal. Still others were ordered to produce a set tonnage of coal a day and in order to keep their jobs, had to work around the clock. The father of Mrs. Virginia Grimmett often stayed at the mine for days, "sneaking a nap on the gob pile" and eating only when Jennie's mother sent him a meal. ${ }^{75}$ Failure to produce the demanded tonnage could result in dismissal without recourse. Between the Thacker field's opening in the early 1890s and the labor strife of 1920-1922, the miners were reduced from "looking like Congressmen" when they left the bathhouse at the end of their shift to "being treated worse than a dog" and sleeping on a pile of mine waste between shifts. ${ }^{76}$

\footnotetext{
${ }^{72}$ Rosa McCoy Wolford interview with Rebecca J. Bailey, Summer 1990 Matewan Oral History Project.

${ }^{73}$ Thelen, 50-51. The process of mechanization had a similar impact in several industries.

${ }^{74}$ Dix, Work Relations, 16.

${ }^{75}$ Virginia Grimmett interview with Rebecca J. Bailey, Summer 1989 Matewan Oral History Project.

${ }^{76}$ Roy, "Thacker Field": 472; Grimmett interview.
} 


\section{The New Century Brings New Struggles in the Thacker Coal Field, 1900-1911:}

Although freed from the threat of unionization, the Thacker field faced new problems shortly after the dawn of the new century. Still in the shadow of the older, larger fields to the east, the opening of the Guyan Field in Logan County added to the pressures on the Thacker field. In less than a decade, coal mines in Mingo's parent county caught up with and surpassed those in the Thacker field. ${ }^{77}$ The close of the field's second decade found it caught between two large and powerful neighbors, the Guyan Field of Logan County and the Pocahontas Field of McDowell County..

By 1900, Mingo County surpassed its parent county in population. As noted by Dr. Sidney B. Lawson and historian Edwin Cubby, in 1895 Mingo barely possessed the 6,000 inhabitants necessary for the formation of a new county, and then only after "considerable conniving. ${ }^{78}$ By 1900 , Mingo's population had risen to $11,359 .{ }^{79}$ By comparison, Logan County's population which had been 11,101 in 1890 fell to 6,955 in $1900 .^{80}$ Table 3 illustrates both how the railroad and the coal industry first precipitated the early growth of Mingo and the contemporaneous decline of Logan, and then, after finally coming to Logan in 1904, reignited development in the older county.

\footnotetext{
${ }^{77}$ Assertion based on data from the 1910 Annual Report of the West Virginia Department of Mines, 8.

${ }^{78}$ Lawson, 47; Cubby, "Transformation," 173.

${ }^{79}$ Abstract of the Thirteenth Census of the United States, with Supplement for the State of West Virginia (Washington, D.C.: GPO, 1913).

${ }^{80}$ Ibid.
} 
Table 3:

Population of Mingo, Logan, and McDowell Counties, 1890-1920

\begin{tabular}{llllll}
\hline \hline County & 1890 & $1895^{*}$ & 1900 & 1910 & 1920 \\
Mingo & na & 6,000 & 11,359 & 19,431 & 26,364 \\
Logan & 11,101 & 5,101 & 6,955 & 14,476 & 41,006 \\
McDowell & 7,300 & na & 18,747 & 47,856 & 68,571 \\
\hline \hline
\end{tabular}

Source: Fourteenth Census of the United States, State Compendium: West Virginia.

*Mingo County did not exist in 1890; it was divided from Logan County in 1895.

Between 1880 and 1910 Mingo, Logan, and McDowell counties underwent a parallel

experience in terms of industrial development. All three counties had been agricultural counties with relatively sparse populations until their local economies were transformed by the railroad and the coal industries. ${ }^{81}$ As Table 3 illustrates, in 1890, just as McDowell was poised to undergo industrial transformation, the then larger, but still farming and timber dependent Logan had more residents.

Ten years later, Logan had been cleaved in two and McDowell was the number one coalproducing county in the state. ${ }^{82}$ In 1900 McDowell, now fully-integrated into the coal-railroad industrial matrix, possessed over two and one half times the population of the still undeveloped Logan. Mingo, which had also undergone an industrial transformation, doubled in population and surpassed Logan. The degree to which Logan had lagged behind because it was remote from the railroad and had no coal development is underscored by these financial statistics from the 1900 Agricultural and Manufacturing Census. In 1900, Mingo County's "capital investment in

\footnotetext{
${ }^{81}$ Corbin, Life, Work, and Rebellion, 1.

${ }^{82} 1922$ Annual Report of the West Virginia Department of Mines, 117.
} 
manufacturing and mechanical industries amounted to $\$ 268,975$, but in Logan investments only came to $\$ 9,285 .{ }^{183}$

The rapidity of Logan's development after being accessed by a railroad and "opened" for the development of its coal properties is the last significant illustration in Table 3. After the Chesapeake \& Ohio rail line to Logan County became operational in 1904, Island Creek Coal Company began mining. ${ }^{84}$ Logan embarked on a transformation that by 1920 eclipsed Mingo. ${ }^{85}$

In 1901, the creation of the U. S. Steel Corporation altered the course of national and regional economic development. ${ }^{86}$ U.S. Steel, the first billion dollar corporation in the United States and the world, effectively dominated the export of southern West Virginia coal after it purchased almost 80 percent of the Pocahontas coal field. ${ }^{87}$ As noted by the UMWA in 1921 , U.S. Steel also eventually accumulated about fifty to sixty thousand acres of coal lands in Mingo County. ${ }^{88}$

${ }^{83}$ Abstract of the Thirteenth Census, with Supplement for West Virginia, 944.

${ }^{84}$ Cubby, "Railroad Building," 246.

${ }^{85}$ Detailed comparisons of coal mining in Logan, Mingo, and McDowell Counties appear in subsequent chapters.

${ }^{86}$ Chernow, 82 .

${ }^{87}$ Ibid., 82; Harold W. Houston, Brief on behalf of the United Mine Workers of America, before the committee on Education and Labor, United States Senate, in the matter of the investigation of violence in the coal fields of West Virginia and adjacent territory, (n.p. 1921), 45. Hereafter "Houston Brief."

88"Houston Brief," 45. 
However, U.S. Steel's attention was not drawn to the Mingo County properties until the First World War precipitated an unprecedented boom in the demand for coal. ${ }^{89}$ A possible explanation for the disregard appears in Ron Chernow's monumental study, The House of Morgan. Chernow asserts that despite what generations of Morgan critics have assumed, it took years for the executives of U.S. Steel to forge the corporate infrastructure that ultimately allowed U.S. Steel to exert the influence so lauded and feared..$^{90}$

For the entire period between 1901 and 1920, Mingo County did not warrant the recognition afforded the U.S. Steel properties in the Pocahontas field. Mingo's coalfield possessed a high quality coal, but it was of lesser quality and commanded less demand than the "Smokeless" coal found in McDowell. ${ }^{91}$ McDowell's "Smokeless" coal was considered of such high quality, demand for it offset the costs of operating in an older less efficient field. The production "ranking" of the two fields underscores the difference in the market value of their coal. Mingo County never placed higher than seventh of West Virginia's coal producing counties. By contrast, neighboring McDowell County, the heart of the Pocahontas field, consistently ranked either first or second. ${ }^{92}$

In 1904, when the Guyan field replaced Thacker as the youngest field in southern West Virginia, the peripheral status of Mingo's coal field became permanent. Although both the

${ }^{89}$ See Chapter 7 for the activities of U.S. Steel in Mingo County between 1917 and 1919.

${ }^{90}$ Chernow, 86.

${ }^{91}$ Corbin, Life, Work, and Rebellion, 4; Lambie, 335.

${ }^{92} 1922$ Annual Report of the West Virginia Department of Mines, 117 . Between 1897 and 1904 McDowell County ranked either first or second in production; from 1905 to 1922 McDowell ranked first in the state. In that same period, Mingo ranked from ninth to seventh. 
Guyan and Thacker fields mined "High Volatile" coal, development of the Guyan field more closely resembled that of the Smokeless fields. Just as in McDowell's Pocahontas field, highly capitalized corporations dominated the development of the Guyan field. The largest, Island Creek, a subsidiary of U.S. Coal \& Oil, owned its coal lands in fee simple, or outright. ${ }^{93}$ As a result, "shoestring operators stayed away." ${ }^{\prime 4}$ Launched after the demise of unionization efforts in southern West Virginia, and free from the distractive presence of small-time would-be entrepreneurs, the operators of the Guyan field ran their empire in Logan County smoothly for almost twenty years. ${ }^{95}$

The relationship between the operators and the railroad during the initial development phase of the Thacker and Guyan fields underscores the contrasting economic power of the two young fields. Andrew Roy observed in 1899 that one of the few disadvantages faced by operators in the Thacker field was their weak bargaining position with the N\&W. As Roy noted, because the $\mathrm{N} \& \mathrm{~W}$ had no competitors for trade in the Thacker field, it required the coal companies to build their own switches. ${ }^{96}$ Just five years later when the Chesapeake \& Ohio

${ }^{93}$ Spence, 289.

${ }^{94}$ Ibid., 318.

${ }^{95}$ Lee, Bloodletting, 136-137. The quietude of the Guyan field was ensured by the administration of peace by the Chafin family, who provided their services to the operators, for a price. As cited in other places in this study, the Chafins were fixtures in Logan County politics from the 1890s until 1924, when with the collusion of Tennis (son of Devil Anse) Hatfield, Sheriff Don Chafin, the "Czar of Logan County" was convicted of violating the Volstead Act. For more on Chafin rule in Logan see Lee, Bloodletting, 87-121. See also Spence, Land of the Guyandot, 465-468.

${ }^{96}$ Roy, "Thacker Coal Field": 472. By contrast to the N\&W's treatment of the Thacker operators, several years later when Island Creek launched operations in Logan County, it forced the $\mathrm{C} \& \mathrm{O}$ to charge a lower haulage rate by threatening to construct its own transportation system. 
lagged in constructing connections to the new Island Creek mines, the Company threatened to renew its own plans to build a connecting line to the N\&W tracks at Canterbury, in Mingo County. ${ }^{97}$ Eager not to lose out to the Norfolk \& Western, the C\&O completed the work and granted favorable rates to Island Creek. Five years after starting production, Logan's Guyan field outranked Mingo's Thacker field. ${ }^{98}$

Basic similarities between the Thacker field and surrounding fields in their early development allowed historians to overlook differences that took years to take effect. For example, the coal mined during the Thacker Field's first decade was shipped east, like the Smokeless fields' coal, for use by steamships. ${ }^{99}$ However, the United Mine Workers of America strikes and unionization drives of the late 1890s and early 1900s in Pennsylvania and the Midwest allowed the coal fields of southwestern West Virginia to capture an increasing share of the Great Lakes coal trade. ${ }^{100}$ The split in the export direction of southern West Virginia coals eventually contributed to greater competition between the southern West Virginia fields. ${ }^{101}$

Spence, 342 .

${ }^{97}$ Edwin A. Cubby, "Railroad Building, 246; Spence, 342. Cubby cites the creation of the Island Creek Railroad Company in 1902 as evidence of Island Creek's financial power and seriousness in its negotiations with the $\mathrm{C} \& \mathrm{O}$.

${ }^{98} 1910$ Annual Report of the West Virginia Department of Mines, 8. Logan ranked 7th and Mingo 9th out of 34 coal producing counties.

${ }^{99}$ Coal Trade Journal 36 (17 February 1897): 899.

${ }^{100}$ Thomas, "Coal Country," 237; Corbin, Life, Work, and Rebellion, 6. According to Corbin, "the West Virginia operators might be termed the pirates of the coal trade, standing ready at all times to descend on any fat prize."

${ }^{101}$ Lambie, 295. 
Haulage rates for these fields differed even when the coal traveled in the same direction on the same railroad. For example, "High Volatile" coal from the Williamson-Thacker field and "Smokeless" coal from the Pocahontas field were both shipped to the Great Lakes region on the Norfolk \& Western Railway. Despite being neighboring fields, and despite the Pocahontas field being farther away from the coal's destination, the Williamson-Thacker field was designated an "inner crescent" field and paid a lower haulage rate than the Pocahontas field which was categorized as an "outer crescent field." 102

In his anecdotal history of mining in southern West Virginia, pioneer coal operator W. R. Thurmond substantiates other important differences between the six coal fields of southern West Virginia. Most important, Thurmond also asserts that historians all too often have erroneously discussed all six fields as a single unit. According to Thurmond, "the basic division . . . is an east-west one." In eastern southern West Virginia were the three "Smokeless" coal fields: the New River, Pocahontas, and Winding Gulf, and in the west were the "High Volatile" coal fields: Kanawha, Logan, and Williamson. Thurmond believed the differences between the six fields extended further than the type of coal they produced. ${ }^{103}$

The three eastern fields Thurmond stated, could be thought of as a "unit" because they "had much in common: capital, markets, labor relations, traditions and personnel." By contrast, Thurmond asserted, "the three western fields developed more or less independently of each other." Thurmond's most telling observation, which stands in marked contrast to most scholarly

\footnotetext{
${ }^{102}$ Ibid., 193, 297-298. The southwestern fields were Williamson-Thacker, Kanawha and Logan; the southeastern fields were Pocahontas and New River.

${ }^{103}$ Thurmond, 15.
} 
treatments of southern West Virginia coal history, is his claim that "the western fields were not developed as a mere extension of the older eastern fields." Thurmond goes further by stating that "the operators in the Smokeless area played on a different stage . . . reading from a different script." 104

Thurmond's analysis of the development of the six southern West Virginia coal fields emerges from a context of armchair reminiscences, but most of his commentary can be substantiated. ${ }^{105}$ Moreover, the differences he stressed contributed significantly to the eruption of labor violence in Mingo County. ${ }^{106}$ First, Thurmond's assertion concerning the cohesion in the eastern fields can be carried too far but it is worth noting that even though they competed against one another, the Smokeless operators all benefitted from the market value of the "Smokeless" label. The western "High Volatile" operators possessed no parallel perk. ${ }^{107}$

Second, as Thurmond states, the operators of the Smokeless fields were a tightly knit group. Several were active members inf more than one of the Smokeless fields' operators' associations. ${ }^{108}$ While the Kanawha and Logan fields were similar to the Smokeless fields in that there were operators with connections to both fields, the Williamson-Thacker field was unique. Many of the investors, operators and employees of mining companies of the Smokeless and High

${ }^{104}$ Ibid., 15-16.

${ }^{105}$ See Chapters 7 and 8 of this study.

${ }^{106}$ See Chapter 10 of this study.

${ }^{107}$ Ibid., 16.

${ }^{108}$ Ibid., 15; This observation is also corroborated by the correspondence files of another Smokeless field operator, Justus Collins. Justus Collins Papers, WVRHC. 
Volatile fields also invested in the Williamson-Thacker field. However, as mentioned before, investment did not involve active, on-site participation in the running of the mines. ${ }^{109}$

A special edition of an early Mingo County newspaper, the Williamson Enterprise, provides an appropriate example of the owner-operator disconnectedness that became increasingly prevalent in Mingo County after 1900. Between 1900 and 1908, Dr. J. M. Mann, the brother of banker and Pocahontas Coalfield financier Isaac T. Mann owned three businesses in Mingo: a coal mine, the Majestic Collieries Company, at Majestic and two stores in Matewan. The Williamson Enterprise disclosed that Dr. Mann organized Majestic through P. P. Flanagan, a thirty-six year old mine superintendent from Pennsylvania. Little could be uncovered about the two stores in Matewan owned by Dr. Mann. The Williamson Enterpise article did not name them and none of the available business directories from the period offer any clues. ${ }^{110}$

By 1904, eight mining companies were operating twenty-five mines in Mingo County, which produced 1,291,375 tons of coal, and marked first year Mingo County surpassed the 1 million ton production mark. ${ }^{111}$ Before 1920, Mingo's production output continued to rise and surpass first the 2 million and then the 3 million ton marks, but in comparison to the Pocahontas

${ }^{109}$ According to W.P. Tams, Justus Collins was the first southern West Virginia operator to move his home away from his mines and that "all" of the other N\&W and C\&O operators lived at the mines. Tams interview, 22, WVRHC. Tams' observation merely underscores this author's assertion that the Thacker field was a tangental concern for the leading operators who invested there, but lived closer to their own mines in other counties.

${ }^{110}$ Williamson Enterprise, 4 June 1908. Flanagan's biographical data was taken from the Twelfth United States Census (1900).

${ }^{111}$ Conley, History of the West Virginia Coal Industry, 260. 
field in McDowell and the Guyan field in Logan (which opened in 1904), Mingo's coal production stagnated after 1904 .

Despite the opening of a new N\&W branch line in 1902, twenty-one of Mingo's twentyfive mines were still located in Lee, Magnolia and Stafford districts in $1904 .{ }^{112}$ The other four mines were located in Harvey District in the northwestern corner of the county, and were operated at Dingess by the Pearl Coal Mining Company, one of the oldest companies in the field. ${ }^{113}$ The relocation of the railroad and the economic downturn of 1904 spelled the end of Dingess as a mining center, and eventually even the train tracks were removed. ${ }^{14}$

In 1905 W. N. Cole organized the Mattie Coal Company, an exceptional event in that year because following the depression of 1904 several Mingo county coal companies had been dissolved. ${ }^{115}$ Between March 8 and April 29, 1905, five of the county's twenty-three companies went under, including: the Mephisto, Sitting Bull, Star, and Pappoose mines. ${ }^{116}$ One company

\footnotetext{
${ }^{112}$ Assertion based on data extrapolation from 1902-1904 Annual Reports of the West Virginia Department of Mines.

${ }^{113} 1904$ Annual Report of the West Virginia Department of Mines.

${ }^{114}$ Cubby, "Transformation," 246; James G. Collier, "Mingo County in World War II," (Master's thesis, West Virginia University, 1956), 55.

${ }^{115}$ Williamson Enterprise, 4 June 1908.

${ }^{116}$ Secretary of State, Report of Incorporations in the State of West Virginia, for the Years 1905-1907 (Charleston, WV: Tribune Printing Company, 1907), 871-872. Prior to 1903, the report of all incorporations, increase or decrease of capital stock of corporations, registrations of foreign corporations and corporate dissolutions were published in the Acts of the Legislature; After 1903 this information was published at least until 1909 by the Secretary of State. 1909 is the last volume in the possession of the West Virginia and Regional History Collection; none of the other archival repositories in the state have that volume. No one in the current Secretary of State's office could shed light on why or when the publication ceased. However, post-1909 incorporation records are kept on microfiche in the Secretary of State's office. By 1915, the Star,
} 
that dissolved, only to rise phoenix-like shortly thereafter, was the Red Jacket Consolidated Coal \& Coke Company. ${ }^{117}$

1906 provided little time for financial recovery before another series of financial crises struck American industry. On October 21, 1907, the United States' copper market collapsed which in turn sparked a general stock market crash and "a sharp financial panic." ${ }^{118}$ In West Virginia, the "so-called 'Bankers' Panic' was anything but a short economic set back," and small businesses went "under" daily. ${ }^{119}$ Just the latest in a long line of United States' financial panics, which recurred "with worrisome regularity every ten years" in the nineteenth and early twentieth centuries, the 1907 Panic precipitated a contraction of the coal industry. ${ }^{120}$

Generally, during an upswing in the business cycle, the price for coal followed demand upward and the number of coal companies in a field would increase. Many of these companies were poorly capitalized, high risk ventures undertaken by investors who sought to make quick money and get out. Other small-time capitalists were investors who were unable to raise

Pappoose, and Mephisto mines had been absorbed by the War Eagle Coal Company. The Coal Catalog: Combined with a Coal Field Directory for the Year 1915 (Pittsburg, PA: Keystone Publishing Company, 1915).

${ }^{117}$ Red Jacket would eventually be the largest coal mining operation in Mingo County. In the 1920-1922 period, Red Jacket and Borderland, the other large operation which was partially in West Virginia and partially in Kentucky, led the final offensive against the union's attempt to organize the coal field. See Lunt, Law and Order vs. The Miners for more on the impact of the Red Jacket and Borderland injunctions on the 1920-1922 strike. Richard D. Lunt, Law and Order vs. The Miners: West Virginia, 1906-1933 (Charleston, WV: Appalachian Editions, 1992).

${ }^{118}$ Chernow, 123; George H. Soule and Vincent P. Carosso, American Economic History (New York: Dryden Press, 1957) 271.

${ }^{119}$ Barkey, 60.

${ }^{120}$ Chernow, 128; Eller, 141. 
sufficient capital to open a coal mine in a tight economy, but benefitted from the easier banking standards of an inflationary cycle. In either case, when the demand for coal decreased, and/or price deflation set in, these companies shut down. The larger, better capitalized companies would then move in and buy out these flagging operations. ${ }^{121}$

The contraction and consolidation of the coal industry in Mingo County that followed the 1907 panic mirrored the state and national reaction to the recession. Twenty-seven companies operated forty-two mines in Mingo County in 1907. Just two years later, in 1909, there were only nineteen companies running thirty-two mines. The depression of 1908 also contributed to the general economic constriction which had begun in $1907 .{ }^{122}$

A West Virginia State Supreme Court of Appeals case underscores how adverse economic conditions in 1907-1908 affected business relations in the coal industry. In September 1907, the Mate Creek Coal Company successfully sued its coal sales agency, the Damascus Coal Company for $\$ 1,030.23$. According to the brief Damascus submitted to the high court, the sales agency had withheld the money from Mate Creek because it had been unable to sell the coal provided for contracted purchasers. Damascus maintained that because Mate Creek had failed to supply a sufficient amount of the agreed upon quality of coal, the coal company should not have had to absorb the cost of selling the coal at a cheaper price and storing it longer than had been anticipated. ${ }^{123}$ However, the high court sided with Mate Creek Coal Company because the

${ }^{121}$ Eller, 141.

${ }^{122}$ Soule and Carosso, 340.

123"Mate Creek Coal Company v. Todd, et al" Report of the West Virginia Supreme Court of Appeals 66 (May 4, 1909 - February 1, 1910): 671-679, 671, 673. 
judges believed that the coal company had fulfilled its obligation and could not be held liable for the sales agency's difficulty in selling the coal. The Court based its decision on the fact that not only had the sales agency failed to provide evidence against Mate Creek, its owners admitted to touring Mate Creek's plant and approving its screening process. ${ }^{124}$

Another company that survived the fluctuations of the 1907-1908 economy was the War Eagle Coal Company. War Eagle was controlled by A. Moore, a leading Norfolk \& Western attorney and former West Virginia Attorney General Edgar P. Rucker, who was also closely allied with N\&W interests. ${ }^{125}$ War Eagle was one of a few long-lived companies in the Williamson-Thacker coal field. Incorporated in 1901, War Eagle was still in operation in at the end of the 1920-1922 strike. ${ }^{126}$ It is probable that War Eagle's longevity depended on its ties to the $\mathrm{N} \& \mathrm{~W}$.

In 1909 two developments in the Williamson-Thacker coalfield mirrored national and/or state trends. More importantly, they mark the beginning of the end of one cycle in the long transformation of the coal industry from a nineteenth century industry to a twentieth century industry. As mentioned earlier, in the coal industry, as in the marketplace at large, economic downturns forced the closure of small and marginally capitalized companies. During the bust or

\footnotetext{
${ }^{124}$ Ibid., 673, 675, 678. An interesting detail revealed in the Supreme Court report is that the contract between Mate Creek Coal Company and the sales agency was an oral contract, and never committed to paper.

${ }^{125}$ undated, unknown newspaper article in Keadle Papers, WVRHC.

${ }^{126}$ 1901-1922 Annual Reports of the West Virginia Department of Mines.
} 
in its aftermath, larger and/or more financially secure operations often exploited a deflationary lull in the demand for coal lands. ${ }^{127}$

Correspondence between a corporate front man and Williamson attorney S. D. Stokes substantiates the effect of this trend in the Williamson-Thacker field. After explaining that he represented "interests" who wanted to buy properties for speculation or rapid development, W. W. Houston informed Stokes that "our people are demanding properties which can be turned over promptly with good title," for which they were willing "to pay spot cash." ${ }^{128}$

The emergence of large multi-state coal corporations and the decline of entrepreneurial owner-operator companies began before the turn-of-the century and was marked in West Virginia by the underwriting of development by Pennsylvania, Maryland, and New York corporations. The consolidation of the rail industry begun by J. P. Morgan and others in 1898, and the creation of U.S. Steel in 1901, accelerated this transformation. ${ }^{129}$ Many contemporary observers and especially the "corporate" coal men argued that their domination of the industry meant progress

\footnotetext{
${ }^{127}$ Eller, 141.
}

${ }^{128}$ W.W. Houston to S. D. Stokes, 10 May 1909 in Stokes Papers, WVRHC. Just who Houston represented could not be found.

${ }^{129}$ In a process that came to be known as "Morganization," J. P. Morgan acquired control of one-sixth of all the United States' railroad trackage. The means of the process of this consolidation centers on the close relationship between railroads and banks. As Chernow, asserts, "every company that failed and was reorganized by a bank ended up the bank's captive client ... before 'Morganization' more than two-thirds of the railroads had offices outside of New York ... by 1900, the nation's railroads were consolidated into six huge systems controlled by Wall Street Bankers." The "Morganization" trend also affected West Virginia's railroads. By 1900 the Morgan interests acquired all of the Chesapeake and Ohio's trackage in southern West Virginia and eastern Kentucky; by 1901 Morgan et al had also acquired the Norfolk \& Western. Chernow, 67-69. 
because inflationary and cutthroat competition would be diminished, which in turn ennabled their companies to focus on efficient and safer coal production. ${ }^{130}$

Mechanization of the extraction process also diminished the need for a skilled and "demanding" work force. The traditional work process was "restructured -- piecework fell away, hour work increased, task specialization, [and] supervision increased." ${ }^{131}$ According to coal historian Keith Dix, 1909 marked the turning point from traditional to modern mining in West Virginia. ${ }^{132}$ Dix based this assertion on an examination of work-related statistics, the most important being the ratio of the "skilled craftsman" pick miners to the number of machine miners. ${ }^{133}$ The advent of machines reduced the importance of the individual man in the mining process. Miners devolved from quasi-autonomous subcontractors into just another type of interchangeable part.

As illustrated by Table 4, employment statistics from Mingo County mirrors the state trend noted by Dix. As the number of mines in the Thacker or Williamson-Thacker coalfield increased so too did the number of pick miners. However, because machine mining had accompanied the field's opening, there had been a corollary increase in the number of machine miners. In Mingo County, machine miners surpassed pick miners three years before the state average. Mechanization also made possible the division of tasks in and around the mines which

\footnotetext{
${ }^{130}$ Paul H. Rakes, "Technology in Transition: The Dilemmas of Early Twentieth Century Coal Mining," Journal of Appalachian Studies 5 (Spring 1999): 27-60, 32. According to Rakes, "larger concerns made conscious efforts to drive smaller operators out of business."

${ }^{131}$ Seltzer, Fire in the Hole, 13.

${ }^{132}$ Dix, Work Relations, 36.

${ }^{133}$ Ibid.
} 
meant that the number of men employed by the mines, but not as pick or machine miners, also increased. The table also illustrates this trend. The change was gradual and was influenced by many factors. For example, the continued decline in the number of pick miners after 1906 was accompanied in the 1908 depression year by an overall decline in the total number of men employed. 
Table 4:

A Comparison in the Number of Pick and Machine Miners in Mingo County, 1898 to 1910

\begin{tabular}{lllll}
\hline \hline Year & $\begin{array}{l}\text { Total \# of Mine } \\
\text { Employees }\end{array}$ & Pick Miners & Machine Miners & $\%$ Pick Miners \\
1898 & 673 & 329 & 105 & $49 \%$ \\
1899 & 617 & 352 & 52 & $57 \%$ \\
1900 & 751 & 371 & 148 & $49 \%$ \\
1901 & 1,414 & 655 & 349 & $46 \%$ \\
1902 & 1,489 & 710 & 395 & $48 \%$ \\
1903 & 1,172 & 615 & 229 & $52 \%$ \\
1904 & 1,781 & 666 & 357 & $54 \%$ \\
1905 & 2,548 & 786 & 708 & $31 \%$ \\
1906 & 2,624 & 574 & 755 & $22 \%$ \\
1907 & 2,624 & 615 & 784 & $23 \%$ \\
1908 & 1,677 & 412 & 717 & $25 \%$ \\
1909 & 2,053 & 245 & 785 & $12 \%$ \\
1910 & 2,358 & 241 & 745 & $10 \%$ \\
\hline \hline
\end{tabular}

Source: Annual Reports of the West Virginia Department of Mines, 1898-1910.

*Data prior to 1898 was not available

In 1910, Mingo's coal production passed the two million tons mark. ${ }^{134}$ The Thacker Coal \& Coke company alone worked ten mines. ${ }^{135}$ The consolidation of larger mines continued as the Magnolia Coal \& Coke Company absorbed the old Mate Creek operation. ${ }^{136}$ However, neither

\footnotetext{
${ }^{134} 1910$ Annual Report of the West Virginia Department of Mines.

${ }^{135}$ Ibid.

${ }^{136}$ Ibid.
} 
increasing coal production and advancing technological sophistication could protect Mingo's miners from misfortune nor prevent the field's marginalization. ${ }^{137}$

Tragedy struck at the old Lick Fork mine shortly after 7 a.m. on December 31, 1910. The ten men who had worked the night shift were in the first of four cars on the upward-moving man trip when the last three cars broke loose. The loss of the back three cars upset the counterbalance between the man trip and the cars traveling down slope. The car with the men came up the twelve hundred foot slope so fast, when it hit the headhouse, seven of the men were killed instantly, and the others died later from their injuries. ${ }^{138}$

The rocketing shot of the Lick Fork man trip in a sense symbolized the growth of Mingo County and the Williamson-Thacker coalfield. Despite enjoying increased coal production, population, and economic expansion, Mingo County failed to keep pace with its neighbors. Comparison of statistics from 1900 and 1910 in the Abstract of the United States Census underscores how far Mingo County had fallen behind McDowell and Logan. The average value of land per acre in Mingo had risen 47 percent between 1900 and 1910, from $\$ 7.57$ an acre to $\$ 16.28 .{ }^{139}$ Comparison of the same statistics for Logan and McDowell Counties reveals that Mingo's land value, which in 1900 had been comparable to McDowell's and ahead of Logan's, lagged in $1910 .{ }^{140}$ Table 5 illustrates this growing disparity in land values.

${ }^{137}$ Conley, History of the West Virginia Coal Industry, 269.

${ }^{138}$ Lacy A. Dillon, They Died For King Coal (Winona, MN: Apollo Books Inc., 1985), 39-41. Unfortunately no extant local records exist for this disaster.

${ }^{139}$ Abstract of the Thirteenth Census, with Supplement for West Virginia, 620-621.

${ }^{140}$ Ibid. 
Table 5:

Comparison of Land Values in Mingo, Logan, and McDowell Counties, 1900-1910

\begin{tabular}{llll}
\hline \hline & Mingo & Logan & McDowell \\
1900 & $\$ 7.57$ & $\$ 5.76$ & $\$ 8.04$ \\
1910 & $\$ 16.28$ & $\$ 32.03$ & $\$ 33.42$ \\
\hline \hline
\end{tabular}

Source: Abstract of the Thirteenth United States Census, with Supplement for West Virginia.

Possessing the premier coal in the state, McDowell, remained West Virginia's top producer, and as the virtually captive source of coal for U.S. Steel, had secure sales. Opened only in 1904, Logan owed its startling growth to an aggressive development by highly capitalized operations. ${ }^{141}$

The most significant indicator that the Mingo operators were aware of their predicament was the West Virginia State Supreme Court of Appeals case Thacker Coal \& Coke v. Norfolk \& Western Railway Company. ${ }^{142}$ After the Norfolk \& Western instituted a coal shipment rate increase for the West Virginia coalfields, at least one Mingo County company challenged the intended hike. Claiming that the increase was "discriminatory, unjust, and unreasonable" in favor of the Pennsylvania and Ohio operators who shipped on the same rail system, Thacker Coal $\&$ Coke filed for, and was granted a temporary injunction to stop the rate hike by the Mingo

\footnotetext{
${ }^{141}$ Cubby, "Railroad Building," 245-246. Also, "no shoestring operations" were allowed to open mines. Spence, 318. The development of the Logan-Guyan coal field was so focused and determined from the beginning that there had been no "hell-raising" during the construction of the railroad like there had been during "the construction of the Ohio Extension."

142"Thacker Coal \& Coke v. Norfolk and Western Railway Company," Reports of the West Virginia Supreme Court of Appeals 67 (February 1, 1910 to October 18, 1910): 448-456.
} 
County Circuit Court. ${ }^{143}$ The injunction was dissolved and the case dismissed, but Thacker appealed to the West Virginia State Supreme Court of Appeals.

On May 3, 1910, the high court affirmed the dismissal of the suit because as Justice Brannon, on behalf of the majority, observed, "the case [was] purely one of inter-state commerce" and therefore subject to the jurisdiction of the Interstate Commerce Commission. In explaining the decision, Brannon observed that Thacker's appeal asked the state court to stop the rate increase from ever reaching the ICC for review. If the West Virginia court granted the request it would be denying the supremacy of federal jurisdiction by undermining the ICC's authority to hear and resolve all such cases. Moreover, Brannon argued, chaos would ensue because different states could impose varying rates and federal oversight of the shipment process would be pointless. ${ }^{144}$

Brannon's review of the case law, utilized by the court in analyzing Thacker's appeal and making its decision, sheds light on the power of both the ICC and the railroad conglomerate which held the coal industry captive. Thacker's attorney, Z. T. Vinson, had based the appeal on the assertion that the Pennsylvania and Ohio operators were benefitting from a violation of the Sherman Anti-Trust Act. Vinson alleged that the Norfolk \& Western had engaged in a conspiracy with other railroads to impose a rate increase, which while favoring Pennsylvania and Ohio operators, would subject Thacker Coal \& Coke to "irreparable injury and probable ruin."

\footnotetext{
${ }^{143} \mathrm{Ibid}$. The coal shipped from southern West Virginia west and northwest to the steel centers on the Great Lakes was first carried on the Norfolk \& Western Ohio Extension and then transferred to the Pennsylvania Railroad system. Both of these systems were controlled by J.P. Morgan and associates.

${ }^{144}$ Ibid., 452.
} 
Justice Brannon rejected Vinson's position, citing that while an individual victimized by a conspiracy could seek damage compensation, only the government could invoke an injunction under the Sherman Law. ${ }^{145}$

Brannon cited the United States Supreme Court decision Texas \& Pacific Railway Company v. Abilene Company to explain the court's decision. Like Thacker, Abilene had sued in protest of a rate it considered unfair and injurious. In Abilene, the lower court judged the rate "final" until reviewed and decided upon by the ICC. The fact that the ICC ultimately ordered the rate reduced was judged immaterial. The U.S. Supreme Court upheld the lower court's decision that the arbiter of the conflict was the ICC, not the courts. Vinson argued that the Abilene decision should not apply because it was a case to recover damages caused by an already established rate whereas the Thacker case sought to stop the establishment of an unfair rate before it could be imposed. Brannon countered Vinson's interpretation of the difference between Thacker and Abilene by reiterating that in both cases the arena of resolution had to be the Interstate Commerce Commission. ${ }^{146}$

1911 proved to be an important turning point for the coal industry in Mingo County. Over the course of the year, two cases marked a separation between the coal interests of Mingo County and the interests of the counties to the east. The first event centered on a conflict

${ }^{145}$ Ibid., 449, 456. Justice Henry Brannon was considered West Virginia's preeminent legal figure of late nineteenth and early twentieth centuries. A pro-industry jurist, Brannon always sided with the railroads. For more on Brannon, see Lewis, Transforming the Appalachian Countryside, 122-127.

${ }^{146}$ Ibid., 452. The tone of Brannon's review of Vinson's argument implies that he found the core assertion of the latter's brief nonsensical: "A state court is asked to say that this schedule shall never reach ... [the] Commission. It does seem to me that the very statement of the proposition is its own refutation." 
between the Williamson-Thacker field and the Pocahontas field over an unfair market advantage. The second case focused on the break between one of Mingo's largest coal operations and the Norfolk \& Western's official coal sales agency. The backdrop for these events was the tense condition of the American economy. 1911 was a low point in the national economic cycle which marked the turning towards recovery." ${ }^{147}$

Competition in the market place was always a source of tension between the coalfields of southern West Virginia because they competed for market shares not only against each other but also with coalfields from the Mid-Atlantic through the Midwest. ${ }^{148}$ Coal from southern West Virginia was shipped to the shipyards of Tidewater Virginia and to the Midwest. ${ }^{149}$ The western coal route was referred to as the Lake Cargo traffic because the coal shipped on the railroads that followed the Ohio River system traveled all the way to the steel producing centers along the Great Lakes. ${ }^{150}$

Although the N\&W coalfields shipped coal to the Great Lakes as early 1903, it did not become the primary market for coal from Mingo County until 1921. ${ }^{151}$ However, from 1911 until

${ }^{147}$ Soule and Carosso, 340.

${ }^{148}$ Hadsell and Coffey, 275.

149"'Confidential': Conservative Statement of the Situation of the Coal-Carrying Railroads, in their relation to the Coal and Coke Development of Kentucky, Virginia, West Virginia, and Tennessee (Compiled from an Official Report for 1903)" (n.p.:n.d.). Pamphlet 7080, Pamphlet Collection, WVRHC.

${ }^{150}$ Lambie, 41, 295.

${ }^{151}$ 'Conservative Statement'" P7080, Pamphlet Collection, WVRHC; Lambie, 291. 
1921 as much coal from Mingo traveled to the northwest as was shipped east. ${ }^{152}$ Superficially this shift appeared to liberate the Mingo coal mines from a competition they could not win against the Smokeless coalfields to east. The shift squeezed Mingo even more, and heightened corporate tensions between the Williamson-Thacker and Pocahontas coalfields. ${ }^{153}$

The source of the adversarial attitude was a geographic-economic division among the coalfields that contributed to the Lake Cargo traffic which he referred to as the "Inner Crescent" and the "Outer Crescent." 154 The Williamson-Thacker field in Mingo County was the southernmost West Virginia "Inner Crescent" field, while its closest neighbor, the Pocahontas field in McDowell, marked the beginning of the "Outer Crescent." As an Inner Crescent field, Mingo paid a lower shipment rate than the McDowell field. To make matters worse, the N\&W fields-West Virginia operators who shipped their coal over the Pennsylvania Railroad system paid lower rates than the Pennsylvania operators. Tension over this rate differential resulted in federal hearings in Washington in March 1911, which pitted the "Inner" and "Outer Crescent" fields against each other as well as against the operators from Pennsylvania. ${ }^{155}$

\footnotetext{
${ }^{152}$ Lambie, 291.
}

${ }^{153}$ Ibid., 297-298. Two issues should be noted here. First, more animosity existed between the southern West Virginia operators and their competitors in Ohio and Pennsylvania than among the southern West Virginia operators. Second, even though as an Inner Crescent field the Williamson-Thacker field paid a lower rate than the Outer Crescent southern West Virginia fields, the Williamson-Thacker field was a smaller field and thus felt constantly besieged by its larger competitors.

${ }^{154}$ Ibid., 297.

${ }^{155}$ Mingo Republican, 20 March 1911. 
Despite the agitation precipitated by the rate differential controversy, the Mingo County coal operators committed themselves to pursuing the western and northwestern markets. On March 24, 1911, the Mingo Republican reported that the Sycamore Coal Company celebrated its first shipment of six coal cars from its new plant to Cincinnati, by arraying the first car with ceremonial bunting. ${ }^{156}$ Also in 1911, Borderland Coal Corporation ended its coal sales contract with the Leckie Coal Company, a coal sales agency in Cleveland, Ohio and opened its own agency which was based in Cincinnati. ${ }^{157}$ The Borderland coal sales agency eventually also served as agent for two other mines in Mingo County. ${ }^{158}$

The decision to concentrate on the western and northwestern markets was probably not Borderland's only consideration in establishing a coal sales agency. The Cooper family coal mines in the Pocahontas field also shipped to Ohio. In establishing their own agency the Coopers claimed to be motivated by "the advantages to both consumer and producer resulting from direct dealings" between the two. ${ }^{159}$ The final factor which might have inspired both Borderland and the Coopers to establish coal sales agencies was the 1911 anti-trust suit filed by the Taft Administration against U.S. Steel. The U.S. Steel suit "miscarried," but the assault on the giant

\section{${ }^{156}$ Ibid.}

${ }^{157}$ History of the Borderland Coal Company, 9. This document is part of the descriptive materials of the E. L. Stone Papers archived in the Special Collections at the University of Virginia, Charlottesville, Virginia.

${ }^{158}$ The Coal Catalog: Combined with Coal Field Directory for the Year 1920 (Pittsburg, PA: Keystone Consolidated Publishing Company, 1920). The other mines were the Matewan Coal Company and the Wigarb Mining Company; the president-general manager and treasurerpurchasing agent for these two companies were C. M. Gates and George Bausewine, Jr.

${ }^{159} 3$ December 1911, newspaper article, probably the Bluefield Daily Telegraph, in the Cooper Collection, ERCA. 
which virtually controlled the Pocahontas field created a window of opportunity for companies seeking to establish a degree of autonomy from the corporate monolith they feared would focus anti-monopoly sentiment against them. ${ }^{160}$

\section{Conclusion:}

The Thacker Coal Field was developed during a period of profound change in the American coal industry. Even though it shared a basic common history with other southern West Virginia fields, the precise timing of the Thacker field's opening and development set it apart from its larger and more important neighbors. Long overlooked by historians, these differences not only affected political and social relations in Mingo County, they also influenced future industrial relations.

Like the surrounding fields, the Thacker field owed its founding to the expansion of the railroad, investment shared the same corporate parentage, and the men who directed the field's development ascribed to the same anti-union philosophy as the other southern West Virginia operators. All of this said, however, the story of the Thacker field's development diverged from the generally acknowledged pattern of southern West Virginia's coal history. Unlike the older Smokeless fields to its east, the Thacker field did not enjoy paternalistic support from the Norfolk \& Western in its early stage of growth and expansion. Also, the coal produced in the Thacker field, although targeted for the same markets as Smokeless coal, was of lower quality, and thus less competitive. In contrast to the younger Guyan field to its northeast, the Thacker field was utterly dependent on the Norfolk \& Western for the exportation of its coal. But most

\footnotetext{
${ }^{160}$ Chernow, 148 .
} 
important, from the outset less powerful men guided the Thacker field's development. The interests of the large corporations' mines were represented by managers, while none of the field's pioneering entrepreneurial operators ever accquired the position or influence of their contemporaries in the surrounding fields.

Cumulatively, the timing of the Thacker field's opening and the differences between it and the other fields in southern West Virginia, created a siege mentality among the men who controlled mining in Mingo County. As producers of a less competitive coal, the companies of the Thacker field perennially had to fight for survival, and their adversaries included not only other coalfields but also an indifferent railroad. Lacking decisive, on-site leadership, the coal elite of Mingo County lived under the gun, striving to meet the production expectations of far removed corporate interests, or reacting to the decisions made by the coal men of the larger, better capitalized fields around them. Most prosperous during times of crisis in other fields, namely during strikes or organization drives, the Thacker field became increasingly dependent on maintaining its own non-union status. ${ }^{161}$

The relative weakness of the coal industry in the Thacker field also affected political and social relations in Mingo County. The industrial elite influenced politics in the county, but not to the degree of their contemporaries in other fields. And, although industrialization transformed the social landscape of Mingo County, it did not utterly sweep aside patterns of behavior that predated the advent of commercial coal mining. The persistence of traditional political dueling, and marginal modernization, set Mingo County further apart from its neighbors.

${ }^{161}$ It could be argued that the Thacker (Williamson-Thacker) operators were the worst of West Virginia's operators who had a reputation in the national industry as "pirates" who preyed on the misfortune of other fields. Corbin, Life, Work, and Rebellion, 6. 


\section{CHAPTER 5}

THE POLITICAL ECONOMY OF A PERIPHERY:

INDUSTRIALIZATION'S SOCIAL IMPACT IN MINGO COUNTY, 1895-1911

\footnotetext{
"Taken altogether Matewan is an ideal little city and one which has a very bright future"1 -- Williamson Enterprise, June 1908
}

During the first two decades of Mingo's existence, industrial expansion precipitated profound economic and political changes which, in turn, affected community growth and social relations. Conversely, both the limits and nature of these changes meant that the new "industrial order" failed to eradicate traditional beliefs and patterns of behavior. Possessing only a tenuous grip on political power and distracted by chronic economic instability, Mingo's coal elite was forced to coexist with, and adapt to, a frequently defiant local culture.

\section{The Railroad and Coal Industries Transform the Social Landscape of Mingo County:}

Despite the long shadow of the economic devastation wrought by the Panic of 1893 , towns continued to appear and grow in the young county. However, older communities bypassed by the railroad and untouched by the race to open commercial coal mines declined. Population statistics found in the 1891-1892 and 1895-1896 West Virginia State Gazetteer and Business Directories document the role of industrial development in the maintenance or loss of community vitality. ${ }^{2}$ For example, the population of Nolan, which was on the main line of the

\footnotetext{
${ }^{1}$ Williamson Enterprise, 4 June 1908. By 1908, Matewan had a population of 800, a waterworks system, gaslit streets, elevated sidewalks, and a new schoolhouse.

${ }^{2}$ In the 1891-1892 West Virginia State Gazetteer and Business Directory, only five communities in the area that would become Mingo County had twenty-five or more residents. In
} 
Ohio Extension to the north of Williamson, expanded 200 percent. Similarly, the number of inhabitants of Dingess, an old settlement near one of the first coal properties to be developed, rose 100 percent. Conversely, Eugene (later renamed Lenore), and Burch (also known as Rockhouse and later Delbarton), had populations of one hundred or more in 1891, but did not list population counts in the State Gazetteer for fifteen or more years. ${ }^{3}$ Connection to a transportation network and industrial development eluded these two older communities until well into the twentieth century. ${ }^{4}$ In the interim, Burch's population fell to 75 and Lenore's to 50, in both cases a loss of 50 percent. ${ }^{5}$ Lacking the railroad and mines, Burch and Eugene withered while neighboring communities emerged and grew. Tables 6 and 7 illustrate the appearance and/or growth of these ten towns.

just four years that number increased to ten, a 100 percent increase. However, until 1909, with the incorporation of Kermit, Mingo's only "towns" defined as "incorporated municipalities" were Matewan and Williamson.

${ }^{3}$ Both Eugene and Burch listed populations in the 1906-1907 Gazetteer and Business Directory.

${ }^{4}$ Smith, Early History of Mingo County, 22.

${ }^{5}$ Ibid. 
Table 6:

Town Growth and Decline in Mingo County, 1891-1896

\begin{tabular}{llll}
\hline \hline Towns in 1891-92 & Population & Towns in 1895-96 & Population \\
Burch & 150 & no listing & \\
Dingess & 100 & Dingess & 200 \\
Eugene & 100 & no listing & \\
Nolan & 25 & Nolan & 75 \\
Spaulding & 25 & no listing & \\
\hline \hline
\end{tabular}

Source: West Virginia State Gazetteer and Business Directory, 1891-1892 and 1895-1896

Table 7:

Mingo County Towns that Had Not Existed in 1891 and their Populations in 1895-1896

\begin{tabular}{llll}
\hline \hline New Towns in 1895 & Population & New Towns in 1895 & Population \\
Breeding/Breeden & 150 & Matewan & 200 \\
Edgarton & 25 & Sheppard & 75 \\
Fairfax & 100 & Thacker & 400 \\
Hinch & 150 & Wharncliffe & 12 \\
& & Williamson & 500 \\
\hline \hline
\end{tabular}

Source: West Virginia State Gazetteer and Business Directory, 1891-1892 and 1895-1896.

Table 7 demonstrates the dramatic impact of the coal and railroad industries on the county's evolution. Several of the new towns had been trading posts at natural crossroads which were the mouths of the Tug Fork tributaries. Matewan, Thacker, and Williamson were such settlements, but their maturation into towns awaited industrial development. All nine of the new towns in 1896 were on the railroad, and five were home to the local offices of seven coal companies. ${ }^{6}$ The development that occurred between 1891 and 1896 (charted in Tables 6 and 7), only expanded in the years between Mingo's founding and 1920.

${ }^{6} 1895-1896$ Gazetteer and Business Directory. 
In 1910, the Thirteenth United States Census confirmed that Mingo had experienced phenomenal growth in the decade and a half after the county's founding. Mingo's population had risen 71 percent from 11,359 in 1900 to 19,431 in 1910. Magnolia district (which included Matewan) was the largest district in the county with a population of 5,077. Williamson city and Stafford districts followed with 3,466 and 3,561 residents, respectively. Matewan more than doubled from 250 citizens in 1900 to 588, while Williamson quintupled from 600 residents to $3,561 .^{7}$ Unfortunately, the rapid urbanization of these young settlements brought a new host of challenges to their residents.

Between 1895 and 1911, towns in Mingo County grew faster than the means of protecting public health. Although contagious diseases were not unknown to the area, the course of the 1909-1910 Williamson typhoid fever epidemic underscores the vulnerability of a community still reliant on pest-house quarantines. ${ }^{8}$ In an eight-month period, 150 typhoid cases were reported in Williamson, and of that number 11 died. The county's industrial development not only had fostered population growth and concentration, it had also compounded the virulence of the recurrent outbreaks of epidemic diseases.

A report submitted to the West Virginia State Board of Public Health divulges both the cause of the outbreak and the coal industry's contributory role. State Inspector W. H. Frost noted that for nearly one hundred miles above Williamson, the Tug Fork River was an almost

${ }^{7}$ Abstract of the Thirteenth Census, with Supplement for West Virginia, 577.

8"Pest-Houses" were used to isolate individuals and/or families suffering from infectious disease; the hope being that removal from a community's general population would protect the rest of its inhabitants. One of Ms. Hatfield's aunts, who would have been a young teen in 1900, recalled that Mingo's pesthouse remained in use well after the turn-of-the century. Margaret Hatfield, interview with Rebecca J. Bailey, Summer 1990 Matewan Oral History Project. 
continuous line of coal mines and the average distance of the dwellings and privies from the river-bank was less than 100 yards. Dr. Frost also found that the river water drawn for use in Williamson was not only too black to be fit for bathing and laundry purposes, it also exuded an offensive odor. Caused by coal washings and human and animal excreta, the pollution of the Tug Fork river remained a community health issue for many years. Unfortunately by 1908 both Williamson's and Matewan's modern water plants drew the town water from the highly polluted river. $^{9}$

Inspector Frost's report on Williamson's public water supply also highlights the community's economic and class stratification. Of the 500 people surveyed by Inspector Frost, less than 10 percent used safe water. Few people consistently boiled the polluted river water piped through the town, and clean water was only available from three other sources. The employees of the Williamson Coal Company, however, drew their water from a properly maintained well. Although the N\&W operated a distilling plant to provide its employees with drinking water free of charge, a private distilling plant in Williamson provided clean water only for residents willing and able to pay. ${ }^{10}$

Because fresh milk could also transmit typhoid, Inspector Frost also studied the use of milk in the city. He excluded milk as a source of the typhoid contagion because there was insufficient correlation between the outbreak and milk usage. Inspector Frost found that milk for

${ }^{9}$ W.H. Frost, "Report of Investigation Relative to Purification of Water Supply of Williamson, West Virginia, for the prevention of typhoid fever," in the West Virginia State Biennial Report of the Board of Health, 1908-1909 (Charleston, WV: News-Mail Co., 1910): 76-95, 84, 77, 78, 79. The Williamson typhoid epidemic is also discussed in Jerry Bruce Thomas, "Coal Country," 303.

${ }^{10}$ Frost, 88. 
the 100 to 200 boarders at the railroad YMCA was shipped in from Portsmouth, Ohio. For the rest of Williamson's citizens, fresh milk was “very scarce, and consequently but little used, many people using only condensed milk."11

Williamson had grown from a village of 600 inhabitants in 1900 to a small city of almost 4,000 in less than a decade. ${ }^{12}$ The rapidity of the town's growth outstripped the physical environment's ability to cleanse itself, and the resulting contagions confounded and overwhelmed the people living there. They understood the need to boil water for drinking, but not for bathing or washing dishes. Lax and corrupt public servants also complicated efforts to deal with contagious diseases. For two years prior to January 1910, Williamson had no health officer and no means of tracking outbreaks. ${ }^{13}$ As demonstrated by the 1909-1910 Williamson typhoid epidemic, "growth" was not always an indicator of "positive" progress.

Despite the health risks associated with living in the new population centers in the county, area natives flocked to the emerging towns and coal communities. Agricultural statistics from Mingo's 1910 aggregate census profile illuminates why Tug Valley natives abandoned their farms and entered the coal camps "popping" up around the county. ${ }^{14}$ After nearly twenty years of coal development, Mingo had lost almost 11 percent of its farm land between 1900 and 1910,

\footnotetext{
${ }^{11}$ Ibid.

${ }^{12}$ Ibid., 76.

${ }^{13}$ Ibid., 84. County and municipal health officers received a yearly stipend in return for the fulfillment of their duties. Given the evidence regarding other forms of corruption in Mingo, it would not be unlikely that the early twentieth century politicians "cut corners" and used the funds saved from not appointing a municipal health officer for other purposes.

${ }^{14}$ According to Mingo County native Margaret Hatfield, "coal camps popped up overnight, like mushrooms after a rain.” Hatfield correspondence, letter no.2.
} 
even though the number of farms increased 50 percent during the period from 957 to 1,059 .

More farms however did not translate into greater economic opportunity. Not only were the farms smaller, those who worked on them were increasingly tenants or share-croppers. ${ }^{15}$

Another government report on conditions in Mingo County underscores why the mountaineers turned from farming to mining. Observations recorded in an 1897 Army Corps of Engineers' report explains why the residents of the Tug Valley were well on the path to economic dependence on the coal industry. ${ }^{16}$ Assistant Engineer B. F. Thomas noted that soil erosion had been exacerbated by the expansion and intensification of farming in Mingo. ${ }^{17}$ Because the timber near the river had already been cut off (which had also weakened the soil), the era of entrepreneurial logging was ending. The thousands of acres of trees still standing away from the Tug Fork's principal contributaries could only be exported by those with the capital to transport them by rail. ${ }^{18}$ With little alternative in the modern cash driven economy, the native population turned increasingly to work in the mines. ${ }^{19}$

${ }^{15}$ Abstract of the Thirteenth Census, with Supplement for West Virginia, 620-621, 621, 626.

${ }^{16}$ Coal Trade Journal 37 (5 January 1898): 12. "One hundred thousand people live in the Valley and six county seats are dependent upon the Big Sandy for an outlet."

${ }^{17}$ B. F. Thomas, "Improvement of the Big Sandy River, West Virginia and Kentucky," Letter from the Secretary of War transmitting in response to the concurrent resolution of the House of Representatives of April 13, 1898, A Letter of the Chief of Engineers, Together with a Report of the Plans and Estimates for the Improvement of the Big Sandy and certain of its branches in West Virginia and Kentucky (9 May 1898) Fifty-Fifth Congress 2d Session, House of Representatives Document \#456.

${ }^{18}$ Ibid.

${ }^{19}$ As population statistics offered in the Abstract of the Thirteenth Census reveals, the native white population of both Mingo and Logan Counties remained roughly on par until the teens, but by the 1920 Census, both Logan and McDowell had significantly fewer native white residents. 
The lack of opportunity for other employment did not, however, make Mingo natives an entirely biddable workforce. The oral testimonies from Mingo County reveal that even though dependency on the coal industry increased, a variety of economic strategies were utilized to retain as much freedom as possible. When out of work, the landless survived because they could set up temporary residence with relatives who were landowners. ${ }^{20}$ Although 94 to 98 percent of southern West Virginia miners resided in company housing, this figure obscures the significance of independence to those who did not. ${ }^{21}$ Testimonials from the Matewan Oral History project 1989-1990 abound with variations of the declaration, "we always lived in our own house, on our own land."22 When labor strife erupted in Mingo in 1920, the strike's most visible local leaders were natives who had adamantly refused to live in company housing. ${ }^{23}$

Abstract of the Thirteenth Census, with Supplement for West Virginia, 592. See Appendix 5.

20"Smokey" Mose Adkins interview with John Hennen, Summer 1989 Matewan Oral History Project.

${ }^{21}$ Corbin, Life, Work, and Rebellion, 8.

${ }^{22}$ Several Matewan Oral History Project narrators stressed the independence land ownership afforded their families: Jim Backus, Bertha Damron, Rufus Starr, Addie Nowlin and Stella Presley.

${ }^{23}$ Three men who standout among this group are Charlie Kiser, John Collins, and Fred Burgraff. A native of Mingo, Kiser became a professional organizer for the UMWA and CIO. Originally from McDowell County, John Collins went to the penitentiary for strike-related activities and served as the first president of a UMW local after union legalization in the 1930s. Only Sid Hatfield and Reece Chambers were accused of more strike-related violence than Burgraff. Stella (Kiser) Presley interview, with Rebecca J. Bailey, Summer 1989 Matewan Oral History Project; Bertha (Collins) Damron, interview with Rebecca J. Bailey, Summer 1989 Matewan Oral History Project; Hawthorne Burgraff, interview with John Hennen, Summer 1989 Matewan Oral History Project. 
Close ties between Mingo's mining and farming populations were seen as autonomypreserving activities. Farmers "peddled" all manner of goods and services through the camps, including their surplus vegetables, fruits and meats. ${ }^{24}$ These transactions helped keep miners who participated from complete dependence on the company, and also diverted some money into the local economy. Many a farming family's income was also supplemented by the mining wages of unmarried sons, or by men who combined farming with seasonal work in the mines. ${ }^{25}$ Unfortunately, the combination of mining and farming contributed to the impoverishment of the local economy. By accepting lower wages for what they deemed supplemental labor minerfarmers helped keep wages depressed. ${ }^{26}$

Peddling benefitted most those who used their profits to establish businesses in the independent towns. Italian immigrant and Matewan businessman Attilio Nenni started his business by traveling from coal camp to camp repairing shoes for just a few cents per pair. ${ }^{27}$

\footnotetext{
${ }^{24}$ Several narrators from the 1989-1990 Matewan Oral History Project discussed the peddling activities of Mingo's farmers: Harry Berman, Edith Boothe, Hawthorne Burgraff, and Daisy Nowlin.

${ }^{25}$ Salstrom, "Newer Appalachia as One of America's Last Frontiers," in Appalachia in the Making, 92. Paul Salstrom's groundbreaking study of the Appalachian economy reveals that the practice of combining farming and mine work "helped to impoverish . . . [the miner-farmers] and their environment while subsidizing coal companies . . . that paid less than family-supporting wages."

${ }^{26}$ Salstrom, Path to Dependency, 40.

${ }^{27} \mathrm{Nel}$ (Gentile) Nenni interview with John Hennen, Summer 1989 Matewan Oral History Project.
} 
John Brown, the grandfather of Matewan's first African American mayor owned Matewan's laundry and provided pick up and delivery service for his patrons. ${ }^{28}$

However, relations between miners, farmers, and peddlers were not always positive. ${ }^{29}$ As one Mingo native miner observed, strikes and other attempts by miners to force concessions from their employers were often undermined by local non-miners who would work as short-term replacement workers. In some cases, members of miners' own families engaged in this activity. ${ }^{30}$ Although most native whites were drawn to mining as an escape from an intensifying poverty, their own neighbors often disdained the "choice" of mining as an occupation which was to be avoided at all costs. ${ }^{31}$ Many of the families who disparaged mining deemed it attractive only to people of marginal social standing. ${ }^{32}$ The haphazard construction, crowded living conditions, and acts of social dysfunction in camps in the early years of Mingo's coal industry cemented this opinion. The murder of a peddler at Thacker on October 24, 1898, seemed to substantiate these impressions. $^{33}$

${ }^{28}$ Johny Fullen interview with Rebecca Bailey, Summer 1990 Matewan Oral History Project.

${ }^{29}$ According to Lynwood Montell, the social and economic tensions that accompanied the transition from farm to industrial work often precipitated a rise in violence among the affected groups. Lynwood Montell, Killings: Folk Justice in the Upper South (Lexington, KY: University Press of Kentucky, 1986), 160-161.

${ }^{30}$ Carey interview, WVRHC.

${ }^{31}$ Hatfield correspondence, letter no.2.

${ }^{32}$ Ibid. What "pushed" many natives into dependence on the coal industry is well documented. Few scholars, however have explored the reasons why others resisted, much less the class division that resulted among these people of comparable economic status.

${ }^{33} 24$ October 1898, Bert Wright diary, Luther Collection, ERCA. 
Coal camp life and the relations between miners and operators have dominated the social history of southern West Virginia. In Mingo County, however, mining operations and independent communities often occupied the same location. The contrasting stories of two early communities, Williamson and Dingess, illuminates the role of industrial development in the escalation and sharpening of social and class divisions in Mingo County. Named for members of pioneering families, both communities owed their early growth to the rail and coal industries. However, Williamson, the county seat, which had not existed before 1891, became a magnet for the county's elite. Once deprived of its rail line, Dingess's mines closed and the community fell into disrepute.

What had been a Williamson family cornfield in 18 90, by 1902 had become a small city of $1,100 .^{34}$ The business and occupation listings in business directories reflected Williamson's emergence as a residential center for the county's new industrial class. ${ }^{35}$ An important marker of the influx of this new group was the establishment of "the Presbyterian Academy" in $1901 .^{36}$ Except for the children who attended this academy, the elite continued to send their children to boarding schools, favorites included the Greenbrier Female Seminary for the girls and the Staunton Military Academy for the boys. ${ }^{37}$ In writing to a friend, S. D. Stokes, a lawyer from

${ }^{34} 1900-1901$ and 1902-1903 Gazetteer and Business Directory. Williamson's growth was so fast in the 1900-1901 the city's population was only 600.

${ }^{35}$ Unfortunately no municipal records prior to 1911 exist. Williamson Area Heritage Book, (Summerville, WV: Walsworth Publishing Company, 1996), 37.

${ }^{36}$ Smith, Early History of Mingo County, 12.

${ }^{37}$ Mattie McCoy Allara attended the Greenbrier Female Seminary; the son and orphaned nephew of S. D. Stokes attended the Staunton Military Academy. Mattie McCoy Allara interview with Rebecca J. Bailey, Summer 1989 Matewan Oral History Project; S. D. Stokes to 
Virginia, explained why the local and new industrial elite sent their children to private schools. According to Stokes, Mingo's public schools were poor and the children who attended them offered only "miserable associations." ${ }^{38}$ By establishing the Presbyterian Academy and/or sending their children away for private education, the elite of Mingo County reinforced the social distance between themselves and the County's other residents. Mingo County may have been where they resided and pursued their livelihood, but they did not want their children socially acculturated to that community. ${ }^{39}$

The story of Dingess, also an amalgamation of company and independent town, encapsulates both the dependence of the local economy on the coal and railroad industries, and the persistent complexity of political and social networks in Mingo County. In 1891, the year Wallace J. Williamson and the Williamson Mining and Manufacturing Company founded the town of Williamson, Dingess was already a village of $100 .{ }^{40}$ Like Williamson, Dingess grew rapidly after becoming the population center for three of the county's first mines. ${ }^{41}$ Within two

Abram Bruner, 18 September 1920, Stokes Papers, WVRHC.

${ }^{38}$ Stokes to Bruner, Stokes Papers, WVRHC.

${ }^{39}$ Sending children away to school was a common Appalachian elite action and was one of the class characteristics this group shared with their contemporaries throughout the United States. Tudiver, 93-94. According to Mary Beth Pudup, "the growth of county seat towns betokened social differentiation within the population and, more generally deepening social and spatial division of labor between town and country." Pudup, "Town and Country," in Appalachia in the Making, 271

\footnotetext{
${ }^{40} 1891-1892$ Gazetteer and Business Directory.

${ }^{41}$ 1902-1903 Gazetteer and Business Directory.
} 
decades, however, Dingess's population had fallen to 75, and the town had become a haven for crime and social degeneracy.

At its peak, in 1903, the town of Dingess had 750 inhabitants, which made it second in population only to the county seat Williamson. In population it surpassed Thacker and Matewan, respectively the center of the largest coal operation in the county and the political rival of Williamson. ${ }^{42}$ In 1904, in recognition of Dingess' growth, J. R. Booth, the superintendent of the Pearl Coal Mining Company was appointed to the Executive Committee of the county Republican organization. ${ }^{43}$ Booth's ascendance seemed to indicate that political power and economic influence had broken free of the Williamson-Matewan, Lee-Magnolia orbit and expanded to incorporate the county's remote areas. However, 1904 proved to be a highwater mark in the long decline in Dingess' history as a community.

In contrast to Thacker, Red Jacket, and Glenalum, which sprang up and continued to grow, Dingess, which had 200 miners at work in 1893, began to deteriorate rapidly after only a decade. $^{44}$ There were two primary and interrelated reasons for this situation. First, the coal seams were thinner and of less quality at Dingess and second, once a new section of the county was accessed by the railroad in 1904, maintaining the high maintenance tracks to Dingess were no longer cost effective. ${ }^{45}$ According to the 1910 United States Geological Survey of Logan and Mingo County, the opening of the N\&W new line marked the end of Dingess, and within a

\footnotetext{
${ }^{42}$ Ibid. Thacker had 600 residents and Matewan 250.

43"Condensed Facts," 4, P8662, Pamphlet Collection, WVRHC.

${ }^{44}$ Cubby, "Transformation," 246.

${ }^{45}$ Collier, 55.
} 
decade the mines there were abandoned and the population dwindled to its pre-development number. $^{46}$

Actually, Dingess declined even more rapidly than the surveyors realized. The town's population had fallen to one-tenth of its 1902-1903 level in less than five years. ${ }^{47}$ With the mines closed, the mobile mining population dispersed, and the rail line fallen into disrepair, the native inhabitants were left behind to fend for themselves. However, Dingess retained political influence far out of proportion to its size. As Mingo's own rotten borough, Dingess offered the machine politicians of the county a secure bloc of votes in return for a steady flow of funds and patronage plums. ${ }^{48}$ By World War I, in recognition of its now dubious reputation, Dingess was identified as the center of Mingo's "wild and rough" region. ${ }^{49}$ In contrast to the thoroughly modern Williamson, local citizens were encouraged to think of Dingess as the ultimate example of Mingo's pre-industrial backwardness. ${ }^{50}$

${ }^{46}$ Cubby, "Transformation," 246; Ray V. Hennen, West Virginia Geological and Economic Survey: Logan and Mingo Counties (Wheeling: n.p., 1914), 16, 465.

${ }^{47} 1902-1903$ and 1906-1907 Gazetteer and Business Directories.

${ }^{48}$ See Huey Perry, They'll Cut Off Your Project: A Mingo County Chronicle (New York: Praeger Publishers, 1972), 49-54, for the story of Dingess, and the refinement of political graft and corruption in Mingo County. The voting results in Dingess, as in other Mingo communities rarely offered an accurate accounting of legally registered voters.

${ }^{49}$ Williamson Daily News, 22 August 1918.

${ }^{50}$ Ibid. 
II. Industrialization and the Culture of Honor: Greed, Violence, and the Law, 1895-1911 $1^{51}$

Industrialization wrought significant changes in Mingo County. Communities prospered or deteriorated depending on access to the railroad and the opening of mines. Although farming and logging continued, fewer families found these activities economically sustaining. Mingo's inhabitants were drawn inexorably into the nexus of commercial mining. The destabilization of traditional living and occupational habits stressed familial and social ties. ${ }^{52}$ As a result, both opportunity for financial gain and the struggle for survival often overwhelmed customary behavior and not infrequently resulted in violence.

A tale of a family torn asunder by a son's greed haunts the town of Matewan. Through marriage to Phoebe, the sister of Devil Anse Hatfield, Anderson Ferrell acquired ownership of the farm that became Matewan. After Phoebe's death, Ferrell married Mary Chambers and started a second family. Seeking to provide financial stability for all of his children by capitalizing on the railroad's proximity, Ferrell divided his land. To his children by Phoebe Hatfield, Ferrell deeded small farms; he sold the remaining land in lots, thus founding the town of Matewan. Among the entrepreneurs who purchased property from Ferrell was his nephew by

\footnotetext{
${ }^{51}$ The phrase, "culture of honor" has been borrowed from a study in cultural psychology by Nisbett and Cohen, see introduction for citation. According to Nisbett and Cohen, in communities undermined by economic scarcity and weak or corrupt governing structures, violence in defense of an individual's status or power is often perceived as justified. Although the author acknowledges the limited applicability of the Nisbett and Cohen study, she would argue that this core assertion is relevant here and complements the following observation by anthropologist Sara Lubitsch Tudiver. According to Tudiver, "mountain culture is best understood as behavioral codes ... which developed in the context of a peripheral region ... where the resources people had were frequently threatened both from those outside and from those within. Tudiver, 10.

${ }^{52}$ The impact of industrialization's impact on families has been documented throughout the Appalachian region. See: Tudiver, "Political Economy and Culture in Central Appalachia," 113.
} 
marriage E. B. Chambers. ${ }^{53}$ Years after the Hatfield-Ferrell farm had grown into a thriving village, one of Anderson Ferrell's sons, from his first marriage, challenged his father's dispensation of the land. ${ }^{54}$

Aided by Henry Clay Ragland, the attorney who had originally served his illiterate father, Floyd Ferrell brought suit to gain a larger portion of the family property, which now encompassed the town of Matewan. When the local circuit court judge granted his son's claim, Anderson Ferrell appealed to the West Virginia State Supreme Court of Appeals. ${ }^{55}$ The court chastised the younger Ferrell by asking, "what right had this son to the property," when it would lead to the "bankruptcy" of his father. ${ }^{56}$ The court also questioned Floyd Ferrell's motives in pursuing the suit, which at one point he had withdrawn in order to "let the second wife and little children of his aged father have something for home and bread." ${ }^{57}$ The court extended its reprimand to include lawyer Ragland for encouraging Floyd Ferrell to take action against his father. ${ }^{58}$ The acrimony generated by Ferrell $v$. Ferrell survived for decades and may have

${ }^{53}$ Smith, Early History of Mingo County, 6; Hatfield correspondence letter no. 6. The marriage connections between the Hatfields, Ferrells, and Chambers families can be confirmed in: Donna L. Brown, Logan County Marriages, Book 1:1872-1892 (Logan, West Virginia: Logan County Genealogical Society, n.d.). E. B. Chambers' purchase of the first lot in Matewan noted in "E. B. Chambers," Williamson Enterprise, 4 June 1908. Anderson Ferrell's wives are sometimes identified as Birdie or Bridget (Phoebe Hatfield) and Sarah or Sally Chambers.

54"Ferrell v. Ferrell," Reports of the West Virginia Supreme Court of Appeals, 53 (March 28, 1903-November 21, 1903): 515-524, 516.

${ }^{55}$ Ibid., 518-524.

${ }^{56}$ Ibid., 517.

${ }^{57}$ Ibid., 523.

${ }^{58}$ Ibid., 522. 
contributed to a rivalry between the Hatfields and Chambers, who struggled against each other for control of Matewan. ${ }^{59}$

Adaptation to the economic transformation of the region not only affected relations within native families, it also heightened tensions between whites and other ethnic groups. ${ }^{60}$ Although the percentage of native whites in the county population only fell from 96 to 86 percent between 1900 and 1910, the influx of African Americans and foreign-born whites coincided with difficult economic times. ${ }^{61}$ In the aftermath of the "Bankers Panic of 1907," mines in the Thacker field were closed or absorbed by larger companies, and miners were forced to compete for fewer jobs. Because of the high percentage of local whites in the Thacker field, they viewed all migrant miners, but especially the foreigners and African Americans, as interlopers who were stealing jobs that rightfully belonged to the natives who were there first. ${ }^{62}$ Although episodes from the 1920-1922 strike period indicate an evolution towards cross-racial and ethnic working-

${ }^{59}$ According to Margaret Hatfield, some Hatfields believed that Matewan had been "stolen" by the Chambers. Hatfield correspondence, letter no. 6.

${ }^{60}$ In 1910, there were 1,197 foreign-born residents in Mingo County, representing seventeen nationalities resided in Mingo County, compared to only 65 foreign-born whites in 1900. Abstract of the Thirteenth Census, with Supplement for West Virginia, 592. See Appendix 5.

${ }^{61}$ See Chapter 4 for an overview of the early strikes in the Thacker coal field, as well as "deskilling" of the mining profession before 1910. In the wake of the flight of the skilled British Isles miners from southern West Virginia, tensions escalated between the mountaineers and the incoming African Americans and foreign-born whites because they shared the same occupational background. See Fagge, 32.

${ }^{62}$ Attacks by native white workers against their African American and immigrant rivals has been a common historical phenomenon in the United States. See Catherine McNicol Stock, Rural Radicals: Righteous Rage in the American Grain (Ithaca and London: Cornell University Press, 1996), 107. For an Appalachian perspective on the impact of economic crises on violence, see: Montell, Killings, 145 and 160-161. 
class solidarity, two episodes from 1908 exemplify the impact of chronic economic instability on heterogeneous mining communities.

In 1906, after Harry Sherburn was recruited by the Marvin Coal Company at Matewan, West Virginia, he and his family left West Riding, England, and migrated to the United States. Upon their arrival the Sherburns became active members of the Matewan community. Devoted Primitive Methodists, the family, together with Mr. Sherburn's employers, the Boothes, who were originally from Yorkshire, England, established the Matewan Methodist Church. The family spent two happy years in Mingo until 1908. During frequent trips into the mines with his father, Edward Sherburn befriended a young African American.

After neighbors witnessed the two boys playing, Mr. Sherburn was warned, "We don't mix with the blacks." This incident not only disgusted Mr. Sherburn, it was also the last straw in his escalating displeasure with conditions in his new country. After the encounter with the unnamed bigot, Harry Sherburn walked into his home and observed to his family, "So much for a free country." Not long after the incident, the Sherburns returned to England. ${ }^{63}$

Also in 1908, at the Pike Colliery mines across the river from Matewan, in Kentucky, a group of men attacked the home of two Hungarian families. In the course of committing "a most revolting and brutal crime," the assailants injured the children so badly that their recovery was

\footnotetext{
${ }^{63}$ T. E. Bowman, "From West Riding to West Virginia." Unpublished manuscript, Matewan Development Center, Matewan, West Virginia. Mr. Bowman is the great-grandson of Harry and Clara Sherburn. After the Sherburns returned to England, young Mary Grace corresponded with her friend from Matewan, Ethel Lambert Hill for 67 years, although they never saw each again. After his own visit to Matewan in the early 1990s, Mr. Bowman wrote about his family's story and sent a copy to the Development Center.
} 
not expected. Five men were convicted for shooting and raping members of the two families and received sentences ranging from five to ten years. ${ }^{64}$

Neither the reason for the crime nor the exact nature of the attacks on the children were specified in the press account of the story. However, one detail provides insight into Mingo County's polarized reaction to a later event. One of the convicted assailants, Van Clay, reappears in Mingo County public records in 1920, as one of the leaders of the miners' strike. ${ }^{65}$ Probably unaware of this incident, most historians have dismissed contemporary condemnation of Mingo's striking miners as "trash," or "criminals" as elitist snobbery ${ }^{66}$ The extralegal and/or criminal excesses of the miners have been excused as a reaction to the environment created by the coal companies and part of the price of fighting for justice. One historian has even described the miners' violence as "politics by other means." ${ }^{67}$

${ }^{64}$ Williamson Enterprise, 4 June 1908. The Enterprise reported that the men convicted of the attack awaited "additional sentences on additional counts." Unfortunately, this issue is one of a set of scattered issues of early Mingo County newspapers, no other details of the case have been uncovered.

${ }^{65}$ Van Clay was one of the Matewan Massacre defendants. In December 1924, his brother C. W. Clay killed Leonard Hatfield, the brother of Bill and McGinnis Hatfield, the brother-sheriffs of McDowell County. James Damron to S. D. Stokes, 20 December 1924, Stokes Papers, WVRHC.

${ }^{66}$ The manuscription collections of West Virginia governors John J. Cornwell (1917-1921) and Ephraim F. Morgan (1921-1925) contain several letters critical of the miners' actions during the strike. John J. Cornwell Papers, and Ephraim F. Morgan Papers, WVRHC. Also at least one narrator from the Matewan Oral History Project discusses how the "good people" in Matewan and the County were influenced by the bad "character" and behavior of some of the strike's leaders and participants. Margaret Hatfield interview with Rebecca J. Bailey, Summer 1990 Matewan Oral History Project.

${ }^{67}$ Fagge, 214. 
The revelation about Van Clay requires a mild adjustment of the historical analysis of both Mingo's miners and local perceptions of the 1920-1922 strike. When his prison term expired, Clay returned home to a small community with a long memory. ${ }^{68}$ Whether or not he was "reformed" would not have mattered to a significant percentage of his neighbors. As in many Appalachian communities, in Mingo County, toleration or censure of criminal behavior depended on a collective assessment of the motive. ${ }^{69}$ While most residents of Mingo County averred judgment of bootlegging or "justifiable" homicides, attacks on children were unforgivable. ${ }^{70}$ For many residents Van Clay's prominence in the miners' struggle in Mingo would have undermined its legitimacy. Although Clay's 1908 criminal record should not be allowed to cast a shadow over the entire miners' movement in Mingo, its impact must be considered in the evaluation of contemporary and subsequent criticism of the strike. ${ }^{71}$

\footnotetext{
${ }^{68}$ Hatfield correspondence, letter no.17. According to Margaret Hatfield, Mingo County had a reputation as being the favorite relocation spot for parolees from the state penitentiary, because at the time Mingo was the farthest they could get from Moundsville and still obey a release stipulation that they had to remain within the state. Circumstantial evidence supports Ms. Hatfield's story. From 1913-1920 Mingo Republican "boss" M. Z. White served as warden of the state penitentiary, and Democrats perennially charged the Republicans with election offenses committed by "ruffians" on their payroll.

${ }^{69}$ Montell, Killings, 165.

${ }^{70}$ Hatfield correspondence, letter no.21. Several Matewan Oral History Project narrators stress Matewan's communal attitude towards children. Youngsters apparently had the run of the town and all of the adults watched over them.

${ }^{71}$ Again, according to Margaret Hatfield, many residents of Matewan possessed strict views on the rights of property and individual morality. These individuals had little sympathy for the evicted miners, because in their opinion, the company houses were the rightful property of the coal companies. Lynwood Montell observed a similar attitude towards property rights in another Appalachian community. Montell, Killings, 153. Community ambivalence and/or hostility to labor organization was not unique to Appalachia. In An Unsettled People, Rowland Berthoff observed of reactions to Haymarket, Homestead and Pullman, that "public sympathy for the
} 
The actions of Floyd Ferrell, an unnamed bigot, and Van Clay illustrate that Mingo County's economic health directly affected social relations. Motivated by greed, Ferrell turned on his father for financial gain. Powerless against the impersonal destructiveness of external market forces, native white miners retreated behind the color line and vented their frustration on their "outsider" peers. Taken together, these cases demonstrate the new stresses experienced by Mingo Countians as a result of the area's industrial transformation. Other examples of conflict from the same period, however, document the limited influence of modernization.

The peripheral status of Mingo's coal field diminished the new coal elite's primacy in the county. One result of this failure can be found in the survival of local attitudes towards customary rights and violence. Three cases from the 1895-1911 period reveal not only how Mingo Countians resolved conflict, but also how the community continued to define the law and justice according to its own standards. Moreover, these same cases expose the historical roots of the community's reaction to the Matewan Massacre. ${ }^{72}$

underpaid workingman at the outset of a strike was apt to turn, as disorders inevitably followed, to a muddled concern for the property rights of capital." Rowland Berthoff, An Unsettled People: Social Order and Disorder in American History (New York: Harper \& Row, 1971), 390. In Matewan, alienation from the miners' struggle only intensified in the Massacre's aftermath. In particular, the untimely marriage of Sid Hatfield and Jessie Testerman caused many to believe that perhaps Hatfield had killed Testerman to get Jessie. Hatfield correspondence, letter no. 1 and Harry Berman, interview with John Hennen, Summer 1989 Matewan Oral History Project. It should be noted that Mr. Berman informed Hennen of the "rumors" that swirled around Sid and Jessie rather than imparting a personal opinion.

${ }^{72}$ This is not to say that the author endorses the interpretation that the Massacre was a latterday episode of "hillbilly feud-type" retributive justice. But rather, that these cases illustrate the survival of traditional attitudes towards, and expectations of, the court and legal system first analyzed by Altina Waller in Feud, 47-48. Waller borrows the phrase "ownership of the law" from Thelen's Paths of Resistance, 77-85. 
In January 1898 W. F. Farley forced the sale of Sanford Hatfield's 250 acre farm. R. C. "Clay" Allison, an acquaintance of Hatfield's, purchased the land for \$271.87. Shortly thereafter Allison sold a half interest in the property to an outsider capitalist William McGee. However, Hatfield remained in possession of his farm and three years later sued to regain ownership. The circuit court decided in Hatfield's favor, but Allison and McGee challenged the ruling. Four years later, or seven years after the original sale occurred, West Virginia's State Supreme Court of Appeals overturned the lower court's decision and upheld Allison's and McGee's ownership of the land. Testimony and case filings from the supreme court report recount the methods used by Hatfield and Allison in their attempts to manipulate the legal system. ${ }^{73}$

According to Sanford Hatfield, Clay Allison purchased the land in trust for him. Angered by Allison's repeated refusals to redeem the farm, Hatfield decided to sue. Hatfield later claimed that he decided to bring suit because he noted at the time of the sale the land was worth $\$ 2,500$ and "if it had not been understood that the land was being bought for him, it would have gone for three times what it did." ${ }^{74}$ Clay Allison's response to Hatfield's claims not only presented an entirely different version of the story, it also brings an awareness of the complex role of merchants in turn-of-the century Appalachia. Prior to the foreclosure on Hatfield's farm, Allison had maintained a line of credit in his store for Hatfield, and also provided basic banking

\footnotetext{
73"Hatfield v. Allison," Reports of the West Virginia Supreme Court of Appeals, 57 (January 24, 1905-April 25, 1905):374-384, 374.

${ }^{74}$ Ibid., 374-375.
} 
services. ${ }^{75}$ Allison countered Hatfield's claim regarding the genesis of the suit by asserting that Hatfield's desire to regain title to the land stemmed from the land's increased value. ${ }^{76}$

The supreme court's review of testimony shows much about how Hatfield and Allison approached proving their cases. Despite noting the inconsistencies in both men's version of events, the reasons why the high court decided in Allison's favor highlights the contrast between interpretation of the law by residents of Mingo County and the state's supreme court judges. The judges were impressed both by Allison's possession of receipts which documented his financial relationship with Hatfield, and the character of Allison's witnesses. ${ }^{77}$ In contrast, the judges found Hatfield's assertions, which were backed only by the testimony of his father, mother and sister, unbelievable and most likely "a manufactured story." Sanford Hatfield's allegations were further undermined because his "Uncle Jim" Hatfield stoutly refused to perjure himself on his nephew's behalf. ${ }^{78}$ The state supreme court's reversal decree exposed the boundaries of local custom and native elite influence.

The local jury may have been swayed by Hatfield's desire to avoid dispossession and the former prominence of his family, but the final arbiter of the law in the state had not. ${ }^{79}$ Hatfield

\footnotetext{
${ }^{75}$ At one point Allison claimed that Hatfield had asked Allison to keep a sum of money, formerly sown into Hatfield's coat, in his store safe. Allison declined, but offered to take it to Williamson for him, and provided a receipt detailing the transaction.

${ }^{76}$ Ibid., 376-377.

${ }^{77}$ Ibid., 378, 382-383.

${ }^{78}$ Ibid., 379, 380-382.

${ }^{79}$ For more on the ability of prominent families to manipulate the law and local court systems see Tudiver, "Political Economy and Culture in Central Appalachia," (1984), and more recently Billings and Blee, The Road to Poverty (2000). For a contemporary criticism of local juries see:
} 
retained the surface rights to his farm, while Allison and McGee owned the mineral resources beneath the land. In return for not "dispossessing" Hatfield, his invalid wife and several children, Allison and McGee did not have to pay taxes on the land, that responsibility remained Hatfield's. ${ }^{80} \quad$ The Hatfield $v$. Allison case underscores how the evolution of legal standards outside the Tug Valley affected social and economic relations within the Valley. ${ }^{81}$ While Sanford Hatfield had successfully manipulated the local court, his methods failed when a higher authority reviewed the case. The higher court's prejudice against Hatfield's reliance on familial witnesses, and the judges" propensity to believe the "good citizen" businessmen summoned by Allison, reflected the divergence of attitudes towards family and social position within and outside the Valley. The conflicting decisions of the jury and the judges emphasize the contrast between local and external interpretations of the law and justice. The jury's decision reflected customary values ignored by the high court. For example, Hatfield's fellow Mingo Countians probably turned a blind eye to perjurious testimony because they believed that it was unjust for Hatfield to pay taxes on land that Allison enjoyed the benefits of developing. By contrast, the West Virginia

Z. T. Vinson, "Railway Corporations and the Juries," Minutes of the West Virginia Bar Association, 17th Annual Meeting, (Clarksburg, February 12-13, 1902): 42-51. Vinson had an interest in the development of Mingo County, having been an investor, along with Wallace $\mathrm{J}$. Williamson, in the Williamson Mining and Manufacturing Company. Vinson also later served as the lead attorney for the Williamson operators during the 1920-1922 strike. Unfortunately records are not available to corroborate the connection, but it is possible that Sanford Hatfield's father Ali was the Sheriff Ali Hatfield visited by 1904 Democratic gubernatorial hopeful, John J. Cornwell. Cornwell, Mountain Trail, 97.

80"Hatfield v. Allison," 384, 377.

${ }^{81}$ See Lewis, Appalachian Countryside for a detailed discussion of the transformation of West Virginia's legal system and the resultant social and political impact of that evolution. 
State Supreme Court of Appeals, which was dominated by proponents of the new order, was swayed by Allison's mustering of evidence of contractual rights. ${ }^{82}$

If the judges of the West Virginia State Supreme Court of Appeals exhibited little patience with the attempt by Mingo Countians to protect Sanford Hatfield's farm, they displayed open disgust and disdain for the community's failure to contain the Hatfields' propensity for violence in the appeal of the State of West Virginia v. Elias Hatfield case. On July 3, 1899 Elias Hatfield, the fifth son of Devil Anse Hatfield, shot and killed Humphrey E. "Doc" Ellis at the train yard at Gray, West Virginia. ${ }^{83}$ The reason for the deadly confrontation most sources agree was Ellis' kidnaping of Elias' brother Johnse, whom Ellis had turned over to Kentucky authorities. ${ }^{84}$ Despite acknowledging that he sought out Ellis, Elias Hatfield pleaded self-defense and justifiable homicide. ${ }^{85}$

Unfortunately for Elias Hatfield, "Doc" Ellis was a popular man. After his death, an open letter was published in the Logan Banner urging Ellis' fellow Masons, Eagles, and Odd Fellows to make sure Hatfield was punished if the proper authorities failed to do their duty. ${ }^{86}$ If West

${ }^{82}$ See Waller, Feud, 47, for an analysis of Tug Valley residents' attitudes towards contracts. For more on the conflicting philosophy of the judges of the West Virginia supreme court, see Lewis, Transforming the Appalachian Countryside, Chapter Four, especially, page 110.

${ }^{83}$ "State of West Virginia v. Elias Hatfield," in Reports of the West Virginia Supreme Court of Appeals, 48 (April 14, 1900-December 21, 1900): 561-576, 571-2.

${ }^{84}$ Rice, Hatfields and McCoys, 120. Johnse was tried and convicted of several charges including murder of three McCoy boys and the New Year's attack on Ranel McCoy's home. After saving Kentucky's lieutenant governor's life during an attack from another inmate, Johnse was pardoned and released from prison.

85"State v. Hatfield," 372.

${ }^{86}$ Logan Banner, 6 July 1899 quoted in Cubby, “Transformation,” 178. 
Virginia governor George W. Atkinson had not intervened by taking him to Charleston for safekeeping, Elias Hatfield may have been lynched. ${ }^{87}$ However, the sentence Elias Hatfield received stirred even more public enmity. Convicted of murder in the second degree, Elias Hatfield was sentenced to just twelve years for the murder of Ellis. ${ }^{88}$

A closer look at the Ellis-Hatfield murder case reveals yet another pattern from the county's early history which would bear fruit in the events of the 1920-1922 period. The basic issue centered on the widening breach between an emerging belief and desire for an impartial application of law and the retention of traditional views and application of moral justice. The two sources for this re-evaluation are: commentary from the majority opinion in Hatfield's appeal to the West Virginia Supreme Court of Appeals and "On the Circuit in Southern West Virginia," a 1901 article in the legal magazine Greenbag.

Penned by Judge McWhorter, the majority opinion in the State v. Hatfield gives voice to the conflict between local customs and the demands of modern law. In commentary on the difficulty of empaneling a jury that would not be dominated by Hatfield kinsmen and close associates, even though the men had expressed their willingness to serve, Judge McWhorter wryly noted that, "it is an old saying that 'blood is thicker than water."'89 Claiming the authority

${ }^{87}$ Logan Banner, 13 July 1898, quoted in Cubby, “Transformation,” 178.

${ }^{88}$ Rice, Hatfields and McCoys, 120; Virgil Carrington Jones, The Hatfields and the McCoys (NY: Ballantine Books, 1948), 216-217. Elias Hatfield served less than eight years of his twelve year sentence. In 1907, he was implicated in a peonage case; he died with his brother Troy in 1911, while trying to arrest an Italian bootlegger. Kenneth R. Bailey, "A Temptation to Lawlessness: Peonage in West Virginia, 1903-1905," West Virginia History 50 (1991): 25-45, 37-38; Jones, 226-227.

89"State v. Hatfield, 572. 
of equally aged wisdom, McWhorter affirmed the local judge's wisdom in refusing to seat the men, although he was concerned by the allowance of a juror who had been advised by his own kinsman to stay on the jury because it would behoove their family to win the Hatfields' regard. ${ }^{90}$ Judge McWhorter's strongest condemnation focused on Elias Hatfield's claim that he had killed Doc Ellis in self-defense. McWhorter castigated Hatfield,

What was [the] defendant doing with his Winchester rifle in his hands? ... He had gone to take some letters to the post office, surely a peaceable mission. It was but a short distance from his place of business to the post office and not through a hostile section infested with wild beasts ... [or] robbers and brigands. ${ }^{91}$

McWhorter went on to express his disappointment with the community in which the confrontation occurred, "it would seem that these reformers would have rid the country by this time of these dangerous characters, so that it would no longer be necessary to carry a Winchester constantly in self-defense when about the ordinary duties of life." 92 With these words, Judge McWhorter proclaimed the end of West Virginia's legal complicity with frontier justice. It was unacceptable for a man to move about polite society armed, much less for him to purposefully

\footnotetext{
${ }^{90}$ Ibid., 566. The "juror and his kinsman" were cousins Guy and M. Z. White. In 1900, Guy White was appointed to the Mingo County Republican Central Committee. About the time of the trial M. Z. White was mayor of Matewan. A brother-in-law and ally of Henry D. Hatfield, M. Z. was appointed warden of the state penitentiary by Hatfield. "M. Z. White" in West Virginia Heritage Encyclopedia, 23: 5079.

91 "State v. Hatfield," 575.

${ }^{92}$ Ibid.
} 
seek out a man with the intent to kill, provoke the intended victim to attack, kill him, and then escape punishment by pleading self-defense. ${ }^{93}$

The notoriety of the Ellis-Hatfield case refused to die. In 1901, Edwin S. Doolittle made the case the centerpiece of an article titled, "On the Circuit in Southern West Virginia." After describing the primitive traveling conditions endured by those who "rode the circuit," the author focused his observations on the antiquated but effective oratorical style of the lawyers.

According to the author of the piece, former West Virginia Governor E. Willis Wilson's defense of Elias Hatfield stands as the paramount example of the traditional legal approach to defense. First, Wilson's two hour long closing argument turned the victim into the villain. Second, the author noted, it was this use "of eloquent but irrelevant oral argument" and not the merits of the case that resulted in a victory for the undeserving. ${ }^{94}$

Despite the best efforts of legal and social reformers, for decades lawyers arguing before juries in southern West Virginia continued to use similar tactics. In 1920, Harold W. Houston, the lead attorney for the Matewan Massacre defendants declined the proffered legal assistance of the American Civil Liberties Union for fear of alienating the jury. ${ }^{95}$ When the case finally went to trial in 1921, Houston dramatically depicted the Massacre defendants as men defending their

\footnotetext{
${ }^{93}$ Another McWhorter also grew disillusioned local application of the law. In the midst on allout assault on the legal rights of striking miners, J. C. McWhorter openly advocated dispensing with the jury system. J. C. McWhorter, "Abolish the Jury," West Virginia Law Quarterly 29 (January 1923):97-108. Based on available biographical information on the McWhorter family, it is unlikely that the two McWhorters were closely related. See West Virginia Heritage Encyclopedia volume 14.

${ }^{94}$ Edwin S. Doolittle, "On the Circuit in Southern West Virginia," Greenbag 12 (1900):284286, 285.

${ }^{95}$ Lunt, 146. Houston however, did accept public relations assistance from the ACLU.
} 
homes and families from an invasion of lawless thugs. He entreated the jury to return the "defenders" of Mingo County to their little children who prayed nightly for their fathers to come home. Lawyer Houston's eloquence left women prostrate and sobbing and defendant Sid Hatfield openly weeping. ${ }^{96}$ In both cases the defense attorneys' ploys worked. Elias Hatfield, although convicted of second degree murder was only sentenced to a twelve year prison term; the Massacre defendants were acquitted. ${ }^{97}$

An incident that occurred between the murder of "Doc" Ellis and the Matewan Massacre highlights another element in the pattern of violent conflict resolution in Mingo County. ${ }^{98}$ The story of the fatal exchange between Thomas Chaf(f)in and the police chief and mayor of Matewan shows that violence involving public officials in Mingo County could rarely be ascribed to a single causation. Moreover, efforts to unravel the why and how of these incidents also always seem to be complicated by the deaths of the principals and deliberate obsfucation by the deceased's partisans. ${ }^{99}$ In the wake of these incidents, members of the community divide over which version of the story they believe, uniting only when outsiders push to know "what really happened."

${ }^{96}$ Bluefield Daily Telegraph, 20 March 1921, Bluefield Daily Telegraph Collection, ERCA.

97"State v. Hatfield," 563; New York Times, 21 March 1921.

${ }^{98}$ In addition to the 1911 Musick, Hoskins, and Chafin incident, in 1914 another of Matewan's police chiefs, O.L. Ackerman died in a "duel to the death" with the mayor's nephew. The Mingo Republican reported that the cause for the violent exchange was "bad blood, renewed by a poker game in R.W. Buskirk's saloon.” Mingo Republican, 13 February 1914.

${ }^{99}$ Two other cases will be discussed later in this study: the shooting of Judge James Damron and the murder of Williamson Police Chief John B. Maynard. 
On Wednesday, April 26, 1911, Tom Chafin, a nephew of Devil Anse Hatfield and miner employed at Red Jacket, shot and killed W. R. Hoskins and Walter E. Musick, respectively the mayor and police chief of Matewan. According to the newspaper accounts of the incident, both Tom Chafin and Walter Musick's wife believed that Musick and Chafin's wife were having an affair. ${ }^{100}$ On the Sunday before the shooting Mrs. Musick had gone to the Chafin home and compelled Mrs. Chafin to accompany her to Matewan where Mrs. Musick tried to have Mrs. Chafin jailed. ${ }^{101}$ At this point the stories presented in the two newspapers diverge.

Published on April 28, the Mingo Republican's (Republican) account purported to be based on the deathbed statement of Mayor Hoskins. Hoskins claimed that Musick, the son of former sheriff E. E. Musick, hoped to convince Chafin that no affair had occurred by taking a solemn oath that "he had not invaded his home." Chief Musick spoke pleasantly at first with Mr. Chafin, but the two eventually ended up in the yard scuffling, whereupon Chafin pulled a gun. Seeing the gun Hoskins hurriedly approached, but Chafin shot Musick twice in the chest whereupon Musick fell dying into Hoskins' arms. Hoskins, who was not armed, turned to flee but was also mortally wounded by Chafin. The Republican closed its story with a brief alternative to the mayor's dying declaration. In this unverified version Hoskins and Musick went to Chafin's home to serve a warrant and upon arrival, as they stood on the threshold, Hoskins allegedly told Chief Musick, "Get Chafin or kill him." Fearing for his safety Chafin opened fire on the two men. ${ }^{102}$

\footnotetext{
${ }^{100}$ Williamson Enterprise, 27 April 1911; and Mingo Republican, 28 April 1911.

${ }^{101}$ Mingo Republican, 28 April 1911.

${ }^{102}$ Ibid.
} 
The Democratic paper, the Williamson Enterprise, published a vastly different and innuendo-ridden version of the events. ${ }^{103}$ The Enterprise claimed that Chafin had returned home and found Musick in the house alone with his wife. Chafin opened fire on Musick, whereupon Hoskins, who just happened to be "in the neighborhood," came to investigate and arrest the shooter, was also wounded. Chafin fled the scene but eventually surrendered to the authorities. ${ }^{104}$ The Enterprise reported that Chafin, accompanied by his brother, turned himself in because he feared being caught by the deceased's relatives who had gone looking for him. ${ }^{105}$

Convicted of voluntary manslaughter and ordered to serve two years in the state penitentiary, Chafin escaped from the local jail and again ended up on the run from the authorities. ${ }^{106}$ A posse chased Chafin to Mercer County where he was found dead at the foot of Pigeon Mountain. ${ }^{107}$ The lack of Mingo County court records denies analysts the opportunity to prove their hypotheses about the Chafin-Musick-Hoskins encounter. However, several influential details teased from the newspaper accounts of the story seem to indicate the existence of a pattern observable in other episodes involving public officials in Mingo County and violence.

First, the differences in the presentation of the story by the Mingo Republican and Williamson Enterprise hints at a political issue lurking in the background. Musick and Hoskins

${ }^{103}$ Williamson Enterprise, 27 April 1911.

${ }^{104}$ Ibid.

${ }^{105}$ Williamson Enterprise, 4 May 1911.

${ }^{106}$ Mingo Republican, 20 October 1911.

107"Thomas Chaffin (Chafin)," West Virginia Heritage Encyclopedia, 5: 919. 
belonged to the Republican leadership of Magnolia district, while most of Mingo's Chafins, like their kinsman Devil Anse Hatfield, had never deserted the Democratic Party. Little wonder then that the Democratic paper, the Enterprise published the account that asserted that Chafin caught Musick, the adulterer in the act. In the unspoken judgement of the paper, Chafin the cuckhold, rightfully punished the man who destroyed the sanctity of his home and abused his honor.

Second, there is the "woman as scapegoat" issue. Other than providing a justification for Musick's death to some, the question of adultery remained. The equally partisan Republican acknowledged Mrs. Musick's suspicions, but by repeating in full the mayor's declaration that Chief Musick went to Chafin's home to plead his innocence, implied that there might have been a misunderstanding. However, the recurrent explanatory presence of women in subsequent episodes of violence involving Mingo's officials suggests a purposeful invocation of moral turpitude.

The confidential investigation of the 1917 shooting of Mingo Circuit Court Judge James Damron revealed that either politics or Damron's womanizing was the likely cause of his injury, even though the local newspapers publicly blamed the incident on the beau of a woman whose father had been jailed by the Judge. ${ }^{108}$ The murder of Williamson police chief John B. Maynard in 1918 by Chattaroy Constable Jesse Huffman, allegedly resulted from "bitter feeling" between the men over a woman. Maynard's recent defiant independence in the faction wars for control of Williamson's municipal politics, while acknowledged in the press acount of his death, apparently was not considered as a possible cause for his demise. ${ }^{109}$ As the cases of Musick, Damron, and

\footnotetext{
${ }^{108}$ See Chapter 9 for more details.

${ }^{109}$ Ibid.
} 
Maynard demonstrate, women, or relations with women, at least in the local iconography of the violent confrontations of Mingo's public officials, pre-date the most infamous case in the county's history.

The specter of illicit passion reared again in June 1920, when Cabell Testerman's widow Jessie married Sid Hatfield less than two weeks after Testerman died in the Matewan Massacre. According to Baldwin-Felts documents and several trial testimonies, Hatfield either staged the confrontation known as the Massacre in order to kill Testerman, or at least capitalized on the ensuing confusion to eliminate his rival. To this day, in some circles, whether Mingo Countians believe or deny the story about the "love triangle" remains an important indicator of individual attitudes about the Massacre, strike, and unionization. ${ }^{110}$

The third recurrent issue first highlighted in accounts of the Musick-Chafin story is the lack of an unassailable reason for the fatal encounter. The mystery surrounding the role of Mayor Hoskins in the Musick-Chafin exchange only intensifies upon examination of the two newspapers' explanation for his presence. The Enterprise derisively, but obliquely, observed that he was "in the neighborhood," while the Republican equally enigmatically alluded to a nonprivate reason for the confrontation when it noted that Musick and Hoskins, armed with a warrant, traveled together to Chafins' home. What breach of the law might Chafin have committed to bring Hoskins and Musick out of their municipal jurisdiction to his door?

Chafin's death silenced the public record. However, the reasons for his death wrap another layer around the story. Why would Chafin surrender, go to trial, receive a light sentence, only to go back on the lam? Neither the Republican nor the Enterprise offer any explanation,

\footnotetext{
${ }^{110}$ This issue will be developed in Chapter 10.
} 
other than the one originally offered to justify his original surrender which was that he feared retribution from the relatives of Musick or Hoskins, or both.

The unanswered questions in this case, when combined with the conflicting assertions regarding its cause, eerily portended future events in the county. Just five years later, Mayor Hoskins' brother John, who was Constable of Magnolia District, shot and killed a man in an encounter also fueled by manly honor. Like Chafin, Hoskins ran, and then returned for trial, only Hoskins was acquitted. However, almost two years to day of his victim's death, John Hoskins' lifeless body was found in Red Jacket's Mitchell Branch mine. ${ }^{111}$

Mingo County's industrialization did not automatically transform community attitudes about the role of law in conflict resolution or the administration of justice. Hatfield v. Allison and State of West Virginia v. Hatfield both document the persistence of what amounted to acceptable manipulation of the law. In Hatfield v. Allison, Sanford Hatfield and members of his family apparently were not troubled by committing perjury in order to regain control of his land. Similarly, Elias Hatfield believed that he could escape punishment for the revenge killing of "Doc" Ellis by concocting a self-defense excuse. Cases explored in subsequent chapters will reveal that Sanford v. Allison and State v. Hatfield stand as indicators of customary behavior in Mingo County.

Details from the accounts of the incident that resulted in the deaths of Matewan's chief of police and mayor in 1911 also expose a pattern of local customary reaction to episodes of violence. First, the deaths of the principals conveniently and permanently obscured an accurate estimation of what initiated the conflict. Second, because of the absence of an irrefutable

\footnotetext{
${ }^{111}$ See Chapter 9 for the details of the John Hoskins incident in 1916.
} 
explanation, partisans of the parties constructed a version of events that divided the community. Either Thomas Chafin murdered Chief Musick and Mayor Hoskins rather than face justice for an unknown offense or he righteously punished an adulterer. Chapter 10's explication of the Matewan Massacre will show that there were parallels between the community's interpretations of the deaths of Musick, Hoskins, and Chafin, and the Matewan Massacre and the subsequent murder of Sid Hatfield. Specifically, public opinion divided over whether Hatfield and his allies were championing a just cause or that Hatfield unnecessarily escalated a confrontation in order to murder the husband of the woman he coveted. Enmeshed in all of these stories is the issue of a growing divergence in social attitudes within Mingo County. However, these differing attitudes towards the law and justice did not place members of the local community into easily divisible categories of traditional and modern, native or outsider, working class or elite.

\section{Conclusion:}

From the time of Mingo's birth in 1895, Matewan and Williamson, like polar lodestones, served as the nexus for rival claims to dominion over the county. Although run by a corrupt machine in the name of the new industrial elite, Williamson appeared to exemplify the progress that had accompanied Mingo's industrial transformation. However, despite being the county seat and the ostensible center of political and economic power in the county, Williamson could not vanquish the perennially fractious Matewan. Incidents in the smaller community perpetuated the notorious reputation of the Tug Valley, and challenges to the industrial elite's control of the county always seemed to emerge from the ranks of Matewan's native elite. Two newspaper 
stories from 1911 capture not only the end of Mingo's first era, they also illuminate the eternal contrast between the county's two most important communities.

In Matewan, at 6:30 in the morning of January 16, 1911, a fire broke out in the buildings that housed R. W. Buskirk's saloon and hotel. The conflagration nearly destroyed the town's business district. Over seventeen commercial buildings and private residences were lost, as well as the town's hospital. The newly constructed brick Schaeffer Brothers' Building was credited with stopping the fire and saving the frame buildings that faced the depot. Because it was "certain" that most of the burned buildings would be replaced with "modern brick or cement structures," Matewan's days of looking like a frontier boom town were over. ${ }^{112}$ In the decades to come many destructive forces would sweep over the little town, but it would always rise phoenix-like from the storm.

Later in 1911, it was reported that Williamson had become one of the most populous cities in southern West Virginia. ${ }^{113}$ In less than twenty years, Williamson had been transformed from a cornfield to one of the largest population centers in southern West Virginia. Of the seventeen towns identified in the article, Williamson ranked below only Bluefield and Huntington, and ahead of Welch and Princeton, the county seats of McDowell and Mercer Counties. ${ }^{114}$ However, Williamson never quite capitalized on its early phenomenal growth. Even though it was the county seat of Mingo, Williamson remained the center of southern West

\footnotetext{
${ }^{112}$ Mingo Republican, 20 January 1911. Between January 1911 and 1912, Matewan survived three fires; the last, reported on 12 January 1912, resulted in thirty thousand dollars damage.

${ }^{113}$ Mingo Republican, 17 February 1911.

${ }^{114}$ Ibid.
} 
Virginia's infamous economic periphery, overshadowed by the irrepressible and defiant Matewan. $^{115}$

Just as industrialization failed to completely transform Mingo County economically and politically, the forces of modernization did not universally improve life in the Tug Valley. Community growth, increasing occupational diversification, and rising ethnic heterogeneity all came at a price. Moreover, the uneven advancement of development in the county facilitated the survival of traditional social values and conceptions of acceptable public behavior. Violence committed in defense of status, honor, and power could still find affirmation. In the years that followed Mingo's initial phase of development, the county remained contested terrain.

${ }^{115}$ Mingo Republican, 15 November 1917. 
PART III: THE DESCENT INTO CRISIS, 1912-1920 


\section{CHAPTER 6}

THE PROGRESSIVE ERA?: MINGO'S POLITICAL MACHINES AND FACTION WARS

"Political strife seems to be perennial in this county." --Williamson Daily News, February 1917

In one sense Mingo County politics between 1912 and 1919 followed the trend that had dominated county politics since 1895 . Every election was bitterly contested with charges and countercharges of graft, illegal voting, and wholesale election fraud and theft. ${ }^{1}$ Noted West Virginia historian John Alexander Williams observed that in West Virginia during the Progressive Era, reform party movements were led more often by "disgruntled outs trying to get back in" than by genuine reformers. ${ }^{2}$ In Mingo County, the appearance of third party tickets like Progressive, Prohibition, and Bull Moose on election ballots merely re-labeled old factions and party splinter groups. ${ }^{3}$ An important yet minor exception was the appearance of the Socialist party in the 1912 election. However, primary and ballot "reform" legislation minimized the

\footnotetext{
${ }^{1}$ Karr, 63. Hatfield biographer Carolyn Karr noted that in McDowell and Mingo counties, the ballots were often held "until it was known what was happening;" in 1912, this meant that the returns could be "adjusted" to help insure a Hatfield victory.

${ }^{2}$ Williams, Captains of Industry, 97. Governors William M. O. Dawson and Henry D. Hatfield gained recognition for advocating many Progressive reforms while relying on "machine politics" as sources of power. While advocating tax reform and other measures in the name of the people, behind the scenes Dawson was, in the words of one contemporary observer, "the right-hand man" of Republican party boss Stephen B. Elkins. McIntosh Memoir, WVRHC.

${ }^{3}$ During the pre-war period Everett Leftwich and B. Randolph Bias were Mingo County's Progressive and Bull Moose party leaders. In the previous decade they had been Republican faction leaders. Leftwich and S. W. Perry, the superintendent of the Margaret Mining Company, were candidates on the Progressive party ticket. The bolt of Leftwich and Perry from Republican ranks underscores the tenuousness of the relationship between Mingo's native Republican and industrial elites. Williamson Daily News, 28 October 1914. Confirmation of Perry's occupation found in the 1906-1907 West Virginia State Gazetteer and Business Directory.
} 
impact of the Socialist party locally and around the state. ${ }^{4}$ County and municipal elections from 1912 through 1919 in Mingo remained extremely fractious contests between the two main parties, the Republicans and Democrats.

There was one significant difference between the elections of the 1912-1919 period and previous elections -- the pendulum of political power swung farther with each election. The period began with the Hatfield machine in control of Mingo County. However, their abuse of power and flagrant manipulation of the political process led to the Hatfields' eclipse in 1916. Temporarily united in opposition to the Republican Hatfields, Mingo's Democratic party regained control of the county in 1916, only to resume its internecine struggles shortly thereafter. Neither Progressive reform agendas nor the war effort inhibited the ongoing faction wars of Mingo County politics. When UMWA organizers arrived in Mingo County in the Spring of 1920, their early success depended, in part, on their ability to capitalize on the volatility of the local political scene. The first half of this chapter chronicles the rise and fall of Mingo's Republican Hatfield Machine, while the second outlines the path to power of the Democrats of Matewan.

\footnotetext{
${ }^{4}$ Barkey, 175. The primary bill opened voter registration records, which as Professor Barkey asserts, in coal counties provided coal company officials with a means of exerting pressure on independent-minded employees. In the Age of Reform, Richard Hofstadter noted that ballot and primary reform measures enacted in several states failed. Richard Hofstadter, The Age of Reform: From Bryan to FDR (New York: A. Knopf, 1956), 265. A more recent study of the Progressive era affirms Hofstadter's assertion. See Diner, 231.
} 


\section{The Hatfield Machine and Republican Control of Mingo County, 1912-1916:}

The 1912 general election marked the Hatfield family's triumphant return to political primacy in the Tug Valley. Native son Henry D. Hatfield, who had migrated to McDowell County and joined the coal operator backed Republican Party, astutely combined a traditional politicking style, a Progressive reform platform, and the coercive strategies of a machine "boss," to win election to the governor's office. ${ }^{5}$ Riding his coattails, Henry D.'s older brother Greenway led the Republican sweep of Mingo's county offices of: sheriff, circuit court judge, prosecuting attorney, assessor, county commissioner, and state delegate. ${ }^{6}$ Between 1912 and 1915, Henry D. and Greenway Hatfield shrewdly co-opted the language of reform to strengthen their control over state and county politics. ${ }^{7}$ At the same time, the Hatfield brothers' bald abuse of power fractured Henry D.'s syncretistic powerbase and inspired a united front of Hatfield opponents who toppled the Republicans from power in $1916 .^{8}$

Henry D. Hatfield oversaw the enactment of more reform legislation than any other West

\footnotetext{
${ }^{5}$ Mingo Republican, 1 November 1912. In a last-minute speech in Mingo, Hatfield stressed his advocacy of the Public Service Commission, better primary election laws, education reform and a more equitable tax structure. See Penn, 286 for references to issues Hatfield raised while campaigning in other counties.

${ }^{6}$ Mingo Republican, 8 November 1912.

${ }^{7}$ Examples that will be discussed include primary and municipal reform.

${ }^{8}$ At the state level, Henry D.'s autocratic and demagogic leadership style turned the industrial elite against him. In Mingo, Greenway's openly corrupt and extortionistic approach to local government fueled a series of scandals that united the otherwise fractious Hatfield opponents. In 1916, the rejection of Hatfield rule resulted in the election of West Virginia's only Democratic governor between 1896 and 1932, and a clean sweep of Democrats in Mingo's county election.
} 
Virginia governor in the Progressive Era. ${ }^{9}$ During his tenure as the President of the West Virginia Senate and his four year-term as governor, Hatfield championed primary and ballot reform, prohibition, bills that called for the eradication of the much hated mine guard system, and the establishment of West Virginia's workmen's compensation fund and Public Service Commission. ${ }^{10}$ Hatfield's success in achieving the passage of these measures emerged largely from his unique political style, which allowed him to elicit support from all segments of West Virginia society, from the working class to the industrial elite.

Running for office in the midst of the Paint Creek and Cabin Creek Strike of 1912-1913, Hatfield, who hailed from West Virginia's most operator-controlled county, won the support of West Virginia's laboring classes by publicly committing himself to addressing the issues that mattered most to them, including strengthening West Virginia's laws against the use of private guards. One incident that revealed how Hatfield convinced coal miners of his sincerity also exposes his canny use of traditional mountain politicking. During a campaign stop in Williamson, Hatfield spotted in the crowd A. D. Lavinder, a childhood friend who had become one of southern Virginia's leading Socialist coal miner activists. Lavinder later recalled that after concluding his speech, Hatfield called him aside and told Lavinder that together they "could run these mine guards out of here." ${ }^{11}$ True to his word, once in office Hatfield shepherded the Wertz mine guard bill through the West Virginia legislature. However, the absence of a key component of the bill illustrates how Hatfield eluded censure from the coal elite -- the Wertz bill had no

\footnotetext{
${ }^{9}$ See the studies of Karr, Penn and Burckel for details.

${ }^{10}$ Ibid.

${ }^{11}$ Lavinder interview, WVRHC.
} 
enforcement clause. ${ }^{12}$

As in the case of the Wertz bill, Hatfield's other reforms contained clauses that diffused their threat to the industrial elite. For example, the 1915 primary election bill, while ostensibly a reform measure, actually enhanced the opportunities for elites and corporation officials to influence primary elections. The bill required voters to register their party affiliations, and in turn opened precinct registers to public display. This "reform" measure limited the free and confidential exercise of the franchise, especially in company towns or even "independent" towns where local coal company officials frequently were appointed poll registrars or worked as poll clerks. As a result of the 1915 bill, these officials were now privy to the political affiliations of their employees. ${ }^{13}$

Another feature of the 1915 primary bill required would-be candidates to pay a registration fee to enter a primary election. This measure reflected a popularly held Progressive belief that political candidacy and public offices should be restricted to "the better class of people" who not only could afford the fee, but also were supposed to be more capable of acting

\footnotetext{
${ }^{12}$ Barkey, 169. During the same campaign, Hatfield's cousin Don Chafin also campaigned for Logan County Sheriff with a promise to get rid of mine guards. After the election, Chafin also "kept his promise" by replacing the guards with an "army of deputies." In Mingo County, Greenway Hatfield, Henry D.'s brother followed Chafin's example. Williamson Daily News, 22 April 1916.

${ }^{13}$ Barkey, 175. Another progressive reform Hatfield shepherded through the legislature was the creation of West Virginia's Public Service Commission which policed all of the utility companies doing business in the state. Originally set up as an equally divided bipartisan four man board, Hatfield forced the legislature to reduce PSC membership from four to three, which allowed the Republicans to take control. According to the Charleston Gazette, the reduction bill "[enabled] the [Republicans] . . . to hold up the corporations of the commonwealth and milk them for large campaign contributions." Undated Gazette article quoted in the Williamson Daily News, 1 February 1915.
} 
in the public interest and not merely their own. Ultimately, the fee requirement did not impede the influence of machine politicians. The "reform," intended to limit political candidacy to the "better classes" merely raised the stakes and honed the machines' desire to select absolutely loyal and controllable candidates. ${ }^{14}$

By the last year of Hatfield's tenure as governor, the strategy behind his legislative accomplishments had become public knowledge. As noted by the Williamson Daily News on January 18, 1915, many of the reform measures passed during Hatfield's term "[were] so framed . . . as to be easily evaded." ${ }^{15}$ Although a Democratic paper, the Daily News expressed a spreading disillusionment with Hatfield's leadership. The most common complaint about Hatfield was his ability to compel others to do his bidding, another component of his political style that had originally propelled him into the governorship.

Hatfield's arrival in Charleston before the opening of the 1913 legislative session, and his own assumption of the governor's office, heralded his departure from the leadership style of his predecessors. Breaking with tradition Hatfield met with the legislators and outlined the bills he wanted passed. ${ }^{16}$ Because the Republicans also controlled the West Virginia legislature, Hatfield did not concern himself with coalition building. ${ }^{17}$ As long as he had sufficient votes to pass a

\footnotetext{
${ }^{14} \mathrm{Ibid}$. This assertion is based on the candidacy of "machine" politicians in subsequent elections.

${ }^{15}$ Williamson Daily News, 18 January 1915.

${ }^{16}$ Karr, 138. Traditionally, because of the timing of the governor's swearing-in ceremony, the first legislative session of a new governor's term was actually the last session of the outgoing governor's term.

${ }^{17}$ See Karr, 157 and 168-170 for a detailed discussion of Hatfield's "techniques of power."
} 
desired piece of legislation, Hatfield did not care if it attracted any Democratic support. ${ }^{18}$ He awarded favorites with plum administrative positions and instilled fear in his opponents. ${ }^{19}$

Hatfield did not shirk from cowing antagonists with physical violence. ${ }^{20}$ Before his election as governor, Hatfield publicly pummeled a racist newspaper editor who had criticized Hatfield's political reliance on African-American votes. ${ }^{21}$ Even after becoming governor, Hatfield resorted to using his fists. During his effort to resolve the Paint Creek strike, Hatfield allegedly knocked a recalcitrant coal operator into a corner of his office. ${ }^{22}$ When a Public Service Commissioner (and his own brother-in-law) threatened to go against the governor's wishes in a well-publicized utility case, Hatfield invited the man to a meeting in the governor's office and as the unsuspecting victim seated himself, leaped upon him and beat him nearly unconscious. ${ }^{23}$

Although Greenway Hatfield was less openly and personally confrontational than his younger brother, his rule of Mingo County from 1912-1915 exposed the machine component of

\footnotetext{
${ }^{18}$ Ibid.
}

${ }^{19}$ For example, Hatfield rewarded an ally Mingo County state senator M. Z. White with appointment to the wardenship of the state penitentiary. See discussion of the 1913 Bribery Scandal later in this chapter, and note 63.

${ }^{20}$ Karr, 144. According to Karr, Hatfiield possessed a "dual personality" attributable to "his early environment . . . it was a personality of compassion, but it was also a personality of vengeance."

${ }^{21}$ Penn, 23, and Bluefield Daily Telegraph, 5 September 1908. The editor in his newspaper aimed repeated attacks on "Hatfield and his gang of niggers."

${ }^{22}$ Lee, Bloodletting, 45-6. It was alleged that the operator was Quinn Martin (Morton), who masterminded the assault by an armored train called the "Bull Moose Special" on a tent colony during the Paint Creek and Cabin Creek Strike. For details see Corbin, Life, Work, and Rebellion, 88.

${ }^{23}$ Williamson Daily News, 12 May 1914, and Karr, 153-154 
the brothers' powerbase. Sheriff Hatfield created an "army of deputies" staffed by an array of cousins and hangers-on. ${ }^{24}$ Political subordinates paid cash or delivered votes in return for appointment to public office. ${ }^{25}$ During his tenure as Sheriff, Greenway Hatfield used inmates of the county jail to cultivate his farm, the proceeds of which he used to feed them and in turn pocketed the money he saved from the county's prisoner maintenance fund. ${ }^{26}$ As one Hatfield descendant noted, it was not uncommon to find Greenway's enemies floating in the Tug Fork River. $^{27}$

Only one thing kept the Hatfield Machine from ruling Mingo County absolutely. Control of Williamson, the county seat, had lodged in the hands of the Democratic relatives and associates of the city's founder Wallace J. Williamson, since Mingo's founding. By 1915, when Henry D. Hatfield decided to use his control of the West Virginia legislature to break the Democrats' hold on Williamson, the mayor, A. C. Pinson, had served seven consecutive terms. The story of the revocation of Williamson's municipal charter and the installation of commission government stands as the penultimate example of the Hatfield Machine's cooptation of Progressive reform methods.

Although he later claimed that "the d---ed thing made him want to puke" every time he thought of it, in the spring session of the 1915 West Virginia legislature, Mingo's Republican

${ }^{24}$ Williamson Daily News, 22 April 1916.

${ }^{25}$ Mingo Republican, 28 September 1916. See Table 9 in this chapter for details.

${ }^{26}$ Venchie Morell interview with Rebecca J. Bailey, Summer 1990 Matewan Oral History Project.

${ }^{27}$ Hatfield correspondence letter no.6. 
state senator Wells Goodykoontz proposed a bill to revoke Williamson's charter. ${ }^{28}$ The bill's passage removed seven-term Democratic mayor A. C. Pinson and the city council and replaced them with a bipartisan commission. ${ }^{29}$ The bill, which passed on a strictly partisan vote, called for Williamson to be governed from July 1, 1915 until July 1917 by an appointed five member bipartisan commission. ${ }^{30}$

As justification for their actions, the Republicans cited a state audit which showed that the Pinson administration had illegally misappropriated funds, left the new courthouse and city street construction unfinished and unpaid, and left the city with a two hundred thousand-dollar debt. ${ }^{31}$ Still, the revocation of Williamson's charter sent shock waves of anger rolling through the state. Newspaper editorials from as far away as Wheeling and Martinsburg condemned the act as a direct assault on the right of local self-government and the will of the people. ${ }^{32}$

Rescinding the charters of machine-controlled, corrupt municipal governments and replacing them with bipartisan commissions had been a popular Progressive reform across

${ }^{28}$ Williamson Daily News, 31 October 1918; The Williamson Daily News reported late in 1915 that in return for proposing the Williamson charter bill Goodykoontz expected to be appointed by Hatfield to the West Virginia State Supreme Court, but was passed over in favor of John W. Mason. Williamson Daily News, 2 November 1915.

${ }^{29}$ Williamson Daily News, 31 October 1918.

30"Williamson Charter," Senate Bill \#199 Acts of the Legislature of the State of West Virginia, 1915: 476-540.

${ }^{31}$ Mingo Republican, 2 November 1916.

${ }^{32}$ Undated quotations from: The Charleston Gazette, the Martinsburg World, the Wheeling Register, the Charleston Mail in the Williamson Daily News: 6 February 1915, 8 February 1915, 16 February 1915 and 2 March 1915. 
America since it was most famously applied in Galveston, Texas in $1901 .{ }^{33}$ Reformers intended commission government to be a means of stripping control of municipal affairs away from avaricious, blindly partisan ward bosses who manipulated the ignorant and unwashed for personal gain. In urban centers in the Northeast and Midwest, ethnic overtones figured prominently in this scenario, with the immigrant ward bosses and their constituents depicted as ignorant of, or unwilling to adapt to, proper American political traditions. ${ }^{34}$ The elimination of the mayor's council with its individually elected ward representatives and the introduction of city wide elections with a mandated bipartisan distribution of seats on the city commission, was intended to promote the selection of a better class of people as city officials. ${ }^{35}$

In the case of Williamson, Republicans claimed that the city's original charter had allowed a regime to impose one of the state's highest municipal tax rates while burying the citizens under a mountain of debt and allowing the city's physical infrastructure to disintegrate. ${ }^{36}$ The Williamson Democratic "City Ring" as it had been dubbed, was not a stereotypical Progressive Era urban-ethnic machine. Its leadership was southern White, Anglo-Saxon Protestants, including prominent native businessmen like Wallace J. Williamson and college-

\footnotetext{
${ }^{33}$ Bradley Robert Rice, Progressive Cities: The Commission Government Movement in America, 1901-1920 (Austin, TX: University of Texas, 1977), 10.

${ }^{34}$ Soule and Carosso, 268-269, and Charles N. Glaab and A. Theodore Brown. A History of Urban America (New York: Macmillan, 1983 [1967]), 196, 201.

${ }^{35}$ Diner, 205.

${ }^{36}$ Mingo Republican, 12 October 1916.
} 
educated migrants like S. D. Stokes. ${ }^{37}$ The Williamson machine manipulated the lower class industrial and railroad workers who lived within the city limits but did so as an agent of corporate capitalism -- the upper echelons of the machine included men like Stokes, who was an attorney who brokered land and mineral deals.

The Williamson Daily News declared the Charter Bill a legislative fiat concocted by Governor Hatfield and his cronies to steal for the Mingo Republicans what they could not win in an honest election. ${ }^{38}$ The bill called for the ouster of the Democratic mayor and council and their replacement with appointed commissioners who would serve two years before a new municipal election would be held. ${ }^{39}$ Among the new commissioners was the editor of Mingo's Republican newspaper, Orland H. "O. H." Booten, whom the Daily News renounced as a "liar, thief, . . . degenerate ... [and] drunkard who [could] be hired to desecrate a graveyard if it were necessary for his own gain." ${ }^{40}$

The Daily News began referring to Governor Hatfield as the "Emperor of Williamson" who, unless his lust for absolute power was checked, posed a threat to any elected municipal

\footnotetext{
${ }^{37}$ No evidence indicates whether Williamson received any formal education or professional training. A contemporary of Devil Anse Hatfield, as a youth Williamson left his father's farm on Pond Creek and eventually settled in Catlettsburg. Successful timber ventures financed Williamson's investments in banking and industry. Ely, Big Sandy, 150, 285, 324; Stokes was born into a southwestern Virginia family that followed the railroad into southern West Virginia, but sent its sons east to be educated at Washington \& Lee College (University). Stokes' biographical materials in the Stokes Papers, WVRHC.

38"An Outrage Upon Our Intelligence,” Williamson Daily News, 30 January 1915.

39"Williamson Charter Bill," 477. O. H. Booten, who was selected to head the commission and serve as "mayor" also had been the editor of the Mingo Republican.

${ }^{40}$ Williamson Daily News, 31 October 1914.
} 
officer in the state who disagreed with or offended him. ${ }^{41}$ Hatfield's ability to strip the Williamson Democrats of their control of Mingo's county seat evoked a vicious screed from the Daily News regarding the source and nature of his power: "it is true that the city elections are not dominated by negroes, dagoes, hunks, criminals and mercenaries as the county is, but under this law it will be." ${ }^{12}$

When the deadline arrived for the mayor and the other municipal officers to pass control of Williamson over to the appointed commissioners, Mayor Pinson and city clerk John S. Hall refused to surrender their offices. Both sides filed lawsuits and despite his periodic defiance of the Mingo Republican machine and his Hatfield cousins, circuit court Judge James Damron upheld the legality of the Charter Bill. ${ }^{43}$ Ousted Democrats appealed Damron's decision to the West Virginia Supreme Court of Appeals on December 12, 1915.

Five separate cases were submitted to the high court, but the judges decided that because they all dealt with the same legal issues, a single decision sufficed to explain the court's ruling. The central issue of the controversy, the supremacy of a state legislature versus the right of

\footnotetext{
${ }^{41}$ The sentiment was inspired not only by the Williamson Charter Bill, but also by the alleged contemplation of similar bills for Fairmont and Huntington. Several Republicans in the West Virginia legislature broke ranks and joined the Democrats in opposing the charters. Williamson Daily News, 4 February 1915 and 5 February 1915.

${ }^{42}$ Williamson Daily News, 30 January 1915. S.D. Stokes wrote fellow Democrat, West Virginia native and United States Solicitor General John W. Davis on 16 April 1915 and asked Davis to review the Charter Bill. In his reply Davis noted that there was "nothing to fight." As late as 1923 Stokes still condemned the bill for being "prompted by the greed of political advantage." S. D. Stokes to John W. Davis, 16 April 1915 and Davis to to Stokes, 3 June 1915; also Stokes to M. Z. White, 8 January 1923, Stokes Papers, WVRHC.

${ }^{43}$ Damron was a cousin of Greenway and H. D. Hatfield, who in an effort to secure his own powerbase, alternately supported and undermined his cousins' actions.
} 
municipal home rule, had such a long history in American jurisprudence, and was so familiar to the judges, that the president of the court, who just happened to disagree with the majority of his fellow judges, wrote both the majority and the dissenting opinions. ${ }^{44}$ The majority decision upheld the lower court's ruling. The judges declared the revocation of the Williamson charter and the institution of commission government was valid because:

(1) Municipalities are ... mere creatures of the legislature, exercising certain delegated governmental functions which the legislature may revoke at will.

(2) The power to create implies the power to destroy.

(3) If the legislature has made a mistake, it is a political one, and it alone can correct it. ${ }^{45}$

President of the Court Judge Poffenbarger held a diametrically opposed opinion regarding the right of municipal home rule. First, Judge Poffenbarger explained that the principle of local self-government traced to Anglo-Saxon England, and had been upheld by both the Glorious Revolution of 1688 and the American Revolution. Second, Poffenbarger noted, "municipal government was not a new or intricate problem" for Williamson. Moreover, the legislature need not have denied the citizens the right of electing commissioners for two years. Judge

\footnotetext{
${ }^{44}$ The right of municipal home rule versus the primacy of the state legislature was a legal and political dilemma as old as the American republic. In Public Property and Private Power, Henrik Hartog focuses on the struggle for municipal home rule in New York in the eighteenth century. Struggles over the issue expanded in the nineteenth and early twentieth centuries as American cities and industrial centers grew large, wealthy and impatient with the attempts of comparatively provincial legislatures to control them. Hendrik Hartog, Public Property and Private Power: The Corporation of the City of New York in American Law, 1730-1870 (Chapel Hill: University of North Carolina Press, 1983).

${ }^{45}$ The cases were as follows: "Booten v. Pinson," "Dudgeon v. Hall," "Nunemaker, et al v. Booten, et al," and "Pinson v. Booten et al," Reports of the West Virginia Supreme Court of Appeals, 77 (October 26, 1915 - March 21, 1916): 412-442, 421, 428.
} 
Poffenbarger's primary reason for dissenting against the majority decision was his belief that it set a dangerous precedent. He warned that, "the conclusion adopted by the court leaves the legislature wholly unrestrained." If it wanted to, the legislature could allow the Governor to appoint non-residents as the rulers of West Virginia's incorporated towns and cities. ${ }^{46}$ Despite Justice Poffenbarger's impassioned plea, the Court's handed down its decision to uphold the new Williamson charter on December 17, 1915. ${ }^{47}$ Mayor Pinson and the old city council "quietly ... handed over the reins of government" on January $1,1916 .^{48}$

Although the decision to use his gubernatorial power to rescind Williamson's charter and force his brother's political enemies out of office came back to haunt Henry D. Hatfield, the public outcry and judicial censure elicited by his actions did not hinder Hatfield's exercise of power. ${ }^{49}$ Even after his chosen successor lost the governorship to Democrat John J. Cornwell in 1916, Hatfield masterfully inflicted harm on his political antagonists. In one of his last acts as governor, Hatfield engineered the passage of what became known as the "Ripper" bill, which limited the ability of incoming governors to replace state level political appointees, thus decimating the amount of patronage the new governor could distribute. ${ }^{50}$ To add insult to injury, passage of the bill also politically humiliated the State Democratic party because the Democrats

\footnotetext{
${ }^{46}$ Ibid., 439.

${ }^{47}$ Ibid., 412.

${ }^{48}$ Mingo Republican, 6 January 1916.

${ }^{49}$ In 1916 the chief rival for Hatfield's chosen successor as governor openly denounced Hatfield's decision. See the discussion of the 1916 Republican primary race later in this chapter.

${ }^{50}$ Mingo Republican, 16 November 1916.
} 
had once hoped to pass a similar bill to destroy what they viewed as one of Governor Hatfield's sources of power. ${ }^{51}$ Angered by Hatfield's maneuver, Cornwell wrote to one friend, "I feel absolutely heartsick to think I shall have to ... [take] all the cussing and not be able to control the important departments of the State." ${ }^{52}$ What Cornwell never acknowledged was that he had not beaten Hatfield so much as he had benefitted from Hatfield's feud with the powerbrokers of his own party. ${ }^{53}$

Two fatal internal weaknesses precipitated the decline of the Hatfield Machine, both in Mingo and at the state level. First, the Hatfield brothers' unabashed reliance on corrupt and coercive election strategies repeatedly imbroigled them in political scandals. ${ }^{54}$ Second, once in the governor's office Henry D. fractured his alliance with the coal elite, first by ignoring his debts to former patrons, and later by openly defying their wishes. By the last year of Henry D.'s gubernatorial tenure the accumulated antipathy generated by these two issues led to a Democratic sweep of the governor's office and Mingo County's political offices.

The beginning of the end of the Hatfield brothers' reign actually occurred during the first legislative session of Henry D.'s governorship, and illuminates both of the Hatfields' major flaws. In 1913 a bribery scandal not only brought national notoriety to the state, it portended the

${ }^{51}$ Penn, 475-478.

${ }^{52}$ John J. Cornwell to C. W. Brandon, 2 December 1916, quoted in Fisher, 274.

${ }^{53}$ Fisher, 273-274.

${ }^{54}$ See Chapter 3 for the Congressional investigation into the 1910 election of West Virginia's Fifth District representative James A. Hughes. 
Hatfield's eclipse for two reasons. ${ }^{55}$ First, it was only one of a series of political incidents involving the Hatfields and/or their associates that seemed to validate their opponents' charges of corruption. Second, the issue at the heart of the scandal, the selection of a United States Senator, opened the schism between Henry D. Hatfield and West Virginia's coal and industrial elite.

When the state representatives converged on Charleston in early 1913, one of the critical issues facing the West Virginia legislature and incoming governor Henry D. Hatfield was the selection of a United States senator. After Stephen B. Elkins' death in 1911, Governor William Glasscock appointed Elkins' son Davis as a temporary replacement. ${ }^{56}$ When the legislature convened in 1913 the younger Elkins expected that he would be granted the senatorship in his own right, but he faced stiff competition from two of southern West Virginia's leading industrial elites, Isaac T. Mann and William S. Edwards. Elkins' "reactionary" views and assumption that the senatorship was automatically "his" angered Glasscock, and his candidacy was not considered seriously. ${ }^{57}$ On the other hand, Mann had contributed generously to the Republican war chest for years. Edwards also had been a long-time loyal party promoter. Both men felt they had earned the honor of representing West Virginia in the United States Senate. ${ }^{58}$

Governor-elect Hatfield's reluctance to back Mann, his old patron in McDowell County politics, forced Mann to compete with Edwards for support among the legislators who would

55"West Virginia's Bribery Scandal," Literary Digest (1 April 1913): 441-442, quoted in Corbin, Life, Work, and Rebellion, 13, note 57. Corbin does not cite the volume number.
${ }^{56}$ Penn, 310.
${ }^{57}$ Ibid., 310-311.
${ }^{58}$ Ibid., 309, 313. 
select the next senator. W. P. Tams, another prominent southern West Virginia coal operator described the events that created the resulting scandal:

til then [1913] it was a reasonably priced legislature . . But unfortunately for Mann another West Virginian, named Edwards . . . began to have money and he wanted to be senator. So they began bidding against each other . . . until the thing was like a madhouse ... men from up in the sticks were going around with money they never had before. It was rumored that both those men spent a couple hundred thousand ... the thing got so scandalous that more sensible people woke up and told both Mann and Edwards that they would have to withdraw and let someone else go up. Even West Virginia couldn't handle a scandal like that. ${ }^{59}$

After twenty-three ballots the legislature selected neither Mann nor Edwards. When state senator M. Z. White of Mingo County threw his support to a third candidate, the honor was handed to Nathan Goff. ${ }^{60}$ Hatfield rewarded White by appointing him warden of the state penitentiary. ${ }^{61}$ When Hatfield and the legislature selected Nathan Goff to be the new senator, Mann withdrew to southern West Virginia and nursed his resentment against Hatfield, whom many felt had betrayed his old political benefactor. ${ }^{62}$

Edwards, however, met with Kanawha county prosecutor T. C. Townsend and Guy Bittinger, a representative of the Burns Detective Agency. In late January and early February, Townsend and Bittinger arranged a sting operation to catch several West Virginia legislators in the act of selling their votes for United States senator. Ultimately five state legislators, including

\footnotetext{
${ }^{59}$ Tams interview, 24, WVRHC.

${ }^{60}$ Penn, 320.

${ }^{61}$ Williamson Daily News, 25 June 1914.

${ }^{62}$ Penn, 247.
} 
S. U. G. Rhodes of Mingo County were convicted and sentenced to the state penitentiary for terms of five to six years. ${ }^{63}$

Hatfield's failure to support the senatorial aspirations of Mann, his former patron, proved to be only the opening salvo of the governor's assault on the state's industrial leadership. Throughout his administration Hatfield publicly represented himself as a defender and spokesman of the people against the corrupting influence of the large corporations, including the coal elite of his own region of the state ${ }^{64}$ Although most of the legislation passed over their objections lacked the enforcement clauses necessary to actually affect corporate primacy in the state, many of southern West Virginia's coal men took what might have been only demagogic posturing seriously ${ }^{65}$ William D. Ord, superintendent of the Red Jacket Consolidated Coal \& Coke Company in Mingo County wrote of Hatfield's behavior to Judge John W. Mason, "Hatfield's personal and political ambitions have become so great that he has ... turned his back upon some of his friends, especially those in the coal industry, and has ... actually 'arrayed' the

${ }^{63}$ Mingo Republican, 8 August 1913. The other legislators were: Rath Duff of Jackson County, Dr. H. F. Asbury of Putnam County, Dr. B. A. Smith of Roane County and Davie Hill of Mason County. In the fall of 1913, Rhodes' teenaged son, who became depressed because of the scandal, committed suicide; Governor Hatfield intervened so that Rhodes could attend the funeral. Mingo Republican, 3 October 1913. Rhodes, who claimed that he and the other indicted legislators were the victims of a retaliatory sting operation, never admitted his guilt. After being pardoned by Hatfield, he even sued former Sheriff Hill for the return of the twenty thousand dollars that had been seized when the legislators were arrested. Mingo Republican, 29 July 1915 and Williamson Daily News, 2 February 1918.

${ }^{64}$ See the discussion of Hatfield's role in the 1916 Republican primary race between A. A. Lilly and Ira E. Robinson.

${ }^{65}$ One reason for the questioning of Hatfield's true allegiance was the marriage of his only child to an heir of a U.S. Steel magnate. 
masses against the classes. ${ }^{166}$ The final straw for the industrial powerbrokers came when Hatfield chose former State Supreme Court Judge Ira Robinson to succeed him as the 1916 Republican nominee for governor.

There were at least two reasons for the Republicans' defiance of the governor. In 1913, during the Paint and Cabin Creek strike, Judge Robinson had broken with the court to criticize the use of martial law restrictions against the miners. ${ }^{67}$ T. E. Houston, president of Thacker Coal \& Coke Company, and many other anti-union operators of southern West Virginia, viewed Robinson as a pro-labor traitor to the party and organized "a fight against the Hatfield gang" who was Robinson's main support. ${ }^{68}$ Amid such discontent, Isaac T. Mann and Davis Elkins, the disappointed candidates from the 1913 bribery scandal, allegedly forged an alliance to defeat Hatfield.$^{69}$ The anti-Hatfield forces chose Secretary of State, A. A. "Abe" Lilly of Raleigh County to challenge Judge Robinson for the Republican gubernatorial nomination. ${ }^{70}$

\footnotetext{
${ }^{66}$ William D. Ord to John W. Mason, 7 June 1915, quoted in Penn, 423. According to Hatfield's daughter, Ord had been one of the first people to whom Hatfield had confided his desire to be governor. Karr, 50 .

${ }^{67}$ Mingo Republican, 26 October 1916.

${ }^{68}$ Justus Collins to J. . Holloway 3 May 1916, quoted in Penn, 453-454. T. E. Houston was one of the leading "coal men" of southern West Virginia.

${ }^{69}$ Williamson Daily News, 22 January 1915. In July 1915, the Mingo Republican, a proHatfield Republican newspaper repeated the charge of the existence of a Mann-Elkins coalition. Mingo Republican, 29 July 1915.

${ }^{70}$ Mingo Republican, 9 March 1916, and 1 June 1916. Both James A. Hughes and Z. T. Vinson, two southern West Virginia Republicans with ties to Mingo County Democratic boss Wallace J. Williamson, backed Lilly. Hughes, who had been publicly humiliated by revelations concerning Hatfield election tactics during the Congressional hearings into his 1910 reelection victory, served as Lilly's campaign manager. Lilly's given name: "Armistead Abraham Lilly," West Virginia Heritage Encyclopedia vol. 13:2795-2796. However, in contemporary documents
} 
The severity of the discord among the Republicans divided the party in Hatfield's home county during the 1916 Robinson-Lilly primary race. The splinter was so pronounced the Democrats knew of it as early as the first week of January, 1916. "City Ring" member S. D. Stokes observed in correspondence, "the local Republicans . . . are into a very bitter fight among themselves. ${ }^{171}$ The Mingo Republicans faced a terrible dilemma. The Hatfield brothers, though still powerful, were estranged from the business wing of the party. On the other hand, the coal operators' candidate Abe Lilly had publicly opined that the Williamson charter bill should be overturned, an act that threatened to return the Democratic "City Ring" to power in Williamson. ${ }^{72}$

When Governor Hatfield and Ira Robinson stopped at Matewan and Red Jacket during their campaign tour of southern West Virginia, Henry D. Hatfield could no longer ignore the hostility his actions had caused. On May 27, 1916, Matewan received its "hometown" boy bedecked in pictures of Abe Lilly. When Hatfield found a large Lilly banner displayed in the lobby of the Urias Hotel he refused to eat there and ate at a lunch counter on the street. As the local Democratic paper the Williamson Daily News observed, when Hatfield spoke to a crowd of "pistol-toting deputies and 30 negroes," his famous temper erupted. He "denounced ... Lilly as an unworthy degenerate ... [attacked] William D. Ord and boasted that no coal operator could control [him]." Hatfield also vilified Matewan for insulting him by displaying Lilly's picture. ${ }^{73}$

and newspapers Lilly was always referred to as A. A. or "Abe" Lilly.

${ }^{71}$ S.D. Stokes to John W. Davis, 7 July 1916, Stokes Papers, WVRHC.

${ }^{72}$ Mingo Republican, 30 December 1915.

${ }^{73}$ Williamson Daily News, 27 May 1916. The manager of the Urias Hotel in 1916 was S.T. Lambert, who had been superintendent of several coal companies in the area since the turn of the century. Ord was the general manager of Red Jacket Consolidated Coal \& Coke Company. 
The atmosphere proved no better for Hatfield at Red Jacket. Although he spoke at the carnival grounds, the crowd was small. Young men in automobiles drove back and forth on the road opposite the gathering and with "jesting and singing so disturbed the governor that he had to pause in his remarks." The open hostility at Matewan and Red Jacket so disconcerted Robinson, he refused to disembark at Williamson. The Daily News hypothesized that Governor Hatfield's behavior "made . . . many bitter enemies" for candidate Robinson. ${ }^{74}$

Despite Mingo's unenthusiastic welcome for Hatfield and Robinson, the HatfieldRobinson ticket defeated the Damron-Lilly faction in Mingo's primary. Hatfield-Robinson candidates for local and state offices won with majorities of 600 to 1,100 votes. In McDowell County, the Hatfield-Robinson faction also triumphed in the primary, but the two counties were out of step with southern West Virginia's Republican majority. Lilly carried southern West Virginia's other Republican counties that were not Hatfield machine dominated. ${ }^{75}$

The primary campaign remained hotly contested until the very end. On primary election day, June 7, at Winding Gulf in Raleigh County, racial strife erupted after an African-American man "knocked" a white man "senseless." When the African American and the man who had come to his aid were arrested, an armed mob freed them and in the process killed a white police officer. Bad weather complicated efforts to arrest participants, but it also helped prevent acts of retaliatory white violence. Although Hatfield was in Chicago attending the national Republican convention, local coal officials, George Wolfe and Justus Collins placed the blame for the

\footnotetext{
${ }^{74}$ Ibid.

${ }^{75}$ Mingo Republican, 8 June 1916. Lilly carried: ercer, Wyoming, Summers and Raleigh.
} 
incident squarely on his shoulders. Wolfe observed to Collins, "the Robinson-Lilly race for the nomination for Governor has seriously affected some of the colored people . . you cannot send for a niggar [sic] and sit him down in the executive mansion and plot with him to overthrow the white people without evil results." 76

Although not directly responsible for the Winding Gulf incident, while in Chicago Hatfield further exacerbated the southern West Virginia operators' animus towards him. While engaged in an argument with fellow conventioner and former patron Isaac T. Mann, Hatfield, according to Mann, sucker-punched him after their mutual friends stepped between the two men. Responding to a sympathy letter from Justus Collins, who referred to the Governor as "that ruffian Hatfield," Mann denied being injured seriously and noted that Hatfield retreated quickly, "as all bullies and cowards are inclined to do."77

After Robinson defeated Lilly in the primary, Lilly did not concede defeat until July 27, 1916. ${ }^{78}$ Although their hand-picked candidate lost, West Virginia's Republican coal operators simply regrouped and vis-a-vis the West Virginia Coal Operators' Association swung their financial support to Democratic gubernatorial candidate John J. Cornwell. ${ }^{79}$ Historically this move has been ascribed to the operators' desire to have a man who was on their side in the

\footnotetext{
${ }^{76}$ George C. Wolfe to Justus Collins, 7 June 1916, Collins Papers, WVRHC.

${ }^{77}$ Justus Collins to I.T. Mann and Mann to Collins, 9 June 1916 and 12 June 1916, Collins Papers, WVRHC.

${ }^{78}$ Mingo Republican, 27 July 1916 and Williamson Daily News, 3 August 1916.

${ }^{79}$ Penn, 463.
} 
governor's office ${ }^{80}$ However, a letter from Williamson Democrat S. D. Stokes to U.S. Solicitor General and West Virginia native John W. Davis, adds new dimension to the operators' actions. As Stokes informed Davis, the friends of General Lilly turned to Cornwell, the Democrat, because they believed that "to ever get as much as a 'toe-hold' in the halls of the G.O.P. they will have to defeat the Hatfield crowd ... for they will never receive quarter at the hands of the Hatfields. ${ }^{81}$ The operators hoped Robinson's defeat would loosen Hatfield's stranglehold on southern West Virginia's Republican organization.

1916 temporarily brought an end to the era of the Hatfield brothers' rule of West Virginia and Mingo County. ${ }^{82}$ Governor Hatfield's autocratic leadership of the party and defiance of the state's industrial elite bolstered the Democratic party's initiative to regain control of the political arena. Sheriff Greenway Hatfield's flagrant subversion of democratic processes in Mingo not only renewed the county's infamy, it also advanced Democratic attempts to return to power at the local level. To understand why the decline of the Hatfields was so instrumental to the "Democracy's" resurgence, one must examine what had kept the Democrats from challenging the Hatfields' dominion before 1916.

II. The Faction Wars of Mingo's Democrats, 1912-1916:

The Democratic Party in West Virginia had always been a coalition party that since the

${ }^{80}$ Ibid.

${ }^{81}$ S. D. Stokes to John W. Davis, 7 July 1916, Stokes Papers, WVRHC.

${ }^{82}$ Henry D. Hatfield later served as U.S. Senator and Greenway served again as sheriff of Mingo. West Virginia Bluebooks, 1928-1936. 
dark days of the early 1890s had been unable to regain control of the state government from the Republicans, who had forged a "party-army" under the guidance of Nathan Goff and Stephen B. Elkins. ${ }^{83}$ Divided between Bryanites and competing industrial powerbrokers, the Democrats' party leaders consistently failed to capitalize on the increasing success of Democratic candidates for state legislative seats. ${ }^{84}$ However, the death of Stephen B. Elkins three days into the 1911 legislative session presented the Democrats with a unique opportunity. In control of the House of Delegates, the Democrats used the even split in the number of state senators to force the selection of two Democrats for West Virginia's United States' Senators. ${ }^{85}$ Seeking unity, the Democrats appointed the party's most contentious faction leaders, Clarence W. Watson of Fairmont and William E. Chilton of Charleston. Because they both aligned with the pro-industrial wing of the the party, Chilton and Watson formed a united front to defeat the liberal faction of the party. ${ }^{86}$ However, as illustrated by the faction wars of the Democrats in Mingo County between 1912 and 1914, the loyal subordinates of Chilton and Watson continued to struggle among themselves long after the two principals found comon ground.

The Mingo Democrats' alliance with state level Democratic leaders was first revealed

\footnotetext{
${ }^{83}$ For a discussion of the differences between the two parties see Williams, The Captains of Industry. The phrase "party-army" is borrowed from McKinney's Southern Mountain Republicans.

${ }^{84}$ Rice and Brown, 214.

${ }^{85}$ Ibid. In an attempt to evade the Democratic demands, several Republican senators were "kidnapped," for several days, which forestalled opening the 1911 legislative session.

${ }^{86}$ William P. Turner, "From Bourbon to Liberal: The Life and Times of John T. McGraw, 1856-1920," (Ph.D. diss., West Virginia University, 1960), 249. The Chilton-Watson coalition focused their energy against John T. McGraw. One of McGraw's lieutenants, John J. Cornwell, later abandoned his mentor in order to gain a second chance at the gubernatorial candidacy.
} 
during the 1912 election. ${ }^{87}$ In that campaign the Mingo Republican accused the Williamson Democratic ring of having at the last minute, "adopted underhand tactics in the interest of Boss Watson," for which they were rewarded with cash. "Boss Watson" is a reference to the same faction-leader and coal operator and United States Senator Clarence Watson of Fairmont, West Virginia. However, the Republicans never raised any specific reason or issue that linked the Mingo County Democratic party with Senator Watson, they only implied that the Democrats had taken Watson's money, and therefore, had become his hirelings. ${ }^{88}$

Two years later, the 1914 campaign exposed the local significance of the Mingo

Democratic alliance with Senator Watson. At a meeting of the Mingo County Democratic Executive Committee in the spring of 1914, G. T. Blankenship of Matewan stepped down from his position on the committee. During the debate that followed, a faction led by Wallace J. Williamson "forced" Executive Committee chairman W. N. Cole to resign and voted to replace him with Williamson. Known locally as "the Old War Horse," Wallace J. Williamson was the leader of the Williamson Democrats, pejoratively known as the "City Ring." 89

The local Democratic newspaper, the Williamson Daily News, asserted that Cole had

\footnotetext{
${ }^{87}$ One reason for the lack of information on the Democratic party in Mingo County is the virtual absence of newspapers prior to 1911 (there are only scattered issues from June 1908) and the lack of manuscript collection materials from a Mingo County Democrat that cover the early period from 1895-1912.

${ }^{88}$ Mingo Republican, 1 November 1912.

${ }^{89}$ Mingo Republican, 21 May 1914. It is likely that W. N. Cole, the ousted Democratic Chairman was the same Cole who had started the Mattie May mine in 1905. If so, the ColeWilliamson power struggles takes on a new dimension, as "Martha May" was the daughter of former Democratic sheriff, Ali Hatfield. (See discussion of the Hatfield v. Allison case in Chapter 5).
} 
resigned for the good of the party and that control of the party had been returned to Wallace J. Williamson. ${ }^{90}$ The Republican newspaper, the Mingo Republican, revealed the deeper cause of the coup. There were two factions in the Democratic party, one that consisted of the politicians and professionals of Williamson's "City Ring," and the other comprised of "Democrats from the rural districts." ${ }^{91}$ The rural, or "County" Democrats did not have a hierarchical organization like the "City Ring." The group generally coalesced around now former Chairman Cole and "the Chambers boys" of Matewan. ${ }^{92}$ Moreover, Cole and the "County" Democrats aligned with Senator W. E. Chilton of Kanawha County. ${ }^{93}$ Table 8 reveals the leadership of the Democrat Party factions in Mingo County.

Table 8:

Democratic Factions in Mingo County, 1912-1916

\begin{tabular}{|c|c|}
\hline $\begin{array}{l}\text { "Rural" or "County" Democrats } \\
\text { (pro-Chilton) }\end{array}$ & $\begin{array}{c}\text { "City Ring" } \\
\text { (pro-Watson) }\end{array}$ \\
\hline Leader: W. N. Cole & Leader: Wallace J. Williamson \\
\hline $\begin{array}{l}\text { E. B. Chambers } \\
\text { (and family) }\end{array}$ & G. R. C. Wiles \\
\hline G. T. Blankenship & A. C. Pinson \\
\hline Dr. R. G. White & W. A. Hurst \\
\hline J. H. Green & S. D. Stokes \\
\hline \multicolumn{2}{|l|}{ W. F. Hutchinson } \\
\hline Boyd Adkins & \\
\hline
\end{tabular}

Source: Mingo Republican, 21 May 1914, and 6 August 1914.

\footnotetext{
${ }^{90}$ Williamson Daily News, May 1914.

${ }^{91}$ Mingo Republican, 21 May 1914.

${ }^{92}$ Ibid.

${ }^{93}$ Ibid.
} 
Ironically, the fighting between the Watson and Chilton factions in Mingo was more virulent and lasted longer than the disagreement between the two principals. ${ }^{94}$ What angered the "County" Democrats most was the "City Ring's" maintenance of power through corruption and bribery, despite being the numerically smaller faction. Before the 1914 Executive Committee meeting, Williamson Mayor A. C. Pinson made several "mysterious" trips through the county. ${ }^{95}$ When the committee convened, Williamson regained power over the party organization in Mingo after the defection of the Lee, Harvey, and Warfield districts' representatives. ${ }^{96}$ Particularly galling was the betrayal of Warfield district Executive Committee member W. T. Meade, who had been appointed postmaster at Kermit as a reward for his loyalty to Chairman Cole and Senator Chilton. ${ }^{97}$

Their loss of control over Mingo's Democratic organization angered some of the "County" Democrats so much that they, "almost to a man ... went home breathing fire." On their way home from the meeting the divided Lee district delegation actually came to blows in what the Mingo Republican gleefully referred to as "The Battle of Lick Mountain." Cole-Chilton loyalist Boyd Adkins accused L. V. S. Curry of "selling out the Pigeon Creek Democrats" to Boss Williamson. When Curry countercharged that Adkins was a "liar," Curry, Adkins, and Rush Floyd, the other member of the delegation, wound up in a three man fistfight. Apparently Adkins

\footnotetext{
${ }^{94}$ Penn, 150-152. By 1916 Watson and Chilton had joined forces against John T. McGraw. For more on the Chilton-Watson v. McGraw situation see: Turner, "From Bourbon to Liberal: The Life and Times of John T. McGraw, 1856-1920."

${ }^{95}$ Mingo Republican, 21 May 1914.

${ }^{96}$ Ibid.

${ }^{97}$ Ibid.
} 
won because Curry and Floyd "left the field with bloody faces." 98

Despite being in control of the municipal government of the county seat and the County Executive Committee, Wallace J. Williamson spent most of the summer of 1914 mending fences. Chairman Williamson "[handed] out ... minor offices as sop to the opposition" but ultimately achieved only moderate success. A primary reason for Williamson's limited achievement was his own short-sightedness. His ability to award patronage plums to the opposition only reached so far. For example Wayne Curry, who had been a candidate for superintendent of Magnolia district schools, was dropped from the ticket because Chairman Williamson learned that he had married into the Chafin family and he would not stand for Curry to be nominated. ${ }^{99}$ Riley Varney, whose blood and marriage ties did not repulse the "Old War Horse," replaced Curry. Williamson's limited peace-offering ultimately failed to mend all the rents in the Democratic organization. As summer faded into fall, the old Williamson-Matewan rivalry resurfaced. ${ }^{100}$

In an anonymous letter published in the Mingo Republican, a "Matewan Democrat" listed both the past and current grievances held by the Matewan and "County" Democrats against the Williamson gang. According to the letter's author, previous elections had been lost because of

${ }^{98}$ Ibid.

${ }^{99}$ Mingo Republican, 6 August 1914. Despite many historians' assertions that the industrialization of southern West Virginia eradicated traditional kinship politics, the alignments and re-alignments of both parties in Mingo County was ascribed by contemporary observers as kinship influenced. For example, one of the Lee District Cole-Chilton defectors, Rush Floyd, and G. R. C. Wiles, a member of "Boss" Williamson's "City Ring" were first cousins, their father and mother respectively were children of George Rogers Clark (G.R.C.) Floyd. On the Republican side, Greenway Hatfield shared control of the county party with his brother-in-law M. Z. White.

${ }^{100}$ Williamson and Matewan had been rivals since 1895 when Williamson narrowly defeated Matewan in the special election to select Mingo's county seat. See Chapter 3 for details. 
betrayals by members of the "City Ring." In 1908, W. A. Hurst had "played into the hands of the Republicans to get the office of sheriff," while A. C. Pinson had "surrendered the Democratic nomination for county clerk ... too late to name another candidate." Despite the earlier betrayals of these "City Ring" Democrats, Boss Williamson trusted them over loyal Democrats elsewhere in the county. Now, in 1914, the "Matewan Democrat" noted, "it must be that all the Democrats of our village have been read out of the party. ... at least none could be found within our gates worthy of being registrar." Rather than select a Matewan Democrat to work the precinct polling, The "Old War Horse" sent Williamson lawyer and party hack Alex Bishop to Matewan to serve as registrar. Within a week bribery charges were leveled against Bishop. ${ }^{101}$

On the eve of the 1914 election, the "County" Democrats of Mingo executed their most defiant act, but, also allowed for a minor rapprochement with the Williamson "City Ring." Ousted county chairman W. N. Cole organized a campaign event and invited Senator Chilton to speak. Although the Mingo Republican declared that "Postmaster Cole Showed The Big Boss Who People Regard as Real Democratic Leader," the "County" Democrats extended an olive branch to the "City Ring," allowing Boss Williamson to name the person who introduced Chilton. Of course Williamson picked one of his own followers, S. D. Stokes. ${ }^{102}$

The Democrats' internal discord during the 1914 campaign had forced Boss Williamson and the "City Ring" to confront the realities of county politics. The Matewan Democrats remained bitterly opposed to Williamson's leadership, and claimed that in order to obtain a victory "the ringsters" would have to depend on "disgruntled Republicans and those who may be

\footnotetext{
${ }^{101}$ Mingo Republican, 15 October 1914, and 22 October 1914.

${ }^{102}$ Mingo Republican, 29 October 1914.
} 
enticed off by the Progressives." ${ }^{103}$ The single largest group of voters was the county's coal miners who lived primarily in two districts: Lee, which had Williamson as its heart, and Magnolia, whose center was Matewan. ${ }^{104}$ The "City Ring" had controlled Democrat dominated Lee district since the defection of L. V. S. Curry in the spring, but Matewan and the votes of the miners of Magnolia district traditionally belonged to the Republicans. ${ }^{105}$

Despite the Democrats' desperate accusations and mercenary appeals, the Republicans again swept the Mingo County election in 1914. Republicans were elected state senator, delegate, county school superintendent, county commissioner, county court clerk and circuit court clerk. ${ }^{106}$ Two years later, a report that "two armed and masked men entered the little school house which served as a polling place" for Rockhouse precinct and stole the ballot box, sparked a political and legal scandal that lasted until $1918 .{ }^{107}$ All of the accused men were Republicans, including county chairman Greenway Hatfield. Although tried in Federal Court, their prosecutors were southern West Virginia Democrats, one of whom, D. E. French was a personal enemy of Governor Henry D. Hatfield. ${ }^{108}$ The resuscitation of the 1914 election fraud cases

${ }^{103}$ Mingo Republican, 15 October 1914.

${ }^{104}$ Mingo Republican, 17 March 1911.

${ }^{105}$ Mingo Republican, 21 May 1914.

${ }^{106}$ Williamson Daily News, 12 November 1914.

${ }^{107}$ McDowell Recorder, 24 May 1918.

${ }^{108}$ Mingo Republican, 14 September 1916. Reprint of editorial from the Huntington Herald Dispatch. Two separate election fraud cases from Mingo reached Federal District court between 1916 and 1918. The "Rockhouse Case" as it came to be known was tried three times by Democrats Lon H. Kelly, district attorney for the southern district of West Virginia and West Virginia legislator D. E. French, one of Governor Henry D. Hatfield's most vociferous opponents. 
stemmed from two critical political developments: the revocation of Williamson's city charter in 1915 and the bitter partisanship of the local, state, and federal general election campaign of 1916.

As detailed previously, the "City Ring" lost control of Williamson's city government in 1915. Unable to recapture their position until the next municipal election in 1917, Boss Williamson's machine lost ground to the "County" Democrats led by the Chambers' family of Matewan. In the interim, two developments affected the "City Ring's" efforts to maintain a viable force in county politics. As discussed earlier, southern West Virginia's Republican elite openly broke with Governor Hatfield in the spring of 1916 over the issue of who would get the Republican nomination for governor. Anxious to capitalize on the Republican schism, southern West Virginia Democrats embraced the dissidents in the spring and summer of 1916.

In Mingo County, evidence of the collusion between Democrats and anti-Hatfield Republicans emerges from the pages of the Williamson Daily News. The paper aggressively sought to undermine support for the Hatfield faction by providing a forum for attacks on Henry D. and Greenway Hatfield's policies and manipulation of the electoral process. The Daily News published details on the internal strife within the opposing party on "the Republican Page" and in a column titled "Matewan News." 109

One prominent Mingo County anti-Hatfield Republican was Hatfield cousin and Mingo County Circuit Court Judge James Damron. In 1916, Damron declared that his primary objective

The animosity between Hatfield and the race-baiting French was so strong, it held up the convening of the 1915 legislative session because the Democrats insisted that French be selected as president of the state senate.

${ }^{109}$ Williamson Daily News, 2 June 1916. The "Matewan News" column was written by Toney Webb, at the time a Republican, who after Matewan Democrat G.T. Blankenship was elected sheriff in 1916, became a Democrat and one of Blankenship's deputies. 
was to clean up the voter registration rolls by "striking from the list . . . illegal voters, dead men, mules and tombstones." Damron's other goal was to stop "Bob Simpkins from stuffing . . ballot boxes," a direct reference to the irregularities in the 1914 election allegedly orchestrated by his Hatfield cousins. Greenway Hatfield and Wells Goodykoontz dismissed Damron's attempts to "clean" the voter registration rolls by claiming that by Damron's method "peace will be converted into riot and chaos will take the place of law and order." Greenway Hatfield's prediction of violence did not dissuade Damron. The State Supreme Court granted Damron a peremptory writ, but nothing else was heard of the issue until May 17, 1920, when clarification of Mingo's voter registration rolls resurfaced. ${ }^{110}$

Two articles the Williamson Daily News disclosed the local reasons for the Republican defection in Mingo in 1916. Yet again, the complaints also reveal how traditional mountain political tactics had survived into the industrial era. On June 2, the Daily News asserted that Greenway Hatfield had appointed "pardoned criminals and deputy sheriffs ... to conduct the primary elections." The News also rhetorically asked "how many brothers, cousins, uncles, and sons-in-law of candidates were appointed on the election board?"111 In case anyone questioned the veracity of its accusations, on June 5, the Williamson Daily News published the names and "offenses" of the precinct election officers appointed by Greenway Hatfield. The following table, while omitting the names of the officers, except one, presents the nature and scope of Hatfield's network.

${ }^{110}$ Williamson Daily News, 2 June 1916. On May 18, 1920, the day before the Massacre, the State Supreme Court squelched an effort to clarify Mingo's voter registration rolls before the primary. See Chapter 10.

${ }^{111}$ Ibid. 
Table 9:

1916 Republican Primary Election Precinct Officers Appointed by Greenway Hatfield

\begin{tabular}{|c|c|}
\hline Precinct & $\begin{array}{l}\text { Offenses and/or Familial or Employment Connections of } \\
\text { Republican Primary Precinct Officers and Greenway Hatfield }\end{array}$ \\
\hline Dingess & $\begin{array}{l}\text { 1- indicted for graft of school bonds } \\
1 \text { - ex-convict and deputy sheriff }\end{array}$ \\
\hline Dempsey & 1- indicted 4 cases of graft of road funds, deputy sheriff \\
\hline Naugatuck & 2- deputy sheriffs \\
\hline Rockhouse & $\begin{array}{l}\text { 1- pardoned criminal, county "sealer of weights" } \\
\text { 1- father is candidate for assessor }\end{array}$ \\
\hline East Williamson & $\begin{array}{l}\text { 1- brother is house of delegates candidate } \\
1 \text { - brother-in-law is candidate for sheriff }\end{array}$ \\
\hline West Williamson & $\begin{array}{l}\text { 1- deputy sheriff and county road engineer } \\
1 \text { - deputy sheriff and prohibition officer }\end{array}$ \\
\hline Upper Red Jacket & 3- all deputy sheriffs and Hatfields or Hatfield in-laws \\
\hline $\begin{array}{l}\text { Lower Red Jacket } \\
\text { (Matewan) }\end{array}$ & $\begin{array}{l}\text { 2- both deputy sheriffs and had been charged with padding the } \\
\text { voting rolls with } 117 \text { names, pardoned by Governor Hatfield }\end{array}$ \\
\hline Magnolia & $\begin{array}{l}\text { 1- notorious for selling whiskey } \\
\text { 1- Hatfield first cousin and deputy sheriff }\end{array}$ \\
\hline Thacker & $\begin{array}{l}\text { 2- not residents of West Virginia, work for coal company of J. } \\
\text { K. Anderson who was appointed to Public Service } \\
\text { Commission by Governor Hatfield }\end{array}$ \\
\hline Lick Fork & $\begin{array}{l}\text { 1- pardoned convict } \\
\text { 1- deputy sheriff } \\
1 \text { - not resident of precinct-- "imported" }\end{array}$ \\
\hline Devon & $\begin{array}{l}\text { 2- deputy sheriffs and first cousins of R. L. "Bob" Simpkins } \\
\text { who was also a cousin of Henry D. and Greenway Hatfield }\end{array}$ \\
\hline Varney & 2- son and foster son of deputy sheriff \\
\hline Glenalum & 1- pardoned criminal \\
\hline War Eagle & Bob Simpkins (defendant in the 1914 election fraud case) \\
\hline
\end{tabular}

Source: Williamson Daily News, 2 June 1916.

As the table illustrates, all of the 1916 Republican precinct officers were Hatfield relatives, owed their freedom from jail to the Hatfields, or relied on serving Sheriff Hatfield for their income. 
The charges of the Hatfields' corruption attracted national attention. According to Toney Webb, the correspondent-author of the "Matewan News," "the citizens of Matewan have borne the brunt of political dishonesty until we are being looked upon by citizens elsewhere as possessing horns like a rhinoceros and ... with bristles on our backs like the wild boars of Africa." Webb's fears regarding the impression held of Matewan and Mingo County by outsiders were inspired by the comments of a federal official who had been sent to investigate election conditions in Mingo County. Described by the Daily News only as "a man high up in the secret service of the United States government," the officer observed to the newspaper's correspondent "that Mingo County was the most corrupt politically of any county in the country."112

The federal investigator sent to Mingo was only one member of an entire contingent that reportedly scoured southern West Virginia in the summer of 1916, searching for evidence of election fraud. Charges were filed against Republican politicians in McDowell and Mingo Counties, including Colonel Edward O'Toole of the U.S. Steel coal mines (McDowell) and Sheriff Greenway Hatfield (Mingo). ${ }^{113}$ The Federal government dropped charges against Colonel O'Toole, but prosecuted the Mingo politicians in two separate cases, referred to as the "War Eagle case" and the "Rockhouse case" after the precincts where fraud was allegedly committed. ${ }^{114}$ Before the cases went to court, Mingo County's newspapers fought over why charges were brought against several of the county's Republicans. The Williamson Daily News claimed

\footnotetext{
${ }^{112}$ Williamson Daily News, 5 June 1916.

${ }^{113}$ Williamson Daily News, 2 November 1916.

${ }^{114}$ Mingo Republican, 12 April 1917.
} 
that it was to stop "Wholesale Election Rascality."115 The Mingo Republican reprinted an editorial from the Huntington Herald Dispatch which stated that "the sole aim" of these cases was "to injure the Republican party and incidentally those leaders in the forefront of the fight against the Chilton-Watson wing of the Democracy." ${ }^{116}$ The Dispatch offered six reasons why it believed that the cases were politically motivated. The two most important reasons were that the federal officials "only investigated alleged Republican fraud cases" and "the employment of a partisan Democratic lawyer and office seeker as special prosecutor shows that the Federal political machine was not above handing a sop to a faithful ally who had sought much and received little."117 Despite the outcry of southern West Virginia's Republicans both the War Eagle and the Rockhouse proceeded in the fall of $1916 .^{118}$

The United States v. R. L. Simpkins, et al case, also known as the War Eagle case,

${ }^{115}$ Williamson Daily News, 5 June 1916.

${ }^{116}$ Mingo Republican, 14 September 1916.

${ }^{117}$ Ibid. In the same issue, an item written by J. Jerome Haddox and first printed in the Lincoln Republican describes a 1914 election abuse committed by Democrats at Sharples precinct in Logan County. According to Haddox, a Democratic election commissioner went to Sharples, gathered all the election materials, destroyed them and "announced there would be no election at Sharples." A grand jury indicted the commissioner, but prosecuting attorney Democrat John Chafin "nolled the indictment." Logan County Republican state senator E.T. England's request for a Federal probe was denied by the U.S. district attorney.

${ }^{118}$ Mingo Republican, 15 June 1916. The investigation began just before the primary and warrants had been issued for several Republican who were scheduled to serve as election officers. According to the Mingo Republican, only the United States Marshal's refusal to become "the tool of the politicians" kept the warrants from being processed on the eve of the primary election. 
convened in federal district court in Huntington in late September $1916 .{ }^{119}$ The prosecution presented a strong circumstantial case against the Mingo Republicans. A string of witnesses revealed how the Hatfield machine bribed, bullied, and carelessly exhibited its power during elections.

According to witnesses Ira Kline, Elihu Boggs, and William Damron, the Hatfields were masters in the art of bribery. Kline testified that Hatfield cousin R. L. "Bob" Simpkins had tried to lure him into the 1914 election scheme with a promise of future employment. Kline stated that "Simpkins told him he was going to organize War Eagle for the unions, and that he was figuring on him for an officer." Elihu Boggs, a coal miner who had been elected clerk of the county court on the Republican ticket, revealed the price of Hatfield patronage. During "several conversations with Greenway Hatfield," Boggs was told he would have to contribute a thousand dollars to the campaign. Along with William Damron, his assistant clerk who contributed half of the money, Boggs delivered the money to Hatfield. That Boggs did not elaborate further about the exchange with Hatfield revealed the depth of the machine's power -- Greenway Hatfield demanded and was obeyed. Damron later illustrated Greenway Hatfield's faith in bribery. Both Damron and Boggs had received reports that Simpkins had "defected." According to Damron, Hatfield dismissed their report, informing them that he had "offered Simpkins a \$50 a month job."120

\footnotetext{
${ }^{119}$ Mingo Republican, 28 September 1916. (reprint from Huntington Herald Dispatch) The prosecutors included: District Attorney W. G. Barnhart, his assistant Lon J. Kelly, and special prosecutor State Senator D.E. French. The defense team consisted of: Lace Marcum of Marcum \& Sheperd (Sheppard), John S. Marcum of Marcum \& Marcum and Judge John H. Holt of Holt, Duncan \& Holt.

${ }^{120}$ Mingo Republican, 28 September 1916 (reprint of article that first appeared in the Huntington Herald-Dispatch).
} 
The state's star witnesses were two former defendants who pleaded guilty and despite having no plea agreement, testified for the prosecution. Noah Lester and Linko Blankenship described how they secured the War Eagle returns for the Republican candidates. First, Lester and Blankenship served as the precinct's Democratic election officers instead of the regularly appointed officers. When the polls closed, the ballots were removed from the boxes and all but eleven of the Democratic ballots were burned. Only a total of sixty-five votes had been cast, but replacements were created to make the vote total equal the number of registered voters in the precinct. $^{121}$

Two women teachers provided the final and most extreme example of the Hatfield machine's arrogant display of power. The first teacher, Miss Blanche Depew, "said . . . that Simpkins told her a mule had voted and that this was more than she could do." Miss Gertrude Rader corroborated Depew's story, adding the detail that "the mule had been voted as 'Vicie Coffee."' The prosecution intended the stories of Simpkins' insensitivity and crass treatment of the two women to underscore his base moral character and, by association, implicate the Hatfields as abusers of women. ${ }^{122}$

The trial of the United States v. R. L. Simpkins et al, also known as the War Eagle election fraud case ended on 5 October 1916, after lasting just one week. Judge Woods instructed the jury to find Greenway Hatfield not guilty and after a thirty minute deliberation his

\footnotetext{
${ }^{121}$ Ibid. In the Williamson Daily News, 6 June 1916, it was reported that only 40 out of 157 registered voters actually cast ballots; "the rest ... [were] copied into the poll book in alphabetical order as they appeared upon the registration books."

${ }^{122} \mathrm{Ibid}$. The story of mule and bulldog voting in Mingo County is also corroborated by oral testimony, and in the case of the bulldog, a contemporary newspaper. Williamson Daily News, 8 August 1914.
} 
co-defendants were also exonerated. The defendants had no time to rejoice however, because the court turned immediately to the Rockhouse case and empaneled a jury. The primary defendants in the Rockhouse and War Eagle cases were the same. ${ }^{123}$

As in the War Eagle case, the Rockhouse case focused on the alleged attempt by members of Greenway Hatfield's machine to steal the 1914 election. However, the Rockhouse controversy centered on the actual theft of the precinct's ballot box by two armed and masked men. ${ }^{124}$ The difficulty faced by the prosecution in this case centered on the attempt to expand the case beyond the prosecution of the thieves into a conspiracy trial. Judge Woods' instructions to the jury included a review of election laws and a reminder that "the greatest menace to the purity of election was the power of unlawful combinations to control the voters or nullify their votes." Judge Woods' definition of conspiracy influenced the outcome of the trial, as he explained to the jury, "a combination to persuade men to vote is not a conspiracy, but a combination of two or more persons is a conspiracy if it is formed to intimidate, threaten, oppress or injure one or more in a certain way or not to vote at all." After a day's deliberation, the jury remained deadlocked leaving Judge Woods no option but to declare a mistrial. ${ }^{125}$

In the midst of the War Eagle and Rockhouse cases, attention in Mingo County turned to

${ }^{123}$ Mingo Republican, 5 October 1916.

${ }^{124}$ McDowell Recorder, 24 May 1918.

${ }^{125}$ Mingo Republican, 12 October 1916. The Rockhouse case ended in acquittal on May 21, 1918. McDowell Recorder, 24 May 1918. The lesson of these "conspiracy" cases was ignored when three years later, 24 men were tried "en masse" for the murder of Albert C. Felts on May 19, 1920. According to one juror, the jury acquitted the men because they believed that it was unfair to hold all of the men accountable for the actions of one, Sid Hatfield. S. D. Stokes to S. B. Avis, 22 March 1921, Stokes Papers, WVRHC. 
the progress of the general election campaign. Former governor Wesley Atkinson "opened" Mingo's Republican campaign on October 5, 1916. He made no references to the election fraud cases, and spent most of his time discussing the tariff. ${ }^{126}$ Although the War Eagle and Rockhouse cases did not end in convictions, they upset the Mingo Republicans' equilibrium. Throughout the month of October until the eve of the election, the Republicans maintained a constant barrage aimed at the Democrats, as though they and not the Democrats, were trying to regain control over the county. By contrast the Mingo Democrats confined themselves to their traditional tactic -race-baiting.

The Republicans' focused their attack during the last weeks of the 1916 campaign on the fiscal record of the Williamson "City Ring" Democrats. The Mingo Republican reminded county residents that under Democratic control Williamson residents paid the second highest municipal tax rate in the state. ${ }^{127}$ A reason for the high taxes was the apparent mismanagement of city funds. A street-paving project cost $\$ 100,000$ because streets that needed paving were bricked, subsequently damaged and then resurfaced. ${ }^{128}$ According to the Republicans, the ultimate example of the "City Ring"'s lack of concern for ordinary citizens centered on efforts to build a second bridge for Williamson. The "City Ring" stymied a transaction to build a free bridge to the town because "Boss" Williamson wanted to protect his privately owned toll bridge. ${ }^{129}$

The Republicans also tried to maintain the loyalty of the county's single largest voting

\footnotetext{
${ }^{126}$ Mingo Republican, 5 October 1916.

${ }^{127}$ Mingo Republican, 12 October 1916.

${ }^{128}$ Mingo Republican, 2 November 1916.

${ }^{129}$ Mingo Republican, 12 October 1916.
} 
bloc -- the miners. The Republican asked, "Has any labouring man had an increase in wages in the last year commensurate with the increase in the cost of living?" The newspaper then reminded its readers who was responsible for this state of affairs by pointing out that Armentrout and Wilburn, two Democratic candidates for the county court, were "a successful coal operator and ... an employee of a big coal corporation." ${ }^{130}$ During a public speech in Williamson just days before the election, Governor Hatfield himself made the final plea for the miners' vote. After reading a list of local beneficiaries of the workmen's compensation law, Hatfield pointed out that it was "a measure threatened with destruction if Boss Watson succeeded in electing his man Cornwell."131 The Mingo Democrats' 1916 campaign utilized their traditional racebaiting tactics. ${ }^{132}$ The November 2 issue of the Williamson Daily News contained a story that ostensibly revealed a Republican scheme to blame illegal voter registration at the Lower Red Jacket (Matewan) precinct on the Democrats. Jerry Brown, a "colored" politician of Red Jacket told the Daily News that documents implicating the Democrats and supposedly signed by him, in reality had been prepared by Greenway Hatfield, Dr. H. M. Coleman, and Republican candidate for sheriff Wayne Damron. ${ }^{133}$ Although the Democrats might have hoped to undermine the Republican loyalty of the African-American voters with Mr. Brown's story, the article also served as a reminder to white voters of the Republican manipulation of elections with black voters.

\footnotetext{
${ }^{130}$ Ibid.
}

${ }^{131}$ Mingo Republican, 2 November 1916.

${ }^{132} \mathrm{Ibid}$. As discussed in Chapters 2 and 3, the Democrats resorted to playing the race card freqently, as they had in the 1870, 1890, and 1908 elections. It was a particular favorite of southern West Virginia Democrats in Logan and Mingo counties.

${ }^{133}$ Ibid. 
That whites were the intended audience of the Brown story is underscored by the Daily News' endorsement of G. R. C Wiles, the bigoted Democratic candidate for United States Congress. ${ }^{134}$ Two days after running the Brown story, the Daily News warned its readers, "Vote for George Wiles and Be Safe." 135 The Daily News presented Wiles to those "living in the black belt section of the state" as a leader "against the hoards of outlaws who have brought disgrace upon the southern section of the state." 136

Both the Democrats and Republicans fought to secure the votes of another ethnic group. As the ranking majority party member on the U. S. Senate Judiciary Committee, W. E. "Ned" Chilton loyally squired U. S. Supreme Court Justice candidate Louis Brandeis through the confirmation process, despite Brandeis being Jewish and disliked by most of corporate America. ${ }^{137}$ In addition to playing the loyal party man, Chilton believed his actions might wean West Virginia's Jewish voters away from the Republican party. He sent several copies of the report on the confirmation of Mr. Brandeis to S. D. Stokes of Williamson because "[they] ought to make good campaign documents if gotten into the hands of the prominent Jews of the State."138

It is not known if Democrats anywhere else in the state did Chilton's bidding in regard to

\footnotetext{
${ }^{134}$ During Wiles' 1903 term as State Delegate he proposed a Jim Crow Bill. "G. R. C. Wiles," Williamson Enterprise, 4 June 1908.

${ }^{135}$ Williamson Daily News, 4 November 1916.

${ }^{136}$ Ibid.

${ }^{137}$ Chernow, 149. Dislike of Brandeis stemmed from his activities as a "trust-busting" lawyer.

${ }^{138}$ United States Senator W. E. Chilton to S.D. Stokes, 15 June 1916, Stokes Papers, WVRHC.
} 
making Brandeis' confirmation an election issue, but editorials in the Mingo Republican reveal that the Mingo Democrats tried. Using the words of the Democrats' own gubernatorial candidate, the Republican countered the Democratic effort to win away the Jewish voters with a two prong attack. First, the Republicans asserted that Cornwell and Chilton were diametrically opposed in their attitudes towards President Wilson. While editor of the Hampshire Review Cornwell had described Wilson as "kid-gloved, cold, and selfish to an almost unheard degree" who only received his first presidential nomination by the "treachery" of William Jennings Bryan. ${ }^{139}$ The readers were intended to see that in playing loyal Democrat to President Wilson, Chilton had gone against the opinions of other state party leaders. Second, the Republican quoted an editorial written by Cornwell about a nationally known banking case, to underscore the contradictions in the actions of the state's and the nation's Democratic leaders. Cornwell had written that the government should have allowed the Attorney-Solicitor General, John W. Davis of West Virginia to prosecute the case instead of turning it over to "two muckraking jew lawyers." Despite the no-holds barred effort of the Republicans, the Democrats swept the 1916

\footnotetext{
${ }^{139} 1912$ and 1913 John J. Cornwell editorials from the Hampshire Review, quoted in Mingo Republican, 5 October 1916.

${ }^{140}$ Mingo Republican, 19 October 1916 quoting another Cornwell editorial from the Hampshire Review, 19 May 1915. The other lawyer was Samuel Untermyer. Brandeis had "tutored" Wilson on economics in the summer of 1912. Untermyer had been lead counsel for the Pujo hearings into the concentration of power on Wall Street, whose primary target, J. P. Morgan, died just a few months after his exchange with Untermyer in the hearings. Chernow, 149-155; Untermyer later became the star witness for the UMWA in the 1921 Senate Hearings into conditions in West Virginia's coal fields. "Testimony of Samuel Untermyer," West Virginia Coal Fields, 697-719.
} 
general election in Mingo County. ${ }^{141}$ There were several reasons for the Republican failure.

First, in 1916, the "County" Democrats, not the "City Ring" dominated the slate. ${ }^{142}$ Second, the Republicans had criticized county commission candidates Armentrout and Wilburn for "practically [being] strangers to the citizens of Mingo County." ${ }^{143}$ This had proven to be another ill-fated ploy because the Chambers of Matewan lead the "County" Democrats and they were not only considered locals but had also been linked by marriage to the Hatfields. ${ }^{144}$

In addition to Magnolia and Kermit, Mingo's traditional Republican strongholds, only four precincts remained loyal to the Republicans: War Eagle, Lick Fork, Thacker, and Cinderella, which the Republican attributed to the loyalty of the African-American voters. The domination of the county's other fifteen precincts meant that for the first time in ten years, the Democrats carried Mingo County. There were at least two local reasons for the Democratic victory. The first reason reflected the conduct of the election itself. The election was quiet and wellconducted because "both Democrats and Republicans agreed to post ... guards 'over the ballots boxes.'" 145 The second reason was the political shift personified by the identity of the Democratic nominee for sheriff, G. T. Blankenship.

A native of Jellico, Tennessee, G. T. Blankenship had originally come to Matewan in

\footnotetext{
${ }^{141}$ Williamson Daily News, 8 November 1916. The banner headline read, "MINGO COUNTY REDEEMED AT LAST!"

${ }^{142}$ Mingo Republican, 1 March 1917.

${ }^{143}$ Mingo Republican, 12 October 1916.

${ }^{144}$ See Chapters 3 and 5 for the links between the Hatfield and Chambers' families.

${ }^{145}$ Mingo Republican, 9 November 1916.
} 
1900 as a station agent for the $\mathrm{N} \& \mathrm{~W} .{ }^{146}$ He married Georgia Chambers and joined the merchant elite of Matewan. When his brother-in-law E. B. Chambers started the Matewan National Bank, Blankenship served as vice-president. ${ }^{147}$ Along with his kinsmen by marriage, Blankenship built a reputation as an honest businessman who fought both the Hatfields' Republican machine and forged the alliance of rural district Democrats who fought the Williamson Democrats. In the 1916 sheriff's race, Blankenship did not stress unique campaign issues, in fact, his focus on good roads, lower taxes, and better management of public funds matched, almost exactly, the agenda of Republican county court candidate S. T. Lambert. ${ }^{148}$ Blankenship's campaign promise reveals how he attracted enough votes to defeat Wayne Damron, the Hatfield machine candidate for sheriff. Blankenship vowed that if elected, he would "serve the masses regardless of fear or favor." 149

To voters in Mingo in 1916 Blankenship appeared a nearly ideal candidate. The elites who were tired of the turmoil caused by the Republican and Democratic machines found in Blankenship a reputable "outsider." ${ }^{150} \mathrm{He}$ was not a member of a machine like his opponent and

146“G.T. Blankenship political advertisement,” Williamson Daily News, 8 April 1916.

${ }^{147}$ Information taken from Matewan National Bank letterhead on correspondence dated March 20, 1916, Stokes Papers, WVRHC.

${ }^{148}$ Williamson Daily News, 8 April 1916 (Blankenship); Mingo Republican, 5 June 1916 (Lambert).

${ }^{149}$ Williamson Daily News, 8 April 1916.

${ }^{150}$ Hatfield correspondence, letter no. 27, and Rose Nenni Ore interview with John Hennen, Summer 1989 Matewan Oral History Project. The disdain of many Mingo Countians for politics reflected a common Progressive Era phenomenon. According to urban historians Glaab and Brown, "many Americans" in the Progressive era had become convinced that "politics was ... a dirty game, beneath the concern of respectable people." Glaab and Brown, 208. 
Hatfield cousin Wayne Damron, but his Chambers' wife satisfied the locals for whom kinship connections were still important. Finally, for the working classes, Blankenship was the first candidate for county sheriff who had actually belonged to a union. ${ }^{151}$

The results of the 1916 general election reflect the divergence of Mingo County and state politics. Mingo came under Democratic control. The sheriff and all three county commissioners were now Democrats. ${ }^{152}$ However, except for the governor's office and the house of delegates, all of the state and federal political offices remained in Republican hands. ${ }^{153}$ Republican Edward Cooper defeated Mingo's own G. R. C. Wiles for the fifth district Congressional seat, even though Wiles carried five counties to Cooper's four. ${ }^{154}$ Cornwell defeated Robinson for the governor's office by a slim margin of 2,755 votes. ${ }^{155}$ As Hatfield biographer Neil Shaw Penn succinctly summed the 1916 election, although "the Republicans had lost the domination of the state government ... the Democrats had not acquired it." ${ }^{156}$

To preserve Republican interests and undermine Cornwell's power, Henry D. Hatfield

\footnotetext{
${ }^{151}$ Williamson Daily News, 8 April 1916.

${ }^{152}$ Williamson Daily News, 8 November 1916.
}

${ }^{153}$ Fisher, 274. Republican James Hughes held on to his fifth U.S. Congressional district seat. Republican Howard Sutherland defeated W. E. Chilton for United States senator. Four out of the six Congressional seats were filled by Republicans. Republicans dominated the state senate by ten and completely controlled the board of public works.

${ }^{154} 1919$ Legislative Handbook and Manual of the West Virginia Legislature, 337. Wiles carried: Logan, Mingo, Monroe, Summers and Wayne counties, while Cooper won Lincoln, Wyoming, Mercer and McDowell. Cooper defeated Wiles by less than two thousand votes.

\footnotetext{
${ }^{155}$ Fisher, 274.

${ }^{156}$ Penn, 472.
} 
called the state legislature into extraordinary session and passed several laws, one of which particularly angered the incoming governor. Referred to as the "Ripper bill," Senate Bill \#3 overturned the governor's right to remove elected and appointed state officials. ${ }^{157}$ The passage of this bill in particular protected Hatfield appointees to the Public Service Commission, the State Board of Control and the State Compensation Commissioner. ${ }^{158}$ Despite controlling a newly limited pool of patronage plums, in the winter of 1916-1917 Cornwell was so deluged by requests for positions in his administration, he regretted abandoning his business interests to run for governor. ${ }^{159}$

The period 1912-1919 opened with the Republican party firmly in control of Mingo County and closed with the Democratic party equally as strong. Backed by a powerful political organization, Mingo's native son Henry D. Hatfield led southern West Virginia's Republicans to the center stage of state politics. Hatfield's forceful and autocratic leadership resolved the state's worst labor crisis and shepherded many needed reforms through the state legislature.

Unfortunately his actions and methods galvanized Hatfield's enemies and insured the election of the only Democratic governor between 1896 and 1932. Ironically, Hatfield's successor, John J. Cornwell was, in several respects, not unlike Hatfield. Cornwell also possessed an imperious and domineering personality; those unwilling to be won over were

\footnotetext{
${ }^{157}$ The other bill passed during the extraordinary session of 1916 that angered Democrats was Senate Bill \#4, which changed the rules governing contested elections. Before the passage of this bill contested electionswere submitted to a three man panel consisting of one judge picked by the original winner of the election, the contestee and the governor. After its passage, contested elections would be argued before the West Virginia State Supreme Court of Appeals.

${ }^{158}$ Mingo Republican, 16 November 1916, and 7 December 1916.

${ }^{159}$ Ibid., 275.
} 
subject to destruction not accommodation. Cornwell juggled a similar dual identity -- a corporate supported man of the people. Cornwell also advocated a legislative program that highlighted Progressive reform. However, by the time labor strife reappeared during Cornwell's tenure, the changed times exposed his anti-union, pro-industry loyalty. Unlike Hatfield, who had compelled the two opposing sides to compromise, Cornwell facilitated the defeat of the miners and the near death of their union in the state. ${ }^{160}$

\section{The Republican Decline and the Democratic Ascendance, 1916-1920:}

The 1916 general election heralded the eclipse of the Hatfield Machine and the ascendance of the Matewan Democrats. However, no single faction of either party established absolute primacy over Mingo. Williamson had remained Democratic until the last year of the Hatfields' reign. Between 1916 and the end of 1919, Republican factions in Williamson and Matewan bedeviled the Democrats. Because only one state and national midterm election occurred during the great war period, county and municipal politics dominated the non-war associated local news. Mingo's traditional rivalries and tensions persisted despite the election reforms of the Hatfield administration and calls for wartime unity. Chief among these were the bitter fights between the Republicans and Democrats for control of the county and municipal governments, the factional struggles in both parties, and the turbulent chaos of election day in Matewan.

Between 1917 and 1919, the county level Republican and Democratic rivalry resulted from an intertwined struggle over control of both Williamson's new commission government and

\footnotetext{
${ }^{160}$ Fisher, 263, 269, 272-273, 276.
} 
the county court. The jockeying began in 1916 when John M. Studebaker, one of three Republican city commissioners, broke ranks and joined the Democratic commissioners in their ouster of commission president and mayor O. H. Booten. ${ }^{161}$ Studebaker, the brother-in-law of Judge James Damron, who was a Hatfield kinsman and frequent opponent, helped force Booten from office and ascended to the mayoral seat himself. ${ }^{162}$ The Hatfield machine helped Booten, who had been their chief advocate as editor of the Mingo Republican, save face by engineering his elevation from Williamson's city commission to the county court. County court commissioner F. B. Shannon resigned from the court and replaced Booten on Williamson's city commission, while Booten took his place on the county court. ${ }^{163}$

The Hatfield machine's strategy preserved its influence over Williamson's city government until the first municipal elections under the 1915 charter in July, 1917, but the November 1916 general election broke the Republicans' hold on the county court. The county court defeat proved especially harsh because all three commissioners' seats were at stake. The Democratic court elected in 1916 consisted of: Alex Bishop, a long-standing member of the "City Ring" machine, and two coal company executives, Harry G. Wilburn and L. E. Armentrout, superintendent of the Borderland Coal Company, one of the largest operations in Mingo

\footnotetext{
${ }^{161}$ Mingo Republican, 5 October 1916.
}

${ }^{162}$ Mingo Republican, 6 July 1916. According to the Republican, after being nominated to succeed Booten, Studebaker refused to vote until he realized that he had only the two votes of his Democratic co-conspirators, whereupon "he . . recalled his vote . . . and voted for himself."

${ }^{163}$ Mingo Republican, 5 October 1916. In addition to the Booten-Shannon switch, county commissioner A. H. Moore resigned and J. T. Reynolds replaced him. The Mingo Republican reported that Booten's resignation-appointment was the first move in an effort to restore "harmony" after the bitter Robinson-Lilly primary battle among Mingo's Republicans. 
County. ${ }^{164}$

The new court wasted little time in challenging the Republicans' waning control over the county. Within a month after the election the new court sought to take office early based on their assertion that as elected commissioners their authority superseded the lame-duck Republican commission which by the fall of 1916 consisted of members who had been appointed to fill the seats of the elected members. For the last two months of 1916, both courts held sessions and attempted to govern the county, although the old court was not legally required to disband until January $1,1917 .{ }^{165}$ Two issues impeded compromise between the old and new courts. The old court was still canvassing the votes of three districts and both courts were attempting to appoint county officers. ${ }^{166}$

In addition to sweeping the county court elections, Mingo's Democrats also elected Matewan Democrat G. T. Blankenship county sheriff. These dual victories should have afforded the party virtually unassailable domination over Mingo County. However, the factional rift between Wallace J. Williamson's "City Ring," and the "County" Democrats led by Blankenship and his Chambers' in-laws, resurfaced even before the new court established its authority. ${ }^{167}$ As

\footnotetext{
${ }^{164}$ Mingo Republican, 7 December 1916.

${ }^{165}$ Mingo Republican, 28 December 1916.
}

${ }^{166}$ Ibid. First, the new court tried to remove Dr. A. G. Rutherford from service as Mingo County health officer. In January, both courts appointed men constable of Magnolia District; the old court selected A. L. "Al" Hoskins and the new court chose Harry Chafin. Mingo Republican, 11 January 1917. In 1917, Harry Chafin served as one of Magnolia District's two constables. For the next two years, Chafin and Hoskins served as Magnolia's constables. 1918 Legislative Handbook and Manual of the West Virginia Legislature, 106.

${ }^{167}$ The scarcity of pre-1911 primary sources complicates efforts to trace the internal divisions within Mingo County's Democratic party. It is likely that the rivalry dated as far back as the fight 
"the only out and out Williamson supporter to be elected to county office," Alex Bishop's further selection as president of the county court provided critical access to power for the "City Ring."168 By contrast Blankenship's allies, Lewis Chafin and John H. Green, held the county assessor and assistant prosecuting attorney positions. From December 1916 until December 1918, Sheriff Blankenship and the Bishop court squabbled frequently, at issue -- who held the reins of power in the Mingo, the Matewan-led "County" Democrats or the "City Ring"? ${ }^{169}$

The first conflict arose from a budget dispute that took nearly a month to resolve. In early December 1916, the new sheriff submitted an eight thousand dollar budget to the county court for approval. The county court only authorized five thousand eight hundred. To Blankenship's embarrassment, the court also "flatly refused" to pay for the purchase of a horse for the sheriff. ${ }^{170}$ The list of Blankenship's intended staff helps explain the court's behavior. Blankenship's budget was intended to cover the salaries of three deputies, one jailer, and an office manager: W. O. Porter, chief deputy, William Brewer, field deputy for the western section of the county, Lee

for Mingo's county seat in 1895. By the election of 1914 solid evidence of the Williamson "City Ring" versus the "County" Democrats appeared in local newspapers.

${ }^{168}$ Mingo Republican, 11 January 1917. Bishop was described as the "handyman of Boss Wallace J. Williamson" for twenty years, and along with A. C. Pinson "dominated city politics." Mingo Republican, 16 January 1916.

${ }^{169}$ Mingo Republican, 7 December 1916, 11 January 1917, 25 October 1917. The Republican described the other two members of the new county court, L. E. Armentrout and Harry G. Wilburn as "representatives of the great coal interests whose views on taxation and the expenditure of public funds are sometimes at odds with those of the native element." Mingo Republican, 11 January 1917.

${ }^{170}$ Except for the railroad, and despite the advent of automobiles, the primary means of transportation throughout southern West Virginia remained horses and mules. There were parts of Mingo and the other southern counties that could only be traversed on horseback or on foot. 
Chambers, field deputy for the eastern portion, William "Red Bill" Damron, jailor, and Toney Webb, sheriff's office manager. ${ }^{171}$ Porter was the only Williamson-affiliated member of Blankenship's intended staff. Both Damron and Webb had recently switched allegiances from the Republican party. Blankenship sought to reward their assistance to him in the campaign. ${ }^{172}$ The county court undermined Blankenship's ability to do so by gutting his budget. ${ }^{173}$

A statewide fiscal reform further complicated the standoff between Mingo's sheriff and county court. As of January 1, 1917, West Virginia's county officers would no longer receive percentages of revenue collections as payments for their services. From January 1917 county officers received fixed salaries and the money they collected from taxes and fines would be considered "public money belonging to the county fund." ${ }^{174}$ The advent of salaried pay combined with the county court's budgetary restrictions altered the make-up of Blankenship's staff. Bill Damron, who already held the position of deputy county court clerk "declined" the now lowerpaying jailer's job. ${ }^{175}$ The position went instead to W. O. Porter, the lone "City Ring" man on the

\footnotetext{
${ }^{171}$ Mingo Republican, 14 December 1916, and 21 December 1916. Toney Webb had resigned his position with the Red Jacket Consolidated Coal \& Coke Company in anticipation of his "reward."

${ }^{172}$ Mingo Republican, 14 December 1916, and 21 December 1916.

${ }^{173}$ Mingo Republican, 21 December 1916. The Republican also asserted that the new court's "economy program," as it applied to reducing the salaries of county officers, also gave them the opportunity to punish their Republican enemies. Over the protest of "nearly every member of the local bar," the court reduced the salary of circuit court clerk Guy White in order to try and force the resignation of deputy clerk, A. Wayne Damron who had just been defeated by Blankenship in the sheriff's race.

${ }^{174}$ Mingo Republican, 28 December 1916.

${ }^{175}$ Ibid. Damron's decision to remain in the clerk's office was also influenced by the actions of county clerk Elihu Boggs. Damron had planned to appoint a Democrat to his place in the clerk's
} 
sheriff's staff. ${ }^{176}$ The first round of the conflicts between Blankenship and the Bishop court ended in tenuous compromise.

The spring and summer of 1917 precipitated new confrontations in Mingo County politics. The first municipal election in Williamson since the 1915 charter reform highlighted not only the ongoing battle between the Republicans and Democrats but also the persistent fissures within each party. As mentioned earlier, the 1917 Williamson municipal election was a critical fight for Mingo's Republicans. Unfortunately, fallout from both the heavy-handed rule of the Hatfield machine and the revolts against it still shadowed the party.

Henry D. Hatfield's single-minded pursuit of political power had precipitated a crisis in Republican state and local politics. In addition to alienating the coal industry with his advocacy of a myriad of reform measures, he also weakened ties with some of his oldest political allies. Since the founding of Mingo County, liquor sales and distribution had been a mainstay of Republican power. ${ }^{177}$ R. W. Buskirk, one of the wealthiest and most powerful native Republican

office, but Republican Boggs let it be known that he would fight any such effort.

${ }^{176}$ Mingo Republican, 4 January 1917.

${ }^{177}$ Henry D. Hatfield advocated approving West Virginia's prohibition amendment during the 1912 campaign, despite the importance of the liquor business to his Mingo allies. In Mingo County the amendment passed with a slim margin of 253 votes, although 13 of the county's 21 precincts approved the amendment, which indicates the closeness of the vote. The 8 precincts that rejected the amendment were "mining" precincts also controlled by the Hatfield machine: Nolan, Lower Red Jacket (Matewan), Lick Fork, Glenalum, Wharncliffe, Chattaroy, and War Eagle. By contrast, "in Williamson the amendment carried by a vote of 5 to 1." "Big Dry Victory," Mingo Republican, 8 November 1912. Inspiration for looking for a connection between mining and the amendment came from: Nash, Conflict and Accomodation: Coal Miners, Steel Workers, and Socialism, 1890-1920. 
elites, was Mingo County's primary purveyor of alcohol. ${ }^{178}$ West Virginia's prohibition of alcohol, which took effect in the summer of 1914, forced Buskirk, who had been considered "the founding father of Matewan," to abandon his base of operations. ${ }^{179}$ After supporting the Democratic slate of candidates in the 1916 election, R. W. Buskirk abandoned the Republican party and joined Mingo's Democratic party in the spring of $1917 .{ }^{180}$ Buskirk's departure from Matewan and Republican ranks further weakened a party already devastated by the Hatfields' strategic blunders and ongoing legal troubles.

Despite the obvious involvement of Hatfield machine hacks in the election fraud at War Eagle and Rockhouse precincts in 1914, the defendants, who included Mingo County Republican party chairman Greenway W. Hatfield, continued to elude legal punishment. ${ }^{181}$ The distraction of recurrent trials encouraged rumors about the Hatfields' slipping power in county politics. Within a week of Buskirk's defection from the party, the Mingo Republican reported that stories had been circulating about Greenway Hatfield's possible replacement as Republican county chairman by Harry Scherr, a well-connected coal attorney. The newspaper countered the rumor with a charge that it had been started by another Republican defector Toney Webb, whose kinsman was a candidate in the upcoming Williamson municipal election. ${ }^{182}$

\footnotetext{
${ }^{178}$ Hatfield correspondence, letter no. 17.

${ }^{180}$ Mingo Republican, 8 March 1917.

${ }^{181}$ McDowell Recorder, 21 May 1918.

${ }^{182}$ Mingo Republican, 1 March 1917.
}

${ }^{179}$ Buskirk literally crossed the Tug Fork river and set up business at what quickly became "Buskirk" Kentucky. However, the lack of legal sanction for alcohol and Buskirk's defection from the Republican party weakened their position in Matewan. 
The Williamson municipal election fired political controversy months before it actually occurred in the summer of 1917. Borrowing a page from the tactics used by his Hatfield kinsmen and frequent adversaries, Judge James Damron orchestrated the reorganization of the primary ballot entries in an effort to boost the re-election chances of his brother-in-law and mayoral hopeful J. M. Studebaker. ${ }^{183}$ Had the commission candidates' names appeared on the ballot as they had in previous elections, the names of Studebaker and W. O. Porter, his chief Democratic rival, would have been arranged so that a vote for one would have canceled a vote for the other. Damron's machinations on behalf of Studebaker resulted in Porter's name being arrayed against that of Gail T. Dudgeon, the Hatfield machine candidate. ${ }^{184}$ To a degree, Damron's strategy worked, Studebaker garnered more votes than Dudgeon, but with only 325 votes, he came in a distant second to Democrat W. O. Porter, who received 478 votes. ${ }^{185}$

The runoff primary proved Studebaker's weakness and forced Damron to appeal to party boss Greenway Hatfield for an end to the factional fighting. ${ }^{186}$ The "deal" offered to Hatfield by Damron and Studebaker reveals the importance of political office and patronage to local party organizations. Damron and Studebaker proposed the replacement of Williamson Chief of Police John B. Maynard with "Red Bill" Damron, Damron's replacement as deputy county clerk by Wayne Damron, and the replacement of Williamson's current street commissioner with "a friend

${ }^{183}$ Mingo Republican, 29 March 1917, and 5 April 1917.

${ }^{184}$ Mingo Republican, 31 May 1917.

${ }^{185}$ Mingo Republican, 26 April 1917.

${ }^{186}$ Mingo Republican, 31 May 1917. 
of Greenway Hatfield's." 187 Buoyed by the second mistrial verdict in the Rockhouse cases less than a month before, Hatfield flatly rejected Damron's offering. ${ }^{188}$ Hatfield explained the rejection by first reminding the Republican's readers that Studebaker had conspired to "throw [Mayor] Booten out of office" and then had voted to appoint Democrats to city assessor and city attorney. Hatfield pointedly noted that Studebaker also had not objected to the firing of Williamson's only African-American employees. Hatfield concluded by noting that the appointments specifically offered by Damron were "all to the advantage of the party traitors," and that a Studebaker victory would actually be a "Democratic victory." 189

Democrat W. O. Porter's victory in the June municipal election resurrected two conflicts that had been dormant for months. Three months after the election Gail T. Dudgeon halfheartedly challenged Porter's victory. Dudgeon based his challenge on the assertion that Porter had not paid city taxes for the year preceding the election and therefore had not been eligible to run. The nature of Dudgeon's claim influenced his decision to make the charges against Porter before the county court in power at the disputed time, which also happened to be a Republican dominated court. Not until September 1917, when West Virginia state supreme court Judge Poffenbarger ruled that only the new court, (the Democratic court elected in 1916), had jurisdiction in the matter, was the fight between Mingo's "old" and "new" county court finally

${ }^{187}$ Ibid. "Red Bill" Damron was James Damron's brother. Mingo Republican, 1 June 1916.

${ }^{188}$ Mingo Republican, 3 May 1917. The second mistrial in the "Election Fraud Cases" was declared on April 29, 1917.

${ }^{189}$ Mingo Republican, 31 May 1917. 
resolved. ${ }^{190}$

The second issue brought back to life by Dudgeon's challenge to Porter's election was the fight between the county court and Sheriff Blankenship. As soon as Porter won the municipal election, Blankenship began trying to force Porter to step down as county jailer. With his election in question, however, Porter refused to abandon his existing salaried position. The county court supported Porter because Blankenship wanted to replace him with one of his own factional allies. As the Mingo Republican revealed, if Blankenship won the dispute over Porter, all of Mingo's paid deputies would be residents of Magnolia district. ${ }^{191}$

Williamson's municipal politics heated up early in 1919 because Republican state senator William York succesfully proposed revisions to the city's 1915 Charter. Suggested changes included expanding the commission from five to six and awarding positions according to the candidates' portion of the electoral returns. ${ }^{192}$ The Daily News commended Dr. York's intention of "trying to better conditions" in Williamson, but also damned the revisions for giving "the politicians carte blanche opportunity to trade on the suffrage of the people." ${ }^{193}$ Moreover, the

${ }^{190}$ Mingo Republican, 20 September 1917. Between the election in June and September, Dudgeon moved to McDowell county where he was "employed in the office of the county clerk W.W. Whyte." The close political relationship between clerk (and former sheriff) Whyte and Henry D. Hatfield lends credence to the supposition that the Hatfield machine "assisted" in Dudgeon's employment after the election loss in Mingo.

${ }^{191}$ Mingo Republican, 25 October 1917.

${ }^{192}$ Williamson Daily News, 18 February 1919. Both the 1915 charter and the 1919 revisions required the commission to be bi-partisan. The increase from five to six commissioners removed the opportunity for one party to dominate and ignore the other commissioners' wishes. The second revision, awarding the position of mayor, clerk, collector and assessor according the number of votes the candidates polled, was also intended to democratize the city government.

${ }^{193}$ Williamson Daily News, 20 February 1919. 
Daily News asserted that the Republicans' constant efforts to force Republican government on a Democratic city only solidified the people's support for the "Democracy."194

Dr. York responded to the Daily News' criticism by asserting that many people were judging the bill based on an inadvertently distributed first draft, and that consideration of the bill's actual provisions would change their minds. York's reform measures, designed to eradicate "strife and ill will" in Mingo's local politics reflected the Progressive belief that legislated bipartisan power-sharing would help destroy political corruption. ${ }^{195}$ The actions of the "City Ring" Democrats in the months between the 1919 legislative session and Williamson's municipal elections illustrated the ways machine politicians circumvented well-intentioned reforms.

First, one week prior to the municipal primary, the Democrats conspired to bring 102 indictments against several leading politicians and citizens, including Dr. York for "falseswearing," and O. H. Booten, Williamson's former Republican mayor, for forgery. ${ }^{196}$ If the accused were found guilty they faced fines, prison time, disfranchisement, and a life-long banishment from public office. Republican judge James Damron weighed in on the controversy, stating that "these evils and crimes must and shall be stamped out."197 Although Booten fled to Kentucky rather than face the grand jury's decision, Dr. York fought back. ${ }^{198}$ Two days after the charges were brought against him, York blamed the situation on Republican defector Toney

${ }^{194}$ Ibid.

${ }^{195}$ Diner, 205, 231.

${ }^{196}$ Williamson Daily News, 22 April 1919.

${ }^{197}$ Ibid.

${ }^{198}$ Ibid. 
Webb and swore that he would be "vindicated."199

The Williamson Democrats' effort to implicate their Republican rivals in illegal activities backfired. Republicans (Dr.) York, Greenway Hatfield and John Sammons polled the highest number of votes in the municipal primary. ${ }^{200}$ The Democrats then tried another strategy to retain control of the city government. They decided the way to win the election was to support one mayoral candidate. ${ }^{201}$ The Democrats boldly asserted that by pursuing this strategy they would also attract "the better element of the Republican party" who would rather vote for the Democratic choice rather than the Machine's candidates. ${ }^{202}$ Former seven-term Democratic mayor A. C. Pinson withdrew from the race and threw his support behind W. O. Porter, the incumbent mayor and "chosen" candidate. ${ }^{203}$ When Porter won the municipal election, the "City Ring” rewarded Pinson's sacrifice. ${ }^{204}$ Mingo County Democratic Party Chairman W. A. Hurst stepped down and Pinson replaced him. ${ }^{205}$

\section{The Portent of Troubles to Come: Matewan's Municipal Elections, 1917-1919 and the}

${ }^{199}$ Williamson Daily News, 24 April 1919.

${ }^{200}$ Williamson Daily News, 30 April 1919. The five highest vote returns went to: Greenway Hatfield (511), Dr. William York (496), John Sammons (486), and W. O. Porter (456). J. M. Studebaker, Republican "traitor" and mayoral aspirant from 1917, polled a mere 13 votes.

${ }^{201}$ Williamson Daily News, 29 May 1919.

${ }^{202}$ Ibid.

${ }^{203}$ Williamson Daily News, 2 June 1919.

${ }^{204}$ Williamson Daily News, 6 June 1919.

${ }^{205}$ Williamson Daily News, 2 June 1919. Hurst died little more than a month later in a train accident in Dunkirk, New York. Williamson Daily News, 7 July 1919. 


\section{General Election of 1918}

As evidenced by the ongoing struggle between the Republicans and Democrats for primacy in Mingo, local politics in the county remained fractious throughout the entire period preceding the Matewan Massacre. The faction wars between the "City Ring" and the "County" Democrats counterbalanced the disintegration of the Hatfield Machine's stranglehold on the county's Republican party. As a result, groups within each party constantly shifted allegiances and formed new alliances in their efforts to seize control. The following discussion of the Matewan municipal elections and the 1918 midterm election highlight the personalities and issues that influenced the temper of Mingo County politics when the United Mine Workers of America launched their organization drive in 1920.

The homebase of Mingo County's most powerful Republican faction and the insurgent Democratic faction, Matewan proved to be the county's most volatile political arena. As mentioned in earlier chapters, election day in Matewan perennially featured displays of drunkenness, fistfights, and charges of illegal voting. While state and national attention had been drawn to events in Matewan on general election days, the true nature of Mingo County politics was most clearly reflected in Matewan's municipal elections. Held in January, months before the primaries, Williamson's municipal elections and the November general elections, Matewan's municipal elections were usually harbingers of the political year to come.

The 1917 municipal election in Matewan proved to be the sole electoral victory in a year of disappointing political setbacks for the Hatfield machine. During the first week of January, Henry D. and Greenway Hatfield's brother A. B. (Andy Barrett) Hatfield won re-election as 
Matewan's mayor, along with the rest of his slate. ${ }^{206}$ Hatfield's opponent in the mayoral race was

Cabell Testerman. Hatfield had won three successive municipal elections and served as mayor from 1915 to 1917 . The Hatfield machine's defeats at the county and state level in November 1916 and Buskirk's defection in March 1917 undermined A. B. Hatfield's ability to retain power in Matewan.

The 1918 municipal election illustrated how far the Hatfield influence had slipped. George Booth, who had served as a municipal councilman under the Hatfield's Independent League, abandoned Hatfield and joined Testerman's Citizen's Party. ${ }^{207}$ The Hatfield machine traditionally benefitted from election day violence and chaos, but the election of Matewan Democrat G. T. Blankenship as sheriff deprived the Republicans of that advantage. Although activity around the elections booths started out "lively," the arrival of Blankenship and his deputies calmed the situation and the election proceeded smoothly. ${ }^{208}$ According to the county's Democratic organ, the Williamson Daily News, the election was "between the highest citizenship of the town on one side and a bunch of fellows on the other who are continually causing

\footnotetext{
${ }^{206}$ Mingo Republican, 11 January 1917. Mayor Hatfield's slate included: N.L. Chancey, town recorder and councilmen: Epp Steele, Eph Boggs, George Booth, H. C. Combs and Young Kennedy. For the municipal elections, the Republicans called themselves the "Independent League" and the Democrats were the "Citizens' Party." A. B. Hatfield of Matewan is an enigmatic figure in Matewan's history. Identified by the Williamson Daily News as the brother of Greenway and Henry D. Hatfield, A. B. (Andy Barrett) does not appear in either contemporary or current genealogies of the Hatfield family. The logical explanation for his omission might illegitimacy, which was not unknown in the Tug Valley or among the Hatfields. Williamson Daily News, 5 June 1916.

${ }^{207}$ Williamson Daily News, 26 November 1918.

${ }^{208}$ Williamson Daily News, 12 January 1918.
} 
trouble." 209 The victory of Testerman and the Citizens' Party inaugurated three years of Democratic rule in Matewan. ${ }^{210}$

The accumulation of political defeats and the on-going election fraud cases inspired the Williamson Daily News to observe: "we had thought the Republican party in Mingo County was dead, eternally dead for all time to come." What the Daily News did not state explicitly was that local Democrats believed that the local Hatfield machine had been crushed. However, in early 1918, when the Republican Executive Committee overhauled its membership the Hatfield machine remained an entrenched force in the county's Republican leadership. Seven of the committeemen were economically and/or socially linked to the Hatfield machine. The resurgence of the Hatfield machine led the Williamson Daily News to declare that Mingo's Republican party was "still kicking" and that the new Republican committee was "a most harmonious gang." 211

The power of the Hatfield machine had reached a low point when it lost control of Matewan, its traditional powerbase, in January 1918. The retention of its majority in the county organization in March marked the Machine's resurgence. Shortly before the May primary, the third and final trial of the Rockhouse cases ended in acquittal. The resolution of these cases

${ }^{209}$ Williamson Daily News, 5 January 1918.

${ }^{210}$ Testerman won the 1918, 1919 and 1920 Matewan municipal elections.

${ }^{211}$ Williamson Daily News, 23 February 1918. The seven committeemen were: John McComas, E. E. Musick, M. V. Crigger, Noah White, Eli Sohn, Hi Maynard, and John Brewer. L. H. Atkins of Kermit and O. H. Booten of Williamson joined the Executive Committee. W. H. Needham, Booten's successor at the Mingo Republican became party secretary, Guy White, M. Z. White's cousin and ally, became Treasurer. 
liberated Greenway Hatfield and several of his associates from the threat of prison. ${ }^{212}$

Unfortunately for the Hatfield machine, the 1918 mid-term election offered only six contests: a United States senatorship, a United States congressional seat, seats in the state senate and house of delegates, and two county positions, commissioner of the county court, short term, and county superintendent of schools. Overshadowed first by the war, and then by the Influenza epidemic, the 1918 campaign in Mingo County was muted and lacked the fire of previous contests.

The dominant reason for the low key course of the campaign was the complete preoccupation with the war effort. Raucous campaigning would have been viewed as unpatriotic. The Williamson Daily News published articles on national politics in which the President urged unity among party leaders because discord only encouraged the Germans. ${ }^{213}$ The campaign advertizing that appeared in Mingo County similarly reflected the overwhelming importance of the war over local issues. West Virginia's Democratic candidate for U.S. Senator, Clarence W. Watson of Fairmont conducted his campaign while still in the Army. His advertisement also included a photograph of Watson in uniform. ${ }^{214}$ The campaign literature of Wells Goodykoontz, the Republican candidate for U.S. Congress from West Virginia's fifth district, focused on how, after the war, he would work to right the wrongs perpetrated by the Southern Democrats during

${ }^{212}$ McDowell Recorder, 21 May 1918.

${ }^{213}$ Williamson Daily News, 2 February 1918.

${ }^{214}$ Williamson Daily News, 31 October 1918. The advertisement also contained an endorsement letter from the father of man on active overseas duty, who urged West Virginians to support Watson. 
the war. ${ }^{215}$ Goodykoontz believed the Democrats had unjustly "scapegoated" the coal industry and overregulated it during the war, while allowing Southern agricultural interests to benefit from wartime inflation. ${ }^{216}$

However, neither Watson's nor Goodykoontz's advertisements appeared until just a few weeks before the election. In fact, the entire campaign had been compressed. In Mingo County the primary was delayed until August and the candidates waited until the fall to actively campaign. ${ }^{217}$ Influenza undermined the 1918 September-October campaign plans. West Virginia's State Health Department banned all public meetings. ${ }^{218}$ Candidates for office, like R. L. Harris, Democratic candidate for the county court seat, restricted their canvassing for fear of spreading contagion. ${ }^{219}$ Some candidates, like Evan A. Justice, Mingo's Democratic candidate for state senate actually fell ill with "the Flu" and were unable to campaign. ${ }^{220}$

Held on November 5, the 1918 election bitterly disappointed Mingo's Republicans. Only two Republicans, Wells Goodykoontz and Dr. William York, defeated their Democratic opponents. Goodykoontz lost in his home county of Mingo, but carried enough votes in the district's other counties to win. ${ }^{221}$ York vanquished Influenza-stricken Evan Justice for Mingo's

${ }^{215}$ Williamson Daily News, 5 November 1918.

${ }^{216}$ Ibid.

${ }^{217}$ Williamson Daily News, 18 July 1918.

${ }^{218}$ Annual Report of the State Department of Health, 1919-1920, 12.

${ }^{219}$ Williamson Daily News, 31 October 1918.

${ }^{220}$ Ibid.

${ }^{221}$ Williamson Daily News, 9 January 1918. Democrat W. H. McNeal won Logan, Mingo, Summers, and Wayne counties, but Goodykoontz like Cooper before him won Lincoln, Mercer, 
State Senate seat. ${ }^{222}$ The victory of Democrats Harris, Evans, and Thomas exposed the continued weakness of the mainstays of Mingo's Republican party: the coal industry Republicans, the Hatfield Republicans, and the Republicans of Matewan. C. M. Gates, the Republican candidate for county commissioner, and general superintendent of the Crystal Block Coal \& Coke properties, lost to Mingo native R. L. Harris. Harris' political advertisement underscored the "class" aspect of the nativity issue. He declared: "I . . . have always lived with you and labored with our people . . . for the good of all alike."223 Harris's assertion implied that Gates, who had been superintendent of Crystal Block for "several years" but had been a county resident for just a few months, could not and should not, represent the people of Mingo County on the county court. ${ }^{224}$ C. M. Whitt, the Hatfield machine candidate for house of delegates lost to the young and virtually unknown Rice Thomas. In the race for county superintendent of schools, Matewan Republican and Hatfield kinsman Wilson Chafin even failed to defeat Floyd Evans, a Democrat from Kermit, a remote town the Republicans had incorporated and named for the son of President Roosevelt less than a decade before. ${ }^{225}$

Monroe, McDowell and Wyoming Counties. Legislative Handbook and Manual of the West Virginia Legislature 1919, 336.

${ }^{222}$ Ibid. Justice was a Blankenship ally.

${ }^{223}$ Williamson Daily News, 31 October 1918.

${ }^{224}$ Mingo Republican, 15 February 1917. The newspaper article revealing Gates' residency came months after the election and actually pertained to his resignation from Crystal Block following his wife's death. In 1916, after the Gates' built a home and established residency in Mingo, he then ran for county commissioner. He lost, she died, and he returned to McDowell County to supervise another U.S. Steel coal operation.

${ }^{225}$ Williamson Daily News, 9 November 1918. 
Still, the Democratic victory over the Republicans in the county elections did not swing the balance of power to the "City Ring." R. L. Harris of Chattaroy, and Floyd Evans, were Democrats from the "County" and as such natural allies of Blankenship. Harris' anti-coal operator advertisement also indicated that it was unlikely he would follow the lead of the Williamson Democrats, most of whom were coal capitalists themselves. Rice Thomas, the winner of Mingo's house of delegates' race, was the sole Democrat who hailed from Williamson. ${ }^{226}$

The last significant political event of 1918 illuminated the consolidation of the "County" Democrats' influence over Mingo's politics. Sometime between the end of November and early December, county court commissioner Harry G. Wilburn resigned and E. B. Chambers, Sheriff G. T. Blankenship's brother-in-law, succeeded him. ${ }^{227}$ The Williamson Daily News remarked that Chambers had repeatedly refused various political honors and would represent "all the people in Mingo County, regardless of whether they are Democrats or Republicans." Finally, nearly two years into his term as sheriff, Blankenship had an ally on the county court. ${ }^{228}$

Within a month of Chambers' ascendance to the county court, Matewan held its 1919 municipal election. Although Chambers' and Blankenship's fellow Democrat and ally C. C. Testerman won his second consecutive election, the election day commotion foreshadowed conflicts to come. Moreover, behind the scenes, the Williamson Democrats regrouped and by the

${ }^{226}$ Williamson Daily News, 31 October 1918.

${ }^{227}$ S. D. Stokes to G. R. C. Wiles, 31 March 1919, Stokes Papers, WVRHC. Wilburn resigned because of "domestic trouble;" after discovering his wife's affair with a discharged sailor, Wilburn engaged in at least one physical confrontation with the man.

${ }^{228}$ Williamson Daily News, 12 December 1918. 
end of 1919, all of Mingo's political factions were gearing up for the campaigns of the 1920 general election year. Despite the plea from the Williamson Daily News that local politicians "give the people of Matewan a square election and stop endeavoring to gain power by manipulation," the 1919 Matewan municipal election served as the opening salvo of several years' discord. ${ }^{229}$

Former mayor and current Matewan chief of police A. B. Hatfield had marshalled a force of men to help him regain the mayoral seat. Described as a gang of "desperado bootleggers" and "mountaineer ruffians from the wilds of Blackberry creek," Hatfield's men tried to "bull-doze" the election for their boss. The situation reached critical mass when Chief Hatfield ordered an African American from Red Jacket to vote over the man's own objection that he was not a legal voter. Hatfield reiterated his order and added, "nobody dares cross my path -- I am a Hatfield." Sheriff Blankenship, who had brought his deputies to Matewan to watch over the election, ordered the man arrested. Hatfield ordered the man, later identified as Will Dudley, a recent parolee from a Virginia penitentiary, released. Blankenship refused to bow to Hatfield's demand. Chief Hatfield and "his blood-thirsty bunch started" but stopped when a constable put a "handcannon" to Hatfield's "thinking cap." Hatfield's men ran, he backed off, and Blankenship restored order. $^{230}$

The armed standoff in Matewan did not end the town's political strife. After Hatfield retreated on election day, Blankenship rounded up suspected illegal voters. Will Dudley and six

\section{${ }^{229}$ Ibid.}

${ }^{230}$ Williamson Daily News, 4 January 1919. The newspaper does not identify the constable who stopped Hatfield. Both constables in Magnolia District: Harry Chafin and A. L. "Al" Hoskins were Republicans. 
other African-American men ultimately appeared in magistrate's court. Dudley pleaded guilty and Republican county chairman and Chief Hatfield's older brother Greenway Hatfield "gave surety" for the other men. ${ }^{231}$ The Williamson Daily News condemned the Hatfields' behavior as "the final chapter" in Matewan's "corrupt elections," but lauded Sheriff Blankenship's actions: "we are glad to see that the day is dawning when we have an official who says he will protect us with all his power . . the citizens are back of you." ${ }^{232}$

The Hatfields' political trouble and public embarrassment continued in the spring of 1919. Ex-mayor and chief of police A. B. Hatfield and N. L. Chancey, who served as town recorder during Hatfield's tenure, faced more public censure. According to a story published in the Daily News, Hatfield and Chancey "tampered" with Matewan's municipal records, and "fixed things to suit their taste." The article specifically charged the pair with excising pages from the "town record ... when sentiments became so hot that an investigation was planned."${ }^{1233}$ However, Chancey had already fallen into disgrace for "filching" funds from the Magnolia district Board of

${ }^{231}$ Williamson Daily News, 7 January 1919.

${ }^{232}$ Williamson Daily News, 4 January 1919.

${ }^{233}$ Williamson Daily News, 22 April 1919. One of the other targets of the accusatory article later asserted that its author was Toney Webb, one of Matewan's more infamous Republicans turned Democrats. Williamson Daily News, 24 April 1919. The charge concerning Webb requires then that the accusations concerning Hatfield and Chancey be viewed cautiously. Webb could have been revealing information he had been privy to prior to his defection, or fabricating a believable story to undermine his former compatriots. The possibility of purposeful record destruction reminds one of the complexity of politics in Mingo County and southern West Virginia; it also enhances the pathos of the loss of historical records to natural disasters like the floods of 1977 and 1984. 
Education, while Hatfield enjoyed his brothers' protection. ${ }^{234}$ Despite the accusations regarding his mismanagement of Matewan's resources, A. B. Hatfield did not fade from the political scene. By 1920, he was serving as a magistrate for Magnolia District. As Chapter 10 will show, the grudges accumulated in the annual fight between Hatfield and his allies and Blankenship, Testerman and the Chambers for control of Matewan directly affected the escalation that led to the Matewan Massacre.

\section{Conclusion:}

Mingo County politics from 1912 through 1919 remained just as volatile as they had been early in the county's history. The one constant theme in all of the maneuvers and machinations of Mingo's leaders was the ability of the machines led by the native elites to survive the efforts of reformers and insurgents. The escalating pressures on the two machines in this period, however, precipitated profound shifts that directly affected the events of 1920. The uneasy alliance between the Hatfield Machine and Mingo's Republican industrial elite broke apart. The ascendance of the "County" Democrats led by the Blankenship-Chambers coalition of Matewan also reconfigured the rhetoric of Democratic party politics in the county. As evidenced by the campaign pronouncements of R.L. Harris in 1918, the "County" Democrats, based their appeal for voter support on the claim that they were the legitimate representatives of local versus corporate interests in Mingo. As the following chapters will show, Mingo's economic development between 1912 and 1919 and the social transformation that accompanied World War

\footnotetext{
${ }^{234}$ This assertion is based on A. B. Hatfield's ability to retain positions of influence despite electoral defeat. Between 1918-1920, Hatfield went from Matewan's mayor, to Chief of Police, to Magnolia District magistrate.
} 
I, combined with the county's political instability to create an atmosphere that was ripe for violence. 


\section{CHAPTER 7}

\section{STORM CLOUDS ON THE HORIZON: \\ THE WILLIAMSON-THACKER COAL FIELD FALLS BEHIND, 1912-1916}

"See, we didn't have any big coal operators in this part of the country."

-- Howard Radford

Between 1912 and 1916, coal production in the Williamson-Thacker field increased. But expansion did not translate into greater economic security for either the companies or their employees. For a variety of reasons Mingo County fell even further behind its coal-producing neighbors. Despite the increased presence of more highly capitalized companies, and the implementation of several "reforms," discontent among the county's mining population rose. The outbreak and resolution of West Virginia's first "mine war," while it did not directly affect the Williamson-Thacker field, altered the course of labor relations in southern West Virginia, and in turn assured another collision between the United Mine Workers of America and the antiunion operators of southern West Virginia.

I. The Intensification of Long-Standing Systemic Industrial Problems, 1912-1916:

Between 1912 and 1916 coal industry development in Mingo County followed the pattern long established in the broader American coal industry. In Power, Culture, and Conflict in the Coalfields, Roger Fagge observes that: "The pattern of seemingly constant growth before the war, and the downturn in fortunes thereafter covered up the extent to which the bituminous industry had long standing structural problems. Cyclical changes in demand and increasing

\footnotetext{
${ }^{1}$ Harold (Howard) Radford interview.
} 
competition had already made themselves felt through the industry prior to the post-war depression."2 An examination of the coal industry in Mingo County between 1912 and 1916 substantiates Fagge's assertion. The obvious indicators of growth in Mingo's coalfield disguised the structural issues to which Fagge alludes and which most affected work relations.

Between 1912 and 1916 annual coal production in Mingo County increased from slightly less than 2.5 million to almost 3 million tons. The number of mines expanded from twenty-nine to forty-four, and mine employees increased from 2,661 to 3,229. However, these numbers obscured indications that all was not well. Even though 41 percent of total employees in Mingo's coal industry were miners in 1912, and still 39 percent of the total in 1916, the number of pick miners actually declined from 228 to 11 , a drop from 9 per cent to 3 percent. The average number of days worked ranged from 227 in 1912 to a high of 243 in 1914 before settling back at 224 in 1916. Although coal production rose over 120 percent between 1912 and 1916, the rate of increase had slowed dramatically from the 1895-1911 period when production had risen over 660 percent. The most telling indicator of conditions in the Mingo coalfield was the average selling price of coal, and the wages earned by miners. In 1912, companies sold the average ton of coal for $\$ 1.01$, for which they paid miners an average of forty-one cents per ton in wages. In 1916, the selling price averaged $\$ 1.03$, while wages averaged fifty cents for the same ton. Coal companies thus spent on average eight cents more per ton to produce coal in 1916 than they had in 1912. Although both the operators and the miners were making more money in 1916 than they had in 1912, this advance was offset by a corollary rise in the cost of production. ${ }^{3}$

\footnotetext{
${ }^{2}$ Fagge, 20.

${ }^{3}$ Annual Reports of the West Virginia Department of Mines, 1912-1916.
} 
In the years before the United States entered the First World War, the boom in coal production in Mingo County had slowed, and the number of skilled miners had declined dramatically. Continued expansion in the number of mines in the county did not necessarily mean that the miners themselves benefitted from better work opportunities. Yearly fluctuation in the number of days the mines operated indicated that although the miners received higher wages, steady employment remained elusive. Moreover, because companies offset wage hikes by boosting prices in the company stores, housing rents or the services provided by the company doctor, the miners' standard of living did not improve. ${ }^{4}$

The consolidation of smaller and/or older mining operations by large corporations received a great deal of press coverage in the period between 1912 and 1916. During Congressional hearings into the consolidation of economic power on Wall Street, federal advocate Samuel Untermyer revealed that the Red Jacket Consolidated Coal \& Coke Company, one of the largest operations in Mingo, was among the "coterie of banks and coal companies" controlled by Isaac T. Mann, of Bramwell, Mercer County. ${ }^{5}$ According to Untermyer, a Mr. Stotesbury, who was a member of Red Jacket's board of directors, was also a member of J. P. Morgan \& Company, and a director of two companies that held a significant number of Red Jacket's bonds. ${ }^{6}$ Under two different corporate monikers since 1902, Red Jacket had in addition

${ }^{4}$ Two indicators that living standards were a concern for the working class in Mingo County were: a short-lived Workingmen's Association which undertook a study of commodity prices in Williamson and planned to co-operatively buy supplies to lower costs, and a 1916 Republican campaign reminder to miners that the cost of living had outstripped their wages. Williamson Daily News, 18 March 1914; Mingo Republican, 12 October 1916.

\footnotetext{
5"Houston Brief," 46.
}

${ }^{6}$ Ibid. 
to opening new mines, absorbed several of the county's oldest mines, including the Lick Fork and Grapevine mines. ${ }^{7}$ Morgan \& Company controlled at least one other mining operation in Mingo County by 1912, the White Star Mining Company, which, along with several other sister mines, provided the coal for Morgan's White Star shipping line. ${ }^{8}$

In addition to the now publicized Morgan interests, also known as U.S. Steel, other large corporations actively pursued developments in the Mingo section of the Tug River. On September 16, 1913, Thomas H. Claggett, an investigator for the Pocahontas Coal \& Coke Company, reported that in addition to the land they already owned, the Berwind-White interests were buying up more acreage on Pond Creek and Tug River. ${ }^{9}$ Since little of Pond Creek except its mouth lay in West Virginia, the Berwind-White lands were actually in Kentucky, in the Pond Creek Coal Field. ${ }^{10}$ The opening of this Kentucky field profoundly affected Mingo's future because it meant that the Williamson-Thacker coalfield became surrounded by fields that were the focal points of intense and heavy development by the most powerful corporations in the Appalachian coal industry. To the southeast, U.S. Steel controlled most of the Pocahontas field. To the north-northeast the Island Creek Coal Corporation dominated the Logan field and after 1912, the Pond Creek field would be divided among the Berwind-White, Island Creek and

${ }^{7}$ Annual Reports of the West Virginia Department of Mines, 1902-1916.

${ }^{8}$ Chernow, 101, 146-147.

${ }^{9}$ Thomas H. Claggett to W.W. Coe, general manager, Pocahontas Coal \& Coke Company, 16 September 1913. Pocahontas Land Corporation Collection, ERCA.

${ }^{10}$ Until the labor strife of the 1920-1922 the Williamson-Thacker field included the Pond Creek area of Pike County, Kentucky. During the strike, the operators along Pond Creek sought, and were granted, an injunction against the UMWA. Lane, Civil War in West Virginia, 71-72. 
Consolidation Coal interests. ${ }^{11}$ As in the case of the opening of the Logan field in 1904-1905, the rapid development of the Pond Creek field underscored the position of the Williamson-Thacker coal field as a marginalized, peripheral field. The big corporations developed their holdings in Mingo, but never on the scale that occurred in surrounding counties. More important, the Williamson-Thacker field also never became the primary base of operations for any of them. A West Virginia State Supreme Court of Appeals case involving coal lands in Mingo County underscored both local impatience with the path of the county's development and the obstacles faced by the large corporations in undertaking a project. The case is noteworthy because of what it reveals about the actions and expectations of the plaintiffs, David Bragg, F.W. Bragg and Greenway Hatfield. The Braggs and Hatfield justified reasserting their claim to the land by an admission that David Bragg and Greenway Hatfield had knowingly sold the land without clear title. United Thacker challenged the presumption of this argument by asserting that its mortgage holders were a party to the suit whom the plaintiffs repeatedly refused to name as co-defendants. The local circuit court judge had sided with the defendants and dismissed the case. The state supreme court of appeals upheld the lower court's decision, and United Thacker retained legal ownership to the coal lands it had purchased from Greenway Hatfield. ${ }^{12}$

\footnotetext{
${ }^{11}$ The company that became Island Creek in 1915 began purchasing land in the Pond Creek field in late 1911. Coal Trade Journal 1 (December 1911): 262. Island Creek eventually expanded into Mingo County in the 1940s when it purchased the mines and holdings of Red Jacket Consolidated Coal \& Coke. Island Creek's hard-nosed managerial style was personified in a common rhyme that was heard in Mingo. According Margaret Hatfield, who was a small child at the time, men were heard to say to one another, "Off your ass and on your feet, Now you're working for Island Creek!" Hatfield correspondence, letter no.20.

12"Bragg, et al v. United Thacker Coal Company," Reports of the West Virginia State Supreme Court of Appeals 70 (November 1911- April 1912): 604-660, 660. The chain of ownership evolved as follows: F. W. Bragg orginally owned the disputed land; his son David sold it to
} 
Several years after the resolution of Bragg et al v. United Thacker Coal Company, the local newspaper revealed what had, in all likelihood, prompted the action of the Braggs and Hatfield. The Mingo Republican reported that the United Thacker Coal Company, a New York corporation, sold its land, which had been owned for twenty years but never developed, to U.S. Steel. ${ }^{13}$ Perhaps the Braggs and Hatfield sought to capitalize on David Bragg's and Greenway Hatfield's admittedly illegal sale of the land to regain title to it, in order to resell at a much inflated value. ${ }^{14}$

Finally clarifying the title to the land allowed the United Thacker Coal Company to exploit its investments in Mingo County. Early in 1916 UTCC sold its timber tracts to a corporation from Ashland, Kentucky. ${ }^{15}$ That a company based in New York sold tracts to a company from eastern Kentucky marked another, frequently overlooked trend in the development of southern West Virginia, especially southwestern West Virginia. From the inception of resource extraction in the area, outside investment had come not only from the east, but also from

Greenway Hatfield who in turn sold it to United Thacker. Shortly before the Braggs and Hatfield filed suit, F. W. Bragg finally conveyed his interest in the land, although it had already been sold twice over.

${ }^{13}$ Mingo Republican, 25 February 1917.

${ }^{14}$ Hatfield based his claim to the Braggs' land based on his purchase of the same at a sheriff's sale, while he was Sheriff of MingoCounty. Interestingly, when UTCC cleared its title and sold its holdings to U.S. Coal \& Coke, the only parcel excluded in the sales was the disputed acreage on the Straight Fork of Mate Creek. For more details see "Plaintiffs' Brief," U.S. Coal \& Coke v. Red Jacket Junior and Greenway Hatfield, Stokes Papers, WVRHC and Mingo Republican, 27 September 1917.

${ }^{15}$ Mingo Republican, 1 January 1916. 
the West. ${ }^{16}$

Between 1915 and 1920, Ohio capitalists and entrepreneurs increased their influence on the development of the Williamson-Thacker coalfield. In 1915, the majority of the coal companies in the Williamson-Thacker field sold their coal through sales agencies based in Ohio. The companies who sold their coal through Ohio agents included some of the smallest companies, such as E. L. Sternberger and two of the largest, Thacker Coal \& Coke and Borderland. Twenty percent of the companies in the Williamson-Thacker field were headed by men from Ohio. ${ }^{17}$

There were at least two reasons for the expanding presence of Ohioans in the field. First, although coal from the Williamson-Thacker field had always been shipped west as well as to the east, after 1911 the amount shipped west continually increased at the expense of the eastward shipments. ${ }^{18}$ Also, by the second decade of the twentieth century, the coal operators and investors of Ohio wanted to escape the political and economic power wielded by the United Mine Workers of America in the Ohio coal fields. In January 1915, the president of the Ohio Coal Operators' Association Walter R. Woolford, announced that many Ohio companies were planning to enter the West Virginia fields because "the Green anti-screen law had killed Ohio

\footnotetext{
${ }^{16}$ Many historians have visualized the opening of southern West Virginia's coalfields as simply following the west-heading advance of the Norfolk \& Western, and hence similarly envision a single path of capital penetration. However, as revealed in Chapter 2, the Ohio Extension was constructed from two directions, and thus offered two conduits for investment.

${ }^{17}$ This assertion is based on data extrapolated from the 1915 Coal Catalog. International Coal Catalog, Combined with Coal Field Directory for the Year 1915 (Pittsburgh: Keystone Publishing Company, 1915).

${ }^{18}$ Lambie, 291.
} 
coal mining." ${ }^{19}$ As one of the staunchly anti-union coal fields in a pro-business state, the Williamson-Thacker field attracted the beleaguered Ohio coal men.

II. The First Mine War and Its Impact on the Williamson-Thacker Field, 1912-1913:

Two months after the ruling in the Bragg case a contract dispute in Kanawha County dissolved into one of West Virginia's worst episodes of labor strife. Known as the first West Virginia Mine War, the Paint Creek and Cabin Creek Strike of 1912-1913 anticipated the Williamson-Thacker Strike of 1920-1922 in several ways.

Dissatisfied with the progress of contract negotiations, the union miners of Paint Creek district walked out of the mines in April 1912. ${ }^{20}$ Quickly joined by several thousand miners from neighboring Cabin Creek, the strike seemingly provided the United Mine Workers of America with yet another opportunity to launch a unionization drive in southern West Virginia. ${ }^{21}$ However, the conflict also set in motion a chain of bitter and often violent confrontations that would not end for decades.

Although the operators of Paint Creek had acquiesced to unionization in 1902, by 1912 they were determined to drive the United Mine Workers of America from the Kanawha field. While the miners' union raised funds for the strike and sent high-ranking officials to the field to assist the local officials of District 17 , the operators also amassed a war chest and braced for fierce resistance. The operators fortified their properties, imported several hundred Baldwin-

\footnotetext{
${ }^{19}$ Williamson Daily News, 2 January 1915.

${ }^{20}$ Corbin, Life, Work and Rebellion, 87. For thorough accounts and analyses of the Paint Creek and Cabin Creek Strike see this study by Corbin and Fagge's Power, Culture and Conflict.

${ }^{21}$ Ibid.
} 
Felts detectives and armed them with machine guns. ${ }^{22}$ By June, the operators had gone on the offensive unleashing the mine guards on the strikers. ${ }^{23}$

Throughout the summer of 1912, the campaign of violence continued. In one instance, a specially equipped train peppered a strikers' tent colony with machine gun fire, killing at least one inhabitant. At a loss to deal with the operators' virulent opposition, the national union leadership's enthusiasm for the strike fell as the cost of the strike mounted. At least two attempts to broker a compromise were flatly rejected. Frustrated by the national officials' waning support and incensed by the vacillating ineffectiveness of their leaders in District 17, the striking miners turned to the radical wing of the local Socialist party. ${ }^{24}$

Galvanized by the financial and moral support of their new allies, the rank-and-file miners of Paint and Cabin Creeks struck back at the operators. Armed with the "bootlegged" guns of the radicals, striker-snipers shot at mine guards and operators, while others blew up tipples and attacked coal trains moving through the district. At the same time, the state's Socialist press publicized the atrocities visited upon the miners. The operators pressured West Virginia's governor, William E. Glasscock, to act. Derisively referred to as "crystal-peter" by union activist Mary Harris "Mother" Jones, Glasscock declared martial law and authorized violators to be arrested and tried by military tribunal. After several hundred miners were taken into custody and many were sentenced to penitentiary terms, confrontations between the strikers

\footnotetext{
${ }^{22}$ Corbin, Life, Work, and Rebellion, 87-88; Lee, Bloodletting, 21. Corbin's and Lee's accounts of the Paint Creek-Cabin Creek Strike highlight the role played by Mingo native and Congressional Medal of Honor recipient,Tony Gaujot.

${ }^{23}$ Corbin, Life, Work, and Rebellion, 88.

${ }^{24}$ Ibid., 88-89.
} 
and the mine guards finally subsided during the winter of 1912-1913. ${ }^{25}$

When only miners were subjected to this harsh justice, which baldly violated United States Constitutional law, union attorneys fought back. The West Virginia State Supreme Court of Appeals endorsed the governor's proclamation and upheld the martial law convictions, but the tide of the strike turned yet again. When martial law focused national attention on West Virginia, the United Mine Workers of America, the new governor Henry D. Hatfield, and the operators once again sought to resolve the conflict. ${ }^{26}$ Hatfield met with union officials and hammered out a compromise which called for a nine hour work day, the miner's right to select a checkweighman, semi-monthly pay, and no discrimination against union members. When he presented the new terms to an operators' delegation, Hatfield won their agreement by physically assaulting the most recalcitrant operator. Unfortunately for all concerned, the Hatfield Agreement ignored the striking miners' two most important demands, complete recognition of the union and the abolition of the mine guard system. ${ }^{27}$

To avoid open confrontation with the local miners, Hatfield encouraged the union to break with the tradition of submitting the proposed contract to a referendum vote. Hatfield and the union leaders instead called a convention of selected miners' delegates to vote on the settlement Despite the arrest of delegates who opposed the contract, the remaining miners'

${ }^{25}$ Ibid., 89, 90, 95.

${ }^{26}$ Corbin, Life, Work, and Rebellion, 95-97. A notable exception to the Court's ruling was taken by state supreme court judge Ira E. Robinson in his dissent to the majority opinion. West Virginia's State Federation of Labor remembered Robinson's position on this 1912 martial law ruling in 1916, when it officially endorsed his gubernatorial candidacy. Harold W. Houston also backed Robinson, but other leading West Virginia socialists backed Lilly. Barkey, 188.

${ }^{27}$ Corbin, Life, Work and Rebellion, 97. 
representatives debated for three days before approving the contract. Hatfield's machinations backfired however, when the rank-and-file miners of Paint and Cabin Creeks learned that the Hatfield Agreement still did not address the issues of union recognition and the abuses of the mine guard system. ${ }^{28}$

Having gained the compliance of the union leadership and the local operators, Hatfield had no patience for the miners' recalcitrance. He issued a thirty-six hour ultimatum for the resumption of work at the mines and sent soldiers to "escort" the miners to work. When two Socialist newspapers criticized Hatfield's action in the settlement proceedings, he had their offices raided and the presses destroyed. Once again national attention focused on West Virginia, and the United States Senate launched an investigation of the strike and the tactics utilized to end it. ${ }^{29}$

After several months the Senate hearings ended with a denunciation of Governor Hatfield, the military authorities of West Virginia, and the operators of the Kanawha field. The Senate committee also asserted that in their attempts to force the miners to end the strike, Hatfield and the operators had committed "numerous violations of the U.S. Constitution and several West Virginia state laws." The rebellious miners capitalized on the uproar caused by the Senate hearings to press for acknowledgement of their original demands. Under pressure, Hatfield and the operators capitulated. More than a year after the conflict began, the miners of Paint and Cabin Creeks won an agreement that guaranteed recognition of their union and an end

${ }^{28}$ Ibid., 97.

${ }^{29}$ Ibid., 98, 98-99. The newspapers sued Governor Hatfield and the National Guard but late in March 1914, the West Virginia State Supreme Court of Appeals killed the case by forbidding any further action. Williamson Daily News, 31 March 1914. 
to their oppression by the mine guard system. ${ }^{30}$

Although the miners of the Kanawha field preserved and expanded their rights as union members, the conflict itself precipitated a series of reactions that bore fruit when the miners and operators of the Williamson-Thacker field squared off in 1920. After the victory of the miners in 1913, the anti-union operators of southern West Virginia launched an organization initiative to protect their interests against future assaults from the union. The operators prepared to resist further encroachment by the union and hoped for an opportunity to "roll it back" from West Virginia's coal fields. More secure in their foothold in Kanawha County, the United Mine Workers of America continued to look for opportunities to finally organize all of southern West Virginia. $^{31}$

After their defeat in the Paint-Cabin Creek strike, the operators began a three part initiative to fortify their position against union attack. ${ }^{32}$ First, after recognizing "that in union there is strength," the operators increased the number of associations organized by fields and created a statewide operators' association. ${ }^{33}$ This movement was led by Z. T. Vinson, whose

${ }^{30}$ Ibid., 99.

${ }^{31}$ Ibid., 113, 110.

${ }^{32} \mathrm{~A}$ full scale propaganda campaign, the third element of the coal operators's anti-union initiative, was not used wholesale until the Williamson-Thacker strike began in 1920. McIntosh Memoir, WVRHC.

${ }^{33}$ Roy B. Naylor made the "in union" observation in an article titled "Commercial Organizations in West Virginia," which was published in James M. Callahan's Semi-Centennial History of West Virginia (Charleston, WV: np 1913): 319-322. In an article first published in the Pittsburgh Gazette, and reprinted in the Williamson Daily News, the founding of the West Virginia Coal Operators Association was described as "the cost of crooked politics." Citing attacks on business by aspiring politicians and recent acts of the West Virginia legislature, the West Virginia Coal Operators' Association presented itself as "an organization for self- 
confrontations with UMWA attorney Harold W. Houston during the Paint Creek hearings only confirmed his long held belief that all challenges to industrial interests in West Virginia were backed by the forces of socialism and communism. Vinson expressed these views in an address to the West Virginia Mining Institute in December 1914. According to Vinson, "the armed revolution in West Virginia ... was partially successful because there was no real co-operation" among the coal operators in resisting the United Mine Workers of America, whom Vinson characterized as robbers and outlaws. Vinson urged the operators present at the meeting to view the union as their enemy and to prepare for war, or face losing the livelihood they gained from mining coal. ${ }^{34}$

One of the operators' associations started in the post-Paint Creek period was the Williamson-Thacker Coal Operators' Association of Mingo County, whose leadership included several of Vinson's political and business allies. ${ }^{35}$ Launched in 1913, the Operators' Association of the Williamson-Thacker coal field did not take a leading role in the coal field's affairs until the strike of $1920{ }^{36}$ Throughout the First World War, another organization, the Coal City Club, voiced the concerns of Mingo's coal operators. Membership in the operators' association was considered a matter of expediency. E. L. Bailey, superintendent of the Portsmouth-Solvay Coal

protection." Williamson Daily News, 24 July 1915.

${ }^{34} \mathrm{Z}$. T. Vinson, "Advocating Co-operation and Organization of West Virginia's Coal Operation," An address before the West Virginia Mining Institute 10 December 1914, in Huntington, WV (n.p.n.d.), 5-6.

${ }^{35}$ Corbin, Life, Work, and Rebellion, 113.

${ }^{36}$ Williamson Daily News, 29 June 1919. In press statements and other public documents, the formal name of the Williamson-Thacker field's operators' association, was always printed as "The Operators' Association of the Williamson-Thacker Coal Field." 
Company, explained that his company only joined the association in order that the company's production statistics would be included in a United States Geological Survey study. ${ }^{37}$

Angered and humiliated by the press' representations of life in West Virginia's coal fields, the operators also started and/or supported a wide array of reforms designed to improve living conditions for their workers while also pacifying their discontent. Many operators voluntarily instituted semi-monthly pay periods and shorter working days. ${ }^{38}$ Some brought in welfare workers to teach personal and home hygiene to the miners' wives. ${ }^{39}$ They also underwrote the construction of Young Men's Christian Association buildings which provided a liquor-free environment for bachelor housing and leisure activities. ${ }^{40}$ In the coalfields dominated by large corporations, a campaign to construct "model company towns" also caught on as companies competed for sober, industrious workers. ${ }^{41}$ Most of these reforms reflected the Progressive era belief that an individual's environment heavily influenced their behavior. ${ }^{42}$ To the operators of southern West Virginia this meant that if they provided regular pay and a clean, regulated living

${ }^{37}$ "Testimony of E. L. Bailey, superintendent of the Portsmouth-Solvay Coal Company" West Virginia Coal Fields, 288. Bailey's reasoning for joining the Williamson operators' association illuminates the attitude of the large corporations in southern West Virginia. The Solvay company operated mines throughout West Virginia; as Superintendent Bailey's statement revealed, the company joined the operators' association out of necessity pertaining to a limited objective. Williamson Daily News, 4 January 1919. Prior to operating the Solvay mine, Bailey had been the owner-operator of the Williamson Coal Company. Mingo Republican, 15 March 1917.

${ }^{38}$ This happened in Mingo before the surrounding coalfields.

${ }^{39}$ Corbin, Life, Work, and Rebellion, 120.

${ }^{40}$ Ibid., 125.

${ }^{41}$ Ibid., 117.

${ }^{42}$ Diner, 201. 
environment, their workers would have no cause to complain; any discontent could be attributed to rabble-rousing radical outsiders. ${ }^{43}$

As discussed in a previous chapter, the development of the coal industry in Mingo County only weakly reflected the development of coal field giants Logan and McDowell Counties. The boom in model company town building only heightened the contrast between Mingo and its neighbors. Although a few of the larger and/or newer operations in Mingo provided their workers with luxuries like electricity, running water, and movie theaters, none of the company towns in Mingo compared to the planned community atmosphere of Holden, Island Creek's town in Logan County, or to Gary, the flagship company town of McDowell County ${ }^{44}$ As late as 1918, an industry publication, Coal Age, praised William Leckie for building a model company town complete with a barbershop at Fireco, Raleigh County. ${ }^{45}$ Leckie, who had investments in several southern West Virginia coalfields, did not engage in any comparable improvements at his

\footnotetext{
${ }^{43}$ Munn, 245. In constructing their company towns, the coal operators of southern West Virginia ignored the advice of one of their own trade magazines. In 1911 an article by the "Sociological Department" of Coal Age warned that company towns should not be the habitation promoted by coal companies because "the dominant note of the company town is coercion." The article also urged operators "not to [dabble] too freely into the private life of its employees ... [because even] the best of men dread the eye which follows them night and day." Coal Age 1 (11 November 1911): 158.

${ }^{44}$ Munn, 248. Munn identifies Holden as one of the first and most well-known model towns in the bituminous coal fields. Even the companies that provided luxuries like electricity usually did so for their benefit, e.g. to attract a more stable workforce, or at their own convenience. For example, Stone Mountain Coal Corporation electrified its company houses, but power was only available at night when it was needed for the preparatory work in the mine. Sallie Dickens interview with Rebecca J. Bailey, Summer 1990 Matewan Oral History Project. According to Mrs. Dickens, this meant that her mother ironed the family's laundry at eleven o'oclock.

45"Fireco- A New Mining Town in West Virginia," Coal Age 12 (12 September 1918): 1217.
} 
Mingo County mine. ${ }^{46}$

Operator-generated welfare work and prohibition faced obstacles in socially divided communities like those in Mingo County. The recipients of the benevolence often resented or ignored those attempting to improve lower class living conditions as tools of the operators or as allies of the town elites. In a report on the recurrence of typhoid in the working class communities surrounding Williamson, a state health official reported that most of the cases had resulted from the inhabitants using contaminated water despite being warned to boil it. ${ }^{47}$

As in many communities around the country, the prohibition of alcoholic beverages in Mingo County was viewed more as a political issue than as a corrective for a social ill. The distribution of liquor on election day and the granting of liquor licenses were substantial sources of political patronage. ${ }^{48}$ The decision to support or oppose prohibition and later to comply with the prohibition law often divided the coal operators and the local political machines with whom they were allied. ${ }^{49}$ Deprived of the use of alcohol as a lubricant at the polls, the machine turned to outright purchase of ballots. ${ }^{50}$ Without the graft income from the sale of liquor licenses the local machine politicians upped the ante for the corporate coal elites. In Mingo County, one of the many political fissures that weakened the Republican party between 1912 and the disastrous

\footnotetext{
${ }^{46}$ At least no records exist to indicate any such improvements.

${ }^{47}$ Biennial Report of the State Board of Health, 1908-1909, 500.

${ }^{48}$ Barkey, 51.

${ }^{49}$ See discussion of the career of R. W. Buskirk in Chapter 6.

${ }^{50}$ See discussion of the Rockhouse Case in Chapter 6.
} 
election of 1916 was the fight over prohibition. ${ }^{51}$

The uneven and often contradictory actions undertaken by the coal operators in the wake of the Paint Creek - Cabin Creek Strike were paralleled by those taken by the District 17 leadership of the United Mine Workers of America. The strike and its resolution fatally divided District 17. The men in charge of the local at the beginning of the strike failed to provide unified, effective direction for the rank-and-file. When the rank-and-file miners put forth their own increasingly radicalized leaders, like C. F. "Frank" Keeney, William H. "Bill” Blizzard, and Fred Mooney, the conservative District 17 officials denounced their new rivals. By labeling the insurgent leadership as Socialists, the old line officials held on to power because of the support of the national organization, despite rank-and-file appeals for their ouster. ${ }^{52}$

After the strike, the reactionary leadership of the UMWA's District 17 turned on the individuals who had contributed to the strike's success. ${ }^{53}$ The most important victim of the poststrike purge was District 17's lead attorney Harold W. Houston. As Secretary of the West Virginia Socialist Party, Houston had pressured the party to financially support and publicize the strike. ${ }^{54}$ Houston had also ably confronted the operators' attorney Z. T. Vinson during the Senate

\footnotetext{
${ }^{51}$ S.D. Stokes to Carl Whitney, Stokes Papers, WVRHC. Stokes reported to Whitney that in return for fifty thousand dollars from coal mogul T. E. Houston, M. Z. White and Greenway Hatfield guaranteed that E. F. Morgan, the coal operators' candidate in the 1920 Republican gubernatorial primary would carry Mingo County. See Chapter 10 for more on the political situation in Mingo County in early 1920. See also: Appendix 3.

${ }^{52}$ Corbin, Life, Work, and Rebellion, 100.

${ }^{53} \mathrm{Ibid}$. Corbin quotes an appeal sent to International headquarters in which the old District 17 leaders were described as "conservative, corrupt, and undemocratic."

54"'Telegram from Harold W. Houston to the National Executive Committee, Socialist Party, read at the meeting of the committee, 11 May 1913," reported by Grace Silver in "National
} 
Hearings. What the District 17 officials refused to overlook was Houston's alliance with the insurgent leadership. ${ }^{55}$

When Frank Keeney and the other miners had grown frustrated with the weak and vacillating leadership of their elected officers, they had turned to local Socialists for support and direction. ${ }^{56}$ Shortly thereafter, the miners initiated a "direct action" campaign and aggressively fought back against the mine guards. ${ }^{57}$ The logical inspiration for the rank-and-file's independent tactical turn was Harold Houston. Although he had first been attracted to socialism intellectually, by the summer of 1912 Houston had become a follower of Big Bill Haywood and a proponent of direct action. During a speech at Holly Grove tent colony on August 14, Houston urged the striking miners to follow the strategy Haywood had outlined for the textile workers of Lowell, Massachusetts. ${ }^{58}$ During his speech Houston exclaimed, "now let us divide the work in proportion to the proceeds." ${ }^{59}$ District 17's conservative leadership rewarded Houston for first guiding and then defending the miners of Paint and Cabin Creeks by relieving him of his duties

Committee Meeting, Socialist Party, in International Socialist Review. Pamphlet 191, WVRHC.

${ }^{55}$ This assertion is based on Houston's resumption of his role as District 17 attorney when Keeney and the other insurgents legally took control of the local.

${ }^{56}$ Corbin, Life, Work, and Rebellion, 89.

${ }^{57}$ Ibid.

${ }^{58}$ Barkey, 114.

59"Extracts from Speech of Harold W. Houston at Holly Grove, on Paint Creek, August 14, 1912," in Conditions in the Paint Creek District, West Virginia: Hearings Before a Subcommittee of the Committee on Education and Labor, Part 3 (Washington: GPO, 1913): 2263. 
as legal counsel for the union. ${ }^{60}$

The loss of Houston did not deter the insurgent miners' efforts to seize control of District 17. When the national organization refused to unseat the elected leaders, Frank Keeney, Bill Blizzard, Lawrence Dwyer, and William Petry bolted District 17 and organized a rival local. For nearly two years the "rump" local as it was called, submitted dues (which were rejected) to the national union and continued to lobby for recognition as the legitimate leadership of the Kanawha district miners. Finally in 1916, the rival local was dissolved and a district election was held. Frank Keeney was elected President of District 17 and Fred Mooney was elected Secretary-Treasurer. ${ }^{61}$

In what proved to be a fateful decision, District 17 leaders, led by Keeney, broke with Houston and the State Federation of Labor to support Democrat John J. Cornwell for governor. Houston and the State Federationists, who viewed Cornwell as a toady of the B\&O and the antiunion capitalists of the state, supported Republican candidate Ira Robinson out of gratitude for his pro-labor stance while on the West Virginia State Supreme Court of Appeals. ${ }^{62}$ Cornwell had been advised to court the labor vote in spite of his own conservative disdain for the radical leanings of leaders like Keeney. Perhaps in retaliation for Hatfield's actions during the last months of the 1912-1913 strike, Keeney and District 17's new leadership responded to Cornwell's

\footnotetext{
${ }^{60}$ Wheeling Intelligencer, 20 March 1914. The period between March 1914 and November 1916 proved trying for Houston. In the political upheavals of the election campaign of 1916, Houston was even sued by other Kanawha County Socialists "for an unauthorized use of the Party name" in campaign literature. Charleston Gazette, 30 October 1916.

${ }^{61}$ Corbin, Life, Work, and Rebellion, 100.

${ }^{62}$ Barkey, 189; Fred Mooney, Struggle in the Coal Fields: The Autobiography of Fred Mooney. (Morgantown, WV: West Virginia University Library, 1967), 59-60.
} 
half-hearted wooing. Unfortunately for the miners of Mingo County, the relationship between the officers of District 17 and Cornwell did not long survive the cooperative spirit of the First World War. ${ }^{63}$

${ }^{63}$ Fisher, 380; Mooney, 60-69. 


\section{The Unexpected Results of Coal Industry Reforms, 1912-1916:}

Had there been uniform and uncomplicated application of the coal company reforms, southern West Virginia's operators might have succeeded in lessening the union's appeal to their workforce. However, "reform" often created new problems for every one involved. The operators in the Williamson-Thacker field instituted semi-monthly paydays in 1913. The local press heralded this innovation as a boon to local business because it brought miners to town more often. ${ }^{64}$ By contrast, for the operators as a group, semi-monthly paydays were a source of discord and unease. Required to pay their miners twice a month, while only bringing in money once a month, small operations strained to secure the necessary capital and resented the larger operations who could bear the expense and always seemed to be waiting for opportunities to eliminate competitors. ${ }^{65}$ More frequent paydays also stressed operations because it created more opportunities for criminals as the case of the Glenalum payroll robbery of 1914 illustrates.

During the second week of August 1914, the Glenalum payroll robbery literally shoved the outbreak of war in Europe from local newspaper headlines. The story of the robbery and hunt for the thieves highlights early twentieth century coal company economic policy, ethnic relations, and social reaction to violent crime. After the Feud and the Massacre, the Glenalum payroll robbery is the third most infamous incident in early Mingo County history.

Around 11:00 in the morning on Thursday, August 13, 1914, a Norfolk \& Western train delivered to the Glenalum station a seven thousand dollar payroll shipment from the Glenalum Coal Company's headquarters in Lynchburg, Virginia. At approximately 11:05, Glenalum's

\footnotetext{
${ }^{64}$ Mingo Republican, 8 August 1913.

${ }^{65}$ Hinrichs, 40-41.
} 
bookkeeper F. D. Johnson, company doctor W. D. Amick, and electrician Joseph Shielor, left the station on a railroad 'speeder' to travel the four miles down a siding to the Glenalum mine and camp. One and a half miles from the mainline station a railroad tie across the tracks forced Johnson, Amick, and Shielor to stop the speeder to remove the obstruction. Shots rang out; Amick and Sheilor died before their attackers left the scene. Johnson lived long enough to describe what happened to a traveling salesman who came down the siding tracks shortly after twelve noon. The salesman raced back to the station where notification of the incident was sent to Sheriff Greenway Hatfield. ${ }^{66}$

By mid-afternoon a posse of sheriff's deputies, Baldwin-Felts detectives, coal company officers and employees, and local citizens converged on Glenalum. ${ }^{67}$ Using bloodhounds, the posse tracked the fugitives to a remote mountainous section of Mingo near Ben Creek on Kentucky border. An early report that the perpetrators of the robbery were natives whose family might harbor them from justice inspired the posse to surround Ben Creek. By Friday, these original suspects were cleared, but by then the posse had closed off all possible escape routes. ${ }^{68}$ Even though the bandits were hemmed in, in Shanty Hollow near Ben Creek, several

\footnotetext{
${ }^{66}$ Mingo Republican, 13 August 1914 and Velke, 137-141. The paper was just going to press when the first reports of the robbery came in. Velke's account was drawn primarily from a story in the Bluefield Daily Telegraph, 18 August 1914. Other than a few details, such as the deaths of Amick, Shielor, and Johnson, the only major difference between the versions of the story told by the Republican and Velke centers around who was described as being in control of the posse that pursued the thieves. The Republican depicted Sheriff Hatfield as the posse's leader while Velke emphasized the role of Baldwin-Felts detective W. W. Phaup. Mingo Republican, 8 October 1914.

${ }^{67}$ Mingo Republican, 13 August 1914, and 20 August 1914.

${ }^{68}$ Mingo Republican, 20 August 1914.
} 
factors kept the situation from resolution until Sunday morning, August 16. First, torrential rains fell Friday night which temporarily impaired the bloodhounds' ability to follow the scent trail. Second, the bandits proved to be heavily armed. Three members of the posse died after coming close enough to the fugitives to exchange gunfire. The final reason for the lengthy manhunt was that the robbers' final hideout in Shanty Hollow was in the heart of "a pathless jungle of dense thickets, deep ravines and a mass of huge vine-covered rocks. ${ }^{169}$

Attempts to assault this position were also complicated by the sheer number of people on the scene. Without the presence of Sheriff Hatfield or an experienced Baldwin-Felts agent, the posse, which had swelled to over five hundred men, turned into a disorganized mob. ${ }^{70}$ Throngs of men, women and children who had followed the posse to the hiding place, swarmed in and out of the line of fire. At one point, a burst of gunfire precipitated a stampede of the sightseers who overran the posse, who in turn dared not shoot, for fear of striking an innocent bystander. ${ }^{71}$

Sheriff Hatfield arrived on the scene late Saturday as gunfire from the bandits dwindled. Hatfield restored order by commanding the posse to cease firing randomly at the bandits. Someone recommended blasting the fugitives from their hiding place, so sticks of dynamite were brought from the nearby War Eagle coal mine. Throughout the night posse members lobbed the

${ }^{69}$ Emick R. Walls, "West Virginia's Greatest Manhunt," West Virginia Illustrated 2 (May-June 1971): 29-33, 29. Although not a scholarly analysis, Walls' account of events provides valuable details gleaned from his own memory and an interview with a posse member.

${ }^{70}$ Ibid.

${ }^{71}$ Mingo Republican, 20 August 1914. After the final assault on the bandits' position revealed that they were all dead, sightseers including Emick Walls and his mother, swarmed the scene. Walls, 33. 
explosives at the bandits, who at first threw several sticks back at their attackers. ${ }^{72}$ The next morning the posse swarmed in and killed the sole survivor of the explosions. ${ }^{73}$ Years later members of the posse recounted that the last bandit had jumped up on a log and crowed like a rooster before being shot dead..$^{74}$

The death of the last survivor kept the true identity of the gang members from ever being discovered. However, their physical appearance, and a few personal articles found with the bodies revealed that the men were Italians. ${ }^{75}$ When the bodies were transported to Williamson, local Italian residents and miners were brought in to see if they could identify the bandits, but no one claimed to recognize any of the dead men. When "one well-known Italian admitted that he would not live long if he divulged any information," local rumors that the dead men were members of the "Black Hand" seemed to be confirmed. ${ }^{76}$

Despite the fact that all but twenty dollars of the payroll money was recovered near the bandits' bodies, developments in the weeks after the robbery only heightened the unease it caused

${ }^{72}$ Walls, 32.

${ }^{73}$ Mingo Republican, 20 August 1914.

${ }^{74}$ Walls, 32, and Harold Radford interview with John Hennen, Summer 1989 Matewan Oral History Project.

${ }^{75}$ The robbers initially had also been suspected of being African-American because of the proximity of an African-American school to the crime scene. Johnny Fullen interview with Rebecca J. Bailey, Summer 1990 Matewan Oral History Project.

${ }^{76}$ Mingo Republican, 20 August 1914. According to John Velke the Black Hand as a secret, Mafia-like society, did not really exist but had been a device used to "describe any criminal of Italian descent . . . from the turn-of-the century until about 1920." Velke, 139. 
throughout southern West Virginia. ${ }^{77}$ Governor Hatfield, to no avail, had photographs of the bandits' corpses distributed throughout the state. ${ }^{78}$ The Baldwin-Felts Detective Agency, which had lost two agents in the manhunt, also initiated an investigation that yielded little. ${ }^{79}$ The detectives confirmed that although the robbers had arrived in Mingo several days before the robbery, they had not mingled with any local Italians. ${ }^{80}$

Distrust of the local Italian community failed to dissipate after it was learned that the bandits had struck on the day when the local Glenalum company officials, the mine's "special officer," who was a Baldwin-Felts agent, and the local magistrate were attending court in Williamson. Their absence had a twofold significance. First, the men who normally picked up the payroll and would have been armed and alert to possible danger were not available, which made the payroll vulnerable. Second, the search for the robbers was delayed because no one at Glenalum that day had the authority to launch the manhunt from there. By the time the bodies of Amick, Johnson and Shielor were discovered, in addition to the time it took the Sheriff to be notified and for the posse to travel the thirty miles from Williamson, the bandits had an almost

\footnotetext{
${ }^{77}$ Mingo Republican, 8 April 1915. In an odd footnote to the robbery, Sheriff Greenway Hatfield kept the blood-stained payroll money until April 1915 when he sent his wife to Huntington to turn it over to federal authorities. "The government" had replaced the original money immediately after the robbery to the Glenalum Coal Company, and had "instituted a friendly suit ... [to] be reimbursed."

${ }^{78}$ Mingo Republican, 20 August 1914. Governor Hatfield became personally involved in the story because at one point during the long weekend, he had been informed that his brother, Sheriff Hatfield had been killed by the bandits.

${ }^{79}$ Walls, 29. According to Emick Walls the two agents died because they ignored warnings from native posse members that they were heading into a "natural ambush."

${ }^{80}$ Mingo Republican, 20 August 1914, and Velke, 140-141.
} 
three hour headstart. ${ }^{81}$ That no one could explain how the bandits could have surmised all this without a local accomplice festered in the memory of local officials. Years later when a local Italian bootlegger was killed by one of Sheriff Hatfield's former deputies, rumors resurfaced that he had been involved with the bandits. ${ }^{82}$

Two incidents involving the most celebrated "hero" of the sheriff's posse, "Big Steve" Hegodish, a Hungarian miner from Glenalum, also prolonged ethnic tension after the robbery. ${ }^{83}$ Just a week after the death of the bandits, Hegodish and some friends were shot at by unidentified assailants. The Mingo Republican's accounts of the incidents revealed the community's persistent suspicion of the local Italians. According to the Republican, the attack on Hegodish only confirmed "that the five bandits ... have friends and sympathizers among their race in the coalfield." Baldwin-Felts agents were dispatched to Glenalum to investigate the attempted murder of Hegodish and other "wild tales about threatened reprisals by Italians at Glenalum." 84

Two years passed without any newsworthy developments. Then, in late August 1916, trouble erupted again between "Big Steve" Hegodish and the Italians of Glenalum. The Mingo

${ }^{81}$ Mingo Republican, 13 August 1914.

${ }^{82}$ Venchie Morrell interview with Rebecca Bailey, Summer 1990 Matewan Oral History Project. Mr. Morrell also had been interviewed in 1989 by John Hennen. Subsequent references to Morrell interviews will include which Morrell interview is being cited.

${ }^{83}$ Walls, 31. Hegodish's bravery had been confirmed by two separate incidents. First, after the two Baldwin-Felts agents were killed, Hegodish crawled to their bodies in order to cut the leashes of their bloodhounds from their wrists; he lost a thumb from the bandits' gunfire. The next day, while still with the posse, "he caught a live rattlesnake in his hat and played with it."

${ }^{84}$ Mingo Republican, 27 August 1914. 
Republican reported that "Big Steve"'s brother got into a fight with the children of an Italian neighbor, Paul Costo. Costo intervened and the Hegodish brothers knocked him down. Costo's children brought his gun from their house and he shot "Big Steve" in the hip. ${ }^{85}$ When another Italian, Angelo Corona, "armed himself with a pistol in defense of his countryman," the authorities issued a warrant for his arrest. Corona fled to Iaeger in neighboring McDowell County, but was captured and returned for trial before a local magistrate. Corona demanded a jury trial and won his freedom when the jury could not agree on whether to convict him. ${ }^{86}$ Unfortunately for the ethnic miners at Glenalum, the Mingo Republican exploited the neighbor's quarrel between Hegodish and Costo. While reporting that Corona would probably leave Glenalum because of the high state of feeling aroused by the Hegodish-Costo conflict, the Republican offered no explanation for why tensions in the community were running so high. ${ }^{87}$ At one point, the Republican asserted that "a race war seemed imminent as a result of the shooting." Several native whites who lived near Glenalum and had participated in the manhunt traveled to Williamson to ask Sheriff Hatfield for "protection." As in the earlier incident involving Hegodish, after the initial uproar, nothing else appeared in the public record. Neither Hegodish nor Costo faced any charges stemming from the incident. ${ }^{88}$

${ }^{85}$ Mingo Republican, 31 August 1916.

${ }^{86}$ Mingo Republican, 7 September 1916.

${ }^{87}$ Kenneth Bailey's "A Judicious Mixture," reveals that coal operators intentionally "mixed" ethnicities in their workforce as a means of keeping the men divided. Steven J. Diner asserts that "members of ethnic groups occupying the same neighborhood often clashed." Diner, 72.

${ }^{88}$ Mingo Republican, 22 February 1917. Steve Hegodish apparently could not shake the paranoia spawned by the events of 1914-1916; in February 1917 he served time in the Mingo County jail on a "pistol-toting charge." 
The long shadow of the Glenalum payroll robbery affected how the Italian families who established permanent roots in Mingo were integrated into the merchant communities in towns around the county. Some of the families found protection through alliances with white powerbrokers, and thus joined the traditionally structured clientelist systems. One woman remembers that her father worked as an "undercover man" for Greenway Hatfield. When he no longer felt safe working in the mines, he moved to Williamson and Hatfield helped launch his first business. ${ }^{89}$

In addition to exposing ethnic tensions in Mingo County and southern West Virginia's coalfields, the Glenalum payroll robbery underscored the financial vulnerability of the southern West Virginia coal industry. Much has been written about the exploitive nature of paying miners in scrip, but the precarious balance between using scrip as a coercive credit system and providing cash for paydays revealed the immaturity of the region's infrastructure. The Glenalum payroll traveled safely by rail from Lynchburg, Virginia to Glenalum, West Virginia, a distance of 250 miles. The money only traveled an additional thirty miles, but the remote isolation of the four short miles between the Glenalum railroad station and the Glenalum mines provided all the privacy needed by the robbers.

The other event which encapsulated the 1912 to 1916 period for the coal industry in Mingo County was the Cinderella mine fire. Opened in 1912, the Sycamore Coal Company's Cinderella mine utilized the latest technology. ${ }^{90}$ There were no pick miners at the Cinderella

\footnotetext{
${ }^{89} \mathrm{Nel}$ (Gentile) Nenni interview with John Hennen, Summer 1989 Matewan Oral History Project.

${ }^{90} 1912$ Annual Report of the West Virginia Department of Mines, 368.
} 
mine; electric machines undercut the coal, and mules and electric motors hauled it to the surface.

91 Three six-foot fans ventilated the mine. ${ }^{92}$ The only safety concern noted by state mine inspectors was a tendency for the roof to be bad in places, which the company addressed by "careful" timbering and removal of the bad sections. ${ }^{93}$ Evan Thomas, the mine's superintendent from its opening through the strike period, was an active community leader. ${ }^{94}$ Under his guidance, the Sycamore Coal Company's Cinderella operation became known as one of the "model" mining towns of the Williamson-Thacker field. ${ }^{95}$

1914, the year of the Cinderella mine fire, was also a peak year for the coal field before America's entry into World War I. The mines averaged 243 working days in 1914, compared to 227 in 1912 and 226 in 1916. Although the number of companies remained the same between 1912 and 1914, and only increased by one by 1916, twelve new mines opened between 1912 and 1914 and three more opened by 1916 . The selling price of Williamson-Thacker coal hit a decade high of $\$ 1.17$ per ton in 1914 . The same ton had brought only $\$ 1.01$ in 1912 and dropped back to

${ }^{91}$ Ibid., 65, 315. Subsequent Annual Reports substantiate that from its opening through the strike period, the Cinderella mine did not employ pick miners.

${ }^{92}$ Ibid., 315.

${ }^{93}$ Ibid. State mine inspectors filed virtually identical positive reports over the next several years. The Cinderellla mine rated "good" or "very good" in all categories including drainage, ventilation, and lack of explosive gas.

${ }^{94}$ Mingo Republican, 9 March 1916. Thomas served as president of the Lee district board of education.

${ }^{95}$ Ibid. 
$\$ 1.03$ in $1916 .^{96}$ In 1914 , the Cinderella mine ranked sixth out of 21 companies in production, falling behind only the largest producers in the field. ${ }^{97}$

At or near midnight on June 30, 1914, the fanhouse of the well-maintained Cinderella mine caught fire. By the time the night foreman noticed the flames, they had spread to a wooden chute that shunted air from the fans to the newly opened seam, where five men were working. The forced air from the fans propelled the fire into the mine causing the first stopping, the entry timbers, and even the coal in the first room to catch fire. The rapid spread of the fire trapped the five men inside and prevented an easy rescue attempt. For the rest of that night, a crew of men tunneled twenty-seven feet to reach the room where the night crew had been working. By their appearance, all five men, including two brothers, were slowly asphyxiated by gases produced by the burning coal and timbers and never attempted to escape. ${ }^{98}$

The Williamson Daily News reported that an electrical short circuit had started the fire, but the Department of Mines blamed the miners' deaths on human error. ${ }^{99}$ According to Department Chief Earl Henry, the mine foreman tried to destroy the chute instead of cutting off the fan. The chief also observed, "accidents of this character fully demonstrate that fan houses should be constructed of non-combustible material, especially where the fan is operated as a

\footnotetext{
${ }^{96}$ Based on data extrapolated from Annual Reports of the West Virginia Department of Mines, 1912-1916.

${ }^{97}$ Based on data extrapolated from the 1914 Annual Report of the West Virginia Department of Mines, production tables, 146-7.

98"Mine Fire: Cinderella Mine of the Sycamore Coal Company" in the 1914 Annual Report of the West Virginia Department of Mines, 70.

${ }^{99}$ Williamson Daily News, 9 July 1914, and 1914 Annual Report of the West Virginia Department of Mines, 70.
} 
force fan." ${ }^{100}$ The Cinderella mine fire demonstrates that in the Progressive Era, even the best maintained mines were dangerous workplaces. The report on the disaster also illustrates that industry experts viewed innovation as a cure for accidents, not a new source of problems, it remained easier to blame humans..$^{101}$

\section{Conclusion:}

On the eve of America's entry into the First World War, the Williamson-Thacker coal field stood at a crossroads. Increased production obscured the fact that the field's rate of growth had slowed, while the cost of production had risen. Corporate consolidation in Mingo had continued, but new highly capitalized ventures focused on the fields around the county. Despite the heightened presence of U.S. Steel and Ohio investors the field remained a subsidiary interest for these corporate giants. As future events would prove, maintaining the non-union status of the Williamson-Thacker field meant keeping a buffer zone between the unionized Central Competitive Field and the more important fields in eastern Kentucky and eastern southern West Virginia.

The first West Virginia mine war failed to resolve the central conflicts in West Virginia's coal industry. The miners of Paint Creek and Cabin Creek had won union recognition and the

${ }^{100} 1914$ Annual Reports of the West Virginia Department of Mines, 70.

${ }^{101}$ Dillon, 47-49. Lacy Dillon's account of the Cinderella mine fire reveals the Department of Mines' own culpability for the disaster. According to Dillon, the Department allowed the Sycamore Company to ventilate the mine by placing the primary fan in a lower seam and shunting air to the upper seam through the infamous wooden chute. Delay in cutting off the fan let the chute and the coal in the surrounding shaft ignite and spread the flames and fumes. Dillon also asserts that had the men who died realized the danger they were in, they could have retreated into the space eventually breached by the rescue team and survived. 
end of the mine guard system for themselves, but not their brethren in the surrounding southern West Virginia fields. The inability of District 17 's conservative leadership to win the strike had resulted in a rank-and-file revolt that brought a new group of officers to power. Young, native, and radical, these men had learned that forging new political alliances increased their bargaining power with state leaders. They also learned that invoking traditional values drew more of their fellow miners to their cause, and that a strategic use of violence increased their access to the court of public opinion.

Observing the forced acquiescence of the Paint Creek and Cabin Creek operators only enhanced the desire of anti-union operators to contain the union presence in the state. The operators instituted social welfare programs and other reforms, while organizing themselves in an attempt to stave off the Union's advance. However, as this chapter has shown, these initiatives met with mixed success in the Williamson-Thacker Field. The uneven and half-hearted improvement of living and work conditions, combined with a declining standard of living and job security, only increased discontent among Mingo’s miners.

The First World War exacerbated the already strained economic and social tensions in Mingo County and the Williamson-Thacker Coal Field. Benefitting less from the "war boom" and federal regulation of the industry, the Williamson-Thacker field fell further behind its neighbors. Efforts to construct social consensus disguised as patriotic "unity" accelerated the polarization of divergent community values in the county. The lingering political grievances from the faction wars, combined with war-induced economic and social destabilization, created in Mingo County the fertile soil the union needed to renew its assault on the anti-union coal empire of southern West Virginia. 


\section{CHAPTER 8}

\section{WORLD WAR I AND THE MARGINALIZATION OF \\ THE WILLIAMSON-THACKER COAL FIELD, 1914-1919}

"There will be no unrest here unless [the] operators get excited."1

-- Mingo County Sheriff G. T. Blankenship, November 1919

When the United States entered the First World War, 70 percent of the nation's mechanical energy came from coal and a full quarter of that coal came from West Virginia. ${ }^{2}$ Forty percent of West Virginia's coal came from its four southernmost counties, one of which was Mingo. ${ }^{3}$ In 1917, the year President Wilson declared war on the Triple Alliance, coal production in Mingo County's Williamson-Thacker coal field reached three million tons for the first time. ${ }^{4}$ Traditionally, historians have asserted that the war dramatically increased the demand for coal and helped smaller, peripheral coal fields and mines escape absorption through corporate consolidation. ${ }^{5}$ However, after peaking in 1917, Williamson-Thacker coal production declined for over half a decade. ${ }^{6}$ The drop in Mingo's production figures before the war's end can only be understood in the context of the Williamson-Thacker field's reaction to the imposition of federal

\footnotetext{
${ }^{1}$ Mingo County Sheriff G.T. Blankenship to Governor John J. Cornwell, 5 November 1919, Cornwell Papers, WVRHC.

${ }^{2}$ Corbin, Life, Work, and Rebellion, 185.

3"Houston Brief," 40.

${ }^{4} 1917$ Annual Report of West Virginia's Department of Mines.

${ }^{5}$ Soule and Carosso, 507. In 1957, economic historians Soule and Carosso asserted that federal price-fixing stabilized the market for coal and allowed marginal mines to maintain production.

${ }^{6} 1917-1922$ Annual Reports of West Virginia's Department of Mines.
} 
regulation on the coal industry. The "order" imposed on coal production accelerated the marginalization of the Williamson-Thacker coal field and reinforced the siege mentality of the men who guided and represented the field's interests. ${ }^{7}$ In particular, the coal elite of the Williamson-Thacker field emerged from the war period determined to fight any further interference in their right to autonomously guide the economic future of Mingo County.

\section{The Boom Before America's Entry into the War:}

The coal industry experienced "a wonderful development" during the first years of the war. ${ }^{8}$ Before the United States' entry, Mingo's existing mines produced more coal in fewer days and profit increasingly outstripped the cost of production. Several companies capitalized on the situation by opening new mines, making improvements at existing mines or selling out to larger corporations. According to the Mingo Republican, most of the new operations were opening "almost at the city gates" of Williamson. Relatively new companies that had bought older mines,

such as E. L. Sternberger and Stone Mountain also instituted changes. Sternberger put in a new conveyor belt and made preparations to open a new seam, while Stone Mountain increased the

\footnotetext{
${ }^{7}$ The reader is reminded that Chapter 4 of this study describes how from its opening, the Williamson-Thacker field struggled for survival, which promoted the development of an adversarial posture among the elites whose political and economic influence depended on the field's well-being.

${ }^{8}$ Mingo Republican, 15 February 1917. According to this article the coal boom's tangental effect was improvement of the Tug River Electric Company's plant. Like its coal supplier, the Crystal Block Coal \& Coke Company, Tug River Electric was a U.S. Steel subsidiary that supplied electricity to Williamson, Matewan, and more than twenty coal companies.
} 
number of its mines by installing two new openings, one west of Matewan and one on Mate Creek, half a mile from the town." 9

The most significant development in the Williamson-Thacker field before the United States entered the war came in February 1917, when the Mingo Republican announced that the United Thacker Coal Company holdings were for sale. Encompassing nearly sixty thousand acres and three coal seams, of four, five, and six feet thicknesses, United Thacker's lands had never been leased or developed. Given the size and potential value of the UTCC lands only the most heavily capitalized corporation could have afforded to buy them outright. To ensure its potential investment, U.S. Steel sent Colonel Edward O'Toole, the general manager of its southern West Virginia holdings, and Howard N. Eavenson, the leading coal expert in America to "inspect" the UTCC lands. In marked contrast to the speculative gambles of a generation before, the O'Toole/Eavenson inspection required shipping nine car loads of coal to laboratories for analysis. ${ }^{10}$ Although the U.S. Steel-United Thacker deal was not finalized for months, the prospect of the giant corporation's move into Mingo dovetailed with existing improvement and expansion efforts to "advance" the price of coal lands in the county. ${ }^{11}$

Six months after the Mingo Republican first reported the possible sale of the United Thacker Coal Company's land in Mingo and Logan counties, the U.S. Coal \& Coke Company bought fifty thousand acres, the majority of UTCC's Mingo holdings. The purchase included: "all of UTCC holdings on Island Creek in Logan County and on Gilbert, Horsepen, Ben and

\footnotetext{
${ }^{9}$ Mingo Republican, 15 March 1917.

${ }^{10}$ Mingo Republican, 15 February 1917.

${ }^{11}$ Mingo Republican, 15 March 1917.
} 
Beech creeks in Mingo and part of its holdings on Pigeon Creek." The Republican celebrated the news because U.S. Coal \& Coke would have to expand rail development in order to fully exploit its property, and because several impediments had been overcome to secure the sale. ${ }^{12}$

Mingo County's experiences in the 1914 to early 1917 period reflected similar developments in southern West Virginia's other coal counties. W. R. Thurmond, a pioneering coal operator and amateur historian of southern West Virginia's coal history, observed that "the runaway market during the First World War attracted a number of operators that soon disappeared" leaving "the very large and heavily capitalized companies ... to dominate the market." ${ }^{13}$ The creation and short history of the Wigarb Mining Company illustrates how the boom of the early war years affected coal production in Mingo County.

The chief investors and officers of Wigarb included: L. E. Armentrout, the superintendent of the Borderland Coal Corporation, and George Bausewine, Jr. and C. M. Gates of the Crystal Block Coal \& Coke Company operations at Sprigg. ${ }^{14}$ Armentrout ran Borderland for several powerful politicians and businessmen from Virginia, and his importance to the local operation was signified by the designation of the local post office as "Armen." ${ }^{15}$ As the chief officers of the U.S. Coal \& Coke, (U.S. Steel) subsidiary Crystal Block mines at Sprigg, Bausewine and Gates were equally powerful figures in the local coal community. Both were members-officers of the

${ }^{12}$ Mingo Republican, 27 September 1917.

${ }^{13}$ Thurmond, 40.

${ }^{14}$ Mingo Republican, 3 May 1917.

${ }^{15}$ Borderland's owner, Edward F. Stone was a successful businessman of southwestern Virginia, another of the corporation's officers-investors was Virginia Congressman James P. Woods. For more on Borderland, see Crandall Shiffllett's Coal Towns. 
Coal City Club. Bausewine also served as an officer of the Williamson Coal Operators'

Association. The organization of Wigarb reveals the go-go atmosphere of the early war period, when the lure of profit inspired the local managers of larger corporations to sink their own funds into coal production. ${ }^{16}$

Before the Unites States entered the war, the consolidation moves of companies like Island Creek and U.S. Steel between 1914 and 1917 attracted unwelcome attention. On March 6, 1917, a New York grand jury charged by the Justice Department with investigating the high cost of food and fuel indicted ten corporations and sixteen individuals involved in the business of producing or selling coal. The indictment alleged that in violation of the Sherman anti-trust act, the accused agreed to "fix" the price of coal at double the previous year's price and to "pool" the proceeds of the sales. All of the indicted corporations operated in the Pocahontas and New River coalfields. No Williamson-Thacker coal companies were named in the suit. However, several of the indicted operators were investors and/or officers in Mingo operations. The list included several of southern West Virginia's most powerful coal men: T. E. Houston, Isaac T. Mann, William Leckie, S. W. Patterson, and Lawrence E. Tierney. ${ }^{17}$ By the end of March, when the date for a trial was set, the list of the indicted coal corporations and operators included 108

\footnotetext{
${ }^{16}$ Williamson Daily News, 10 December 1920. The Wigarb Coal Company also became a victim of the post-war slump and labor strife. No production figures were published for Wigarb in the 1920 Annual Report of the Department of Mines, although it was reported in early December 1920, that Wigarb and several other mines were about to resume production.

${ }^{17}$ Mingo Republican, 8 March 1917. David Alan Corbin in Life, Work, and Rebellion cites this case as an example of the "operators' lack of patriotism," and allows the reader to assume that from the beginning of the case, the operators were charged with violating the Lever Act, a federal law not passed until after America entered the war and some five months after the original indictments were handed down. Corbin, Life, Work, and Rebellion, 185.
} 
corporations and sixty-six operators from southern West Virginia and southwestern Virginia. ${ }^{18}$ Not long after the indictment of the southern West Virginia "war profiteers," the Federal Trade Commission issued a report advocating the "pooling" of all coal production."19

\section{Wartime Regulation Transforms Coal Industry Relations:}

The United States' entry into World War I significantly affected relations both within the coal industry and between the industry's leaders and government officials. Disillusioned by previous peacetime efforts to bring the coal industry's endemic and persistent problems with cutthroat competition and overproduction under control, Progressives in the Wilson administration used the war crisis to seize control of the industry. ${ }^{20}$ Initially justified as an attempt to punish and prevent further war profiteering by the corporate giants who dominated the national coal industry, federal regulation ultimately became another weapon of those same corporations in their fight to eradicate their smaller, poorly capitalized competitors. ${ }^{21}$ This phenomenon is illustrated by the contrasting response to federal regulation by the Williamson-Thacker coal elite and the more powerful coal men of the Guyan and Smokeless Coal Fields.

\footnotetext{
${ }^{18}$ Mingo Republican, 29 March 1917. Two cases were actually filed by the Justice Department. One case was dismissed, but what came of the case against the southern West Virginia operators is not known. Johnson, The Politics of Soft Coal, 47.

${ }^{19}$ The FTC report originally intended to be a "study of overdevelopment in coal ... [turned] into an investigation of shortages and price increases." Johnson, The Politics of Soft Coal, 32.

${ }^{20}$ Ibid., 12.

${ }^{21}$ Ibid., 60.
} 
In late June, 1917, and only one week following the publication of the FTC "pool" report, four hundred operators converged on Washington. During a three day conference sponsored by the Committee on Coal Production, FTC Commissioner Frank J. Fort urged the operators to lower prices voluntarily. The coal industry followed Fort's advice and set maximum prices at three dollars a ton. The plan backfired miserably. Barely less than the price for which the Justice Department won the initial extortion indictment in March, the voluntary maximums ignited public outrage. The cooperative action among so many coal operators also convinced many Progressives in the Wilson administration that a "coal trust" existed and needed to be policed. ${ }^{22}$

The industry's second move to protect its interests only reinforced the belief that the coal operators' actions stemmed from ulterior motives. Between late July and early August, 1917 the coal industry founded the National Coal Association. Previous attempts to create an effective national organization, to promote a good public image for the industry and protect its interests in the halls of power, had failed. The last serious effort, in 1909, had collapsed because southern coal operators refused to join out of fear that membership translated into tacit recognition of the union. The successful organization of the NCA in the summer of 1917 proved to be a strategic blunder. The NCA's apparent unity led government officials to condemn "an essentially fragmented and leaderless industry as if it were a monopoly." ${ }^{.23}$

\footnotetext{
${ }^{22}$ Ibid., 19, 34-43. Created by the Committee for National Defense, the Committee on Coal Production consisted of fifteen members including representatives of coal operators, miners and consumers.

${ }^{23}$ Ibid., 59, 25, 19.
} 
"When America entered the war, the [coal] industry ... was disorganized, highly competitive, inefficient and wasteful." ${ }^{24}$ Once heralded as the very source of America's modernization, by the height of the Progressive era, the national coal industry was perceived as a reactionary, ill-managed relic of a bygone age. ${ }^{25}$ Citing the need to ensure a steady supply of coal for the war effort, President Woodrow Wilson on August 23, 1917, authorized the federal government to control the national distribution of coal. The president's directive divided the country into twenty-nine production-distribution districts. Particularly angered by the coal industry's voluntary maximum price of three dollars a ton, President Wilson used the June FTC report on the cost of coal production to set maximum prices at a nearly a third less. West Virginia's coal prices were set at $\$ 2.00$ a ton for run of mine, $\$ 2.25$ for prepared sizes and $\$ 1.90$ for slack or screened coal. ${ }^{26}$ Following Wilson's lead, Congress passed the Lever Act, which authorized the creation of an agency to implement regulatory policies regarding the sale and distribution of coal. ${ }^{27}$ Stunned by the public and federal reaction to what it believed had been a patriotic action, the coal industry felt betrayed by the Federal government's rejection of its

${ }^{24}$ Ibid., 19.

${ }^{25}$ Ibid., 51. In the Invention of Appalachia, Allen Batteau argues that the popular view of Appalachia in the Progressive era influenced media representations of the coal industry as "sick' . . . irrational, unprogresssive, [and] violence-prone.” Allen W. Batteau, The Invention of Appalachia (Tucson: University of Arizona Press, 1990), 125.

${ }^{26}$ Mingo Republican, 23 August 1917. Coal from the New River field was priced a little higher than the coal from the other West Virginia fields.

${ }^{27}$ Johnson, Politics of Soft Coal, 48-49. 
voluntary self-regulation. ${ }^{28}$ Although the price control recommendations had been based on the FTC cost of production estimates the move still outraged the industry and their political allies. ${ }^{29}$

The coal industry had so "little clout" in Washington, it could not even influence the wording of the Lever Act, which passed through the Senate in a vote of fifty to twenty-seven. ${ }^{30}$ The lack of unity and the level of disorganization was so high in the coal industry, the newly founded National Coal Association could not even orchestrate an official response to federal regulation. Some operators wanted to challenge Wilson's prices in the courts, but others, like James D. Francis, president of Island Creek Coal Company believed that reasonable profits could be earned even with the two dollar minimum price. ${ }^{31}$ The division within the National Coal Association reflected the differences between operations like U.S. Coal \& Coke, Island Creek and the myriad of smaller companies that dotted southern West Virginia.

Companies such as Logan County's Island Creek and McDowell County's U.S. Steel subsidiary, U.S. Coal \& Coke, which were securely capitalized and integrally linked to multiindustry conglomerates, could absorb the cost of federal regulation. ${ }^{32}$ Moreover, these leading

${ }^{28}$ Ibid., 45.

${ }^{29}$ Mingo Republican, 23 August 1917. In the same issue, Mingo's state senator and president of the state senate, Wells Goodykoontz blasted President Wilson for "scapegoating" the coal industry, while allowing other essential commodities to go unregulated.

${ }^{30}$ Johnson, Politics of Soft Coal, 46, 50.

${ }^{31}$ Ibid., 50.

${ }^{32}$ Goodykoontz's complaint about the railroad, particularly about the sidings, allows an illustrative contrast in relative "power" to be made. As Andrew Roy had noted in 1899, Williamson-Thacker coal operations were forced to fund the construction of their sidings. By contrast, when Island Creek, pioneered the opening of Logan County's Guyan field in 1904, it successfully demanded that the railroad voluntarily supply the necessary connections, because if 
producers of coal ultimately were able to emulate better organized industries with political influence and established a successful working relationships with the Wilson administration. ${ }^{33}$ Comparison of U.S. Steel's 1914 and 1917 profit figures illustrates how the large corporations not only survived the vicissitudes of the wartime economy, but also thrived under government regulation. In 1914, U.S. Steel's annual profits were \$76 million dollars, in 1917 annual profits were $\$ 478$ million dollars. ${ }^{34}$

By contrast, even before the imposition of federal regulation, the representatives of the smaller, peripheral coal fields angrily denounced the move. In June, 1917, the president of West Virginia's state senate and Mingo's own state senator, Wells Goodykoontz wrote to two West Virginia congressmen, Senator Howard Sutherland and fifth district Representative Edward Cooper, and condemned national control of coal production as a "fanatic extreme." Goodykoontz asserted that the adequate production of coal could only be secure if businessmen were "left free to earn reasonable profits." Goodykoontz declared that the real trouble lay with the railroad industry. If the railroads would deliver on their promises of more coal cars, and build more sidings to mine sites, coal prices would come down, without "the county [being] Germanized." ${ }^{35}$ Throughout the course of the war, Goodykoontz maintained his barrage on behalf of small coal producers. In addition to berating the railroad industry, he railed at the injustice of the

it did not, Island Creek would build its own, or barge their coal out if necessary. Island Creek won. See Chapter 4 for details.

\footnotetext{
${ }^{33}$ Johnson, Politics of Soft Coal, 50.

${ }^{34}$ Diner, 236.

${ }^{35}$ Williamson Daily News, 28 June 1917.
} 
escape of steel, copper, and cotton from any regulation. As Goodykoontz noted, even wheat had been protected by a minimum price, only coal had been singled out "as a burnt offering to the people." ${ }^{136}$ The coal boom of 1916 had not only elevated the price of coal, as Goodykoontz noted, the increase in the expense of coal production combined with price-fixing threatened to "whittle down coal prices to a ruinous figure. ${ }^{37}$ Poorly or precariously capitalized companies simply could not absorb the higher production costs, competition for workers, and the limited rate of return that accompanied wartime regulation..$^{38}$

\section{The Establishment of the Fuel Administration and The Effect of Its Policies:}

Created by the Lever Act in late August 1917, the Fuel Administration, for the duration of the war directed the implementation of the guidelines stipulated by President Wilson's executive order. The head of the agency, Dr. Harry A. Garfield and his top assistants were almost all professional academics with no intimate knowledge of the industry they intended to supervise. The son of president James A. Garfield, and a personal friend of Woodrow Wilson, Harry Garfield had been the president of Williams College before accepting appointment as Fuel

${ }^{36}$ Mingo Republican, 23 August 1917.

${ }^{37}$ Ibid.

${ }^{38}$ Not all of Mingo's political leaders sympathized with the operators' "plight," as the following observation by Williamson attorney, Democratic politician and businessman S. D. Stokes emphasizes. According to Stokes, "Business here [in Mingo] seems to be good, although the coal operators, for the lack of something to talk about, are still chewing the rag on the street corners about coal prices, when ... I know that at two dollars a ton they will really make more than they are entitled to when one considers the amount of capital they have invested, and the brains they use to lubricate the business." S. D. Stokes to J. A. Ferrell, 19 September 1917, Stokes Papers, WVRHC. 
Administrator. ${ }^{39}$ His only preparation for the position had been a previous assignment to study the impact of federal price control on wheat production. ${ }^{40}$

Although many in the coal industry initially applauded Garfield's ascension as Fuel Administrator because they feared the appointment of more radical candidates, Garfield's attitude toward the business community soon elicited concern. Garfield agreed with "socialist engineering wizard" Charles Steinmetz that the war "rang the death knell for chaotic individualism in economic and political life." When given control of the Fuel Administration Garfield and his staff excluded representatives of the coal industry from critical decisions. ${ }^{41}$

Early support for Garfield transformed into bitter denunciation. The pronouncements of the Mingo Republican illustrates the timbre of the anti-Garfield mutterings. Citing the existing anthracite shortage as an example of Garfield's mismanagement, the Republican lashed out at the Administration's apparently inept handling of the pending crisis -- "the coal question is reaching a point where it cannot be settled by the issuance of biographical data by Dr. Harry A. Garfield and his corps of gifted literary assistants." The Republican went on to note that conditions in the bituminous industry were rapidly approaching the same dangerous levels because federal policies had created an untenable imbalance between the supply and demand for coal. Precipitated by

\footnotetext{
${ }^{39}$ Johnson, Politics of Soft Coal, 54. Despite Garfield's lack of qualifications, some in the industry admired him as an individual. One, George C. McIntosh, a West Virginia newspaperman and coal industry propagandist eventually worked for Garfield. McIntosh Papers, WVRHC.

${ }^{40}$ George C. McIntosh, despite close ties to West Virginia's coal industry, admired Garfield for being "deliberate," "conscientious," and "patriotic." McIntosh Papers, WVRHC.

${ }^{41}$ Ibid. Despite his respect for Garfield as an individual, McIntosh observed that the Fuel Administration was a "hastily thrown together operation" full of men who "cussed and anathematized" the coal operators whom they blamed for the nation's fuel problems.
} 
price-fixing, mine closings in more than a dozen states endangered the production and shipment of war materiel. Undersupplied with coal, government contractors nonetheless were expected to produce goods at "rush order" speed. The Republican warned that the discontinuity between industrial production and fuel supply had led to overtapping of coal reserves and would generate a dangerous shortage. ${ }^{42}$

The Mingo Republican and self-appointed Williamson-Thacker spokesman Wells Goodykoontz were particularly angered by Garfield and staff's ignorance or lack of concern for the industrial idiosyncrasies that affected coal mining along the Tug Fork River. The efforts of the Republican and Senator Goodykoontz highlight how the macrocosmically designed Fuel Administration policies disadvantaged the operators of the Williamson-Thacker field.

Among the smallest and weakest mines in southern West Virginia were the "wagon mines," that did not produce enough coal to either justify or pay for a direct rail connection or "siding" to their mines. Instead these mines had to haul their coal in wagons to the nearest coalloading rail location, hence the name wagon mines. On behalf of the wagon mines in Mingo County, Goodykoontz launched a campaign to persuade the Fuel Administration to make exceptions for these small mines. ${ }^{43}$

Goodykoontz began by seeking clarification of the Administration's policy regarding wagon mines. Responding for the Fuel Administration, P. B. Noyes explained to Goodykoontz that reasonable charges for hauling could be added if the mines were transporting coal to local

${ }^{42}$ Mingo Republican, 11 October 1917.

${ }^{43}$ Williamson Daily News, 14 August 1920. According to the Daily News, "the great wartime demand for coal" had led to the proliferation of wagon mines in Mingo. However, as this chapter shows, the boom period for these mines ended with federal regulation. 
consumers or to the railroad if the railroad was purchasing coal for its own consumption. ${ }^{44}$ An article in the September 27, 1917 issue of the Mingo Republican revealed that these stipulations provided no relief for Mingo's wagon mines. Convened to discuss ways and means of securing relief from the price of $\$ 2.00$ per ton for coal, a meeting of Mingo's wagon mine operators resulted in the decision to send a three man committee to Washington to meet with Fuel Administrator Harry A. Garfield. The impetus for the meeting and the appeal to Garfield stemmed from the fact that many of the small operators in Mingo had been compelled to stop producing coal. ${ }^{45}$

However, by the time Mingo's small operators decided to appeal for relief, the Fuel Administration had been forced to acknowledge that coal production had fallen following Wilson's announcement. ${ }^{46}$ When Garfield realized that the imposition of the two dollar limit had "priced out" the marginal producers, he moved to rectify the situation. Just two weeks after the meeting in Williamson, the Fuel Administration authorized wagon mines to charge an additional seventy-five cents per ton where the coal is loaded into box cars. ${ }^{47}$ Unfortunately, this small concession did not help the mines already driven out of the market, nor did it provide relief for the wagon mines of Mingo County. As the Mingo Republican revealed, unlike other railroads,

${ }^{44}$ P. B. Noyes to Wells Goodykoontz, 21 September 1917. Copy of letter sent by Goodykoontz to S. D. Stokes. Stokes Papers, WVRHC.

\footnotetext{
${ }^{45}$ Mingo Republican, 27 September 1917.

${ }^{46}$ Johnson, Politics of Soft Coal, 57.

${ }^{47}$ Mingo Republican, 11 October 1917.
} 
the N\&W did not use many box cars for transportation, and coal had to compete with merchandise and other freights for the remaining limited space. ${ }^{48}$

The actions of the Norfolk \& Western in the late summer and early fall of 1917 further exacerbated the frustration felt by Mingo's small operators and their advocate Goodykoontz. sought to help them. While price regulation cut its first swathe through Mingo's small mines in August and September 1917, the N\&W purchased operations at Vulcan and Chattaroy in order to secure a coal supply in Mingo County. The N\&W's expansion of its captive coal supply nullified the minor concession of the Fuel Administration which allowed wagon mines to charge extra for coal provided to railroads. Moreover, the N\&W's insufficient supply of freight cars further compounded the wagon operators' dilemma. Obsessed with holding coal operators accountable for coal price inflation, the federal government blithely disregarded the N\&W's self-serving actions. $^{49}$

The Fuel Administration also ignored the economic implications of its policies' geographic determinants. For example, West Virginia and Kentucky coal sale rates were set differently despite the irrelevance of their sharedl border. Several mines in the Pond Creek district of Pike County, Kentucky actually dumped their coal onto trains passing through the Williamson-Thacker district of Mingo County, West Virginia. The mines of both the Pond Creek and Williamson-Thacker districts tapped into the same three seams of coal: the Thacker, Pond Creek, and Winifrede. Disregarding the unique conveyance system and the commonality of the coal produced in the two districts, the Fuel Administration allowed the Pond Creek operators

\footnotetext{
${ }^{48}$ Ibid.

${ }^{49}$ Ibid.
} 
to benefit from the Kentucky price for coal, which exceeded the West Virginia rate by forty cents per ton. ${ }^{50}$

Although the challenges faced by operators in fields like the Williamson-Thacker field failed to substantively affect Fuel Administration policies, the onset of the winter of 1917-1918 dramatically influenced the course of government control of the national coal industry. A difficult adjustment to wartime industrial production and one of the coldest winters in American history threatened social stability and led to outbreaks of civil unrest. Residents of Ohio communities suffering from coal shortages tore up the train tracks bypassing them on the way to industrial centers, while people in Brooklyn rioted for fuel for their homes. ${ }^{51}$ Allowed by the government to be "underfinanced and undermaintained" for years, the railroad industry could not meet the demands of the war and the public that winter. By December the railroads were effectively paralyzed..$^{52}$

President Wilson and other federal officials were forced to acknowledge that the coal industry was not solely responsible for the inadequate and uneven distribution of the nation's fuel supply. However, rather than lift price controls on coal and stimulate production, on December 26, 1917, President Wilson "abruptly placed control of the [rail] industry in the hands of his son-

\footnotetext{
${ }^{50}$ Mingo Republican, 8 November 1917. The "inequity" of the Pond Creek and WilliamsonThacker situation was broadcast by the Coal City Club, which had been started to promote Williamson's business potential, and almost immediately became the means of protesting the city's economic mistreatment by the railroad and then the federal government.

${ }^{51}$ Johnson, Politics of Soft Coal, 58.

${ }^{52}$ Ibid., 64.
} 
in-law, Secretary of the Treasury William Gibbs McAdoo." ${ }^{53}$ Unlike the coal industry, the rail industry's full property rights were assured and the railroads were promised annual compensation equal to the average of the three prior years to 1917. Many railroads did not benefit from these pledges because they had been in an earnings slump since 1915. However, the N\&W, which serviced Mingo County and the Williamson-Thacker coalfield, was primarily a coal carrier that had escaped the decline in revenue and had its compensation set at $\$ 20$ million." ${ }^{54}$ The income security proffered the Norfolk \& Western contrasted sharply with the disregard exhibited toward the idiosyncratic needs of the Mingo coal operators. The exacerbation of those needs by the railroad's limitations further underscores the lack of balance in federal policy. ${ }^{55}$

Nationally, the creation of the Railroad Administration and the conciliatory gestures of the Fuel Administration helped stem the fuel crisis caused by the unusually severe winter. Coordinated by the two agencies, coal production increased as a result of the ending of crosshauls and an improved car supply. Resolution of the immediate impediments to sufficient transportation allowed the Fuel Administration to turn to appeasing public outrage and fears. ${ }^{56}$

Alarmed by the public unrest caused by coal shortages, the Fuel Administration also authorized the expansion of its investigatory operations at state and local levels. State Fuel Administrators, appointed "to help insure equitable local distribution of coal," were supposed to

\footnotetext{
${ }^{53}$ Ibid., 64-65.

${ }^{54}$ Striplin, 144-145.

${ }^{55}$ The inability of Mingo's "wagon mines" to capitalize on price increases because the N\&W would not or could not provide a sufficient number of box cars, is just one example of the limitations the railroad placed on the county's mines.

${ }^{56}$ Johnson, Politics of Soft Coal, 63.
} 
be public-minded civic leaders with no connections to the industry. ${ }^{57}$ West Virginia's state Fuel Administrator, J. Walter Barnes of Fairmont, met Dr. Garfield's criteria. Barnes' professional credentials bore a distinct Progressive stamp. A lawyer and educator, Barnes had been principal of the Fairmont Normal School and the general manager of a utility company. At the time of his appointment, he was a member of Fairmont's City Commission and chairman of the Marion County Council of Defense. ${ }^{58}$

State Fuel Administrator Barnes appointed former state senator Hiram S. White of Matewan as Mingo's local Fuel Administrator. White selected William T. Meade of Kermit and Edward R. Juhling of Williamson as his assistants. White, Meade, and Juhling were empowered to investigate reports of operators and/or retailers charging "greater prices than allowed" under the federal mandate. Within three weeks of their appointment at the beginning of January 1918, Mingo's Fuel Administrators had heard several such cases, but refused to publicly reveal any details, and whether any of the accused were guilty. The Board simply reported that no action was recommended. ${ }^{59}$

Despite the official silence on who faced charges before Mingo's Fuel Administration board, the membership of the board itself reveals that the application of Fuel Administration policies could not have escaped the vagaries of local politics. White, Meade, and Juhling were

\section{${ }^{57}$ Ibid.}

${ }^{58}$ Progressive West Virginians compiled by John W. Kirk (Wheeling: Wheeling Intelligencer, 1923), 125. After the war, Barnes was appointed to the State Board of Control. When this edition of the Progressive West Virginian was published Barnes' wife was president of the West Virginia W.C.T.U.

${ }^{59}$ Mingo Republican, 7 January 1918, and 24 January 1918. 
all veterans of Mingo's political intrigues and faction wars, and all three were known "bolters." The older brother of Dr. Israel C. White, West Virginia's state geologist, Hiram S. White had frequently benefitted from the distribution of patronage. Before the war, his wife served as the postmistress of Matewan while he acted as a state workmen's compensation investigator. A resident of Matewan since the county's founding, White had also actively participated in the county's Republican party's bitter factional fights. The sole Democrat on Mingo's Fuel Administration Board William T. Meade lead the Democrats who controlled Kermit. Edward R. Juhling, had been a founding member of the Coal City Club, a businessmen's organization from Williamson that had repeatedly protested Norfolk \& Western and federal policies deemed unjust and injurious to local business. ${ }^{60}$

One example of charges against a local coal company underscores both the means of evading federal price policy and the role of local politics in accusations of abuse. Details of the alleged conspiracy also illuminate the economic hierarchy of southern West Virginia's coal companies. According to the charges, a well-connected large corporation subsidiary, based in Charleston, used the officers of a local entrepreneur-backed company to prey on financiallystrapped small mines. Coincidentally, the accuser and the accused shared a long, but recently heated history of political animosity.

In a letter to the Assistant U.S. District Attorney for southern West Virginia, Williamson attorney S. D. Stokes accused J. Levine, the General Manager of the Levine-Goodman Coal Company, Blaine York, a local attorney, and the Logan Pocahontas Fuel Company of violating

\footnotetext{
${ }^{60}$ White, Meade, and Juhling were all well-known "bolters" from Mingo's Republican ranks. See Chapters 3 and 6 of this study.
} 
the Federal regulations in regard to the price of coal. According to Stokes, Logan Pocahontas deposited money in Williamson which York and Levine used to pay "bonuses" for coal from small mines. Stokes learned of the scheme from Levine-Goodman's president, who professed ignorance until Levine offered to divide the profit with him. ${ }^{61}$ Assistant dstrict attorney Kelly informed Stokes that a special agent would be assigned to the case but also warned that the investigation could be delayed by several months. ${ }^{62}$

Stokes, Levine, and York were old adversaries in Williamson municipal and county-wide politics. Stokes served as a lieutenant in the Democratic "City Ring" controlled by Wallace J. Williamson. Also from Williamson, Levine and York were Republicans with close ties to the Hatfield machine, and both had been elevated to power in city politics when Henry D. Hatfield orchestrated the revocation of Williamson's charter which had stripped the "City Ring" of its power. Stokes had spearheaded the effort to undo the charter, even going so far as to seek advice from John W. Davis, then serving Assistant United States Solicitor General. ${ }^{63}$

Whether Stokes had first brought charges against Levine and York before Mingo's Fuel Administration board is unknown. The tone of his appeal to Assistant district attorney Kelly however, reveals that he did expect satisfaction from the federal officer. As if to emphasize the

${ }^{61}$ S. D. Stokes to the Honorable Lon Kelley, 24 May 1918, Stokes Papers, WVRHC.

${ }^{62}$ Honorable Lon Kelly to S. D. Stokes, 25 May 1918, Stokes Papers, WVRHC.

${ }^{63}$ See the discussion of the Williamson Charter bill in Chapter 6. See also the discussion of Williamson municipal politics in Chapter 6. Blaine York's brother, Dr. William York won election to the house of delegates in 1916 and had successfully proposed revisions of the Williamson charter in the 1917 legislative session. Thus, in 1918, the charter issue was still a "hot topic" when Stokes accused Levine and York of profiteering. 
probability of York's guilt, Stokes reminded Kelly that the district attorney's office had investigated York for another unrelated federal violation. ${ }^{64}$

The detail not mentioned in the Stokes-Kelly correspondence was Kelly's familiarity with Mingo County politics. For four years Kelly had helped prosecute the Mingo's "Election Fraud" cases. The primary defendant in those cases was Greenway Hatfield, chairman of Mingo's Republican party, brother of Governor Henry D. Hatfield, and the arch rival of Stokes' mentor Wallace J. Williamson. The final "Election Fraud" case had ended in acquittal only three days before Stokes wrote to Kelly. ${ }^{65}$ By reporting the Levine-York incident, Stokes offered Kelly a new opportunity to strike at Hatfield through his associates, which in turn would allow Mingo's Democrats to accuse the county's Republican businessmen of being unpatriotic profiteers. ${ }^{66}$ Kelly carefully hedged around Stokes' implicit offer. He explained why York had not been prosecuted on the other matter, and then closed the letter with a carefully phrased, "you can rest assured, that the matter will be attended to." ${ }^{67}$

\section{Reconfiguration of Federal Regulation Fails to Benefit the Williamson-Thacker Field:}

Only a day after the Mingo Republican first reported on the activities of the local Fuel Administration, Fuel Administrator Garfield and Rail Administrator McAdoo reconfigured federal regulation of the production and distribution of coal for the second and last time. The

\footnotetext{
${ }^{64}$ Stokes-Kelly correspondence, Stokes Papers, WVRHC.

${ }^{65}$ McDowell Recorder, 21 May 1918.

${ }^{66}$ See Chapter 6 for the discussion of the Rockhouse and War Eagle "election fraud" cases.

${ }^{67}$ Kelley-Stokes correspondence, Stokes Papers, WVRHC.
} 
Garfield-McAdoo "Zone" plan divided the country into twenty consumption districts and eleven production districts. Set to take effect on April 1, 1918, the "Zone" plan revived Garfield's reputation with the coal industry, which hailed the system as finally making "the distribution of coal rational and efficient." ${ }^{168}$ To the operators of the Williamson-Thacker coal field of Mingo County however, the "Zone" plan reinforced their feeling of being ignored and discounted in favor of other and/or larger fields.

From the macrocosmic perspective however, the plan made sense. First, the plan required consumers from the Midwest to purchase coal from their region instead of from Pennsylvania, West Virginia, or eastern Kentucky. Second, the Norfolk \& Western and the coal producers along its line were confined to distribution zones allocated to the "Pocahontas zone." Requiring Midwestern consumers to purchase the coal mined nearest them alleviated congestion on the rail lines. In turn, the policy opened "bottlenecks in the Appalachian gateways" and allowed nine percent more coal to move through the mountains. Under the "Zone" plan, production and prices rose, and the operators could now sell all their output at prices nearly double those of a few years before. ${ }^{69}$

From the microcosmic perspective of Mingo's operators, the same two elements of the plan seemed designed to undermine the marketability of Mingo's coal. By the late 'teens the Midwestern or Lake Cargo trade was the only market where Williamson-Thacker coal could compete against both the Central Competitive and Smokeless Fields. As a non-union field, despite the rate differentials on coal shipments, Williamson-Thacker coal sold more cheaply than

\footnotetext{
${ }^{68}$ Johnson, Politics of Soft Coal, 71, 73.

${ }^{69}$ Ibid., 73, 71, 73, 73.
} 
the Midwestern coal produced in the unionized mines of the Central Competitive Field. It also underpriced the Pocahontas coal shipped west because the Pocahontas coal producers paid an even higher rate differential than the Williamson-Thacker operators. Deprived of the Midwestern outlet, Williamson-Thacker coal could only be shipped to areas long dominated by the Smokeless coalfields' producers of superior quality coal. To the operators of the WilliamsonThacker coalfield, the zone plan enforced yet another "squeeze" while the benefits accrued to larger, more powerful interests. ${ }^{70}$

As the Zone plan became fully operational, economic and social pressure mounted in Mingo. According to prevailing coal industry practice at the time, the only way for Mingo's coal operations to endure was to produce more coal. All business decisions were aimed at achieving that goal. Social controls were extended to better harness the workforce. Survival depended on increased production.

One method used by companies to enhance their financial viability was to dissolve the existing corporate entity and reorganize under a different name or in a different state. In the spring of 1918, the Allburn Coal \& Coke Company dissolved and re-incorporated as the Allburn Coal Corporation. Reorganization allowed Allburn to overhaul its finances and capitalization, before economic pressures destroyed its viability as a company. ${ }^{71}$ That same year Borderland

\footnotetext{
${ }^{70}$ See Lambie, From Mine to Market for a detailed discussion of the benefits of the rate differentials assigned to the various coal fields.

${ }^{71}$ Williamson Daily News, 8 March 1918. Allburn was one of the companies with mines on the Kentucky side that transported from the West Virginia side of the river.
} 
Coal Company reincorporated in Virginia, where its stockholders, which included a U.S. congressman, could better protect the company. ${ }^{72}$

Relations between the coal companies, Mingo's county government, and private citizens suffered during the spring and summer of 1918. Cutthroat competition also intensified the county's traditional adversarial politics between Democratic and Republican businessmen. Williamson Democrat S. D. Stokes' charges of profiteering against the Republican-backed Levine-Goodman Coal Company were leveled only a month after the "Zone" plan went into effect. Other companies directed their cost-saving efforts to Mingo's county government. The newly renamed Allburn Coal Corporation challenged a \$137.15 tax assessment because it's West Virginia tax liability was limited to a shared responsibility for two acres of land, a tipple, and personal property that consisted of "two old boilers and a little machinery." ${ }^{173}$ After pleading their case before Mingo's Board of Equalization, Allburn had to wait four months before learning that it had been taxed erroneously. ${ }^{74}$

The Grey Eagle Coal Company sacrificed community and government relations in its drive to increase production. After opening a mine in the town of Kermit in the spring of 1917, Grey Eagle expanded its operations throughout the following year. In May 1918, farmer Pyrrhus Meade filed suit against Grey Eagle for building a blacksmith shop "almost in the door of Mr.

72"Borderland company history," 11, Stone Papers, UVA.

${ }^{73}$ Unsigned corporate letter to S. D. Stokes, 9 July 1918, Stokes Papers, WVRHC.

${ }^{74}$ S. D. Stokes to F. A. Lindsay, manager of the Allburn Coal Corporation, 23 November 1918, Stokes Papers, WVRHC. Stokes assured Lindsay that because of a bookkeeping error, Allburn had mistakenly been double-taxed." Although no obvious evidence exists to suggest criminal behavior, it was widely known at the time that commissioners on county boards of equalization could be paid to assess lower taxes for cooperative corporations. 
Meade's residence." The description was no exaggeration, the shop's intended location was only twenty feet from Meade's back door. ${ }^{75}$ Grey Eagle's conflict with Meade soon escalated into head-on confrontations with the county court and Kermit's town council.

The root of Grey Eagle's problem with Meade, the county court, and the town council of Kermit lay in the tangle of rights held by mineral leaseholders and surface-rights holders. The mineral rights held by Grey Eagle had first been conveyed in 1904, five years before Kermit was incorporated. After opening a mine within the town's limits, Grey Eagle ran afoul of the town and county government when it constructed a tramroad and tipple to facilitate loading its coal at the $\mathrm{N} \& \mathrm{~W}$ station. As an affected neighbor and active town leader, Meade repeatedly asked the company to stop construction. Grey Eagle responded to Meade's entreaties by taking refuge behind a strict interpretation of its lease. The company claimed, that "their lease to do what they want with their surface rights predates and supersedes any other claim." ${ }^{76}$

Prior to the construction of Grey Eagle's tramroad and tipple, Mingo's county court had acquired surface rights in Kermit to build a county road through the town. However, the county did not build a road. Instead the path became a wagon trail used by residents and Grey Eagle. When hauling its coal by wagon limited Grey Eagle's coal production, the company built the tramroad and tipple. On behalf of the town's residents, the county court reasserted its surface rights which Grey Eagle refused to acknowledge. ${ }^{77}$

\footnotetext{
${ }^{75}$ S. D. Stokes to B. Randolph Bias, 12 May 1918, Stokes Papers, WVRHC. Stokes and Bias were attorneys for Meade and Grey Eagle, respectively.

${ }^{76}$ Defendant's answer to chancery suit in circuit court, 13 January 1920, Stokes Papers, WVRHC.

${ }^{77}$ Ibid.
} 
In a strange twist, when the county court renewed its claim, Pyrrhus Meade's attorney S. D. Stokes was serving as acting prosecuting attorney for the county. Stokes' exchanges with Grey Eagle's superintendent reveal the animosity fostered by the protracted conflict. On behalf of the county court, Stokes informed Superintendent Shewey that for "obstructing" the county road, the company would be fined nearly one hundred dollars plus the cost of damages. Shewey responded that the company would pay the fine, but the county would have to pay to remove three dwelling houses and two powder houses from the land the company had planned on donating to the county. Stokes countered with a reminder that the fine accrued daily, which he had not reported to the Grand Jury in order to "spare" Grey Eagle "a hardship" but Shewey's letter had "reminded" him of his duty." Moreover, Stokes continued, "so far as the matter of right of way is concerned, the people of Mingo County ... will not compound a crime to get a piece of right away for nothing." ${ }^{178}$

The last round between Grey Eagle and the county court ended with Superintendent Shewey's attempt to intimidate Stokes with the law. After warning Stokes to "check his facts" before "proceeding in the drastic course" he and the county court apparently had chosen, Shewey reminded Stokes that when the court had acquired surface rights for the road, it failed to seek permission from Grey Eagle to cross its holdings. Shewey then noted that in the absence of county action, and at an expense of nearly two thousand dollars, Grey Eagle had built and maintained roads in and around Kermit without any compensation. As a coup de grace, Shewey wrote "we must insist that either you get your right away from us or move your road out of way."

\footnotetext{
${ }^{78}$ Thomas Shewey to S. D. Stokes, 5 May 1919, and Stokes to Shewey, 8 May 1919, Stokes Papers, WVRHC.
} 
In closing the letter however, Shewey provided the court with a face-saving "out." He observed that from Grey Eagle's perspective "this controversy is all uncalled for and is only part of a malicious scheme being worked out by some few parties."79 Just who those parties were emerged when Grey Eagle squared off against the town council of Kermit. ${ }^{80}$

The county court abandoned its claim to the road obstructed by the Grey Eagle tramroad and built a road approved by the state highway commission on the other side of town. ${ }^{81}$

However, the court's withdrawal did not end Grey Eagle's troubles. Led by Mayor Hawkins, the Kermit town council revived the issue and threatened to demolish Grey Eagle's tramroad and tipple if the company did not relocate them voluntarily. Claiming that the town council was "openly hostile" to it and its business interests, Grey Eagle hired guards for its property and sought a restraining order from James Damron, the local circuit court judge. ${ }^{82}$

${ }^{79}$ Thomas A. Shewey to S. D. Stokes, 28 May 1919, Stokes Papers, WVRHC.

${ }^{80}$ Like Matewan, Kermit suffered from extremely fractious municipal politics. Grey Eagle superintendent Shewey was one of the leaders of the Republican faction, while the Meade family were the leaders of the Democratic faction. In 1912, Pyrrhus Meade had been appointed clerk by the commissioners of the town council over the protestations of its Republican members who had also appointed a clerk. Immediately following Meade's appointment his Republican opponent had been removed from the council meeting at gunpoint. Mingo Republican, 5 January 1912. On primary election day, May 19, 1925, a gunfight between rival political factions in Kermit left two dead, and two wounded. Lee, Bloodletting, 51.

81 "Complainant's Brief," Grey Eagle Coal Company vs. S. A. Hawkins, Mayor et al, 6-7, Stokes Papers, WVRHC.

82"Plaintiff's Statement," Grey Eagle Coal Company vs. S.A. Hawkins, Mayor et al. (approximate date 11 March 1920), Stokes Papers, WVRHC. 
Despite the work stoppage caused by the Influenza Epidemic in September and October, 1918, American coal production and consumption reached all-time highs in $1918 .^{83}$ When the Armistice took effect on November 11, the national surplus of nearly one hundred million tons of coal confirmed the miners' patriotic effort. ${ }^{84}$ Unfortunately,

as whistles blew on mine tipples and individual plants, buyers of war materials jammed switchboards with order cancellations. Within a month the War Department retracted half its outstanding contracts ... [and the] dramatically reduced demand for coal brought falling prices, particularly for poorer grades. ${ }^{85}$

Moreover, the Armistice technically did not end the war or wartime regulation of the coal and rail industries. The dismantling of federal control dominated the year following the cessation of hostilities. The February 1, 1919 issue of the Williamson Daily News gleefully announced that "All Control Exercised by the Fuel Administration Is Over." ${ }^{186}$ Expressing the hopes of Mingo's operators, the newspaper opined that the end of regulation would reinvigorate coal production in the county. As the events of the rest of 1919 revealed, the Daily News' announcement proved premature. ${ }^{87}$

The general recession that followed the end of hostilities persisted into the first quarter of 1919. Even though the coal industry had not produced at maximum capacity during the war, the

\footnotetext{
${ }^{83}$ Johnson, Politics of Soft Coal, 88.

${ }^{84}$ McAlister Coleman, Men and Coal (NY: Farrar \& Rinehart, 1943), 96.

${ }^{85}$ Johnson, Politics of Soft Coal, 91.

${ }^{86}$ Williamson Daily News, 1 February 1919.

${ }^{87}$ Ibid.
} 
diminution of demand had created a 100 million ton surplus. ${ }^{88}$ This reservoir of excess coal inspired Fuel Administrator Garfield's decision to suspend, but not rescind, the agency's regulatory stipulations regarding production zones and prices. ${ }^{89}$

Within months Mingo's leaders realized that the lifting of certain Fuel Administration policies and the suspension of some wartime regulations did not mean that all federal interference in the coal trade had ended. In May, Congressman Wells Goodykoontz released an angry letter to the Williamson Daily News, in which he protested the actions of Henry Spencer, a regional purchasing director of the Railroad Administration. According to Goodykoontz, Spencer had ordered operators in Northern Ohio, Michigan, and Indiana to purchase only Ohio coal. ${ }^{90}$ Considering that at the beginning of the war nearly half of Mingo's coal output traveled to the now restricted area, one can understand Goodykoontz's frustration.

However, by the time of the publication of Goodykoontz's letter, market forces had already swung favorably. In the second quarter of 1919 "a sharp upswing of business activity and employment" ended the post-Armistice recession. ${ }^{91}$ Barely a week after showcasing Goodykoontz's letter, the Daily News reported that the venerable Thacker Coal \& Coke Company which had been shut down since the suspension of federal regulation, was reopening. ${ }^{92}$

\footnotetext{
${ }^{88}$ Coleman, 96.
}

${ }^{89}$ Johnson, Politics of Soft Coal, 92.

${ }^{90}$ Williamson Daily News, 10 May 1919.

${ }^{91}$ Soule and Carosso, 513.

${ }^{92}$ Williamson Daily News, 18 May 1919. The closing and re-opening of Thacker Coal \& Coke underscores another aspect of the role of Mingo's large and absentee-owned and controlled mines. Only a part of the U.S. Steel coal empire in southern West Virginia, and a producer of 
As spring warmed into summer, other indicators of revival dotted the pages of the Williamson Daily News. A single issue of the newspaper carried two notices that reveal how work picked up in the Williamson-Thacker coalfield. The Sharondale Coal \& Coke Company published a notice that stated simply "work has been resumed," and where miners and company men could apply for employment. The West Virginia Bi-Product Company advertized for twenty-five coal loaders, noting that it had enough orders to run full-time and could offer loaders and laborers steady work at "good wages." 93

\section{Conclusion:}

According to the data gathered by West Virginia's Department of Mines, federal regulation similarly affected the coal industry in Mingo and Logan Counties. As illustrated in Tables 10-12 at the end of this chapter, the statistics compiled by the Department of Miners indicates that the number of mines and miners in Mingo and Logan Counties increased, also the mines in both counties also worked more days during the war. Only McDowell County suffered more losses than gains in the categories that indicated growth. What the numbers and percentages do not convey is the way federal regulatory policy exacerbated the crisis mentality of Mingo's coal operators. Local coal industry advocates resented the Fuel Administration's failure

less sought after coal, Thacker Coal \& Coke could be shut down and reopened based on macroeconomic industry sales. Even though similar evidence has yet to be uncovered, it can be surmised that the temporary shutdown of the Thacker Coal \& Coke operations was not uncommon at the other large corporations' mines in Mingo.

\footnotetext{
${ }^{93}$ Williamson Daily News, 7 July 1919.
} 
to recognize and accommodate the unique position of the Williamson-Thacker coal field. ${ }^{94}$ The imposition of the "Zone Plan" compounded the injustices Mingo County's coal elites believed had been heaped upon them because the distribution system denied access to the Midwestern coal market, the only arena where the Williamson-Thacker field had an advantage over its larger neighbors. ${ }^{95}$ One statistic underscores the scale of Mingo's loss. Just as Island Creek president James D. Francis had predicted, federal regulation benefitted Logan County, where coal production increased by nearly a million tons during the war. By contrast, tonnage output in Mingo and McDowell Counties fell, but McDowell, despite suffering an 800 percent greater loss, still produced almost 6 times the amount of coal mined in Mingo. As a result, the operators in Mingo County emerged from the war more determined than ever to resist any constraints on their autonomy. When U. S. Department of Labor mediators followed union organizers into Mingo County, they were firmly rebuffed. ${ }^{96}$ The operators of the Williamson-Thacker coal field would brook no more interference in the running of their mines, not even from the United States government. $^{97}$

\footnotetext{
${ }^{94}$ Chief among these complaints were the Kentucky-West Virginia price differentials and the federal government's tardy and inconsistent regulation of the Norfolk \& Western railroad.

${ }^{95}$ As an "inner crescent" field, Williamson-Thacker paid a lower haulage rate to the Midwestern "Lake Cargo" market than the Pocahontas field. See Chapter 4 for details.

${ }^{96}$ Williamson Daily News, 2 July1920 and 14 August 1920.

${ }^{97}$ This does not mean that the operators objected to the imposition of martial law or, the presence of federal troops in the strike district, because the restoration of order benefitted the operators' effort to resume a normal production schedule.
} 
Table 10:

The Impact of Federal Control on the Coal Industry in Mingo County, 1917-1918*

\begin{tabular}{llll}
\hline \hline Production Figures & 1917 & 1918 & Percentage \\
\hline Number of Mines & 53 & 58 & increase 9\% \\
Tonnage Output & $3,207,162$ & $3,104,419$ & $-102,743$ \\
Total \# of Employees & 3,383 & 3,581 & increase 5\% \\
\# of Pick Miners & 182 & 194 & increase 6\% \\
\# of Machine Miners & 1,132 & 1,064 & loss of 4\% \\
Miners as a Percentage of Total & $39 \%$ & $35 \%$ & loss of 4\% \\
Employees & & & \\
\# of Days Worked & 220 & 238 & increase 8\% \\
Average Price per ton & $\$ 1.84$ & $\$ 2.77$ & increase 34\% \\
\hline \hline
\end{tabular}

Source: Annual Reports of the West Virginia Bureau of Mines, 1917-1918.

*Mingo County was in the Williamson-Thacker Coal Field 
Table 11:

The Impact of Federal Control of the Coal Industry in Logan County, 1917-1918*

\begin{tabular}{llll}
\hline \hline Production Figures & 1917 & 1918 & Percentage \\
\hline \# of Mines & 124 & 141 & increase 9\% \\
Tonnage Output & $8,859,122$ & $9,229,975$ & increase 4\% \\
Total \# of Employees & 7,965 & 9,653 & increase 17\% \\
\# of Pick Miners & 203 & 634 & increase 68\% \\
\# of Machine Miners & 3,591 & 3,450 & loss of 4\% \\
Miners as a Percentage of Total & $48 \%$ & $43 \%$ & loss of 5\% \\
Employees & 189 & 203 & increase 7\% \\
\# of Days Worked & $\$ 2.06$ & $\$ 2.83$ & increase 27\% \\
Average Price per ton &
\end{tabular}

Source: Annual Reports of the West Virginia Bureau of Mines, 1917-1918.

*Logan County was located in the Guyan Coal Field

Table 12:

The Impact of Federal Control on the Coal Industry in McDowell County, 1917-1918*

\begin{tabular}{llll}
\hline \hline Production Figure & 1917 & 1918 & Percentage \\
\hline \# of Mines & 152 & 157 & increase 3\% \\
Tonnage Output & $18,671,942$ & $17,812,416$ & loss of 5\% \\
Total \# of Employees & 19,170 & 17,639 & loss of $8 \%$ \\
\# of Pick Miners & 4,195 & 3,288 & loss of $22 \%$ \\
\# of Machine Miners & 4,801 & 4,059 & loss of $15 \%$ \\
Miners as a Percentage of Total & $47 \%$ & $42 \%$ & loss of 5\% \\
Employees & & & \\
\# of Days Worked & 225 & 250 & increase $9 \%$ \\
Average Price per ton & $\$ 2.01$ & $\$ 2.85$ & increase 29\% \\
\hline \hline
\end{tabular}

Source: Annual Reports of the West Virginia Bureau of Mines, 1917-1918.

*McDowell was located in the Pocahontas Coal Field 


\title{
CHAPTER 9
}

\section{WORLD WAR I AND THE ESCALATION OF CLASS TENSIONS IN MINGO}

\author{
"We hope our people can get along better in the future and \\ strive to have a better community in which to live."1 \\ -- Williamson Daily News
}

For most of the period between 1917 and 1919, World War I dominated the social atmosphere of Mingo County. Civic organizations and public activities focused almost completely on supporting the war effort. However, government sanctioned compulsory patriotism ultimately exacerbated existing social strains such as the county's ongoing struggles with criminal behavior, sporadic acts of violence, and public health crises. Although state and federal war policies had facilitated the seizure of control of Mingo's public sphere by the coal elite, the county's social transformation proved temporary. The war not only had empowered the "better classes," it also inspired marginalized groups to seek greater autonomy. Ostensibly united to fight the nation's enemies, Mingo Countians emerged from the war with disparate and conflicting views of what the future should hold. This new agitation, along with the cumulative effect of Mingo's systemic political and economic dilemmas, facilitated the descent into violence in the spring of 1920 .

\footnotetext{
1"Hatfield Vindicated," Williamson Daily News, 13 December 1919. The quoted observation came from a story about an attack by Matewan's Chief of Police Sid Hatfield, on former mayor A. B. Hatfield.
} 


\section{Wartime Policies and the Ascendance of Mingo's "Better Classes":}

At the end of the First World War, Governor John J. Cornwell crowed that West Virginia, per capita, had sent more men than any other state into the Armed Services. ${ }^{2}$ Over three hundred thousand West Virginians registered for the draft. Of that number 14 percent, or over forty-five thousand men were mustered into service. Mingo County exceeded the state percentage by inducting 15 percent of the residents who registered. ${ }^{3}$

West Virginia's National Guard units were the first group of citizens mustered into service. Only two weeks after returning home from six months on the United States-Mexico border, the Williamson contingent of the Guard returned to active duty on April 5, 1917. Among Williamson's nationalized guard unit was Antoine A. "Tony" Gaujot, veteran of the Philippine campaign and the Paint Creek and Cabin Creek Strike. ${ }^{5}$ Promoted to captain in September 1917, Gaujot commanded a company of the 150st Infantry, and led his men through

\footnotetext{
${ }^{2}$ John J. Cornwell and others, "West Virginia in the War," West Virginia Legislative Handbook and Manual and Official Register for the Year 1918, compiled and edited by John T. Harris, clerk of the Senate, (Charleston, WV: Tribune Printing Company, 1918): 775-948, 823824.
}

${ }^{3}$ Ibid., 823-824. By comparison, McDowell sent 16 percent and Logan sent 12 percent; Mingo's war casualties totaled 25-- 10 killed in action, 2 died from wounds, 4 died from disease in Europe, and 9 died in the United States from disease and other causes. Compiled from data in Jim Comstock, ed., "Casualties in World War I," in The Soldiery of West Virginia, West Virginia Heritage Encyclopedia, vol. 9, supplemental series, (Richwood, WV: Jim Comstock, 1974), 229272.

${ }^{4}$ Mingo Republican, 29 March, and 5 April 1917.

${ }^{5}$ (Gaujot as mine guard) Lee, Bloodletting, 21; (war activities) Williamson Daily News, 31 May 1919. 
the Argonne campaign. ${ }^{6}$ First mustered for national service in June 1916, Gaujot and Mingo's other Guard members returned home in May 1919, after nearly three years of continuous military service. $^{7}$

The wartime activities of Mingo's elites were celebrated in the Williamson Daily News and the formal reports of state officials. Local political and coal industry leaders dominated civic organizations' efforts on behalf of the war. Mingo's Red Cross, YMCA, and Salvation Army campaigns were guided by political and economic leaders Dr. Tunis Nunemaker and Randolph Bias. ${ }^{8}$ Parapolitical organizations such as Mingo's County and Community Councils of Defense and Four Minute Men featured bipartisan membership and prominent participation from coal company superintendents. Half of the twelve member County Council of Defense was linked to the coal industry. ${ }^{9}$

To most elites, America's entry into the war justified the adoption of a centralized, "paternalistic" public policy that validated the repression of "individualism and diversity of opinion in order to secure ... unwavering allegiance. ${ }^{\text {"10 }}$ West Virginia's application of war

${ }^{6}$ Mingo Republican, 23 September 1917, and Williamson Daily News, 31 May 1919.

${ }^{7}$ Williamson Daily News, 31 May 1919.

8"West Virginia in the War," 931, 941, 944.

${ }^{9}$ The "coal" people on the county council were: George Bausewine, Jr. (officer in the Williamson Coal Operators' Association), William N. Cummins (superintendent of Red Jacket Consolidated Coal \& Coke Company), and Mrs. Mark Russell (Mark Russell was a coal dealer in Williamson). These three were joined by pro-coal business leaders and investors E. F. Randolph, B. Randolph Bias, and Harry Scherr of the Coal City Club.

${ }^{10} \mathrm{Paul}$ L. Murphy, World War I and the Origins of Civil Liberties in the United States (New York: Norton, 1979), 26-27. 
policies and programs was among the most extreme in the country. ${ }^{11}$ The implementation of state and federal war regulations fulfilled the long delayed dream of enforcing a rationalized work "discipline" in the Tug Valley. ${ }^{12}$ By cloaking their efforts at social and economic control in patriotism, Mingo's political and industrial leaders legitimized the suppression of dissent and deviation.

Although the war effort apparently elicited an unprecedented bipartisanship from Mingo's political leaders, local disputes still interfered with the establishment of the most significant war committees. Within four months of the creation of Mingo's Selective Service Board, the Chairman, N. H. Manakee resigned after requesting the removal of the other two members, Dr. A. G. Rutherford and J. M. Studebaker. ${ }^{13}$ These turnovers on Mingo's draft board also affected the next important committee work in the county because the State Council of Defense appointed County and Community Councils of Defense based on recommendations from the local conscription boards..$^{14}$

Newspaper accounts attributed Manakee's resignation and the removal of Rutherford and Studebaker to charges of partiality and friction among members of the board. Chairman

\footnotetext{
${ }^{11}$ John Hennen, The Americanization of West Virginia: Creating a Modern Industrial State, 1916-1925 (Lexington: University Press of Kentucky, 1996), 15.

${ }^{12}$ Gordon B. McKinney, "Industrialization and Violence in Appalachia in the 1890s," An Appalachian Symposium: Essays Written in Honor of Cratis Williams edited by J. W. Williamson, (Boone, NC: Appalachian State University Press, 1977), 131-144, 137.

${ }^{13}$ Mingo Republican, 30 September 1917. The story was also reported in the Martinsburg Herald, 7 September 1917. The Herald story is cited here because there are inconsistencies in the dating of the Republican's issues, before and after this incident. It is likely that the Republican issue was actually dated 30 August 1917.

14"West Virginia in the War," 793.
} 
Manakee reportedly sought to bar Dr. Rutherford from judging cases involving his business associate, Howard Schoew, a local coal operator. However, this does not explain why Rutherford and Studebaker were dismissed. The reconfiguration of Mingo's draft board resulted in Manakee, Rutherford, and Studebaker accepting too many exemptions. ${ }^{15}$ The favoritism shown by the original board apparently had jeopardized Mingo meeting its quota even after a second enlistment call. ${ }^{16}$

What was unknown outside Mingo County was the undercurrent of political and economic tensions that led to the replacement of Mingo's original draft board. Less than a year before their elevation to the county selective service board, Studebaker, Rutherford, and Manakee had been embroiled in the turmoil that surrounded the 1916 general election and Williamson's 1917 municipal election. A Republican city commissioner, Studebaker had betrayed his party and helped the Democratic commissioners force O. H. Booten, Williamson's first commission mayor and Hatfield Republican from office. ${ }^{17}$ After the Democrats swept the county commission election of 1916 , the "new" county court attempted to take over early from the Republican "old" county court because the old court consisted of individuals appointed to replace members who had stepped down. One act in the tug-of-war between the old and new courts involved the authority to appoint and/or remove other county officials. For example, the old court dismissed Dr. A. G. Rutherford, president of the county board of health, who was

\footnotetext{
${ }^{15}$ Martinsburg Herald, 7 September 1917.

${ }^{16}$ Mingo Republican, 30 September (30 August?) 1917.

${ }^{17}$ Mingo Republican, 5 October 1916.
} 
reappointed by the new court. ${ }^{18}$ Just four months before being selected chairman of the county draft board, N. H. Manakee had been caught in the struggle between the Democratic factions that ostensibly shared power over the county. "City Ring" Democrat and newly elected president of the county court, Alex Bishop wanted to appoint Manakee county road engineer, but "County" Democrats led by Sheriff G. T. Blankenship wanted another engineer. ${ }^{19}$

The inability of Manakee, Rutherford, and Studebaker to function properly as a draft board precipitated two overhauls of the committee and perpetuated the influence of local politics over what should have been bipartisan wartime organizations. The removal of Rutherford and Studebaker led to the appointment of Harry G. Williams of Thacker and Harry Scherr of Williamson. The last adjustment of the draft board's membership came when A. C. Pinson assumed the chairmanship from N. H. Manakee. ${ }^{20}$ The final roster of Mingo's draft board, Pinson, Scherr, and Williams, illuminated the internal nature of Mingo County politics. ${ }^{21}$ After the turmoil caused by the in-fighting among three of Mingo's lesser political figures, two leading politicians stepped into the void -- Pinson, the deposed "City Ring" Democratic mayor of

${ }^{18}$ Mingo Republican, 11 January 1917.

${ }^{19}$ Ibid. Blankenship's candidate prevailed.

20"West Virginia in the War," 789, 828.

${ }^{21}$ Harry G. Williams' occupation at the time of his appointment has not been determined. Six years previous, he ran the company store of the Shanklin Coal Company at Blocton. Mingo Republican, 8 December 1911. Three years later he was an insurance and real estate agent living in Williamson. 1914-1915 State Gazetteer and Business Directory. 
Williamson, and Scherr, the non-Hatfield machine Republican with strong ties to the Republican coal leadership of the county. ${ }^{22}$

The domination of the Mingo draft board by Democrats and Williamson Republicans influenced the selection of the county's next important war committees. The state Council of Defense appointed the County Councils of Defense and the community Councils of Defense based on recommendations from the county draft boards. As a result, Matewan Democrats and members of the Hatfield machine played no significant role in the war committee work of Mingo County. Despite being the second largest independent town in the county, Matewan had no representative on the County of Council of Defense. Citizens of Williamson held eight of the twelve positions on the council. William N. Cummins, the superintendent of Red Jacket served on the County Council as the member from Magnolia district. Democrat Dr. W. F. McCoy chaired the Matewan Community Council of Defense..$^{23}$

The lack of Hatfields and Hatfield associates in Mingo's patriotic organizations coincided with their political eclipse from 1916 through $1920 .{ }^{24}$ As corrupt as the Hatfield machine appeared to be, it had cultivated support among the native working class and the ethnic communities of Mingo. ${ }^{25}$ The absence of the Hatfields and the corollary increased prominence of

${ }^{22}$ For more on Pinson, see Chapter 6; on Scherr, Chapter 3.

23"West Virginia in the War," 793, 806.

${ }^{24}$ This refers only to homefront, non-military organizations. Several Hatfields, including former West Virginia governor Henry D. Hatfield served in the military during the war.

${ }^{25}$ County court clerk and Hatfield Republican Elihu Boggs was by profession a coal miner. Fred Burgraff, coal miner, Matewan Massacre defendant, and union activist from 1920-1922, had served as a deputy sheriff under Greenway Hatfield from 1912-1916. See Chapter 6 for details. 
coal men on the war committees underscored for many in Mingo County that they were not represented in those groups.

Two weeks before America entered the war, the Mingo Republican jested that the first American battle had already occurred in the streets of Williamson. A group of local youths set upon and mercilessly beat another young boy simply because his last name hinted at German heritage. ${ }^{26}$ Within weeks however, the same paper somberly advised coal operators and their employees to be wary of transient miners. According to the Republican some of the "roving workers" were undoubtedly spies for the enemy. ${ }^{27}$ One Mingo County operator, Edward L. Sternberger, changed his name to Stephenson, out of a "patriotic" desire to support the war effort. ${ }^{28}$ The war had legitimized the pursuit of public consensus and social conformity, and anyone who did not accede to that demand was now suspect and subject to punishment.

Great social pressure was exerted on the men of service age in Mingo County. On August 9, 1917, the Mingo Republican published the names of the men selected in the first draft under the headline, "Honor Roll of Mingo County."29 One week later, the Republican printed the "List of Ones Failing to Report." ${ }^{30}$ The August 23, 1917 issue contained the names of thirty-six "Alleged Slackers." 31

\footnotetext{
${ }^{26}$ Mingo Republican, 22 March 1917.

${ }^{27}$ Ibid., 3 May 1917.

28"Obituary of Edward L. Stephenson,” Williamson Daily News, 9 September 1919.

${ }^{29}$ Mingo Republican, 9 August 1917.

${ }^{30}$ Mingo Republican, 16 August 1917.

${ }^{31}$ Mingo Republican, 23 August 1917.
} 
Measures were taken to exert even greater control over the working population in West Virginia in 1918. At the end of May, the Williamson Daily News published an article whose very title reveals the parameters of the renewed effort to harness people to the war effort. Mingo Countians were told, "GO to War, GO to Work, or GO to Jail!"32 The article pinpointed likely suspects for police roundups when it noted that Williamson's eight poolrooms would be watched and that "jitney drivers" transporting "lewd women" after 9 p.m. would be arrested and prosecuted. ${ }^{33}$ Imposing limitations on acceptable leisure activities were followed by the extension of work surveillance. In July 1918, the state Council of Defense requested all employers in the state to submit weekly reports on employees who failed to work a full thirty-six hour week. ${ }^{34}$

The growing social distance among Mingo Countians during the war years was encapsulated in an incident that began on the morning of August 21, 1918, near Breeden, in Harvey district, a remote section of the county. Two deputies surprised a "gang" of "army deserters," "slackers," and "sympathizers" who had come out of the mountains to eat at the house of a gang member's relative. While attempting to put two of the men under arrest, the deputies were shot and killed by the gang's leader, Albert McCloud. For nearly two years, Mingo's Sheriff

\footnotetext{
${ }^{32}$ Williamson Daily News, 30 May 1918.

${ }^{33}$ Ibid.

34"West Virginia in the War," 786.
} 
G. T. Blankenship, U.S. Marshals and a unit of West Virginia "Home Guards" repeatedly tried to subdue the gang and failed. ${ }^{35}$

Several issues raised in the newspaper coverage of the incident reveal social attitudes in Mingo County at the time. First, the Daily News attributed both the gang's initial actions and their success in eluding the authorities to their familiarity with the terrain. According to the paper, the gang were all natives of that section, "a wild and remote corner of the counties of Mingo, Logan, Lincoln, and Wayne." Second, the gang's families and other residents of the area aided their efforts to elude the law. In one case, the Sheriff even arrested a young boy who had carried ammunition to the fugitives. ${ }^{36}$

Social prejudices influenced presentation of the story to the public. After eight months of intermittent searches, Sheriff Blankenship and a posse followed a line of dugouts to the farm of Jack Marcum. The law officers conducted a thorough search of Marcum's home and barn, which reportedly had been turned into "a bristling fortress" equipped with "subterranean passageways" between the buildings, and gun "portholes" notched into the log walls. In addition to finding McCloud's discarded Army uniform, the posse discovered evidence that Jack Marcum was a bootlegger. Marcum and his wife were arrested for prohibition violations and shielding the

\footnotetext{
${ }^{35}$ Four newspaper articles from the Williamson Daily News tell the story of this incident: Williamson Daily News, 22 August 1918, 24 August 1918, 5 March 1919, and 17 April 1920. The "Home Defense Guards" were a unit from Huntington that was one of four units started in the state; the other three were in Point Pleasant, Morgantown, and White Sulphur Springs. "West Virginia in the War," 786. Breeden is located in the same district as Dingess. Despite the lawless reputation of this section, very few special deputies were posted here, but instead most served in Mingo's heavily developed coal districts. The specifics of the special deputy allocation are discussed later in this chapter.

${ }^{36}$ Williamson Daily News, 5 March 1919.
} 
deserters. To emphasize for its readers just who had succored the gang, the Daily News thus described the Marcums and their home. The cabin was a sorry old "hut" that was about "fifty years old" and measured a mere twelve by fourteen feet. When Marcum stated that he had raised eighteen children there, the arresting officers noted that it seemed that "more than four-fifths of the family was still living there." ${ }^{37}$ This commentary on the people who harbored the fugitives underscored that the deserter-slacker gang came from a backward section of the county inhabited by lawless and socially retarded people. ${ }^{38}$

McCloud eventually surrendered to authorities on April 16, 1920, almost two years after the deadly encounter. ${ }^{39}$ He angrily denied allegations that he had been a moonshiner and had hidden for almost two years near his family's home. McCloud indignantly declared that he worked steadily at lumber camps in Lincoln County, and only briefly visited his family. ${ }^{40}$ The Williamson Daily News offered no commentary on why McCloud's neighbors or family failed to report his intermittent visits to local law enforcement. But, both before and after this incident, the Harvey district was considered "wild" and "frightening" to other county residents. ${ }^{41}$ One

${ }^{37}$ Ibid.

${ }^{38}$ The first published "slacker list" in Mingo County contained the names of thirty-six men, half of whom hailed from Breading/Breeden, which is in the notorious Harvey District. Mingo Republican, 23 August 1917. See Chapter 5.

${ }^{39}$ Williamson Daily News, 17 April 1920. This article revealed that McCloud was only 22 years old when the deputies were killed.

${ }^{40}$ Ibid.

${ }^{41}$ Perry, They'll Cut Off Your Project, 49. 
local writer noted that "it was common practice to have a killing once a month," and that since 1900, seventeen lawmen had been among the victims. ${ }^{42}$

Unfortunately for the working people of Mingo County, this series of articles was the only individualized newspaper coverage of non-elite Armed Service members during the war. The coal companies and the County's elites received all of the positive public accolades. ${ }^{43}$

\section{The Persistence of Traditional Patterns of Violence and Conflict Resolution:}

Several incidents during the war period illustrate that despite their self-exalted stature in the community, the leaders of Mingo County were not, as figures of authority, immune to acts of violence. In some cases, they were unwitting victims, but in others, they embroiled themselves in situations in which their positions offered no shelter. Taken together, these events demonstrate that when Mingo Countians entered the traumatic strike period of 1920-1922, neither social, political, or economic prominence protected individuals from attack.

The first assault involving an authority figure occurred shortly before the United States entered the war. On February 1, 1917, Mingo County Circuit Court Judge James Damron was shot while walking home from his office in Williamson. According to local published accounts, Damron's assailant attacked the judge because Damron had sentenced his girlfriend's uncle to three years in jail for shooting a young man who survived, but subsequently lost an arm. ${ }^{44}$

\footnotetext{
${ }^{42}$ Ibid.
}

${ }^{43}$ This assertion is based on examination of the available copies of Mingo County's two newspapers from the 1917-1919 period.

${ }^{44}$ Mingo Republican, 1 February 1917. 
Unbeknownst to the public however, Governor John J. Cornwell hired Pinkerton detectives to investigate the case. After eight months of interviewing Mingo's political and economic leaders, the investigators' only conclusion was that the initial suspect was probably innocent, a fact never publicly disclosed. ${ }^{45}$ Including Damron himself, and a first cousin, the detectives identified a variety of local figures who might have had reason to shoot the judge; the possible motives ranged from Damron's penchant for colleagues' wives to political animosity. ${ }^{46}$ With the case officially closed, the attempt on Damron's life was never solved. The disparity between the public and private resolution of the case became another element in the pattern of Mingo's criminal history. ${ }^{47} \quad$ Seven months after the attack on Judge Damron, a jury acquitted Matewan's former town sergeant John Hoskins of the murder of Henry Brewer. According to the Mingo Republican, the death of Brewer had resulted from a minor incident involving Hoskins, Brewer and Brewer's brother-in-law, Lewis Hatfield. In May 1916, Hoskins stopped Brewer and Hatfield from driving over a waterhose being used in a street dampening, which Hoskins was supervising. As the three men exchanged words, Hoskins slapped Hatfield whereupon Brewer hit Hoskins from behind. While Hoskins tried to regain his bearings, Brewer advanced on him with his hand in his hip pocket. Still reeling from the blow to his head Hoskins shot and killed

${ }^{45}$ See "Judge Damron case" file in the Cornwell Papers, WVRHC.

${ }^{46}$ Ibid. The detectives pointedly noted that Damron's romantic activities had occurred after the death of his first wife and before his remarriage.

${ }^{47}$ Years after the strike Damron was shot again and left for dead, but recovered; his assailants in the second attack also were never apprehended. H. B. Lee recounts the story in Bloodletting in Appalachia as part of a general discussion on the lack of respect shown officers of the law in Mingo County. Lee, Bloodletting, 51. 
Brewer, then fled to Kentucky, where he remained for a year before returning to Mingo and to trial. $^{48}$

The recounting of the Hoskins-Brewer incident emphasizes several aspects of the approach to violence and justice in Mingo County. First, the actions of Brewer and Hatfield reveal that they were not intimidated by Hoskins' position as Chief of Police. Second, the escalation to physical violence occurred after Hoskins slapped Hatfield, which indicates that male honor became an issue in the exchange between the three men. Third, and most important, Hoskins' acquittal resulted from the jury's acceptance of his claim of self-defense. Interestingly, Hoskins faced no additional punishment as a result of his flight to Kentucky. ${ }^{49}$

After the acquittal, John Hoskins simply rejoined the community. Mysteriously however, nearly two years to the day of Henry Brewer's death, men discovered Hoskins' lifeless body in Red Jacket's Mitchell Branch mine. Since no suspicious marks were found on the body, no one was charged in his death. ${ }^{50}$ Whether the Hoskins-Brewer incident led to Hoskins' death or influenced subsequent interaction between the families cannot be proven. However, it should be

${ }^{48}$ Mingo Republican, 13 September 1917.

${ }^{49} \mathrm{As}$ the discussions of previous murder cases in Mingo County illustrates, "self-defense" arguments occurred frequently in the county. See Chapter 5 . This trend continued during the strike period, most notably in the "Massacre trial" itself. Lead defense attorney Harold W. Houston depicted Sid Hatfield and the other Massacre defendants as men who were protecting their homes and families from "an invasion" of armed Baldwin-Felts agents. Two issues are illuminated by these cases. First, they exemplify the invocation of "honor" as a defense for violence committed by individuals seeking to protect or exert their public status. See Nisbett and Cohen, Culture of Honor, xvi, 26, 86. Second, they illustrate the phenomenon described by Lynwood Montell as "symbolic aggression," in which the perpetrator seeks to avoid punishment or gain approbation by claiming that their victim "did or said something that brought on the conflict. Montell, Killings, 149.

${ }^{50}$ Williamson Daily News, 7 May 1919. 
noted that during the strike period, 1920-1922, Hoskins and Brewers temporarily wound up on opposing side of the conflict. ${ }^{51}$

Although Matewan and a few other communities had achieved notoriety for violence involving public officials, until the summer of 1918, Williamson had escaped such infamy. At nine o'clock in the evening on July 29, Jesse Huffman, the Constable of Chattaroy precinct and an officer of the Sycamore Coal Company, shot and killed Williamson's Chief of Police John B. Maynard. Maynard's brothers, who were standing nearby grabbed Huffman and arrested him. The Williamson Daily News concluded that Huffman's attack amounted to a crime of passion because "there seems to have been bitter feeling between the two men in which, as usual, women played their part, and may have caused the tragedy." ${ }^{152}$

Maynard's murder indeed may have resulted from a dispute over a woman, but a not so distant political controversy may also have contributed to Maynard's demise. Just one year before his death, Maynard actively campaigned against incumbent mayor J. M. Studebaker, a member of his own party. At the time Maynard allegedly was disgusted by "Studebaker's long debauch, during which he tried and fined men for being intoxicated when he was worse intoxicated than the culprits." In return, Studebaker, his brother-in-law James Damron, and their

\footnotetext{
${ }^{51}$ John Hoskins had come to Matewan from Kentucky with his two brothers, A. L. "Al" and W. R. "Remine" Hoskins. All three brothers eventually served as law officers in Matewan and/or Magnolia District. During the strike period, Al, by then the only surviving brother, attracted animosity from the pro-union forces. Isaac Brewer, a kinsman of Henry Brewer, started out a union activist and Massacre trial defendant before turning state's evidence. The Hoskins' brothers were linked by marriage to Matewan's pro-union Chambers family. Isaac Brewer was the uncle by marriage to Ed Chambers, who would be murdered in August 1921 by the same man who convinced Brewer to switch sides in March 1921, but Brewer, through his own mother was also the cousin of Logan County's infamous sheriff Don Chafin. See Chapter 10.

${ }^{52}$ Williamson Daily News, 30 July 1918.
} 
political allies tried to fire Maynard. Maynard survived Studebaker's machinations and remained Chief of Police even after the Democrats regained control of Williamson in $1917 .^{53}$ Two months after the incident a jury found Huffman not guilty of murdering Maynard, and all public discussion of the case abruptly ended..$^{54}$

The last episode of violence involving public officials during the 1917-1919 period exposed the roots of the festering resentments that influenced the chain of events that caused the Matewan Massacre. According to the Williamson Daily News, on Sunday morning, December 7, 1919, Matewan's Chief of Police Sid Hatfield attacked Squire A. B. Hatfield. Ill-will between the two Hatfields stemmed from a controversy that had erupted between Mayor Testerman and Ance Hatfield, the proprietor of the Urias Hotel earlier in the year. ${ }^{55}$ A. B. Hatfield had testified on behalf a Urias Hotel employee who had successfully sued the Police Chief for improper arrest. ${ }^{56}$ The December incident between A. B. and Sid Hatfield spawned a flurry of rumors by "partisan friends," but the Daily News noted that despite the "lurid stories" circulating through

${ }^{53}$ Mingo Republican, 31 May 1917.

${ }^{54}$ Williamson Daily News, 17 September 1918. Unlike coverage of other murder cases involving public officials, the Daily News' coverage of the Maynard-Huffman case was extremely brief.

${ }^{55}$ Williamson Daily News, 20 February 1919. Shortly after taking office, Testerman had revoked the Hotel's license on charges relating to alleged illegal and lewd activities. Since William Anderson "Devil Anse" Hatfield lived until 1921, it is likely that Matewanians referred to Anderson Hatfield, the Urias Hotel proprietor, as Ance or Ancie, as a way of differentiating between them.

${ }^{56}$ Details of this incident appear in "Sid Hatfield, by Isaac Brewer," Lewis Collection, ERCA. Although Brewer errs in the chronology of some of the events, his story otherwise matches accounts from the Williamson Daily News. 
the town, "it was apparent the Chief gave [the squire] a good pummeling." ${ }^{57}$ Although hauled into magistrate's court for later feloniously assaulting A.B. Hatfield, Police Chief Hatfield escaped punishment because no one showed to press the issue. ${ }^{58}$

To the disgust of the Daily News, Chief Hatfield asserted that the incident had been misconstrued. Emboldened perhaps by the case's dismissal, Hatfield claimed that he had not attacked the squire, but only interceded in an unfortunate barnyard incident. According to Chief Hatfield, "Squire" Hatfield had gone to feed his swine and while bending over to slop them, "one of the pigs grabbed him by the nose and came very near biting it off," before he (Sid Hatfield) could rescue him. Hatfield's sly mockery inspired the Daily News to wearily editorialize in the article's conclusion, that "we hope our people can get along better in the future and strive to have a better community in which to live." 59

The violent exchange between Squire A. B. Hatfield and Matewan Chief of Police Sid Hatfield directly influenced the chain of events that led to the Matewan Massacre on May 19, 1920. First, despite sharing a last name with Sid Hatfield, Matewan's former mayor Andy Barrett Hatfield did not claim him as "kin.” As one Hatfield descendant observed, Sid probably was reminded of that rejection on a daily basis by the legitimate Hatfields of the town. ${ }^{60}$ Second, Sid

${ }^{57}$ Williamson Daily News, 13 December 1919.

${ }^{58}$ Ibid.

${ }^{59}$ Ibid.

${ }^{60}$ Hatfield correspondence, letters no. 17 and 29. Ms. Hatfield states, "the absolute worst thing . . . one Hatfield could say about another" was, "'He may have the name, but not the blood."' According to Ms. Hatfield, this statement underscores the subtextual significance of the questions surrounding Sid Hatfield's origins, the death of Massacre witness "Ancie" Hatfield, and McDowell Sheriff Bill Hatfield's role in Sid Hatfield's death. 
had not been elevated to his position as Matewan's police chief by the Hatfields or their allies.

By the time of Sid's appointment, Cabell Testerman held Matewan's mayoral office. ${ }^{61}$ Third and last, when Albert Felts led a party of Baldwin-Felts agents into Matewan on May 19, 1920, he did so in direct violation of a peace bond issued by Sheriff Blankenship. The agents came with eviction warrants that Sid Hatfield later alleged were issued by A. B. Hatfield. ${ }^{62}$

\section{The War's Impact on the Local Social Infrastructure:}

Two otherwise unrelated wartime developments illustrate the limits of elite control in Mingo County. As an unprecedented public health crisis, the Influenza Epidemic of 1918 exposed the superficiality of modern quality of life improvements in the county. Although programs designed to build consensus and conformity curtailed the social activities of Mingo's lower class white population, the war facilitated unparalleled autonomy initiatives by two of Mingo's largest minority groups. The local communal memory of the 'Flu' epidemic

${ }^{61}$ Williamson Daily News, 7 July 1919. Based on the legally required publication of his application for a pistol license, it can be determined that Sid Hatfield had become Matewan's chief of police by the summer of 1919. Given the paucity of town records, it is not known how Sid Hatfield was chosen to serve as chief of police, or who sponsored his candidacy. According to Margaret Hatfield, Sid Hatfield was most likely one of R. W. Buskirk's "hangers-on," and not an intimate associate of Testerman's. Hatfield correspondence, letter no.17. This depiction of Hatfield matches the one drafted by Isaac Brewer for Thomas L. Felts. According to Brewer. Ance Hatfield claimed to have bought Sid Hatfield's vote for two dollars. "Sid Hatfield by Isaac Brewer," Lewis Collection, ERCA.

${ }^{62}$ Williamson Daily News, 29 April 1920. Albert Felts was arrested on April 28, 1920 and placed under a $\$ 2,000$ peace bond. Exactly who issued the eviction warrants became a major dispute in the Massacre's aftermath. Magistrate R. M. Stafford testified during the trial that he had authorized them, but documents Sid Hatfield claimed to have removed from Felts' body allegedly were signed by A. B. Hatfield. "Testimony of R. M. Stafford," 15 March 1921, unknown newspaper, Matewan Omnibus Collection, ERCA. 
underscores both the ability of Mingo Countians to come together during a crisis and the quiet heroism of the socially marginalized. By contrast, the role of the native white community in the erasure of the evidence of an independent ethnic presence speaks volumes about social hegemony in the county.

The social maelstrom that accompanied World War I included two public health crises. At both the war's beginning and end, epidemic disease devastated communities throughout Mingo County. Since the second incident was part of the Influenza global pandemic, it had a much more profound impact than the first. Viewed together however, the two wartime epidemics symbolized how the war and its aftermath unleashed social forces that swept over and irrevocably altered social interaction in the county.

Measles struck in Mingo during the late winter of 1916-1917. By the third week of February 1917, seven people had died in the coal camps between Chattaroy and Hatfield. ${ }^{63}$ When the state department of health tabulated the final tally of the outbreak, 458 Mingo residents had fallen ill, four times higher than the next most afflicted county. ${ }^{64}$ Mingo Countians thus entered the war weakened from infectious disease. Coincidentally, less than two years later, and just weeks before the war's end, another epidemic swept through the county.

On September 26, 1918, the Daily News informed its readers that the "Spanish Influenza" had hit the nation's capitol and was poised to spread all over the country. ${ }^{65}$ Twelve days later, the

${ }^{63}$ Mingo Republican, 22 February 1917.

${ }^{64}$ Biennial Report of the State Department of Health, For the Years 1917-1918 (Charleston, WV: Tribune Printing Company, 1918), 103.

${ }^{65}$ Williamson Daily News, 26 September 1918. 
newspaper reported that 480 people had already died at Camp Sherman, Ohio. ${ }^{66}$ After just two more days, and only two weeks after the Daily News' first mention of the outbreak, the Influenza "reached a violent stage in Williamson." 67 In a chilling testament to the pitfalls of progress, the paper had unwittingly chronicled the approach of the rapidly spreading disease. After appearing first in the eastern Panhandle, the 'Flu traveled westward and southward along West Virginia's rail lines to Mingo. ${ }^{68}$

The 'Flu's virulence and the rapidity of its diffusion forced the state's health department to shut down public intercourse -- theaters, schools, and churches were closed, and public meetings and parades were strictly forbidden. ${ }^{69}$ Two items from the Williamson Daily News illustrate how ill-equipped communities were to handle the crisis. The same day that the Daily News confirmed the 'Flu's arrival in the county, it published the following medical advice:

-- go to bed immediately ... with a comfortable amount of bed clothing.

-- open your windows and leave them open day or night.

-- eat a light diet and take an occasional laxative.

-- keep away from those who have it.

-- don't spit.

-- if you cough or sneeze, cover your mouth with a handkerchief.

-- use your own towels and drinking cup.

-- stay at home and keep your children at home. ${ }^{70}$

${ }^{66}$ Williamson Daily News, 8 October 1918.

${ }^{67}$ Williamson Daily News 10 October 1918.

${ }^{68}$ Biennial Report of the State Department of Health, For the Years 1919-1920 (Charleston, WV: Tribune Printing Company, 1920), 12.

${ }^{69}$ Ibid.

${ }^{70}$ Williamson Daily News, 10 October 1918. 
Armed only with basic illness and hygiene advice and alarmed by the ramifications of total public quarantine, the citizens of Mingo Count held an open air meeting on October 12 to discuss whether the community should comply with the state's proscriptions. ${ }^{71}$ At the time of the meeting's announcement, the Williamson Daily News reported that most of those afflicted were only ill three or four days, and then rapidly recovered. ${ }^{72}$ Not until the epidemic had run its course did the disease's impact sink in.

The state health department's report revealed the essential scope of the Influenza's rampage through West Virginia. Based on data reported from every county, state health officials determined that the disease generally ran its course in seven weeks and that most of the fatalities stemmed from secondary illnesses such as pneumonia or meningitis. ${ }^{73}$ The 'Flu lasted forty-three days in Mingo, afflicting 1,158 and killing 144, almost six times the number of Mingo men who died while in service in the war. ${ }^{74}$

The 'Flu so disturbed the social and economic balance in Mingo that five young women worked at Glenalum in order to keep the mines running. According to the Daily News, the young women, who included a doctor's daughter, took up positions at the powerhouse, the switch, and

${ }^{71}$ Williamson Daily News, 12 October 1918.

${ }^{72}$ Ibid.

${ }^{73} 1920$ State Health Report, 12.

${ }^{74}$ Ibid; and Williamson Daily News, 10 October - 22 November 1918. Mingo County ranked nineteenth out of the state's fifty-five counties in the number of Flu-related fatalities. Kanawha County ranked first with 700 . However, high death rates did not necessarily result from population concentration in industrialized counties; with 600 deaths, agrarian Berkeley County in the eastern panhandle suffered the state's second highest mortality rate. The common denominator between the agricultural and industrial counties' rates of infection appears to have been the railroad. 
the picking table, for "patriotic motives only." Modestly, the young women refused public acknowledgment of their sacrifice. ${ }^{75}$ The most complete record of the social impact of the 1918 Influenza epidemic in Mingo County appears in the oral testimonies recorded in 1989-1990. The stories recounted by survivors not only individualize and humanize the epidemic's statistical profile, they also illuminate elements of the community's social structure and how crisis challenged the bonds of family and community.

The most startling aspect of the spread of the disease was who it seemed to target. Unlike other contagious diseases which generally kill more of the very young and the very old, the 'Flu killed those in the prime of their lives -- from teenagers to men and women with young children. ${ }^{76}$ Individual stories reflect the incomprehensibility of this affliction. Mrs. Addie Dixon recalled that one boy, "out of his mind with fever, cut his own throat with a razor."77 The mining community at Red Jacket felt especially exposed when the company doctor became the 'Flu's first victim. After Dr. Goings' death, Mrs. Stella Presley observed that at Red Jacket, "about every other house had somebody dead in it." ${ }^{178}$

The search for an explanation for the devastation led, in at least one case, to ascribe two deaths to divine retribution. When the two draft age sons of Mrs. Bertha Staten's favorite uncle

\footnotetext{
${ }^{75}$ Williamson Daily News, 2 November 1918.
}

${ }^{76}$ Several of the Matewan Oral History Project narrators discussed the fatalities that resulted from the epidemic: Mrs. Mattie (McCoy) Allara, Mrs. Bertha Staten, Mrs. Eva Cook, Mrs. Edith Boothe, and Mrs Vicie (Hatfield) Simpkins Blackburn.

\footnotetext{
${ }^{77}$ Addie Dixon interview with Rebecca J. Bailey, Summer 1990 Matewan Oral History Project.
}

\footnotetext{
${ }^{78}$ Stella Presley interview.
} 
died from the 'Flu, Mrs. Staten's mother observed, "she got her wish" because the young men's mother had reportedly declared that "she'd rather see them dead as to see them go to war."79 $M r s$. Staten remembered that the father's grief was compounded by the fact that "nobody would go help him . . . he had to make the caskets and bury them himself." 80 The implication seemed to be that somehow the community held the boys' mother accountable for their deaths, but other interviews offer alternative explanations for why no one assisted the grieving father.

The communities in Mingo were overwhelmed by the weather and the widespread sickness. Mr. Harry Berman noted that at Matewan, "ice was jammed up in the river fifteen, twenty feet." 81 The rapidity of death also impeded burying the victims in the cold weather. Matewan resident Hawthorne Burgraff observed that people died so fast, "there couldn't be enough caskets brought in." ${ }^{82}$ Whole families fell ill, and "Hog" Floyd Hatfield's daughter and son-in-law died, leaving behind their young child. ${ }^{83}$ Mrs. Eva Cook painted a particularly evocative portrait of the atmosphere of death hanging over the county. According to Mrs Cook, "the hearse was horse drawn with four lanterns . . . so many people died, they would bury them

${ }^{79}$ Bertha Staten interview.

${ }^{80}$ Ibid.

${ }^{81}$ Harry Berman interview with John Hennen, 1989 Matewan Oral History Project.

${ }^{82}$ Hawthorne Burgraff interview with John Hennen, 1989 Matewan Oral History Project.

83"Entire families" -- from Hawthorne Burgraff interview; Cordelia (Hatfield) Ferrell and her husband "lay corpse at the same time" -- Vicie (Hatfield) Simpkins Blackburn interview. 
after dark ... when you saw that hearse coming with those four lanterns lit . . you knew it was an Influenza death." 84

Contemporary newspaper accounts reveal that a county-wide Influenza Relief Committee tried to organize assistance, in particular calling upon those with nursing experience and Boy Scouts. Survivors however, remember the efforts undertaken by individuals in the community. ${ }^{85}$ Clarence "Dutch" Hatfield remembered that "one or two old people . . . went house to house taking care of people." 86 Daisy Nowlin stated that in the Matewan area, only "John and Mary Brown were not afraid and they would come . . take the families' washing . . . and see that they didn't want for anything." ${ }^{87}$ Hawthorne Burgraff's aunt Elizabeth "Babe" Burgraff stands out as the county's most colorful angel of mercy. Six feet tall and as "tough as a man," (she once shot her own husband), Babe Burgraff cared for her extended family and claimed to have escaped the 'Flu by drinking a shot of moonshine "every once in awhile." 88 The stories of these private citizens who nursed others all celebrate the generosity of individuals who were in other ways marginalized -- the elderly, an African-American couple, and a woman who did not obey the strictures of contemporary society.

\footnotetext{
${ }^{84}$ Eva Cook interview. Mrs. Cook was born during the epidemic; her mother fell ill while recuperating from the birth, but survived.

${ }^{85}$ Williamson Daily News, 22 October 1918. The article revealed that the Relief Committee worked out of the office of the County Council of Defense, and pleaded for volunteer nurses and Boy Scouts to aid the sick. Project.

${ }^{86}$ Clarence "Dutch" Hatfield interview with Rebecca J. Bailey, 1989 Matewan Oral History

${ }^{87}$ Daisy Nowlin interview with Rebecca J. Bailey, 1989 Matewan Oral History Project.

${ }^{88}$ Hawthorne Burgraff interview.
} 
The Influenza epidemic survivor stories, however unintentionally, also illuminate how socioeconomic differences influenced responses to the epidemic. Families who could afford to, took extraordinary measures to protect their families. R. T. Hatfield followed the medical advice printed in the Cincinnati Post, not the Williamson Daily News. ${ }^{89}$ The merchant Berman family imported drugs from Topeka, Kansas. ${ }^{90}$ However, these efforts did not always work. Sailor McCoy shipped in oranges from Huntington, but still lost his oldest daughter. ${ }^{91}$ Most families relied on traditional remedies used for generations on a variety of ills: herbs, groundhog grease, onion poultices, mustard poultices, and a mixture of whiskey, ginger and lemon. ${ }^{92}$ However inadequate these restoratives may seem in retrospect, they appear far less harmful than one homeopathic cure advertized in the Williamson Daily News, which consisted of an injection of iodine, criosote, and guniacol. ${ }^{93}$

The rapid and tremendous devastation caused by the contagion was not easily forgotten. Almost a year and a half later in the late winter of 1919-1920, a recurrence of the 'Flu was

${ }^{89} \mathrm{Hatfield}$ correspondence, letter no.5.

${ }^{90}$ Harry Berman interview.

${ }^{91}$ Mattie (McCoy) Allara interview.

${ }^{92}$ Daisy Nowlin interview, and Jeanette Simpkins interview with Rebecca J. Bailey, 1990 Matewan Oral History Project. These remedies were common throughout the state. In the eastern panhandle, recommended treatments also included heart stimulants, alcoholic stimulants and onion plasters. William T. Doherty, "A West Virginia County's Experience with the Influenza Epidemic," West Virginia History 39 (January 1977): 136-140, 140.

${ }^{93}$ Williamson Daily News, 15 October 1918. According to the newspaper, Dr. George F. Baer of the Pittsburgh Homeopathic Hospital devised the injection-cure. 
reported near Mingo in the Tug River field. ${ }^{94}$ At about the same time, some of the operators in the Williamson-Thacker field raised fees for service by the company doctor. The manifest insensitivity of this gesture encapsulated the growing distance between Mingo's mining class and their employers. When asked to share examples of the grievances that led to union agitation, one miner cited the ill-timed hike in medical fees. ${ }^{95}$

One of the first miners to speak out in protest of post-war conditions in Mingo County was W. E. Hutchinson, an African American. In fact, Hutchinson was one of the two miners sent to Charleston to request District 17's assistance in organizing Mingo County. For the last twenty years scholars have stressed the role of black miners in the struggle to unionize southern West Virginia. However, the full scope of the significance of African-American involvement in the Williamson-Thacker strike has been underappreciated. African-American miners were far fewer in number in Mingo than in neighboring coal counties, and that it was they who rose and demanded better treatment inspired a reexamination of the history of race relations in Mingo County. What was uncovered indicates that, just as in other African-American communities in the United States, World War I unleashed long pent-up aspirations. The actions of Mingo's African-American community during the war highlight the unintended corollary effect of wartime propaganda. ${ }^{96}$ After the war, many of Mingo's African-Americans funneled their hopes

${ }^{94}$ Coal Trade Journal 51 (18 February 1920): 174.

95"Testimony of W.E. Hutchinson,” West Virginia Coal Fields, 79.

${ }^{96}$ Historians John Hope Franklin and August Meier assert in Black Leaders of the Twentieth Century, that after World War I, African Americans grew disenchanted with white America and turned "inward" and independently launched community improvement efforts. John Hope Franklin and August Meier, eds., Black Leaders of the Twentieth Century (Urbana: University of Illinois Press, 1982), 113-114. 
into the union movement. Sadly, the impact of the 1920-1922 strike on Mingo's AfricanAmerican community emphasizes the often overlooked local effect of such divisive conflicts. ${ }^{97}$ In 1900, only 309 African Americans lived in Mingo County, and constituted a mere 2 percent of the population. Although Mingo's black community expanded 400 percent by 1910 , African Americans still comprised a mere 6 percent of the population of the county. ${ }^{98}$ Because so few African Americans lived in Mingo County, their low numbers exacerbated the significant challenges faced by blacks in West Virginia's singular sociopolitical system. Unlike their contemporaries in the South, African Americans in West Virginia retained the right to vote but faced a patchwork of inconsistent segregation practices. ${ }^{99}$ Beginning with David Corbin, several scholars have documented the experiences of African Americans who were lured to southern West Virginia's coalfields by the promise of higher wages and the hope of exercising rights denied them in other states. ${ }^{100}$ However, the experiences of African Americans in Mingo County

\footnotetext{
${ }^{97}$ The actions of Mingo's African-American community probably were inspired by, or were part of, a broader movement of southern West Virginia's black elite during World War I and its aftermath. For more on this regional effort and its effect on race relations during the second mine war see: Joe William Trotter, "Black Miners in West Virginia: Class and Community Responses to Workplace Discrimination, 1920-1930" in The United Mine Workers of America: A Model of Industrial Solidarity? edited by John H.M. Laslett (University Park, PA: The Pennsylvania State University Press, 1996): 269-296, 294.

${ }^{98}$ Abstract of the Thirteenth United States Census, with Supplement for West Virginia, 592. See Appendix 5.

${ }^{99}$ Because most of West Virginia's in-migrating African Americans came from southern states that had restricted voting rights after Reconstruction, the retention of the franchise in West Virginia was an important "draw." Despite repeated attempts by West Virginia Democrats, the state never adopted a consistent "Jim Crow" segregation policy. For example, although schools, neighborhoods, churches and civic organizations were segregated, railway cars were not.

${ }^{100}$ Corbin, Life, Work, and Rebellion, (1981), Lewis, Black Coal Miners (1987) and Joe William Trotter, Coal, Class, and Color (1990). See bibliography for complete citations.
} 
demonstrate that opportunities for African Americans in West Virginia varied greatly, depending on the size of their community. ${ }^{101}$ In Mingo County, the low number of African Americans not only delayed community-building within the black community, it also complicated relations with whites.

Table 13:

Population Growth of Mingo County's African-American Community, 1900-1920 102

\begin{tabular}{llll}
\hline \hline & 1900 & 1910 & 1920 \\
\hline African Americans & 309 & 1,236 & 2,191 \\
$\%$ of total population & $3 \%$ & $6 \%$ & $8 \%$ \\
\hline
\end{tabular}

Source: Abstract of the Thirteenth Census, with Supplement for West Virginia and Fourteenth Census of the United States, State Compendium for West Virginia.

Because almost all of Mingo's African Americans migrated from elsewhere, there was no pre-existing community to welcome and succor the new arrivals. ${ }^{103}$ Moreover, they entered a community where even white migrants' access to power and influence depended on their ability

\footnotetext{
${ }^{101}$ David A. Corbin, Joe William Trotter, and most recently Roger Fagge have constructed a paradigm of African-American life in southern West Virginia out of the experiences of African Americans in Kanawha and McDowell Counties. The author cautions against utilizing the generalizations of this model in explaining the actions of African Americans in Mingo County. The author argues throughout this thesis that Mingo's much smaller African-American population, and the county's greater political volatility, affected the reality of race relations in Mingo in ways that may not have applied in the counties with much higher concentrations of African Americans. For comparison, in neighboring McDowell County in the period under study here, African Americans represented between 25 and 30 percent of the total population, versus a maximum of 8 percent in Mingo. See Appendix 5.

${ }^{102}$ Readers are reminded that 1900 was the first United States Census for Mingo County. Sources: Abstract of the Thirteenth United States Census, with Supplement for West Virginia, 592, and Fourteenth United States Census, State Compendium for West Virginia, 27.

${ }^{103}$ Corbin, Life, Work, and Rebellion, 62.
} 
to assimilate into the existing social hierarchy. ${ }^{104}$ Since their color automatically excluded them from intermarrying with the native population, pioneering African Americans such as John Brown of Matewan, were forced to construct alliances with whites in order to safely establish residency. In the years before the Massacre, for John Brown this meant an alliance with the Republican leaders of the town, R. W. Buskirk and the allies of Greenway Hatfield. Brown's position and prosperity resulted from his own "wiles" -- an ability to walk the fine line between accommodation and community leadership. ${ }^{105}$

Unfortunately, African-American loyalty to the Republican party in Mingo did not mean as much as it did in other southern West Virginia coal counties. Political power in Mingo County vacillated, not only between the Republicans and the Democrats, but also between factions of both parties. When the Democrats controlled the county, or even individual towns, the small flow of patronage to African Americans dried up. Moreover, because the AfricanAmerican community in Mingo was smaller than in the neighboring coal counties, white Republicans in Mingo felt free to betray their most loyal supporters. ${ }^{106}$ African Americans in

${ }^{104}$ See earlier chapters for discussion of the centrality of the Williamson, Lawson, and Hatfield families in the construction of Mingo's early economic and political networks.

${ }^{105}$ Johnny Fullen interview and Harold Dickens interview with Rebecca J. Bailey, Summer 1990 Matewan Oral History Project. Several generations of Matewan residents, black and white, respected John Brown. When Mr. Dickens, a white former resident of Matewan, spoke of Brown using his "wiles," he was lauding Brown's ability to survive and thrive in an era of challenging race relations.

${ }^{106}$ This assertion is based on F. H. Evans' support for Jim Crow bills in the 1907 legislature and J. M. Studebaker's tacit endorsement of the firing of Williamson's African-American employees in 1917. On Evans, see: Charleston Advocate, 14 February 1907; on Studebaker, see Mingo Republican, 31 May 1917. 
Williamson and Matewan were frequently caught up in the intrafactional disputes of their political patrons. ${ }^{107}$

The most significant obstacle to African-American community-building was the lack of a single African-American population center in the county. Unlike John Brown of Matewan, most of the county's black population lived in company-controlled communities. ${ }^{108}$ An AfricanAmerican neighborhood and business district eventually grew up in Williamson, but the lives of the "town" blacks were almost as circumscribed as those of the black miners. ${ }^{109}$

No evidence has been located to indicate that African Americans in Mingo County successfully launched community-building projects before 1917. World War I, however, precipitated a dramatic change when segregated war programs legitimized gatherings of black elites. ${ }^{110}$ African Americans from Mingo's towns and coal camps enthusiastically served in the county's Auxiliary Advisory Council of Defense and founded Red Cross chapters in Williamson

\footnotetext{
${ }^{107}$ The two best documented cases of this phenomenon are the Studebaker incident mentioned in the previous note, and the 1910 Matewan election incident. In 1910, native elite-machine politician Greenway Hatfield, who with great cunning cultivated black political support, slapped a coal company doctor and fellow Republican for criticizing the way Hatfield was allowing the "darkies" to vote. See the discussion of the "Wiley v. Hughes"contested election in Chapter 3.

${ }^{108}$ Cubby, "Transformation," 161, and Abstract of the Thirteenth Census, with Supplement for West Virginia, and Fourteenth Census, West Virginia State Compendium. The aggregation of population statistics shows that the majority of Mingo's African-American residents lived in Lee/Williamson, Magnolia, and Stafford districts -- the centers of commercial coal mining in the county.

${ }^{109}$ The center of the African-American neighborhood in Williamson was Vinson Street. Perry, They'll Cut Off Your Project, 54. The black business district was Third Avenue. Archie Bland interview with Rebecca J. Bailey, Summer 1990 Matewan Oral History Project.

${ }^{110}$ Hennen, Americanization, 51. Hennen briefly discusses the response of black West Virginians to both the war and white West Virginians' efforts to include them in the various war programs.
} 
and Red Jacket. ${ }^{111}$ Within a year, a non war-related African-American organization appeared. In the spring of 1918, the Colored Boosters' Club held its first meeting in Williamson. ${ }^{112}$ Meetings consisted of debates and presentations by guest speakers such as state commissioner of agriculture J. H. Stewart. ${ }^{113}$ The coalescence of Mingo's African-American leaders led to a dramatic and bold move in 1918. That year, community leaders including John Brown of Matewan, renamed the Williamson "Colored" School, the "DuBois" School, in honor of W. E. B. DuBois. ${ }^{114}$ Unfortunately, no records survive that would indicate whether the intent was to honor DuBois for his pioneering advocacy of racial pride and equality or for his leadership of African American patriotic efforts during the war. ${ }^{115}$ However, even the obstinance of the allwhite Democratic county court could not intimidate the DuBois School trustees. When the

111"West Virginia in the War," 815. Williamson Daily News, 19 February 1918.

${ }^{112}$ Williamson Daily News, 4 April 1918. Members included E. D. Britton, P. L. Hines, E. S. Campbell, and R. B. Hill.

${ }^{113}$ Ibid. The first debate topic was "Bad Whiskey is More Destructive than Bad Women."

${ }^{114}$ M.P. Shawkey, West Virginia Education Directory, for the School Year 1917-1918 (Charleston, WV: Tribune Printing Company, 1918) and from an interview with Johnny Fullen, grandson of John Brown, of Matewan. The event which might have inspired this particular move was a visit by DuBois to Blufield in 1918. Memphis Tennessee Garrison: The Remarkable Story of a Black Appalachian Woman, edited by Ancella R. Bickley and Lynda Ann Ewen (Athens, OH: Ohio University Press, 2001), 158. The author has cited an advance copy of this work, and advises that page numbering could be subject to change in the final published version.

${ }^{115}$ The African Americans of Mingo County who would have been privy to this decision had all passed by the time the author learned of the DuBois School. Contemporary local newspapers and the West Virginia State Directory of schools were silent on the matter. Also, archivists of the W. E. B. Dubois papers were unable to locate any materials that might have revealed that DuBois had learned of this action. Regardless of the mystery surrounding their motivation, when Mr. Brown and the other African-Americans decided to rename the "Colored" School the DuBois School, they were taking a brave step, given the temper of race relations in this period. 
county court refused to assist in transporting children to the school, Mr. Brown and the other leaders raised money to purchase a canvas-covered truck to ferry the students to school. ${ }^{116}$ Sadly, by 1921, the school was simply, yet again called the Williamson "Colored" School in the West Virginia education directory. However, the self-empowerment symbolized by the brief life of the DuBois School bore fruit during the political and labor events of 1920.

Before the strike began, several African-American leaders started the "Independent Colored Voters Club," in the spring of $1920 .{ }^{117}$ One of the leading pro-union African-American miners Frank Ingham, was married to the sister of the DuBois School's principal. ${ }^{118}$ The prominence of African Americans in the strike drew the attention of federal investigators. ${ }^{119}$ However, a casualty of the protracted bitterness of the strike seems to have been the united and independent activism of the African-American community. At a meeting of the Independent Colored Voters Club, community leader and war veteran, Dr. James M. Whittico was shouted down for expressing his continued support for the Republican Party. ${ }^{120}$ African-Americans John and Mary Brown, and Maggie Washington were driven from Matewan by death threats from

\footnotetext{
${ }^{116}$ Johnny Fullen interview.

${ }^{117}$ Williamson Daily News, 15 May 1920.

118"Testimony of Frank Ingham," West Virginia Coal Fields, 33.
}

119"Negro Activities," 9 October 1920, "Reports by Informant C-61 to A. E. Hayes, for the Southern District of West Virginia, 9 October - 30 October 1920," in Federal Surveillance of Afro-Americans (1917-1925): The First World War, the Red Scare, and the Garvey Movement, edited by Theodore Kornweibel, Jr. (microfilm project of University Publications of America).

${ }^{120}$ Williamson Daily News, 15 May 1920. 
union supporters. ${ }^{121}$ Striking black miners also physically abused black replacement workers. ${ }^{122}$ The African-American community apparently never regained its wartime unity in the years after the strike. ${ }^{123}$

As in the case of Mingo's African-American community, World War I presented Mingo's second largest ethnic community with an opportunity to seek greater autonomy. In 1917 southern West Virginia's first co-operative mine was founded by and for Hungarian-American miners. Backed by Martin Himler, a Hungarian-American newspaper publisher and philanthropist who had worked briefly in the coal mines of Ohio, the Himler mining company operated for eleven years on the West Virginia-Kentucky border. Himler started the company with two objectives, to realize "the ideal of cooperation between labor and capital" and to "Americanize" Hungarian miners. The story of the Himler mine and the independent community

\footnotetext{
${ }^{121}$ (John and Mary Brown), Johnny Fullen interview. (Maggie Washington), unknown newspaper, Lewis Collection, ERCA. Maggie Washington was a domestic servant in the home of Matewan Massacre defendant Art Williams.

122"Memoranda of Mingo Conditions Compiled Monday," undated, Cornwell Papers, WVRHC.

${ }^{123} \mathrm{Dr}$. Whittico remained a devoted Republican and he also served as family physician to several Hatfields for the rest of his life. "Dr. James M. Whittico," Williamson Area Heritage Book, 105. John Brown returned to Matewan only upon the urging of Democrat E. B. Chambers, and his grandson, Johny Fullen later became mayor of the town. Johnny Fullen interview. Only a child during the 1920-1922 strike, James Curry later served as an officer in his union local in Mingo County. James Curry interview with Rebecca J. Bailey, Summer 1990 Matewan Oral History Project. One indication that Mingo's black elite retained their commitment to racial issues came with the founding of Mingo's NAACP chapter in 1923, five years after Bluefield, but four years before Logan. Trotter, Coal, Class, and Color, 246.
} 
it created reflects the impact of both the labor strife and the decline of the coal economy in the 1920s. ${ }^{124}$

As the prototypical eastern European immigrant group, Hungarian-Americans have occupied a singular place in ethnic, labor, and coal history. Known for their determination to work under any conditions, Hungarians gained a reputation for being resistant to unionization and their willingness to work as strikebreakers. ${ }^{125}$ A primary reason for the Hungarian miners' disinterest in unionization allegedly stemmed from their disinclination to put down roots in America. A subsidiary goal of the Himler experiment centered on the desire to encourage Hungarians to invest in business ventures in America and not send all of their money back to Hungary. ${ }^{126}$ Unfortunately for the Hungarians, their work ethic placed them in the epicenter of labor conflicts. ${ }^{127}$

Exactly why Martin Himler and company chose a remote corner of Mingo County for their socioeconomic experiment is not clear. While Hungarian miners were first noted in the Big Sandy Valley in the 1890s, the following table illustrates that Mingo County attracted far fewer

${ }^{124}$ Chapman, "The Influence of Coal in the Big Sandy," 224-226, 236. Chapman's source was the Paintsville Herald, 24 January 1924. Himler, who was also Jewish, immigrated to the United States in 1907, and had learned "the coal trade in the mines of Ohio." Before becoming the New York-based publisher of Magyar Banyaszlap, Himler had also worked as a painter, peddler, and salesman.

${ }^{125}$ Bailey, "Judicious Mixture," 150. According to Bailey, as early as 1889 , many West Virginia miners held this opinion of Hungarians.

${ }^{126}$ Logan Banner, 21 May 1921.

${ }^{127}$ Bailey, "Judicious Mixture," 150. 
Hungarians than its neighboring counties. ${ }^{128}$ In Mingo County, Hungarians never exceeded 9 percent of the mine employee total, while in McDowell County, they comprised 25 percent of the total. $^{129}$

Table 14:

Comparison of the Hungarian Population in Mingo, Logan, and McDowell Counties, 1910-1920

\begin{tabular}{llll} 
Hungarian Population In & Mingo & Logan & McDowell \\
\hline 1910 & 309 & 239 & 1,816 \\
1920 & 206 & 1,154 & 1,409 \\
\hline \hline
\end{tabular}

Source: Abstract of the Thirteenth United States Census and Fourteenth United States Census Compendium.

Moreover, in at least one case noted in an earlier chapter, two Hungarian families had been brutalized by Valley natives. ${ }^{130}$ Unfortunately for the Hungarians, the same traits that provoked animosity from co-workers elicited praise from their employers and other elites. "Old timers" in Mingo claimed that other miners hated the Hungarians because two on a section crew of eight "would work the other six to death." ${ }^{131}$

The opportunity that drew Hungarian miners to the Himler co-operative venture in Mingo centered on the promise of becoming worker-owners, since every employee was a stockholder in

\footnotetext{
${ }^{128}$ Crowe-Carraco, 91.

${ }^{129}$ (Mingo) Based on data extrapolated from the Annual Reports of the West Virginia
} Department of Mines, 1907-1921. (McDowell) Bailey, "Judicious Mixture," 152. In fact, for much of the period under examination in this study, the Hungarian percentage of the mining population of Mingo hovered around 6 percent, one-fourth of McDowell's percentage.

${ }^{130}$ The attack took place in 1908 , See Chapter 5 for details.

${ }^{131}$ Hatfield correspondence, letter no.22. Despite the reverse exodus generally associated with World War I, Hungarians with special talents did arrive in Mingo after 1919. Miss Hatfield recounted that a Hungarian miner played his violin for her aunt's students at Lobata; before coming to America, the man had been a professional violinist with the Budapest Symphony. 
the company. ${ }^{132}$ In addition to this unique economic opportunity, the Himler Coal Company also constructed a model village. The miners could occupy a company house equipped with the latest amenities including electric lighting and electric or gas heat, or they could build their own home. ${ }^{133}$ A bakery specializing in Hungarian breads and cakes also served the community. ${ }^{134}$ Himler provided the company with a printing press in order to produce reading materials in Magyar. ${ }^{135}$ The company subsidized education, paying for three additional months of instruction and requiring teachers to hold college degrees. After attending the regular school, children studied Hungarian language every day for two hours. The secretary of the company offered night classes in English and civics for the adults of the community. ${ }^{136}$ Himlerville even had its own bank. $^{137}$

Unfortunately, the Himler experiment did not survive. Constructed at the peak of wartime inflation, the Himler plant's modernity could not offset the disparity between production cost and market prices. The company had budgeted a quarter of a million dollars to launch the operation, but ultimately spent three quarters of a million dollars. ${ }^{138}$ One of the largest

${ }^{132}$ Chapman, 232-233.

${ }^{133}$ Ibid., 230. In The Big Sandy, Carol Crowe-Carraco states that the Himlerville cottages contained: "five rooms, two windows per room, tubs and showers and electric lights." CroweCarraco, 93.

${ }^{134}$ Chapman, 231.

${ }^{135}$ Ibid.

${ }^{136}$ Ibid., 232.

${ }^{137}$ Williamson Daily News, 12 September 1919.

${ }^{138}$ Chapman, 235, 228. 
expenditures incurred by the young company was the erection, between 1919 and 1921 , of the Warfield-Kermit bridge. ${ }^{139}$ Initially only one of several underwriters of the project, the Himler Company eventually had to shoulder most of the construction costs. ${ }^{140}$ The other investors, also owners of coal lands or coal operators in Warfield and Kermit, were distracted by the strife which accompanied the Williamson-Thacker strike. ${ }^{141}$ Along with the unfortunate swings in the economy, the full-scale launch of the Himler mine coincided with one of West Virginia's worst labor struggles.

By all indications, the Hungarian miner-owners of the Matta-May (Himler) co-operative mine did not join the strike. Their indifference however, failed to protect the operation from the attendant violence. On November 10, 1920 someone blew up the drum and set fire to the headhouse of the Matta-May mine. Bloodhounds tracked a scent to the homes of Ira Maynard and Flem Stafford, who later denied participation in, or knowledge of, the assault. Although Maynard and Stafford were not linked to the UMWA in the public record, a minor detail of the story indicates that the men were union supporters. At the magistrate's hearing, attorney Thomas West, the local UMWA lawyer represented Maynard and Stafford. ${ }^{142}$

A newspaper account of Himler's expansion in the spring of 1921 provides insight into awkward position occupied by Hungarians in Mingo. The Logan Banner snidely dismissed

${ }^{139}$ Ibid., 229.

${ }^{140}$ Ibid.

${ }^{141}$ Description of other investors quote from Chapman, 229; the falling away of other coal men verified by materials in Box 6 of the Stokes Papers, WVRHC.

${ }^{142}$ Williamson Daily News, 19 November 1920. 
Martin Himler's ambitious vision as "a little group of Hungarian coal miners" who have taken upon themselves "the task of healing the industrial wounds of West Virginia's bituminous fields through a co-operative plan." ${ }^{143}$ The pro-union miners engaged in Mingo's strike were equally hostile.

Prior to the attack on the Matta-May plant, the union's key strategy in organizing Mingo depended on shutting down the mines. ${ }^{144}$ Miners who continued to work threatened that plan and were subjected to intimidation. One group targeted early, just one week after the Massacre, were the Hungarian miners employed by the Crystal Block Coal \& Coke Company. Crystal Block's superintendent J. M. Tulley informed Governor Cornwell that the Hungarians were warned that they would be "riddled" with bullets if they persisted in their defiance of the strike. ${ }^{145}$ Although the Hungarian miners continued to work, they told Tulley that were afraid to continue ignoring the union miners' threats. ${ }^{146}$ After the strike call took effect on July 1, 1920, coal production in

${ }^{143}$ Logan Banner, 27 May 1921. The author has been unable to locate a Mingo County newspaper of that date; therefore she feels compelled to note the following. First, all the news items published in the Mingo newspapers between 1917 and 1919 expressed support for the Himler venture, e.g. "The Himler Coal Company Corporation," Williamson Daily News, 19 August 1919. Therefore she urges caution in ascribing the 1921 response of the Banner to Mingo's press. Second, the author believes, despite her own reticence in interjecting the Banner's response, that it is an accurate representation of the large corporations' opinion of the Himler venture. Since the same large corporations' profile in Mingo expanded during the strike, it would be logical to assume that the Banner's derision of Himler was shared by many in Mingo.

${ }^{144}$ The union had briefly achieved this goal at the beginning of the strike in July 1920 . By importing replacement workers, and enticing men back to work with inflated wages, the operators returned the field to almost full production by the date of the attack on the Himler plant. Williamson Daily News, 26 November 1920 .

\footnotetext{
${ }^{145}$ J. M. Tulley to Governor John J. Cornwell, 26 May 1920, Cornwell Papers, WVRHC. ${ }^{146}$ Ibid.
} 
Mingo stopped almost completely. ${ }^{147}$ By November when the Himler plant was attacked, the mines in Mingo were almost back to full production and frustration among the union miners and their sympathizers was high. ${ }^{148}$ In early December, a union miner was arrested for attacking John Florez, an employee of the Matta May mine. ${ }^{149}$ According to the report on the incident, Will White beat and kicked Florez "mercilessly" because he was employed at a non-union mine and refused to quit working. ${ }^{150}$

Strike-related violence and intimidation failed to chase the Hungarian miners out of Mingo. After hitting a ten year low of 127 miners in 1920, by 1923 their number had rebounded to $185 .^{151}$ The Himler experiment also briefly survived the strike, but on May 22, 1925, the accumulated effect of cost overruns, an industry-wide recession, and the chaos of the strike years drove the company into receivership. ${ }^{152}$ Despite a valiant attempt to save it, four years later Himler's West Virginia assets were auctioned off, the new owners repaired the mines, and American miners moved in. ${ }^{153}$ Across the river in Kentucky, at the Hungarian village of Himlerville, the bank failed, the schoolhouse burned and the houses were sold and torn down. ${ }^{154}$

\footnotetext{
${ }^{147}$ Williamson Daily News, 26 November 1920.

${ }^{148}$ Ibid.

${ }^{149}$ Williamson Daily News, 14 December 1920.

${ }^{150}$ Ibid.

${ }^{151}$ 1908-1923 Annual Reports of the West Virginia Department of Mines.

${ }^{152}$ Chapman, 235 .

${ }^{153}$ Ibid., 236.

${ }^{154}$ Ibid., 237.
} 
The experiment described by Martin Himler as "the greatest single movement ever undertaken in this country" failed just ten years after its launch during the heady atmosphere of war. ${ }^{155}$

The key to understanding the violence visited upon Mingo’s African-American and Hungarian communities by union activists during the Williamson-Thacker strike lies in examining World War I's effect on the miners of Mingo County. Exhorted and bullied into producing coal for the war effort, Williamson-Thacker miners emerged from the war convinced that they deserved a share of the prosperity created by their sacrifices. When their employers failed to deliver, the miners rose in protest and attacked anyone who appeared to oppose their goals.

IV. Benevolent Paternalism and Wartime Policies Sow the Seeds of the Miners' Discontent:

In contrast to their employers, Mingo's miners did not materially benefit from the heightened demand for coal early in the First World War. The war boom did not result in better employment opportunity or security for Mingo's miners. The number of pick miners fell from 128 in 1914 to 11 in 1916, a decline of 91 percent, before rebounding to 181 in 1917 . Machine miners increased from 1,089 in 1914 to 1,132 in 1917, a meager 4 percent rise. By contrast, the number of men who worked as laborers inside the mines rose consistently from 872 in 1914 to 1,319 in 1917. The increase in less skilled labor positions and the fluctuation in work opportunities for pick and machine miners, undermines the image that increased coal production caused by wartime demands translated into better employment possibilities for the average mine

\footnotetext{
${ }^{155}$ Logan Banner, 27 May 1921. The 1921 run of the Williamson Daily News was not available.
} 
employee. In fact, for the men who had mining skills, the immediate future seemed far from sure. ${ }^{156}$

The lack of stability in employment was compounded by significant differences in the increase of wages and coal prices and the number of days the mines operated. The average miner earned an average of forty-one cents a ton in 1914 and an average of fifty-nine cents a ton in 1917, a 7 percent increase. The benefits of the wage hikes were undone by a drop off in opportunities to work, because the average number of days mines in Mingo operated fell from a high of 243 in 1914 to 220 in 1917, a 10 percent loss. ${ }^{157}$

Further exacerbating the miners' condition, food prices in Mingo County rose an average of 30 percent between 1914 and 1917. More importantly, the price of staple items like potatoes rose more than 50 percent. ${ }^{158}$ A comparison of the percentages of rise in wages and food prices underscores how the war's inflationary effect adversely affected Mingo's miners. The cost of food outstripped the rise in miners' wages by nearly 400 percent. ${ }^{159}$ Lack of certainty in job opportunities, fewer work days, and a higher cost of living all combined to lower the standard of living for Mingo's miners.

${ }^{156}$ 1914-1917 Annual Reports Department of Mine Reports.

${ }^{157}$ Ibid.

${ }^{158}$ Mingo Republican, 1 March 1917. According to the article, two-thirds of the 30 percent increase had occurred in a single year between January 1916 and 1917. The inflation of food prices in Mingo County inspired "old timers" to compare their current situation to that of the 1860s, during the Civil War.

${ }^{159}$ Author's extrapolation based on the comparative rise of food prices and wages in Mingo County. Food price figures taken from the Mingo Republican, and wage rates from Annual Reports of the Department of Mines. 
After the United States entered World War I in the Spring of 1917, the conscription of millions of American men dramatically affected labor relations. Around the country, and even in Mingo County, increased competition for workers necessitated a corollary improvement in wages, and workplace and living conditions. The global scope of the war also inspired the funding of a wide variety of patriotic indoctrination or "Americanization" programs. In addition to undertaking these initiatives however, and in collusion with West Virginia's governor, the industrial elite also imposed compulsory work restrictions that clearly defined the miners' place in the war effort. Although the operators intended to thus construct a pacified and biddable workforce, the uneven implementation of the improvements, combined with omnipresent coercive policies only heightened the miners' desire for a more autonomous voice in determining the material betterment of their lives.

The drafting of able-bodied men into the army heightened competition for miners throughout West Virginia. The threat of losing their employees to unionized districts compelled non-union operators to offer inducements such as higher wages and better living conditions to their miners. ${ }^{160}$ In the Williamson-Thacker field this meant that the companies that had perpetuated the "rough and tumble" existence of the early years of mining were finally forced to institute improvements in and around their mines. ${ }^{161}$ Undertaken by the Williamson-Thacker operators as a group and as individuals, the policies' implementation underscores important trends in the field's transformation during the war.

\footnotetext{
${ }^{160}$ Keith Dix, What's A Miner to Do, 205.

${ }^{161}$ Munn, 251.
} 
First, and most important, miners' wages improved as a result of America entering the war. On May 1, 1917 wages in the Williamson-Thacker field went up 10 percent, the third pay raise in just four weeks. ${ }^{162}$ In an attempt to thwart unionization, companies who could afford to grant them, awarded wage increases throughout the war period. In Mingo, wages rose only three more times between 1917 and 1919, but that translated to a 50 percent increase over the 1914 rate. By 1919, some miners in the Williamson-Thacker field were earning close to seven dollars a day, which equalled the pay of union miners in the Kanawha field. ${ }^{163}$

In addition to increasing economic incentives to lure miners to the field, the operators of the Williamson-Thacker coalfield launched Safety First and First Aid programs. On November 4, 1917 the Thacker and Pond Creek districts of the Williamson-Thacker field held a First Aid competition in the Williamson courthouse yard. Supervised by J. M. Webb of the Bureau of Mines, miners vied for cash and small prizes supplied by local wholesale firms and supply houses. ${ }^{164}$ At least one company continued the training begun for the 1917 competition. On March 25, 1919, the Pond Creek Coal Company reported that despite a 21 percent increase in the number of employees, accidents decreased 77 percent. ${ }^{165}$

Both traditional and more recent studies of the company town system in southern West Virginia have documented that the war dramatically affected the appearance of, and living conditions in, the area's coal communities. In vying for skilled miners, even the most

${ }^{162}$ Ibid.

163"Testimony of W.E. Hutchinson," West Virginia Coal Fields, 79.

${ }^{164}$ Williamson Daily News, 8 November 1917.

${ }^{165}$ Williamson Daily News, 25 March 1919. 
unenlightened operators were forced to improve the "villages of shacks" that had dotted the landscape since the pioneer days of mining in Mingo County. ${ }^{166}$ One such operator, Edward L. Stone of the Borderland Coal Company, reluctantly approved first the painting of his company houses, and ultimately, the construction of brick homes. ${ }^{167}$ The return on Stone's investment, according to his on-site manager, L. E. Armentrout, was the assurance that the quality of Borderland's housing exceeded 90 percent of the Williamson-Thacker Field. ${ }^{168}$ When the New Howard Colliery opened in the winter of 1919, its miners were housed in dwellings that would have been recognizable to most contemporary Americans. Located on carefully laid out streets, the houses were plastered, and had electricity, porches, and washrooms. ${ }^{169}$

In conjunction with the efforts to improve their miners' physical environments during the war, operators of Mingo County also started programs to foster the development of community and company loyalty. Finally following the lead of the corporate owners of the "model" company towns in Logan and McDowell counties, several companies in Mingo between 1917 and 1919 sponsored an array of community beautification and educational enhancement projects.

Analysis of the costs and benefits of annual lawn, vegetable and flower garden contests reveals how the operators justified such non-production oriented expenses. The companies often provided the seeds for the grass, vegetables and flowers and awarded cash and other prizes to the winners of the competitions. In return for an outlay of a few hundred dollars, the companies

\footnotetext{
${ }^{166}$ Munn, 251, and Shifflett, 67.

${ }^{167}$ Shifflett, 41, 58.

${ }^{168}$ Ibid., 58.

${ }^{169}$ Williamson Daily News, 24 December 1919.
} 
instituted an incentive based form of social control. The beautification of their camps helped attract a "better class of workers." The operators believed, or at least hoped that miners and their wives who entered in the contests would be too busy caring for their gardens and lawns to drink and engage in rowdy behavior. Participation by foreign born miners and their families also facilitated their "Americanization" by drawing them into the local community of workers. ${ }^{170}$

On August 16, 1917, the Mingo Republican recounted the results of the Crystal Block Coal \& Coke Company's first garden contest. Fifty gardens and lawns were entered in the contest. First place winners received fifteen dollars apiece and second place winners were given ten dollars each. The winning contestants were: Steve Doby, Mike Liptic, Pat Browning, Andy Verba, and Andy Bakos, four of whom were foreign-born. The Republican lauded the officers of Crystal Block for sponsoring the competition and expressed hope that other companies would emulate its example. ${ }^{171}$

In the interim, West Virginia's state department of agriculture drew inspiration from the garden competitions. In 1917, Mingo's county extension agent H.W. Prettyman served as one of the judges in the Crystal Block competition and pledged to advise the miners for the 1918 competition. However, the Department of Agriculture soon initiated its own garden program as part of a wartime initiative to promote self-sufficiency and food production among the state's residents. The Department's Biennial Report revealed that across the state, extension agents

\footnotetext{
${ }^{170}$ Munn, 245.
}

${ }^{171}$ Mingo Republican, 16 August 1917. "After 1914's Smith-Lever Act, the federal government began to encourage agriculture among the miners ... 'Mingo County ... was one of the early counties to raise local funds and request a county agent.'" Salstrom, Path to Dependency, 62. 
worked with thirty-four coal companies to encourage coal mining families to grow their own food. The program summary also provides insight into the coal companies' contributions to the effort. According to the report, many of the companies furnished the land, plowed and fenced it free of charge, provided fertilizer and seeds at cost, and distributed prizes to the contest winners that ranged from $\$ 60$ to $\$ 150 .{ }^{172}$

The most aggressive and yet beneficient programs launched in Mingo during the First World War focused on education. Within six months of America's entry into the war, the Howard Colliery underwrote an extensive renovation of the Chattaroy school. The company paid for grading the school lot, sidewalk construction, the installation of sanitary drinking fountains, and a six hundred dollar playground apparatus. To ensure protection of the company's investment in the Chattaroy school, Howard Colliery also supplemented the principal's salary. According to the newspaper story on the Chattaroy school project, Howard Colliery received not only local approbation, but statewide attention. ${ }^{173}$

The most ambitious education project undertaken by a coal company in Mingo County was launched in mid-November 1919. One of the Norfolk \& Western captive mines, the Vulcan

\footnotetext{
${ }^{172}$ J.H. Stewart, Commissioner of the State of West Virginia Department of Agriculture, Third Biennial Report of the West Virginia Department of Agriculture, 1917-1918 (Charleston, WV: Tribune Printing Company, 1918), 37, 37-38, 39; Perhaps as an act of bureaucratic selfpromotion the Department stated that in coal communities, prior to1917 "no effort" was extended to encourage food production. The report did not list Crystal Block as a participant in the program; only two companies in Mingo were identified as participants -- Red Jacket Consolidated Coal \& Coke Company and the Himler Coal Company. Not formally listed as a U.S. Steel subsidiary, Red Jacket's corporate leadership included high level members of Morgan \& Company. Himler was a co-operative mine headed by Martin Himler, a nationally known Hungarian newspaper editor and philanthropist.

${ }^{173}$ Mingo Republican, 27 September 1917.
} 
Colliery announced its intention to offer night school courses for its employees. Although segregated, the night school program was open to both whites and African Americans. ${ }^{174}$ Far ahead of the rest of the Williamson-Thacker coalfield, the Vulcan night school program followed the most progressive efforts coming in to vogue throughout American industry.

The story of the school and educational improvements in Mingo illuminates the many layers of the "benevolent paternalism" unleashed during World War I. On the surface, providing good schools helped the companies attract miners with families, who were believed to be more sober and reliable employees. In return, the companies not only gained a stable workforce, they also received "good press," for their concern and voluntary contribution to the local community. At the deepest level, subsidizing the salaries of teachers and principals also served a dual purpose. Dependent educators could be relied upon to promote values endorsed by the companies. Through the schools, the next generation of miners and miners' wives could be indoctrinated. Underwriting the cost of education eased the local tax burden, but more importantly, it could also be cited during the periodic outbreaks of complaints about the coal companies comparatively light tax liability. By helping to provide good schools for community children, the coal companies thus also promoted an informal political subordination that benefitted the companies' interests on several levels. ${ }^{175}$

A minor scandal that erupted in Matewan illustrates the impact of the intertwining of local politics, education, and company paternalism. In April 1918 Professor N. L. Chancey, the Superintendent of Schools in the Magnolia district, suffered public disgrace when he admitted to

\footnotetext{
${ }^{174}$ Williamson Daily News, 19 November 1919.

${ }^{175}$ See Hennen, Americanization, 77-79.
} 
"filching" funds from the Magnolia Board of Education. Part of the Hatfield machine and the closest associate of Matewan's recently defeated incumbent mayor A. B. Hatfield, Chancey might have escaped public censure with a gesture of restitution had he not roused the ire of several large coal corporations in the district. ${ }^{176}$

The Williamson Daily News revealed that despite Chancey's vow to replace what he had stolen, an investigation was pending because of the intervention of local coal companies. The Daily News story implied that the companies' action stemmed from an on-going dispute between Chancey and the companies over the length of the district's school term. From the article's tone, the companies' officers believed that Chancey, while rejecting demands to expand the term, had pocketed the money which would have funded the extension. ${ }^{177}$

A single common factor unites all of the examples of the expansion of company paternalism in the Williamson-Thacker coal field during World War I -- in every case, the companies were among the largest in the field and most were subsidiaries of the great corporations that mined vast deposits of coal in southern West Virginia. ${ }^{178}$ The projects sponsored by the Pond Creek Coal Company, Crystal Block Coal \& Coke, Vulcan Coal

${ }^{176}$ Williamson Daily News, 4 April 1918.

${ }^{177}$ Ibid.

${ }^{178}$ The same investment consortium that owned and operated Logan's Island Creek Coal company backed the Pond Creek Coal Company which operated across the Tug Fork River from Williamson. The U.S. Steel subsidiary, U.S. Coal \& Coke, through local management, controlled the Crystal Block Coal \& Coke Company; the N\&W operated captive mines at Vulcan and Chattaroy. See an earlier section in this chapter and Chapter 7 for details on corporate expansion in Mingo County. 
Company and Red Jacket in Mingo County conform with findings that assert that the most ambitious community-promoting projects were undertaken by the larger coal corporations. ${ }^{179}$

The end of the war did not translate into the cessation of corporate experiments to “construct" communities. In 1919, the Solvay coal interests, which had bought the local mines of coal entrepreneur E. L. Bailey, started publishing a company magazine, ostensibly in the interest of, and for the "benefit" of its employees. The Williamson Daily News lauded the decision of Solvay's management to start the magazine Solvay Folk because the company's size and ownership of mines in several coalfields made its leadership seem distant and impersonal. The Daily News asserted that Solvay Folk would "bring the workers of this big coal combination closer to the management." ${ }^{180}$ Solvay entrusted the magazine's content to a veteran West Virginia newspaperman, George C. McIntosh, who coincidentally during Word War I had also devised the Fuel Administration's “patriotic production” campaigns in which wounded veterans traversed the coal fields, exhorting miners to do their duty. ${ }^{181}$

The material improvement of the lives of Mingo's miners and their families during World War I, however, did not produce the anticipated results. First, only those who worked for the largest and/or newest companies actually enjoyed the benefits of luxuries such as electricity and indoor plumbing. In the case of Borderland, the company merely built new and better houses for

\footnotetext{
${ }^{179}$ Munn, 247.
}

${ }^{180}$ Williamson Daily News, 4 January 1919. Both Solvay and Island Creek entrusted their company magazine projects to veteran newspaperman George C. McIntosh. The projects lasted approximately two years until both companies sold their properties in the Williamson-Thacker, or more accurately Pond Creek, Kentucky coalfield. McIntosh Memoir, WVRHC.

${ }^{181}$ McIntosh Memoir, WVRHC. 
some of their workers near the older structures. ${ }^{182}$ New companies founded during the war boom often lacked the funds to maintain the communities in the post-war recession. ${ }^{183}$ The disparate living and work conditions that coexisted in the Williamson-Thacker field ultimately contributed to the miners' discontent. ${ }^{184}$ Ironically, when labor strife erupted in the Williamson-Thacker field, the miners who most vehemently and violently rebelled against their employers' anti-union stance lived in, or in the vicinity of, the communities that had most aggressively pursued "paternalistic" policies. ${ }^{185}$

The subsequent rebellion of the miners who had received so much beneficence from their employers emphasizes the unfortunate timing of Mingo's adoption of benevolent paternalism, a

${ }^{182}$ See notes 161,162 , and 163 .

${ }^{183}$ One such case was the Hungarian cooperative mine at Himler.

${ }^{184}$ Although the Williamson operators claimed that many companies provided amenities like tennis courts and movie theaters for their miners, a contemporary source reveals hidden inequities of their "company system" the operators sought to disguise. For example, several companies in Mingo County provided goods at cost through the company store, a privilege offered to employees above the rank of "bank boss." Also, access to amenities like the tennis courts was also restricted. Floyd Bunyon Shelton, "An Investigation of the Social Life of a West Virginia Coal Field" (Bachelor's thesis, Emory University, 1920), 19-20, 39, 46. Although critical of miners' habits and values, Shelton observed of the operators, "It is painful to observe how little consideration the operators gives their employees. They regard them so much as mere underlings who have no rights as members of a human brotherhood." For examples of the amenities which the Williamson-Thacker operators claimed to provide for their employees see: The United Mine Workers in West Virginia, 25.

${ }^{185}$ Contemporary accounts of the 1920-1922 strike, including local newspapers, state police reports to Governor Cornwell, and several subsequent Matewan Oral History Project narratives assert that strike "hotspots" included Sprigg, Chattaroy, Pond Creek, and New Howard, all of which were communities dominated by highly capitalized mines. Ironically, as early as 1911 an industry journal advised against excessive social engineering in company towns. According to the "Sociological Department" of Coal Age, "the company usually gains by not dabbling too freely in the private life of its employees . . the best of men dread the eye which follows them too closely." "The Company House," Coal Age 1 (11 November 1911): 158-159, 159. 
practice which coincided with the imposition of state and federal mandated policies designed to guarantee steady production and worker compliance. The state government of West Virginia responded to the declaration of war by calling an extraordinary session of the legislature and enacting a body of laws that openly and deliberately marshalled West Virginia's citizenry for the war effort. ${ }^{186}$ Proud to have passed the nation's first compulsory work law, Governor Cornwell, the state legislature, and other civic and business leaders, used the war crisis to promote a more a rigid concept of social order and discipline than would have been acceptable in peacetime. ${ }^{187}$ Mingo County's application of two of the laws passed during the special session illuminates how West Virginia's coal communities in particular, were harnessed to the war effort.

First, in response to the nationalization of the state's National Guard units, the West Virginia legislature passed a law requiring each county to deputize ten to one hundred men to serve as public safety officers. ${ }^{188}$ Mingo County appointed ninety-seven deputies but only four of Mingo's seven districts garnered 75 percent of these special officers. The four districts, Lee,

\footnotetext{
${ }^{186}$ Most of West Virginia' initial wartime legislation was passed during the second extraordinary session of 1917, from May 14-26. Acts of the West Virginia Legislature (Charleston, WV: Tribune Printing Company, 1917).

${ }^{187}$ Hennen, Americanization, 37.

${ }^{188}$ Chapter 9: “ Special Deputy Bill," House Bill \#34, Acts of the West Virginia Legislature for the year 1917 (Charleston, WV: Tribune Printing Company, 1917), 46-47; also reported in Mingo Republican, 7 June 1917. The special deputies law was passed over the opposition of West Virginia's Federation of Labor. Frank W. Snyder, the editor of the West Virginia Federationist denounced both the special deputies' law and the vagrancy (Slacker) law as weapons which could be used to suppress labor organizations in the state. Snyder cited as evidence the alleged strikebreaking activities of special deputies in Boone, Braxton, and Logan counties. West Virginia Federationist, 4 August 1917 quoted in Merle T. Cole, "The Department of Special Deputy Police, 1917-1919," West Virginia History 44 (Summer 1983): 321-333, 32728.
} 
Magnolia, Williamson, and Stafford were the political and economic centers of the county. Lee, Williamson and Magnolia districts possessed over half of the county's coal mines and received two-thirds of the new deputies. ${ }^{189}$ Despite its reputation as a center for lawlessness and danger, Harvey District was assigned just eight deputies. Red Jacket and Borderland, the centers of production for the county's two largest coal companies received nine deputies, five for Red Jacket and four for Borderland. Borderland, which had used the services of Baldwin-Felts detectives since 1915, now also received state and local subsidy for the surveillance and intimidation of its employees. ${ }^{190}$

The state legislature guaranteed a steady supply of workers by passing the country's first compulsory work law on May 19, 1917. Officially titled the "Idleness and Vagrancy Act," Senate Bill \#7, popularly known as the "Slacker Law," criminalized unemployment. West Virginia's male residents, aged sixteen to sixty, were required to work thirty-six hours a week. Those afflicted with habitual intoxication and narcotic addition were not exempted, nor were professional gamblers, or able-bodied men dependent on their wives and/or children for support. ${ }^{191}$ State and local peace officers could challenge suspected violators of the law without waiting for sworn complaints. ${ }^{192}$ Private citizens were encouraged to watch for potential

${ }^{189}$ Until the 1910 U.S. Census, Williamson had been the center of Lee District; the city's rise in population validated Williamson becoming its own district. Abstract of the Thirteenth Census, with Supplement for West Virginia, 577.

${ }^{190}$ Mingo Republican, 19 July 1917.

${ }^{191}$ Chapter 12 "The Idleness and Vagrancy Act" Senate Bill \#7, in Acts of the West Virginia Legislature, Second Extraordinary Session, May 14-26 (Charleston, WV: Tribune Printing Company, 1917), 51-53.

${ }^{192} 1917$ Legislative Handbook and Manual of the State of West Virginia, 463. 
slackers; turning in loiterers was designated a patriotic act. ${ }^{193}$ Men convicted of "slacking" could be assessed a one hundred dollar fine and/or sixty days public service work. ${ }^{194}$

Accounts of the law's enforcement and efficacy illustrates its effect in coal communities.

Two of Mingo county's three municipalities responded to a state Council of Defense enforcement survey. Matewan and Williamson reported one and twenty arrests respectively; in Matewan four slackers were forced to work, while Williamson sent seventy-five men into the labor force. ${ }^{195}$ Governor Cornwell's Report on West Virginia in the War revealed that a majority of state and local officers, and industry leaders believed that coal production in the state increased because of the Slacker law. ${ }^{196}$ According to the secretary of the state Council of Defense, many of the mayors who submitted compliance reports advocated the permanent retention of the law on the statute books. ${ }^{197}$

\section{The War Revives the Desire to Unionize Southern West Virginia:}

Although the leaders of the United Mine Workers of America had initially opposed America entering the war, the union eventually made great sacrifices to the war effort. In return,

\footnotetext{
${ }^{193}$ Hennen, Americanization, 47.

${ }^{194}$ West Virginia State Council of Defense, Report of the Secretary on the Operation of the Compulsory Work Law, for the Year Ending June 19, 1918. (Charleston, WV: Tribune Printing Company, 1918), 7. Pamphlet 2902, Pamphlet Collection, WVRHC.

${ }^{195}$ Ibid.

196"West Virginia in the War," 792.

197"West Virginia in the War," 791.
} 
the union was granted concessions that it was reluctant to surrender in the war's aftermath. ${ }^{198}$ In what became known as the Washington Agreement, the nation's organized miners had agreed not to strike, and thereby disrupt production, for the war's duration for which they received a federally mandated wage increase. ${ }^{199}$ The UMWA also gained a small foothold in the New River field when the Labor Bureau of the Fuel Administration ordered the coal companies in southern West Virginia to allow the miners to organize. ${ }^{200}$ Finally, the imposition of the zone plan during the war had also provided a brief respite in the on-going battle between the unionized Central Competitive Field and the non-union Southern Appalachian fields. Federal regulation had temporarily halted the non-union assault on the markets traditionally served by the older organized fields.

However, after the Armistice, UMWA members began to chafe under the continued restrictions of the Washington Agreement. ${ }^{201}$ Union miners had not only complied with its terms, they had willingly produced record amounts of coal. ${ }^{202}$ But when the Fuel Administration had

${ }^{198}$ Diner, 236; Corbin, Life, Work, and Rebellion, 177, 180.

${ }^{199}$ Johnson, Politics of Soft Coal, 82. The Washington Agreement, once ratified by the rankand-file in January 1918, imposed a penalty clause for strikes in return for higher wages. What became problematic was the stipulation that the agreement was binding "'during the continuation of the war,' and not to exceed two years from April 1, 1918."

${ }^{200}$ Corbin, Life, Work, and Rebellion, 184, 198. Although the New River (Smokeless) field was the only southern West Virginia anti-union field organized during the war, individual miners like Richard Burgett of Mingo County claimed to have surreptiously taken "the obligation" at roughly the same time. Richard Burgett interview, On Dark and Bloody Ground: An Oral History of the U.M.W.A. in Central Appalachia, 1920-1935, edited by Anne Lawrence (Charleston, WV: Miner's Voice, 1973): 105-109, 107.

\footnotetext{
${ }^{201}$ Johnson, Politics of Soft Coal, 97.

${ }^{202}$ Corbin, Life, Work, and Rebellion, 181.
} 
suspended regulation of the coal operators in February 1919, the government informed the UMWA that union miners were still prevented from striking until the end of the war or April 1920 whichever came first. ${ }^{203}$

Thus, after the Armistice, the UMWA and the men it represented felt betrayed. An inflationary cost of living had deflated their wages. The incentives offered in the non-union coalfields had angered many devoted union miners, and eroded others' commitment to, and confidence in, their union. ${ }^{204}$ The dismantling of the zone plane also meant that competition for the Midwestern and Lake Cargo markets would probably resume between the non-union southern West Virginia coalfields and the Central Competitive Field. The final straw came in the summer of 1919, when the operators in the New River field renounced their wartime agreement and set out to eliminate the union presence at their mines. ${ }^{205}$ By the time union delegates convened in Cleveland in September 1919, the men they represented were spoiling for a fight. ${ }^{206}$

In 1916, John J. Cornwell had wrested the governorship of West Virginia from Henry D. Hatfield's chosen successor Ira Robinson with the assistance of the unionized miners of the Kanawha Field. ${ }^{207}$ Angered by the limitations of the Hatfield Agreement, the insurgent officers of the UMWA's District 17 ignored the State Federation of Labor's advocacy of Robinson, and

${ }^{203}$ Johnson, Politics of Soft Coal, 97.

${ }^{204}$ Dix, Work Relations, 205.

${ }^{205}$ Corbin, Life, Work, and Rebellion, 197.

${ }^{206}$ Johnson, Politics of Soft Coal, 97.

${ }^{207}$ Mooney, Struggle in the Coalfields, 59. See Chapter 6 for the contributions of West Virginia's anti-union coal operators. 
supported Cornwell's candidacy in return for assistance in organizing miners in the Fairmont field of northcentral West Virginia, and a promise to eradicate the mine guard system. ${ }^{208}$ Once in office, Cornwell maintained contact with District 17's president Frank Keeney and secretary Fred Mooney, but repeatedly betrayed the interests of West Virginia's organized miners. ${ }^{209}$ In particular, when Baldwin-Felts agents attacked UMWA organizers in Clarksburg, Cornwell wrote to Keeney and apologized, but refused requests to order local operators to stop employing the agents. ${ }^{210}$ Cornwell also tolerated operator misuse of the slacker law. ${ }^{211}$

By the summer of 1919, just as the wartime advances in organization were being crushed in the non-union southern West Virginia fields, the lines of communication between the politically left-leaning leadership of District 17 and the governor dissolved. ${ }^{212}$ Within months, Cornwell became a vehement enemy of his former allies and turned increasingly towards the Local's conservative and accomodationist leaders who had originally been ousted by Keeney and Mooney in 1917. ${ }^{213}$

\footnotetext{
${ }^{208}$ Ibid., 59-60 and Barkey, 188. West Virginia's State Federation of Labor had backed Robinson in gratitude for his dissent during the Paint Creek martial law cases in 1912-1913. However, Hatfield's actions during the resolution of the strike, particularly the suppression of the Socialist press, divided the political left during the 1916 campaign. Although their own attorney, Socialist Harold W. Houston backed Robinson, Keeney and District 17's other leaders may have seized the opportunity the dissent presented them to capitalize on Cornwell's bid for support.

${ }^{209}$ See pages $184-188$ of Corbin's Life, Work, and Rebellion, for details.

${ }^{210}$ Ibid., 187.

${ }^{211}$ Ibid., 188.

${ }^{212}$ Johnson, Politics of Soft Coal, 211.

${ }^{213}$ The old leaders, who had been driven from power following the Paint and Cabin Creeks strikes were gearing up to challenge the insurgents in District 17's pending election. John J.
} 
In late June, Mingo's operators decided to celebrate the apparent end of the postArmistice coal recession by turning its sixth annual meeting into a two-day event. After a daylong business meeting, the Association's closing banquet featured entertainment by comedian Luke McLuke and addresses by National Coal Association Vice-President J. D. A. Morrow and West Virginia governor John J. Cornwell. Despite the festive and optimistic atmosphere, the subjects discussed by both Morrow and Cornwell hinted at the crises to come. ${ }^{214}$

After warning the Association of the danger posed by Mexican crude oil, Vice-President Morrow exhorted the men present to foster a greater spirit of co-operation among the producers of coal. Morrow claimed that the road to prosperity depended on friendliness and trust between coal operators. ${ }^{215}$ Hastily formed in response to wartime exigencies, the National Coal Association could not withstand the hostility between the unionized the Central Competitive Field and the non-unionized fields of southern Appalachia. In spite of the efforts of members such as Vice-President Morrow, the Association virtually collapsed by $1921 .^{216}$

Unlike Vice-President Morrow, Governor Cornwell spoke directly about issues close to the heart of the Williamson operators. Cornwell began with a congratulatory recitation of West Virginia's war record and proceeded to what he considered the ongoing crisis in the body politic. According to Cornwell, social unrest menaced the state and the nation because of the high cost of

Cornwell to N.A. McKenzie, 24 September 1920, and N.A. McKenzie to John J. Cornwell, 3 December 1920, Cornwell Papers, WVRHC.

${ }^{214}$ Williamson Daily News, 29 June 1919.

${ }^{215}$ Ibid.

${ }^{216}$ Johnson, Politics of Soft Coal, 95-96. 
living and changed economic conditions. Cornwell asserted that the radicalism spawned in such situations could not be thwarted by force or coercion, but only by treating the aspirations of the working class with respect. Speaking specifically to his audience, the Governor urged the Association to support fair legal treatment, wages, and living conditions for their mine employees, as well as educational opportunities for their children. Cornwell asserted that only by prioritizing these issues could the well-defined effort to lead the organized labor movement in West Virginia into a radical socialist party be defeated. ${ }^{217}$

During the operators' convention and in the weeks that followed, the actions of the Williamson Operators' Association proved that Cornwell had found a receptive audience in Mingo County. His exhortation to diminish the attractiveness of unionism by paying fair wages, improving living conditions, and offering better educational opportunities elicited a sense of selfcongratulation among Mingo's operators. Cornwell's words offered the final validation they were seeking. After decades of fighting for survival, the Williamson-Thacker coal operators looked forward to a peaceful prosperity. ${ }^{218}$ In the business meeting of the convention, the operators approved a resolution that called for the use of a standardized proof of age form. ${ }^{219}$ Less than two months after the gathering, the operators' association of the Williamson-Thacker coal field also approved an eight-hour work day for their employees. Commenting on the decision, the

${ }^{217}$ Williamson Daily News, 29 June 1919. See Hennen, The Americanization of West Virginia for more on the sinister goals behind Cornwell's platitudes.

${ }^{218}$ Williamson Daily News, 29 June 1919.

${ }^{219}$ Ibid. 
Williamson Daily News noted that the Mingo operators had chosen this course of action without regard for conditions in the surrounding coal fields. ${ }^{220}$

Freed from federal constraints, in the late summer of 1919, the operators of the Williamson-Thacker coal field believed they had finally immunized their employees against the lure of unionism. Having granted semi-monthly pay in 1913, the operators capped a six year effort to improve living and work conditions for their workers with the granting of the eight hour day. However, far from the banks of the Tug, brewed a conflict that in less than a year would undo all of their work. Deluded by their own benevolence, the operators of the WilliamsonThacker coalfield ignored the storm warning issued by the events of the early fall of 1919 .

In the late summer of 1919, Frank Keeney made a fateful decision. Ignoring the pleas of his fellow officer Fred Mooney, Keeney responded to the anti-union rollback efforts of the New River operators by ordering union organizers into Logan's Guyan field. ${ }^{221}$ Despite a warning issued personally by Logan sheriff Don Chafin, Keeney sent the men who had openly criticized his conciliatory relationship with Governor Cornwell into the heart of non-union southern West

\footnotetext{
${ }^{220}$ Williamson Daily News, 18 August 1919. The tone of the observation indicates that implementation of the eight hour day in Mingo would not please operators in the surrounding fields. Although nothing suggests that Cornwell was informed of the decision, he would probably have approved and applauded the action; his biographer Lucy Lee Fisher asserts that Cornwell, although a dedicated business conservative, was a devoted advocate of the eight hour work day. Fisher, 376.

${ }^{221}$ Mooney, Struggle in the Coal Fields, 59-71. In this passage Mooney describes how the relationship between Keeney and Cornwell fell apart. Mooney places much of the blame for Keeney's rashness on Bill Blizzard.
} 
Virginia. ${ }^{222}$ Not surprisingly, Chafin and his army of deputies met the organizers' train, and sent them back to Charleston under escort. ${ }^{223}$ War had been declared in southern West Virginia.

As the UMWA's delegates traveled to Cleveland, Ohio for the 1919 national convention, rumors began to circulate in the Kanawha field that miners and their families in the neighboring Guyan field were being abused and even killed by mine guards. Incited by the reports of murder and violence, the union miners of the Kanawha Field armed themselves, gathered just outside of Charleston, the state capitol, and announced they would march to Logan County, the center of the Guyan field, and liberate and organize Logan's miners. ${ }^{224}$

Although District 17 officers were probably the instigators of the march or at least coconspirators in spreading the rumors, they went to great lengths to convince observers that the miners' gathering had resulted from a spontaneous eruption of mass indignation. ${ }^{225}$ Late on September 4, 1919, District President Frank Keeney and governor Cornwell traveled to the miners' gathering together to urge the men to disband. ${ }^{226}$ Believing that his promise to

${ }^{222}$ (Chafin) Lee, Bloodletting, 92-93. Mooney, Struggle in the Coal Fields, 64.

${ }^{223}$ John L. Spivak, A Man in His Time (New York: Horizon Press, 1967), 58 and Mooney, Struggle in the Coalfields, 63-64.

${ }^{224}$ Fisher, 377. David A. Corbin's Life, Work and Rebellion, and Roger Fagge's Work, Power and Community, offer more extensive analyses of the "First Armed March on Logan."

${ }^{225}$ Spivak, 69-70. Spivak had traveled to West Virginia just before the armed march after meeting West Virginia organizers working in Pennsylvania during the 1919 steel strike. Spivak quickly became an intimate of Fred Mooney, secretary of District 17. Before the march on Logan began, Spivak traveled with Mooney to see the gathering. After looking over the crowd, Spivak observed to Mooney that he could not believe that so many people had come together spontaneously; Spivak later recorded in his memoir that Mooney never responded, but just smiled.

${ }^{226}$ Corbin, Life, Work, and Rebellion, 100. 
investigate the rumors had convinced the miners to go home, Cornwell returned to Charleston. ${ }^{227}$ When the march started on September 5, Cornwell claimed that after he spoke and left, radicals and socialists incited the men again. He also felt personally betrayed by Keeney, whom he felt had not done enough to stop the march. ${ }^{228}$

As the miners approached Logan on September 6, Cornwell telegraphed Newton Baker, the Secretary of Defense, and General Leonard Wood, the head of the United States Army, to warn them that the situation in the coalfields of southern West Virginia threatened to deteriorate beyond state control. ${ }^{229}$ Shortly after Cornwell shared with Keeney that the army would be available, the armed march on Logan ended. ${ }^{230}$ The Williamson Daily News reported that on September 7, the miners gave up their "pilgrimage," disbanded, and returned home. ${ }^{231}$ On September 9, Cornwell wrote to Keeney to inform him that he had appointed Colonel Thomas B. Davis, West Virginia's acting Adjutant General, to head a commission to investigate not only the rumored abuses in Logan County, but also who was responsible for the assemblage of armed miners. ${ }^{232}$

As the Commission prepared to launch its investigation, the national organization of the UMWA weighed in with its opinion of the situation in West Virginia. The delegates at the

\footnotetext{
${ }^{227}$ Fisher, 377.

${ }^{228}$ Ibid.

${ }^{229}$ Ibid., 378.

${ }^{230}$ Ibid.

${ }^{231}$ Williamson Daily News, 8 September 1919.

${ }^{232}$ Fisher, 378-379.
} 
Cleveland convention authorized acting President John L. Lewis to send Governor Cornwell a telegram. On September 11, Lewis wrote to Cornwell:

if the Governor would exercise the authority and influence of his office to have the laws of West Virginia guarantee free speech and free assemblage and the right to organize it would not be necessary for freeborn American citizens to arm themselves to protect their Constitutional rights. ${ }^{233}$

Cornwell did not respond to Lewis' telegram directly. However, as subsequent events during his administration illustrated, while publicly supporting workers' organizations, Cornwell actively opposed any actions undertaken by the UMWA in West Virginia.

The resolutions passed during the UMWA convention of 1919 and the Governor's Commission investigation of the Armed March on Logan profoundly affected the subsequent interaction of the coal companies and miners in southern West Virginia, and in particular Mingo County. Although the delegates at the UMWA convention voted to ban syndicalists from membership in the union, they also passed resolutions viewed as radical and dangerous by most coal industry executives. ${ }^{234}$ The policy committee endorsed nationalization of the mines, and the entire delegation supported the Plumb plan for nationalizing the railroads. ${ }^{235}$

The most decisive action taken by the UMWA convention was to officially challenge the federal government's assertion that the Washington Agreement remained in effect. The convention also issued a list of demands that sent shock waves through the coal industry and the federal government. The miners called for a sixty percent increase in wages, a six-hour work day

\footnotetext{
${ }^{233}$ John L. Lewis to Governor John J. Cornwell, 11 September 1919, quoted in Fisher, 380.

${ }^{234}$ Williamson Daily News, 20 September 1919.

${ }^{235}$ Johnson, Politics of Soft Coal, 101; Williamson Daily News, 13 September 1919.
} 
and a five day work week, an end to the penalty fines imposed by the Washington Agreement, and a nationwide contract without sectional settlements. If the coal industry failed to grant these concessions, a national strike of coal miners would begin on November $1,1919 .{ }^{236}$

Efforts to stave off the national strike ended miserably. Brought together by federal mediators, union officials and operators' representatives found no middle ground and abandoned negotiations. ${ }^{237}$ In West Virginia, although the commission empaneled to investigate the Armed March issued a report of its findings, the actual investigation had not been completed ${ }^{238}$ When the commission denied District 17 's request for immunity for testifying miners, too few witnesses cooperated. ${ }^{239}$ Convinced that the commissioners sought only to blame the miners and not address the injustices occuring in Logan County, District 17 published a request for a federal investigation. $^{240}$

A power vacuum in both the national government and the UMWA further complicated the descent into crisis in the Fall of 1919. President Wilson suffered two strokes in October 1919, and his incapacitation allowed the hardliners in the administration to move decisively against the UMWA. ${ }^{241}$ By this time illness had also forced UMWA president Frank J. Hayes to

${ }^{236}$ Johnson, Politics of Soft Coal, 102-103.

${ }^{237}$ Ibid., 103.

${ }^{238}$ Fisher, 379.

${ }^{239}$ Ibid., and Hennen, Americanization, 93.

${ }^{240}$ Fisher, 379.

${ }^{241}$ Johnson, Politics of Soft Coal, 102. 
entrust control of the union to Vice-President John L. Lewis. ${ }^{242}$ Lewis had moved rapidly up through the union ranks, and the events of 1919 allowed him to grasp even greater power. As one historian noted, better than anyone else Lewis "commanded the statistical data of the coal industry." ${ }^{243}$ This knowledge and his own intractable nature made Lewis as determined as his opponents in the growing crisis. As the November 1 strike deadline approached, the men who were in a position to effect a compromise refused to budge.

The state level confrontation between District 17 President Keeney and Governor Cornwell reflected the belligerence of the national standoff. When Keeney informed Cornwell that West Virginia's union miners would obey the strike call, Cornwell responded by calling troops into the coalfields two days before the strike was supposed to begin. ${ }^{244}$ Congressman Wells Goodykoontz of Williamson declared that in striking, the union "paid no more attention to ... [their contracts] than did the Germans to their treaty obligations with the Belgians."245 Goodykoontz implied, of course, that if the miners obeyed Lewis and Keeney, they were unpatriotic and disloyal.

Once the strike began, Wilson Administration hardliners led by Attorney General A. Mitchell Palmer moved to destroy it. Palmer and his allies engineered a restoration of the Lever

${ }^{242}$ Ibid., 98.

${ }^{243}$ Ibid., 102.

${ }^{244}$ Corbin, Life, Work, and Rebellion, 197.

245"The West Virginia Miners: Extension of Remarks of Honorable Wells Goodykoontz, of West Virginia in the House of Representatives," Saturday, November 1, 1919: Congressional Record: 8349-8350, 8350. Someone, probably Goodykoontz, sent a copy of the speech, which had been printed in the Congressional Record, to S. D. Stokes, Stokes Papers, WVRHC. 
Act, which stipulated that any conspiracy to limit the supply or distribution of coal was illegal. Based on this clause and the terms of the Washington Agreement, Palmer got an injunction against the strike on November 8, 1919. After two days of deliberation, Lewis and the other UMWA leaders decided to end the strike, but the miners stayed out. Slightly less than a month after the injunction went into effect, Lewis and eighty-three other union leaders were arrested on contempt charges. At a White House conference on December 7, John Lewis agreed to call off the work stoppage. In return, the federal government agreed to establish a commission to study conditions in the industry and ordered an immediate 14 percent increase in miners' wages. ${ }^{246}$

Although the Williamson Daily News reported on the strike, no strike-related activity occurred in Mingo County. There were at least two possible reasons for the calm. First, during his testimony in the 1921 Senate Investigation, Fred Mooney admitted that District 17 officers rejected a request for organization from Mingo County in $1919 .{ }^{247}$ Second, during the strike, the miners in Mingo were making good wages with a greater opportunity to work. ${ }^{248}$ When the strike stalled work in West Virginia's union fields, the operators in the non-union fields seized the opportunity to increase their own output. ${ }^{249}$ Spurned by the union and offered the chance to make more money by their employers, the miners in Mingo worked on through the strike. In fact, at the strike's height, Mingo Sheriff G. T. Blankenship reported to Cornwell that since the mines

${ }^{246}$ Johnson, Politics of Soft Coal, 98-104.

247"Testimony of Fred Mooney," West Virginia Coal Fields, 15.

${ }^{248}$ Williamson Daily News, 19 November 1919.

${ }^{249}$ Fisher, 380. According to Cornwell biographer Lucy Lee Fisher, during the general strike, non-union miners produced 75 percent of the state's normal output. 
were working at full capacity, he doubted there would be labor unrest in Mingo County "unless the operators get excited. ${ }^{250}$

The coal operators of the Williamson-Thacker coal field and the conservative businessmen of Mingo County acted vigorously during the 1919 strike, and their response hinted at the issues that would be raised the following year. They wrote to Governor Cornwell to endorse his efforts against radicalism in the state. ${ }^{251}$ Several of the paternalistic programs discussed earlier in this chapter were started during the period of the general strike. ${ }^{252}$ Like Cornwell, the coal men of Mingo County claimed to support unionism in spirit, but when confronted directly by unionists, they denounced their opponents as radicals who were being swayed by "anarchistic teachings. ${ }^{253}$ Having followed Cornwell's advice regarding higher wages and improved living conditions, the operators of the Williamson-Thacker field believed their employees were immune to the siren call of organization.

Wells Goodykoontz's November 1, 1919 speech on the floor of the House of Representatives reveals the depth of the coal operators' self-delusion. According to Goodykoontz, only one out of ten West Virginia miners supported the 1919 strike because they

${ }^{250}$ G.T. Blankenship to John J. Cornwell, telegram, 11 November 1919, Cornwell Papers, WVRHC. During the strike Governor Cornwell had requested status reports from the county sheriffs throughout the state.

${ }^{251}$ C. M. Gates to John J. Cornwell, 19 November 1919, Cornwell Papers, WVRHC. Gates wrote the letter on behalf of the membership of the Coal City Club of Williamson, Mingo County.

${ }^{252}$ The cases referred to are: the Vulcan Collieries night school program and the founding of the Pond Creek Improvement Club, a voluntary association of operators, miners, and private citizens. Williamson Daily News, 19 November, and 14 November 1919.

${ }^{253}$ Gates to Cornwell, Cornwell Papers, WVRHC. 
happened "to have a favored lot, mining thick seams ... under genial surroundings, at wages, in some cases, higher than the union scale." The UMWA's $\$ 15,000,000$ campaign fund "to corrupt non-union miners" would not sway the miners of West Virginia because they were "the most happy ... independent . . a and contented . . . of all our citizenry." ${ }^{254}$ Seven months after Goodykoontz painted this rosy picture of life in southern West Virginia's coalfields, the miners in Mingo County defied their employers and flocked to join the UMWA. ${ }^{255}$

Statistics reported in the 1919 Annual Report of the Department of Mines offer the first clues to why the miners of the Williamson-Thacker coalfield would move to organize almost six months after the 1919 national strike. Between 1918 and 1919, six mines closed. Although more men worked for coal companies in 1919 than in 1917, 8 percent fewer of those jobs were held by miners. The men worked nearly a month less in 1919 than they had in 1918, and almost two weeks less than in 1917 . The average per ton wage paid to the miners rose almost 30 percent between 1917 and 1919, but the operators' gross profits approached 600 percent. $^{256}$

Table 14

Comparison of Average Wage and Coal Prices in Mingo County, 1917-1919

\begin{tabular}{cccc}
\hline \hline Year & Average Wage* & Average Selling Price+ & $\begin{array}{c}\text { Wages as a Percentage of } \\
\text { Selling Price }\end{array}$ \\
\hline 1917 & .59 & 1.84 & $32 \%$ \\
1918 & .75 & 2.77 & $27 \%$ \\
1919 & .82 & 2.56 & $32 \%$ \\
\hline \hline
\end{tabular}

Source: Annual Report of the Department of Mines.

254"Goodykoontz House of Representatives speech," Stokes Papers, WVRHC.

${ }^{255}$ United Mine Workers' Journal 30 (30 July 1920): 8. The Journal claimed that Mingo's miners were 100 percent organized.

${ }^{256}$ United Mine Workers Journal 32 (15 November 1921): 10. 
*Average based on wages paid by car and ton

+ Selling Price based on per ton

The mines in Mingo County produced over one half million tons less coal in 1919 than in 1918, and nearly three quarters of a million tons less than in $1917 .^{257}$ Despite the decrease in overall production in Mingo County, the high selling price of Mingo's coal in 1918 allowed some companies to reach record profits. For example, the Borderland Coal Company before World War I paid average yearly dividends between 15 and 30 percent. In 1918, despite the cost of building new company houses and a tipple, Borderland paid dividends of 60 percent, the highest in the company's entire history. ${ }^{258}$

Not only were there fewer mines, producing less coal in Mingo County in 1919, the Williamson-Thacker field fell further behind its neighboring fields, the Guyan and Pocahontas fields of Logan and McDowell Counties. A smaller percentage of miners lost ground to laborers in those fields. Like the Williamson-Thacker field, the Pocahontas field lost work days and mines, and also produced less coal than it had in 1917 and 1918. But to understand the different impact of those losses in Mingo and McDowell counties, one has only to look at the scale of the losses in Mingo and McDowell. McDowell's loss of tonnage output in 1919 exceeded Mingo's output for the entire year. ${ }^{259}$

\footnotetext{
${ }^{257}$ Figures extrapolated from the 1917, 1918, and 1919 Annual Reports of the West Virginia Department of Mines.

${ }^{258}$ Shiflett, 41.

${ }^{259}$ Figures extrapolated from the 1917, 1918, and 1919 Annual Reports of the West Virginia Department of Mines.
} 
In contrast to Mingo and McDowell, Logan County added sixteen new mines in 1919, miners worked nearly two weeks more and produced nearly a half million tons more coal. ${ }^{260}$ Unlike Mingo and McDowell, Logan benefitted from the high wartime prices and special market conditions in the immediate post World War I period which stimulated expansion of production in existing mines and encouraged the opening of many new mines. ${ }^{261}$

Comparison of the statistics from Mingo, Logan, and McDowell Counties illustrates that the coal industry in Mingo County emerged from the war period less secure than Congressman Goodykoontz's speech led his contemporaries to believe. Although the war boom had brought improved wages and living conditions for many of Mingo's miners, these advances were undermined by a higher cost of living and the perception that their employers were prospering even more than the miners themselves.

\section{Conclusion:}

World War I precipitated the political, economic and social cleavage that brought Mingo County into the cross-hairs of the conflict over the unionization of southern West Virginia. Empowered by their control of Mingo's wartime patriotic effort, the coal and Williamson elite believed they had finally vanquished the Hatfield machine and all it personified. In the name of patriotism, the elites imposed new forms of social delineation and control that exacerbated old class conflicts. The war also unleashed the desires of the county's minority population. By

\footnotetext{
${ }^{260} \mathrm{Ibid}$.

${ }^{261}$ Dix, What's a Miner to Do, 141.
} 
1920, undercurrents of seething political, economic and social tensions massed, needing only the right spark to explode.

Mingo County had never been a socially homogenous community. ${ }^{262}$ Despite the impressions left by previous historians, industrialization had not automatically imposed a modern feudal system with distinct class barriers. People in the county did not inhabit only isolated, locked down, operator-dominated coal camps. In fact, just the opposite had occurred in Mingo County. Independent towns had grown up around the mines and provided an outlet for activities that defied social constraints. ${ }^{263}$ The kinship connections between miners and some native elites had also provided opportunities for some miners to participate in the public sphere in ways that have gone unacknowledged for decades. ${ }^{264}$

However, World War I set in motion a social transformation that crystallized during the 1920-1922 strike. First, as this chapter has shown, administration of local wartime programs had

\footnotetext{
${ }^{262}$ Until 1912, Mingo ranked third among West Virginia's counties that had sent inmates to the West Virginia state penitentiary. By 1919, Mingo sent fewer than any other coal-producing county, but at the war's height in 1918, there were 11 murder indictments in the County. "Judge James Damron" entry in George W. Atkinson, Bench and Bar of West Virginia (Charleston, WV: Virginia Law Book Company, 1919), 354; Number of murders: Lane, Civil War in West Virginia, 100.

${ }^{263}$ As alluded to an earlier chapter, Matewan and Thacker, in particular, were combination coal and independent towns. In both, the saloons operated by elites like M. Z. White and R. W. Buskirk catered to the miners who were an important "constituent" base for White and Buskirk. Buskirk's departure from Matewan had been heralded as opportunity for the "good citizens" of the town to build a new reputation for the community. Mingo Republican, 29 April 1915.

${ }^{264}$ Elihu Boggs, although a miner by profession, also came from a pioneering family with distinguished social connections, which included prominence in Matewan's Methodist Church. As a result Boggs served as clerk of the county court from 1914-1920. Similarly, at least one Matewan Massacre defendant had served as a deputy sheriff. See Chapters 6 and 10 for details on these examples.
} 
been dominated by the industrial elite and their Williamson allies. The corollative eclipse of the Hatfield Machine had fostered a sense among this group that control of Mingo County had finally come into the hands of the "better classes."265 At the same time, the war had also liberated the expectations of the county's working class and ethnic populations. ${ }^{266}$ In the Spring of 1920 when UMWA representatives appeared in Mingo County, miners and African Americans responded enthusiastically to their dual message of unionism and political freedom. ${ }^{267}$

The degree to which the war divided Mingo County is illustrated by an event that occurred in the midst of the drama surrounding Logan and Kanawha counties during the 1919 coal strike. In late October 1919, Mingo County veterans launched the Eph Boggs Post of the American Legion. Members asserted that their goal was to enlist all of Mingo's veterans in the post, but the roster of the officers selected by the thirty-five men present at the first meeting reveals who claimed Mingo's patriotic war legacy. Mingo Keadle, John Chafin, and Hyman

\footnotetext{
${ }^{265}$ Readers are reminded that several leaders of the "war effort" in Mingo, including Randolph Bias and Hiram S. White, had, throughout the period before the war, fought repeatedly against the Hatfield Machine. See Chapters 3 and 6.

${ }^{266}$ Two minor examples of working class defiance from the 1914-1919 period ironically come from Williamson, the center of industrial elite influence. In 1914, in response to the establishment of a "businessmen's" association, another small group started the "Workingmen's Association," and announced that it intended to "reduce the cost of living" for its members by cooperatively purchasing the "necessities of life." Williamson Daily News, 18 March 1914. Five years later in the midst of the Red Scare year, a baseball team known as the "Bolsheviki Nine" played in the Williamson community league. Williamson Daily News, 21 June 1919. See discussion of the DuBois School earlier in this chapter.

${ }^{267}$ District 17 officers and representatives not only advocated union organization but also campaigned for Samuel B. Montgomery who was seeking the 1920 Republican gubernatorial nomination. "Testimony of C.E. Lively," February 25-26, 1921, unknown newspaper Matewan Omnibus Collection, ERCA. Also, many in the county's African-American population defied Mingo's traditional Republican leaders, white and black, to support Montgomery and the Union. Williamson Daily News, 15 May 1920. See Chapter 10 for more on this issue.
} 
Crigger, respectively were the sons of: a former Republican newspaper editor, Mingo's first county clerk and a coal company official. Most important, the veterans selected Congressional Medal of Honor winner and Paint Creek strike terror, A. A. "Bad Tony" Gaujot, post commander. ${ }^{268}$ Two years later when anti-union community members started the Mingo Militia to assist the strike-busting efforts of the state police, six of the nine founding members of Mingo's American Legion post joined the anti-union vigilance committee. ${ }^{269}$

By the end of 1919, the local and external causes of the 1920 conflagration were falling into place. Chapter 10 begins with a discussion of how these factors combined to create the national, state, and local prelude to the events of May 19, 1920. In the Massacre's aftermath, the responses it elicited not only reflected Mingo County's singular history, but also predicted how generations would view the people of Matewan and Mingo County.

\footnotetext{
${ }^{268}$ Williamson Daily News, 13 October 1919. Several World War veterans stand out in accounts of the 1920-1922 period. Charlie Kiser, was a Matewan Massacre defendant who became a professional UMWA organizer. Thomas Chapman, the foreman of the Massacre Trial jury was another veteran who also joined the Legion. The most poignant story is that of William H. "Willie" Ball, who served eighteen months in France, was awarded a Victory Medal, and joined the American Legion. Ball however, later joined the miners' strike and resided in the Lick Creek tent colony. When the Mingo Militia, led by his fellow Legion members, and the state police raided the colony in the summer of 1921, they took Ball's medal and desecrated the colony's American flag. (Kiser), Stella Presley interview; (Chapman), United Mine Workers Journal 32 (1 April 1921): 7; (Ball), "Testimony of William H. Ball," West Virginia Coal Fields, 167.

269"Olmsted Exhibit No.3," in "Testimony of Harry Olmsted," West Virginia Coal Fields, 223-271: 230-236; and Williamson Daily News, 13 October 1919. "Olmsted Exhibit No.3" contains a list of all of the registered members of the Mingo Militia and which community they resided in. For the members from Williamson, individual occupations were also listed.
} 


\title{
CHAPTER 10
}

"THE WORST HAS COME": THE MATEWAN MASSACRE, MAY 19, 1920¹

\author{
"Hell [Has Been] Turned Loose in Mingo County"2 \\ -- West Virginia Federationist, 20 May 1920
}

During the early months of 1920, a series of local, state, and national events began a slow implosion that resulted in tragedy on the streets of Matewan on May 19, 1920. The external causative factors of the terrible tragedy that left ten men dead or dying in the little town included the uncertain economic state of the coal and rail industries as federal wartime regulation finally ended; the escalation of tension between the UMWA and southern West Virginia's coal operators; and the political contests that played to and focused the discontent of various voting groups. However, the Matewan Massacre also simultaneously vented long-brewing local political, economic, and social resentments. How this whirlwind touched down violently in Matewan on May 19, illuminates why the Matewan Massacre became a pivotal turning point in Mingo County history.

\section{Prelude to Tragedy: The Convergence of Contributory Factors, January - May 1920}

Although 1920 later proved to be another banner year for national coal production, in the early months of the year sluggish economic conditions complicated by inadequate railcar supplies fostered tension in Mingo County. Preparations for the general election in November had also

\footnotetext{
${ }^{1}$ Williamson Daily News, 20 May 1920.

${ }^{2}$ West Virginia Federationist, 20 May 1920.
} 
begun early. The Republicans hoped to recapture control of the county government, while Democrats aspired to retain their primacy. In scrambling for ways to improve their respective positions, the local coal and political leaders of Mingo made decisions that directly influenced their subsequent response to the violence in Matewan on May 19, 1920.

At seven o'clock in the morning on Monday, January 12, 1920, an explosion rocked the city of Williamson. The blast shook every building within a mile radius of the city and shattered every window from the plate glass of the storefronts to those of the private residences. As the frightened and confused citizenry wandered the streets, "fragments" of the body of James Childers, the foreman of the Superior-Thacker Coal Company, were found throughout the city. It was soon learned that the company's magazine building, which had contained ten cases of composition mining explosives, had exploded shortly before the company's miners had lined up to receive their daily allotment of the material. Although relieved that the blast had claimed only one casualty, the citizens of Williamson were outraged that such a danger had lain "almost in the heart of the town." How and why the explosion occurred was never clearly established. In the months that followed, Superior-Thacker refused to accept responsibility for the incident. Citing economic hardship, the company offered the citizens of the city a settlement which allowed Superior-Thacker to repay only 25 percent of the cost of the property damage. Most of the citizens who had actually pursued claims against the company accepted the terms. ${ }^{3}$

The Superior-Thacker explosion symbolizes the status of the coal industry and labor relations in Mingo County in the months before the Matewan Massacre. Generally poor employment, production, and transportation conditions, combined with the escalating conflict

\footnotetext{
${ }^{3}$ Williamson Daily News, 13 January 1920, 23 March 1920, and 25 March 1920.
} 
between the union and the operators did not present any new danger that would have alerted observers to the potential for the raw violence of the Massacre. Familiar with the vicissitudes of the economic situation and labor relations rhetoric, no one noticed the danger until the fateful blast. However, an examination of the status of the coal industry nationally, and in southern West Virginia in early 1920, reveals how it provided the backdrop to the events that occurred on the streets of Matewan on May 19.

In the late winter and early spring of 1920, the federal government was preoccupied with resolving the leftover tensions from the national coal strike of 1919. Despite the general effectiveness of wartime federal regulation, the fitful and uneven dismantling of government controls created a climate of resentment and distrust. While the government had released the coal industry from price controls and distribution directives, it denied the UMWA request for a wage increase with a specious semantic argument over whether the war had actually ended. ${ }^{4}$ On January 22, 1920, when the Chairman of the Senate Committee on Education and Labor introduced a bill to create a National Labor Board, (which would have extended the federal role in labor relations) the measure received little support or attention. ${ }^{5}$ Both the UMWA and the leaders of the coal industry were themselves busy with shoring up their own positions, and with

${ }^{4}$ Barkey, 214.

${ }^{5}$ U.S. Congress, Senate, Committee on Education and Welfare, West Virginia Coal Fields: Personal Views of Senator Kenyon and views of Senators Sterling, Phipps and Warren [67th Congress, 2d. Session, Senate Report 457] (Washington: GPO, 1922), 20. 
presenting their case to the Bituminous Coal Commission, the federal investigative body created as part of the settlement of the 1919 strike. $^{6}$

While UMWA representative Van Bittner testified before the commission that miners' earnings had lagged far behind both the inflation of the cost of living and the wages paid to other industrial workers during the war, acting president John L. Lewis traveled to West Virginia to announce that the UMWA was launching an organization drive that would, once and for all, unionize southern West Virginia. ${ }^{7}$ Lewis had foreseen the potential of a unique situation. First, it was highly likely that the Coal Commission would find that union miners deserved a wage increase. Second, Lewis would also have seen that given the prevailing economic conditions in southern West Virginia, the miners employed in the non-union fields would likely clamor for the same concession. By renewing the union's pledge to organize southern West Virginia before the Bituminous Coal Commission issued its report, John L. Lewis positioned the union to materially benefit from both the federally sanctioned wage increase and the discontent rampant in southern West Virginia at the time.

During the late winter of 1919-1920, national coal production had been curtailed at least 25 percent. ${ }^{8}$ In the Williamson-Thacker coal field production fluctuated between 30 and 60

${ }^{6}$ Mildred Allen Beik, The Miners of Windber: The Struggles of New Immigrants for Unionization, 1890s-1930 (University Park, PA: The Pennsylvania University Press, 1997 [1996]), 260.

${ }^{7}$ Bittner's testimony was reported in The Coal Trade Journal 51 (4 February 1920): 13-14.; "John L. Lewis, Head of United Mine Workers of America, Here for Purpose of Organizing Local Coal Fields," Bluefield Daily Telegraph 31 January 1920.

${ }^{8}$ Coal Trade Journal 51 (21 January 1920): 25. 
percent, well below the national figure. ${ }^{9}$ A major contributing factor to the dismal coal situation was a transportation crisis. The national rail systems were still under federal regulation and there were not enough cars to move southern West Virginia coal. ${ }^{10}$ Those hardest hit by the prevailing conditions were the miners. Working fewer and shorter days, the miners faced increasing tangential pressures that heightened resentment against their employers. Shortly after a neighboring coal field reported an outbreak of influenza, some companies raised the miners' compulsory payment for medical services. ${ }^{11}$

While struggling to survive the closing days of winter with less income and high living expenses, miners in the Williamson-Thacker field watched helplessly as their employers belligerently defied local governments. The Hunt-Forbes Coal Company refused to compensate the city of Williamson for the damage its coal hauling had inflicted on the city streets. ${ }^{12}$ In Kermit, the Gray Eagle Coal Company concluded a three-year fight with the town council and the county court over a public road, by hiring guards to protect company property that occupied the contested land. ${ }^{13}$ As the actions of these companies illustrate, the coal companies of the Williamson-Thacker field either blindly or arrogantly disregarded the potential impact of their actions.

${ }^{9}$ Coal Trade Journal 51 (7 January 1920): 13, and 51 (4 February 1920): 120.

${ }^{10}$ Striplin, 153. Federal regulation ended on March 1, 1920.

${ }^{11}$ Coal Trade Journal 51 (18 February 1920): 174; “Testimony of W. E. Hutchinson,” West Virginia Coal Fields, 79.

${ }^{12}$ City Attorney S. D. Stokes to Hunt-Forbes Coal Company, 8 January 1920, Stokes Papers, WVRHC.

${ }^{13}$ Court Documents relating to the case, in Box 5 of the Stokes Papers, WVRHC. 
In addition to imposing higher prices for company services, and yet sidestepping their own local financial responsibilities, the coal companies engaged in speculative ventures that further destabilized employee relations. In January, M. A. Hanna \& Company purchased one of the largest companies in the field, the Red Jacket Consolidated Coal \& Coke Company. ${ }^{14}$ Less than two months later Red Jacket reportedly went on sale again. Although accounts of the pending sale proved false, the company's approximate sale value of two million dollars was revealed. ${ }^{15}$ Moreover, another company, the Buffalo-Thacker Coal Company purchased a mining operation in another field on the Little Coal River. ${ }^{16}$ These and other coal business deals underscored to the miners of the Williamson-Thacker field that not everyone was suffering from the hard times.

Between February 6 and April 16, 1920, a series of seemingly disconnected events underscored why the miners of Mingo County responded, after nearly twenty years' indifference, to the union's call. Taken together, the events illuminate why the miners came to believe that their best hope for economic security and political freedom lay with joining the UMWA.

First, just one week after John L. Lewis "invaded" Bluefield, Governor Cornwell addressed the West Virginia Lumber and Builders' Supply Association in the same city. ${ }^{17}$ The governor, while claiming to be a trade unionist, praised the role of southern West Virginia's non-

${ }^{14}$ Coal Trade Journal 51 (7 January 1920): 17.

${ }^{15}$ Coal Trade Journal 51 (17 March 1920): 292, and 51 (24 March 1920): 319.

${ }^{16}$ Coal Trade Journal 51 (24 March 1920): 319.

17"Flurry Caused By Invasion of Head of Mine Workers," Bluefield Daily Telegraph, 1 February 1920. 
union operators in breaking the 1919 strike. Cornwell went on to explain that if the union succeeded in organizing these same non-union fields, nothing would stop the nationalization of the coal industry. When Cornwell pledged to resign if he failed to keep the peace during the pending effort, his audience leaped to its feet in a standing ovation and shouted its support. ${ }^{18}$ Deliberately or not, the governor exposed whose ally he would be.

If the miners had any doubts about Cornwell's position, just a month later, on March 13, the hearings of the governor's commission investigating the 1919 Armed March on Logan ended. Headed by Governor Cornwell's hand-picked proponents of law and order, the commission had lost the cooperation of District 17 officials and concluded not with substantive recommendations for addressing the endemic problems of labor relations in southern West Virginia, but with a blanket condemnation of the miners' actions and those of District 17's leadership in particular. ${ }^{19}$ The Governor of West Virginia not only allied with their employers, the miners of southern West Virginia were forced to acknowledge that he also had no interest in giving their grievances an impartial public hearing.

The public announcement on March 29, 1920, that the Bituminous Coal Commission had recommended that coal miners receive a 27 percent wage increase only underscored the benefits of union membership. ${ }^{20}$ To add insult to injury, one of Mingo County's two newspapers, the Williamson Daily News, printed an editorial proclaiming coal a mismanaged industry, that a

\footnotetext{
${ }^{18}$ Bluefield Daily Telegraph, 7 February 1920.

${ }^{19}$ Merle T. Cole, "Martial Law and Major Davis as 'Emperor of Tug River'" West Virginia History 43 (Winter 1982): 118-144, 126.

${ }^{20}$ Williamson Daily News, 30 March 1920.
} 
wage increase for miners was "only right," and that the miners should not have to suffer because of "the mismanagement of others."21 Less than a week after the Daily News' apparent statement of empathy for the miners' cause, strikes broke out among the railroad workers of the Norfolk \& Western. ${ }^{22}$

Despite the building pressure these incidents represented, there was one more culminating event that drove the miners of Mingo to action. In late March or early April 1920, the miners at the Howard Colliery at Chattaroy asked for a ten cents a car raise, to offset the increase in the cost of living. After calling in his superintendent from Bluefield, the Howard manager asked the men to give them a week to consider the request, and also asked the men to continue working, which they did. Three days later the miners of the Howard Colliery were offered a nine cents raise to which they agreed and were "well satisfied." At the end of their shift that same day, however, the men exited the mines only to find a notice that the prices of all their necessary work articles had been raised five to twenty-five cents, and moreover, that it would now be compulsory that the miners buy exclusively in the Howard Colliery company store. ${ }^{23}$ The miners of the Howard Colliery had negotiated in good faith and felt betrayed.

On the morning of April 16, the miners of the Burnwell Coal \& Coke arrived at the mines and found the following sign posted on the drift mouth:

To the miners of Burnwell Coal Company: We shall have this 27 per cent raise; we want this 27 per cent raise which the Government has granted us.

\footnotetext{
${ }^{21}$ Williamson Daily News, 1 April 1920.

${ }^{22}$ Coal Trade Journal 51 (7 April 1920): 368.

23"Testimony of Frank Ingham," West Virginia Coal Fields, 29.
} 
The Burnwell miners refused to enter the mines. Eighty of the ninety-two Burnwell employees signed a letter and sent two of their own to Charleston to request a charter from District 17 of the United Mine Workers of America. When asked why they undertook this action, one of the men sent to union headquarters replied that it was because the miners wanted "to belong to an organization of [their] own craft." District 17 Secretary-Treasurer Fred Mooney sent the Burnwell miners back to Mingo with a promise to send organizational assistance if the men returned to work. ${ }^{24}$ The Mingo organization drive had begun.

Within days, large gatherings of miners were orchestrated. Miners flocked by the hundreds to take the union obligation. On April 22, approximately 500 men attended a meeting at the Baptist Church in Matewan and between 275 and 300 joined the union. ${ }^{25}$ The next day, also in Matewan, between 700 and 800 miners congregated. ${ }^{26}$ The response seemed to portend that the miners of Burnwell would get their wish. For four heady days, W. E Hutchinson, and the other employees of the Burnwell Coal \& Coke Company went into the mines as union men. However, dismissal notices were delivered on April 27 and the union miners and their families were given just three days to vacate company housing. ${ }^{27}$ Their employer Mr. Pritchard, declared

\footnotetext{
${ }^{24 " T e s t i m o n y ~ o f ~ W . ~ E . ~ H u t c h i n s o n, " ~ W e s t ~ V i r g i n i a ~ C o a l ~ F i e l d s, ~ 80-81 . ~ W h o ~ p l a c e d ~ t h e ~ n o t i c e ~}$ at the mine entrance remains a mystery.

${ }^{25}$ Ibid., 84-85.

${ }^{26}$ Williamson Daily News, 23 April 1920.

27"Hutchinson Testimony,’West Virginia Coal Fields, 83.
} 
that "he would let his mine go until moss grows over it, until it falls into the huckleberry ridge, before he would ever work a union man." ${ }^{28}$ The line of confrontation had been drawn.

Shortly after the organizational flurry began, the coal companies of the WilliamsonThacker field launched their effort to stem the tide. The day the Burnwell miners received their eviction notices, the Williamson Daily News reported that it had "talked to both sides, but got no hope as to a reasonable settlement." The News pleaded with both sides to "remember that people will suffer," and to "keep within the bounds of the law." ${ }^{29}$ Just two days later, on April 29, reports of operator activity revealed that the News' appeals had fallen on deaf ears. The companies began evicting the men who were assisting in the organization of the miners. The operators also imported detectives, machine guns and high powered rifles. Although the operators would later deny any culpability in the escalation to violence, a single item from the same story illuminated the first clue to the immediate cause of the Matewan Massacre, now less than three weeks away. ${ }^{30}$

On April 27, 1920, Mingo County Sheriff G. T. Blankenship arrested Albert C. Felts, brother of the head of the Baldwin-Felts Detective Agency, for illegally processing evictions. ${ }^{31}$

${ }^{28}$ Ibid., 85.

${ }^{29}$ Williamson Daily News, 27 April 1920.

${ }^{30}$ Williamson Daily News, 29 April 1920.

${ }^{31}$ Although no sources explain exactly how Felts violated the law, the date of his arrest suggests that a company, possibly Burnwell, hired Felts to proceed with evictions before the expiration of the eviction notice deadline. As was later revealed before the Senate Investigating Committee, West Virginia law did not expressly indicate how many days' notice the companies were required to give. During the testimony of W. E. Hutchinson, operators' attorneys explained that the state required only that "reasonable notice" be given. In practice during the WilliamsonThacker conflict, except for the illegal summary evictions, the miners received a minimum three 
Felts posted a two thousand dollar bond and appeared in magistrate's court two days later, where he and twenty-seven other agents were placed under a peace bond. ${ }^{32}$ Hoping to de-escalate the situation Sheriff Blankenship called a meeting with miners before the courthouse in Williamson. Blankenship asked the miners if they would peacefully comply with their evictions if he and his deputies processed the writs. According to Blankenship, the miners agreed. ${ }^{33}$ Although Blankenship later claimed to have processed hundreds of evictions for the coal companies, less than two dozen were undertaken between mid-April and May $19 .{ }^{34}$

There were at least two reasons for the low number of evictions. First, despite a promise to process any evictions lawfully ordered by the circuit court, Blankenship in fact engaged in stalling tactics, asking companies to obtain both ten-day notices from the court and then, threeday notices from justices of the peace. ${ }^{35}$ Second, in early May, after holding a strategy session

days' notice, which was standard for evictions authorized by the local justice of the peace, a tenday notice, or both. "Testimony of W. E. Hutchinson," West Virginia Coal Fields, 92.

${ }^{32}$ Williamson Daily News, 29 April 1920; Charleston Gazette, 20 May 1920.

${ }^{33}$ Charleston Gazette, 20 May 1920.

34"Testimony of C.(sic) T. Blankenship," West Virginia Coal Fields, 490. During the testimony of Harry Olmsted, coal company attorney S. B. Avis noted that prior to the beginning of the strike on July 1, 1920, only 20 evictions: a total of 16 from two separate occasions at Matewan, 2 at Red Jacket, and 2 at Burnwell had taken place; by the time the Senate Hearings began in July 1921, a total of 369 evictions had been processed in Mingo County. Avowal of S. B. Avis, during “Testimony of Harry Olmsted," West Virginia Coal Fields: 223-271, 257. While it is possible that the operators deliberately downplayed the official eviction count, the fact that UMW attorneys did not dispute Avis' statement lends credence to the numbers he offered into evidence. When the UMW was equally sure that their counts were correct, they did not hesitate to dispute the figures cited by the operators, for example, one consistently disputed number in 1921 was the population of Mingo's tent colonies.

${ }^{35}$ Avowal of S. B. Avis, during "Testimony of Harry Olmsted," West Virginia Coal Fields: 223-271, 257. 
with Baldwin-Felts Detective Agency Chief Thomas L. Felts, the operators began compelling their employees to sign "yellow dog" contracts. ${ }^{36}$ The contracts not only precluded union membership, but also contained a clause that must have been particularly galling to many miners. In addition to agreeing not to join the union, the men who signed the contracts also put their endorsement to a denunciation of the union. ${ }^{37}$ At least two of the companies within the vicinity of Matewan, the Stone Mountain Coal Corporation and the Red Jacket Consolidated Coal \& Coke Company, instituted this policy in early May. ${ }^{38}$

Despite the evictions and the imposition of the "yellow dog" contracts, the organization of Mingo's miners continued unabated during the first two weeks of May. Emboldened by Sheriff Blankenship's vow to protect them from unlawful acts by the companies, the miners held mass public meetings. ${ }^{39}$ Three thousand attended a union meeting at Matewan on May 6, 1920. ${ }^{40}$

36"Testimony of T. L. Felts," West Virginia Coal Fields, 881-905, 891. Felts did not reveal any details of the strategy session, but the timing of Red Jacket's and Stone Mountain's imposition of the contracts, when combined with the revelation of Blankenship's reluctance to undertake evictions, strongly suggest that the operators were seeking to strengthen their positions with all the sources of legal sanction at their disposal.

${ }^{37}$ Arthur Warner, "West Virginia: Industrialism Gone Mad," Nation 113 (5 October 1921): $372-373,373$.

${ }^{38}$ (Stone Mountain contract) United Mine Workers Journal 51 (15 February 1921):17; (Red Jacket contract) “Affidavit of C. L. McKinnon," Red Jacket, et al v. John L. Lewis, et al: 788a791a, 789a. McKinnon testified that Red Jacket imposed its contract on May 10, 1920, following a union meeting at Matewan. The labor situation never seriously impaired operation of the Red Jacket mines and ultimately, the company assumed the lead role in the anti-union initiative in Mingo County.

${ }^{39}$ Charleston Gazette, 20 May 1920.

${ }^{40}$ Daniel P. Jordan, "The Mingo War: Labor Violence in the Southern West Virginia Coal Fields, 1919-1922," Essays in Southern Labor History; Selected Papers, Southern Labor History Conference, 1976, edited by Gary M. Fink and Merl E. Reed, Contributions in Economics and 
Eight days later, two hundred miners took the union pledge at Williamson. ${ }^{41}$ On that same day, May 14, another meeting was held at Matewan, although no organizers or representatives of the UMWA were present. The speakers included Hugh Combs, a miner and Southern Methodist "exhorter," an African-American minister, and George Allen, a merchant from Thacker, all of whom endorsed the union as the miners' advocate. Combs informed the miners that joining the union was a just act of self-protection against the operators who were themselves organized. The African-American minister, identified only as "Johnson," informed his fellow black miners that Abraham Lincoln had given them their freedom, but now the union would "give them their liberty." Allen told those assembled that he had once been a miner, and because he was in sympathy with their cause, pledged the use of his store if the miners needed a place to meet. ${ }^{42}$ That the miners spoke so freely because of Blankenship's protection, and had an open forum in his hometown of Matewan, soon also received public acknowledgment. During the annual meeting of the West Virginia State Federation of Labor, District 17 Secretary Fred Mooney informed his fellow conventioners that "the UMW had the support and backing of the Mingo County officials, a condition which had never existed before in the history of the organization." ${ }^{43}$ Reported in the Bluefield DailyTelegraph, Mooney's comments further galvanized the anti-union sentiments of Mingo’s coal operators.

Economic History, no. 16 (Westport, CT: Greenwood Press, 1977), 107.

${ }^{41}$ Williamson Daily News, 15 May 1920.

${ }^{42}$ Report of Operative \#24, dated 14 May 1920, submitted to George Bausewine by T. L. Felts, 17 May 1920, reprinted as part of "Hatfield Exhibit No. 2," in "Testimony of Sid Hatfield," West Virginia Coal Fields: 205-221: 215.

${ }^{43}$ Bluefield Daily Telegraph, 15 May 1920. 
While Fred Mooney celebrated the establishment of the union beachhead in Mingo, the Williamson Daily News made increasingly ominous observations about conditions in Mingo County. The May 8 issue noted, "there is a general restlessness among our laboring people ... what will be the outcome of this discontent no one can predict."44 Just six days later the Daily News, after reporting on yet another miners' meeting, noted that "the operators have made nothing public ... as to what position they will take ... secrecy seems to prevail on both sides." ${ }^{45}$

Just what the Daily News expected the two opponents to reveal is not clear. The operators' intractability concerning the UMWA had been openly admitted to their employees. In addition to Pritchard of Burnwell, other companies publicly advertized their position. On May 5, Borderland posted a notice that paralleled Pritchard's comment in clarity. The notice read, "This is a free country . . . but . . no union men shall be employed by this company."46 Stone Mountain posted a similar notice on the front window of its company store in Matewan. ${ }^{47}$

For its part, District 17 and the national leadership of the UMWA also moved forward with the formalities of its organization effort. After the state Federation of Labor convention ended, the first international organizers arrived in Mingo. ${ }^{48}$ By Monday, May 17, 1920, the union had initiated efforts to set up a tent colony near Matewan for the evicted union miners. District

${ }^{44}$ Williamson Daily News, 8 May 1920.

${ }^{45}$ Williamson Daily News, 14 May 1920.

${ }^{46}$ Shifflett, 123.

${ }^{47}$ Arthur Gleason, "Public Ownership of Private Officials," Nation 110 (29 May 1920): 724$725,724$.

48"Testimony of W. E. Hutchinson,” West Virginia Coal Fields, 80. 
17 official C. H. Workman arrived that day with tents and instructions to lease all land available for a tent colony. ${ }^{49}$ Just two days later, on Wednesday, May 19, Albert and Lee Felts, leading a contingent of Baldwin-Felts agents stepped off the train at 11:47 a.m. Their assignment -- to ensure the eviction of several families from Stone Mountain company housing in the town of Matewan. ${ }^{50}$ Less than six hours later, the Felts brothers, five of their men, Matewan's mayor, and two bystanders would lay dead or dying on the streets of the town. However, as other studies of violence in Appalachia have shown, economic oppression is not sufficient unto itself to spark an encounter like that which occurred in Matewan on May 19. ${ }^{51}$

As 1919 drew to a close and the political season of 1920 opened, at the national, state, and local levels, Republicans dominated the stage. After orchestrating the defeat of President Wilson's internationalist agenda (personified by the League of Nations), and driving him to utter physical collapse, the nation's leading Republicans turned on each other. At issue was the direction an internally focused nation would follow. The leading liberal contender for the presidential nomination was Hiram Johnson, a Progressive, railroad-trustbusting Senator from California, whose chief allies were Senators William E. Borah and William S. Kenyon of Iowa. ${ }^{52}$ Although Kenyon, leader of the United States Senate's "agricultural bloc," was sympathetic to

${ }^{49}$ Charleston Gazette, 20 May 1920.

50"Testimony of Sid Hatfield," West Virginia Coal Fields, 219.

${ }^{51}$ See: Billings and Blee, The Road to Poverty: The Making of Wealth and Hardship in Appalachia. This new work by Billings and Blee addresses the historical connection between political and economic dysfunction in the construction of poverty in eastern Kentucky.

${ }^{52}$ (Johnson) Wesley M. Bagby, The Road to Normalcy: the Presidential Campaign and Election of 1920 (Baltimore: Johns Hopkins Press, 1968 [1962]) ,31-32. 
the complaints of organized labor, he had openly denounced civil disorder as a means of addressing these issues. ${ }^{53}$ The party's conservative wing backed Army General Leonard Wood, a law and order advocate. In part because both Johnson and Wood claimed to be the heir of Theodore Roosevelt, the 1920 Republican national convention deadlocked, which resulted in the nomination of Warren G. Harding. ${ }^{54}$ However, the election year politics of Wood, Johnson, and Kenyon still affected the labor-dominated politics of West Virginia. Wood, who drew substantial support from southern West Virginia's Republican coal elite, concluded his primary stumping in Williamson, Mingo County on May 22, 1920, just three days after the Massacre. ${ }^{55}$ Both Johnson and Kenyon later served on the Senate's Investigating Committee into conditions in the West Virginia coal fields in $1921 .^{56}$

Ostensibly united in their determination to regain the governorship after Cornwell's anomalous tenure, West Virginia's Republican party suffered from a schism that mirrored the national conflict. Samuel B. Montgomery, a former leader of the West Virginia State Federation of Labor, UMWA attorney, and commissioner of labor under Governor Hatfield, had the support

\footnotetext{
${ }^{53}$ (Kenyon) Bluefield Daily Telegraph, 1 February 1922; Robert K. Murray, Red Scare: A Study of National Hysteria, 1919-1920 (New York: McGraw Hill, 1964), 30-31, 206. According to Murray, Kenneth D. McKellar of Tennessee, (another future member of the Committee) had advocated creating an island penal colony for native radicals.

${ }^{54}$ Bagby, 32.

${ }^{55}$ Williamson Daily News, 20 May 1920; Charleston Gazette, 21 May 1920.

${ }^{56}$ See member list of the Committee which follows the title page, West Virginia Coal Fields, (1921).
} 
of the liberal wing of the party and the laboring classes of state. ${ }^{57}$ Judge Ephraim F. Morgan of northcentral West Virginia had the support of the conservative wing of the party, except for the ultraconservative coal elite of southern West Virginia, who supported Colonel Paul Grosscup, an oil and gas executive from Charleston. ${ }^{58}$ The three-way contest between Montgomery, Morgan, and Grosscup revealed that the factional legacy of Henry D. Hatfield's gubernatorial tenure not only had persisted, but had expanded. More importantly, two of the counties soon to be swept up in the crisis between the UMW and West Virginia's non-union operators, Mingo and McDowell, were the focal point of this state-level political controversy. ${ }^{59}$

The intrafactional fight did not play out in smoke-filled backrooms, but on the frontpages of southern West Virginia's newspapers. ${ }^{60}$ On January 18, 1920, the Bluefield Daily Telegraph revealed the first indication that disharmony ruled in the southern coal counties. According to the Telegraph, Mingo Republican party chairman, M. Z. White, issued an endorsement letter for Morgan, while his counterpart in McDowell, Colonel Edward O'Toole, had done the same for Colonel Grosscup. ${ }^{61}$

${ }^{57}$ West Virginia Heritage Encyclopedia, volume 15: 3302; Evelyn L.K. Harris and Frank J. Krebs, From Humble Beginnings: West Virginia State Federation of Labor, 1903-1957 (Charleston, WV: Jones Printing Co., 1960), 119; Williamson Daily News, 15 May 1920.

${ }^{58}$ (Morgan) West Virginia Heritage Encyclopedia, vol. 15: 3340-3341; (Grosscup) West Virginia Heritage Encyclopedia, vol. 10: 2064-2065.

${ }^{59}$ To see how close was the 1920 West Virginia gubernatorial contest, see Appendix 1.

${ }^{60}$ The Williamson Daily News, a Democratic paper described the months-long machinations of the three Republicans gubernatorial hopefuls in its May 15, 1920 issue.

${ }^{61}$ Bluefield Daily Telegraph, 18 January 1920. As mentioned in an earlier chapter, O'Toole directed all of the U.S. Coal \& Coke (U.S. Steel) coal properties in McDowell County, and historically had been Henry D. Hatfield's rival in McDowell's county politics. For more on the 
In the weeks before the primary election, White utilized traditional machine tactics to ensure Mingo's support for Morgan. The March 9 issue of the Williamson Daily News asserted that White convened the county's nominating convention by reading a list of candidates he hoped would be considered. When a smattering of objections were raised White "angrily" adjourned the meeting without considering alternative candidates. The Daily News concluded its report by noting that what remained in question was whether "the better citizens in the Republican party . . . resented their continued sale and delivery" enough to act. ${ }^{62}$

Led by Edward O'Toole and T. E. Houston, two of the most powerful coal executives in the Smokeless fields, McDowell's political factions turned to the West Virginia Supreme Court of Appeals. Less than three weeks before the primary, the Court issued a mandamus ruling that ordered both the unseating of McGinnis Hatfield (a Grosscup partisan) as county chairman, and the selection of the Morgan list of election officers. ${ }^{63}$ While these actions appeared to indicate politics as usual for southern West Virginia, the fight over the Republican gubernatorial bid released two new forces that profoundly influenced events in southern West Virginia for the next two years.

For the first time, West Virginia's laboring classes, especially its coal miners, had a legitimate advocate-candidate, and their votes could swing the gubernatorial election. The regular party machinery's infighting over Morgan and Grosscup meant that the deciding bloc of votes

Hatfield-O'Toole relationship see: A. D. Sowers, Some Facts about McDowell County, West Virginia (Keystone, WV: A. D. Sowers, 1912), in Rare Book Collection, WVRHC.

${ }^{62}$ Williamson Daily News, 9 March 1920.

${ }^{63}$ Williamson Daily News, 15 May 1920. 
belonged to Montgomery. The anticipated loyalty of the "organized faithful" inspired what the Williamson Daily News referred to as an "entente cordiale" between Grosscup and Montgomery. ${ }^{64}$ Unfortunately for Grosscup and Montgomery, in southern West Virginia, the single largest group of potential Montgomery supporters, the miners, were not organized.

It was at this point that the simmering political and labor unrest in southern West Virginia coalesced in Mingo County. According to S. D. Stokes, a Williamson Democrat, it was the three-way fight between Morgan, Montgomery, and Grosscup that actually spawned District 17's effort to unionize southern West Virginia, starting with Mingo. Stokes wrote to a friend that Mingo's Republican chairman, M. Z. White, with the collusion of Greenway Hatfield, had sold the county's primary returns to Morgan supporter T. E. Houston for fifty thousand dollars. However, because White could not keep quiet, and publicly proclaimed Mingo for Morgan, Grosscup's campaign manager visited Montgomery's campaign manager in Charleston, and reminded him of two important things. First, that Montgomery could carry southern West Virginia if the miners were free to vote their consciences, and second, that the way to "liberate" these voters was to organize them. Thus, Stokes claimed, "in about ten days, the coal operators in this field observed unrest among their laboring men and woke up to the fact that the ordinary labor agitator was ... abroad in the land." ${ }^{65}$ What prevents dismissal of Stokes' version of

${ }^{64}$ Williamson Daily News, 15 May 1920.

${ }^{65}$ S. D. Stokes to Carl E. Whitney, 19 August 1920, Stokes Papers, WVRHC. In this letter Stokes also reveals that White broke with Henry D. Hatfield, his long-term ally because of Hatfield's betrayal of White's own political aspirations for the 1920 election. Moreover, Stokes ascribes the actions of Greenway Hatfield as a proactive attempt to heal the breach between White and his brother in the interest of securing White's supporting for Henry D.'s future U.S. Senate candidacy. See Appendix 3. 
events as partisan gossip is a review of the timing of White's public actions and the launch of District 17's organization drive. White's letter of support for Morgan had appeared in the January 18 issue of the Bluefield Daily Telegraph. Thirteen days later, John L. Lewis announced that the UMWA would initiate a unionization offensive in southern West Virginia.

The turmoil in Republican ranks in McDowell and Mingo counties extended into their most loyal constituency -- the African-American community. On the same day that the Bluefield Daily Telegraph revealed the schism between the leaders of the party, it also noted that a "New Emancipation Movement" had been started by the Colored Republican Laboring Men's Organization of McDowell County. The avowed intent of the organization was not hostile to the operators or any other business interests, but had as its only goal "to make an effort to end negro political slavery." ${ }^{\prime 66}$ By May, the movement had spread to Mingo County. At a meeting held at the county courthouse in Williamson on May 14, the African-American voters of Mingo County were exhorted to vote independently because, the "Republican bosses hang on their necks at election time," but promptly forget them after. As the Williamson Daily News observed, the speakers and their audience also spoke enthusiastically in favor of the organization efforts of the $\mathrm{UMW}^{67}$

Besieged by the union organizers, who also stumped for Montgomery, and threatened with the defection of the black vote, Mingo's Republican machine intensified its efforts to regain

\footnotetext{
${ }^{66}$ Bluefield Daily Telegraph, 18 January 1920.

${ }^{67}$ Williamson Daily News, 15 May 1920.
} 
control over the pending primary election. ${ }^{68}$ County chairman White sued the Democratcontrolled county court because it required the list of registered voters in Mingo to exclude voters whose registrations were disputed by precinct officers. The West Virginia Supreme Court of Appeals granted White a writ of mandamus on May 18, 1920, the day before the Matewan Massacre. ${ }^{69}$

Although the report of the supreme court of appeals does not reveal that the disputed registrations included any from those in Matewan's precinct, there is evidence that indicates how the town came to be the focal point for the political and labor agitation in Mingo. First, in the spring of 1920, the county's two most powerful officials, Sheriff Blankenship and the president of the county court, Blankenship's brother-in-law E. B. Chambers, were from Matewan. Second, the town's mayor and Chambers' ally, C. C. Testerman, shortly after winning a second term was targeted for criminal prosecution. The statement he issued after being found not guilty of prohibition violations reveals not only the town's political tensions, but also his determination to oppose the forces arrayed against him. Testerman asserted:

I am mayor of Matewan, elected by the people for a second term, which speaks for itself. They can say what they please, law when they please, fight when they please, but I am going to run the town according to the laws of this state and the best of my ability. Instead of our town having the name it has possessed these many

68"Testimony of C.E. Lively," 25-26 February 1921, unknown newspaper, Matewan Omnibus Collection, ERCA. Lively asserted that he "got acquainted" with Sid Hatfield on May 7-8 1920, while in Matewan with Dan Mooney, campaigning for Samuel Montgomery.

69"State ex rel. M. Z. White, Relator v. County Court of Mingo County," Reports of the West Virginia Supreme Court of Appeals 86 (March 16- September 21 1920): 517-518. In granting the writ the judges ordered the county court to accept the existing lists of registered voters for the primary election, and to use time between the primary and the general election to "sort out" any disputes. 
years, you are going to hear of Matewan representing the highest order of good government. Our elections are held quietly now. We have no drunks, and our people at last can go to church unmolested and worship as they please. I intend to do what is right the best I know how and the threats of evil doers won't alter me in my course one inch. ${ }^{70}$

Under Testerman's tenure, during the early Spring of 1920, Matewan became a free assemblage haven for the organization of Mingo's miners. Testerman's allies, Blankenship and the county court, also provided protection for the union cause. Half of the county's miners lived in Magnolia District, of which Matewan was the center. To effectively disfranchise these voters, the protective power of the Matewan Democrats had to be neutralized. ${ }^{71}$ The Matewan Massacre occurred six days before the primary election was held. ${ }^{72}$

II. The Matewan Massacre and Its Local Impact, 1920-1960s:

The basic facts of the Massacre and the events it set in motion are indisputable. On May 19, Matewan's Chief of Police Sid Hatfield and a group of deputized citizens and miners engaged in a gun battle with representatives of the Baldwin-Felts Detective Agency. Ten men, including Mayor Testerman died as a result. Within weeks the Operators' Association of the WilliamsonThacker field initiated a lockout, in an attempt to defeat the rampant success of the UMW

\footnotetext{
${ }^{70}$ Williamson Daily News, 30 January 1920.

${ }^{71}$ Violence and/or murder as a means of removing or undermining political rivals has been documented in other Appalachian communities. See Tudiver, 113 and Billings and Blee, 281.

${ }^{72}$ Williamson Daily News, 25 May 1920. The Williamson Daily News' report of voting activity on May 25 hints at the impact the Massacre had on the primary election in Mingo County. According to the News, "there seems to be very little interest in the primary election today ... there will be nothing like a full vote, judging from the limited number of voting early in the day."
} 
organization drive. In retaliation, the union issued a strike call, which it rescinded only after twenty-eight months of bloody conflict and violent oppression, including the retaliatory assassination of Hatfield, and the Battle of Blair Mountain, the largest armed civilian insurrection since the United States' Civil War. History has recorded the impact of this second "mine war" on the future of the United Mine Workers of America in West Virginia. What has been overlooked is the local effect of the Massacre and subsequent events, and also how the story of those events was transformed to serve the agendas of people and interests far from Mingo County.

May 19, 1920, dawned dreary and overcast, and rain drizzled from the clouds intermittently throughout the day. Still, Matewan teemed with miners because union relief funds were being distributed that morning. ${ }^{73}$ In the midst of the activity, at 11:47 a.m., a party of Baldwin-Felts agents disembarked train 29 at Matewan, having come to enforce eviction notices on behalf of the Stone Mountain Coal Corporation. ${ }^{74}$ According to Walter Anderson, one of the surviving agents, Albert Felts contacted Sheriff Blankenship seeking his and his deputies' assistance in processing the evictions. ${ }^{75}$ Failing to achieve this objective, Felts secured authorization for the detectives' party to undertake the evictions from a Magnolia District justice of the peace. ${ }^{76}$ On their way back through the town, the Baldwin-Felts agents were confronted by Chief of Police Hatfield and Mayor

\footnotetext{
73"Trial Testimony of Hugh Combs," Lewis Collection, ERCA.

74"Testimony of Sid Hatfield," West Virginia Coal Fields, 219.

${ }^{75}$ Telegram of Walter Anderson to John J. Cornwell, 20 May 1920, Cornwell Papers, WVRHC.

${ }^{76}$ Ibid. The two Justices of the Peace for Magnolia District in 1920 were: R. M. Stafford of Thacker and A. B. Hatfield of Matewan. 1920 West Virginia Legislative Handbook and Manual, 763.
} 
Testerman. Both Hatfield and Testerman contested the agents' authority to process the Stone Mountain evictions. Their primary arguing point, Hatfield later asserted, was that because the houses in question lay within Matewan's municipal limits, he and Testerman possessed the jurisdictional sovereignty to halt the evictions. ${ }^{77}$

At this point, the confrontation ended and the Baldwin-Felts agents crossed the railroad tracks and proceeded up Warm Hollow to process the evictions. (From this point on, accounts of further activity reflect the observers' bias.) Hatfield and Testerman sought out a telephone to contact county officials. Testerman allegedly called Mingo's prosecuting attorney Wade Bronson to enquire about the legality of the evictions. ${ }^{78}$ After being read the "Red Man's Act-- the riot act," by Bronson, Testerman authorized Hugh Combs, a local miner and Methodist "exhorter," "to obtain reliable men to protect the town." ${ }^{, 79}$ One of Matewan's two telephone operators later

77"Testimony of Sid Hatfield," West Virginia Coal Fields, 206. Insight into Testerman's behavior on May 19, 1920 comes from the trial testimony of Hugh Combs. According to Combs, Testerman was angered by Albert Felts' dismissal of his mayoral authority. Combs alleged that Testerman stated, "These men have (sic) treated me wrong ... from now on ... I am not going to allow them to come in here and violate the law and get away with it." "Testimony of Hugh Combs," Lewis Collection, ERCA. The intersection of "civil behavior" with other stresses in tense situations is a phenomenon often discussed in studies of "domination and resistance." See: Jane Dailey, "Deference and Violence in the Postbellum South: Manners and Massacres in Danville, Virginia," Journal of Southern History 63 (August 1997): 553-590, 556.

${ }^{78}$ According to the timekeeper of Stone Mountain, Testerman spoke to Judge Damron who told him the warrants were legal. Deputy Sheriff Jesse Pendleton "Toney" Webb, claimed Testerman spoke with Bronson who said they were not legal and that warrants should be issued for the agents' arrest. Possible validation for Webb's claim stems from the fact that one of the evicted, Charlie Kelly, was dispatched to Williamson to file the necessary complaint. "Statement of Mr. E.C. Price," Excerpt from Report of \#9, 29 May 1920, Lewis Collection, ERCA; "Trial Testimony of Jesse P. “Toney” Webb," Lewis Collection, ERCA.

${ }^{79 "}$ "Trial Testimony of Hugh Combs," Lewis Collection, ERCA. Passed in 1882, the "Red Man's Act" criminalized conspiracies between two or more men to steal, damage, or destroy another's property; it also allowed any individual involved in the conspiracy to be tried for first 
testified that Hatfield told either Blankenship or Deputy Sheriff Webb "those sonsabitches will never leave here alive." ${ }^{" 80}$ Throughout the afternoon, armed men arrived in Matewan, and the town became "a powder keg." the children were sent home to get them off the streets of the town. ${ }^{82}$

Hatfield, Testerman, and a crowd of miners, men, women, and children watched as the Baldwin-Felts agents carried out the Stone Mountain evictions. Hatfield allegedly approached Albert Felts who raised his gun and told Hatfield he was trespassing on private property. Smiling, Hatfield replied, "That's alright, I'm a private man," and advanced. When Hatfield drew near, Felts observed that at Paint Creek, he had been shot at from ambush, but had refused to be "bluffed out." Hatfield assured Felts that if there were any trouble here, "no one will go to the hills on you .

degree murder if anyone died during the commission of a conspiratorial act. See Sections 10 and 13 of Chapter 35 “An Act Concerning Deadly Weapons, Etc," in Acts of the West Virginia Legislature for the year 1882 (Wheeling, WV: W. J. Johnston, Public Printer, 1882): 421-424.

${ }^{80}$ McDowell Recorder, 4 March 1921; Query by defense attorney, “Testimony of Jesse P. “Toney” Webb," Lewis Collection, ERCA.

${ }^{81}$ Hawthorne Burgraff interview and Venchie Morrell interview(s), Summer 1989 and Summer 1990 Matewan Oral History Project.

${ }^{82}$ Ibid. According to Mr. Burgraff, his uncle Albert Burgraff had also been indicted for the Massacre, but charges were dismissed by the Judge when learned of Burgraff's efforts to protect the children. 
.. they will come face to face." ${ }^{" 83}$ Testerman again asked Felts to desist, which Felts refused, but offered to stop and return to town if Testerman could prove that he was acting illegally. ${ }^{84}$

About 3:30 p.m. the Baldwin-Felts agents came back across the tracks into Matewan and checked into the Urias Hotel. ${ }^{85}$ Although miners and Police Chief Hatfield had observed the six evictions, there had been no more confrontations. ${ }^{86}$ A surviving Baldwin-Felts agent recalled that the processes had gone smoothly, citing as proof the agents' transfer of one family's belongings to another location upon the request of the evictee. ${ }^{87}$ In contrast, local recollections of the evictions present the actions of the agents as a primary stimulus for the gun battle. The agents reportedly arrived heavily armed, and proceeded to bully all whom they encountered, for example callously

\footnotetext{
${ }^{83}$ In two diametrically opposed versions of the events preceding the Massacre, the word "bluff" was applied to the actions of both sides. Witness Dan Chambers asserted that Albert Felts told Sid Hatfield that he would not be "bluffed out" of doing his duty, while Jennie Mullens reported that she heard a man on his way to watch the evictions angrily exclaim that the BaldwinFelts agents had "come down here for a bluff game." "Trial Testimony of Dan Chambers," and "Statement of Miss Jennie Mullens," 21 August 1920, Lewis Collection, ERCA. One BaldwinFelts agent who refused to go to Matewan on May 19, later claimed that he had "predicted that Albert (Felts) would lead his men, as did General Custer, into a death trap." Ernie Reynolds, "After the Round-Up Where Do all the Brave Men Go?," Ernie Reynolds Collection, ERCA. Historian Rhodri Jeffreys-Jones asserted that companies undertook actions like those of the Baldwin-Felts agents on May 19, 1920, "to provoke incidents that would blacken the name of the union and induce anti-strike injunctions.” Jeffreys-Jones, 91.

84"Trial Testimony of Mrs. Elizabeth Barrett, ” Lewis Collection, ERCA.

${ }^{85}$ Walter Anderson telegram, Cornwell Papers, WVRHC.

${ }^{86}$ Notarized Statement of Dudley Williams, 14 September 1920, Lewis Collection, ERCA. Williams delivered to the warrant issued by Justice of the Peace

${ }^{87}$ Walter Anderson telegram, Cornwell Papers, WVRHC.
} 
and haphazardly piling the belongings of a miner's sick wife in the rain. ${ }^{88}$ However the agents comported themselves, on their return to Matewan they made their way to the Urias unmolested. ${ }^{89}$

Once at the hotel, the agents sought rooms in which to freshen up, and to disassemble and pack their large firearms, a legal necessity since only three of the agents, the Felts brothers and C. B. Cunningham, possessed the required license to carry pistols in Matewan. ${ }^{90}$ Several individuals reported to Albert Felts that trouble was brewing and that armed miners were milling about the town. ${ }^{91}$ Felts' gathered his men and told them that if a conflict erupted, they were not to fight or resist arrest, but to go quietly because bail would be posted and the situation resolved peacefully. ${ }^{92}$ After repacking their weapons, all but one of the agents sat down to a meal. ${ }^{93}$ As time approached for the 5:15 p.m. train to Welch, the agents thanked proprietor Ance Hatfield for his hospitality,

${ }^{88}$ Hawthorne Burgraff interview; Venchie Morrell interview (1990); "Trial Testimony of Charlie Kelly," Lewis Collection, ERCA. Kelly's wife was the sick woman.

${ }^{89}$ Hence their mood was light as they made their way back into town, laughing and joking among themselves. Walter Anderson telegram, Cornwell Papers, WVRHC; Dudley Williams statement, Lewis Collection, WVRHC.

${ }^{90}$ Walter Anderson telegram. Oral History Project narrator Harry Berman noted that because the agents' weapons were strapped to their cases, they "never had a chance." Harry Berman interview.

${ }^{91}$ Statement of Miss Jennie Mullens, 21 August 1920, Lewis Collection, ERCA; "Trial Testimony of Joe C. Jack," 25 February 1921, unknown newspaper, Matewan Omnibus Collection, ERCA. According to Mullens, she had been told by Mae Chafin that Sid Hatfield had said all of the agents would be killed, whereupon Mullens told Urias proprietor, Ance Hatfield and together they told Albert Felts. Jack also claimed to have warned Felts.

${ }^{92}$ Jennie Mullens statement, Lewis Collection, ERCA.

${ }^{93}$ Charleston Gazette, 21 May 1920. The absent agent had already returned to Matewan's depot. Mingling anonymously with other bystanders, the agent witnessed the Massacre, and escaped by slipping unnoticed onto the outgoing 5:15 train. 
again brushed aside concern for their safety, and made their way across Mate Street to the railroad depot. $^{94}$

While the agents waited for the train, Sid Hatfield approached Albert Felts and requested that he accompany him to a meeting with Mayor Testerman. ${ }^{95}$ Standing just inside the doorway of the Chambers' Hardware store, Hatfield, Testerman, and Felts again began to argue. ${ }^{96}$ Hatfield threatened Felts with arrest, to which Felts responded that he too possessed a warrant, for Hatfield. ${ }^{97}$ Mayor Testerman offered to post bond, because as Hatfield told Felts, as police chief he was needed in Matewan. ${ }^{98}$ Felts demurred and Testerman asked to see the papers, which upon

${ }^{94}$ Jennie Mullens statement, Lewis Collection, ERCA.

${ }^{95}$ Ernest Hatfield interview with John Hennen, Summer 1989 Matewan Oral History Project; "Trial Testimony of C.E. Lively, " 25 February 1921, unknown newspaper, Matewan Omnibus Collection, ERCA. Lively was not in Matewan on the day of the Massacre. He claimed to have learned this in a conversation with Sid Hatfield.

${ }^{96}$ (Location of argument), "Trial Testimony of Joe C. Jack, ” 25 February 1921, unknown newspaper, Matewan Omnibus Collection, ERCA. "Trial Testimony of C.E. Lively," 25 February 1921, unknown newspaper, Matewan Omnibus Collection, ERCA. Again, Lively testified that he heard this after the fact from Massacre participant William Bowman, who claimed to have fired the fatal shot into Albert Felts after coming upon Felts attempting to rise. According to Lively, Bowman had a grudge against Felts from years before after an incident at Van Lear, Kentucky.

97"Trial Testimony of C.E. Lively, ” 25 February 1921, unknown newspaper, Matewan Omnibus Collection, ERCA. Again, alleged Hatfield and Lively conversation.

98"Testimony of Sid Hatfield," West Virginia Coal Fields, 206. 
perusal, he declared "bogus." 99 Whereupon, depending on the witness, either Hatfield or Felts pulled a gun and fired. ${ }^{100}$

Within seconds, a blaze of gunfire erupted. Mayor Testerman staggered away clutching his stomach while Albert Felts fell where he stood, mortally wounded. ${ }^{101}$ Pandemonium ensued, John Brown, who was standing at the depot awaiting a laundry shipment, led state senator and Mrs. White, who were awaiting the train at the station, to safety in a nearby basement. ${ }^{102}$ According to one child witness, a thousand shots rang out in under ten minutes. ${ }^{103}$ As the only other armed

\footnotetext{
${ }^{99}$ Ernest Hatfield interview; “Testimony of Joe C. Jack,” 25 February 1921, unknown newspaper, Matewan Omnibus Collection, ERCA.

${ }^{100}$ Claims that Felts fired first: G.T. Blankenship, Charleston Gazette, 21 May 1920; Hawthorne Burgraff interview. Twelve Matewan Massacre trial witnesses stated that Sid Hatfield shot first, "Closing Argument of Wade Bronson," 19 March 1921, unknown newspaper, Matewan Omnibus Collection, ERCA; John McCoy interview with John Hennen, Summer 1989 Matewan Oral History Project; a third man, Isaac Brewer, an uncle by marriage to Ed Chambers, was also fingered as the first shooter. According to C. E. Lively, the other Massacre defendants sought to blame Brewer to escape punishment. Lively used the "frame-up" allegation to convince Brewer to turn state's evidence. "Trial Testimony of C.E. Lively, " 26 February 1921, unknown newspaper, Matewan Omnibus Collection, ERCA. Brewer's alleged culpability also became fixed in the public memory, at least one Matewan Oral History Project narrator, "Smokey" Mose Adkins asserted that Brewer had shot and killed Albert Felts. "Smokey" Mose Adkins interview with John Hennen, Summer 1989 Matewan Oral History Project.

101 "Trial Testimony of Joe C. Jack," 25 February 1921, unknown newspaper, Matewan Omnibus Collection, ERCA.

${ }^{102}$ Johnny Fullen interview with Rebecca J. Bailey, Summer 1990 Matewan Oral History Project. Mr. Fullen did not specify whether "Senator White" was Hiram S. White or M. Z. White, both of whom had served as state senators. But given that M. Z. White had been in Charleston, just the day before, it was likely that he, and not H. S. White, had nearly been caught in the crossfire.

${ }^{103}$ Dixie Accord interview with John Hennen, Summer 1989 Matewan Oral History Project. One of the children who had just been released from school, Mrs. Accord stated that just as she was mounting the steps to her home, the shooting started and it seemed like the world was coming to an end.
} 
Baldwin-Felts agents, C. B. Cunningham and Lee Felts, who were standing nearby, drew their guns, but neither made it to Albert Felts' side. ${ }^{104}$ The other agents scattered, seeking cover. One agent, as he ran past Mary Brown, who was looking for her husband, asked, "What's the best way to get out of this town?" Pointing to the river she shouted, "Split the Creek!"105 Two agents, the Anderson brothers, who were wounded, managed to climb aboard the waiting train before it quickly pulled out of the station. ${ }^{106}$ Another agent, who later claimed to have hidden in a coal shed, slipped out of town undiscovered. ${ }^{107}$ The other five agents received no mercy. J. W. Ferguson fled wounded to the backporch of Mary Duty's home and begged her to hide him. On the verge of hysteria herself, Mrs. Duty fled back into her house as armed men approached. She heard Ferguson say, "Gentlemen I have not fired a shot in your town." ${ }^{108}$ Despite his pleas,

${ }^{1044}$ "Testimony of Joe C. Jack,"25 February 1921, unknown newspaper, Matewan Omnibus Collection, ERCA. C. E. Lively later testified that Reece Chambers claimed responsibility for Lee Felts' death, explaining that because Lee had shot Chambers' brother, "he had a right" to kill Lee in retaliation. "Trial Testimony of C. E. Lively," 25 February 1921, unknown newspaper, Matewan Omnibus Collection, ERCA.

${ }^{105}$ Johnny Fullen interview. At least two other agents went in the river before catching a train back to Bluefield. William Salter, who along with C.E. Lively murdered Sid Hatfield and Ed Chambers, in August 1921, hid in a "waste container" until after dark. Lee, Bloodletting, 54; The other agent was John McDowell, Charleston Gazette, 21 May 1920.

${ }^{106}$ Charleston Gazette, 21 May 1920.

${ }^{107}$ Ruby Aliff interview with Rebecca J. Bailey, Summer 1989 Matewan Oral History Project.

${ }^{108 "}$ "Statement of Mrs. Billy (Mary) Duty," in 9 September 1920 Report of \#19, Lewis Collection, ERCA. 
Ferguson was shot again, allegedly by Fred Burgraff, who told him, "You ---, you've gone too far. You're going to die."109

As quickly as it had started, the Matewan "Massacre" ended. Several men loaded Mayor Testerman on a train bound for Welch where he died later that night, his only words, "Why did they shoot me? I can't see why they shot me." 110 The bodies of the dead agents lay where they had fallen until Sheriff Blankenship, accompanied by Williamson mayor W. O. Porter, arrived from Williamson at 7:15 p.m. ${ }^{111}$ Mayor Porter supervised loading the corpses onto a Williamson-bound train, which left the men "literally covered with blood."112 For the rest of the night, the armed men of Matewan patrolled the town, tensely watching the trains as they sped by on the way to Williamson. ${ }^{113}$ Unbeknownst to them, one train carried the first contingent of the State Police, who thought it best to arrive in Matewan the following morning. ${ }^{114}$

${ }^{109}$ Alleged statement by Fred Burgraff, “Trial Testimony of C. E. Lively,” 25 February 1921, unknown newspaper, Matewan Omnibus Collection, ERCA.

${ }^{110}$ Notes taken (probably by T. L. Felts) following meeting with owner of the Mingo Republican, Dr. R. M. Musick, 22 May 1920, Lewis Collection, ERCA.

111 "Slight Flare-Up," Charleston Gazette, 21 May 1920.

${ }^{112}$ Ibid; "Trial Testimony of Jack Gallion," Lewis Collection, ERCA. When asked if the bodies were handled respectfully, Gallion replied that the only disrespect he remembered being shown was by several watching children.

113"Slight Flare-Up," Charleston Gazette, 21 May 1920.

${ }^{114}$ J. W. Weir to John J. Cornwell, 20 May 1920. Cornwell Papers, WVRHC. Cornwell, who at the time was on a trip to the eastern panhandle, was notified of the Massacre by a telegram from Weir, his secretary. 
How that night passed in Matewan remains as hotly contested as the issues of who fired first and whether Albert Felts or Sid Hatfield killed Mayor Testerman. ${ }^{15}$ Many residents claimed that the mood on the street was somber because people feared that each approaching train carried a vengeful Tom Felts at the head of an army anxious to blow up the town of Matewan. ${ }^{116}$ Others countered that in "wild fury ... a howling, jeering, shrieking mob" swept through the streets, as men and women rifled through the clothing and satchels of the dead detectives. ${ }^{117}$ According to one account, men shook hands with the corpses, asking, "how they liked Matewan, and when they were coming back to see them." ${ }^{118}$ Another claimed to have seen tobacco juice spat at the bodies. ${ }^{119}$ By the morning of Thursday, May 20, 1920, an irrevocable division had been carved in the hearts and minds of the people of Matewan and Mingo County.

In the space of a few minutes the event that became known as the Matewan Massacre transformed the social, economic, and political relations of Mingo County. Prior to May 19, 1920, class or occupation had not been the determining factor in an individual's access to political power

${ }^{115}$ See note 100 for details.

${ }^{116}$ Dixie Accord interview; Charleston Gazette, 21 May 1920.

${ }^{117}$ Lee, Bloodletting, 55-6. Lee's source was Hiram S. White. Another Massacre witness who shared information with Lee, Dr. Wade Hill, was married to the first cousin of Lee's own wife. After testifying in the Massacre trial, Hill moved away from Matewan. Lee, Bloodletting, 60-61. Margaret Hatfield asserts that the robbing of the detectives' corpses was one of the major reasons why many in Matewan turned against the miners, Hatfield correspondence, letter no. 16.

118"Statement of Mrs. Alex Hatfield,” Reported by \#19, June 1920, Lewis Collection, ERCA.

${ }^{119}$ Lee, Bloodletting, 55. 
or social status. ${ }^{120}$ However, how the local citizens viewed the Massacre reconfigured the course of their public associations. To the striking miners and their allies, the Massacre was a glorious instance of retributive justice, Sid Hatfield and his compatriots simply gave the Baldwin-Felts agents what they had coming. ${ }^{121}$ For other members of the community, the incident did not reflect the "identity" of Matewan and as such was a source of outrage and shame. ${ }^{122}$ As one

\footnotetext{
${ }^{120}$ As mentioned in previous chapters, Elihu Boggs, although a coal miner, enjoyed considerable social status. In 1914, he served as mayor of Matewan. Mingo Republican, 2 January 1914. At the time of the Massacre Boggs was serving as clerk of the Mingo county court, but he resigned with no explanation in the fall of 1920, one month before the expiration of his term. Williamson Daily News, 26 November 1920. Fred Burgraff, also a miner, and the alleged murderer of agent J. W. Ferguson, had served as a deputy sheriff under Greenway Hatfield, and as an election officer in the 1916 primary election. Williamson Daily News, 2 June 1916. In Miners, Millhands, and Mountaineers, Ron Eller sheds light on this issue. According to Eller, in Appalachian society, communities were simply divided between "respectable" and "non-respectable" members. Eller, 10. Ties between politicians and "subcultures"also have been documented outside of Appalachia. See Herbet Gutman, "Joseph P. McConnell and the Workers' Struggle in Paterson, New Jersey," in Herbert Gutman, Power and Culture: Essays on the American Working Class, edited by Ira Berlin (New York: Pantheon Books, 1987), 93-116.

${ }^{121}$ John Collins daughter asserts that although the mood was somber in Matewan, many people probably "gloried in their hearts." Bertha Damron interview. According to historian Catherine McNichol Stock, defense of community, and especially "women and children," has throughout the history of the American nation provided sufficient justification for violence. See Stock, Rural Radicals: Righteous Rage in the American Grain. In Appalachia, Lynwood Montell has documented the ways in which those who have committed criminal acts have been transformed into "folk heroes." Montell, 138. An example of Sid Hatfield's status as the miners' hero appeared during the Massacre trial. Mrs. Stella Scales, who had been called to testify about the statements and actions of prosecution witness Joe C. Jack, was asked if she also knew Sid Hatfield. After responding that she did not, she added that she would like to and also wished to "shake his hand." "Testimony of Mrs. Stella Scales," Lewis Collection, ERCA.

${ }^{122}$ Hatfield correspondence, letter no.16. Margaret Hatfield asserts that the "good people" of Matewan, regardless of nativity, occupation, or status were repulsed by the cowardly annihilation of the agents. Several Matewan Oral History Project narrators acknowledged the existence of a "rumor" regarding Hatfield's murder of Testerman. A few narrators admitted that some had always believed that Hatfield was guilty. Common elements of the "Sid Did It" story include: Sid and Jessie had been lovers, Testerman had beaten Jessie for her infidelity, Sid planned the deadly exchange, the agents were unarmed and never had a chance, and that Sid shot first. See
} 
contemporary reporter observed, "the difficulty has now become a bigger proposition than any ordinary strike . . . it is the ranging of a community into opposing factions."123

Social affiliations directly influenced, and, in turn, were affected by the Massacre and strike. The Red Cross and the local chapter of the YMCA refused humanitarian aid to the inhabitants of Mingo's tent colonies. ${ }^{124}$ The Red Cross denied assistance because "no Act of God" was responsible for the miners' plight, while the YMCA denounced the colonies as centers of immorality. ${ }^{125}$ After another "battle" occurred in Mingo shortly before the first anniversary of the Massacre, the local chapter president of the YMCA helped organize a vigilante organization that helped restore "law and order" to Mingo County. ${ }^{126}$

In a similar vein, the Massacre and strike divided people of faith in Mingo County. Before May 19, 1920, religious affiliation had not automatically characterized an individual's class status. For example, area natives, including miners' families, and operators together had founded and

the following Matewan Oral History Project interviews with: Harry Berman, Everett Faddis, Josephine Hope, Paul Lively, and John McCoy.

${ }^{123}$ Roy Hinds, “The Last Stand of the Open Shop,” Coal Age 18 (8 November 1920): 10371040, 1038. Hinds visited Mingo County months after the Massacre and thus was not referring specifically to the Massacre, however he noted that the local cumulative effect of the Massacre and subsequent strike had loosed a variety of brewing local conflicts that further fueled the conflict.

${ }^{124}$ Coleman, 100. Although the Red Cross and other relief agencies denied assistance to the striking miners in Mingo County, during the winter of 1921-1922, these same agencies did extend aid to miners' families in Fayette and Raleigh Counties. Bluefield Daily Telegraph, 27 January 1922.

${ }^{125}$ Ibid.

126"Mine Dynamited On Matewan Day” New York Times, 20 May 1921. 
attended the Matewan Methodist Church. ${ }^{127}$ However, when Church of Christ minister Mose Alley "went bond" for Massacre defendant Reece Chambers, at least one member of his congregation denounced him. ${ }^{128}$ Mrs. Mary Duty, on whose porch agent J. W. Ferguson had been killed, made her condemnation of Alley succinctly by stating, "If Preacher Alley will swallow and shield this I am through with him. ${ }^{129}$

The social-religious cleavage over the Massacre rapidly took on class overtones. After the Massacre, one woman remembered, "the churches gave no haven to the poor miners." 130 This comment reflects the social differentiation based on religious affiliation brought into sharp focus by the labor conflict in Mingo. "Mainstream" Protestants, whose churches were led by educated clergy remained aloof from the situation, with the prominent exception of Williamson's Presbyterian minister, J. W. Carpenter, who condemned the strike from his pulpit and also helped organize the Mingo Militia. ${ }^{131}$ By contrast, the miners drew strength and inspiration from their

\footnotetext{
${ }^{127}$ Hatfield correspondence, letters no. 16 and 24; T.E. Bowman, "From West Riding." According to Hatfield the miner Elihu Boggs' family helped found the Matewan Methodist Church, while Bowman noted that the Booth(e) family the original owners of the Marvin mine also contributed to its establishment. Anthropologist Sara Lubitsch Tudiver explains why native Appalachian elites and coal elites were drawn together in the Methodist Church. According to Tudiver, the attraction stemmed from "the Church's emphasis on education, the discipline of work, and on rewards and punishments secured through acts in this life." Tudiver, "Political Economy and Culture in Central Appalachia," 122.

128"Statement of Mrs. Billy Duty," report by \#19, 9 September 1920, Lewis Collection, ERCA. ${ }^{129}$ Ibid.

${ }^{130}$ Jeannette Simpkins, interview with Rebecca J. Bailey, Summer 1990 Matewan Oral History Project.

131 "Testimony of J. R. Brockus," West Virginia Coalfields, 344.
} 
evangelical Christian beliefs. ${ }^{132}$ The inhabitants of the striking miners' tent colonies, in addition to singing hymns, used religious imagery to express their commitment to the struggle in letters to the United Mine Workers Journal. ${ }^{133}$ The centrality of the miners' faith was underscored by the attention religious affiliation received during the Matewan Massacre trial in 1921. When Hugh Combs, the man entrusted by Mayor Testerman to select men to protect Matewan on May 19, testified during the Massacre trial, he was forced to explain his vocation as a Methodist exhorter because prosecuting and defense lawyers argued about Combs being a "Holy Roller." In the wake of the 1920-1922 strike in Mingo, membership in mainstream Protestant churches or Pentecostal and Holiness churches became an automatic indicator of an individual's place in the local social order. $^{134}$

Because it elicited such a divisive reaction from the inhabitants of Mingo County, the Matewan Massacre transformed the atmosphere of everyday public intercourse. For the first year of the conflict, Sheriff Blankenship's and Sid Hatfield's support for the strike made Matewan the

${ }^{132}$ In The Promise of the New South, Edward Ayers explains the connection between the theology of the Southern evangelical sects and the labor ideology of the period. According to Ayers, these sects "rejected the dominant vocabulary of human worth, replacing it with a language of glorious struggle." Edward L. Ayers, The Promise of the New South: Life After Reconstruction (New York: Oxford University Press, 1992), 408. Jacquelyn Dowd Hall and her fellow researchers documented a similar religious schism in their study of cotton mill life in the southern Piedmont. Jacquelyn Dowd Hall, et al, Like a Family: The Making of a Southern Cotton Mill World (Chapel Hill and London: The University of North Carolina Press, 1987), 126, 178-179.

${ }^{133}$ Virginia Grimmett, interview with Rebecca J. Bailey, Summer 1989 Matewan Oral History Project; "From Nolan, W.Va,"United Mine Workers Journal 32 (15 April 1921):15. Identified only as the wife of Borderland \#2 local's secretary, the correspondent wrote to the Journal, "I am a union woman.... We are more determined than ever to win. We are like the Holiness song, 'we are determined to hold out to the end.'”

${ }^{134}$ Hatfield correspondence, letter no. 16 
miners' town. ${ }^{135}$ Non-cooperative merchants were boycotted. ${ }^{136}$ Without fear of official

retribution, many miners harassed and intimidated those who failed to support them. ${ }^{137}$ Two

weeks after murdering an abusive former deputy sheriff and railroad guard, miners erected a mock

effigy of his gravesite on a sandbar in the river at Matewan. ${ }^{138}$ The slain man's widow also

claimed that one of the men acquitted of the murder confronted her on the street, raised her veil

${ }^{135}$ The election of A. C. Pinson as Mingo County Sheriff in November 1920 and S. T. Lambert as mayor of Matewan in January 1921, signalled the turning of official support away from the miners in Mingo County. Williamson Daily News, 4 November 1920; Cincinnati Enquirer, 28 May 1921, Matewan Omnibus Collection, ERCA. As one Matewan resident noted, the retaliatory murder of Sid Hatfield and Ed Chambers by Baldwin-Felts agents on August 1, 1921 "effectively halted the anarchy" that had reigned in Mingo since May of 1920. Hatfield correspondence, letter no.29. For example, in late July Keeney had announced the union would invade Mingo with an army of martial law protesters. After the deaths of Hatfield and Chambers, those plans were abruptly cancelled. Charleston Gazette, 2 August 1921, quoted in Corbin, Life, Work, and Rebellion, 210.

136"Report of \# 9," 29 July 1920, Lewis Collection, ERCA.

${ }^{137}$ The most damning evidence of intimidation by the miners and their allies can be found in the manuscript collections of John J. Cornwell, (who was governor until March 1921) and Thomas L. Felts. It should be noted that evidence exists that suggests the miners' behavior in Matewan in 1920-1921 might have been a case of "turn about is fairplay" because vigilante acts committed by Matewan's "better citizens" were not unknown. For example, according to Thomas Felts' own files, the citizens of Matewan had burned a town brothel and chased off its' inhabitants. "Record of Mrs. Sid Hatfield," Lewis Collection, ERCA.

${ }^{138}$ The abusive mine guard was Berman Hatfield. The newspaper account of the arrest of Hatfield's suspected murderers mentioned that he had antagonized union miners and that his home had been burned down shortly before his death in July, 1920. Williamson Daily News, 13 December 1920; "Statement of Mrs. Pearl Hatfield," 1 November 1921, "Berman Hatfield Case," Lewis Collection, ERCA. The use of effigies and mock funerals can be traced to England, where E.P. Thompson noted they were used to signify "a terrible community judgement, in which the victim was made an outcast." E. P. Thompson, Customs in Common (New York: New Press: Distributed by W.W. Norton, 1991), 480. 
and laughed in her face. ${ }^{139}$ After the murder of Ance Hatfield, the proprietor of the Urias Hotel and star witness against Sid Hatfield and the other Massacre defendants, an "exodus" from Matewan began that lasted for more than a year. ${ }^{140}$ Those who remained in the town either supported the miners for their own political or material reasons, or sought to remain neutral. ${ }^{141}$ The merchants who had aided the miners during the strike were rewarded with the miners'

${ }^{139}$ "Statement of Mrs. Pearl Hatfield." Ironically, the daughter of John Collins, the man accused of this cruel act, asserted that her father's motivation for participating in the murder was the victim's own abusive treatment of Collins' wife. Bertha Damron, interiew with Rebecca J. Bailey, Summer 1989 Matewan Oral History Project. Unfortunately, the allegations made by Mrs. Pearl Hatfield against John Collins in 1921 were unknown at the time of the interview, and thus were not discussed.

${ }^{140}$ Williamson Daily News, 16 August 1920. Among those who left Matewan were: Charlie McCoy, the town barber, George Gunnoe, the principal of Matewan High School, Dr. Wade Hill, and John and Mary Brown, the proprietors of Matewan's laundry. Sources: (McCoy) Hatfield correspondence, letter no. 5; (Gunnoe) "Affidavit of George H. Gunnoe," Lewis Collection, ERCA; (Hill) Lee, Bloodletting, 61; and Johnny Fullen interview. Like Ance Hatfield, all of these individual had been "warned"; after his death on August 14, 1920, the threats were taken seriously. Gunnoe's affidavit includes a recreation of the letter his wife received. The term "exodus" is a direct quote from a 1921 New York Times article about the situtation in Matewan -"an exodus of practically everybody living in that stormy community who is not in sympathy with the strike and the era of violence it ushered in." "Good People Flee Matewan," New York Times, 21 May 1921.

${ }^{141}$ The Chambers, who supported the miners for political as well as economic reasons, used their stores in Matewan to acquire rifles and ammunition for the miners. Dixie Accord interview and Rufus Starr interview. At least one merchant in Williamson also profited from supplying the miners with weapons. "Testimony of A. E. Hester," West Virginia Coal Fields, 826. An example of one who sought to remain neutral was merchant E. K. Beckner, who served out the rest of Testerman's mayoral term. In a letter to Governor Cornwell, Beckner revealed that Matewan's merchants "are not directly interested in either side of the controversy. . . we are all, of course indirectly interested in both sides." E. K. Beckner to John J. Cornwell, 13 July 1920, Cornwell Papers, WVRHC. Beckner, who had been a purchasing agent for Red Jacket, became a favored merchant of the miners. Sources: (Beckner's employment with Red Jacket) The Coal Catalog: Combined with a Coal Field Directory for the Year 1915 (Pittsburg, PA: Keystone Publishing Company, 1915); (relationship with miners) Jim Backus, interview with John Hennen, Summer 1989 Matewan Oral History Project. 
patronage for as long as they remained in business. ${ }^{142}$ Although some businessmen, like John Brown, eventually returned to Matewan, others like brothers Joseph and Samuel Schaeffer left forever. $^{143}$

The most profound and lasting impact of the Massacre lay in its effect on local politics. As illustrated in previous chapters of this study, Mingo County had never been governed by a single party funded by absentee industrial interests. There is also much to suggest that District 17 chose Mingo County to launch the 1920 southern West Virginia organization drive because the union hoped to turn the factional divisiveness of the county's political elite to its own advantage. ${ }^{144}$ Moreover, testimony from the Massacre trial suggests that old political animosities might have

${ }^{142}$ The principal recipients of the miners' gratitude were the Chambers' and Beckner \& Hynes. Dixie Accord interview; Jim Backus interview. Mingo County lawyers also were concerned about public perception of their actions on behalf, or against the miners. One attorney, S. D. Stokes, wrote a business associate that he had raised his fees because of animus generated by his work for several local coal companies. S. D. Stokes to James P. Woods, 26 January 1921, Stokes Papers, WVRHC. See also the correspondence between L. A. Sampselle and F. H. Evans and District 17 lead attorney Harold W. Houston in "Matewan Massacre" Papers, WVRHC.

${ }^{143}$ Johnny Fullen interview. Although John Brown had been prominent among Magnolia District's African-American Republicans, he returned to Matewan nearly three years after the Massacre upon the urging of E. B. Chambers, president of the Matewan National Bank, Chambers' family patriarch, and a leading "County" Democrat. Of Russian-Jewish origin, Joseph and Samuel Schaeffer had been important fixtures in Matewan's merchant community since their arrival in 1905. Abraham J. Shinedling, West Virginia Jewry: Origins and History 3 vols. (Philadelphia: Maurice Jacobs, Inc, 1963), volume 2: 1038. Although no direct evidence exists to suggest that the Schaeffer's ethnicity or reaction to the events played a role in their decision to leave Matewan in 1920, other members of Mingo's Jewish community "appeared" to take the operators' side. Eli Sohn was a character witness against Sallie Chambers during the C.E. Lively trial and Massacre witness Harry Berman was among the few who named Sid Hatfield as the mayor's murderer. "Statement of Eli Sohn" State of West Virginia v. C.E. Lively, George Pence, and William Salter, Lewis Collection, ERCA.

${ }^{144}$ Union organizers sent into Mingo also sought to secure the miners' support for the candidacy of Samuel Montgomery in the 1920 Republican gubernatorial primary. 
played a role in the escalation to violence on May $19,1920 .{ }^{145}$ In the Massacre's aftermath, at least initially, the actions of certain Mingo County leaders indicates that the union strategy had succeeded. E. B. Chambers and A. C. Pinson, the leaders of the two Democratic factions in the county, both contributed to the bonds of the Matewan men indicted for the Massacre ${ }^{146}$ Judge Damron, a maverick Republican who won over the miners by overseeing the indictments of local coal officials, guards, and Baldwin Felts detectives, received the miners' endorsement for his 1920 re-election bid. ${ }^{147}$ Even the former chairman of the County Republican organization Greenway Hatfield signed a union contract for his mine. ${ }^{148}$

\footnotetext{
${ }^{145}$ Various sources allude to the political undercurrents that swirled in Matewan at the time of the Massacre. For over a year, ill-will had existed between Urias Hotel proprietor Ance Hatfield and Mayor Testerman and Sid Hatfield. See Williamson Daily News, 20 February 1919 and "Sid Hatfield by Isaac Brewer" Lewis Collection, ERCA. After Ance Hatfield's murder in August 1920, the Urias Hotel closed. "Trial Testimony of Elizabeth Burgraff," Lewis Collection, ERCA. Also, Testerman's predecessor as mayor, A. B. Hatfield, crops up in accounts of the Massacre. Assaulted by Sid Hatfield in December 1919, A. B. Hatfield was alleged to have authorized the arrest warrant for Sid on May 19. The possibility that A. B. Hatfield had conspired to use the Baldwin Felts detectives to rid Matewan of Testerman and Sid Hatfield is given credence by the trial testimony of Hugh Combs who asserted that during the final confrontation between Albert Felts and Sid Hatfield, he saw A. B. Hatfield and William Cummins (the superintendent of Red Jacket) watching the exchange and smiling with "the finest looking smile on their faces of any men I had ever looked at." "Trial Testimony of Hugh Combs," Lewis Collection, ERCA. For more on the Sid Hatfield-A. B. Hatfield incident see Chapter 9.

${ }^{146}$ Broadside "Remember Your Friends --- Also Your Enemies," Lewis Collection, ERCA. This pro-union handbill, listed who had contributed to the bonds posted by the men on both sides who had been indicted as a result of events surrounding the Massacre and strike-related activities.

147"Report of \#9," 6 August 1920, Lewis Collection, ERCA. Undercover agent \#19 reported that he had heard an International (UMWA) officer claim that he had spoken with Damron, who promised to do all he could for the Massacre defendants. "Report of \#19," 5 August 1920, Lewis Collection, ERCA.

${ }^{148}$ Coal Trade Journal 52 (5 January 1921): 7. The Bishop-Hatfield mine may have been a wagon mine and, as such, did not appear in the annual reports of the West Virginia Department of Mines.
} 
However, by the early fall of 1920 most of Mingo's leaders had abandoned their pro-union stance. James Damron resigned from the bench and withdrew from the judge's race. ${ }^{149}$ By the time the Massacre defendants went to trial in January 1921, Damron had joined the prosecutorial team. ${ }^{150}$ A. C. Pinson, after defeating Greenway Hatfield in the 1920 sheriff's race, cooperated wholeheartedly with the efforts of Governor Cornwell and the operators to secure the miners' defeat. ${ }^{151}$ One miner later alleged that Pinson had accepted the bribes Blankenship refused, and in return for fifteen thousand dollars, allowed the operators to mount machine guns in Matewan. ${ }^{152}$ Even E. B. Chambers evaded public identification with the miners' cause when members of the senate committee traveled to West Virginia on a fact-finding mission in $1921 .^{153}$

After the UMWA abandoned the Williamson-Thacker strike in October 1922, it appeared that the pre-strike political equilibrium of machine rule had been restored in Mingo County. Fellow Williamson "City Ring” man, Alex Bishop, succeeded Pinson as Sheriff in 1924, and was in turn followed by Greenway Hatfield. ${ }^{154}$ However, with the long-delayed liberation of the miners

${ }^{149}$ Williamson Daily News, 12 October 1920.

${ }^{150}$ Bluefield Daily Telegraph, 19 January 1921. Damron's betrayal was not forgotten. Years later he was shot by an unknown assailant. Lee, Bloodletting, 51.

${ }^{151}$ Unlike Blankenship, Pinson offered no resistance to the imposition of martial law. See correspondence between Governor Cornwell and various Mingo County elites regarding Blankenship from late November 1920. Cornwell Papers, WVRHC

${ }^{152}$ Burgett, in On Dark and Bloody Ground, 107.

${ }^{153}$ West Virginia Coalfields, 486. According to transcribed information, when Senator Kenyon and his entourage traveled to the Matewan National Bank to interview E. B. Chambers, he was "absent from the city."

${ }^{154}$ West Virginia Bluebooks, 1925-1935. 
by Franklin Roosevelt's New Deal legislation, the pro-union stand taken by G. T. Blankenship and his Chambers' in-laws was finally rewarded. Although Blankenship never reentered Mingo County politics, Thurman "Broggs" Chambers and several other Chambers' family members or allies served as Mingo County Sheriff. ${ }^{155}$ For the next three decades, the politicians who ruled Mingo held power as a result of tactics pioneered by the Chambers' family, or themselves had connections to families that had also sided with the miners during the $1920-1922$ strike. ${ }^{156}$ Unfortunately for the miners, the politicians they rewarded with control of Mingo County proved as exploitive as the old Williamson and Hatfield machines. ${ }^{157}$ Remarking on the corruption

${ }^{155}$ (Blankenship never re-entered politics) Tom Blankenship interview with C. Paul McAlister, Summer 1990 Matewan Oral History Project; (Thurman "Broggs" Chambers supplied the miners with guns) Rufus Starr interview. E. B. Chambers' son, Dan, who later became president of the Matewan National Bank, and an important political and business leader in southern West Virginia, was accused of forging the A. B. Hatfield warrant Sid Hatfield claimed to have removed from Albert Felts' body. S. B. Avis avowal, "Testimony of C. E. Lively," West Virginia Coal Fields, 355.

${ }^{156}$ One Mingo County resident credits certain members of the Chambers' family with the creation of the "kick back" system used to advantage by "Blind Billy" Adair and his nephew Noah Floyd, two latter day Mingo County "bosses," whose machinations were documented in Huey Perry's They'll Cut Off Your Project. Hatfield correspondence, letter no.16. Among the four Mingo political bosses indicted in 1970 for subverting the 1968 general election, two, Harry Artis and Arnold Starr were from families prominent in the 1920-1922 strike. Perry, They'll Cut Off Your Project, 252. One flaw in Perry's account of the fight over Mingo County's War on Poverty program is the absence of Perry's own emergence as a "boss." See: "James Washington interview," in On Dark and Bloody Ground, 119-121, 119. The political loyalty of Mingo's miners can be interpreted as an example of the American Federation of Labor's policy of "reward your friends, and punish your enemies." Quote source: Laslett, Colliers, 231.

${ }^{157}$ By the late 1960s, many former miners in Mingo County felt abandoned and betrayed by their former political allies and the UMWA. After mines in the county closed in the 1950s, the union withdrew all benefits, including healthcare coverage and pensions. See: Perry, They'll Cut Off Your Project, 155-156, and 209-210. One such miner, A.D. Lavinder, had worked in the mines for 63 years and fought for the union in the Paint Creek strike of 1912-1913, and the Williamson-Thacker strike, 1920-1922. A.D. Lavinder interview, WVRHC. 
uncovered during a Justice Department investigation of Mingo County politics in the late 1960s, a United States' Attorney observed, “Freedom has been lost in Mingo County. There is a government of the organization, by the organization, and for the organization." ${ }^{158}$ How little times had changed along the banks of the Tug Fork river. ${ }^{159}$

The abandonment of the Williamson-Thacker strike nearly two and a half years after the Matewan Massacre underscores the fatal tragedy of May 19, 1920. Mingo's miners, who had been earning nearly seven dollars for an eight hour shift in 1920, were, by the mid-1920s laboring for two dollars for a twelve hour or longer day -- if they worked. ${ }^{160}$ In 1924 , District 17 was stripped of its autonomy and union membership among the state's miners fell to a negligible number. ${ }^{161}$ Despite John L. Lewis' vigorous and forceful leadership, or maybe because of it, the UMWA nearly collapsed in the decade between the Williamson-Thacker strike and the dawn of the New Deal. ${ }^{162}$ By 1925 , only six of the mining companies operating in Mingo County in 1910 were still

\footnotetext{
${ }^{158}$ Perry, They'll Cut Off Your Project, 255.
}

${ }^{159}$ Matewan native Venchie Morrell offers valuable insight into the town's attitude towards politicians. Referring to a post-Massacre mayor, Ira Cooper, Mr. Morell noted that despite the fact that everyone knew that Cooper was "crooked," people still liked and supported him. Venchie Morrell (1990) interview.

${ }^{160} \mathrm{Jim}$ Backus interview.

${ }^{161}$ Mooney, Struggle in the Coalfields, 128.

${ }^{162}$ Ibid., 127. See also Chapter 10 "Catastrophe in Coal" of Bernstein's The Lean Years. Irving Bernstein, The Lean Years: A History of the American Worker, 1920-1933 (New York: Da Capo Press, 1983 [1960]), 358-390. Contemporary reporters and more recently, historians have rightly criticized Lewis' self-aggrandizing strategies and goals during the union's decline in the 1920s. Examples include: Edmund Wilson, "Frank Keeney's Coal Diggers," New Republic 67 (8 July 1931/15 July 19 1931): 195-199, 229-231, and Hennen, Americanization of West Virginia, 105. 
running, and they were all subsidiaries of industry giants like U.S. Steel. ${ }^{163}$ In spite of the success of the anti-union campaign of the early 1920s, the national coal industry, as one historian has noted, "went from riches to rags" even before the Great Depression hit in 1929. ${ }^{164}$ How the union, the operators, and the government reacted to the Matewan Massacre and Williamson-Thacker strike provides insight into how this state of affairs transpired.

III. Repercussions: The Massacre's Influence on Subsequent State and National Developments, 1920-1933:

The Matewan Massacre was more than just a deadly encounter between outraged miners and the agents of their oppression. Previous scholars, by focusing only on the Massacre's relevance to the long struggle for labor rights in West Virginia, have misunderstood not only its impact on life in Mingo County, but also what it illuminates about post-World War I America. An examination of the reactions of the miners' union, the coal industry, and the state and national governments to the chain of events set in motion by the Massacre, fosters a new understanding of the relationship between these groups.

In the aftermath of the First World War, the United States' largest labor union squared off against the country's most powerful corporation. ${ }^{165}$ Beginning in 1919, the United Mine Workers of America and the United States Steel Corporation fought repeatedly in a monumental struggle

\footnotetext{
${ }^{163}$ Conley, History of the West Virginia Coal Industry, 262.

${ }^{164}$ Johnson, Politics of Soft Coal, 95.

${ }^{165}$ (UMWA) Bernstein, 127; (U.S. Steel) Chernow, 82. According to Bernstein, the UMWA, with 500,000 members, was America's largest and most powerful union. U.S. Steel, the world's first billion dollar corporation, dominated the coal and steel industries of this country for most of this century.
} 
over the direction of the nation's industrial development. In the decades that followed, the struggle between these two giants transformed American labor relations, the role of government in the economy, and the meaning of individual rights in a modern society.

One of the first battlegrounds was West Virginia, where the armies that took the field were motivated by philosophies forged in an era that had already passed. The majority of District 17's officers were West Virginians who believed strongly in the customary rights that came from an elemental connection to their native soil. ${ }^{166}$ Their desire to promote the collectivization of their fellow miners reflected a devotion to protecting the inherent dignity of men who toiled in the bowels of the earth. ${ }^{167}$ Their opponents in the Williamson-Thacker strike of 1920-1922 believed just as strongly in the absolute right of property. ${ }^{168}$ Although these equally intractable groups fought for two and half years over the unionization of southern West Virginia, neither side gained from the struggle, the benefits accrued to their external allies. To understand how both John L. Lewis and the corporate giants of southern West Virginia's coal industry profited from the bloody

${ }^{166}$ Corbin, "Frank Keeney Is Our Leader," 147; Mooney, Struggle in the Coal Fields, 16.

${ }^{167}$ Mooney, Struggle in the Coal Fields, 13.

${ }^{168}$ According to the pro-union economist Jett Lauck, operator attorney Z. T. Vinson argued for the operators rights in terminology reminiscent of southern slaveholders before the Civil War. During one exchange with Vinson, Lauck asserted that the operators' claims were upheld by "legal technicalities" which were "constitutionally right, but morally wrong." Testimony of W. Jett Lauck," West Virginia Coal Fields: 1045. Vinson, who had helped found the West Virginia Coal Operators' Association, believed that the UMWA was an organization of robbers and outlaws bent on "murder and riot and revolution." (Vinson and the operators' association) McIntosh Memoir, WVRHC. (Vinson on UMWA) "Opening Statement of Z. T. Vinson," West Virginia Coal Fields, 8-15, 8. Despite his prominence in the West Virginia coal elite, several West Virginia politicians were concerned about his role in the 1920-1922 labor strife. Former West Virginia governor A. B. White to C. D. Elliott, 21 May 1921, A. B. White Papers, WVRHC. 
and protracted strike, one must first understand how the local combatants wound up fighting a war of attrition that allowed their allies to move in, take over, and transform the conflict. ${ }^{169}$

When the organizers of District 17 arrived in Mingo County in the Spring of 1920, they found a uniquely receptive audience. Unlike their compatriots in Logan and McDowell, almost half of Mingo's miners were native, white, and the descendants of the Tug Valleys original settlers. ${ }^{170}$ When organizers preached about the need to unionize in order to defend against the encroachment of "capitalists from New York and London," Mingo's miners understood. ${ }^{171}$ To leaders of the national and district leadership of the UMWA, Mingo County seemed an ideal beachhead for their renewed effort in southern West Virginia. In the past, Mingo's miners had responded repeatedly to the union's call. ${ }^{172}$ Even the sheriff of the county had defied the coal operators and refused to intervene against the union. ${ }^{173}$ The venality of local politics ensured that at least one faction would ally with the union in the hopes of gaining primacy over the county. ${ }^{174}$

Should the situation turn dangerous, the proximity of the Kentucky border offered an escape route

169،"War of attrition" was borrowed from the memoir of journalist Jack Spivak, a participantobserver of the Williamson-Thacker strike. Spivak, A Man in His Time, 102.

${ }^{170} 45$ percent of the men who worked in Mingo's mines in 1920 came from families that had lived in the greater Big Sandy Valley since before 1850. See Appendix 2.

${ }^{171}$ Invocation of "us versus the outsiders" was a favorite theme of District 17 president Frank Keeney. Corbin, "Frank Keeney Is Our Leader,” 147.

${ }^{172}$ See Chapter 4.

${ }^{173}$ In 1901, Greenway Hatfield had refused to make his deputies mine guards for the operators. United Mine Workers Journal 11 (4 July 1901): 2. See Chapter 4.

${ }^{174}$ Mingo Republican, 3 June 1920. 
for beleagured organizers. ${ }^{175}$ If, or when, violence broke out, the union could disclaim responsibility because after all, Mingo was Hatfield-McCoy country, and the county's reputation spoke for itself. ${ }^{176}$

Despite all of these advantages, District 17 squandered its early organizational success in Mingo by committing a series of strategic blunders. Internal divisions among District 17 leadership further undermined the Williamson-Thacker drive. Because their eyes were focused on Logan and McDowell Counties, District 17 leaders failed to understand the goals of Mingo's miners and the work conditions that prevailed in the Williamson-Thacker field. ${ }^{177}$ The operators seized each of these mistakes, and as the strike wore on used them to undermine the miners' resolve and the union's public integrity.

The primary demand of Mingo's miners had been for the 27 percent wage increase which had been granted to union miners at the end of March 1920. ${ }^{178}$ District 17 Secretary Fred Mooney

${ }^{175 "}$ "Seven Prisoner After Mingo Battle," New York Times, 27 May 1921. The ability of "troublemakers" to cross the river into Kentucky and out of West Virginia's jurisdiction led to discussion of moving the tent colonists from the riverbanks to "concentration camps" in the county's interior where they could be submitted to 24 hour "surveillance." By choosing Mingo as their point of entry into southern West Virginia the UMWA made a grave error. Because several companies including Borderland straddled the interstate border, injunction proceedings were allowed to pass immediately into federal court, where the cases would be heard only by a judge and not a local jury. Once the other companies in southern West Virginia joined the injunction, the strike was doomed. See Lunt, 147, 152-153.

176"Testimony of C. F. (Frank) Keeney,” West Virginia Coal Fields, 184.

${ }^{177}$ Contemporary press reports highlighted the idea that Mingo was just a launch point for the assault on the surrounding fields. New York Globe, 27 August 1920. One journalist, Arthur Gleason noted that "the stronghold of the operators' power is not Mingo, but Logan County." Arthur Gleason, "Private Ownership of Public Officials," Nation 110 (29 May 1920): 724.

178"Testimony of W. E. Hutchinson," West Virginia Coal Fields, 74; Williamson Daily News 30 March 1920. 
knew that the miners in southern West Virginia's non-union fields did not qualify for the increase, and had expressed displeasure at Bill Blizzard's demagogic manipulation of miner discontent over the issue. ${ }^{179}$ Still, the union organizers did nothing to dissuade the miners' expectation of just such a reward. In contrast, the first public announcement made by the Williamson operators' association after announcing a lockout on June 1, was an advertisement in the Williamson Daily News about the 27 percent increase. “That 27 Percent Increase” informed Mingo's miners that because the Bituminous Coal Commission awarded the increase only to union miners bound by the terms of the Washington Agreement, the UMWA could not compel the federal government to grant it to miners organized after the war. ${ }^{180}$ As the lockout turned strike dragged on and Mingo's miners faced increasing numbers of replacement workers who were enjoying the benefits of inflated wages, the union's attractiveness began to fade. ${ }^{181}$

The union coupled its disingenuous manipulation of the wage issue with an appalling ignorance of work conditions in Mingo County. Despite having declared Mingo completely organized and in spite of responding to the operators' lockout with a strike call, the union failed to shut down coal production in the county for more than a few days. ${ }^{182}$ One of the largest

${ }^{179}$ Mooney, Struggle in the Coal Fields, 67.

180"That Twenty-Seven Per Cent Increase,” Williamson Daily News, 2 June 1920.

${ }^{181}$ Williamson Daily News, 19 October 1920. The News reported that for the first time since "the war" there were more men than jobs in Mingo.

${ }^{182}$ (Lockout) Coal Trade Journal 51 (5 June 1920):22; (strike) “Testimony of C. F. Keeney," West Virginia Coal Fields, 104. 
companies, Borderland, never ceased production. ${ }^{183}$ Within weeks, the only organized mines in Mingo were the wagon mines and four modest-sized tipple mines. ${ }^{184}$ As late as July 1921, District 17 President Frank Keeney obstinately refused to acknowledge the full import of this turn of events. In a letter to Governor Morgan, which he later read before the Senate investigating committee, Keeney outlined the union's six demands for resolution of the Williamson-Thacker strike. ${ }^{185}$ The second and third demands called for the granting of semi-monthly paydays and an eight-hour work day. ${ }^{186}$ When then governor Ephraim F. Morgan inquired of Mingo's acting prosecuting attorney, S. D. Stokes, about Keeney's demands, Stokes pointed out to the governor that the Williamson operators association had voluntarily insitituted semi-monthly pay in 1913, and the eight-hour day in $1919 .{ }^{187}$ The union had ignored the fact that because wagon mines did not qualify for membership in the operators association, only those mines had to grant those

\footnotetext{
${ }^{183}$ District 17 sent strike notices to 70 mines, miners at 40 responded, but by August, 1920, 18 of those companies had resumed production, with only 22 still idle. Williamson Daily News, 14 August 1920.

${ }^{184}$ Williamson Daily News, 14 August 1920; “Testimony of C. F. (Frank) Keeney,” West Virginia Coal Fields, 124.

${ }^{185}$ Letter from Keeney to Governor Morgan, 11 July 1921, read into the record by Keeney, "Testimony of C. F. (Frank) Keeney," West Virginia Coal Fields, 107.

${ }^{186}$ Ibid.

${ }^{187}$ Ephraim F. Morgan to S. D. Stokes, 11 August 1921 and Stokes to Morgan, 12 August 1921, Stokes Papers, WVRHC.
} 
concessions without union compulsion. ${ }^{188}$ Unfortunately for Keeney, his ignorance of the situation was gleefully pointed out before the Senate committee by operator attorney S. B. Avis. ${ }^{189}$

As the operators whittled away at the union effort in Mingo, District 17's internal divisions emerged to further weaken the union's position. Never a united group, the officers of District 17 disliked and distrusted each other even before the beginning of the Mingo organization drive. ${ }^{190}$ The two issues which further complicated relations between the district officers and the organizers sent to Mingo were politics and violence. As in their misreading of the labor situation, District 17's lack of understanding regarding local politics handed the operators another advantage. The union's contradictory stance on the violence committed by Mingo's miners also served the operators' agenda.

Although the union organizers who first entered Mingo stumped for Samuel Montgomery, the most successful local alliance the union had forged was with the Democratic leadership of the county. ${ }^{191}$ Angered by the union's early alliance with the Democrats, and then the splinter movement lead by union leaders in support of Montgomery and the Non-Partisan League, Mingo's Republicans schemed to weaken the union's political pull in the county. ${ }^{192}$ The union's ties to

${ }^{188}$ Exchange between S. B. Avis and Keeney, "Testimony of C. F. (Frank) Keeney," West Virginia Coal Fields, 124.

${ }^{189}$ Ibid.

${ }^{190}$ Mooney, Struggle in the Coal Fields, 53, 69-70.

${ }^{191}$ See notes earlier in this chapter that reveal the interaction between the union, Sheriff Blankenship, Mayor Testerman, and Blankenship's successor A. C. Pinson.

${ }^{192}$ (Republican reaction) Mingo Republican, 3 June 1920; District 17 vice-president William Petry and Mother Jones were both NPL supporters, in fact Petry was the head of the West Virginia NPL. (Petry officer) Mooney, 56; (Petry in NPL) Harris and Krebs, 176. (Jones) 
Mingo's Democrats and then the Non-Partisan League, also undermined its appeal to the AfricanAmerican population, within the county and in the surrounding fields. ${ }^{193}$ The operators lured away Judge Damron, whose kinsman, Massacre participant Isaac Brewer later became a star witness against his fellow defendants. ${ }^{194}$ Perhaps the most damaging miscalculation made by District 17 in the Williamson-Thacker strike was its mishandling of the violence that frequently erupted in Mingo County, between 1920 and 1922. ${ }^{195}$

Winding Gulf Coal Operators' Association “Bulletin U,” 30 August 1920, Collins Papers, WVRHC. The NPL advocated an increased rights for industrial workers, an end of monopoly, nationalization of the transportation industry, and a steeply graduated income tax." Stock, 75.

${ }^{193}$ Before the Massacre, Mingo's African Americans saw the union as potential liberators from politics as usual in the county. Mingo Republican, 15 May 1920. When Montgomery failed to win the Republican nomination for governor and ran as an independent under the endorsement of West Virginia's Non-Partisan League, pro-union African Americans remained loyal to him. (endorsement) Williamson Daily News, 4 June 1920; (loyalty) "Negro Activity,” October 23-30, 1920 in Surveillance. However, the far larger black population of McDowell followed the lead of their own politicians, who remained tied to the Hatfield machine and who also actively sought to undermine the spread of the strike to McDowell. For more on the anti-union activities of McDowell's black leadership see: Trotter, "Black Miners," in The United Mine Workers of America: A Model of Industrial Solidarity? edited by John H.M. Laslett, 291-292.

${ }^{194}$ (Damron-Brewer relationship) “Testimony of Sid Hatfield," West Virginia Coal Fields, 216. Brewer was the sole witness called in the trial of the surviving Baldwin-Felts agents. “Testifies Hatfield Killed Mayor," New York Times, 25 May 1921. Reports by Baldwin-Felts secret agents from August 1920 suggest that Damron had convinced union leaders that he supported them. See note 147 in this chapter. During the Senate hearings Houston accused Damron of stating that the only mistake made by the Massacre defandants was their failure to kill all of the Baldwin-Felts agents. See "Testimony of C. E. Lively," West Virginia Coal Fields, 390-391.

${ }^{195}$ Although union representatives from International organizer David Robb to John L. Lewis publicly maintained that the miners' violence was purely defensive, or resulted from a reaction to operator oppression, their pronouncements wore thin. (Robb) "Mine Dynamited on Matewan Day," New York Times, 20 May 1921; (Lewis) United Mine Workers Journal 31 (1 June 1920): 15. 
Mingo Countians grew tired of living in a war zone. ${ }^{196}$ West Virginians grew resentful of the drain on public funds and the notoriety attached to the state. ${ }^{197}$ Journalists, while primarily intending to elicit support for the union, sensationalized tales of murder and mayhem, and ultimately diminished national support for the miners' cause. ${ }^{198}$ Union funds were drained by the legal costs of defending striking miners' attacks on replacement workers, law officers, and private citizens. ${ }^{199}$ Privately, union attorneys and organizers expressed distaste for the miners' actions. ${ }^{200}$

\footnotetext{
${ }^{196}$ Hatfield correspondence, letter no. 29; Conditions described by Matewan Oral History Project narrators included: lying on the floor of passenger train cars to avoid gunfire (Vicie Blackburn interview) and hiding in basments for weeks, also to avoid stray bullets (Bertha Staten interview). Circuit court judge R. D. Bailey observed to a reporter, "if the violence were to cease, public sentiment would compel the coal operators to accept unionism." Arthur Warner, "Fighting Unionism with Martial Law," Nation 113 (12 October 1921): 396.
}

197"Testimony of H. C. Ogden," West Virginia Coal Fields: 944-948, 946. Ogden, the publisher of the Wheeling Intelligencer, was one of the leading proponents of the industrial democracy movement in West Virginia.

${ }^{198}$ Batteau, 125. For more on the press and national public opinion see Batteau's Chapter 6 "Which Side Are You On?," and also Jeffreys-Jones, 34.

${ }^{199} \mathrm{By}$ the time of the Massacre trial, the union had spent over one hundred thousand dollars on strike-related legal expenses. Between 1920 and 1922 the UMWA's total legal expenses exceeded eight hundred thousand dollars. Dubofsky and Van Tine, 79. Miners' attacks on: (replacement workers) Williamson Daily News, 14 December 1920; (law officers, e.g. prohibition officer Harry Staten) "State of West Virginia v. J. S. (Calvin) McCoy," Reports of the West Virginia Supreme Court of Appeals 91 (April 25, 1922-October 17, 1922): 262-268; (private citizens- e.g. Ance Hatfield) Bluefield Daily Telegraph, 10 September 1920.

\footnotetext{
${ }^{200}$ Mingo's local union attorney, Thomas West was disgusted particularly by the Massacre defendants' efforts "to frame up their own defense." Report of \#9, 25 June 1920, Lewis Collection, ERCA. West, who like District 17's lead attorney Houston, was also a Socialist, had worked as a miner until age 21. "Thomas West," in Progressive West Virginians (1923): 235. West also represented the striking miners who attacked the Hungarian co-operative mine and miner. See Chapter 9. Union organizer J. L. Workman confided to another secret agent that Frank Keeney gave the striking miners at Matewan whatever they wanted because they knew details about the "Matewan murders" that could cause "the organization a great deal of harm." Report of \#5, 19 February 1921, Lewis Collection, ERCA.
} 
One organizer who left the county in disgust only to be accused of embezzling strike funds, ultimately testified against the union. ${ }^{201}$ Even UMWA President John L. Lewis steered clear of West Virginia, returning to the state only when the officers of District 17 were tried for treason following the Battle of Blair Mountain. ${ }^{202}$ In turn, the operators used each incident to justify escalating state and federal intervention, ostensibly aimed at restoring "law and order" in Mingo County, but in reality designed to break the strike. ${ }^{203}$

The cumulative effect of the violence can be measured by the conflicting outcomes of the Senate investigations in 1913 and 1921. The 1913 investigation into the Paint Creek and Cabin Creek strike of 1912-1913 had helped force a resolution of the strike which, at at least in some ways, benefitted the affected miners. ${ }^{204}$ By contrast, despite the involvement of at least one U.S. senator from the 1913 investigation, the 1921 committee failed to even file a report of its findings. ${ }^{205}$ District 17 officers, who had agitated for a senate investigation as early as June, 1920 ,

201 "Testimony of A. E. Hester," West Virginia Coal Fields: 802-838. Hester, who had helped buy rifles for miners with unused relief funds grew increasingly disenchanted with what he considered the misuse of the weapons. When he announced his intention of leaving the strike zone and returning to Charleston, he discovered that District 17 had accused him of embezzling strike funds. After surrendering to the Kanahwa County sheriff, he spent 41 days in jail, despite the absence of an indictment.

${ }^{202}$ (Lewis in West Virginia) Philip S. Foner, Women and the American Labor Movement: From Colonial Times to the Eve of World War I (New York: The Free Press, 1980), 244; (At treason trial) Lunt, 159.

${ }^{203}$ C. F. (Frank) Keeney to Secretary of War Newton Baker, October 14, 1920, copy sent by \#19 to Governor Cornwell, Cornwell Papers, WVRHC. In the letter Keeney quotes an observation from Coal Mining Review 15 September 1920, concerning the correlation between the arrival of federal troops and the demise of strikes. See also Fagge, 139.

\footnotetext{
${ }^{204}$ Corbin, Life, Work, and Rebellion, 99.

${ }^{205}$ Lunt, 151.
} 
watched helplessly as as their own leaders attempted to transform the hearings from an investigation into conditions in Mingo and anti-union southern West Virginia into a public denunciation of U.S. Steel. ${ }^{206}$

After spending nearly eight million dollars on the West Virginia unionization drive of 1920-1922, the union admitted defeat in October 1922. ${ }^{207}$ Although District 17's officers escaped legal punishment for strike-related activities in Mingo and charges of treason following the Battle of Blair Mountain, their days as leaders of West Virginia's miners were numbered. ${ }^{208}$ John L. Lewis, who had barely won reelection as UMWA president in 1922, forced Keeney and Mooney to resign in $1924 .^{209}$ Lewis simultaneously stripped District 17 of the right to autonomously elect its officers. ${ }^{210}$ Until his own death in 1960, Lewis maintained his grip on West Virginia's miners; from District 17 headquarters down to the local level, union officers held their positions based on

\footnotetext{
${ }^{206}$ A delegation from Matewan traveled to Washington and met with Senator Kenyon in early June. Mingo Republican 3 June 1920. Among the last witnesses called by the union were economist Jett Lauck and lawyer Samuel Untermyer. "Testimony of Jett Lauck," West Virginia Coal Fields: 1036-1037 and "Testimony of Samuel Untermyer," in same, 697-719. Lauck and Untermyer attempted to connect U.S. Steel to the anti-union effort in southern West Virginia, but in the opinion of the Senate committee, failed to reveal a direct link. Lunt, 151. Even some sympathetic to the operators resented the investigation's shift in focus. Williamson lawyer and politician S. D. Stokes wrote to Virginia congressman and Stone Mountain corporate, James P. Woods that he thought that the investigation had become a "mistake" because it did not focus on the threats to law and order in Mingo County. S. D. Stokes to James P. Woods, 2 July 1921, Stokes Collection, WVRHC.

${ }^{207}$ (expenditure) Hennen, Americanization, 112 and Lewis, Black Coal Miners, 163; (end of strike) New York Times, 28 October 1922.

${ }^{208}$ Mooney, Struggle in the Coal Fields, 124-127.

${ }^{209}$ (Lewis) Dubofsky and Van Tine, 81; (Keeney and Mooney) Mooney, Struggle in the Coal Fields, 127-128.

${ }^{210}$ Mooney, Struggle in the Coal Fields, 128.
} 
their loyalty to Lewis. ${ }^{211}$ Frank Keeney, Fred Mooney, and Bill Blizzard died broken men, outcasts from their union. ${ }^{212}$ In contrast, John L. Lewis emerged a hero from the chaos of the 1920-1922 strike and the union's disintegration in the 1920s and early 1930 s.

Like the leadership of District 17, the operators of the Williamson-Thacker field were also unwitting foot soldiers of a larger army. Their failure to contain the 1920 unionization drive resulted in Mingo's capitulation to the interests of neighboring competitors and ultimately, the absorption of the Williamson-Thacker field into the U.S. Steel coal empire. ${ }^{213}$ A brief overview of the strike from the operators' perspective reveals how the corporate giants of southern West Virginia's coal industry used the strike, not only to defeat the union, but also to drive out their smaller competitors.

Dismissed by other southern West Virginia operators as "gentry" who had to be "forced" into adopting anti-union policies, the Williamson-Thacker operators made several critical mistakes

${ }^{211}$ Ironically at least one of the men who served in the union in Mingo from the 1930s to the 1960s, and was backed by Lewis henchmen despite charges of corruption by other union officers, was also one of the men implicated in the 1920-1922 violence. Melvin Triolo, interview with John Hennen, Summer 1989 Matewan Oral History Project.

${ }^{212}$ Keeney tried his hand at a variety of occupations before trying to start a rival union in 1931 , as a result he lost his home, his savings, and was permanently barred from membership in the UMWA. Cabell Phillips, "The West Virginia Mine War," American Heritage 25 (August 1974): 58-61, 90-96, 94. Mooney drifted arounded the country and returned to the mines in northern West Virginia, but committed suicide in 1954. Mooney, Struggle in the Coal Fields, x. Blizzard, after leading the nearly as infamous Widen strike in 1952, also fell out with union leadership and died in 1958. "William (Bill) Blizzard," West Virginia Heritage Encyclopedia, vol. 3: 470-471.

${ }^{213}$ Conley, History of the West Virginia Coal Industry, 262 and David E. Whisnant, Modernizing the Mountaineer: People, Power, and Planning in Appalachia (Knoxville: University of Tennessee Press, 1994), 110. 
that ultimately cost them their autonomy. ${ }^{214}$ First, they failed to enforce their "no mediation" stance throughout the coal field. ${ }^{215}$ Although Red Jacket, Borderland, and Stone Mountain moved quickly to evict union miners, other companies in the field waited until federal troops had come to Mingo for the second time in December $1920 .{ }^{216}$ Second, even after the force of the state and federal governments had been brought to bear on the strike, the coal and political leadership of the county allowed themselves to be led "astray on side issues" that prolonged the effort to restore law and order. ${ }^{217}$ A dispute over who Governor Morgan would recognize as the commander of the Mingo Militia illustrates that not even the strike could prevent the habitual squabbling of the county's elites. ${ }^{218}$ Third, the operators resorted to tactics that the union could expose and manipulate in the court of public opinion, for example, several operators faced charges of bribery and complicity in agent provocateur activity. ${ }^{219}$

${ }^{214}$ Justus Collins to George C. Wolfe, 16 September 1920, Collins Papers, WVRHC.

${ }^{215}$ In response to appeals from the Labor Department's Commissioners of Conciliation, the Williamson Coal Operators'Association refused absolutely to either recognize or negotiate with the UMWA. Bluefield Daily Telegraph, 2 July 1920. However, as shown earlier in this chapter, the WCOA's pronouncements did not prevent the organization of two dozen small mines in the county.

${ }^{216}$ F. A. Lindsay, on behalf of Allburn Coal \& Coke Company, to S. D. Stokes, 21 December 1920, Stokes Papers, WVRHC.

${ }^{217}$ S. D. Stokes to James P. Woods, 2 July 1921, Stokes Papers, WVRHC.

${ }^{218}$ M. Z. White to Greenway W. Hatfield, 28 August 1921, Ephraim F. Morgan Papers, WVRHC. Particular substantiation can be found in the following letter: "I fear there is too much politics being played and the labor situation is being lost sight of." S. D. Stokes to G. W. Coffey, 19 August 1920, Stokes Collection, WVRHC.

${ }^{219}$ (operators and officials indicted for bribery): J. M. Tully, W. A. Wilson, and G. R. C. Wiles, Mingo Republican 8 July 1920. Tully, Wilson, and Wiles were indicted by the same grand jury that heard the charges stemming from the Matewan Massacre. (agent provocateur) 
But perhaps the most egregrious and ill-timed act by the operators was the Lick Creek tent colony raid on June 14, 1921, which took place on the same day that the West Virginia State Supreme Court of Appeals ordered the release of three men who had been jailed for infractions againt an illegal enaction of martial law. ${ }^{220}$ Since June 14 was also Flag Day, the accounts of the attack on the tent colonists by a force of state police and local vigilantes reinforced the union's assertion that they, and not the operators, were the defenders of America's most sacred ideals. ${ }^{221}$

District 17 President Frank Keeney accused superintendent Armentrout of Borderland of paying a man $\$ 1,000$ to dynamite Borderland's powerhouse. C. F. Keeney to Newton Baker, 4 October 1920, Cornwell Papers, WVRHC. R. H. Kirkpatrick, foreman of the Pond Creek By-Product Company claimed his superintendent staged a gun battle, to scare off striker-snipers and to maintain the presence of federal troops. "Statement of R. H. Kirkpatrick," West Virginia Coal Fields, 101. During the questioning of state police captain J. R. Brockus, attorney Houston alluded to another reason why the operators may have colluded with attacks on their property. According to Houston, one of the leaders of the Williamson vigilance committee sold "civil commotion and riot insurance." "Testimony of J. R. Brockus," West Virginia Coal Fields, 344345.

${ }^{220}$ (Timing of Raid) "Testimony of Frank Ingham," West Virginia Coal Fields, 34; (martial law case) "Ex Parte Lavinder, et al," Reports of the West Virginia State Supreme Court of Appeals, 88 (February 22, 1921-June 24, 1921): 713-721, 721. The sole fatality in the raid, African-American Alex Breedlove was portrayed by the operators as an armed sniper, but as an unarmed victim, killed while surrendering, by the union. (Breedlove by operators) "Testimony of Albert E. McComas," West Virginia Coal Fields, 303; (by union) "Keeney Exhibits, \#18 and 19," "Testimony of C. F. (Frank) Keeney," West Virginia Coal Fields, 166-167. What neither side acknowledged at the time was Breedlove's local notoriety. In 1913, the "well-known" Breedlove had been jailed in Williamson for repeatedly fighting with another African American. Mingo Republican 23 May 1913. Given Breedlove's ethnicity and reputation, it is unlikely that his death was coincidental. The possibility that the operators targeted African-American troublemakers is further substantiated by what became of his fellow tent colonost Garfield Moore. At the same time that Breedlove was fatally wounded, another vigilante was shooting at Moore. "Keeney Exhibit \#18"; In 1922, during another raid on Lick Creek, Moore was arrested for operating a still in his tent. Major Thomas B. Davis to Ephraim F. Morgan, 5 June 1922, Morgan Papers, WVRHC.

${ }^{221}$ Journalist Heber Blankenhorn made the connection between Flag Day and the timing of the Lick Creek raid. Heber Blakenhorn, "Marching Through West Virginia," Nation 113 (14 September 1921): 288. (Flag Day) June 14 "is the anniversary of the adoption (1777) of the 
Not long after the Lick Creek incident, the United States Senate finally approved an investigation into conditions in West Virginia. ${ }^{222}$ Distracted by the chaos that had swept over the county, the Williamson operators were forced to seek alliances with their more powerful neighbors. ${ }^{223}$

The extent to which Mingo's elites bungled their handling of the strike is most evident when their actions are contrasted to the reaction of operators in the neighboring fields. During the early heady days of the union drive in Mingo, the operators of the Guyan, Pocahontas, and Winding Gulf fields quickly moved to erect a cordon sanitaire around Mingo. Wage hikes were ordered and compulsory donations to the operators' "insurance" fund were raised. ${ }^{224}$ To better coordinate their activities, the Tug River and Winding Gulf operator associations moved their headquarters to Welch, where the Pocahontas operators were based and where a regional office of

national flag of the United States." Webster's Encyclopedic Dictionary, 356. In a speech on the floor of the U.S. Senate, on June 21, 1921, California Senator Hiram Johnson recounted details of the attack on Lick Creek and likened them to events in Ireland. Johnson quoted by Randolph Bias, "Testimony of Albert E. McComas," West Virginia Coal Fields, 304-305.

${ }^{222}$ The Senate subcommittee that undertook the investigation first endorsed doing so after the "Three Days in May Battle." New York Times, 27 May 1921. However, the investigation was not approved by the full Senate until a month later, after the West Virginia State Supreme Court of Appeals challenged Governor Morgan's martial law declaration and the Lick Creek raid. Assertion based on correlation of information revealed during the Ingham and McComas testimonies and the New York Times' article.

${ }^{223}$ The first sign that larger interests would take over was the announcement that rather than send their own representative to the 1920 annual meeting of the National Coal Association, the Williamson operators gave James D. Francis of Island Creek in Logan County, proxy authority to vote for them. Winding Gulf Coal Operators' Association, Bulletin \#62, 31 May 1920, Collins Papers, WVRHC. (Date of meeting) Coal Trade Journal 51 (2 June 1920): 588.

${ }^{224}$ Justus Collins to George C. Wolfe, 16 April 1920 and "Bulletin F," 21 May 1920, Justus Collins Papers, WVRHC. The wisdom of these actions contrasts sharply with the wage hike and then reduction undertaken by a Williamson-Thacker company. On March 16, 1920, the Pond Creek By-Product Company raised wages, only to reduce them again on April 1, 1920. "Testimony of R. C. Kirk," West Virginia Coal Fields, 471. 
the Baldwin-Felts agency had been established. ${ }^{225}$ When strike-related disturbances spread to the surrounding fields, the operators again acted vigorously. In Logan County, Sheriff Chafin received the necessary funds to enlarge his army of deputies. ${ }^{226}$ When coal company property on the Mingo-McDowell border was attacked, McDowell Sheriff S. A. Daniel requested state police officers from Governor Cornwell. ${ }^{227}$ The most decisive, if ill-advised and reprehensible action supported, if not orchestrated by the operators, was the retaliatory murder of Sid Hatfield and Ed Chambers on August 1, 1921.228

Even while the operators of the surrounding fields worked to contain the WilliamsonThacker strike, they also scrambled to turn the Mingo operators' trouble to their own benefit. Union miners from McDowell County, West Virginia and Pike County, Kentucky were driven into

${ }^{225}$ Collins to Wolfe, 16 April 1920, and "Bulletin F," 21 May 1920, Collins Papers, WVRHC.

${ }^{226}$ Chafin's deputy fund was raised from $\$ 41,000$ to over $\$ 60,000$ between 1920 and 1921. “Testimony of W. R. Thurmond,” West Virginia Coal Fields, 867. By contrast, Mingo Sheriff G. T. Blankenship received a mere $\$ 4,800$ a year for 8 deputies, 6 of whom who were "taxcollecting deputies." "Testimony of C.(sic) T. Blankenship," West Virginia Coal Fields, 487.

${ }^{227}$ McDowell County sheriff S. A. Daniel to John J. Cornwell, 2 September 1920, Cornwell Papers, WVRHC. Again by contrast, during the last months of his tenure, Sheriff Blankenship not only refused to do the coal operators' bidding, he also refuted their claims in his own correspondence with Governor Cornwell. William N. Cummins to John J. Cornwell 17 November 1920 and G. T. Blankenship to same, 6 November 1920, Cornwell Papers, WVRHC.

${ }^{228} \mathrm{Hatfield}$ and Chambers were in Welch to answer an indictment for an attack on a coal company on the Mingo-McDowell County line. While approaching the McDowell County courthouse they were gunned by two Baldwin-Felts agents, and a McDowell County deputy sheriff. McDowell County sheriff William (Bill) Hatfield, who allegedly promised to provide safe conduct to Hatfield, Chambers, and their co-defendants, left McDowell "the day before to 'take the waters"' at a resort in Virginia. Lee, Bloodletting, 67. The deaths of Hatfield and Chambers also halted Keeney's plan to "invade" Mingo and fill the jails in challenge to the new martial law edict. Charleston Gazette 2 August 1921, quoted in Corbin, Life, Work and Rebellion, 210. 
Mingo's tent colonies. ${ }^{229}$ When the UMWA launched the Mingo strike, the N\&W coal cars assigned to the Williamson-Thacker district were diverted to the Tug River and Pocahontas fields. ${ }^{230}$ Unfortunately because the strike also coincided with a resurgence in the demand for coal, while the mines in Mingo were idle, or producing at diminished capacity, Tug River and Pocahontas operators commanded $\$ 9$ a ton. ${ }^{231}$ The coup de grace for many Mingo operators came when their mines were being gobbled up by giant corporate interests. ${ }^{232}$ In 1920 , Williamson entrepreneur E. L. Bailey sold out to the Solvay combine, a subsidiary of the American Rolling Mills Company, but stayed on as superintendent. ${ }^{233}$ Later that same year, the Thacker Fuel Company purchased the Grey Eagle Coal Company of Kermit. ${ }^{234}$ The Williamson-Thacker strike's failure had not resulted from Mingo County's membership in the anti-union southern West

\footnotetext{
${ }^{229}$ Neil Burkinshaw, “Labor's Valley Forge,” Nation 110 (8 December 1920): 639. The refugees from McDowell and Pike Counties swelled the ranks of the strikers' tent colonies. At one point, relief funds for the tent colonists approached \$40,000 a week. Report of \#5, 19 February 1921, Lewis Collection, ERCA.

${ }^{230}$ Bluefield Daily Telegraph, 2 July 1920.

${ }^{231}$ Coal Trade Journal 51 (2 June 1920): 588.

${ }^{232}$ Notices of dissolution sent the Williamson Daily News for publication, S. D. Stokes to Thomas B. Garner, 26 May 1920.

233"Testimony of E. L. Bailey," West Virginia Coal Fields, 277, 284. Bailey's company was one of those dissolved in May 1920. See note 229. By the time Bailey testified in 1921, Solvay had closed the mine because the Ohio steel mills supplied with the company's coal had been idle since January 1921.

234"Strike Activity" 9 October 1920, Surveillance.
} 
Virginia monolith. Instead, the strike gave the monolith the much needed opportunity to "quietly" but "effectively" move in and defend its Achilles' heel. ${ }^{235}$

The reaction of the state and federal governments to the 1920-1922 West Virginia conflict also illuminates much about post-World War I America. In fact, the second West Virginia mine war could hardly have been more ill-timed. Wartime regulations had demonstrated that the bureacratization of American society, and more importantly, the American economy, had resulted in efficient production expansion. ${ }^{236}$ Politicians and business leaders emerged from the war aware that a new era of business and government relations was dawning. ${ }^{237}$ Convinced more than ever that elites should be entrusted with directing the ship of state, politicians and business leaders set about "engineering" the "consent" of the society they governed. ${ }^{238}$ As a result, the national debate on civil liberties was transformed. ${ }^{239}$ Voices of dissent, especially those that rose from the working class, were denounced and stifled. ${ }^{240}$ After decades of upheaval and reform, the American

${ }^{235}$ The quotations are borrowed from: "West Virginia's War," Literary Digest 67 (18 December 1920), 16. As noted by the Digest, "the open shop interests . . quietly, but effectively ... are protecting and sustaining the smaller operations." That the "open shop" interests, were actually protecting themselves is evidenced by their subsequent absorption of Mingo's coal companies.

${ }^{236}$ William K. Klingaman, 1919: The Year Our World Began (New York: Harper \& Row, 1989 [1987]), 548-549; and Robert H. Wiebe, The Search for Order: 1877-1920 (New York: Hill and Wang, 1967), 293-302.

${ }^{237}$ Wiebe, 302.

${ }^{238}$ Hennen, Americanization, 1-2. See Chapters 1-2 of Americanization for a synopsis of both the national and West Virginia application of this concept.

${ }^{239}$ See Murphy, World War I and the Origin of Civil Liberties, 57, 82, 101-102, and 271.

${ }^{240}$ Wiebe, 288-289. By the end of the war, the American middle class had become convinced that economic growth and social progress depended on the preservation of order. Hennen, 
public fell in behind the country's business and political leaders and entered the 1920s intolerant of challenges to the status quo. ${ }^{241}$ In 1920, the average American was more interested in the maintenance of a steady supply of coal than in the individual human rights of West Virginia's miners. ${ }^{242}$

Against this backdrop, the political and business elite of West Virginia declared themselves the guardians of the nation's most important fuel supply and proceeded to wage war on the rights of the state's working class. ${ }^{243}$ When a local jury acquitted Sid Hatfield and the other Massacre defendants, the state legislature passed a bill that abrogated defendants' rights. ${ }^{244}$ Although the West Virginia State Supreme Court of Appeals later criticized abuse of the law, it did not overturn

Americanization, 69.

${ }^{241}$ Ibid., 292-293; Bernstein, 75.

${ }^{242}$ Hinrichs, 181.

${ }^{243}$ West Virginia's two governors during the 1920-1922 crisis, John J. Cornwell (1917-1921) and Ephraim F. Morgan (1921-1925) claimed to be union supporters, but consistently supported the anti-union operators in the strike. (Cornwell) "Resign As Governor Whenever Unable To Preserve Order," Bluefield Daily Telegraph 7 February 1920; (Morgan) "Governor Explains Why Federal Troops Brought Into West Virginia -- Six Thousand Deluded Men In Insurrection, Reason He Offers (New York Commercial, 1921 [reprint]), Pamphlet 7640, WVRHC.

${ }^{244}$ Chapter 69 "The Jury Bill," Senate Bill \#14, Acts of the West Virginia Legislature for the Year 1921, 183-184. Proposed by the father-in-law of Judge James Damron and passed two days after the Massacre acquittal, the jury bill allowed judges and prosecuting attorneys to import juries from other counties in felony cases. Ironically, the Massacre acquittal had not been a simple case of jury nullification, but rather had resulted from careful attention to the rules of evidence. The jury had refused to convict all of the defendants for the actions of one or two, and having been given no alternative, chose to free the defendants. S. D. Stokes to S. B. Avis, 22 March 1921, Stokes Papers, WVRHC. Stokes learned about how the jury came to its decision by interviewing the sole member who had originally supported a guilty verdict. 
it. ${ }^{245}$ A former West Virginia circuit court judge even advocated the abolition of juries because they all too often acted like mobs. ${ }^{246}$ The West Virginia legislature also passed a law, proposed by Mingo's state senator, M. Z. White, that empowered coal companies to seek compensation from unions for property damage suffered during strikes. ${ }^{247}$ Inspired by the example of the injunction cases used to kill the Williamson-Thacker strike, West Virginia's coal operators spent the 1920s slowly strangling and bleeding dry the UMWA. ${ }^{248}$ By 1928, over 200 injunction cases had been

\footnotetext{
245 "State of West Virginia v. J. S. McCoy," Reports of the West Virginia State Supreme Court of Appeals 91 (April 25, 1922-October 17, 1922): 262-268. The court overturned the conviction of Calvin McCoy for the murder of prohibition officer Harry Staten during the 1921 "Three Days in May" battle for two reasons: the judge and prosecuting attorney imported a jury without attempting to empanel a jury from Mingo and because they undertook this action in McCoy's absence. When John Collins and several other men were indicted for their roles in an attack on coal company at Mohawk, McDowell County, they were convicted by a jury in Greenbrier County. Bluefield Daily Telegraph, 1 October 1921.
}

${ }^{246}$ J. C. McWhorter, “Abolish the Juries,” West Virginia Law Quarterly 29 (January 1923): 97-108. McWhorter also advocated the involuntary trial, en masse of defendants, and the compulsory testifying of defendants.

${ }^{247}$ Senate Bill\# 359, Acts of the West Virginia Legislature for the Year 1921, 322-329. The first company to bring suit under the law's provisions was the Willis Branch Coal Company, which brought suit for one million dollars in 1922. United Mine Workers Journal 33 (1 October 1922): 3. According to the owner of Willis Branch, William McKell, between January 1920 and February 1921, union miners and sympathizers had launched 38 attacks on company property and personnel. Rather than continuing the fight, McKell simply closed the mine. "Testimony of William McKell," West Virginia Coal Fields, 941. Ironically, prior to the labor strife at Willis Branch, McKell had been known as one of southern West Virginia's more tolerant and moderate mine operators. Barkey, 122.

${ }^{248}$ Three injunction cases from the Williamson-Thacker strike deserve note here: The Pond Creek, Borderland and Red Jacket injunctions. The Pond Creek injunction not only forbade the UMWA to advertize the existence of a strike along the Tug River, it denied union leaders the right to assert that the strike even existed. Lane, Civil War, 22. Ultimately combined into one case, the Red Jacket-Borderland injunctions expanded the legality of individual or "yellow dog" contracts first defined by the 1917 Hitchman decision. Finally ajudicated in 1927, the Red Jacket case encompassed 62 southern West Virginia coal companies and 40,000 miners. See Lunt, 96, 152-153, and 172. 
won by the state's coal elite; miners were prevented from parading on public highways and meeting on private property or even in churches. ${ }^{249}$ Denied the basic constitutional right of freedom of speech, West Virginia's miners believed that they not only had been silenced, but enslaved. ${ }^{250}$

The collusion of the federal government in West Virginia's mistreatment of the miners stemmed primarily from inertia. ${ }^{251}$ While generally supportive of the rights of industrial workers, national leaders on both ends of the political spectrum perceived themselves primarily as the protectors of the public interest. ${ }^{252}$ As a result, the federal government became an often unwilling collaborator in the oppression of West Virginia's miners. ${ }^{253}$ Unable to compel the anti-union

${ }^{249}$ Lunt, 166-167.

${ }^{250}$ Ibid., 145-149, 154. The centrality of freedom of speech in the West Virginia miners' struggle was recognized early on by Roger Baldwin, the head of the newly founded American Civil Liberties Union. For three years, from before the Massacre until a year after the end of the Williamson-Thacker strike, the ACLU not only advised District 17's legal team, it also helped advertize the plight of West Virginia's miners.

${ }^{251}$ Journalist James M. Cain observed that except for the 1921 Senate investigation, "nothing was done" about the situation in West Virginia's coal fields. James M. Cain, "The Battleground of Coal," in The West Virginia Mine Wars: An Anthology, edited by David A. Corbin (Charleston, WV: Appalachian Editions, 1991): 151-159, 155. Cain's article originally appeared in the Atlantic Monthly, in October 1922.

${ }^{252}$ President Harding, in an August 1922 message to Congress, noted that except for the coal produced in the non-union coal fields, "the country is at the mercy of the United Mine Workers." The United Mine Workers in West Virginia, 6. Senator Kenyon expressed concern that the union-industry struggle would adversely affect the public. Personal Views of Senator Kenyon, 6.

${ }^{253}$ Clayton Laurie, "The United States Army, The Return to Normalcy in Labor Dispute Interventions: The Case of the West Virginia Coal Mine Wars, 1920-1921," West Virginia History 50 (1991): 1-24, 8. Federal disenchantment was intensified by the disingenuity of Mingo's operators. For example, a federal agent reported to his superiors that the operators were "lying" when they claimed that only 100 of the 1,302 men at work in October 1920 were "replacements" or "scabs." As he noted, "special cars" (railroad) arrived daily with 50 to 150 
operators to negotiate a settlement of the Williamson-Thacker strike, Washington could only step in and restore peace when West Virginia's leaders proved to be part of the cause of civil unrest. ${ }^{254}$

The United States Supreme Court provided little guidance in the resolution of labor conflicts because for decades it simultaneously recognized a small number of union rights while primarily protecting the interests of the open shop. ${ }^{255}$ Only violent public upheaval seemed to motivate federal legislators into action, whereupon they empaneled investigating committees or commissions. ${ }^{256}$ By the time of the Williamson-Thacker strike, the efficacy of the seemingly

men on board. "Strikes," 23 October 1920, Surveillance.

${ }^{254}$ In 1920, the federal government possessed "no legal way to compel arbitration or union recognition. Edward Eyre Hunt, F. G. Tryon, and Joseph H. Willits., eds., What The Coal Commission Found: An Authoritative Summary By The Staff (Baltimore: The Williams \& Wilkins Company, 1925) 34. Having grown tired of the hysterical requests of governors Cornwell and Morgan for federal troops, in the summer of 1921, President Harding and his advisers tried to force West Virginia to "solve her own problems." However two events forced a final intervention of federal troops. When miners marched on Logan in protest of Sid Hatfield's assassination and the illegal detention of strikers in Mingo County, Governor Morgan bleated that West Virginia was being invaded by an army of Bolsheviks. Harding sent General H. H. Bandholtz to investigate and "persuade" District 17's leaders to disperse the miners. As the miners' "army" disbanded, state police captain J. R. Brockus led a renegade attack on a group of miners at Sharples, in Logan County. Outraged, the miners regrouped and launched an assault on Logan County that resulted in the "Battle of Blair Mountain." Only the threat of fighting their own government's troops convinced the miners to disarm and go home. Laurie, 15-18.

${ }^{255}$ Bernstein, 190-191. For more on labor law in this period see: Bernstein, The Lean Years, Chapter 4 "Labor v. The Law." An example of the Court's straddling is evidenced by the opinions of Justice Louis Brandeis. Brandeis, while alarmed by the use of federal troops in West Virginia, also believed that unions did not possess "an absolute right to strike." Brandeis quoted in Urofsky and Levy, 514-515, and Bernstein, 191.

${ }^{256}$ Arthur Gleason, “Company-Owned Americans," Nation 110 (12 June 1920): 794-795, 795. As journalist Gleason observed in 1920, "these reports are always made after the killing." 
endless string of senate committees and federal commissions was openly questioned ${ }^{257}$ Known as "that puttering and futile investigating committee," the committee entrusted with the examination of conditions in West Virginia in 1921 not only failed to arrive at a solution for the state's labor woes, its chairman also managed to antagonize both sides in the controversy. ${ }^{258}$ The inability or unwillingness of the federal government to guide the course of labor relations in the 1920s, contributed to the arrival of "desolate days in America." ${ }^{259}$

\section{Conclusion:}

While the Matewan Massacre resulted from a unique convergence of local tensions, it also stands as a tragic example of the inherent conflicts that have periodically erupted throughout our nation's history. In the spring of 1920, Mingo County, like a pressure-cooker, steamed under the accumulated weight of decades of political corruption and chronic economic instability. When

${ }^{257}$ Ibid. Gleason, who was one of the first investigative journalists to visit Mingo in 1920, noted that, "of the making of reports on West Virginia there is no end."

${ }^{258}$ Since the committee failed to publish a report, its members published "opinions." West Virginia's coal elite were heartened by the conservative members' open support for the compulsory incorporation of unions. Bluefield Daily Telegraph, 28 January 1922. Senator Kenyon condemned the intransigience of both sides, and likened their conflict to "an irresistible force meeting an unmovable object." Personal Views of Senator Kenyon, 4. In the interest of "the great third party -- the public" Kenyon outlined an "industrial code" that "prefigured" the National Industrial Recovery Act. Johnson, Politics of Soft Coal, 111. Kenyon's proposal angered the union, who refused to commit to compulsory arbitration unless the federal government formally sanctioned collective bargaining. The operators also balked because the union was not financially liable for strike-induced breaches of contract.

${ }^{259}$ Arthur Gleason, The Book of Arthur Gleason: My People, and "A.G." An Appreciation By Helen Hayes Gleason (New York: William Morrow \& Company, 1929), 183. This quote and other reflections on post-World War I America by Gleason were recounted after his death in 1923 by his wife. 
violence swept through the streets of Matewan, the local community, West Virginia, and America was forced to confront the issues that had precipitated the fatal confrontation. Unable to arrive at a consensus over the meaning of property versus individual rights, the residents of Mingo County divided and perpetuated a cycle of mutual exploitation and denigration. The survival of any semblance of community necessitated a retreat behind a wall of silence. As one Matewan native observed, "how do you explain to a child that the nice old man who runs the post office was once indicted for murder?"260

Beyond the boundaries of Mingo County, the meaning of the Matewan Massacre was surrendered to the agendas of whomever invoked it. ${ }^{261}$ The United Mine Workers of America transformed the ambush of the Baldwin-Felts agents into a righteous attack on the forces of oppression, which they hoped would inspire all of West Virginia's miners to rise. ${ }^{262}$ To the proponents of the open shop and welfare capitalism, the Massacre demonstrated the disruptive and destructive influence of trade unionism, which must be defeated in order for liberty to survive. ${ }^{263}$ Liberals and conservatives alike manipulated details of the story in order to frighten Americans

\footnotetext{
${ }^{260}$ Margaret Hatfield interview. This comment was made off-tape, but the interview does contain Ms. Hatfield's memories of Clare Overstreet, the subject of her statement.

${ }^{261}$ As in other stories of violence, the Massacre's impact on subsequent events resulted from its utility as a source of propaganda. As historian Jane Dailey observed of the 1883 Danville, Virginia race riot, the violence of that day influenced the 1883 Virginia election because of how Democrats and Readjusters portayed the causes of the event. See Dailey, "Deference and Violence," 581-582.

${ }^{262}$ David Fowler and David Robb, "Statement of Conditions in Mingo County, W.Va.," United Mine Workers Journal 31 (1 January 1921): 10.

${ }^{263}$ National Coal Mining News, editorial, 29 September 1921. Wightman Roberts, the editor of the Mining News corresponded frequently with Governor John J. Cornwell.
} 
into supporting industrial reform. ${ }^{264}$ However, the Massacre and the two years of strife it ushered in evaded definition and thus proved of limited utility to any one faction in the body politic. The American people were already accustomed to dismissing Appalachian violence as the outbursts of a backward subculture. ${ }^{265}$ Because both the defenders and the critics of the events in Matewan on May 19, 1920, felt compelled to note that the little town on the Tug was also the home of the "feudin' Hatfields and McCoys," the Massacre passed into the realm of myth. ${ }^{266}$ Secure in their own modernity and prosperity, the rest of the United States ignored the ravages of the war being waged between the forces of capitalism and unionism. Until the dark days of the Great Depression when the wail of another Appalachian community torn asunder echoed through the hills of Eastern Kentucky, Americans turned a blind eye and a deaf ear.

The contrast between what was born of the suffering in "Bloody Mingo" and "Bloody Harlan" illustrates the callousness of contemporary American society. ${ }^{267}$ In a nation weary of reform and intoxicated by the wealth of the post-World War I economy, the miners of Mingo and

\footnotetext{
${ }^{264}$ Jeffreys-Jones, 37 and 155-157. Charles Frederick Carter, "Murder to Maintain Coal Monopoly" Current History 15 (1922): 597-603. The article's title refers to what Carter asserted was the UMWA's "twenty-three years of arson, assault, and assassination in West Virginia.

${ }^{265}$ Batteau, 124.

${ }^{26} \mathrm{Ibid} .$, 115. Batteau asserted that the near constant invocation of the feud resulted in the construction of "feud-feudal homonym." An example of the homonym can be found in a 1920 issue of the Literary Digest. "West Virginia's War," Literary Digest 67 (18 December 1920):1617. The subject bullet at the top of these pages reads "Feudalism in America," while the article refers to the strike as West Virginia's bloodiest feud.

${ }^{267}$ For more on Harlan County, Kentucky miners see: George J. Titler, Hell in Harlan (Beckley, WV: BJW Printers, n.d.). Harlan, like Mingo, had a reputation for violence before its labor strife. Hell in Harlan is the memoir of Titler, who organized Harlan for the UMWA in the late 1930s.
} 
southern West Virginia were acceptable casualties, after all, had not these people always been unfortunate reminders of our violent past? ${ }^{268}$ To a nation brought to its knees by utter economic collapse, the miners of eastern Kentucky became a symbol that America had to change. The head of yet another federal commission, liberal crusader Robert LaFollette, sent Heber Blankenhorn, who had also documented events in West Virginia, into Harlan. ${ }^{269}$ Armed with the information gathered by Blankenhorn, the federal government indicted the coal operators and the deputies for their crimes. In search of votes, Franklin Roosevelt and the Democratic party courted organized labor. ${ }^{270}$ Once in office, when Roosevelt and the liberal Congressmen set about repaying their debt to the unions, they enlisted the aid of Jett Lauck, who in 1921 had compared West Virginia's antiunion operators to slaveholders. ${ }^{271}$

But what of Matewan, Mingo County, and the miners of southern West Virginia? The news of the passage of the National Industrial Recovery Act sent the United Mine Workers of America sweeping back into the coal fields. Inspired by the union's revival, the former "mayor" of the Lick Creek tent colony joyously observed, “All the demons in Hell can't keep us from organizing . . now!"272 However, in the decades that followed, members of the generation “traumatized" by the events of 1920-1922 often fell victim to divorce, alcoholism, madness, and

${ }^{268}$ What the Coal Commission Found, 235-236.

${ }^{269}$ (The LaFollette Commision) Batteau, 123; (Blankenhorn as chief investigator) Beik, 267. ${ }^{270}$ Spivak, 59.

${ }^{271}$ Lunt, 181. Specifically, Lauck helped draft the National Industrial Recovery Act.

${ }^{272}$ Richard Burgett interview, On Dark and Bloody Ground, 108. 
the ugliness of their memories. ${ }^{273}$ For others, to forget was to heal, as a result, the son of a Massacre participant preached the funeral of a woman driven from her home because of what she had seen that day. ${ }^{274}$ The rediscovery of the Matewan Massacre by a new generation of outsiders could have meant the reopening of old wounds. Instead, it became a path for a community in search of its own past and a way for the people of Matewan to reclaim their story. ${ }^{275}$

${ }^{273}$ Hatfield correspondence, letter no. 29; Hiram Phillips interview with John Hennen, Summer 1989 Matewan Oral History Project; Virginia Grimmett interview; Venchie Morrell (1990) interview; Hawthorne Burgraff interview. The same devastation was visited upon the Baldwin-Felts agents who participated in the 1920-1922 strife. See Velke, 200 and Paul Lively interview.

${ }^{274}$ Johnny Fullen interview.

${ }^{275}$ Another positive outgrowth of the rediscovery of Matewan has been the willingness of descendants of those who have been vilified to finally come forward and tell their story. The Matewan Oral History collection now includes an interview with the son of C. E. Lively. Also, Dick Redden, the grandson of Albert Felts, has visited the Eastern Regional Coal Archives. In a local newspaper interview, Mr. Redden explained that his mother (Felts' daughter) never discussed his death, and as a result Mr. Redden never learned of his family's "role in the coalfields until 1982." Bluefield Observer, 13 May 1992. 


\section{CONCLUSION}

\section{CONSTRUCTION OF THE MATEWAN MYTH: ELEVATION THROUGH DENIGRATION}

In 1978 Henry D. Shapiro's Appalachia On Our Mind challenged scholars to consider "what problem [the study of Appalachian history] solves and whose interests -- intellectual as well as practical -- it thereby serves." ${ }^{1}$ Drawing inspiration from the parting thrust of Shapiro's ground breaking monograph, this study has sought to expose the story behind the story of the events of May 19, 1920. In the process, it was discovered that for decades journalists and historians have constructed and cultivated a version of the Matewan Massacre that imposed an essentialistic dialectic which left no room for an examination of the human agency among the people of Matewan and Mingo County. ${ }^{2}$ From the reporters who were contemporary eyewitnesses to the events set in motion by the Massacre to the historians seeking to understand Appalachia's rural-industrial working class, those who wrote of the Massacre edited and defined it to fit into the larger picture of American working class activism. ${ }^{3}$ Why the Massacre occurred

${ }^{1}$ Henry D. Shapiro, Appalachia On Our Mind: The Southern Mountains and Mountaineers in the American Consciousness, 1870-1920 (Chapel Hill: University of North Carolina Press, 1978), 265.

${ }^{2}$ In a seminal work on the social history of the American working class, Herbert Gutman reiterated a central theme of the work of British historian E. P. Thompson: "to understand how people respond to industrial change,' you have to understand what kind of people they were before and 'to take account of continuities as well as new ways of thinking." Herbert Gutman, "Work, Culture, and Society in Industrializing America, 1815-1919," in Herbert Gutman, Work, Culture and Society in Industrial America: Essays in American Working Class and Social History (New York: Vintage Books, 1976 [1966]): 3-78, 53.

3“"Edited" and "defined" were borrowed from Edward Said, whose intellectual history of Western Europe's response to Eastern culture provides a framework for the study of the phenomenon of "othering," the means by which one culture is defined through contrast with 
in Matewan and what impact it had locally was left out of the analysis of the broader struggle for workers' rights in the region's anti-union coal fields.

Within days of the Massacre, journalists arrived in Matewan titillated by "vague ideas of romance, adventure and bravour," and by the inherent danger of investigating industrial atrocities in a "lawless section" already made infamous by the Hatfield-McCoy Feud. ${ }^{4}$ Since most had spent their professional lives in the urban centers of the Eastern seaboard, the reporters who came to West Virginia between 1920 and 1922 possessed little first-hand knowledge of Appalachia. Therefore, their impressions of Mingo County were shaped by fifty years of local color literature which portrayed the upcountry South as a place in, but not of America. ${ }^{5}$ They described the men of Matewan as being "of an inheritance and habit apart," and "members of an atrophied race, a weaker strain of American stock." Also overwhelmed by the events they witnessed, the reporters lost their objectivity and were swept up into what they perceived as a fight against the

another. Edward W. Said, Orientalism (New York: Pantheon Books, 1978), 167, 54.

4"Baby Footprints in the Snows of Mingo County," United Mine Workers Journal 32 (15 January 1921): 14-15, 14; “A. G." by Helen Hayes Gleason, in The Book of Arthur Gleason, 99.

${ }^{5}$ Shapiro, 18. Heber Blankenhorn, Arthur Gleason, Winthrop Lane, and Jack Spivak spent most of their journalistic careers in New York, while James M. Cain, who later became famous as the author of Double Indemnity and The Postman Always Rings Twice, worked for the Baltimore Sun during the 1919-1922 mine war. (Blankenhorn) Heber Blankenhorn interview, Columbia University; (Gleason) Book of Arthur Gleason, 99; (Lane) "Testimony of Winthrop Lane," West Virginia Coal Fields, 997; (Spivak) A Man In His Time, 102; (Cain) Corbin, Mine Wars Anthology, 143.

6"The Primitive Mountaineer" New York Times, 3 August 1921; Cain, "Battleground of Coal," Mine Wars Anthology, 154. 
injustices perpetrated by industrial capitalism. " which undergirded the union-company struggle, the reporters transformed the miners of Mingo County and southern West Virginia into faceless "people who had lost a culture" and were now imprisoned in an unending string of rural ghettos. ${ }^{8}$

When it became evident that the miners were losing the battle to unionize Mingo, they were dismissed as "flotsam cast up by the backwash of a mighty struggle, pathetically loyal to a cause" they never really understood. ${ }^{9}$ Disheartened, the journalists retreated to New York and moved on to other causes. ${ }^{10}$ Arthur Gleason became the vice-president of the League for Industrial Democracy. ${ }^{11}$ Heber Blankenhorn worked with John Brophy on the UMWA's Nationalization Research Committee. ${ }^{12}$ Jack Spivak accepted a commission from the Call to

\footnotetext{
${ }^{7}$ Spivak, 110. Spivak later lamented his loss of impartiality because his direct involvement in the strike not only undermined his role as an observer, it also exhausted him. Another journalist, Mildred Morris, who was wounded during the Battle of Blair Mountain, became a media celebrity after her account of the battle drew the ire of West Virginia governor Ephraim F. Morgan. By the time the Massacre trials resumed in mid-September, 1921, Morris openly proclaimed her leanings by sitting with Sallie Chambers, the widow of Ed Chambers and the other defendants' wives. West Virginia Federationist, 15 September 1921.

${ }^{8}$ (oblivious) Batteau, 125; (serfs) ; (lost culture) Ross, Death of a Yale Man, 94-95; Lane, Civil War in West Virginia, 21-22. Lane's simplified depiction of Mingo's communities in 19201922 mirrors the representation of the Tug Valley by journalist T. C. Crawford, who wrote the first popular account of the Hatfield-McCoy feud in the late 1880s. Both Lane and Crawford painted a picture of the local community that excluded any elements that would have been recognizable to their contemporaries in other parts of the country. See Waller, Feud, 7-8 for a synopsis and analysis of Crawford's An American Vendetta.

${ }^{9}$ Cain, "Battleground of Coal," in Mine Wars Anthology, 154.

${ }^{10}$ Ross, Death of a Yale Man, 106.

${ }^{11}$ Gleason, The Book of Arthur Gleason, 204.

${ }^{12}$ Coleman, 106.
} 
cover the Sacco and Vanzetti trial. ${ }^{13}$ Although the memory of Matewan and the West Virginia mine war remained with them, only one seemed to grasp the impact of the press coverage on the lives of those whom the reporters sought to help. Shortly before his death in 1923, Arthur Gleason lamented that "the brilliant crusading of [these] outsiders" had been "attended by unwitting damage to obscure people."14 The journalists who wrote about Mingo County and the Williamson-Thacker strike immortalized the UMWA's struggle to unionize southern West Virginia, but in so doing, diminished both the humanity and the Americanness of the people at the epicenter of the contest.

However, the reporters should not bear alone either the blame for the "othering" of the people of Mingo County and southern West Virginia, or the loss of a localized focus to the story. In the absence of a local consensus regarding the Massacre and strike, much less their root causes, explanations were gladly provided by others interested in the outcome. ${ }^{15}$ As a result the United Mine Workers of America moved to the foreground of the narrative, while Mingo County and its inhabitants were pushed to the background.

${ }^{13}$ Spivak, 131.

${ }^{14}$ Gleason, The Book of Arthur Gleason, 202.

${ }^{15} \mathrm{~A}$ divided community reaction to struggles involving fundamental social, political, and economic principles is not unique to Appalachia or the United States. The ability of people from the same community, possessing essentially the same values, to "narrativize" an event differently is universal. See Ann Kane, "Reconstructing Culture in Historical Explanation: Narratives as Cultural Structures and Practice," History and Theory 39 (October 2000): 311-330, 317-318. Kane studied the Irish Land War of 1879-1882. The co-option of an event's meaning and importance is also examined in Dailey, "Deference and Violence," 581-582. Dailey studied the Danville, Virginia race riot of 1883. 
Representatives of the UMWA also set the tone for the denigration of Mingo's miners. Although black miners spoke most eloquently about the constitutionality of their struggle, the union's spokesman stressed the whiteness of the county's mining population. ${ }^{16}$ However when challenged to explain strike-related violence in West Virginia, both District 17 President Frank Keeney and the union's lead attorney, Harold W. Houston both invoked the feuding mountaineer stereotype ${ }^{17}$ In seeking to underscore the union's ability to prevent such strife, District 17 Secretary Fred Mooney purposefully likened the Williamson-Thacker strike to the 1912-1913 Paint Creek and Cabin Creek strike. ${ }^{18}$ Because Mooney's observation was offered before a U.S. Senate committee chaired by the same senator who had led the 1913 investigation, his intent was clear -- to convince the federal government that unionization was the only cure for the periodic disruption of the state's coal production. ${ }^{19}$

The intervention of federal power on behalf of the companies allowed the operators to win the 1920-1922 mine war. ${ }^{20}$ Intoxicated by the success of driving the union out of Mingo County, the operators promptly launched a propaganda campaign in which they claimed that

\footnotetext{
${ }^{16}$ (black miner) "Testimony of George Echols," West Virginia Coal Fields, 470; (spokesman) "Opening Statement of Neil Burkinshaw," West Virginia Coal Fields, 7. Burkinshaw, a newspaper reporter and "public relations man" had been hired by ACLU president Roger Baldwin to help publicize the UMWA's position on West Virginia. After the first two weeks of the 1921 senate hearings generated bad press for the miners, Burkinshaw was fired. Lunt, 146, 148.
} 33.

17"Testimony of C. F. "Frank" Keeney, West Virginia Coal Fields, 184; Houston Brief,

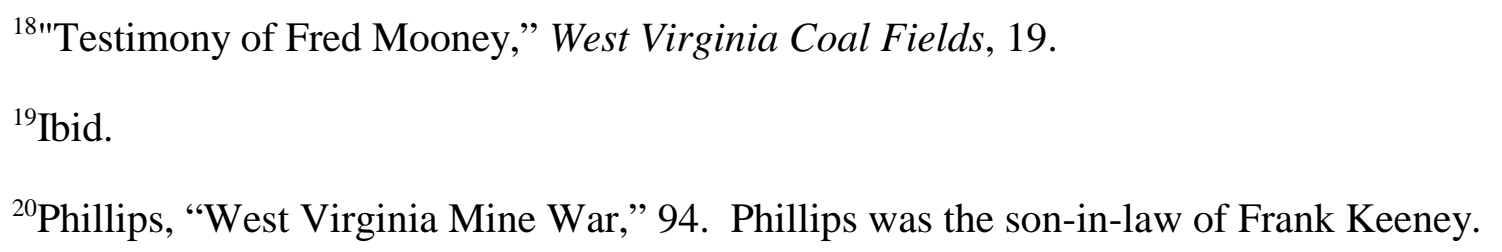


because of West Virginia's industrialization, little poverty existed in the state. ${ }^{21}$ West Virginia governor Ephraim Morgan excoriated the UMWA for fomenting rebellion at the behest of radical agitators. $^{22}$ The editor of the industry magazine, Coal Age, declared that "the name of Mingo has become [more than] . . . a household word ... the name of Mingo has become a stench in the nostrils of good American citizens and the source of that malodorous smell bears the union label.”23 Even contemporary academics' criticism of the union's actions in West Virginia appeared to endorse the operators' claim that they had been the defenders of the public's interest. ${ }^{24}$ Not until New Deal legislation formally endorsed the UMWA's legitimacy did southern West Virginia's operators realize that although they had won the 1920-1922 battle, they had lost the war with the union. ${ }^{25}$

The union's ascension in the 1930s was accompanied by a more subtle historiographic victory. From that time until recently, the UMWA has been portrayed as the proactive, and eventually ennobled agent in the organization of West Virginia's and Appalachia's working

${ }^{21}$ As one spokesman, Randolph Bias of Williamson, explained to the Kiwanis Club of Portland, Oregon, because property values in West Virginia exceeded two billion dollars, the average family of five was worth six thousand dollars. "'The Truth About West Virginia,' an address by Randolph Bias, an attorney of Williamson, W.Va. to the Kiwanis Club of Portland, Oregon on September 12, 1922," (Williamson, WV: n.p., 1923), 13. P4344, Pamphlet Collection, WVRHC.

22"Governor Explains," P7640, Pamphlet Collection, WVRHC.

23"Is Insurrection Proof of Americanism?," Coal Age 52 (7 September 1921), editorial page.

${ }^{24}$ See Hinrichs, The United Mine Workers of America and the Non-Union Coalfields, (1923), and Mary Hurst, "A Social History of Logan County, West Virginia, 1765-1928" (Master's thesis, Columbia University, 1928).

${ }^{25}$ Phillips, "Mine War," 94; Fred Mooney, Struggle in the Coal Fields, 164. 
class. ${ }^{26}$ Events such as the Matewan Massacre were mentioned, but depicted as only one of a series of "'outbreaks of violence' that were exclamation points to the economic hardships of the times and the operators' unrelenting campaign to cut wages and break the union."${ }^{27}$ Following the rediscovery of Appalachia during the turbulent 1960s, historians, inspired by the New Left critique of American capitalism turned their attention to the equally volatile history of West Virginia's coal fields. In their rush to celebrate the miners' challenge to the status quo, recent scholars also naively assessed the past through the lens of their own era, and forgot these words of warning from Malcolm Ross, author of Machine Age in the Hills, "I tried to show how the impersonal thread of economic interest can tangle tragically with the threads of human lives and without anyone being egregiously at fault."${ }^{, 28}$

Whether knowingly or unwittingly, historians from the 1970s through the 1990s, by analyzing the West Virginia mine wars, and the Matewan Massacre in particular, as events in

${ }^{26}$ Corbin, Introduction, Mine Wars Anthology, ii. After criticizing Lon Savage, the author of the popular account of the mine wars, for comparing the Matewan Massacre to the "Gunfight at the O.K. Corral," Corbin asserts that the West Virginia mine wars were like the AfricanAmerican civil rights movement. Since, and in contrast to African Americans, the humanity of white workers was never questioned, many scholars of the black experience in America consider such analogies "patronizingly insensitive." Dr. Jose Pimienta-Bey, <jpb@wvnvm.wvnet.wvnet.edu> "re: assertion dilemma," 1 May 2001, personal email, 1 May 2001. See Cornel West, Race Matters (Boston: Beacon Press, 1993), and Anti-Black Thought vols. 1-11, edited by John David Smith (New York: Garland Publishers, 1993) for more on the historical record concerning the difference between "seeking 'social equality' and recognition of one's 'humanity."”

${ }^{27}$ "John L. Lewis and the International Union of the UMWA: The Story from 1917-1952," (International Executive Board of the UMWA: Washington, D.C.: 1952), in the John L. Lewis Papers, State Historical Society of Wisconsin.

${ }^{28}$ Ross, Death of a Yale Man, 106. 
labor history have forged a new cognitive dissonance. ${ }^{29}$ Like the contemporary observers criticized by Allen Batteau, historians of the mine wars have ignored the other historical and political causes that influenced the miners' struggle, and thus unintentionally perpetuated the cycle of elevation through first begun by the UMWA and the journalists of the $1920 \mathrm{~s} .{ }^{30}$ The pioneer of the new interpretation, David Corbin, by focusing on the leadership of District 17, fell into the trap of the "Great Man" methodology and turned the miners into "essentially passive" victims in need of liberation. ${ }^{31}$ In an otherwise excellent explication of the legal ramifications of the West Virginia unionization struggle, Richard Lunt contextualized the miners' violence by stating that Matewan and Mingo County was "Hatfield-McCoy country." 32 As if following a cue left behind by the contemporary observers of the events of 1920-1922, historians collectively have focused their "discursive efforts" on southern West Virginia as a single entity with little regard for the unique experiences and motivations of "the historical actors" of Mingo County. ${ }^{33}$

${ }^{29}$ In Appalachia On Our Mind, Shapiro defines cognitive dissonance as the contrast between perception of reality and the reality that actually exists. Shapiro, xvi.

${ }^{30}$ Batteau, 125 . The author would argue that the historians' primary analytical failing mirrors the "error" identified by Herbert Gutman in "Work, Culture and Society." According to Gutman, American labor historians, from the Commons' School to the New Left have "spun a cocoon around American workers, isolating them from their own particular subcultures and the larger national culture." Gutman, "Work, Culture and Society," in Work, Culture and Society, 11.

${ }^{31}$ Critique of Corbin's "Frank Keeney Is Our Leader," by Warren Van Tine and John W. Hevener in Essays in Southern Labor History: Selected Papers from the Southern Labor History Conference, 157.

${ }^{32}$ Lunt, 146.

${ }^{33}$ Quoted phrases borrowed from Billings and Blee, 16. 
The resulting paradigm of the non-union coalfields of southern West Virginia created "not only knowledge but also the very reality [it appeared] to describe." 34 Don Chafin's dictatorial rule of Logan County symbolized the operators' subversion of the political autonomy of southern West Virginia's coal counties, but also precluded a discussion of the impact of Mingo County's unique political volatility which placed the pro-union G. T. Blankenship in the sheriff's office in $1920 .{ }^{35}$ The isolation of the coal camps in the more developed fields prevented an examination of the economic and political tensions fostered by the coexistence of the “company system" and independent merchants in communities such as Matewan. ${ }^{36}$ The emergence of an interracial working class solidarity was ascribed to the racial and ethnic

${ }^{34}$ Said, 94. To illustrate what historians left out of the new narrative of the second West Virginia mine war, the following quotations include parallel or contrasting citations from the (contemporary) reporters and historical analyses.

${ }^{35}$ (contemporary) Arthur Gleason, "Company-Owned Americans," Nation 110 (12 June 1920): 794-795. In explaining how operators dominated southern West Virginia's coal counties, Gleason discusses only Logan, and its sheriff, Don Chafin. (historian) Like Gleason, Corbin names only Chafin, and discusses at length his corrupt and oppressive regime, but does not mention Blankenship. Corbin, Life, Work, and Rebellion, 115-116, 210-235.

${ }^{36}$ (contemporary) At one point in his description of life in southern West Virginia's coal communities Winthrop Lane denies the existence of any towns that other Americans could recognize as such, and states there were only "camps" which clustered around the mines. Lane, Civil War in West Virginia, 21-22. (historians) Corbin uses the company town of Iaeger, in McDowell County, which was fifteen miles from the nearest commercial center, as an example of the miners' economic isolation from businesses which would have competed with the "company store." Corbin, Life, Work, and Rebellion, 68. Fifteen years after the publication of Corbin's monograph, Roger Fagge expanded on the isolation theme in order to argue that the lack of independent towns retarded the growth of political culture among southern West Virginia's mining class. Fagge, 210-211. Both of these scholars overlooked the contrasting experience of several communities in Mingo, and the critical example Matewan, which at one point was home to the local offices of five coal companies, and later, the Stone Mountain company store. See: 1912-1913 West Virginia State Gazetteer and Business Directory, 469 and Chapter 10 , note 50 . 
heterogeneity of the mining camps, while the actual low number of African Americans and European immigrants in Mingo and the white miners' bigotry was ignored. ${ }^{37}$ The scholars' prounion bias and macrocosmic representation of southern West Virginia ultimately has led to the inclusion of factual errors as scholars have increasingly relied on their predecessors' conceptualizations when examining the available body of evidence. ${ }^{38}$

${ }^{37}$ (historian) Skeen, "Industrial Democracy, Social Equality, and Violence," abstract. Skeen states that African Americans and European immigrants comprised 50 percent of southern West Virginia's mining population. In fact, Mingo's ethnics comprised a mere 11 percent of the population, one-fifth of Skeen's figure. See Appendix 5. Moreover, the sustained effort to defeat the strike reawakened the prejudice of many native white miners as the following exchange between a journalist and Martin Justice, the "mayor" of the Lick Creek tent colony demonstrates. "The foreigners all lit out when the shooting began ... we're all Americans here." New York Times, 7 December 1920. Joe William Trotter's essay, "Black Miners in West Virginia," explains that Mingo's black miners suffered a "disproportionate" share of the operator-directed reprisals. Trotter, "Black Miners in West Virginia," in The United Mine Workers of America: A Model of Industrial Solidarity?, 289. The only documented case of permanent exclusion, or "blackballing" from mine employment in Mingo County involved Joe Morrell, an Italian-born miner who spoke several European languages. Because of his linguistic facility, Morrell would meet the "transportation" trains of replacement workers and in their native tongues reveal that they were entering a strike district. Venchie Morrell 1989 and 1990 interviews.

${ }^{38}$ Perhaps the most egregious example of factual error appears in Roger Fagge's comparative study of political culture in southern West Virginia and South Wales. By accepting without question the assertion of previous scholars regarding the political omnipotence of southern West Virginia's coal operators, Fagge notes that because the operators were so powerful, the Baldwin-Felts agents involved in the Massacre and the deaths of Sid Hatfield and Ed Chambers never faced legal judgment. Fagge, 146. As this author has documented, although the operators power allowed them to subvert the law to protect the agents, they assiduously observed the form of the law by not interfering with the trial of either the agents who survived the Massacre or the ones who assassinated Hatfield and Chambers. See Chapter 10 for citation. Although more eminent scholars may disregard Fagge's study because of its outdated premise -an exploration of the failure of West Virginia miners to develop a political radical class consciousness, his novel approach to analyzing the mine wars will ensure it inclusion in the historiography. 
Because historians have stubbornly persisted in confining the story of the Matewan Massacre within the boundaries of Appalachian labor studies, the history of the Massacre and Mingo County still exemplifies an assertion made by Christian missionary John C. Campbell in 1921. As Campbell noted, "this is a land ... about which perhaps more things are known that are not true than any part of the country. ${ }^{\prime 39}$ By restricting the parameters of the conflict to the struggle between the miners and the operators, historians also have constructed a distorted historical narrative that allows other Americans to continue "trivializing" the experiences of the people of Matewan and Mingo County. ${ }^{40}$ A contemporary spectator of the Williamson-Thacker strike presciently predicted the cumulative effect of the historiography of the second mine war. As James M. Cain noted, their fellow Americans flock to Matewan hoping to find the notorious Devil Anse or Sid Hatfield, but instead find "the Last of the Mohicans turned tourists' cook." Offered the enticement of capitalizing on outsiders' interest in their "history," the people of Matewan and Mingo County have been expected to remain frozen in time, caretakers of an historical place maintained to remind the rest of America of "how far the nation has come from its essential self." ${ }^{42}$

${ }^{39}$ John C. Campbell, The Southern Highlander and His Homeland (Lexington, KY: University Press of Kentucky, 1969 [reprint of 1921 edition published by the Russell Sage Foundation]), original foreword, xxi. Southern Highlander was published two years after Campbell's death in 1919.

40"Trivializing" is borrowed from Altina Waller, "Feuding in Appalachia," in Appalachia in the Making, 370.

${ }^{41}$ James M. Cain, "West Virginia: A Mine-Field Melodrama," in Corbin, Mine Wars Anthology: 144-50, 146. This essay first appeared in Nation 113 (27 July 1923).

${ }^{42}$ Shapiro, 261. Durwood Dunn's Cades Cove documents a more extreme example of how Appalachian communities have been forced to surrender their futures to an externally 
Verification that the people of Matewan and Mingo County know that they have been "othered" can be found in the Matewan Oral History project interviews from the summers of 1989-1990. ${ }^{43}$ Although the interviews offer tantalizing glimpses of the Feud and the Massacre, they also demonstrate the community's ability to synthesize apparently contradictory actions and events to a degree that has eluded a score of academicians. When Venchie Morrell spoke kindly of both Sid Hatfield and P. J. Smith, the superintendent of the Stone Mountain mine, despite witnessing an incident during which Hatfield assaulted Smith, he invited his interviewer to reexamine the historical record of coal company officials in Mingo County. ${ }^{44}$ Not surprisingly, she found evidence that Smith was also a casualty of the industrial struggle ${ }^{45}$ By restoring the

defined conception of their past. In the case of Cades Cove, a century of growth and development was sacrificed to the construction of a "representative" Appalachian frontier settlement that little resembled the community destroyed to erect it. Durwood Dunn, Cades Cove: The Life and Death of a Southern Appalachian Community, 1818-1937 (Knoxville: University of Tennessee Press, 1988).

${ }^{43}$ Author's Assertion based on an ethnographic analysis of Matewan Oral History project interviews for the seminar paper, "Lost Voices: Memories of the Matewan Massacre," written in the spring of 1994.

${ }^{44}$ Venchie Morrell, (1990) interview. Mr. Morrell remembered Hatfield's kindness to children, but he also observed that Smith was nice, quiet man who had done nothing to provoke Hatfield's attack. (contemporary documentation) James P. Woods to S. D. Stokes 21 May 1921, Stokes Collection, WVRHC, and, "Matewan Firebugs Burn Mine House, Firemen Refuse Aid," New York Times 23 May 1921. Angered that Smith was using "scabs" from North Carolina to operate the Stone Mountain mine, Hatfield struck Smith twice in the head with his rifle butt. When the men from North Carolina refused to continue working, Stone Mountain had no choice but to close the mine.

${ }^{45} \mathrm{~A}$ Baldwin-Felts secret agent reported to company headquarters that he overheard Smith telling two of his former (and now union) employees that did not have the authority to reopen Stone Mountain as a union mine, and had to adhere to the company's non-union policy. "Report of \#49," 30 July 1920, Lewis Collection, ERCA. Apparently galvanized by his strike experience, Smith eventually attempted to run for local political office in defiance of the political consensus evoked by the strike. S. D. Stokes to James P. Woods, 3 November 1922, Stokes Papers, 
human complexity of those caught up in the Massacre and strike, the narrators fleshed out people who had been reduced to archetypal caricatures. ${ }^{46}$ Who could imagine that a man who, with murderous intent, stalked the streets of Matewan in the Massacre's aftermath, would later tearfully beg his firstborn to not to ever move away and leave him $?^{47}$ Or that this same individual would befriend a man he would have gladly killed on May 19, 1920, partner with him in the mines, and upon their deaths lie in the same cemetery. ${ }^{48}$ Unlike the incident related by Venchie Morrell, the veracity of this story could not be established. Given the subsequent religiosity of the man who first told it, the tale of friendship between two former enemies might have been just an instructional parable concocted for his children. ${ }^{49}$ However, cynics tempted to dismiss the

WVRHC. Not long after Stokes wrote to Woods asking that something be done about Smith, Smith lost his position as Stone Mountain superintendent. Assertion based on information from the 1922 Annual Department of Mines.

${ }^{46}$ The two most prominent examples are Sid Hatfield and C. E. Lively. Even before his death, Sid Hatfield was viewed as either a folk hero or a bully "in a cheap snuff-colored suit." See: "Testimony of Mrs. Stella Scales," Lewis Collection, ERCA, and "Sid Hatfield Bows to Mingo Sheriff," New York Times, 25 May 1921. Contemporary newspaper descriptions of Lively depict him as a man of "gentle speech" and "suave manners." "Fed Miners to Get Truth About Battle," unknown newspaper, 25 February 1921, Matewan Omnibus Collection, ERCA. While Hatfield's stature as hero has grown, Lively has been vilified. Paul Lively interview. However, most of the project narrators had little difficulty acknowledging the duality of Hatfield's and other Massacre participants' natures. See the interviews of: Hawthorne Burgraff, Venchie Morrell (1990), and Bertha Damron.

${ }^{47}$ Ruby Aliff interview.

${ }^{48}$ Ibid. According to Mrs. Aliff, Baldwin-Felts agent Bob Buckhannon returned anonymously to Mingo and worked at Red Jacket with her father, Massacre defendant, Ben Mounts. She related that when Buckhannon confessed his true identity, he declared to Mounts "that no amount of money could hire him to do a thing like that again. Mounts kept Buckhannon's secret until he died.

${ }^{49}$ Ibid. Mrs. Aliff recounted that after years of hard-drinking, her father found religion and to the delight of his neighbors, would sit on the porch of his home singing gospel hymns in a 
story as a myth should be cautioned by this observation by historian Sean Wilentz: "myths after all, draw on popular beliefs and ... once formulated, they help order people's understanding of the world and tell us something about social relations." ${ }^{n 0}$ The story of the miner and the repentant Baldwin-Felts agent symbolizes the resilience of the people of Matewan, who perceived the need to make peace with their past and move forward.

As a document of communal expression, the 1989-1990 interviews also contain a poignant plea for recognition that the history of Matewan and Mingo County be seen as more than just a string of violent incidents and notorious characters. Once motivated to share their memories, the Matewan narrators exhibited little interest in proving that they knew who shot Mayor Testerman or who fired the Massacre's first shot. Rather, they wished to show that outsiders' preoccupation with the event has created a distorted historical narrative that culturally isolates them and diminishes their status as Americans. What they could not know was that they had inspired a historian to explore ways of affirming their desire to integrate the Massacre and strike into the broader continuum of the history of their community. That was the genesis of this study.

"Matewan Before the Massacre" demonstrates that the story of the Massacre, unshackled from the rhetoric of outside interests and observers is, at its core, an American story, which captures a pivotal moment in our national history. ${ }^{51}$ Political machines and reformers vied for

beautiful booming voice that reached to the mouth of their hollow.

${ }^{50}$ Sean Wilentz, Chants Democratic: New York City \& The Rise of the American Working Class, 1788-1850 (New York: Oxford University Press, 1986 [1984]), 13.

${ }^{51}$ In an interview with Michael Morrell, Herbert Gutman noted that David Montgomery's studies of American labor history have shown that certain eras in American history are 
power in communities across the nation, not just in Appalachia. ${ }^{52}$ Industrialization reconfigured the economic and social landscape of the entire country, not just southern West Virginia. ${ }^{53}$ Domination through violence occurred not only on the streets of Matewan, but also in the tenement districts of New York, the cotton fields of the South, and the plains of the Southwest. ${ }^{54}$ Still, no other community has been so enslaved to an externally imposed version of its past as the town of Matewan.

If liberated from the shadow of the Massacre myth, the oral histories of Matewan could reveal hundreds of stories which would resonate with Americans from all walks of life. Joe Morrell, the only man blackballed for his union activism, arrived in America from Italy with five brothers whom he never saw again after departing New York for West Virginia. ${ }^{55}$ He married Sophie, an Austrian immigrant who delivered twins in the winter's cold, sheltered only by the thin canvas of a union tent. ${ }^{56}$ They reared a son, who along with other children, mocked the local

noteworthy because they were hallmarks in the recurrent struggle over the meaning of America. Interestingly the three cited: the 1830s, the 1880s, and the 1910s-1920s, were also pivotal decades in the history of the Tug Valley. "Herbert Gutman Interview," in Herbert Gutman, Power and Culture: Essays on the American Working Class, edited by Ira Berlin (New York: Pantheon Books, 1983): 329-356, 334.

${ }^{52}$ One scholar has noted that in "nine-tenths" of the counties across America, local politicals affairs have been controlled by "courthouse gangs." Lane W. Lancaster, Government in Rural America (New York: Van Nostrand, 1952), 57.

\section{Society.}

${ }^{53}$ For a social history of American industrialization, see Gutman, Work, Culture and

${ }^{54}$ As historian Irving Bernstein has noted, violence is an "extraordinary American tradition of resolving disputes with guns instead of words.” Bernstein, 43.

${ }^{55}$ Venchie Morrell, 1989 and 1990 interviews.

${ }^{56}$ Sallie Dickens interview. 
Klansmen who marched through Matewan, their identities betrayed by the way they walked. ${ }^{57}$ The son of Joe and Sophie grew to manhood and joined the other sons of Matewan and went off to fight for his country in the second World War. ${ }^{58}$ How many American families can recount the initial sighting of the Statue of Liberty by an ancestor? Would they not empathize with Manuel Barrios, the son of a Spanish mason recruited by Red Jacket in the midst of the Williamson-Thacker strike, who sixty years later could still vividly recall his first glimpse of "the beautiful lady"? ${ }^{59}$ Should his story of learning English by shopping for his mother at the company store be forgotten because his father was a "scab?" If the stories of the Morrell and Barrios families reveal another side of Matewan, the story of the Collins' family encapsulates the tragic injustice of isolating Appalachian history. John and Steve Collins, two of the few men sent to prison for Mingo's strike-related violence, held onto their faith in the union, and in their country. Steve sent a son off to war and lost him the day before Christmas eve, $1944 .^{61}$ John's $^{\text {' }}$ grandson survived the killing fields of Vietnam, only to die at age 21 in a mining incident two months after his return. ${ }^{62}$

\footnotetext{
${ }^{57}$ Venchie Morrell (1990) interview.

${ }^{58} \mathrm{Ibid}$; Bertha Damron interview; Harold Dickens interview.

${ }^{59}$ Manuel Barrios, interview with Rebecca Bailey, Summer 1989 Matewan Oral History
} Project.
${ }^{60}$ Ibid.
${ }^{61}$ Bertha Damron interview.
${ }^{62}$ Ibid. 
Many other stories from Matewan mirror the poignancy of those described above. The youth of Matewan and Mingo County need to hear them, not just the stories of the Feud and the Massacre. Because like their forbearers, they also are caught up in the ongoing struggle over Appalachia's economic future, and they too will be judged for the decisions they make. In the classrooms of Mingo County today, the sons and daughters of union men again sit beside the children of nonunion men. If there is any hope that they can break the cycle that has kept their community divided and impoverished, a reconceptualized and demythologized history must be written. ${ }^{63}$ It is my hope that perhaps, however infinitesimally, "Matewan Before the Massacre" will assist the community in this enterprise, and help remind historians that all history is local.

63"Mingo County Has Highest Unemployment Rate in State," Charleston Gazette, 24 August 1999. 


\section{BIBLIOGRAPHY}

\section{Archival Collections}

Catholic University, Washington, D.C.

John Mitchell Papers. Microfilm copy of this collection also available in Microfilm Collection, Wise Library, West Virginia University.

Eastern Regional Coal Archives. Craft Memorial Library. Bluefield, West Virginia. Bluefield Daily Telegraph Collection

William Y. Cooper Collection

David E. Johnston Collection

William S. Leckie Collection

H. C. Lewis Collection

Roland Luther Collection

Matewan Omnibus Collection

Pocahontas Land Corporation Collection

Ernie Reynolds Collection

Matewan Development Center. Matewan, West Virginia.

Bowman, T.E. "From West Riding to West Virginia." Unpublished manuscript.

Dixie Accord, interview with John Hennen, Summer 1989 Matewan Oral History Project.

"Smokey" Mose Adkins, interview with John Hennen, Summer 1989 Matewan Oral History Project.

Ruby Aliff, interview with Rebecca J. Bailey, Summer 1989 Matewan Oral History Project. Mattie Allara, interview with Rebecca J. Bailey, Summer 1989 Matewan Oral History Project. Jim Backus, interview with John Hennen, Summer 1989 Matewan Oral History Project. Manuel Barrios, interview with Rebecca Bailey, Summer 1989 Matewan Oral History Project. Harry Berman, interview with John Hennen, Summer 1989 Matewan Oral History Project. Vicie Blackburn, interview with Rebecca J. Bailey, Summer 1990 Matewan Oral History Project. Archie Bland, interview with Rebecca J. Bailey, Summer 1990 Matewan Oral History Project. Tom Blankenship, interview with C. Paul McAlister, Summer 1990 Matewan Oral History Project.

Edith Boothe, interview with Rebecca J. Bailey, Summer 1989 Matewan Oral History Project. Hawthorne Burgraff, interview with John Hennen, Summer 1989 Matewan Oral History Project. Eva Cook, interview with Rebecca J. Bailey, Summer 1990 Matewan Oral History Project. James Curry, interview with Rebecca J. Bailey, Summer 1990 Matewan Oral History Project. Bertha Damron, interview with Rebecca J. Bailey, Summer 1989 Matewan Oral History Project. Harold Dickens, interview with Rebecca J. Bailey, Summer 1990 Matewan Oral History Project. Sallie Dickens, interview with Rebecca J. Bailey, Summer 1990 Matewan Oral History Project. Addie Dixon, interview with Rebecca J. Bailey, Summer 1990 Matewan Oral History Project. Everett Faddis, interview with John Hennen, Summer 1989 Matewan Oral History Project. Johnny Fullen, interview with Rebecca J. Bailey, Summer 1990 Matewan Oral History Project. Virginia Grimmett, interview with Rebecca J. Bailey, Summer 1989 Matewan Oral History Project. 
Basil Hatfield, interview with Rebecca J. Bailey, Summer 1989 Matewan Oral History Project. Clarence "Dutch" Hatfield, interview with Rebecca J. Bailey, Summer 1989 Matewan Oral History Project.

Ernest Hatfield, interview with John Hennen, Summer 1989 Matewan Oral History Project. Margaret Hatfield, interview with Rebecca J. Bailey, Summer 1990 Matewan Oral History Project.

Josephine Hope, interview with Rebecca J. Bailey, Summer 1990 Matewan Oral History Project. Paul Lively, interview with Rebecca J. Bailey, Summer 1990 Matewan Oral History Project. John McCoy, interview with John Hennen, Summer 1989 Matewan Oral History Project. Venchie Morrell, interview with John Hennen, Summer 1989 Matewan Oral History Project. Venchie Morrell, interview with Rebecca J. Bailey, Summer 1990 Matewan Oral History Project. Nel Nenni, interview with John Hennen, Summer 1989 Matewan Oral History Project.

Daisy Nowlin, interview with Rebecca J. Bailey, Summer 1989 Matewan Oral History Project. Rose Ore, interview with John Hennen, Summer 1989 Matewan Oral History Project. Hiram Phillips, interview with John Hennen, Summer 1989 Matewan Oral History Project. Kenny Phillips, interview with John Hennen, Summer 1989 Matewan Oral History Project. Stella Presley, interview with Rebecca J. Bailey, Summer 1989 Matewan Oral History Project. Harold Radford, interview with John Hennen, Summer 1989 Matewan Oral History Project. Jeannette Simpkins, interview with Rebecca J. Bailey, Summer 1990 Matewan Oral History Project.

Rufus Starr, interview with John Hennen, Summer 1989 Matewan Oral History Project. Bertha Staten, interview with Rebecca J. Bailey, Summer 1989 Matewan Oral History Project. Melvin Triolo, interview with John Hennen, Summer 1989 Matewan Oral History Project. Rosa Wolford, interview with Rebecca J. Bailey, Summer 1990 Matewan Oral History Project.

Special Collections of the University of Virginia. Alderman Library. University of Virginia. Charlottesville, Virginia.

E. L. Stone Papers

State Historical Society of Wisconsin. Madison, Wisconsin.

The Papers of John L. Lewis. Microfilm Collection.

West Virginia and Regional History Collection. West Virginia University. Morgantown, West Virginia.

\section{Manuscript Collections:}

Johnson Newlon Camden Papers

George Rogers Clark Floyd Papers

Justus Collins Papers

John J. Cornwell Papers

Henry D. Hatfield Papers

Roy H. Keadle Papers

Matewan Massacre Papers

George C. McIntosh Papers

Ephraim F. Morgan Papers

Samuel Davis Stokes Papers 
W. P. Tams, interview with Richard Hadsell. Typescipt. Although this is an oral history interview, it was accessioned by the West Virginia and Regional History Collection into the Manuscript Collection.

\section{Microfilm Collection:}

State of West Virginia. County Records. Logan County. "Index to Grantee Records, W-Z," Reel 172.

State of West Virginia. Historic Records Survey of County Records. "Mingo County Commissioners' Records, Book I,” Reel 125.

\section{Oral History Collection:}

Carey, William. Interview with Keith Dix, 17 October 1971, at Red Jacket, Mingo County, WV.

Lavinder, A. D. Interview with Bill Taft and Lois McLean, 22 June 1973, at Matewan, Mingo County, WV.

\section{Pamphlet Collection:}

Bias, B. Randolph. "Condensed Facts: Relating to the Republican Organization in Mingo County, W.Va." n.p., n.d. Pamphlet 8662.

------. “The Truth About West Virginia,' an address by Randolph Bias, an attorney of Williamson, W.Va. to the Kiwanis Club of Portland, Oregon on September 12, 1922," (Williamson, WV: n.p., 1923), 13. Pamphlet 4344.

"'Confidential': Conservative Statement of the Situation of the Coal-Carrying Railroads, in their relation to the Coal and Coke Development of Kentucky, Virginia, West Virginia, and Tennessee (Compiled from an Official Report for 1903)." n.p.:n.d. Pamphlet 7080.

"Governor Explains Why Federal Troops Brought Into West Virginia -- Six Thousand Deluded Men In Insurrection, Reason He Offers (New York Commercial, 1921 [reprint]), Pamphlet 7640.

Shattuck, Henry L. "Horse and Buggy Days in the West Virginia Appalachians," in Massachusetts Historical Society Proceedings 80 (1968): 71-78. Removed from its parent journal, this article was accessioned into the WVRHC Pamphlet Collection as Pamphlet 12796.

"Telegram from Harold W. Houston to the National Executive Committee, Socialist Party, read at the meeting of the committee, 11 May 1913," reported by Grace Silver in "National Committee Meeting, Socialist Party, in International Socialist Review. Several sections of this issue, pertaining to the Paint Creek and Cabin Creek Strike, 1912-1913 were removed and accessioned into the WVRHC Pamphlet Collection as Pamphlet 191.

West Virginia State Council of Defense. Report of the Secretary on the Operation of the Compulsory Work Law, for the Year Ending June 19, 1918. Charleston, WV: Tribune Printing Company, 1918. Pamphlet 2902. 
Young, Houston G., Secretary of State of West Virginia, State of West Virginia: Official Returns of the General Election, held November 2, 1920. Charleston, WV: Tribune Printing Co, 1920. J. Hop Woods Bound Pamphlet Collection, 11476, volume 15.

Rare Book Collection:

"A Virginia Boy," [pseudonym]. Sodom and Gomorrah Today, or the History of Keystone, West Virginia. n.p. 1912.

Sowers, A. D. Some Facts about McDowell County, West Virginia. Keystone, WV: A. D. Sowers, 1912.

\section{Unpublished Materials in the Author's Possession}

Bailey, Rebecca J. "Lost Voices: Memories of the Matewan Massacre," seminar paper. 1994. Hatfield, Margaret. Undated Correspondence with Author, 1997-1998.

\section{United States Documents}

Bituminous Operators Special Committee. United Mine Workers in West Virginia; submitted to the United States Coal Commission, August 1923. n.p., 1923.

"Contested Election Case of Rankin Wiley v. James A. Hughes from the Fifth Congressional District of West Virginia." Sixty-Second Congress, 2d session, Report No.1229 [Mr. Covington, from the Committee on Elections No.1 submitted the following report to accompany H.Res.703]. Washington: Government Printing Office, 1912.

Coolidge, William H. Brief in behalf of Island Creek Coal Company. Boston; n.p., 1921.

"Extracts from Speech of Harold W. Houston at Holly Grove, on Paint Creek, August 14, 1912," in Conditions in the Paint Creek District, West Virginia: Hearings Before a Subcommittee of the Committee on Education and Labor, Part 3 (Washington: GPO, 1913).

Houston, Harold W. Brief on behalf of the United Mine Workers of America, before the committee on Education and Labor, United States Senate, in the matter of the investigation of violence in the coal fields of West Virginia and adjacent territory. n.p. 1921.

"Memorial for Congressman James A. Hughes." Memorial Services Held in the House of Representatives of the United States, Seventy-First Congress, 2d Session, House Document \#506. Washington: Government Printing Office, 1930.

Murray, Philip. The Case of the Coal Mine Workers: Opening Statement . . Before the Committee on Education and Labor of the United States Senate, October 1921. Washington, DC: UMWA, 1921. 
Olmsted, Harry. Statement of Harry Olmsted, Chairman of the Labor Committee of the Operators Association of the Williamson Field to the Senate Investigating Committee, July 14, 1921. Washington: W.F. Roberts Co., 1921.

Operators' Association of the Williamson Field. Statement Before the Subcommittee of the Committee on Education and Labor of the United States Senate. n.p.; 1921.

Red Jacket v. John L. Lewis, et al. Transcript of the Record: District Court of the United States for the Southern District of West Virginia at Charleston: Red Jacket Consolidated Coal and Coke Company, et al, plaintiffs, versus John L. Lewis, president, et al. 3 vols. Charleston, WV: Jarrett Printing Company, 1923.

Thomas, B. F. Improvement of the Big Sandy River, West Virginia and Kentucky, Letter from the Secretary of War transmitting in response to the concurrent resolution of the House of Representatives of April 13, 1898. A letter of the Chief of Engineers, Together with a report on the plans and estimates for the improvement of the Big Sandy and certain of its branches in West Virginia and Kentucky, May 9, 1898. Fifty-Fifth Congress, 2d Session, House of Representatives, Document \#456.

United States. Bureau of the Census. Census of Agriculture and Manufactures, for the Year 1850. National Archive Microfilm Publication (NAMP).

United States. Bureau of the Census. Census of Agriculture and Manufactures, for the Year 1860. (NAMP)

United States. Bureau of the Census. Twelfth Census, Population of the United States in 1900. (NAMP)

United States. Bureau of the Census. Thirteenth Census, Population of the United States in 1910. (NAMP)

United States. Bureau of the Census. Thirteenth Census, Abstract of the Census, with Supplement for West Virginia. Washington, D.C.: GPO, 1913.

United States. Bureau of the Census. Fourteenth Census, Population of the United States in 1920. (NAMP)

United States. Bureau of the Census. Fourteenth Census, State Compendium: West Virginia. Washington, D.C.: GPO, 1925.

U.S. Congress. Senate. Committee on Education of Labor. West Virginia Coal Fields: Hearings . . to investigate the recent acts of violence in the coal fields of West Virginia and adjacent territory and the causes which led to the conditions which now exist in said territory. Washington: GPO, 1921. 
U.S. Congress. Senate. Committee on Education and Welfare. West Virginia Coal Fields: Personal Views of Senator Kenyon and views of Senators Sterling, Phipps, and Warren. . .. Washington: GPO, 1922. (67th Congress. 2d Session Senate Report 457).

\section{West Virginia Documents}

State of West Virginia. State Board of Agriculture. Biennial Report of the State Board of Agriculture, for the Year, 1917-1918. Charleston: Tribune Printing Company, 1918.

State of West Virginia. State Board of Health. Biennial Report of the State Board of Health, 1908-1909. Charleston: News-Mail Company, 1910.

State of West Virginia. Department of Agriculture, Third Biennial Report of the West Virginia Department of Agriculture, 1917-1918. Charleston, WV: Tribune Printing Company, 1918.

State of West Virginia. Department of Health. Biennial Report of the West Virginia State Department of Health, 1917-1918. Charleston: Tribune Printing Company, 1918.

State of West Virginia. Department of Health. Biennial Report of the West Virginia State Department of Health, 1919-1920. Charleston: Tribune Printing Company, 1920.

State of West Virginia. Department of Mines. Annual Report of the West Virginia Department of Mines, 1891-1922.

State of West Virginia. Education Department. West Virginia Education Directory, for the School Year 1917-1918, edited by M. P. Shawkey. Charleston, WV: Tribune Printing Company, 1918.

State of West Virginia. Secretary of State. Report of Incorporations in the State of West Virginia, for the Years 1905-1907. Charleston, WV: Tribune Printing Company, 1907.

State of West Virginia. West Virginia Legislature. Acts of the West Virginia Legislature, for the year 1915. Charleston, WV: Tribune Printing Company, 1915.

State of West Virginia. West Virginia Legislature. Acts of the West Virginia Legislature, for the year 1917. Charleston, WV: Tribune Printing Company, 1917.

State of West Virginia. West Virginia Legislature. Acts of the West Virginia Legislature. 2d Extraordinary Session. Charleston: Tribune Printing Company, 1917.

State of West Virginia. West Virginia Legislature. Acts of the West Virginia Legislature, for the year 1921. Charleston, WV: Tribune Printing Company, 1921.

State of West Virginia. West Virginia Legislature. John J. Cornwell and others, "West Virginia in The War." In West Virginia Legislative Handbook and Manual and Official Register, 
for the year 1918, compiled and edited by John T. Harris, clerk of the Senate, 775-948. Charleston, WV: The Tribune Printing Company, 1918.

State of West Virginia. West Virginia Legislature. West Virginia Legislative Handbook and Manual and Official Register, for the year 1917, compiled and edited by John T. Harris, clerk of the Senate. Charleston, WV: The Tribune Printing Company, 1917.

State of West Virginia. West Virginia Legislature. West Virginia Legislative Handbook and Manual and Official Register, for the year 1919, compiled and edited by John T. Harris, clerk of the Senate. Charleston, WV: The Tribune Printing Company, 1919.

State of West Virginia. West Virginia Legislature. West Virginia Legislative Handbook and Manual and Official Register, for the year 1920, compiled and edited by John T. Harris, clerk of the Senate. Charleston, WV: The Tribune Printing Company, 1920.

State of West Virginia. West Virginia Legislature. Chapter 68 "An Act establishing the County of Mingo," Acts of Legislature of West Virginia, Twenty-Second Regular Session. Charleston: Moses W. Donnally, 1895.

State of West Virginia. West Virginia Legislature. Chapter 35 "Concerning Deadly Weapons, Etc. (Red Man's Act), in Acts of the West Virginia Legislature, for the year 1882. Wheeling, WV: W. J. Johnston, Public Printer. 1882.

State of West Virginia. West Virginia Legislature. Chapter 12 "The Idleness and Vagrancy Act" Senate Bill \#7, in Acts of the West Virginia Legislature, Second Extraordinary Session, May 14-26. Charleston, WV: Tribune Printing Company, 1917.

State of West Virginia. West Virginia Legislature. Chapter 9 "Special Deputy Bill” House Bill \#34, Acts of the West Virginia Legislature for the year 1917. Charleston: Tribune Printing Company, 1917.

State of West Virginia. West Virginia Legislature. Chapter 4 "Williamson Charter Bill" Senate Bill \#199, Acts of the Legislature of the State of West Virginia, 1915.

State of West Virginia. West Virginia Legislature. "Williamson Mining and Manufacturing Company," Reports of Incorporation. Acts of the West Virginia Legislature for 1891. Charleston, WV: Moses W. Donnally, 1891.

West Virginia. West Virginia State Supreme Court of Appeals. "Bragg, et al v. United Thacker Coal Company." Reports of the West Virginia State Supreme Court of Appeals 70 (November 1911- April 1912): 604-660.

West Virginia. West Virginia State Supreme Court of Appeals. "Ex Parte A. D. Lavinder, et al." Reports of the West Virginia Supreme Court of Appeals, 53 (March 28, 1903-November 21, 1903): 515-524. 
West Virginia. West Virginia State Supreme Court of Appeals. "Ferrell v. Ferrell." Reports of the West Virginia Supreme Court of Appeals, 53 (March 28, 1903-November 21, 1903): 515524.

West Virginia. West Virginia State Supreme Court of Appeals. "Hatfield v. Allison." Reports of the West Virginia Supreme Court of Appeals, 57 (January 24, 1905-April 25, 1905): 374384.

West Virginia. West Virginia State Supreme Court of Appeals. "Mate Creek Coal Company v. Todd, et al." Report of the West Virginia Supreme Court of Appeals, 66 (May 4, 1909 February 1, 1910): 671-679.

West Virginia. West Virginia State Supreme Court of Appeals. "Runyon v. Rutherford." Reports of the West Virginia Supreme Court of Appeals, 55 (February 9 1904-June 1904): 436442.

West Virginia. West Virginia State Supreme Court of Appeals. "Slaughter v. Thacker Coal \& Coke Company." Reports of the West Virginia Supreme Court of Appeals, 55 (February 9, 1904-June 9, 1904): 642-644.

West Virginia. West Virginia State Supreme Court of Appeals. "Stafford v. Board of Canvassers." Reports of the West Virginia Supreme Court of Appeals, 56 (June 14, 1904): 670-675.

West Virginia. West Virginia State Supreme Court of Appeals. "Stafford v. Sheppard." Reports of the West Virginia Supreme Court of Appeals, 57 (January 24, 1905-April 25, 1905): 81-90.

West Virginia. West Virginia State Supreme Court of Appeals. "Stafford v. County Court." Reports of the West Virginia Supreme Court of Appeals, 58 (April 25, 1905-February 6, 1906): 88-94.

West Virginia. West Virginia State Supreme Court of Appeals. "State ex rel. M. Z. White, Relator v. County Court of Mingo County." Reports of the West Virginia Supreme Court of Appeals 86 (March 16- September 21 1920): 517-518.

West Virginia. West Virginia State Supreme Court of Appeals. "State of West Virginia v. J. S. McCoy." Reports of the West Virginia Supreme Court of Appeals 91 (April 25, 1922October 17, 1922): 262-268.

West Virginia. West Virginia State Supreme Court of Appeals. "State of West Virginia v. Elias Hatfield." Reports of the West Virginia Supreme Court of Appeals, 48 (April 14, 1900December 21, 1900): 561-576.

West Virginia. West Virginia State Supreme Court of Appeals. "State of West Virginia v. Henry C. King." Reports of the West Virginia Supreme Court of Appeals 64 (March 3,1908December 23, 1908): 553-557. 
West Virginia. West Virginia State Supreme Court of Appeals. "Thacker Coal \& Coke Company v. Burke et al." Reports of the West Virginia Supreme Court of Appeals 59 (February 15, 1906 - April 24, 1906): 253-262.

West Virginia. West Virginia State Supreme Court of Appeals. "Thacker Coal \& Coke v. Norfolk and Western Railway Company." Reports of the West Virginia Supreme Court of Appeals 67 (February 1, 1910 to October 18, 1910): 448-456.

West Virginia. West Virginia State Supreme Court of Appeals. "Williamson, et al v. County Court," "Hurst, et al v. Same," "Stafford, et al v. Same." Reports of the West Virginia Supreme Court of Appeals, 56 (June 14, 1904): 38-43. These cases were heard together.

West Virginia. West Virginia State Supreme Court of Appeals. "Williamson v. Musick." Reports of the West Virginia Supreme Court of Appeals, 60 (April 24, 1906-November 27, 1906): 58-75.

\section{Newspapers}

Bluefield Daily Telegraph, Special Industrial Edition 1896, 1920-1922

Charleston Advocate 1907

Charleston Daily Mail 1894

Charleston Evening Mail 1894

Charleston Gazette 1916, 1920, 1999

Huntington Advertiser 1891, 1902

Martinsburg Herald 1917

Mingo Republican 1911-1917, 1920

McDowell Recorder 1918, 1920

New York Times 1920-1921

West Virginia Federationist 1920-1921

Wheeling Intelligencer 1914

Williamson Daily News 1913-1920, 1982

Williamson Enterprise 1908

\section{Journals}

Coal Age 1911, 1918, 1920

Coal Trade Journal 1890-1893, 1897-1898, 1911, 1920-1922

United Mine Workers Journal 1901, 1920-1922

\section{Books, Articles, and Theses}

Allen, Barbara. “The Genealogical Landscape and the Southern Sense of Place.” In Sense of Place: American Regional Subcultures, edited by Barbara Allen and Thomas J. Schlereth, 152-161. Lexington: University Press of Kentucky, 1990.

Anti-Black Thought. Edited by John David Smith. 11 volumes. New York: Garland Publishers, 1993. 
Atkinson, George W. and Alvaro F. Gibbens. Prominent Men of West Virginia. Wheeling, WV: W.L. Callin, 1890.

Ayers, Edward L. The Promise of the New South: Life After Reconstruction. New York: Oxford University Press, 1992.

Bagby, Wesley M. The Road to Normalcy: the Presidential Campaign and Election of 1920. Baltimore: Johns Hopkins Press, 1968 [1962].

Bailey, Kenneth R. "A Judicious Mixture: Negroes and Immigrants in the West Virginia Mines, 1880-1917." West Virginia History 34 (January 1973): 141-161.

-----."A Temptation to Lawlessness: Peonage in West Virginia, 1903-1908." West Virginia History 50 (1991): 25-45.

Barb, John M. "Strikes in the Southern West Virginia Coal Fields, 1912-1922." Master's thesis, West Virginia University, 1949.

Barkey, Frederick A. "The Socialist Party in West Virginia from 1898 to 1920: A Study in Working Class Radicalism." Ph.D. diss., University of Pittsburgh, 1979.

Barns, William D. "The Grange and Populist Movements in West Virginia, 1873-1914." Ph.D. diss., West Virginia University, 1946.

Batteau, Allen W. The Invention of Appalachia. Tucson: University of Arizona Press, 1990.

Beik, Mildred Allen. The Miners of Windber: The Struggles of New Immigrants for Unionization, 1890s-1930. University Park, PA: The Pennsylvania University Press, 1997 [1996].

Bell, Robert R. Philadelphia Lawyer: A History, 1735-1945. Selinsgrove, PA: Susquehanna University Press, 1992.

Bernstein, Irving. The Lean Years: A History of the American Worker, 1920-1933. New York: Da Capo Press, 1983 [1960].

Berthoff, Rowland. An Unsettled People: Social Order and Disorder in American History. New York: Harper \& Row, 1971.

Billings, Dwight B. and Kathleen M. Blee. The Road to Poverty: The Making of Wealth and Hardship in Appalachia. Cambridge: Cambridge University Press, 2000.

“The Blame for West Virginia's War." Literary Digest 68 (10 September 1921): 16-17. 
Blankenhorn, Heber. The Reminiscences of Heber Blankenhorn. New York: Microfilming Corporation of America, 1979. (Blankenhorn interview from the Columbia University Oral History Collection)

Blocker, Jack S. Jr. Retreat from Reform: The Prohibition Movement in the United States, 18901913. Westport, CT: Greenwood Press, 1976.

Briceland, Alan V. "Batts and Fallam Explore the Backbone of the Continent." In Appalachian Frontiers: Settlement, Society, \& Development in the Preindustrial Era edited by Robert D. Mitchell, 23-36. Lexington, KY: University Press of Kentucky, 1991.

Brown, Donna L. Logan County Marriages, Book 1:1872-1892. Bruno, WV: the author, n.d.

Brumfield, Darrell G. and Richard N. Ellis. More Stories About Gilbert, West Virginia and Surrounding Communities. Baltimore, MD: Gateway Press Inc, 1995.

Burckel, Nicholas C. "Progressive Governors in the Border States: Reform Governors of Missouri, Kentucky, West Virginia, and Maryland, 1900-1918." Ph.D. diss., University of Wisconsin, 1971.

Burgett Richard. Interview. In On Dark and Bloody Ground: An Oral History of the UMWA in Central Appalachia, 1920-1935 edited by Anne Lawrence, 105-109. Charleston, WV: Miner's Voice, 1973.

Burkinshaw, Neil. "Labor's Valley Forge." Nation 111 (December 1920): 639.

Callahan, James M. Semi-Centennial History of West Virginia. Charleston, WV: SemiCentennial Commission of West Virginia, 1913.

Carter, Charles Frederick. "Murder to Maintain Coal Monopoly." Current History 15 (1922): 597-603.

"Casualties in World War I." In The Soldiery of West Virginia. [reprinted in West Virginia Heritage Encyclopedia, vol. 9, supplemental series] edited by Jim Comstock, 229-272. Richwood, WV: Jim Comstock, 1974.

Caudill, Harry M. Night Comes to the Cumberlands: A Biography of a Depressed Area. Boston: Little, Brown, \& Company, 1963.

Chafin, Raymond. Just Good Politics: The Life of Raymond Chafin, Appalachian Boss. Pittsburgh: University of Pittsburgh Press, 1996.

Chapman, Mary Lucille. "The Influence of Coal in the Big Sandy Valley." Ph.D. diss., University of Kentucky, 1945. 
Chernow, Ron. The House of Morgan: An American Banking Dynasty and the Rise of Modern Finance. New York: Simon \& Schuster, 1990.

Clark, Frederick Winslow. "A Case Study of E.W. Clark and Company: Investment Banking Firm, 1837-1957." Master's thesis, University of Nebraska, Lincoln, 1958.

The Coal Catalog: Combined with a Coal Field Directory for the Year 1915. Pittsburg, PA: Keystone Publishing Company, 1915.

The Coal Catalog: Combined with a Coal Field Directory for the Year 1920. Pittsburg, PA: Keystone Publishing Company, 1920.

Cole, Merle T. "The Department of Special Deputy Police, 1917-1919." West Virginia History 44 (Summer 1983): 321-333.

------. "Martial Law in West Virginia and Major Davis as `Emperor of Tug River'." West Virginia History 43 (Winter 1982): 118-144.

Coleman, McAlister. Men and Coal. New York: Farrar and Rinehart, 1943.

Collier, James G. "Mingo County in World War II." Master's thesis, West Virginia University, 1956.

Conley, Phil M. History of the West Virginia Coal Industry. Charleston: Education Foundation Inc., 1960.

------ “The Founder of the City of Williamson.” West Virginia Review 2 (February 1925): 162.

Corbin, David A. “"Frank Keeney is Our Leader and We Shall Not Be Moved': Rank and File Leadership in the West Virginia Coal Fields." In Essays in Southern Labor History: Selected Papers from the Southern Labor History Conference, 1976 edited by Gary M. Fink and Merle E. Reed, Contributions in Economics and Economic History, no. 16, 144156. Westport, CT: Greenwood Press, 1976.

-----. Life, Work, and Rebellion, The Southern West Virginia Miners, 1880-1922. Urbana: University of Illinois Press, 1981.

-----. The West Virginia Mine Wars: An Anthology. Charleston, WV: Appalachian Editions, 1991.

Cornwell, John J. A Mountain Trail: From the Farm to Schoolroom, to the Editor's Chair, the Lawyer's Office and the Governorship of West Virginia. Philadelphia: Dorrance and Company Publishers, 1939.

Crowe-Carraco, Carol. The Big Sandy. Lexington, KY: University Press of Kentucky, 1979. 
Cubby, Edwin A. "Railroad Building and the Rise of the Port of Huntington." West Virginia History 32 (October 1970): 234-247.

------. "Timbering Operations in the Tug and Guyandot Valleys in the 1890s." West Virginia History 26 (January 1965): 110-120.

------. "Transformation of the Tug and Guyandot Valleys, Economic Development and Social Change in West Virginia, 1888-1921.” Ph.D. diss., Syracuse University, 1962.

Dailey, Jane. "Deference and Violence in the Postbellum South: Manners and Massacres in Danville, Virginia.” Journal of Southern History 63 (August 1997): 553-590.

Dillon, Lacy A. They Died For King Coal. Winona, MN: Apollo Books Inc., 1985.

Diner, Steven J. A Very Different Age: Americans in the Progressive Era. New York: Hill and Wang, 1998.

Dix, Keith, What's a Miner to Do: The Mechanization of Coal Mining. Pittsburgh: University of Pittsburgh Press, 1988.

------. Work Relations in the Coal Industry: The Handloading Era, 1880-1930. Morgantown, WV: Institute for Labor Studies, Division of Social and Economic Development, Center for Extension and Continuing Education, West Virginia University, 1989.

Doherty, William T. "A West Virginia County's Experience with the Influenza Epidemic." West Virginia History 39 (January 1977): 136-140.

Doolittle, Edwin S. "On the Circuit in Southern West Virginia." The Green Bag 13 (1901): 284286.

Dubofsky, Melvyn and Warren Van Tine. John L. Lewis: A Biography. New York: The New York Times Book Company, 1977.

Dunaway, Wilma A. The First American Frontier: Transition to Capitalism in Southern Appalachia, 1700-1860. Chapel Hill: University of North Carolina Press, 1996.

------. "Speculators and Settler Capitalists: Unthinking the Mythology about Appalachian Landholding, 1790-1860." In Appalachia in the Making: The Mountain South in the 19th Century,edited by Dwight Billings, Mary Beth Pudup, and Altina Waller, 50-75. Chapel Hill: University of North Carolina Press, 1995.

Dunbar, John L. "Two Periods of Crisis in Labor-Management Relations in the West Virginia Coalfields, 1912-1913 and 1920-1922. Master's thesis, Columbia University, 1946.

Dunn, Durwood. Cades Cove: The Life and Death of a Southern Appalachian Community, 18181937. Knoxville: University of Tennesse Press, 1988. 
Eller, Ronald D. Miners, Millhands, and Mountaineers: Industrialization of the Appalachian South, 1880-1930. Knoxville: University of Tennessee Press, 1982.

Ely, William. The Big Sandy Valley: A History of the People and Country from the Earliest Settlement to the Present Time. Catlettsburg: Central Methodist Publishing, 1887.

Fagge, Roger. Power, Culture and Conflict in the Coalfields: West Virginia and South Wales, 1900-1922. New York: University of Manchester Press, 1996.

Fairchild, Herman L. Memorial of Israel C. White. n.p:1928, [reprint from the Bulletin of the Geological Society of America, vol.39].

Farragher, John Mack. "Open-Country Community: Sugar Creek, Illinois, 1820-1850." In The Countryside in the Age of Capitalist Transformation: Essays in Social History of Rural America, edited by Steven Hahn and Jonathan Prude, 233-258. Chapel Hill: University of North Carolina Press, 1985.

Ferrell, Barbara Ann. "West Virginia and the Election of 1896." Master's thesis, West Virginia University, 1967.

Fetherling, Dale. Mother Jones, the Miners' Angel: A Portrait. Carbondale, IL: Southern Illinois University Press, 1979.

"Feudalism in America: The War That No Peace Treaty Can Stop." Current Opinion 71 (October 1921): 413-415.

Fisher, Lucy Lee, “John J. Cornwell, Governor of West Virginia, 1917-1921" West Virginia History 24 (April 1963/July 1963): 258-288, 370-389.

Foner, Philip S. Women and the American Labor Movement: From Colonial Times to the Eve of World War I. New York: The Free Press, 1980.

Franklin, John Hope and August Meier, eds. Black Leaders of the Twentieth Century. Urbana: University of Illinois Press, 1982.

Garrison, Memphis Tennessee. Memphis Tennessee Garrison: The Remarkable Story of a Black Appalachian Woman, edited by Ancella R. Bickley and Lynda Ann Ewen. Athens, OH: Ohio University Press, 2001.

Gaventa, John. Power and Powerless: Quiescence and Rebellion in an Appalachian Valley. Urbana: University of Illinois Press, 1980.

Gerofsky, Milton. "Reconstruction in West Virginia." Master's thesis, West Virginia University, 1942. 
Glaab, Charles N. and A. Theodore Brown. A History of Urban America. New York: Macmillan, 1983 [1967].

Gleason, Arthur. The Book of Arthur Gleason: My People. New York: W. Morrow and Company, 1929.

------. “Gunmen in West Virginia,” New Republic 28 (21 September 1921): 90-92.

------. "Private Ownership of Public Officials.” Nation 110 (May 1920): 724-725.

Goodrich, Carter. The Miner's Freedom: A Study of the Working Life in a Changing Industry. Boston: Marshall Jones Co., 1925.

Gutman, Herbert. Power and Culture: Essays on the American Working Class, edited by Ira Berlin. New York: Pantheon Books, 1987.

------. Work, Culture, and Society in Industrializing America: Essays in American Working Class and Social History. New York: Vintage Books, 1976 [1966].

Hadsell, Richard M. and William E. Coffey. "From Law and Order to Class Warfare: BaldwinFelts Detectives in the Southern West Virginia Coal Fields," West Virginia History 40 (Spring 1979): 268-286.

Hall, Jacquelyn Dowd, et al. Like a Family: The Making of a Southern Cotton Mill World. Chapel Hill and London: The University of North Carolina Press, 1987.

Harris, Evelyn L. K. and Frank J. Krebs, From Humble Beginnings: West Virginia State Federation of Labor, 1903-1957. Charleston, WV: Jones Printing Co., 1960.

Hartog, Hendrik. Public Property and Private Power: The Corporation of the City of New York in American Law, 1730-1870. Chapel Hill: University of North Carolina Press, 1983.

Hatfield, G. Elliott. The Hatfields. Stanville, KY: Big Sandy Valley Historical Society, 1974.

Hennen, John. The Americanization of West Virginia: Creating a Modern Industrial State, 19161925. Lexington, KY: University Press of Kentucky, 1996.

------."Benign Betrayal: Capitalist Intervention in Pocahontas County, West Virginia, 18901910." West Virginia History 50 (1991): 46-62.

Hennen, Ray V. West Virginia Geological and Economic Survey: Logan and Mingo Counties. Wheeling: n.p., 1914.

Hinrichs, A. F. The United Mine Workers of America and the Non-Union Coalfields. New York: np, 1923. 
Hofstadter, Richard. The Age of Reform: From Bryan to FDR. New York: Alfred A. Knopf, 1956.

Howe, Barbara J. "West Virginia Women's Organizations, 1880s-1930 or 'Unsexed Termagants . . Help the World Along." West Virginia History 59 (1990): 81-102.

Hurst, Mary. "A Social History of Logan County, West Virginia, 1765-1928." Master's thesis, Columbia University, 1928.

Inscoe, John. Mountain Masters, Slavery, and the Sectional Crisis in Western North Carolina. Knoxville: University of Tennessee Press, 1989.

Ireland, Robert M. Little Kingdoms: The Counties of Kentucky, 1850-1891. Lexington: University Press of Kentucky, 1977.

Jacobs, James Henry. "The West Virginia Gubernatorial Contest, 1888-1890." West Virginia History 7 (April 1946): 159-220.

Jeffreys-Jones, Rhodri. Violence and Reform in American History. New York: Franklin Watts, 1978.

Jillson, Willard Rouse. The Big Sandy Valley: A Regional History Prior to the Year 1850. Louisville, KY: John P. Morton \& Co., 1923.

Johnson, James P. The Politics of Soft Coal: The Bituminous Industry from World War I through the New Deal. Urbana: University of Illinois Press, 1979.

Johnson, Ludwell H. III, ed. "The Horrible Butcheries of West Virginia: Dan Cunningham on the Hatfield-McCoy Feud." West Virginia History 46 (1985-1986): 25-44.

Jones, Virgil Carrington. The Hatfields and the McCoys. New York: Ballantine Books, 1948.

Jordan, Daniel P. "The Mingo War: Labor Violence in the Southern West Virginia Coal Fields, 1919-1922." Essays in Southern Labor History; Selected Papers, Southern Labor History Conference, 1976, edited by Gary M. Fink and Merl E. Reed, Contributions in Economics and Economic History, no. 16, 102-143. Westport, CT: Greenwood Press, 1977.

Kane, Anne. "Reconstructing Culture in Historical Explanation: Narratives as Cultural Structure and Practice." History and Theory 39 (October 2000): 311-330.

Karr, Carolyn. "A Political Biography of Henry Hatfield." West Virginia History 28 (October 1966/January 1967): 35-63, 137-140.

Kirk, John W., compiler. Progressive West Virginians. Wheeling: Wheeling Intelligencer, 1923. 
Klingaman, William K. 1919: The Year Our World Began. New York: Harper \& Row, 1989 [1987].

Kornweibel, Theodore, Jr., ed. "Reports by Informant C-61 to A. E. Hayes, for the Southern District of West Virginia, 9 October - 30 October 1920." In Federal Surveillance of AfroAmericans (1917-1925): The First World War, the Red Scare, and the Garvey Movement. (microfilm project of University Publications of America).

Lambert, Oscar Doane. Stephen Benton Elkins. Pittsburgh: University of Pittsburgh Press, 1955.

Lambie, Joseph T. From Mine to Market: The History of Coal Transportation on the Norfolk and Western Railway. New York: New York University Press, 1954.

Lancaster, Lane W. Government in Rural America. New York: Van Nostrand, 1952.

Lane, Winthrop D. Civil War in West Virginia: A Story of the Industrial Conflict in the Coal Mines. New York: B.W. Huebsch, 1921 [reprint 1994].

Lanham, Robert Eugene. "The West Virginia Statehouse Machine: Structure, Function and Process." Ph.D. diss., Claremont Graduate School and University Center, 1971.

Laslett, John H. M. Colliers Across the Sea: A Comparative Study of Class Formation in Scotland and the American Midwest, 1830-1924. Urbana: University of Illinois Press, 2000.

Laurie, Clayton. "The United States Army, The Return to Normalcy in Labor Dispute Interventions: The Case of the West Virginia Coal Mine Wars, 1920-1921." West Virginia History 50 (1991): 1-24.

Lawson, Sidney B. Fifty Years a Country Doctor: Autobiography and Reminiscences of Sidney B. Lawson, M.D. Logan, WV: n.p., 1941.

Lawson, W. B. "The Hatfield-McCoy Vendetta, or Shadowing a Hard Crowd." New York: Street \& Smith, Log Cabin Series (1894): 2-28. [reprint \#292, 18 October 1892]. University of Minnesota, Hess Collection.

Lee, Howard B. Bloodletting in Appalachia: The Story of West Virginia's Four Major Mine Wars and Other Thrilling Incidents of Its Coal Fields. Morgantown, WV: West Virginia University Library, 1969.

Lewis, Ronald L. Black Coal Miners in America: Race, Class, and Community Conflict, 17801980. Lexington, KY: University of Kentucky Press, 1987.

------. Transforming the Appalachian Countryside: Railroads, Deforestation, and Social Change in West Virginia, 1880-1920. Chapel Hill: University of North Carolina Press, 1998. 
Lightfoot, William Edwin. Folklore of the Big Sandy Valley of Eastern Kentucky. Indianapolis: Indiana University Press, 1976.

Lunt, Richard D. Law and Order vs. The Miners: West Virginia, 1906-1933. Charleston, WV: Appalachian Editions, 1992.

MacCorkle, William Alexander. The Recollections of Fifty Years of West Virginia. New York: G.P. Putnam's Sons, 1928.

Mann, Ralph. "Diversity in the Antebellum Appalachian South: Four Farm Communities in Tazewell County, Virginia." In Appalachia in the Making: The Mountain South in the Nineteenth Century, edited by Mary Beth Pudup, Dwight B. Billings, and Altina L. Waller, 132-162. Chapel Hill: University of North Carolina Press, 1995.

Maury, M. F. and William M. Fontaine. Resources of West Virginia, (Prepared under the direction of the State Board of Centennial Managers). Wheeling: The Register Company, Printers, 1876.

McCoy, Homer Claude. "The Rise of Education and the Decline of Feudal Tendencies in the Tug River Valley of West Virginia and Kentucky in relation to the Hatfield and McCoy Feud. Masters' thesis, Marshall College, 1942.

McDowell County DAR. McDowell County. Fort Worth, TX: University Supply and Equipment Company, 1959.

McKinney, Gordon B. Southern Mountain Republicans: Politics and the Appalachian Community, 1865-1900. Knoxville: University of Tennessee Press, 1998 [1978].

----- "Industrialization and Violence in Appalachia in the 1890s." In An Appalachian Symposium: Essays Written in Honor of Cratis Williamsedited by J.W. Williamson, 131144. Boone, N.C.: Appalachian State University Press, 1977.

McWhorter, J. C. “Abolish the Jury.” West Virginia Law Quarterly 29 (January 1923): 97-108.

Men of West Virginia, vol.II. Chicago: Biographical Publishing Company, 1903.

Montell, William Lynwood. Killings: Folk Justice in the Upper South. Lexington: Unversity Press of Kentucky, 1986.

Mooney, Fred. Struggle in the Coal Fields: The Autobiography of Fred Mooney. Morgantown, WV: West Virginia University Library, 1967.

Moore, Tyrel G. "Economic Development in Appalachian Kentucky, 1800-1860." In Appalachian Frontiers: Settlement, Society, and Development in the Pre-Industrial Era, edited by Robert D. Mitchell, 222-234. Lexington, KY: University Press of Kentucky, 1991. 
Morris, Homer L. The Plight of the Bituminous Coal Miner. Philadelphia: University of Pennsylvania Press, 1934.

Morton, Oren F. A History of Monroe County, West Virginia. Staunton, VA: The McClure Company Inc., 1916.

Munn, Robert F. "The Development of Model Company Towns in the Bituminous Coal Fields." West Virginia History 40 (Spring 1979): 243-253.

Murray, Robert K. Red Scare: A Study of National Hysteria, 1919-1920. New York: McGraw Hill, 1964.

Murphy, Paul L. World War I and the Origins of Civil Liberties in the United States. New York: Norton, 1979.

Murphy, Robert E., compiler. Progressive West Virginians: Some of the Men Who Have Built Up and Developed the State of West Virginia. Wheeling, WV: The Wheeling News, 1905.

Nash, Michael. Conflict and Accomodation: Coal Miners, Steel Workers, and Socialism, 18901920. Westport, CT: Greenwood Press, 1982.

Nisbett, Richard E. and Dov Cohen. Culture of Honor: The Psychology of Violence in the South. Boulder and Oxford: Westview Press, 1996.

Noe, Kenneth W. Southwest Virginia's Railroad: Modernization and the Sectional Crisis. Urbana: University of Illinois Press, 1994.

-----. "'Appalachia's' Civil War Genesis: Southwest Virginia As Depicted By Northern and European Writers, 1825-1865." West Virginia History 50 (1991): 91-108.

Owens, John W. "Gunmen in West Virginia" New Republic 28 (September 1921): 90-92.

Palladino, Grace. Another Civil War: Labor, Capital, and the State in the Anthracite Regions of Pennsylvania, 1840-1868. Urbana and Chicago: University of Illinois Press, 1990.

Payne, Dr. Henry M. "The Future of Williamson and the Tug River Coal Field." The Illustrated Monthly West Virginian 7 (August 1908): 45-49.

Pendleton, William C. History of Tazewell County and Southwest Virginia, 1748-1920. Richmond: W.C. Hill Printing, Co., 1920.

Penn, Neil Shaw. "Henry D. Hatfield and Reform Politics: A Study of West Virginia Politics from 1908 to 1917." Ph.D. diss., Emory University, 1977.

Perry, Huey. They'll Cut Off Your Project: A Mingo County Chronicle. New York: Praeger Press, 1972. 
Phillips, Cabell. "The West Virginia Mine War." American Heritage (August 1974): 58-61, 9096.

Pimienta-Bey, Jose.<jpb@wvnvm.wvnet.edu> “re: assertion dilemma," 1 May 2001. Personal email (1 May 2001).

Plunkett, H. Dudley and Mary Jean Bowman. Elites and Change in the Kentucky Mountains. Lexington: University Press of Kentucky, 1973.

Posey, Thomas E. "Some Significant Aspects of the West Virginia Labor Movement." West Virginia Academy of Science Proceedings vol.22, West Virginia University Bulletin ser. 51, no.12-3 (June 1951): 120-127.

Prichard, A. M. Descendants of William Prichard. Charleston, WV: Tribune Printing Co., 1912.

[Prospectus], The Big Sandy Land and Manufacturing Company: Logan, Wyoming, and McDowell Counties, West Virginia. Camden, NJ: np., 1882.

Pudup, Mary Beth, Dwight B. Billings, and Altina L. Waller. "Taking Exception with

Exceptionalism: The Emergence and Transformation of Historical Studies of Appalachia. In Appalachia in the Making: The Mountain South in the Nineteenth Century, edited by Mary Beth Pudup, Dwight B. Billings, and Altina L. Waller, 1-24. Chapel Hill: University of North Carolina Press, 1995.

------. "Social Class and Economic Development in Southeastern Kentucky, 1820-1880." In Appalachian Frontiers: Settlement, Society, and Development in the Pre-Industrial Era, edited by Robert D. Mitchell, 235-260. Lexington, KY: University Press of Kentucky, 1991.

------. "Town and Country in the Transformation of Appalachian Society." In Appalachia in the Making: The Mountain South in the 19th Century, edited by Dwight Billings, Mary Beth Pudup, and Altina Waller, 270-296. Chapel Hill: University of North Carolina Press, 1995.

Rakes, Paul H. "Technology in Transition: The Dilemmas of Early Twentieth Century Coal Mining." Journal of Appalachian Studies 5 (Spring 1999): 27-60.

Rasmussen, Barbara. Absentee Landowners and Exploitation in West Virginia, 1760-1920. Lexington, KY: University Press of Kentucky, 1994.

------. "The Politics of the Property Tax in West Virginia." Journal of Appalachian Studies 6 (Spring 1996): 141-147.

Rice, Bradley Robert. Progressive Cities: The Commission Government Movement in America, 1901-1920. Austin, TX: University of Texas, 1977. 
Rice, Otis K. The Hatfields and The McCoys. Lexington, KY: University of Kentucky Press, 1982.

Rice, Otis K. and Stephen W. Brown. West Virginia: A History. 2d ed. Lexington, KY: University Press of Kentucky, 1993.

Roper, Peter W. Jedidiah Hotchkiss: Rebel Mapmaker and Virginia Businessman. Shippensburg, PA: White Mane Publishing Co., 1992.

Ross, Malcolm. Death of a Yale Man. New York: Farrar and Rinehart, 1939.

-----. Machine Age in the Hills. New York: The MacMillan Co., 1983.

Roy, Andrew. "The Advantages of the Coalfield to Be." Coal Trade Journal 30 (24 June 1891): 302.

------. A History of the Coal Miners of the United States. Columbus, OH: Press of J. L. Trauger Printing Co, 1902.

------. “The Thacker Coal Field of West Virginia.” Mines and Minerals 19 (May 1899): 472.

Said, Edward W. Orientalism. New York: Pantheon Books, 1978.

Sakolski, Aaron M. Land Tenure and Taxation in America. New York: R. Schalkenbach Foundation, 1957.

Salstrom, Paul. Appalachia's Path to Dependency: Rethinking a Region's Economic History, 1730-1940. Lexington, KY: University Press of Kentucky, 1994.

------. "Newer Appalachia as One of America's Last Frontiers." In Appalachia in the Making: The Mountain South in the 19th Century, edited by Dwight Billings, Mary Beth Pudup, and Altina Waller, 76-102. Chapel Hill: University of North Carolina Press, 1995.

Seltzer, Curtis. Fire in the Hole: Miners and Managers in the American Coal Industry. Lexington, KY: University Press of Kentucky, 1985.

Shapiro, Henry D. Appalachia On Our Mind: The Southern Mountains and Mountaineer in the American Consciousness, 1870-1920. Chapel Hill: University of North Carolina Press, 1978.

Shelton, Floyd Bunyon. "An Investigation of the Social Life of a West Virginia Coal Field." Bachelor's thesis, Emory University, 1920.

Shifflett, Crandall. Coal Towns: Life, Work and Culture in Company Towns in Southern Appalachia, 1880-1960. Knoxville: University of Tennessee Press, 1994. 
Shinedling, Abraham J. Shinedling. West Virginia Jewry: Origins and History 3 vols. Philadelphia: Maurice Jacobs, Inc, 1963.

Skeen, David O. "Industrial Democracy, Social Equality, and Violence: The West Virginia Mine Wars: 1912-1921.” Masters' thesis, California State University, 1996.

Smith, G. Wayne. Nathan Goff, Jr.: A Biography. Charleston, WV: Education Foundation Inc, 1959.

Smith, Nancy Sue. An Early History of Mingo County, West Virginia. Williamson, WV: Williamson Printing Co., 1960.

Soule, George H. and Vincent P. Carosso. American Economic History. New York: Dryden Press, 1957.

Spence, Robert Y. Land of the Guyandot: A History of Logan County. Detroit: Harlo Press, 1976.

Spivak, John L. A Man in His Time. New York: Horizon Press, 1967.

Stock, Catherine McNicol. Rural Radicals: Righteous Rage in the American Grain. Ithaca: Cornell University Press, 1996.

Striplin, E. F. The Norfolk and Western: A History. Roanoke, VA: Norfolk and Western Railway Company, 1981.

Sullivan, Kenneth. "Coal Men of the Smokeless Coalfields." West Virginia History 41 (Winter 1980): 142-165.

Summers, Festus P. Johnson Newlon Camden: A Study in Individualism New York: G.P. Putnam's Sons, 1937.

Summers, George W. "Owned A Sixth of W.VA. Died in Prison For Debt," Pages From the Past: Recollections, Traditions, and Old Timers' Tales of the Long Ago reprinted in West Virginia Heritage Encyclopedia vol. 21, 56-74, supplemental series, edited by Jim Comstock, 56-74. Richwood, WV: Jim Comstock, 1974.

Thelen, David. Paths of Resistance: Tradition and Dignity in Industrializing Missouri. Columbia: University of Missouri Press, 1991, [reprint New York: Oxford University Press, 1986].

Thomas, Jerry Bruce. "Coal Country: The Rise of the Southern Smokeless Coal Industry and Its Effect on Area Development, 1872-1910." Ph.D. diss., University of North Carolina, 1971.

Thompson, E. P. Customs in Common. New York: New Press: Distributed by W.W. Norton, 1991. 
------.The Making of the English Working Class. New York: Vintage Books, 1966 [1963].

Thurmond, Walter R. The Logan Coal Field of West Virginia: A Brief History. Morgantown, WV: West Virginia University Library, 1964.

Titler, George J. Hell in Harlan. Beckley, WV: BJW Printers, n.d.

Trail, William R. "The History of the United Mine Workers in West Virginia, 1920-1945." Master's thesis, New York University, 1950.

Trotter, Joe William. "Black Miners in West Virginia: Class and Community Responses to Workplace Discrimination, 1920-1930." In The United Mine Workers of America: A Model of Industrial Solidarity? edited by John H.M. Laslett, 269-296. University Park, PA: The Pennsylvania State University Press, 1996.

-----. Coal, Class, and Color: Blacks in Southern West Virginia, 1915-1932. Urbana: University of Illinois Press, 1990.

Tucker, Gary J. "William E. Glasscock and the Election of 1910," West Virginia History 40 (Spring 1979): 254-267.

Tudiver, Sara Lubitsch. "Political Economy and Culture in Central Appalachia, 1790-1977." Ph.D. diss., University of Michigan, 1984.

Turner, William P. "From Bourbon to Liberal: The Life and Times of John T. McGraw, 18561920.” Ph.D. diss., West Virginia University, 1960.

Urofsky, Melvin I. and David W. Levy. Half Brother, Half Son: The Letters of Louis D. Brandeis to Felix Frankfurter. Norman, OK: University of Oklahoma Press, 1991.

Velke, John A. Baldwin-Felts Detectives, Inc. Richmond, VA: s.n., 1997.

Verhoeff, Mary."The Big Sandy River Navigation," In Proceedings and Papers of the Ohio Valley Historical Association for the year 1919, 25-42. Columbus, OH: F.J. Heer Printing Company, 1925.

Vinson, Z. T. (Zachary Taylor). "Advocating Co-operation and Organization of West Virginia's Coal Operation," An address before the West Virginia Mining Institute 10 December 1914, in Huntington WV. n.p.: n.d.

------. "Railway Corporations and the Juries." Minutes of the West Virginia Bar Association, 17th Annual Meeting. Clarksburg, February 12-13, 1902: 42-51.

-----. Singing on the Pints, and Other Stories. Huntington, WV: M.V. Clark, private printing, 1949. 
Wallace, George S. Cabell County Annals and Families. Richmond: Garrett \& Massie, 1935.

Waller, Altina L. Feud: Hatfields, McCoys and Social Change in Appalachia, 1860-1900. Chapel Hill: University of North Carolina Press, 1988.

------. "Feuding in Appalachia: The Evolution of a Cultural Stereotype." In Appalachia in the Making: The Mountain South in the 19th Century, edited by Dwight Billings, Mary Beth Pudup, and Altina Waller, 347-376. Chapel Hill: University of North Carolina Press, 1995.

Walls, Emick R. "West Virginia's Greatest Manhunt." West Virginia Illustrated 2 (May-June 1971): 29-33

Warner, Arthur. "West Virginia: Industrialism Gone Mad." Nation 113 (October 1921): 372-373.

-----. "Fighting Unionism with Martial Law." Nation 113 (October 1921): 395-396.

Washington, James. Interview. In On Dark and Bloody Ground: An Oral History of the UMWA in Central Appalachia, 1920-1935 edited by Anne Lawrence, 107-109. Charleston, WV: Miner's Voice, 1973.

West, Cornel. Race Matters. Boston: Beacon Press, 1993.

West Virginia Heritage Encyclopedia. Edited by Jim F. Comstock. 25 vols. Richwood, WV: Jim Comstock, 1976.

West Virginia State Gazetteer and Business Directory, 1882-1883 vol. 2. Detroit: R. L.Polk, 1883.

West Virginia State Gazetteer and Business Directory, 1891-1892 vol. 4. Detroit: R. L.Polk, 1892.

West Virginia State Gazetteer and Business Directory, 1895-1896 vol. 5. Detroit: R. L.Polk, 1896.

West Virginia State Gazetteer and Business Directory, 1900-1901 vol. 7. Detroit: R. L.Polk, 1901.

West Virginia State Gazetteer and Business Directory, 1902-1903 vol. 8. Detroit: R. L.Polk, 1903.

West Virginia State Gazetteer and Business Directory,1912-1913 vol. 13. Detroit: R. L.Polk, 1913.

West Virginia State Gazetteer and Business Directory, 1914-1915 vol. 14. Detroit: R. L.Polk, 1914. 
West Virginia State Gazetteer and Business Directory, 1916-1917 vol. 15. Detroit: R. L.Polk, 1917.

"West Virginia's War." Literary Digest 67 (18 December 1920): 16-17.

Edward Eyre Hunt, F. G. Tryon, and Joseph H. Willits., eds. What The Coal Commission Found: An Authoritative Summary By The Staff. Baltimore: The Williams \& Wilkins Company, 1925.

Whisnant, David E. Modernizing the Mountaineer: People, Power and Planning in Appalachia. Knoxville: University of Tennessee Press, 1994.

Wiebe, Robert H. The Search for Order: 1877-1920. New York: Hill and Wang, 1967.

Wilentz, Sean. Chants Democratic: New York City \& The Rise of the American Working Class, 1788-1850. New York: Oxford University Press, 1986 [1984].

Williams, John A. "A Note on the Documents on the Wayne County Shooting Incident During the Election Campaign of 1894." West Virginia History 33:2 (January 1972): 152-156.

------. "Class, Section, and Culture in Nineteenth-Century West Virginia Politics." In Appalachia in the Making: The Mountain South in the 19th Century edited by Dwight Billings, Mary Beth Pudup, and Altina Waller, 210-232. Chapel Hill: University of North Carolina Press, 1995.

-----. "Davis and Elkins: Businessmen in Politics.” Ph.D. diss., Yale University, 1967.

------."The New Dominion and the Old: Antebellum and Statehood Politics as the Background of West Virginia's 'Bourbon Democracy.'" West Virginia History 33 (July 1972): 317-407.

------.West Virginia and the Captains of Industry. Morgantown: West Virginia University Libraries, 1976.

Williamson Area Heritage Book. Summerville, WV: Walsworth Publishing Company, 1996.

Wilson, Edmund. "Frank Keeney's Coal Diggers" New Republic 67 (8 and 15 July 1921): 195199, 229-231.

Women's Christian Temperance Union of West Virginia. Report of the Twenty-Sixth Annual Meeting of the Women's Christian Temperance Union of West Virginia, held at Huntington, WV, October 2-6, 1908, edited by Mrs. K. M. Murill. Charleston, WV: Tribune Printing Company, 1909.

------. West Virginia Woman's Christian Temperance Union, Twenty-Eighth Year, Charleston, WV, October 5,6, 7, 1910. Fairmont, WV: Index Print, n.d. 
Workman, Michael E. "Political Culture and the Coal Economy of the Upper Monongahela Region, 1776-1933." Ph.D. diss., West Virginia University, 1995. 


\section{APPENDICES}

Appendix 1

The 1920 West Virginia Gubernatorial Election Results

\begin{tabular}{lllll}
\hline \hline & $\begin{array}{l}\text { Arthur B. } \\
\text { Koontz (D) }\end{array}$ & $\begin{array}{l}\text { Ephraim F. } \\
\text { Morgan (R) }\end{array}$ & $\begin{array}{l}\text { S.B. } \\
\text { Montgomery } \\
\text { (Non-Partisan) }\end{array}$ & $\begin{array}{l}\text { M.S. Holt } \\
\text { (Socialist) }\end{array}$ \\
\hline Mingo County & 2,116 & 3,413 & 3,398 & ------ \\
State Totals & 184,762 & 242,327 & 81,330 & 2,695 \\
\hline
\end{tabular}

*Although Morgan carried Mingo by a mere 15 votes, Cox the Democratic candidate for President defeated Harding by almost a thousand votes.

*Koontz carried Logan and received one and half times the number of votes of Morgan, by contrast, Morgan carried McDowell and received three times the number of votes as Koontz. ${ }^{1}$

${ }^{1}$ Houston G. Young, Secretary of State of West Virginia, State of West Virginia: Official Returns of the General Election, held November 2, 1920 (Charleston, WV: Tribune Printing Co, 1920), 3. J. Hop Woods Bound Pamphlet Collection, 11476, vol.15, WVRHC. 
Appendix 2

Nativity Profile of Coal Miners in Mingo County, 1920: A Statistical Analysis

Explanation of Statistical Analysis

In 1920, there were 3,378 men employed in the mines of Mingo County, of which 2,491 were American-born whites. ${ }^{1}$ From the 1920 United States Census returns for the three most heavily developed districts of Mingo County: Lee, Magnolia, and Stafford a sample of 1,900 of American born white miners was identified. Of this 1,900 sample, 857 men stated that their place of birth was either West Virginia or Kentucky. ${ }^{2}$ This group of 857 men also possessed last names that suggested that their nativity was regionally focused in the greater Big Sandy Valley, which encompassed Logan and Mingo Counties in West Virginia and Pike, Martin, and Floyd Counties in Kentucky. ${ }^{3}$ Based on an analytical triangulation from these sources, $45 \%$ of the miners in the Mingo County sample were by definition "locals." 108 of the 1,900 sample also stated that they owned their own home, or lived with a family member who did, which meant that $94 \%$ of these "native" miners lived in company housing. The following table illustrates the surname-nativity connection of Mingo's miners.

${ }^{1} 1920$ Annual Report of the West Virginia Department of Mines, 254-255.

${ }^{2}$ Mingo County enumeration, Fourteenth Census of the United States.

${ }^{3}$ Surname Lists in: William Ely, The Big Sandy Valley and Willard Rouse Jillson, The Big Sandy Valley. 
Table of Names used in determining the Nativity Profile of Mingo County Coal Miners

\begin{tabular}{|c|c|c|c|}
\hline Abbott (1) & Chambers (3) & Evans (5) & Isom (5) \\
\hline Accord(s) (6) & Chapman (9) & Farley (11) & Jackson (4) \\
\hline Adair/Addair (5) & Christian (5) & Ferrell (6) & Johns (1) \\
\hline Adkins (14) & Clark (8) & Fields (2) & Jones (1) \\
\hline Akers (9) & Cline (2) & Floyd (1) & Justice (17) \\
\hline Allen (7) & Combs (2) & Fowler (2) & Keesee (1) \\
\hline Alley (2) & Compton (2) & Fraley (3) & King (11) \\
\hline Altizer (1) & Cooper (1) & Frazier (1) & Kirk (6) \\
\hline Auzier (1) & Copley (8) & Fry (2) & Kirkpatrick (1) \\
\hline Ayers (1) & $\operatorname{Cox}(3)$ & Gobel (1) & Lawson (3) \\
\hline Baisden (18) & Crabtree (9) & Goff (4) & Lewis (1) \\
\hline Baker (2) & Crane (1) & Gooslin(g) (1) & Litteral (4) \\
\hline Baley/Bailey (4) & Crum (9) & Graham (1) & $\begin{array}{l}\text { Marcum/Markham } \\
\text { (16) }\end{array}$ \\
\hline Blair (4) & Curry (1) & Grimmett (5) & $\begin{array}{l}\text { Mahon/Mayhon/ } \\
\text { Mayhorn (5) }\end{array}$ \\
\hline Blevins (5) & Damron (2) & Hager (4) & Maynard (33) \\
\hline Boggs (2) & Davis (14) & Hall (17) & McCoy (18) \\
\hline Boyd (9) & Delong (2) & Hampton (3) & Mead(e) (7) \\
\hline Brewer (8) & Dempsey (4) & Harmon (4) & Meek (1) \\
\hline Brown (2) & Deskins (6) & Harper (2) & Miller (6) \\
\hline Browning (5) & Dingess (4) & Harrison (1) & Mitchell (3) \\
\hline Buchanan (1) & Dotson (11) & Hatfield (24) & Mounts (20) \\
\hline Burchett (1) & Dowden (3) & Haynes (1) & Muncy/Munsey (9) \\
\hline Canterbury (2) & Duty (7) & Henry (1) & Murphy (4) \\
\hline Carter (3) & Edwards (5) & Hensley (14) & Newman (1) \\
\hline
\end{tabular}




\begin{tabular}{|c|c|c|c|}
\hline Castle (14) & Ellis (1) & Howell (1) & Newsom (4) \\
\hline Chafin(s) (24) & Estep (10) & Hunter (2) & Nicholas (2) \\
\hline & Scaggs (2) & Tiller (6) & Wilson (6) \\
\hline \multicolumn{4}{|l|}{ Parsley (9) } \\
\hline Patten (1) & $\begin{array}{l}\text { Simkins/Simpkins } \\
\text { (13) }\end{array}$ & Tinsley (1) & Wolford (6) \\
\hline Patrick (1) & Sipple (1) & Triplett (2) & Workman (7) \\
\hline Phillips/Phillipps (8) & Sizemore (2) & Underwood (1) & Yates (1) \\
\hline Pinson (2) & Smith (12) & Vance (7) & York (2) \\
\hline Preece (1) & Spaulding (2) & Varney (19) & Young (2) \\
\hline Preston (3) & $\operatorname{Spradlin}(g)(5)$ & Vaughan (1) & \\
\hline Ramsey (2) & Stafford (3) & Vinson (3) & \\
\hline Reed (3) & Starr (7) & Ward (12) & \\
\hline $\begin{array}{l}\text { Robertson/Roberson } \\
\text { (3) }\end{array}$ & Staten (15) & Webb (5) & \\
\hline Robison (5) & Stepp (14) & Wellman (3) & \\
\hline Ronans (4) & Stewart (2) & White (6) & \\
\hline Runyon(s) (14) & Sutters (1) & Whitt (1) & \\
\hline Rutherford (1) & Taylor (2) & Williams (8) & \\
\hline Savage (3) & Thompson (22) & Williamson (11) & \\
\hline
\end{tabular}


Appendix 3

The Miners of Lick Creek Tent Colony:

Mingo County miners or imported agitators?

During the 1921 United States Senate Hearings on conditions in West Virginia's coal fields the operators' attorneys asserted that the majority of the inhabitants of the striking miners' tent colonies were not only non-natives, but also had never worked in the mines of Mingo County. ${ }^{1}$ The operators further contended the tent colonists had been imported into the county by the UMWA, as part of a propaganda strategy designed to win public symapthy. ${ }^{2}$ To support their claim, they offered statements taken when 47 Lick Creek tent colonists who were arrested during the June 14, 1921 raid on the colony. ${ }^{3}$ Examination of the 35 statements entered into the Senate hearings' records however, reveals that the operators themselves were attempting, at least in part, to mislead the members of the Committee. As the data tabulated below reveals, while the majority of the men arrested were not native West Virginians, almost two- thirds were employed in Mingo County when the strike was called in July 1920. Moreover, 11 men or almost onethird, were not asked about either their birthplace or whether they worked as miners in Mingo. 4 men were asked if they were miners, but not asked about their nativity or employment at the time of the strike.

Nativity of the Lick Creek Tent Colonists

\begin{tabular}{llll}
\hline $\begin{array}{l}\text { West Virginia } \\
\text { Natives }\end{array}$ & $\begin{array}{l}\text { Eastern Kentucky } \\
\text { Natives }\end{array}$ & $\begin{array}{l}\text { Non-Native, } \\
\text { employed in Mingo } \\
10+\text { years }\end{array}$ & $\begin{array}{l}\text { Non-Native, } \\
\text { employed in Mingo } \\
<10 \text { years }\end{array}$ \\
\hline 2 & 10 & 2 & 4 \\
\hline \multicolumn{4}{c}{ Men Employed as Miners at time of Strike } \\
\hline \hline $\begin{array}{l}\text { Employed in Mingo } \\
\text { Mines }\end{array}$ & $\begin{array}{l}\text { Employed in Pike } \\
\text { County Mines* }\end{array}$ & Not Asked & $\begin{array}{l}\text { Miner, but location } \\
\text { not revealed }\end{array}$ \\
\hline 19 & 1 & 11 & 4 \\
\hline
\end{tabular}

1"Testimony of J. R. Brockus," West Virginia Coal Fields, 334.

${ }^{2}$ Ibid.

${ }^{3}$ West Virginia Coal Fields, 559-601. 
Appendix 4

"The Smoking Gun":

Documentary Evidence of The Role of Politics

in the 1920 Unionization Drive in the Williamson-Thacker Coal Field ${ }^{1}$

August 19, 1920

Mr. Carl E. Whitney

c\% Wise, Whitney, \& Parker

15 William Street,

New York, N. Y.

My dear Mr. Whitney,

In several of your letters to me you have stated that you are very much interested in the labor situation, and especially down here in this section.

I quite agree with the old adage that the truth is stranger than fiction, and as I am thoroughly familiar with all the facts leading up to the present labor troubles here, and as you say that you are interested, I will briefly give you a summary of what has taken place, but of course, you will treat it in confidence.

First I must introduce to you one or two characters who have a part in the game with whom I am satisfied that you are not acquainted, and also outline to you briefly the condition in Mingo.

As to Mingo County. Before they took all the joy out of life, Mingo County had many saloons, and those saloons operated under a license granted by the County Court of Mingo County. That court was made up of what I have usually termed "renegade democrats", for at one time, Mingo County was democratic, but the leading democrats went to the republican party.

The republican party in the county had an executive committee headed by one M. Z. White, a renegade democrat, and he was standing chairman.

The County Court was composed of three members, likewise renegade democrats, and of course, the system was very simple. There would be no license granted unless the applicants for the same came across with whatever tribute this chairman decided to levy upon them. This condition continued until the oasis went dry.

Just about that time, the chairman was appointed the warden of the penitentiary here in the state,

\footnotetext{
${ }^{1}$ This letter faithfully reproduces the original, which is part of the S. D. Stokes Papers, A\&M 2542, WVRHC.
} 
and he knew well how to govern those in duress vile, and several other tricks in politics.

On his retirning from the county chairmanship, G. W. Hatfield, a brother of Dr. H. D. Hatfield, also a renegade democrat, took up the reins of party government, but as the saloons were gone and no tribute could be levied from that source, disaster overtook the republican machine, and the democrats captured the organization. This drifted along until last spring, when the term of Mr. White as warden of the penitentiary expired and he returned to the placid waters of the Tug, very much disgruntled, pessimistic on all subjects of politics, and in a frame of mind to beat his wife or scuttle the ship.

The immediate bringing about of this mental attitude was in the fall just preceding. He had become a candidate for the state senate, but Dr. H. D. Hatfield, who had previously aided his appointment as warden of the penitentiary, notwithstanding the fact that he had promised his support in Mr. White's candidacy, a few days prior to the election, by certain manipulations in the County of McDowell, sometimes termed "the free state of McDowell, defeated Mr. White, which of course made that gentleman exceedingly sore on the aforesaid ex-governor, Dr. Hatfield. His vocabulary in swearing vengeance was considerably extended.

Just prior to the time that the said Mr. White arrived in Williamson, three candidates loomed up on the republican side for nomination for governor, Mr. Morgan, representing one faction of the republican party, and in opposition to what is known as the Hatfield faction which was represented by a candidate by the name of Grosscup, sometimes called Col. Grosscup, and a third knight ceded (sic) his lance and entered the race on the republican ticket, but to champion the cause of the downtrodden laboring man, whose moniker was Montgomery. ${ }^{1}$

Pardon the digression, but four years ago the republican party had been split from stem to stern over a fight between Hatfield on the one side, advocating the candidacy of a man named Robinson, and certain vested interests advocating the candidacy of one Abraham Lilly, out of which a contest grew, and in which your humble servant took part, but that is another story. The point is that these factions were eager to get at each other's throats.

Now, while Dr. Hatfield, or Ex-Governor Hatfield, had been defeated in what might be called a dog-fall, he was by no means a dead one, and he had ambitions to become Henry Clay and to participate in the deliberations of this government in the United States Senate.

Leaving the field of state politics, and returning to Mingo County, you can readily see that while M. Z. White had been a part of the Hatfield organization, on account of the unjust treatment as alleged by him in his senatorial race by Dr. Hatfield, he was violently opposed to the Hatfield faction, and he landed into the Morgan fold.

G. W. Hatfield, a brother of Dr. H. D. Hatfield, as aforesaid, then County Chairman of Mingo

${ }^{1}$ It is likely that Stokes meant "seated" rather than "ceded." 
County, realized that the Ex-County Chairman White would have considerable influence with some of the organization of the republican fold in the county, and thought it wise to make friends and smooth over the difficulties and down the ruffled feathers brought about by the treatment of White by his brother.

Now G. W. Hatfield was not especially interested in the gubernatorial race, but he was interested in his brother's candidacy, two years hence, for the United States Senate, and he realized that on account of the intrenchment of the democrats, they could not be ousted by the voters at the polls, but that it would be necessary to do it by force in the playful manner of stealing ballot boxes and intimidating the voters away from the polls. A way must be found, however, whereby those who did such things would not receive any punishment, and to do that, it would be necessary to have upon the bench a good-natured, not too particular judge, who was willing to work for the party good, and there resided here such a man.

With these thoughts in mind, Hatfield called on Mr. White, and said, "No matter how bitter the pill may be, and how much I reget to go aginst my brother, who is at this time is supporting Grosscup, let me and you bury the hatchet, and I will support your man for governor if you will, in the coming Judicial Convention, support my man for judge.

White, lacking the vision of two years in the future, readily assented to this arrangement, and immediately sat down to write to Morgan that would carry Mingo County solid for him in the coming primary election, and there was squeezed out of his soul considerable animosity that had resided there for some time; but this was not a bad play on the part of G. W. Hatfield.

There is a gentleman by the name of T. E. Houston whose residence is in McDowell County, but who is domiciled in Cincinnati, with ample funds to finance almost any kind of enterprise, but who was a bitter opponent of Ex-Governor H. D. Hatfield, and manifested that, of course, in his advocacy of Morgan.

G. W. Hatfield, knowing this suggested to M. Z. White that they take a trip to Cincinnati, and there see Mr. Houston as he had always taken considerable interest in Mingo and McDowell politics, and would no doubt be useful to them, both being poor men.

So these two gentlemen took the train from here to Cincinnati, and called upon Mr. Houston, Hatfield doing most of the talking, White sitting by and smiling peacefully.

The sum and substance of the conversation was this, that while G. W. Hatfield was very fond of his brother, and would follow him in almost any political enterprise, yet for the good of the republican party, and to bring about harmony in Mingo County, on this particular occasion he would have to admit that his brother was wrong in his advocacy of Grosscup. And therefore, if Mr. Houston would lend substantial support to the installing of the republican party in Mingo County once more, he, Hatfield would promise to oppose Grosscup, resign as Chairman of the Republican Executive Committee, have M. Z. White elected to his old place, provided that mr. 
Houston would help him, G. W. Hatfield, in electing a judge of the Circuit Court of Mingo County who would be acceptable to all the organized republicans.

Houston, also lacking the vision to carry him over two years hence, readily agreed to this proposition, and as some of us do when we are gaining our points, he plumed and plucked himself by telling these gentlemen that Morgan would undoubtedly be elected governor, and that he would contribute $\$ 50,000.00$ to his candidacy in the primary and as much more as might be necessary in the general election to put him over.

So they all laughed, slapped each other on the back, and Mr. Houston invited them out to lunch, but just before leaving the office, Mr. Hatfield called to Mr. Houston's attention a matter which he had overlooked, and that was that some of the Republican Executive Committee might not vote readily for Mr. White on his, Hatfield's resignation, but that they could be easily fixed with a little money, and suggested that Col. Houston write his check for $\$ 1000.00 .^{2}$ All the gentlemen being in a pleasant frame of mind, each having received, or about to receive what his heart wished, the colonel promptly called for his secretary and drew his check for the said amount and delivered it to Mr. Hatfield.

Thereupon they all meandered over to the Sinton Hotel to take up nourishment for their stomach's sake. After lunch was over, Col. Houston smiled and bowed himself away on the excuse of pressing business, and the other two gentlemen gravitated over to the Third National Bank, cashed the check, returned to their rooms and divided fifty-fifty, and caught the night train to Williamson very much elated, each one having gained that which his soul most desired, but a thing that neither one knew.

Now Mingo County is supposed to be an organized county, and in an organized county, the republican votes the way his chairman wishes. Mr. White, Chairman, feeling so elated over his success with the united party in Mingo County, felt that he could carry it solidly for Morgan in the primary, and rushed into the newspapers to herald it to the world.

Grosscup's manager saw these articles, and he knew what an interview from the County Chairman, so far as the vote was concerned in the coming primary meant, and that was that his man would not have a look-in.

Thereupon he put on his hat, walked over to the headquarters of Mr. Montgomery, the champion of the downtrodden laboring man, and an interview followed in which was said to $\mathrm{Mr}$. Montgomery, "Neither you nor Mr. Grosscup will receive any votes in Mingo County, for the organization is against you. Now any vote that can be taken away from Mr. Morgan will weaken him throughout the state, and enue to your or my benefit. I would suggest that in view of the fact that you are the champion of the downtrodden laboring man that you see Mr. Keeney and suggest

\footnotetext{
${ }^{2}$ Given that the previous number indicated that Houston would pay White and Hatfield $\$ 50,000.00$, Stokes probably meant that Hatfield asked Houston to give them $\$ 100,000.00$.
} 
to him that the coal field known as the Thacker Coal Field, and embracing Mingo County, is unorganized, and that it is high time to have it organized. In that way, sentiment will be created for you in Mingo County which will take away votes for the said Morgan.

This appealed very much to the champion of the downtrodden laboring man, and especially in view of the fact that Mr. Grosscup agreed to finance the proposition.

The sum and substance of the matter was that in about ten days, the coal operators in this field observed unrest among their laboring men and woke up to the fact that the ordinary labor agitator was abroad in the land.

This, of course, was the counter-move on the part of Grosscup, and looking at it from a purely political standpoint, it was not bad.

But lo and behold! While the republicans kicked off the ball, a few democrats who knew something about the political game caught it. The game was opened, and notwithstanding the rushes, blocks and tackles, the democrats still have the ball, and the republicans have not been able to recover it.

For the Sheriff of the County, a democrat, rose up in his boots and announced that he himself was a union man, and that the United Mine Workers of America, so far as the law would permit, would have the protection of his office in the peaceful, honorable and charitable work of organizing their union.

This is how our troubles started. Of course they have not yet ended, but many things have happened from the time of kicking off the ball in the town of Matewan until the present day.

I might say that G. W. Hatfield and M. Z. White kept their promise to Col. Houston so far as they could, but only succeeded in carrying Mingo for Morgan by about five hundred votes. If however, Grosscup had not made the counter-move, Morgan would have received at least two thousand more votes in Mingo County.

Under our law, the primary election is held in May, and in the following August of this year, a judicial convention is held to elect a judge.

As the month of August approached, Mr. John L. Stafford, a practicing attorney of this bar, who was nominated on the republican ticket pursuant to this agreement reached in Cincinnati between Houston, Hatfield and White, became more active in his candidacy for the nomination. Thereupon certain men, who knew him intimately, announced that he would not do for judicial timber as his law partner had been convicted and sent to the penitentiary for accepting a bribe of $\$ 20,000.00$ in the senatorial contest before the legislature some years prior, and that he, Stafford, was also cognizant of the gentle art of extending his hand behind his back, and violent opposition manifested itself. Col. Houston, however, who was never known to back out of a political 
promise, insisted that the thing be done.

More opposition developed, and in spite of the inconvenience and the dirt, smoke and soot of traveling on the Norfolk \& Western from Cincinnati to this point, a distance of about two hundred miles, Col. Houston favored us with a visit to settle the matter, calling upon the opposition to Mr. Stafford in the republican party.

The opposition announced to Col Houston that they would accept any reputable member of the republican bar within the district except Stafford, as he was not fit to put on the bench, and they suggested four republican lawyers.

Col. Houston, satisfied that the matter could be easily adjusted, called on these gentlemen, but each and every mother's son of them refused to run as their business was paying them more than the salary on the bench, and then again they were not acceptable to Mr. G. W. Hatfield, as they were men of such character that they would not permit methods to go unpunished which would take place two years from now when Ex-Governor Hatfield became a candidate for the United States Senate.

Thereupon Col. Houston returned to Cincinnati, but still sought to bring about an amicable adjustment of the political situation.

About this time Mr. G. W. Hatfield became uneasy, fearing that Col. Houston might be back out of his promise on account of the opposition to Mr. Stafford. He therefore called on Mr. White, the Chairman, stating that he had given the matter considerable thought, and suggested that he, Mr. White, should go to Cincinnati, and have an interview with Col. Houston and find out whether he was in earnest in trying to get some one else on the ticket instead of Mr. Stafford.

White, pleased with the thought that possibly Hatfield was weakening, went to Cincinnati, and after an interview with Col. Houston, returned to Williamson, and stated that Col Houston was very much in earnest about the matter and was of the opinion that Stafford would not do, and in a conversation which consisted of both pleading and bluffing, sought to bring Hatfield around.

At this point I will have to digress.

After the primary was held last May, Montgomery filed a contest against Morgan, and among other things, alleged that a slush fund had been used to nominate Morgan, naming some eighteen to twenty men in the state, which men were of considerable prominence, and among others, Col. Houston as having contributed $\$ 50,000.00$, all this solemnly alleged and supported by affidavits and the petition filed.

With that in mind, we will return to the interview between Hatfield and White on White's return from Cincinnati. 
After Hatfield had listened to White's pleading and bluffing, he turned to him and said, with several uncomplimentary oaths, "I have been suspicious of you and Col. Houston and your good feelings in this matter. Suppose you take the train to Cincinnati again to-night, and tell Col Houston that I said that I have not forgotten the statement that he made in our first interview in Cincinnati, in which he assured me that Morgan would be nominated, and that he would contribute $\$ 50,000.00$ to his campaign, and unless our contract is carried out to the letter, I will be glad to lend my testimony to the cause of Mr. Montgomery, the champion of the downtrodden laboring man.

It is useless to say that this had the desired effect and the word went forth that Stafford was to be nominated.

Now while your humble servant had been cognizant of all that had taken place, he had been a spectator, but he was violently opposed to Mr. Stafford as Judge because of certain facts within his own knowledge, and he realized fully that Stafford would be nominated unless something was done.

Without communicating with the other republican candidate who was running, he saw two men their names are of no consequence.

The first one I asked a simple question - "Whom can I see who is actually running the labor organization in this field and who can deliver the goods or votes?"

He gave me the name of a man, and in a few hours I was with him. After fifteen minutes' conversation, he stated that he would let me know his decision on the morrow as to whether he would support the man I named, a republican, for judge, and on the next day, I received the simple word, "All right."

At the district convention held a few days later to name delegates to the judicial convention, my man was supported by from two to three hundred and fifty men, while Mr. Stafford in one district had three votes, and in no district in this country had over eleven votes.

It was really wonderful the way it worked.

Of course, there are very many other features to the situation, but as I am retained as counsel in some matters, I shall pass them by.

You have the true beginning of this trouble, and the snow will fly before it ends unless as one of the two things is done, and I, not being in a position to do these things, it would be useless for me to state what they are.

With kindest regards, I am

Very truly yours, 
Appendix 5

The Impact of Coal Production on:

Mingo, Logan and McDowell Counties, 1895-1940

Tri-County Population Growth Comparison, 1900-1920

Tri-County Comparison: Average Land Per Acre Value Tri-County Number of Mines Comparison

Tri-County Comparison: Ethnicity of Population

Tri-County Comparison: Coal Production, 1895-1940

Tri-County Comparison: Coal Production,1895-1922

Tri-County Comparison: Coal Production,1923-1940 
Tri-County Population Growth Comparison, 1900-1920

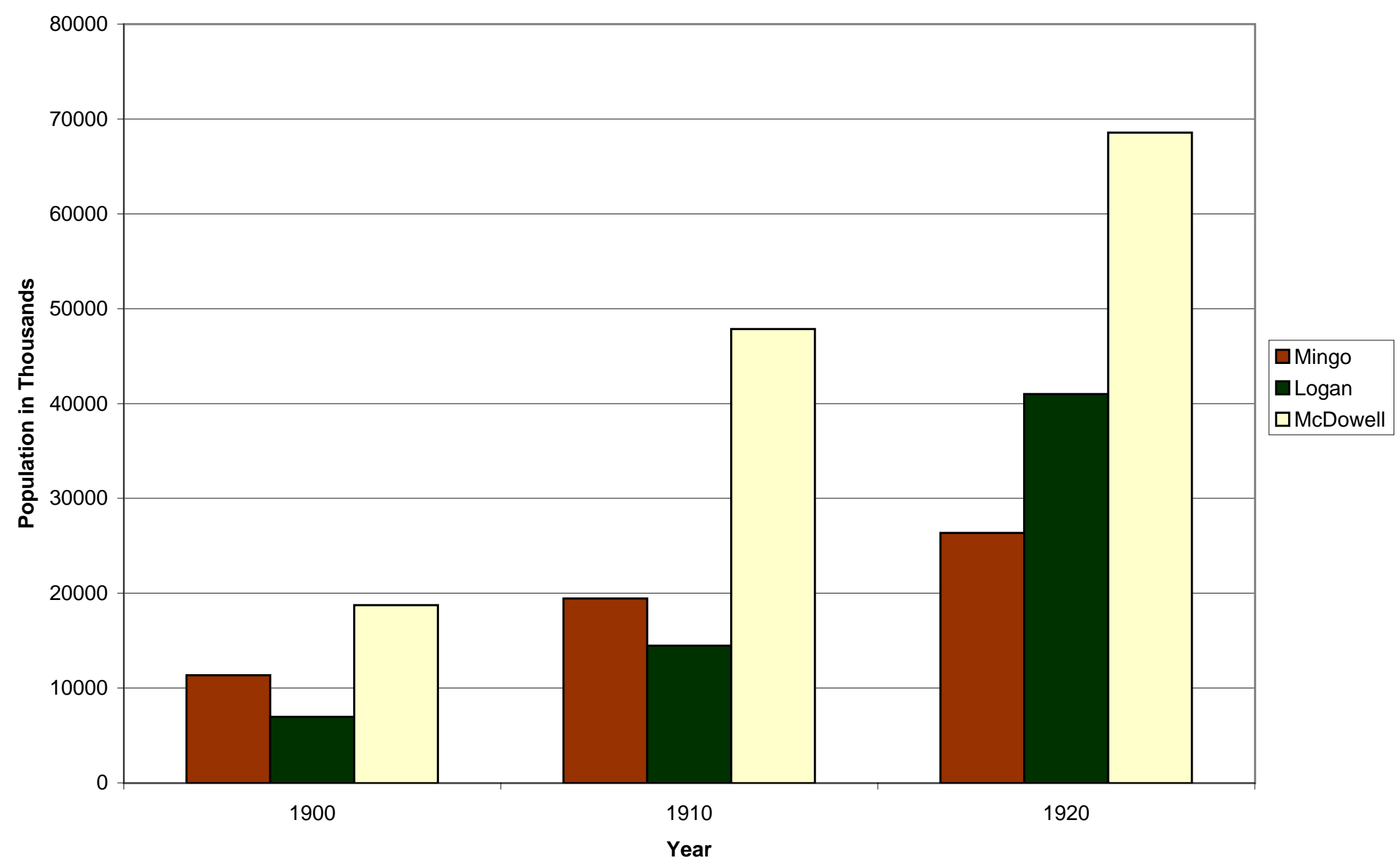


Tri-County Comparison: Land Value Per Acre, 1900-1920

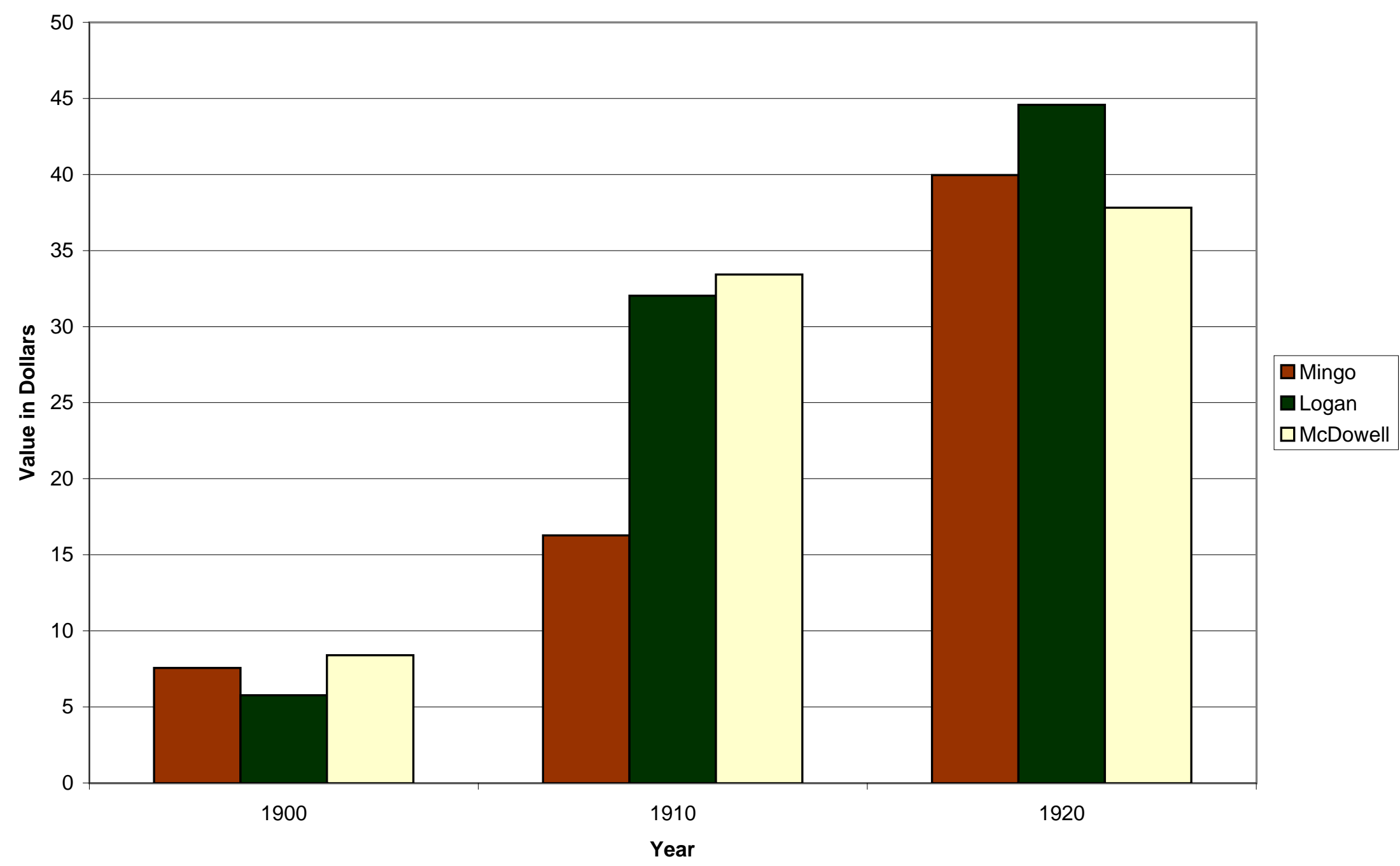


Tri-County Comparison: Number of Mines, 1905-1922

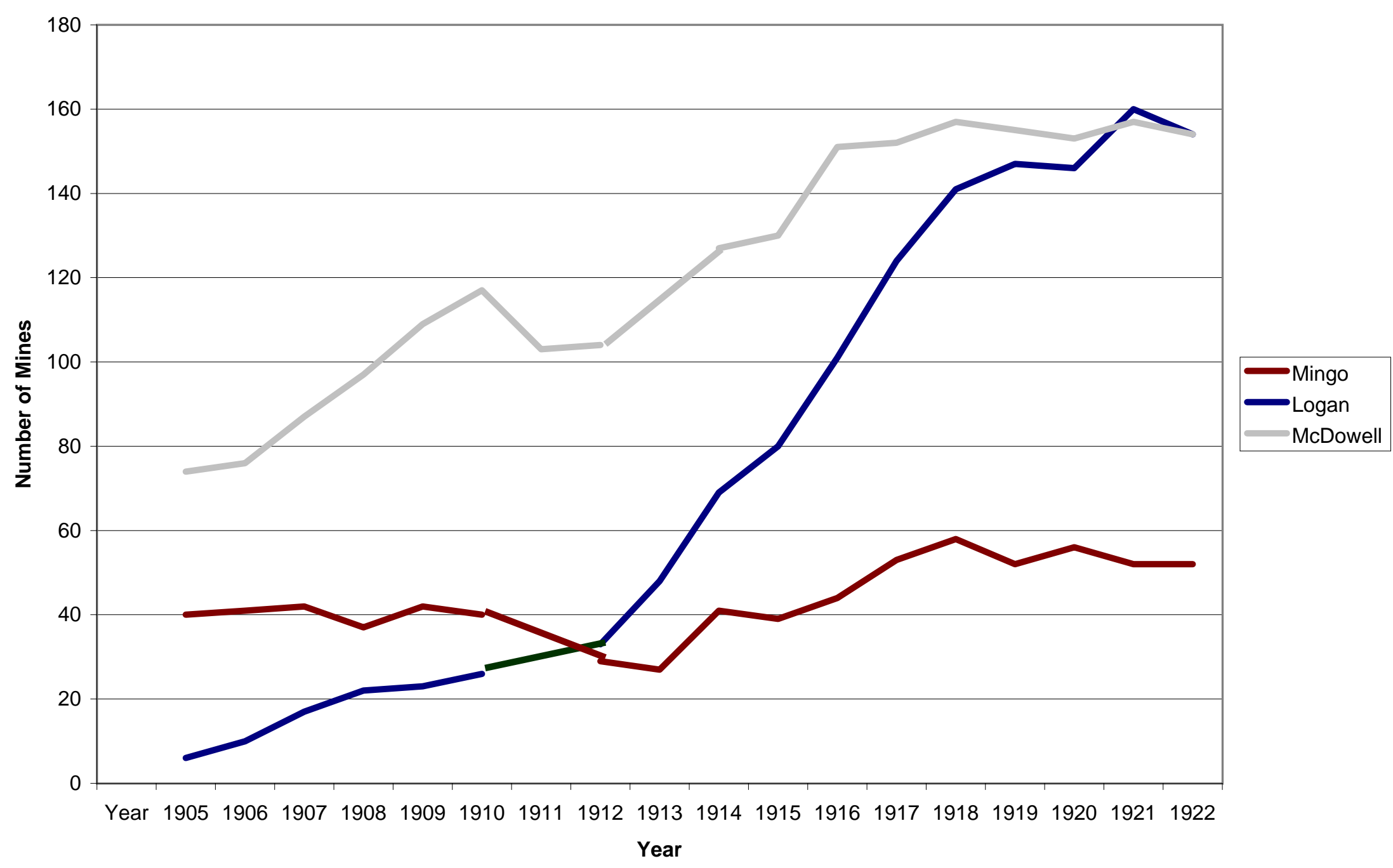


Mingo County Ethnic Percentages 1900-1920
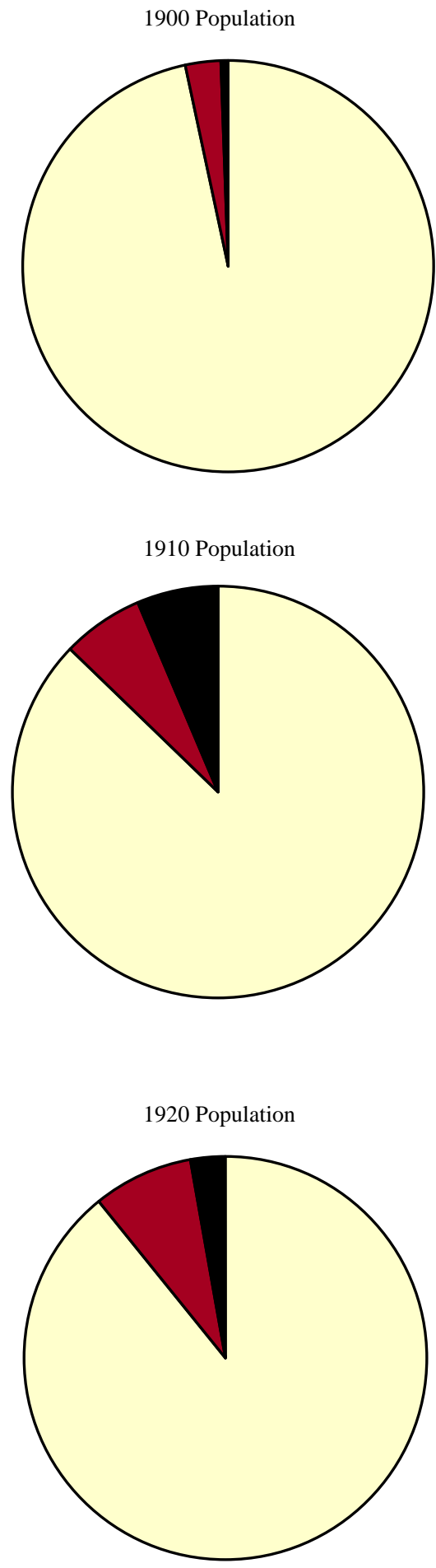

$\square$ Native White $\square$ African American $\boldsymbol{\square}$ Foreign-Born 
Logan County Ethnic Percentages 1900-1920
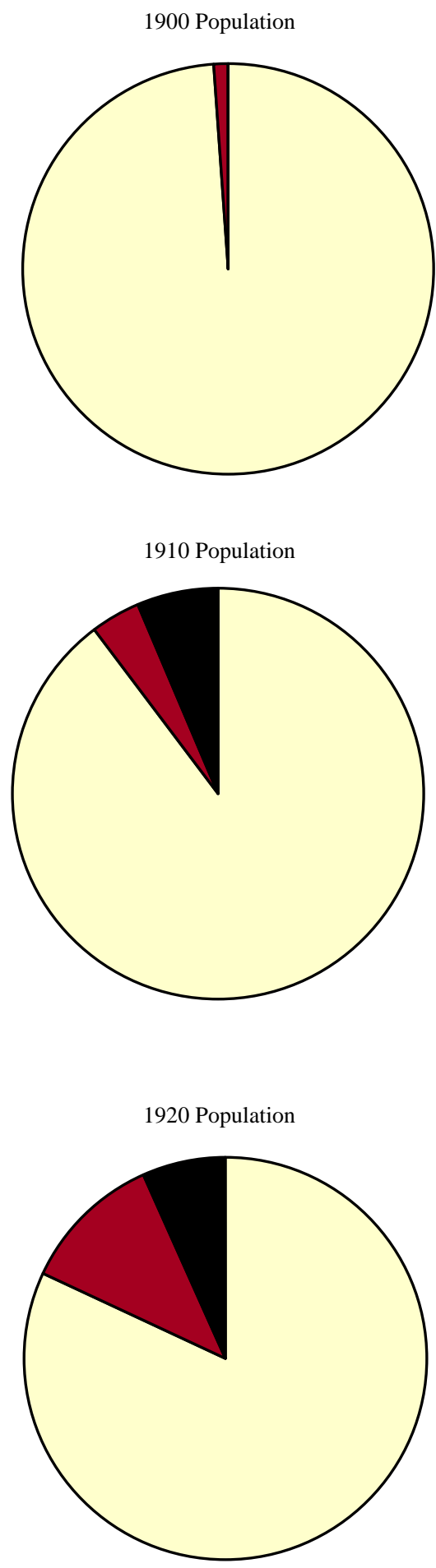

$\square$ Native White $\square$ African American $\boldsymbol{\square}$ Foreign-Born 
McDowell County Ethnic Percentages 1900-1920
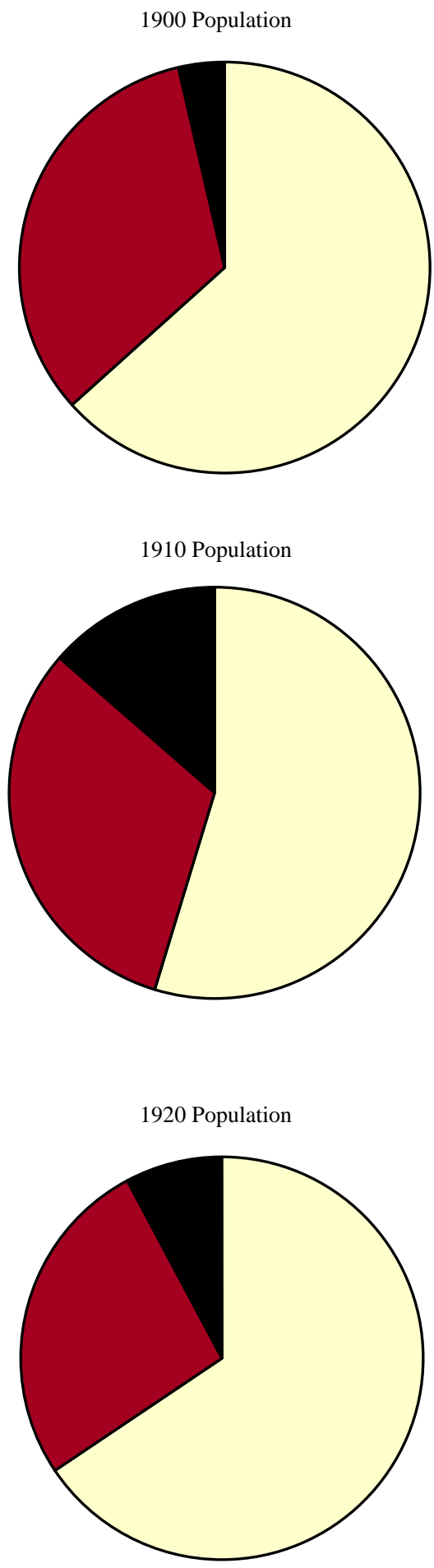

$\square$ Native White $\square$ African American $\square$ Foreign-Born 
Tri-County Coal Production Comparison, 1895-1940

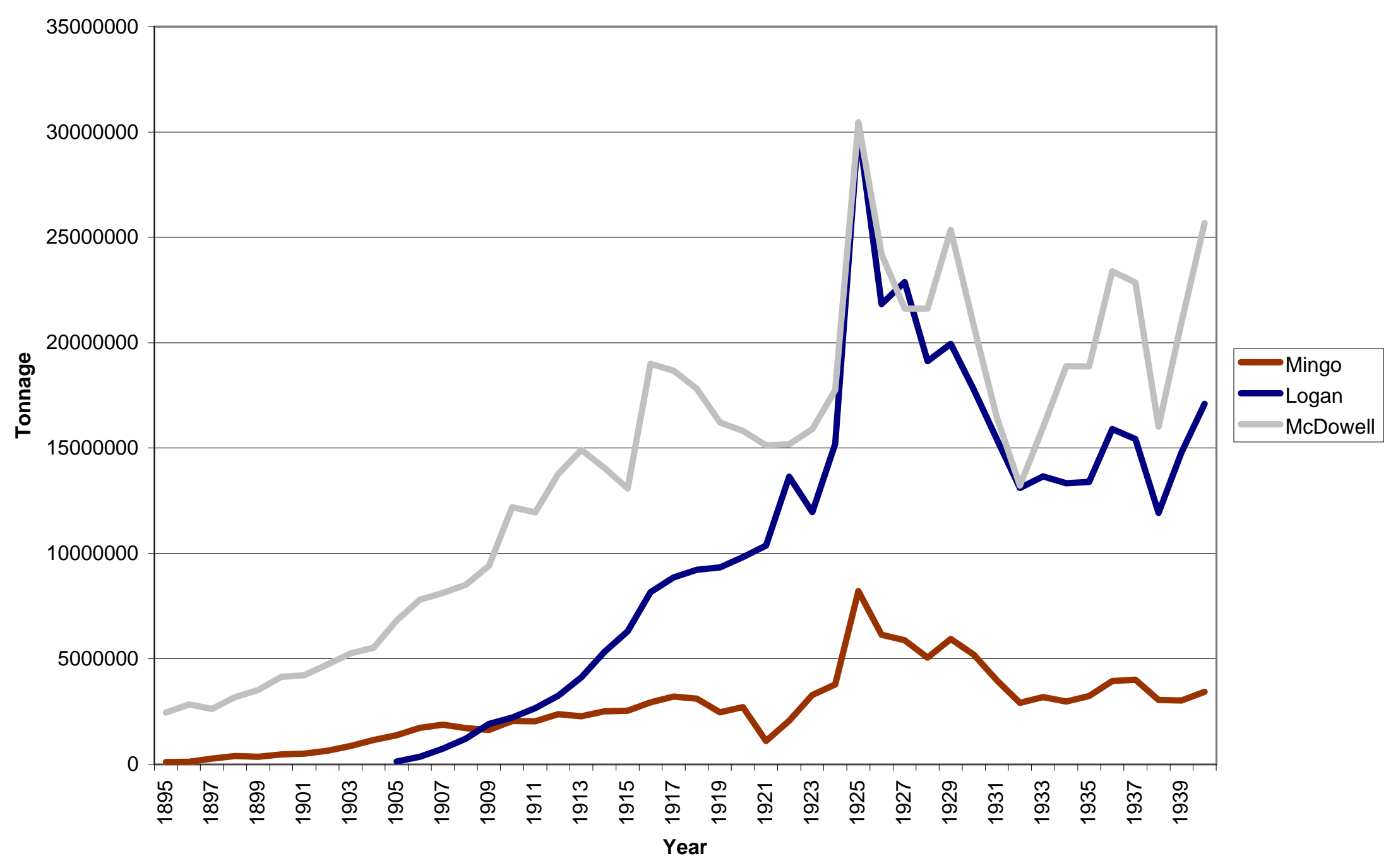


Tri-County Coal Production Comparison, 1895-1922

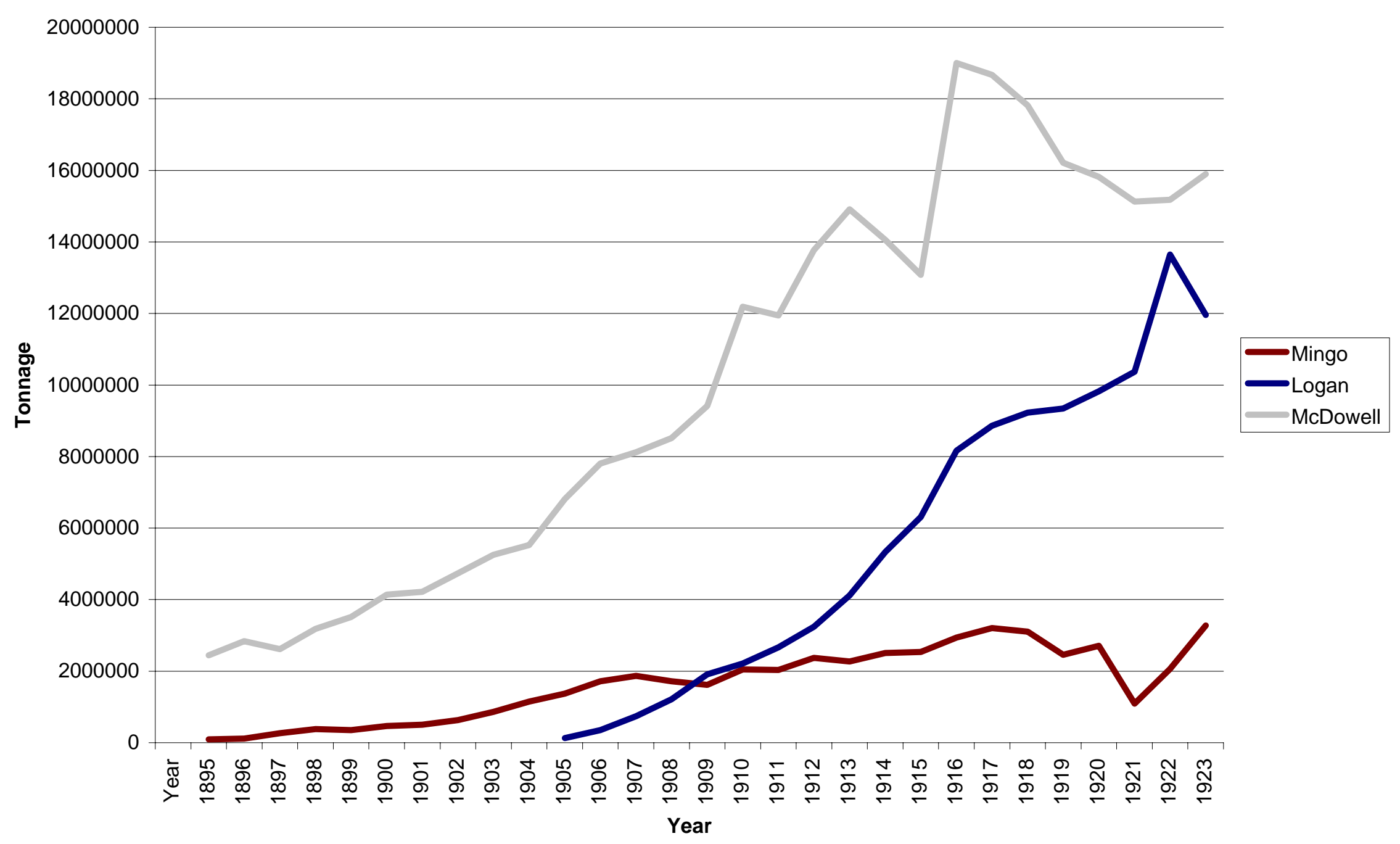


Tri-County Coal Production Comparison, 1923-1940

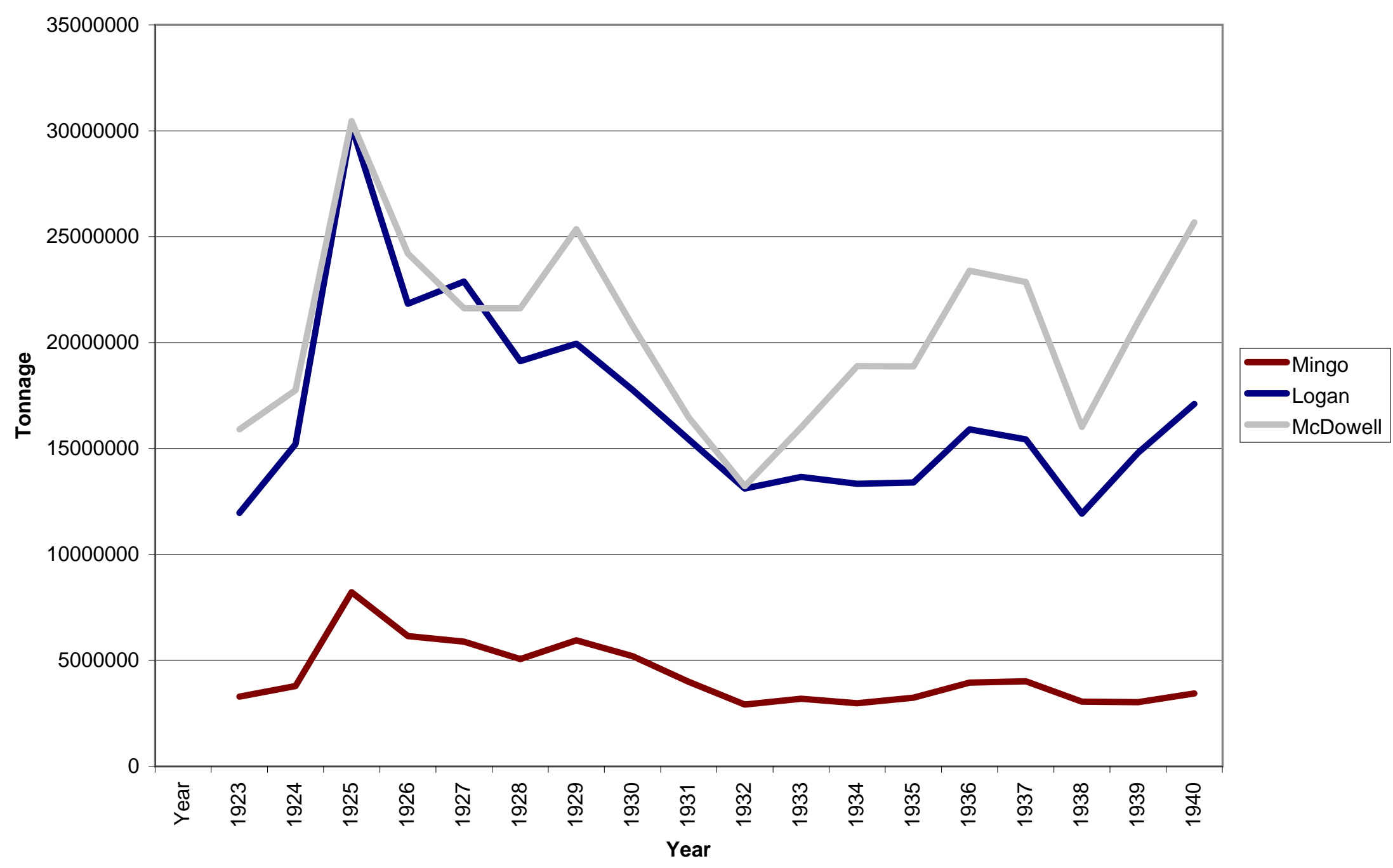


Map 1: The Tug Valley Border Country

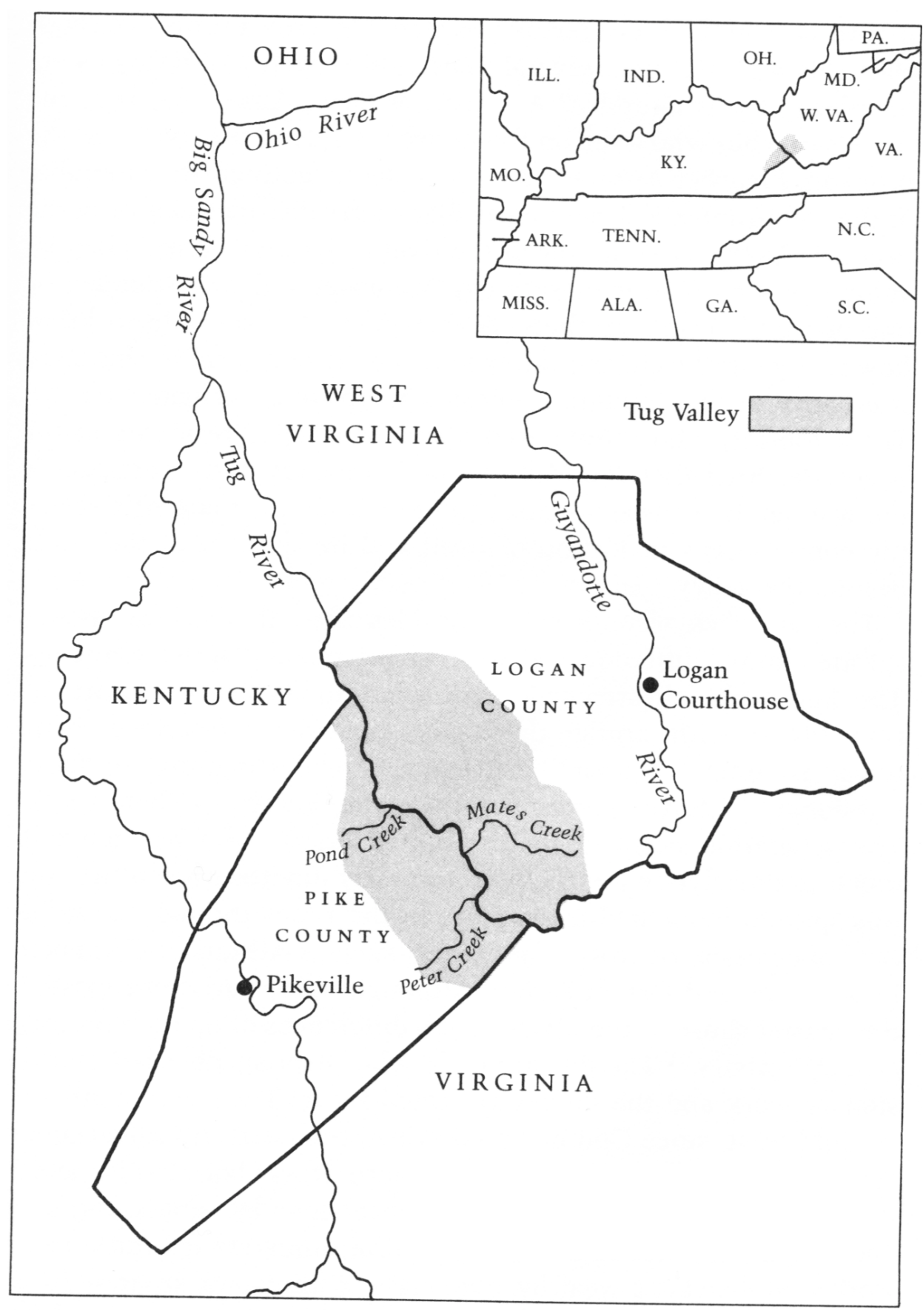


Map 2: Mingo County, West Virginia, ca. 1895

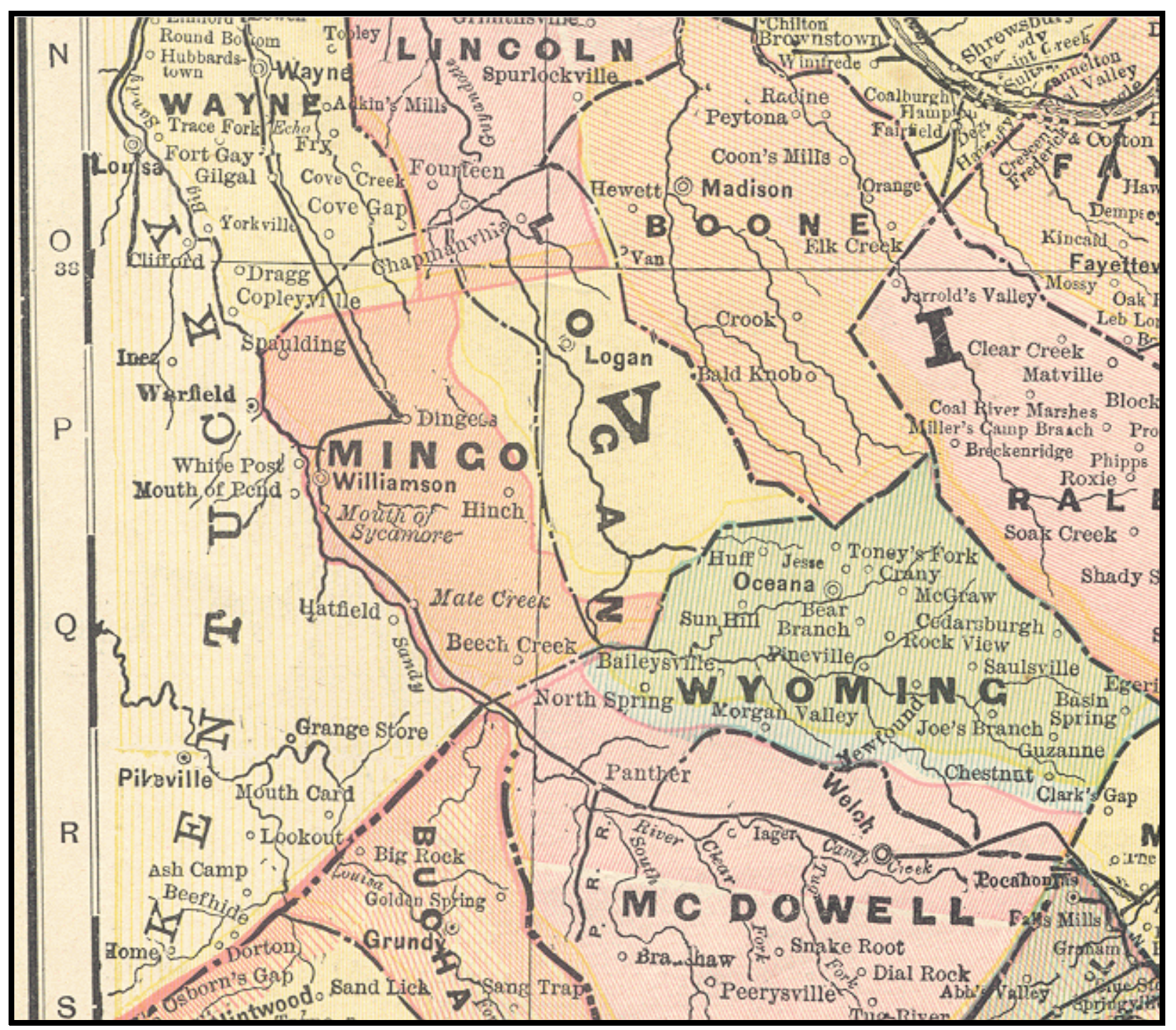


Map 3: Coal Fields of the Norfolk \& Western Territory

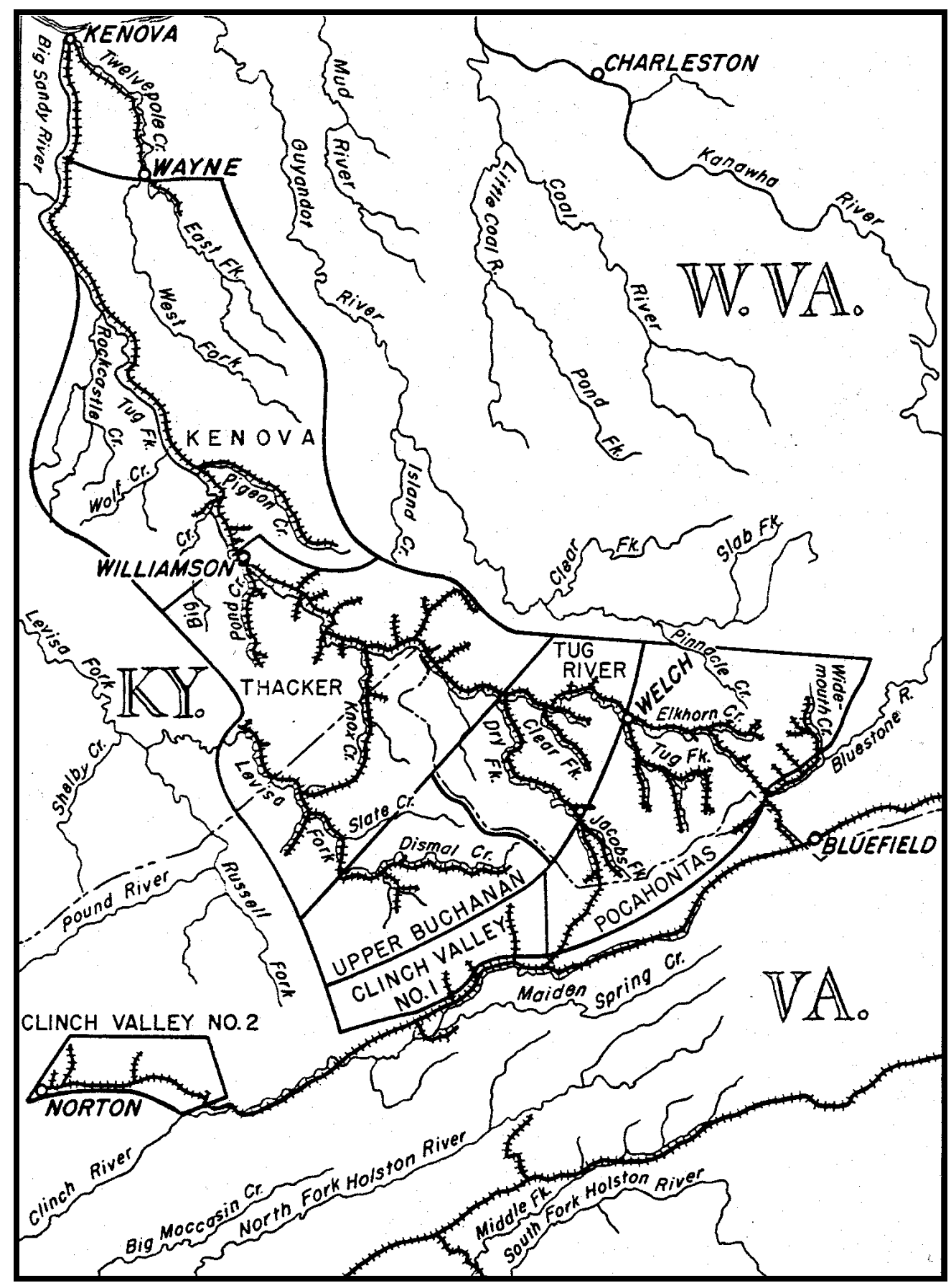


Map 4: The Southern West Virginia Coal Fields, ca. 1921

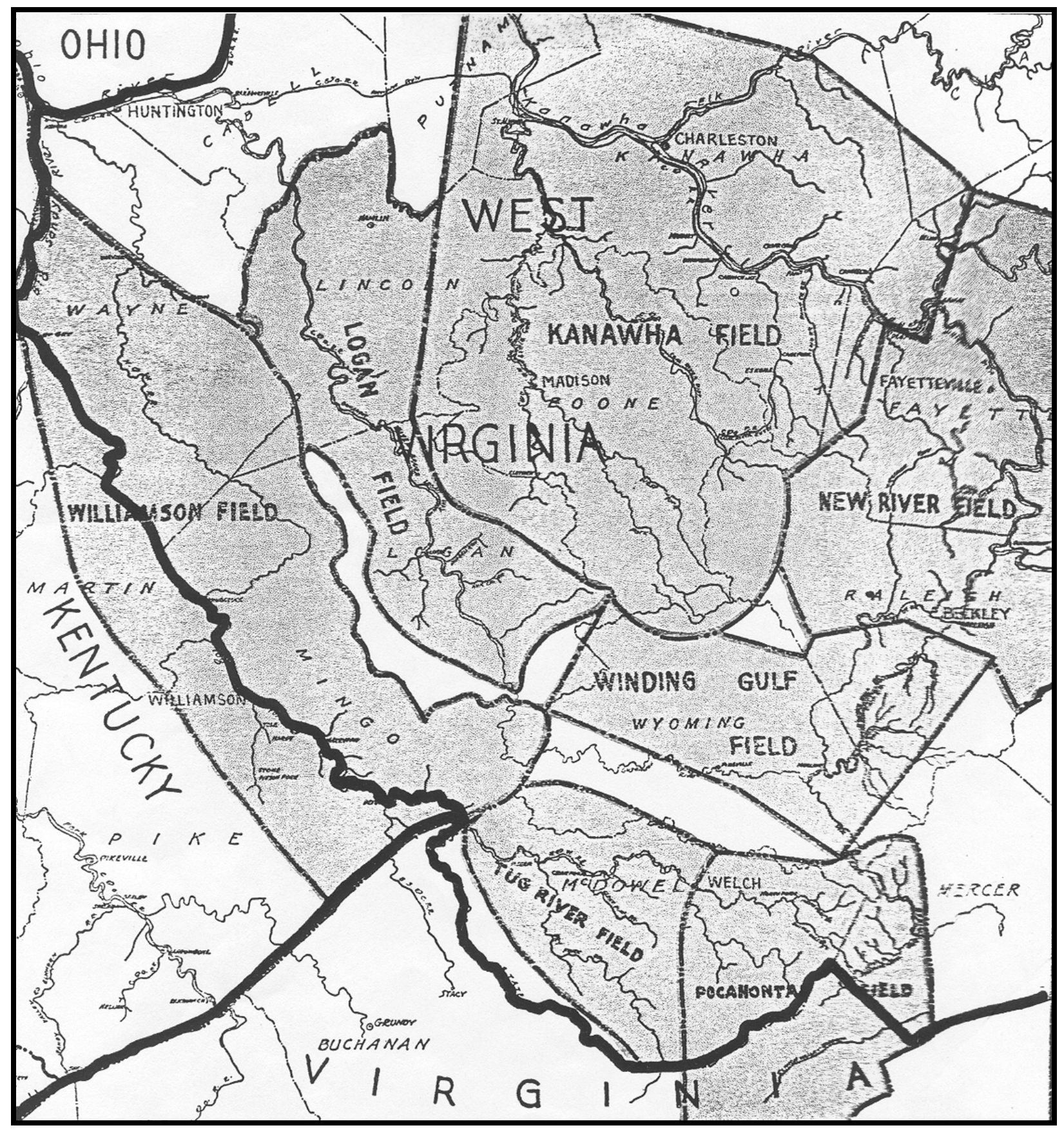

